UNIVERSIDADE DE SÃO PAULO

FFCLRP - DEPARTAMENTO DE BIOLOGIA

PROGRAMA DE PÓS-GRADUAÇÃO EM BIOLOGIA COMPARADA

\title{
Taxonomia e relações filogenéticas do gênero Astyanacinus Eigenmann, 1907 (Characiformes: Characidae)
}

Fernando Cesar Paiva Dagosta

Orientador:

Prof. Dr. Ricardo Macedo Corrêa e Castro

Ribeirão Preto - SP

2011 


\section{Taxonomia e relações filogenéticas do gênero Astyanacinus Eigenmann, 1907 (Characiformes: Characidae)}

\section{Fernando Cesar Paiva Dagosta}

Orientador:

Prof. Dr. Ricardo Macedo Corrêa e Castro

Dissertação apresentada à Faculdade de Filosofia, Ciências e Letras de Ribeirão Preto da USP, como parte das exigências para a obtenção do título de Mestre em Ciências, Área: Biologia Comparada.

Ribeirão Preto - SP 
Dagosta, Fernando C. P.

Taxonomia e relações filogenéticas do gênero Astyanacinus

Eigenmann, 1907 (Characiformes: Characidae)

Ribeirão Preto-SP, 2011

409p.

Dissertação apresentada à Faculdade de Filosofia, Ciências e Letras de Ribeirão Preto da USP, como parte das exigências para a obtenção do título de Mestre em Ciências, Área: Biologia Comparada.

Orientador: Castro, Ricardo M. C.

1. Astyanacinus, 2. Characidae, 3. Characiformes, 4. Taxonomia, 5. Filogenia 
UNIVERSIDADE DE SÃO PAULO

FFCLRP - DEPARTAMENTO DE BIOLOGIA

PROGRAMA DE PÓS-GRADUAÇÃO EM BIOLOGIA COMPARADA

\section{Taxonomia e relações filogenéticas do gênero Astyanacinus Eigenmann, 1907 (Characiformes: Characidae)}

\section{Fernando Cesar Paiva Dagosta}

Orientador:

Prof. Dr. Ricardo Macedo Corrêa e Castro

Orientador

Avaliador

Avaliador

Ribeirão Preto - SP

2011 


\section{Advertência}

Este trabalho é apresentado como parte dos requisitos para obtenção do título de mestre em Biologia Comparada e não é uma publicação científica. Portanto, os novos dados, opiniões e hipóteses expressas aqui, assim como qualquer nome, não estão disponíveis na literatura zoológica. Os leitores são advertidos que referências públicas ao conteúdo deste estudo somente devem ser feitas com aprovação prévia do autor.

\section{Notice}

This work is presented in partial fulfillment of the dissertation requirement for the master degree on Comparative Biology and is not a scientific publication. Therefore, the new data, opinions, and hypothesis expressed herein, as well as any new names, are not available in the zoological literature. Readers are advised that public references to this document should only be done after previously acceptance of the author. 


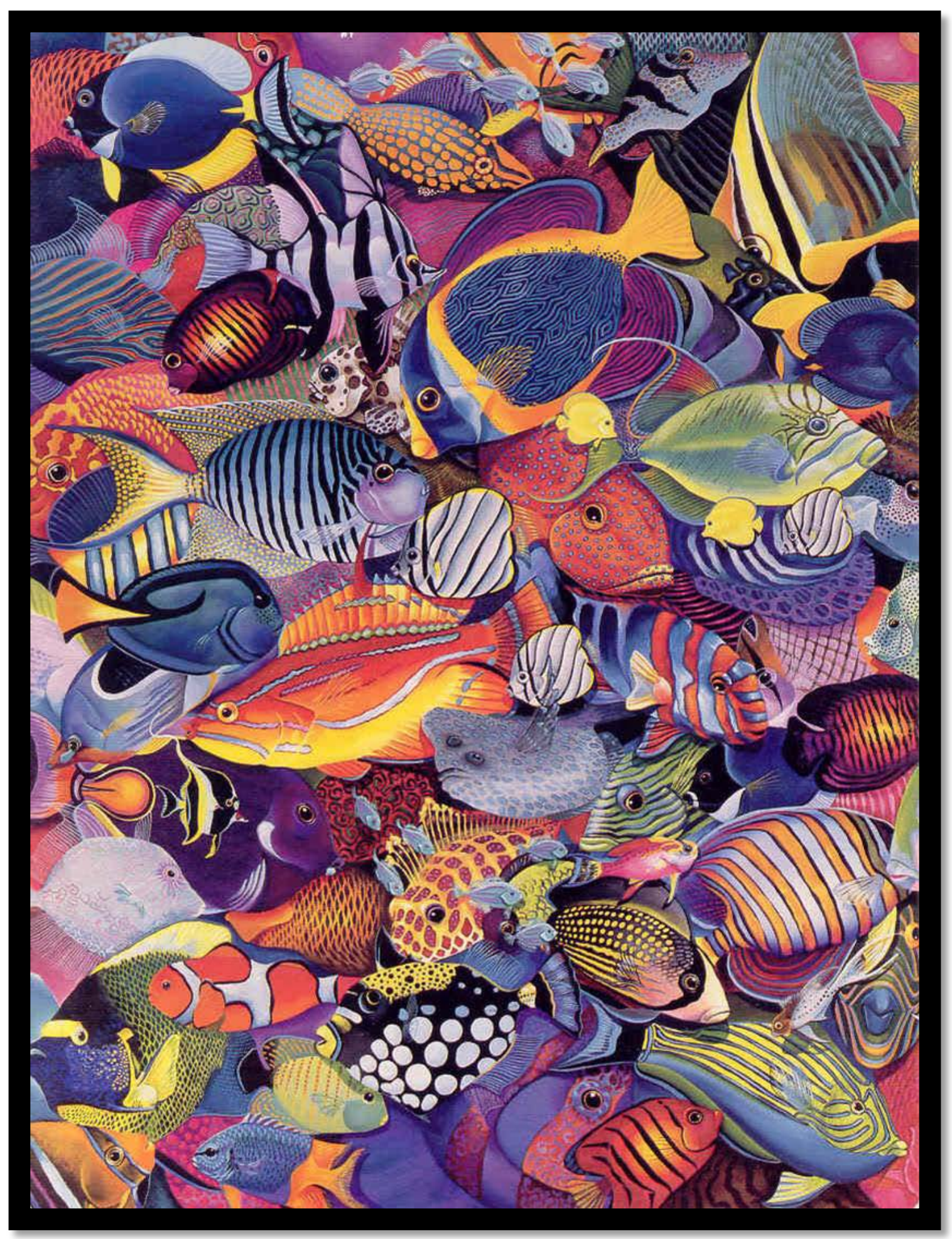

Dedico este trabalho a todos os peixes do planeta e aos apaixonados por eles. 
* Agradeço meu orientador Dr. Ricardo M. C. Castro que sempre apoiou minhas iniciativas e teve sólida influência em minha formação como ictiólogo e foi capaz de transformar um pescador em um pesquisador.

* Ao Dr. Flávio A. Bockmann pelas valiosas sugestões a este trabalho, pelas discussões sempre bem humoradas e pelo seu entusiasmo em falar sobre os peixes.

* À The Lake Side Foundation por ter financiado minha visita ao museu da California Academy of Sciencies em San Francisco.

* Ao Marcel Cavallaro que gentilmente examinou e fotografou o parátipo de Astyanax superbus depositado no Smithsonian Institution.

* Aos responsáveis pelas coleções ictiológicas Osvaldo Oyakawa (MZUSP), José Lima de Figueiredo (MZUSP), Carlos A. Lucena (MCP), Zilda M. Lucena (MCP), Paulo Buckup (MNRJ), Hernan Ortega (MUSM), Hérnan Ortega (MUSM), César Román-Valencia (IAVHP), Ruth Reina (STRI), Ralph Britz (BMNH), Patrick Campbell (BMNH), James Maclaine (BMNH), Luiz R. Malabarba (DZUFRGS), Tomio Iwamoto (CAS), David Catania (CAS) e Marcelo Loureiro (MHNM) pelo empréstimo de material e/ou pelo envio de informações.

* Aos pesquisadores Pablo Lehmann (UNISINOS), Raquel Ruiz-C (IAVHP), Flávio C. T. Lima (MZUSP), Fernando Jerep (MCP), Vinícius Bertaco (DZUFRGS) e Donald Taphorn por compartilhar comigo informações sobre os Astyanacinus.

* Agradecimento ao Marcel Cavallaro e Murilo Carvalho pela troca de informações e ajuda com detalhes de minha ida à Califórnia.

* Aos funcionários Dr. Hertz Figueiredo dos Santos e Dra. Ana Carla Aquino pelo auxílio em dezenas de pequenos detalhes durante todos esses anos, por sempre estarem dispostos a ajudar e pelos momentos sempre muito bem humorados. A.C.A auxiliou nas fotografias

* Ao Aléssio Datovo e à Ana Carla Aquino pelas fotografias, respectivamente, 9192 e 79-90.

* À CAPES (Coordenação de Aperfeiçoamento de Pessoal de Nível Superior) pelo financiamento oferecido.

* Ao Projeto Temático "Relações em Characidae” (processo nº 04/09219-6) pela utilização de materiais e alguns terminais empregados.

* Aos colegas do LIRP Thiago-Jupi, Vitor Masson, Fernando Apone, AndréDurval, Murilo-Vaca, Marcel-Chubas, Ana Carla, Aléssio, Osmar-Oscar, Murilo Carvalho, Verônica, Flávia-Sininho e Mônica pelas conversas agradáveis e sempre muito divertidas. Em especial ao Murilo Pastana, fiel companheiro de discussões sobre peixes. 
* Ao André Esquícero e Murilo Pastana pela ajuda, companhia e entusiasmo durante o trabalho de peixes do Rio Juruena.

* Aos meus pais Carlos Leandro D’Agosta e Célia Paiva por terem sido os grandes incentivadores e provedores dos meus sonhos. Obrigado por tudo!

* Ao meu grande irmão Murilo D’Agosta, companheiro de todas as horas e momentos, por ser o irmão que qualquer pessoa gostaria de ter.

* À vó Con, minha segunda mãe, que me ensinou o nome dos primeiros "bichos" e depois de cada almoço foi companheira de incontáveis programas de animais na Tv Cultura. Tudo começou lá vó...

* Ao meu vô Chará (in memorian) que me ensinou a pescar e, de alguma forma, me transmitiu seu fascínio pelos peixes.

* À minha namorada Helena Krauss por me ensinar, me inspirar e me fornecer energia e estímulo durante todos esses anos, e por ser essa pessoa maravilhosa que tanto me faz bem!

* Aos meus amigos que fizeram parte da minha história: Rodinolfo, Cipó, Piruca, Caião, Amarildson (agora Amagrildson), Mira, Nader, Gonça, Dilbert e Otávio. 


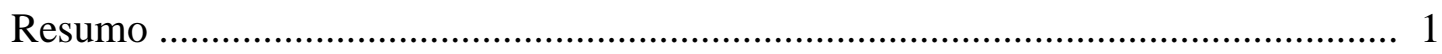

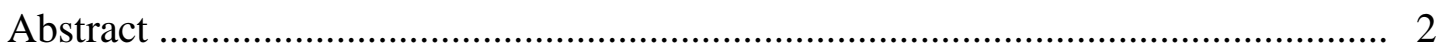

Capítulo 1. Introdução .................................................................................. 4

1.1 Histórico do estudo dos Characiformes e dos Characidae ................................. 6

1.2 Histórico de Astyanacinus .......................................................................... 13

1.3 Histórico taxonômico de Astyanacinus .......................................................... 14

1.4 Histórico das Relações Filogenéticas .......................................................... 16

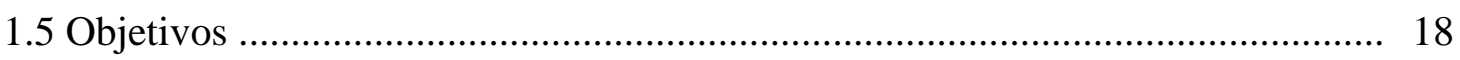

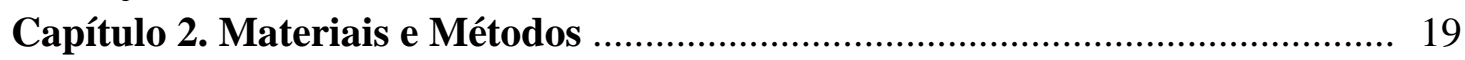

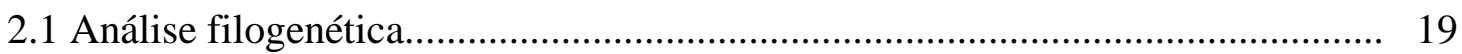

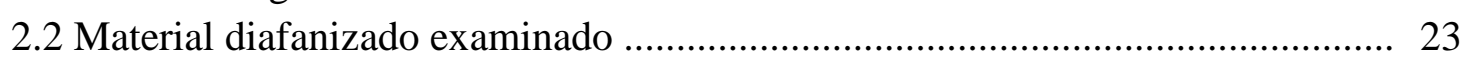

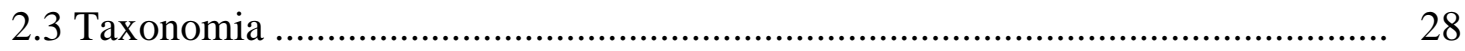

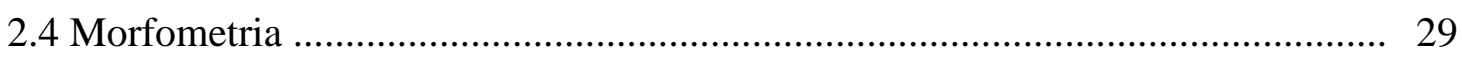

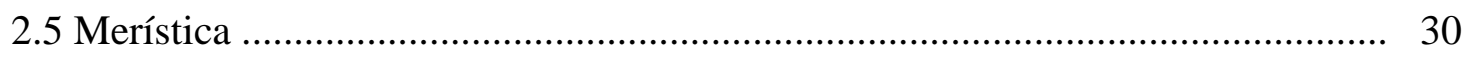

Capítulo 3. Resultados e Conclusões ….......................................................... 34

3.1 Revisão Taxonômica ................................................................................ 34

Astyanacinus Eigenmann, 1907 .................................................................... 34

"Astyanax orthodus" Eigenmann, 1907 ....................................................... 36

"Astyanax" superbus Myers, 1942 ...................................................................... 44

Astyanacinus moorii (Boulenger, 1892) ..................................................... 52

Astyanacinus multidens Pearson, 1924 ....................................................... 61

Astyanacinus sp. nova Bolívia .................................................................... 69

Astyanacinus sp. nova Purus ................................................................... 76

Astyanacinus sp. nova Peru ...................................................................... 81

"Astyanacinus" platensis Messner, 1962 ...................................................... 88

Astyanax goyanensis (Miranda-Ribeiro, 1944) ............................................... 93

Chave de identificação das espécies de Astyanacinus ...................................... 97

3.2 Análise Filogenética ................................................................................. 99

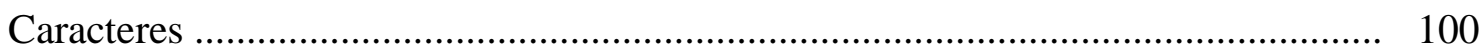

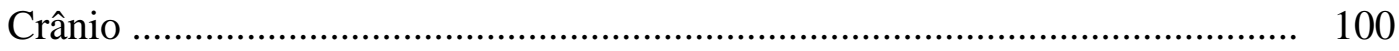

Neurocrânio ........................................................................... 100

Região etmóide ...................................................................... 101

Região orbital .......................................................................... 102

Região ótica ........................................................................ 118

Região basicranial ................................................................. 121

Esplâncnocrânio ................................................................................. 122

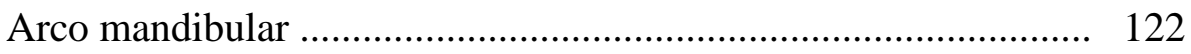

Arco hióide e suspensório ........................................................ 152

Arco branquial .................................................................... 162

Série opercular ...................................................................... 151

Pós-crânio ............................................................................................. 171

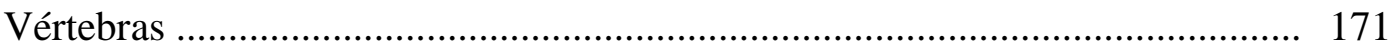




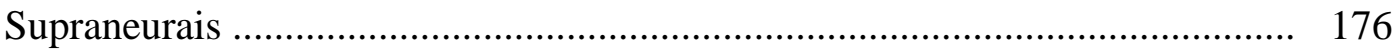

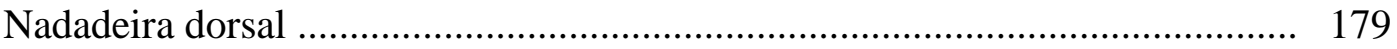

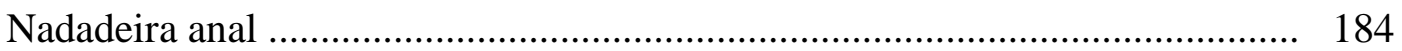

Nadadeira peitoral ........................................................................... 192

Nadadeira pélvica .................................................................................. 202

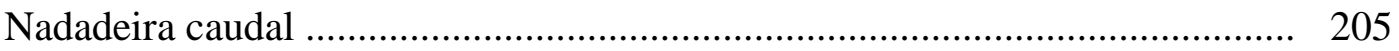

Miscelânea ..................................................................................................... 210

Posição filogenética de Astyanacinus em Characidae ............................................ 218

Astyanacinus como grupo-irmão de Astyanax ....................................................... 219

Monofilia e redefinição do gênero Astyanacinus ..................................................... 222

Relações entre as espécies de Astyanacinus ........................................................ 224

Biogeografia de Astyanacinus ........................................................................ 227

Comentários sobre os outros clado obtidos na filogenia ....................................... 239

Piscivoria em Characidae ............................................................................ 241

Monofilia e posição filogenética da subfamília Agoniatinae ................................. 252

Capítulo 4. Referências Bibliográficas ............................................................. 258

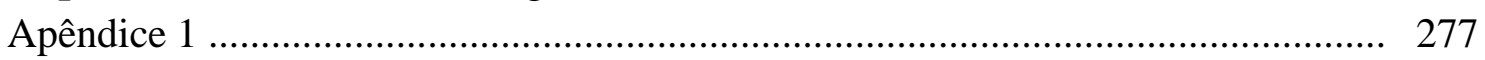

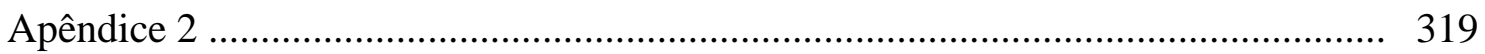

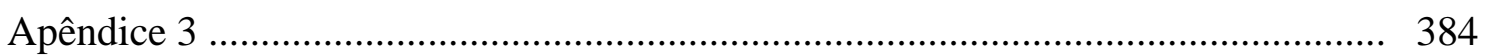




\section{LISTA DE FIGURAS}

Figura 1 Mapa da distribuição geográfica do gênero Astyanacinus. 35

Figura 2 Mapa da distribuição geográfica de A. orthodus. 41

Figura 3 Mapa da distribuição geográfica de A. superbus. 49

Figura 4 Mapa da distribuição geográfica de A. moorii. 57

Figura 5 Mapa da distribuição geográfica de A. multidens. 65

Figura 6 Mapa da distribuição geográfica de A. sp nov. Bolívia. 72

$\begin{array}{llll}\text { Figura } & 7 & \text { Mapa da distribuição geográfica de A. sp nov. Purus. } & 79\end{array}$

Figura 8 Mapa da distribuição geográfica de A. sp nov. Peru. 84

Figura 9 Parte da árvore de consenso entre as oito árvores obtidas com a inclusão de Astyanacinus multidens 219

Figura 10 Maxila superior de a. Astyanacinus moorii MZUSP 78752 (43,3 mm CP) b. Astyanax fasciatus LIRP 132 (75,3 mm CP) c. Astyanacinus sp. nova Bolívia MCP 35017 (60 mm CP) d. Astyanax altiparanae LIRP 6041 (54,2 $\mathrm{mm} \mathrm{CP})$.

Figura 11 Parte da árvore de consenso estrito entre as outras 18 das 26 árvores obtidas com a inclusão de Astyanacinus multidens

Figura 12 a. Consenso estrito entre as 8 árvores mais parcimoniosas em que Astyanacinus é relacionado ao clado 228 de Mirande (2010) b. Consenso estrito entre as 18 árvores em que Astyanacinus é grupo-irmão de Astyanax c. Consenso estrito entre as 26 árvores mais parcimoniosas.

Figura 13 Consenso estrito entre as 6 árvores mais parcimoniosas obtidas sem a inclusão de Astyanacinus multidens.

Figura 14 Mapa da distribuição geográfica do gênero Astyanacinus e a relação com os eventos geológicos

Figura 15 Distribuição das espécies de Ctenolucius (retirado de Vari, 1995).

Figura 16 Distribuição das espécies de Aphanotorulus (retirado de Armbruster \& Page, 1996).

Figura 17 Hipótese resumida de Mirande (2010) sobre as relações evolutivas entre os Characidae.

Figura 18 a-c Abertura bucal de um Characidae piscívoro generalizado. e-g Abertura bucal de um Characidae invertívoro generalizado. d,h mesmo ângulo de abertura bucal para os dois morfótipos.

Figura 19 Vista lateral esquerda de: a. Deuterodon iguape LIRP 1049 (66,67 mm CP); b. Oligosarcus pintoi LIRP 300 (82,06 mm CP); c. Galecharax knerii LIRP 4081 (137 mm CP); d. Acestrorhynchus falcatus LIRP 5115 $(128,6 \mathrm{~mm} \mathrm{CP})$.

Figura 20 Vista medial da mandíbula de: a. Agoniates halecinus MZUSP 92807 (104,8mm CP); b. Hydrolycus scomberoides LIRP 5943 (133,23 mm CP); c. Charax leticiae LIRP 5998 (67,8mm CP); d. Galecharax knerii LIRP 4081 (137 mm CP); e. Oligosarcus pintoi LIRP 300 (82,06 mm CP); f. Salminus hilarii LIRP 369 (122,87 mm CP).

Figura 21 Vista lateral da maxila superior de: a. Acestrorhynchus falcatus LIRP 5115 (128,6mm CP); b. Hydrolycus scomberoides LIRP 5943 (133,23 mm CP); c. Agoniates halecinus MZUSP 92807 (104,8mm CP); d. Charax leticiae LIRP 5998 (67,8mm CP); e. Galecharax knerii LIRP 4081 (137 mm CP); f. Oligosarcus pintoi LIRP 300 (82,06 mm CP).

Figura 22 Vista dorsal da porção direita da cesta branquial de: a. Hydrolycus scomberoides LIRP 5943 (133,23 mm CP); b. Acestrorhynchus falcatus LIRP 5115 (128,6mm CP); c. Charax leticiae LIRP 5998 (67,8mm CP); d. Agoniates halecinus MZUSP 92807 (104,8mm CP). 
Figura 23 a) Dendograma modificado de Géry (1962); b) hipótese resumida de Malabarba \& Weiztman (2003); c) parte da topologia de Mirande (2009, 2010).

Figura 24 Relações de parentesco entre os Distochodontidae e Citharhinidae na 320 proposta de Vari (1979)

Figura 25 Relações na superordem Ostariophysi segundo Fink \& Fink (1981).

Figura 26 Relações internas entre os serrasalmíneos de acordo com Machado-Allison (1982).

Figura 27 Relações internas entre os Anostomoidea, proposta de Vari (1983).

Figura 28 Relações internas entre os Xenurobryconini de Weitzman \& Fink (1985) 324 (modificado, porém sem alteração da hipótese dos autores).

Figura 29 Relações internas entre os Stethaprioninae segundo Reis (1989).

Figura 30 Relações filogenéticas entre as famílias da ordem Characiformes segundo 326 Uj (1990).

Figura 31 Relações filogenéticas entre as famílias da ordem Characiformes de acordo 327 com Buckup (1998).

Figura 32 Relações filogenéticas na família Characidae segundo Lucena (1993).

Figura 33 Relações filogenéticas dos de Ctenoluciidaee suas relações com outros 329 Characiformes de acordo com Vari (1995).

Figura 34 Hipótese das relações das famílias Erythrinidae, Lebiasinidae e 330 Pyrrhulinidae segundo Oyakawa (1998).

Figura 35 Consenso estrito das relações filogenéticas entre os gêneros de 331 Lebiasinidae e a relação com outras famílias de Characiformes de acordo com Netto-Ferreira (2006).

Figura 36 Cladograma de consenso estrito das relações filogenéticas na ordem 332 Characiformes segundo Moreira (2007).

Figura 37 Cladograma de consenso estrito das relações filogenéticas na ordem 333 Characiformes segundo Moreira (2007).

Figura 38 Cladograma de consenso estrito das relações filogenéticas entre os gêneros 334 de Cheirodontinae segundo Malabarba (1998).

Figura 39 Hipótese das relações filogenéticas entre os gêneros de Glandulocaudinae 335 de Weitzman \& Menezes (1998).

Figura 40 Representação das relações entre gêneros de Characidae segundo 336 Weitzman \& Menezes (2003).

Figura 41 Relações entre os Glandulocaudinae e Stevardiinae segundo Weitzman et 337 al. (2005).

Figura 42 Relações entre os Glandulocaudini segundo Menezes \& Weitzman (2009). 338

Figura 43 Hipótese das relações em Characidae de Mirande (2009) usando a pesagem 339 implícita.

Figura 44 Hipótese das relações entre as grandes linhagens de Characidae segundo 340 Mirande (2010).

Figura 45 Hipótese das relações entre os Characiformes segundo Orti \& Meyer 341 (1997).

Figura 46 Relações de parentesco entre os Characidae Neotropicais segundo 342 Calcagnotto et al. (2005).

Figura 47 Hipótese das relações entre as grandes linhagens de Characidae segundo 343 Javonillo et al. (2010).

Figura 48 Dados morfométricos utilizados na revisão taxonômica do presente 344 trabalho.

Figura 49 Diagrama apresentado por Eigenmann (1917-1921) indicando as relações 345 entre os Tetragonopterinae.

Figura 50 Hipótese das relações filogenéticas de alguns Characiformes, segundo Abe 346 (2007).

Figura 51 Hipótese das relações entre algumas espécies de Astyanax e Bramocharax 347 
centro-americanos segundo Ornelas-Garcia et al. (2008).

Figura 52 Parte do clado da hipótese das relações filogenéticas de Characidae, 348 segundo Mirande (2007).

Figura 53 Diferentes ilustrações de Astyanacinus moorii presentes nas publicações 349 de: a) Boulenger (1892); b) Eigenmann (1917-1929); c) Britski et al. (2007); d) Fowler (1948).

Figura 54 Astyanacinus moorii: a. e b. Síntipos (BMNH 1892.4.20.50-51, foto Natural History Museum, London); c. Topótipo (MZUSP 78752) 43,3mm CP.

Figura 55 Figura de Astyanacinus multidens presente na publicação de Pearson (1924). “Cotype”, no 17323, $122 \mathrm{~mm}$.

Figura 56 Vista lateral esquerda do síntipo de Astyanacinus multidens Pearson, 1924 CAS 38955 (IU 17323).

Figura 57 Astyanacinus multidens MZUSP 27829 (94,0 mm CP).

Figura 58 Ilustração do holótipo de Astyanax superbus (retirado de Myers (1942)).

Figura 59 Holótipo de Astyanax superbus SU 36489, macho, 107 mm CP.

Figura 61 a. Astyanax superbus MZUSP 103071 (70 mm CP). b. Astyanax superbus MZUSP 103071 (60,8 mm CP).

Figura

62 Ilustração de Astyanax orthodus (retirado de Dahl (1942)).

Figura 65 a. "Astyanax" orthodus CAS 68769 (69,8 mm CP). b. "Astyanax" orthodus CAS 68769 (69,0 mm CP).

Figura 66 Astyanacinus sp. nova Bolívia a. MCP 35017 (65,42 mm CP) macho b. MCP 35017 (60 mm CP) fêmea; c. MZUSP 27809 (66,86 mm CP).

Figura 67 Astyanacinus sp. nova Peru a. MUSM 37978 (96,4 mm CP) b. MUSM 37978 (106,7 mm CP); c. MUSM 13101 (56,4 mm CP).

Figura 68 a. Astyanacinus sp. nova purus MCP 39773 (58,3 mm CP). b. Astyanacinus sp. nova purus MCP 103071 (41,77 mm CP).

$\begin{array}{lll}\text { Figura } & 69 & \begin{array}{l}\text { a. Astyanax goyanensis presente na publicação de Miranda-Ribeiro (1944); } \\ \text { b. topótipo de Astyanax goyanensis UFRGS 11291, macho, } 56.7 \text { mm CP }\end{array} \\ \text { Figura } & \mathbf{7 0} & \text { Holótipo de Astyanacinus platensis CL } 762 \text { Holótipo fêmea (96,75mm }\end{array}$

$\begin{array}{llll}\text { Figura } & 69 & \text { a. Astyanax goyanensis presente na publicação de Miranda-Ribeiro (1944); } \\ \text { b. topótipo de Astyanax goyanensis UFRGS 11291, macho, } 56.7 \text { mm CP } & 359 \\ \text { Figura } & 70 & \text { Holótipo de Astyanacinus platensis CL } 762 \text { Holótipo fêmea (96,75mm }\end{array}$ $\mathrm{CP})$.

Figura 71 A-B vista lateral esquerda da região ventral de Astyanax superbus (MZUSP 103071); C-D vista ventral (MZUSP 103071).

Figura 72 Vista lateral esquerda da nadadeira anal de Astyanacinus sp nov. Bolívia lote CAS 68367.

Figura 74 Exemplares de Astyanacinus sp nov. Bolívia lote CAS 68367 demonstrando o dimorfismo sexual com relação no formato do corporal.

Figura 75 Vista lateral esquerda do formato da mancha no pedúnculo caudal de a. "Astyanax" orthodus (IAVHP 7146, 50mm CP); b. Astyanacinus moorii (MZUSP 78752, 43,3mm CP); c. ilustração do formato da mancha do pedúnculo caudal de "Astyanax" orthodus; d. ilustração do formato da mancha do pedúnculo caudal das demais espécies de Astyanacinus.

Figura 76 Vista frontal da cavidade bucal de Astyanacinus multidens (CAS 38955) com destaque à presença de um parasita Isopoda.

Figura 77 Árvore de consenso com 922 passos das 6 árvores mais parcimoniosas

Figura 77 Árvore de consenso com 922 passos das 6 árvores mais parcimoniosas
obtidas na análise filogenética sem pesagem.

Figura 78 Árvore de consenso das 6 árvores mais parcimoniosas obtidas na análise filogenética com índice de Bremer e numeração dos nós. 
Figura 79 Anel orbital de: a) Brycon pesu LIRP 5962 (82,9 mm CP); b) Astyanacinus moorii MZUSP 78752 (43,3mm CP).

Figura 80 Neurocrânio de: a) Astyanax fasciatus LIRP 132 (75,3 mm CP); b) Agoniates halecinus MZUSP 92807 (104,8mm CP). 368

Figura 81 Ossos faciais de: a) Charax leticiae LIRP 5998 (82,43 mm CP); b) Triportheus paranensis LIRP 5935 (67,57 mm CP). 369

Figura 82 Vista lateral esquerda da cabeça de: a) Astyanax fasciatus LIRP 132 (75,3 mm CP); b) "Astyanax" orthodus CAS 68769 (69,0 mm CP). 370

Figura 83 Maxila superior de: a) Galeocharax knerii LIRP 4081 (95,2mm CP); b) Knodus moenkhausii LIRP 2273 (33,05 mm CP). 371

Figura 84 Complexo hióide de: a) Cheirodon cf galusdae LIRP 5968 (45 mm CP); b) Hydrolycus scomberoides LIRP 5943 (133,23 mm CP). 372

Figura 85 Cesta branquial de: a) Agoniates halecinus MZUSP 92807 (104,8mm CP); b) Hollandichthys multifasciatus LIRP 5744 (70,60 mm CP). 373

Figura 86 Nadadeira dorsal de: a) Ctenobrycon hauxwellianus LIRP 5932 (68,7mm CP); b) Stethaprion erythrops LIRP 5967 (49,4 mm CP). 374

Figura 87 Nadadeira anal de: a) Triportheus paranensis LIRP 5935 (67,57 mm CP); b) Poptella paraguayensis LIRP 5940 (39,8 mm CP). 375

Figura 88 Nadadeira peitoral de: a) Bryconamericus exodon MZUSP 90275 (40,2mm CP); b) Chalceus epakros MZUSP 7054 (102,4mm CP). 376

Figura 89 Nadadeira pélvica de: a) Poptella paraguayensis LIRP 5940 (39,8 mm CP); b) Hollandichthys multifasciatus LIRP 5744 (70,60 mm CP). 377

Figura 90 Nadadeira caudal de: a) Agoniates halecinus MZUSP 92807 (104,8mm CP); b) Astyanax lineatus LIRP 5574 (84,4 mm CP).

Figura 91 Vista lateral esquerda das nadadeiras dorsais de: a) Astyanax fasciatus LIRP 132 (75,3 mm CP); b) Hollandichthys multifasciatus LIRP 5744 (70,60 mm CP).

Figura 92 Diferentes posições relativas da nadadeira dorsal. a) Astyanax fasciatus
LIRP 132 (75,3 mm CP); b) Hollandichthys multifasciatus LIRP 5744
(70,60 mm CP); c) Mimagoniates microlepis LIRP 5942 (45,61 mm CP);
d) Chalceus epakros MZUSP 7054 (102,4 mm CP).

Figura 92 Diferentes posições relativas da nadadeira dorsal. a) Astyanax fasciatus
LIRP 132 (75,3 mm CP); b) Hollandichthys multifasciatus LIRP 5744
(70,60 mm CP); c) Mimagoniates microlepis LIRP 5942 (45,61 mm CP);
d) Chalceus epakros MZUSP 7054 (102,4 mm CP).

Figura 92 Diferentes posições relativas da nadadeira dorsal. a) Astyanax fasciatus
LIRP 132 (75,3 mm CP); b) Hollandichthys multifasciatus LIRP 5744
(70,60 mm CP); c) Mimagoniates microlepis LIRP 5942 (45,61 mm CP);
d) Chalceus epakros MZUSP 7054 (102,4 mm CP).

Figura 92 Diferentes posições relativas da nadadeira dorsal. a) Astyanax fasciatus
LIRP 132 (75,3 mm CP); b) Hollandichthys multifasciatus LIRP 5744
(70,60 mm CP); c) Mimagoniates microlepis LIRP 5942 (45,61 mm CP);
d) Chalceus epakros MZUSP 7054 (102,4 mm CP).

Figura 93 Vista lateral esquerda de: a) Hyphessobrycon heliacus (foto retirada de Moreira et al., 2002); b) Jupiaba pinnatus (fonte USNM) *; c) Pseudochalceus lineatus (foto retirada de Zarske \& Gery, 2006); d) Creagrutus mucipu (foto retirada de Vari \& Harold, 2001).

Figura 94 Vista lateral esquerda de: a) Hyphessobrycon bifasciatus (foto modificada de Oyakawa et al., 2006); b) Moenkhausia pittieri *; c) Nematocharax venustus (foto modificada de Menezes et al., 2007); d) Astyanax leopoldi *; e) Phenacogrammus aff. caudomaculatus

Figura 95 Figura 95. a) Desenho esquemático do corte transversal do corpo de um Astyanacinus. b) Vista lateral esquerda da superfície corporal de Astyanacinus sp. nova Bolívia MCP 35017 (52,22 mm CP) com escamas e epiderme removidas expondo a vascularização superficial dos vasos que formam os "chevrons". 


\section{LISTA DE GRÁFICOS}

Gráfico 01. Distribuição da quantidade de dentes no maxilar dos exemplares examinados de A. orthodus.

Gráfico 02. Distribuição da quantidade de raios ramificados na nadadeira anal dos exemplares examinados de $A$. orthodus.

Gráfico 03. Distribuição da quantidade de escamas na linha lateral dos exemplares examinados de $A$. orthodus.

Gráfico 04. Distribuição da quantidade de dentes no maxilar dos exemplares examinados de A. superbus.

Gráfico 05. Distribuição da quantidade de raios ramificados na nadadeira anal dos exemplares examinados de $A$. superbus.

Gráfico 06. Distribuição da quantidade de escamas na linha lateral dos exemplares examinados de $A$. superbus.

Gráfico 07. Distribuição da quantidade de dentes no maxilar dos exemplares examinados de A. moorii.

Gráfico 08. Distribuição da quantidade de raios ramificados na nadadeira anal dos exemplares examinados de $A$. moorii.

Gráfico 09. Distribuição da quantidade de escamas na linha lateral dos exemplares examinados de A. moorii.

Gráfico 10. Distribuição da quantidade de dentes no maxilar dos exemplares examinados de A. multidens.

Gráfico 11. Distribuição da quantidade de raios ramificados na nadadeira anal dos exemplares examinados de $A$. multidens.

Gráfico 12. Distribuição da quantidade de escamas na linha lateral dos exemplares examinados de $A$. multidens.

Gráfico 13. Distribuição da quantidade de dentes no maxilar dos exemplares examinados de A. sp. nova Bolívia.

Gráfico 14. Distribuição da quantidade de raios ramificados na nadadeira anal dos exemplares examinados de $A$. sp. nova Bolívia.

Gráfico 15. Distribuição da quantidade de escamas na linha lateral dos exemplares examinados de A. sp. nova Bolívia.

Gráfico 16. Distribuição da quantidade de dentes no maxilar dos exemplares examinados de A. sp. nova Peru.

Gráfico 17. Distribuição da quantidade de raios ramificados na nadadeira anal dos exemplares examinados de $A$. sp. nova Peru.

Gráfico 18. Distribuição da quantidade de escamas na linha lateral dos exemplares examinados de A. sp. nova Peru.

Gráfico 19. Altura do corpo pelo comprimento.

Gráfico 20. Distância pré-dorsal pelo comprimento.

Gráfico 21. Distância pré-ventral pelo comprimento.

Gráfico 22. Distância focinho-peitoral pelo comprimento.

Gráfico 23. Distância focinho-anal pelo comprimento.

Gráfico 24. Distância pélvica-anal pelo comprimento.

Gráfico 25. Altura do pedúnculo caudal pelo comprimento.

Gráfico 26. Base da nadadeira dorsal pelo comprimento.

Gráfico 27. Base da nadadeira anal pelo comprimento.

Gráfico 28. Distância dorsal-caudal pelo comprimento.

Gráfico 29. Maior raio da nadadeira peitoral pelo comprimento.

Gráfico 30. Maior raio da nadadeira pélvica pelo comprimento.

Gráfico 31. Maior raio da nadadeira dorsal pelo comprimento.

Gráfico 32. Maior raio da nadadeira anal pelo comprimento. 
Gráfico 33. Comprimento da cabeça pelo comprimento.

Gráfico 34. Comprimento do focinho pelo comprimento da cabeça.

Gráfico 35. Diâmetro da órbita pelo comprimento da cabeça.

Gráfico 36. Distância maxila-pré-maxilar pelo comprimento da cabeça.

Gráfico 37. Distância interorbital pelo comprimento da cabeça.

Gráfico 38. Altura da cabeça pelo comprimento da cabeça.

409 


\section{LISTA DE TABELAS E QUADROS}

Tabela 1. Dados merísticos e morfométricos de "A. orthodus"

Tabela 2. Dados merísticos e morfométricos de todos os lotes examinados de "Astyanax" superbus.

Tabela 3. Dados merísticos e morfométricos de todos os lotes examinados de Astyanacinus moorii.

Tabela 4. Dados merísticos e morfométricos de todos os lotes examinados de Astyanacinus multidens.

Tabela 5. Dados merísticos e morfométricos dos síntipos examinados de Astyanacinus multidens.

Tabela 6. Dados merísticos e morfométricos de Astyanacinus sp. nova Bolívia

Tabela 7. Dados merísticos e morfométricos de Astyanacinus sp. nova Purus

Tabela 8. Dados merísticos e morfométricos de Astyanacinus sp. nova Peru

Tabela 9. Dados merísticos e morfométricos de "Astyanacinus" platensis.

Tabela 10. Dados merísticos e morfométricos de Astyanax goyanensis.

Quadro 1. Matriz dos estados e caracteres empregados na análise filogenética

Quadro 2. Quantidade de vértebras nas espécies de Astyanax.

Quadro 3. Índices de consistência e retenção dos caracteres da análise filogenética 
O gênero Astyanacinus foi descrito por Eigenmann (1907) para realocar Tetragonopterus moorii Boulenger (1892). No presente estudo Astyanacinus é revisado e redescrito. Com base na revisão taxonômica envolvendo 21 medidas e 13 contagens, Astyanacinus é redefinido e é composto por 7 espécies, incluindo três novas. Astyanacinus moorii e Astyanacinus multidens são reconhecidas como espécies válidas; "Astyanax" orthodus e "Astyanax" superbus são realocados em Astyanacinus; "Astyanacinus goyanensis" e “Astyanacinus" platensis são reconhecidos, respectivamente, como pertencentes aos gêneros Astyanax e Oligosarcus; três novas espécies são descritas: Astyanacinus sp n. Bolívia, Astyanacinus sp n. Peru e Astyanacinus sp n. Purus. A distribuição do gênero é extremamente expandida alcançando a Bacia do Alto Paraguai (A. moorii), Alto Madeira (A. multidens, $A$. sp n. Bolívia e A. sp n. Peru), Purus (A. sp n. Purus), Orinoco (“Astyanax” superbus) e os rios Cis-andinos Patia e Atrato (“Astyanax” orthodus). A análise filogenética com 47 táxons e 136 caracteres morfológicos infere o gênero como uma unidade monofilética com base no compartilhamento de seis sinapomorfias: alongamento da mandíbula, 3 dentes no dentário, margem posterior da maxila bem posterior a vertical que passa pela asa do etmóide lateral, primeiro radial proximal da nadadeira anal direcionado dorsalmente, pós-cleitros 1 e 2 próximos (espaço entre eles menor que a altura do pós-cleitro 1) e presença de chevrons. Somente A. moorii, "Astyanax" orthodus, "Astyanax" superbus, Astyanacinus sp $n$. Bolívia e Astyanacinus sp $n$. Peru foram dissecadas e incluídas na análise uma vez que nenhum material de Astyanacinus sp $n$. Purus e A. multidens pode ser disponibilizado para diafanização. A. multidens foi parcialmente incluída na análise filogenética com base no exame de radiografias e gerou baixa resolução no estudo das afinidades evolutivas do gênero Astyanacinus com os outros caracídeos. O gênero é obtido como grupo-irmão de Astyanax ou pode estar relacionado a um clado formado por Oligosarcus, Hollandichthys e Rachoviscus, assim a posição do gênero continua indefinida, esperando mais estudos e material adicional de A. sp n. Purus e A. multidens. De acordo com os resultados da filogenia $A$. sp n. Bolívia é grupo-irmão de todas as outras espécies de Astyanacinus examinadas com base, por exemplo, na posse de ganchos nas nadadeiras pélvica e anal de machos adultos maduros. Com relação à biogeografia do grupo, alguns padrões geológicos são sugeridos como responsáveis pelos eventos cladogenéticos do gênero. A distribuição de A. moorii no Alto Paraguai pode ser resultado do intercâmbio faunístico ocorrido entre as cabeceiras do Alto Paraguai e Alto Madeira através de uma suposta rota de dispersão que data de aproximadamente 10 m.a.. A existência de uma espécie Cis-Andina fornece uma idade mínima para o gênero que teria evoluído, pelo menos, antes de 12 m.a. (data da formação da Cordilheira Noroeste Andina). O padrão de distribuição de "Astyanax" orthodus na América Central é explicado pela emergência do Ístmo do Panamá no Plioceno (3 m.a.) que formou uma conexão terrestre entre as Américas Central e do Sul e promoveu uma rota de dispersão para a espécie. A presença de "Astyanax" orthodus na Bacia do Orinoco pode ser explicada como um resultado de uma conexão pretérita entre o Paleo-Amazonas-Orinoco que se separou com a formação do Arco Vaupes entre 8-5 m.a.. Adicionalmente, o presente estudo fornece o primeiro registro de ganchos nas nadadeiras de machos adultos para o gênero Astyanacinus. 
The genus Astyanacinus was described by Eigenmann (1907) in order to reallocate Tetragonopterus moorii Boulenger (1892). In the present study Astyanacinus is reviewed and redescribed. Based on the taxonomic revision involving 21 morphometric measurements and 13 meristic counts, Astyanacinus is redefined and is composed by seven species, including three new forms. Astyanacinus moorii and Astyanacinus multidens are recognized as valid species; "Astyanax" orthodus and "Astyanax" superbus are re-allocated on Astyanacinus; "Astyanacinus goyanensis" and "Astyanacinus" platensis are recognized, respectively, as belonging to Astyanax and Oligosarcus; three new species are described: Astyanacinus sp n. Bolívia, Astyanacinus sp $n$. Peru and Astyanacinus sp n. Purus. The distribution are of the genus is extremely enlarged reaching the Upper Paraguay basin ( $A$. moorii), Upper-Madeira Basin ( $A$. multidens, A. sp n. Bolivia and A. sp n. Peru), Purus basin (A. sp n. Purus), Orinoco basin ("Astyanax" superbus) and Cis-andin Patia and Atrato basins ("Astyanax" orthodus). The phylogenetic analysis including 47 taxa and 136 morphological characters hypothesizes the genus as a monophyletic unit based on the sharing of six sinapomorphies: enlargement of mandible, three teeth on maxilla, posterior tip of maxilla outreaching the vertical which passes from the wing of the lateral ethmoid, first proximal radial from the anal fin dorsally directed, postcleithrum 1 and 2 near each other (space between them smaller than the greatest deep from the postcleithrum 1), presence of chevron-like marks. Only A. moorii, "Astyanax" orthodus, "Astyanax" superbus, Astyanacinus sp n. Bolívia and Astyanacinus sp n. Peru were dissected and included in the present study, since no available material from Astyanacinus sp $n$. Purus and $A$. multidens is founded. A. multidens was partially included in the phylogenetic analyses based on the exam of radiographs and causes low resolution concerning the phylogenetic relationships of Astyanacinus with other characids. The genus is hypothesized as sister-group of Astyanax or could be related with a clade composed by Oligosarcus, Hollandichthys and Rachoviscus, thus the position of the genus is still undefined, pending more studies and additional available material from $A$. sp $n$. Purus and A. multidens. According to the phylogenetic results $A$. sp $n$. Bolívia is the sistergroup from the remaining Astyanacinus species examined based on the sharing of, for example, presence of bony hooks on pelvic and anal fins of adult males. Regarding the biogeography of the group, some geological patterns were hypothesized as responsible for the cladogenetic events of the genus. The distribution of A. moorii on the Upper Paraguay basin can be a result of faunistic exchanges occurred between the headwaters of the Upper Madeira and Upper Paraguay through the influence of a putative dispersal route dating about 10 m.a.. The presence of a Cis-Andin species provides a minimum age for the genus which has evolved, at least, before 12 m.a. (the date of formation of the northwest Cordillera). The distribution pattern of "Astyanax" orthodus on Central America is explained by the emergence of Isthmus of Panama in the Pliocene ( 3 m.a.) which formed the terrestrial connection between Central and South America and provides a dispersal route for the species. The presence of "Astyanax" orthodus in the Orinoco basin can be explained as a result of the ancient connection between PaleoAmazonas-Orinoco which was separated with the formation of the Vaupes Arch between 8-5 m.a. Additionally, the present study provides the first record of bony hooks on pelvic and anal fins of adult males of the genus Astyanacinus. 
“Pois a natureza é isso; sem medo, nem dó, nem drama...

Almir Sarter

Valorize mais os homens que colecionam conchinhas do que os que colecionam carros. 


\section{Introdução}

Isaac Newton

Os peixes (entendidos aqui como os Vertebrados Não-Tetrapoda) representam, segundo Nelson (2006), mais da metade da diversidade de vertebrados do planeta. Apesar da Terra ter 70\% de sua área coberta por oceanos e apenas cerca de $1 \%$ coberto por água doce, 43\% (aproximadamente 12.000 espécies) da diversidade da ictiofauna do planeta é encontrada nesse último ambiente (Nelson, 2006). Diante dessa notável diversidade dulcícola destaca-se a ictiofauna encontrada nas águas continentais neotropicais que representam, sem dúvida, a mais complexa e diversa fauna de vertebrados. Conforme pode ser observado em Reis et al. (2003) os peixes de água doce neotropicais são representados por cerca de 71 famílias, várias centenas de gêneros e, com aproximadamente 4.500 espécies descritas. Essa diversidade, assim como em outras regiões ictiofaunísticas como a Etiópica, é dominada, tanto em termos de diversidade taxonômica quanto em biomassa, por peixes da série Otophysi, que representam quase 8.000 das espécies descritas, ou seja, 28\% de todas as espécies de peixes do planeta e quase o dobro de espécies de mamíferos.

Uma das ordens de Otophysi é Characiformes, que juntamente com Lophiiformes, é a quarta ordem com o maior número de famílias, 18 no total, sensu Nelson (2006). É também a quarta ordem com o maior número de espécies descritas somando mais de 1674 em 270 gêneros (Nelson, 2006). Não obstante, segundo Vari (1998) estes números provavelmente estão subestimados, como pode ser depreendido do exame de Eschmeyer (2010) que somente 4 anos após a publicação de Nelson já lista mais de 1940 espécies para a ordem.

Dentro da ordem Characiformes está contida a quarta maior família de peixes do planeta em número de espécies; a família Characidae. Essa família possui em torno de 1100 espécies descritas válidas (Eschmeyer, 2010) e mais de 160 gêneros distribuídos pelo continente americano sendo que os representantes mais austrais são encontrados na Argentina e os mais boreais, ao sul dos Estados Unidos. Só no Brasil são aproximadamente 600 espécies (Buckup et al., 2007). A família Characidae representa 
um caso singular de diversidade dentre os vertebrados. Aproximadamente um terço dos gêneros dessa família (47) são monotípicos e outros 23 contêm somente duas ou três espécies (Reis et al., 2003). Tal padrão é ainda mais corroborado nos últimos anos com a descrição de novos gêneros monotípicos de Characidae à taxa de aproximadamente um por ano como em: Castro et al. (2003), Mirande et al. (2004), Zanata \& Akama (2004), Weitzman et al. (2005), Zarske \& Géry (2006), Bührnheim et al. (2008), Menezes et al. (2009) e Zarske (2010).

Os caracídeos, como serão denominados aqui os peixes da família Characidae, possuem grande importância econômica na Região Neotropical. Espécies que atingem maior porte como Salminus, Brycon e os Serrasalminae são importantes fontes de alimento, principalmente para a população ribeirinha dos cursos de água em que ocorrem. Outros como, por exemplo, Gymnocorymbus, Hyphessobrycon, Moenkhausia e Paracheirodon são espécies freqüentemente utilizadas em aquários.

Grandes ícones da ictiologia mundial como Carl Eigenmann e Franz Steindachner tiveram a família Characidae como objeto de estudo e contribuíram enormemente para a rica história taxonômica da família. Apesar disso, ainda há muito a ser feito quanto à taxonomia desses peixes e, principalmente, sobre as relações de parentesco entre seus componentes. Pouco se sabe a respeito disso e não há praticamente nenhuma hipótese das relações filogenéticas para boa parte dos gêneros de Characidae (exceto Mirande, 2010) e a família ainda carece de uma diagnose consistente. Algumas das características que dificultam o entendimento das relações entre os caracídeos são: a pouca variação morfológica de alguns táxons (por exemplo, em Astyanax que é o maior gênero da ordem Characiformes e um dos maiores do mundo em número de espécies) e o ainda muito incompleto conhecimento sobre a taxonomia desses peixes. Uma amostra da complexidade da família Characidae é dada por suas divisões. Atualmente são reconhecidas 13 subfamílias: Agoniatinae, Aphyocharacinae, Bryconinae, Characinae, Cheirodontinae, Clupeacharacinae, Glandulocaudinae, Iguanodectinae, Rhoadsiinae, Serrasalminae, Stethaprioninae, Tetragonopterinae e Triportheinae (cf. Reis et al. 2003; Buckup et al, 2007), porém a esmagadora maioria dos gêneros e espécies descritos ainda possui posição sistemática incerta.

Recentemente, Mirande (2010) inclui diversos táxons em sua análise filogenética de Characidae e define grandes clados dentro de família e propõe 
efetivamente uma nomenclatura supragenérica para a esta. Entretanto, os clados propostos pelo autor devem ser utilizados de forma bastante conservadora uma vez que diversos gêneros da família não foram inclusos na análise tornando a mesma instável e passível de alterações quando da inclusão de novos terminais. Ciente dessas limitações prefiro seguir a proposta de Reis et al. (2003) que apesar de ser muito mais inconclusiva do que a de Mirande (2010) é mais conservadora.

\subsection{HISTÓRICO DO ESTUDO DOS CHARACIFORMES E DOS CHARACIDAE}

A história do conhecimento acerca das relações dos caracídeos mistura-se com o reconhecimento e concepção do que são os Characiformes e inicia-se em um contexto pré-cladista com autores como Müller (1842), Müller \& Troschel (1845), Günther (1864, 1867), Gill (1893), Boulenger (1904), Regan (1911) e Gregory \& Conrad (1938) que, direta ou indiretamente, começaram a construir um arcabouço do conhecimento para o entendimento do que é Characidae. Grosso modo, são os seminais trabalhos de Eigenmann (1917, 1918, 1921, 1927) e Eigenmann \& Myers (1929) que definem, através da combinação de alguns caracteres, a grande maioria dos gêneros e divisões da família que, segundo os próprios autores, era insuficiente para abarcar toda a complexidade desses peixes, mas era o possível de se realizado no contexto da época. Subseqüentemente, autores como Greenwood et al., (1966) e Géry (1977) seguem a classificação dos trabalhos de Eigenmann.

O trabalho de Weitzman (1962) que descreve minuciosamente a osteologia de Brycon meeki, uma espécie que o autor acreditava representar um caracídeo genérico, tem fundamental importância no estudo das relações de Characidae porque se tornou modelo para muitos estudos osteológicos. A importância dessa publicação amplia-se no fato de que o grupo de caracteres mais amplamente utilizados em trabalhos que versam sobre as relações dos Characiformes e dos Characidae são os baseados em estruturas ósseas. Além disso, o autor comenta sobre a classificação dos Characiformes previamente propostas por outros autores e ainda tece importantes considerações sobre elas. Nos anos seguintes, Tyson R. Roberts publica uma série de trabalhos Roberts (1966; 1969; 1973a; 1973b; 1974) ricos em ilustrações de complexos ósseos de Characiformes, além de tecer comentários sobre a evolução desses. 
O advento das técnicas de diafanização tal como a proposta por Taylor \& Van Dyke (1985) permitiu estudos osteológicos mais acurados sobre peixes ósseos de pequeno porte que anteriormente eram praticamente inexistentes. Outro trabalho importante para o estudo da evolução dos Characiformes foi o de Hennig (1950, 1966) descrevendo a metodologia cladística que revolucionou a biologia ao permitir gerar hipóteses falseáveis sobre as relações evolutivas dos organismos analisados.

O primeiro trabalho sistemático com caracídeos utilizando a metodologia cladística foi o de Rosen (1972) no qual o autor discute as relações do gênero centroamericano Bramocharax com outros Tetragonoterinae. Dois anos depois o trabalho de Fink \& Weitzman (1974) trata dos Cheirodontinae da América Central. O trabalho de Vari (1979) é o primeiro a propor um grande grupo monofilético dentro dos Characiformes com base na metodologia cladística. Para o autor as famílias Distichodontidae e Citharinidae formariam um grupo monofilético (figura 24). O trabalho, embora tenha sido pioneiro, é bastante consistente tendo sido corroborado por outros autores (c.f. Buckup, 1998; Moreira, 2007). Dois anos mais tarde em Fink \& Fink (1981) é publicada a hipótese que propõe, pela primeira vez utilizando a metodologia cladística, a relação de parentesco da ordem Characiformes com as ordens Gonorynchiformes, Cypriniformes, Siluriformes e Gymnotiformes formando a superordem Ostariophysi (figura 25), além de propor o monofiletismo dos Characiformes. Os resultados apresentados pelos autores nesse trabalho são raramente contestados. Em Fink \& Fink (1996) há uma atualização do trabalho de 1981, porém a estrutura geral da proposta é a mesma.

No ano seguinte foi defendida a tese de doutorado de Antonio Machado-Allison sobre as relações da subfamília Serrasalminae em que esta é tratada como uma unidade monofilética dentro de Characidae (figura 26) (Machado-Allison, 1982). A tese resultou em diversos trabalhos sobre a subfamília Machado-Allison (1982b; 1985; 1986) e seu monofiletismo ainda não foi contestado. Outro importante trabalho sobre a evolução dos Characiformes é publicado em Vari (1983). Nesse, o autor novamente propõe uma unidade monofilética envolvendo famílias de Characiformes, o clado dos “Anostomoidea” (nome cunhado posteriormente) que inclui as famílias Curimatidae, Prochilodontidae, Anostomidae e Chilodontidae (figura 27). Nesse ínterim, Richard P. Vari inicia uma série de trabalhos sobre a taxonomia e relações dos gêneros da família Curimatidae Vari (1982; 1984; 1988; 1989a; 1989b; 1989c; 1989d; 1991; 1992a; 
1992b) fazendo com que essa seja uma das famílias com distribuição, taxonomia e evolução mais bem conhecidas dentre os peixes neotropicais.

Weitzman \& Fink (1983) versam sobre as relações de parentesco dos "Neon Tetras” com base em caracteres osteológicos e ressaltam a importância da classificação da família refletir as considerações filogenéticas do grupo. No Brasil, é defendida a dissertação de Castro (1984) com a descrição osteológica do gênero monotípico Engraulisoma e uma análise filogenética sobre a relação deste com outros caracídeos. O autor conclui que o gênero é grupo-irmão de Clupeacharax com base em uma série de caracteres osteológicos. Posteriormente, Weitzman \& Fink (1985) publicam um trabalho agrupando os gêneros Argopleura, Iotabrycon, Scopaeocharax, Tyttocharax e Xenurobrycon na tribo Xenurobryconini (Glandulocaudinae: Characidae) (figura 28).

Reis (1989) (figura 29) propõe a monofilia dos Stethaprioninae (Poptella, Orthospinus, Stethaprion e Brachychalcinus) que foi a primeira proposta publicada por um autor brasileiro sobre as relações de um grupo de Characiformes com base cladística.

Já o trabalho de Uj (1990) (figura 30) estudou as relações de praticamente todas as famílias então reconhecidas de Characiformes, mas seu trabalho, apesar de algumas qualidades, apresenta sérios problemas metodológicos quanto à verdadeira natureza de alguns de seus caracteres e também quanto à forma de sua análise. A hipótese do autor recobra, de forma geral, a classificação anteriormente proposta por Géry (1977).

No ano seguinte Buckup (1991) em sua Tese de doutorado, publicada posteriormente em Buckup (1993a; 1993b; 1998), objetivava determinar o grupo-irmão de seu objeto de estudo principal, os Characidiinae, e utilizando alguns terminais de Characiformes e Characidae obteve em sua análise como resultado a análise filogenética de Characiformes atualmente mais conhecida e empregada. Sua proposta (figura 31) deve ser vista com cautela já que apenas vinte e sete terminais foram incluídos na análise e seu “clado 14” (=Characidae) contém apenas sete terminais, ou seja, apenas quatro por cento dos gêneros da família (considerando que a família possui 165 gêneros, dados de Nelson (2006)).

A primeira e única tese que, como um todo, se propôs especificamente a analisar as relações filogenéticas em Characidae foi a de Lucena (1993). Apesar de ter obtido como resultado uma árvore filogenética sem muitas resoluções para os caracídeos (figura 32), o autor apresenta ineditamente dezenas de caracteres que foram e são 
largamente empregados nos estudos das relações de parentesco desses peixes, sendo assim, uma das mais importantes (talvez a mais) contribuições ao estudo das relações internas da família Characidae. Um ano depois Malabarba (1994) defende sua tese tratando das relações de parentesco na subfamília Cheirodontinae (Characiformes: Characidae).

Vari (1995a) publica um trabalho sobre as relações internas da família Ctenoluciidae e sua relação com outros Characiformes (figura 33). A proposta de que Ctenoluciidae é grupo-irmão de Erythrinidae é controversa e diversos autores (c.f. Lucena, 1993 figura 32; Buckup, 1998 figura 31; Oyakawa, 1998 figura 34; NettoFerreira, 2006 figura 35; Moreira, 2007 figura 36), grosso modo, sugerem o parentesco mais próximo entre Ctenoluciidae e Hepsetidae ao passo que Erythrinidae seria mais relacionada aos Lebiasinidae. No mesmo ano outra família de Characiformes (Chilodontidae) tem sua as relações internas de parentesco proposta (Vari et al., 1995b).

Em 1998 é publicado o livro "Phylogeny and Classification of Neotropical Fishes” editado por Luiz R. Malabarba contendo diversos artigos versando todos os mais importantes grupos de peixes que habitam a região Neotropical. O livro representou um grande avanço no conhecimento das relações evolutivas dos peixes Neotropicais, pois sintetiza boa parte do conhecimento evolutivo sobre esses peixes produzido nos anos que antecederam sua publicação. Em relação aos Characiformes, o livro traz nove ensaios dentre eles destaca-se o de Langeani (1998) sobre as relações filogenéticas de Hemiodontidae, Lucena \& Menezes (1998) (figura 37) que apontam as famílias Cynodontidae e Acestrorhynchidae como grupos-irmãos e o de Buckup (1998) anteriormente já discutido. Mais especificamente sobre os Characidae, o volume apresenta uma proposta de monofilia dos Cheirodontinae de Malabarba (1998) (figura 38), a hipótese de relações entre os gêneros de Glandulocaudinae de Weitzman \& Menezes (1998) (figura 39) e o trabalho de Malabarba (1998) sobre as relações de parentesco entre o fóssil Lignobrycon (com um representante fóssil L. ligniticus e um vivente L. myersi) e Triportheus além de considerações sobre possíveis conexões pretéritas entre o antigo rio Paraíba do Sul e cabeceiras do rio Tietê e drenagens do sudeste brasileiro.

A partir da virada do século XX uma série de trabalhos de pós-graduandos que estudaram diversos grupos da família Characidae a partir de análises com bases anatômicas (principalmente esqueléticas) foram desenvolvidos, tais como os de Zanata 
(2000), Moreira (2002), Bertaco (2003), Cardoso (2003), Piton-Serra (2003), Benine (2004), Bührnheim (2006), Lima (2006), Quevedo (2006), Ferreira (2007), Ribeiro (2007), Bertaco (2008), Pezzi da Silva (2009), Cavallaro (2010), Piton-Serra (2010), Cavallaro (2010), Pereira (2010), Jerep (2011) e outros.

É importante que seja feito um destaque para a Tese ainda não publicada de Moreira (2007) sobre a filogenia de Characiformes. Nessa análise um notável número de caracteres foram investigados (410) e, como resultado, o autor obteve uma filogenia em que a família Characidae seria monofilética (nó 143) com a exclusão da subfamília Serrasalminae e dos gêneros Brycon e Salminus e com a inclusão de Gasteropelecidae. O trabalho de Moreira (2007) é, sem dúvida, de grande importância para a elucidação das relações de parentesco entre os caracídeos, porém a relativa pequena representação de táxons de Characidae, principalmente dos incertae sedis, torna a hipótese gerada por Moreira (2007), em certo nível, potencialmente instável. Conforme exposto por de Pinna (1992), a inclusão de táxons adicionais pode modificar substancialmente hipóteses prévias.

Nesse meio tempo, além das Dissertações e Teses dos pós-graduandos, também foram publicados diversos artigos sobre os Characiformes e os Characidae. Com relação aos Characiformes destacam-se trabalhos de Toledo-Piza (2000) Cynodontinae (Cynodontidae); Castro \& Vari (2004) Prochilodontidae; Zanata \& Vari (2005) Alestidae; Toledo-Piza (2007) Acestrorhynchidae e Sidlauskas \& Vari (2008) Anostomidae.

Sobre os Characidae, Vari \& Harold (2001) estudaram as relações entre as espécies de Creagrutus e Piabina e concluíram que esses dois gêneros são gruposirmãos. Malabarba \& Weitzman (2003) objetivando posicionar filogeneticamente o novo gênero de Characidae Cyanocharax, propuseram, com base na presença de ganchos principalmente nos raios das nadadeiras pélvicas e anal de machos adultos, um grupo monofilético incluindo as subfamílias Aphyocharacinae, Characinae, Cheirodontinae, Gasteropelecidae, Iguanodectinae, Rhoadsiinae, Roestinae, Serrasalminae, Stethaprioninae, parte de Tetragonopterinae juntamente com gêneros incertae sedis, os gêneros Brycon, Bryconops, Lignobrycon, Salminus, Triportheus e o “clado A (Attonitus, Boehlkea, Bryconacidnus, Caiapobrycon, Ceratobranchia, Creagrutus, Cyanocharax, Hemibrycon, Hypobrycon, Knodus, Microgenys, Monotocheirodon, Odontostoechus, Othonocheirodus, Piabarchus, Piabina, 
Rhinobrycon e Rhinopetitia" (figura 40). Este último clado seria sustentado pela presença de duas características: nadadeira dorsal com ii, 8 raios e quatro dentes na série interna do pré-maxilar. Apesar desse trabalho fornecer um pouco de luz sobre o entendimento das relações filogenéticas dos caracídeos, a hipótese é relativamente frágil uma vez que é sustentada por poucos caracteres. Diversos outros autores corroboram a hipótese dos autores de que o clado A trata-se de um agrupamento monofilético.

O importante trabalho de Weitzman et al. (2005) (figura 41) segrega a subfamília Glandulocaudinae ao elevar o nível taxonômico da tribo Stevardiini de glandulocaudíneos à subfamília Stevardiinae. Assim, a composição de ambas as subfamílias ficaram assim: Glandulocaudinae (Glandulocauda, Lophiobrycon e Mimagoniates) e Stervadiinae (Acrobrycon, Argopleura, Chrysobrycon, Corynopoma, Diapoma, Gephyrocharax, Hysteronotus, Iotabrycon, Landonia, Phenacobrycon, Planaltina, Pseudocorynopoma, Pterobrycon, Ptychocharax, Scopaeocharax, Tyttocharax, Xenurobrycon). Menezes \& Weitzman (2009) propõem o monofiletismo e as relações internas dos Glandulocaudinae (Glandulocauda, Lophiobrycon e Mimagoniates) com base principalmente em caracteres reprodutivos (figura 42).

O trabalho de Mirande (2009) (figura 43) com 360 caracteres e 160 espécies (a maioria de Characidae), embora tenha recebido algumas críticas como a falta de ilustração dos caracteres e falta de discussão sobre os caracteres e os clados propostos, corroborou diversos clados propostos previamente por outros como Cheirodontinae (Malabarba, 1998); Clado A (Malabarba \& Weitzman, 2003); Iguanodectinae (Moreira, 2002), Stethaprioninae (Reis, 1989), Rhoadsiinae (Cardoso, 2003), entre outros. O trabalho enriqueceu a discussão sobre a discussão sobre as relações em Characidae e cumpriu o objetivo do autor que ressalta "This paper is far from providing a conclusive phylogeny of the family, but instead it intends to be a starting point for future studies, encouraging colleagues to discuss in common terms and conciliate a phylogeny of the family from different contributions".

Até Mirande (2010) a esmagadora maioria do conhecimento produzido por alunos de pós-graduação na forma de Dissertações e Teses geradas a partir do ano 2000 não tinha sido reunido e publicado formalmente. Com isso, Mirande (2010), apesar de suas qualidades pelo ineditismo de diversos caracteres e insights filogenéticos sobre os caracídeos, o autor nesse trabalho reuniu toda informação disponível nessas Dissertações e Teses e produziu a mais recente hipótese sobre a relação dos membros de 
Characidae (figura 44). Nesse trabalho o autor propõe grandes clados dentro da família e torna-se um ponto de partida o estudo filogenético do grupo. Para o autor, a família Characidae é monofilética com a inclusão das famílias Cynodontidae e Acestrorhynchidae (proposta semelhante ao apresentado por Mirande (2009) e Datovo (2011)) e é formada por 22 grandes clados (Salmininae, Agoniatinae, Cynodontinae, Acestrorhynchidae, Bryconinae, Iguanodectinae, Bryconops clade, Heterocharacinae, Characinae, Bramocharax clade, Pseudochalceus clade, Rhoadsiinae, Tetragonopterinae, Hyphessobrycon luetkenii clade, Astyanax paris clade, Astyanax clade, Bryconamericus scleroparius clade, Gymnocharacinae, Aphyocharacinae, Aphyoditeinae, Cheirodontinae e Stevardiinae. Na proposta do autor, como muito se especula, alguns gêneros como Astyanax, Hyphessobrycon, Hemigrammus, Moenkhausia e Bryconamericus são propostos como sendo polifiléticos mesmo com a inclusão de poucas espécies de cada um desses gêneros. Tal constatação denota o quão árduo é caminho pelo qual os especialistas em Characidae, principalmente desses gêneros, trafegam.

Em relação aos dados moleculares, somente dois trabalhos visando à análise das relações de Characiformes foram publicados. O pioneiro, de Ortí \& Meyer (1997) (figura 45), utilizou representantes de 16 famílias de Characiformes e representantes dos seguintes gêneros por eles considerados como parte de Characidae: Acestrorhynchus, Alestes, Aphyocharax, Astyanax, Brycon, Chalceus, Cheirodon, Colossoma, Corynopoma, Cynopotamus, Gephyrocharax, Gnathocharax, Hydrocynus, Oligosarcus, Phenacogrammus, Poptella, Pygocentrus, Rhaphiodon, Salminus e Tetragonopterus. Os autores reconheceram as limitações metodológicas e esclareceram que os genes escolhidos para a análise não foram úteis suficientemente para que o objetivo proposto fosse alcançado.

A outra análise das relações de Characiformes com dados moleculares foi realizada por Calcagnotto et al. (2005) (figura 46) e teve mais sucesso. Eles utilizaram dois genes mitocondriais (16S e Citocromo b) e três genes nucleares (RAG2, sia, fkh e trop). Foram examinados 124 terminais, mas a maioria é componente das famílias africanas Alestidae e Distichodontidae. Os autores obtiveram como resultado uma hipótese em que Characidae seria monofilético com a inclusão de Acestrorhynchidae e a exclusão de Serrasalminae. Outro trabalho de cunho filogenético sobre caracídeos e envolvendo bases moleculares foi o de Hilsdorf et al. (2008). Nele, diferente de Ortí \& 
Meyer (1997) e Calcagnotto et al. (2005), poucos terminais foram analisados e o objetivo foi entender as relações entre as espécies do gênero Brycon.

Em Hubert et al. (2005) os autores investigam as relações de parentesco entre os gêneros de Alestidae com ênfase na tribo Petersiini com base em caracteres moleculares e morfológicos. Outro trabalho versando sobre os Characiformes a partir de caracteres moleculares foi publicado por Freeman et al. (2007) e se propôs a estudar as relações de parentesco entre os Serrasalminae (Serrasalmidae na concepção do autor) com ênfase nos gêneros popularmente denominados de Piranhas.

Mais recentemente é publicado por Javonillo et al. (2010) (figura 47). Esse trabalho trata a família Characidae como sendo monofilética formada pelos clados A, B, C além da inclusão dos Gasteropelecidae, de Acestrorhynchus. Outras informações que o artigo fornece é a polifilia de gêneros como Astyanax, Hyphessobrycon e Bryconamericus. Corrobora a monofilia de Cheirodontinae e do "Clado A" além de apresentar dois outros grandes clados monofiléticos dentro de Characidae: o "Clado B" composto pelas subfamílias Cheirodontinae, Aphyocharacinae, Tetragonopterinae e Characinae e o gênero Exodon; e o “Clado C” formado pelos Stethaprioninae, pela maioria dos gêneros incertae sedis e pelos gêneros com mais espécies da família (e.g. Astyanax, Hemigrammus, Hyphessobrycon).

\subsection{HISTÓRICO DE ASTYANACINUS}

Grande parte dos gêneros da família Characidae são caracterizados taxonomicamente com base na combinação de caracteres não-exclusivos (e.g. sistema látero-sensorial, escamação nas nadadeiras anal e caudal, morfologia dos dentes e outros) propostos por Carl H. Eigenmann. É evidente, entretanto, que o sistema proposto por Eigenmann é insuficiente para abarcar toda a complexidade de formas de caracídeos tornando alguns dos gêneros de Characidae entidades não-monofiléticas. É interessante notar que de acordo com o sistema de combinação de caracteres de Eigenmann (1917 pag. 42) o gênero Astyanax possui o estado mais comum de todos os caracteres presentes em caracídeos e essa é a provável razão pela qual este gênero possui o maior número de espécies em Characidae e, provavelmente, ser um dos maiores problemas taxonômicos da ictiologia neotropical. 
O gênero Astyanacinus é morfologicamente bastante semelhante ao gênero Astyanax compartilhando com este inúmeras características bastante comuns entre os Characidae como, por exemplo, pré-maxilar com duas séries de dentes com quatro dentes na série mais externa do e cinco dentes na série mais interna, linha lateral completa, presença de nadadeira adiposa, nadadeiras anal e caudal nuas, nadadeira dorsal com dois raios anteriores não-ramificados e nove posteriores ramificados entre outros caracteres. Segundo Eigenmann (1921 pag. 338) o gênero Astyanacinus se diferencia de Astyanax por características referentes ao formato da boca: maxila longa formando com o pré-maxilar, metade do comprimento da cabeça e ausência de um ângulo distinto entre os ossos maxilar e pré-maxilar.

\subsection{HISTÓRICO TAXONÔMICO DE ASTYANACINUS}

O gênero foi descrito por Eigenmann (1907) para realocar a espécie Tetragonopterus moorii proveniente da Chapada dos Guimarães - MT descrita por Boulenger (1892) já que, segundo o autor, o mesmo não se tratava de um Tetragonopterus sensu Cuvier (1816). Na descrição do gênero Eigenmann (1907) é bastante sucinto e não explica a razão do nome do gênero criado. Embora não haja nenhuma menção direta sobre a origem do nome Astyanacinus, uma possível origem seja a combinação entre as palavras Astyanax (gênero de lambaris com semelhanças morfológicas com Astyanacinus) e o radical grego “kynos” que designa cachorro, talvez em alusão ao distinto formato da boca desses peixes com um osso maxilar bastante desenvolvido e que pode ser considerado um tanto quanto mais "agressivo" do que o presente em outros lambaris e afins.

A publicação em que George Boulenger descreve o peixe em questão segue o padrão da época (pelo menos da maioria dos autores) e é bastante concisa e, de certo modo, muito imprecisa. Destaco a informação apresentada por Boulenger (1892), que a meu ver é duvidosa, que o maxilar do peixe em questão era edentado. Alguns anos depois, Eigenmann (1907) examinou o mesmo material e cita a presença de cerca de 6 dentes no osso maxilar. No mesmo trabalho Eigenmann também descreve de forma bastante resumida o gênero Astyanacinus para realocar a espécie Tetragonopterus moorii já que, segundo Carl Eigenmann, o mesmo não se tratava de um Tetragonopterus sensu Cuvier (1816). 
Alguns anos depois em Pearson (1924) é descrita uma segunda espécie para o gênero, Astyanacinus multidens, de material proveniente de bacia hidrográfica distinta da espécie-tipo da tendo como localidade-tipo o Rio Colorado, sistema do Baixo Rio Bopi na Bolívia. Após isso, duas décadas se passaram até que fosse descrita a terceira espécie do gênero, a segunda para o território nacional brasileiro. A espécie Astyanacinus goyanensis é formalmente descrita em Miranda-Ribeiro (1944) a partir de material, como o epíteto específico indica, originário do Estado de Goiás e tendo como localidade-tipo a Chapada dos Veadeiros. Mais recentemente, Malabarba et al. (2004) reconheceram que o trabalho mimeografado de Emil Messner em 1962 ficou desconhecido do meio científico; trabalho este no qual Messner descreve uma nova espécie de Astyanacinus para o sul do Uruguai; Astyanacinus platensis.

Mais recentemente, Bertaco et al. (2010) re-descrevem a espécie Astyanacinus goyanensis realocando-a no gênero Astyanax. Devido à falta de informações disponíveis sobre os peixes do gênero Astyanacinus, a hipótese inicial deste trabalho previa que os peixes deste gênero não eram raros em coleções e a pequena quantidade de lotes disponíveis nas coleções ictiológicas refletiam identificações equivocadas desses peixes como pertencendo ao gênero Astyanax. Essa hipótese revelou-se apenas parcialmente verdadeira uma vez que somente alguns lotes disponíveis em coleções estavam identificados anteriormente como Astyanax. No entanto, a pequena quantidade de lotes de Astyanacinus disponíveis em coleções reflete uma tendência geral o que é causado provavelmente por três fatores:

As regiões mais a montante (de "cabeceira”), onde geralmente são encontrados os espécimes de Astyanacinus, são, de maneira geral, mal amostradas e menos conhecidas que as regiões mais baixas. Os resultados da expedição Trans-continental (com participação do MZUSP, MNRJ, MCP) denotam o quanto algumas áreas são subamostradas, principalmente em relação ao gênero em questão. Essa expedição foi responsável pela coleta do primeiro registro de Astyanacinus em Rondônia-BR (Bacia do Rio Madeira) e primeiro na Bacia do rio Purus, apresentado aqui como uma nova espécie.

Segundo Flávio C. T. Lima (comun. pessoal) os peixes do gênero Astyanacinus preferem águas límpidas, com alto teor de oxigenação e, aparentemente, tem baixa tolerância à impactos antrópicos como a destruição de matas ciliares. Assim, a ocorrência desses peixes torna-se restrita aos cursos d’água mais preservados. 
Dos lotes disponíveis em coleções ictiológicas, a esmagadora maioria deles são compostos por poucos espécimes, o que pode ser indício de que as espécies do gênero Astyanacinus ocorram em baixa densidade populacional. Outro indício é o trabalho de Winemiller (1990) em que uma dada região de Venezuela foi estudada e dentre as diversas espécies de peixes amostradas, somente 10 exemplares de “Astyanax” superbus foram coletados. Taphorn (2003) comenta que Astyanacinus superbus é uma espécie pouco comum, porém o autor faz a ressalva de que esta pode ser mais encontrada em regiões ainda pouco amostradas.

\subsection{HISTÓRICO DAS RELAÇÕES FILOGENÉTICAS}

O primeiro autor a comentar as relações de parentesco do gênero Astyanacinus foi Eigenmann (1927) (figura 49) que em um contexto pré-cladista comenta brevemente em dois trechos a proximidade de relações entre o gênero Astyanacinus e Astyanax como em "Closely allied to Astyanax" p.338 e "This genus grades into Astyanax" p.339. Quase um século se passou desde as inferências de Carl Eigenmann e muito pouco se foi feito para testar as relações envolvendo o gênero Astyanacinus. Até o presente momento quatro trabalhos propõem hipóteses filogenéticas baseadas em metodologia cladística utilizando alguma espécie de Astyanacinus como táxon terminal, porém todos a partir de caracteres moleculares.

O primeiro trabalho foi realizado por Calcagnotto et al. (2005) visando discutir as relações filogenéticas na ordem dos Characiformes com base em caracteres moleculares. Os autores propõem que Astyanacinus seria polifilético e parte de um clado parcialmente resolvido composto pelos gêneros Hemigrammus, Hyphessobrycon, Astyanax, Moenkhausia e Inpaichthys.

Também a partir de caracteres moleculares, o trabalho de Abe (2007) (figura 50) propõe que Astyanacinus seria grupo-irmão de Astyanax bimaculatus. Entretanto, faz-se necessário dizer que dos inúmeros táxons presentes na proposta, apenas Bryconops sp., Salminus hilarii, Salminus brasiliensis, Triportheus pantanensis, Triportheus orinocensis e as espécies de Gasteropelecidae foram seqüenciadas pela autora e todas as outras foram obtidas no GenBank, sendo que a maioria delas são do trabalho de Calcagnotto et al. (2005). Dessa forma, a proposta de Abe (2007) de que Astyanacinus 
sp. é grupo-irmão de Astyanax bimaculatus aparentemente repete o que foi proposto por Calcagnotto et al. (2005).

Novamente, a partir da utilização de caracteres moleculares Ornelas-Garcia (2008) fazem uma filogenia incluindo espécies de Astyanax e Bramocharax centroamericanos (figura 51). Um dos táxons terminais incluídos pelos autores no trabalho foi Astyanax orthodus, considerado aqui como um Astyanacinus. Como resultado os autores sugerem uma extensa polifilia de várias espécies de Astyanax, principalmente $A$. fasciatus, A. mexicanus, A. jordani, e do gênero Bramocharax. Astyanax orthodus é sugerido como grupo-irmão de um grande clado composto por diversas espécies de Astyanax e Bramocharax.

Em Javonillo et al. (2010) duas espécies de Astynacinus são incluídas na análise, mas os autores utilizaram a seqüência de genes de Calcagnotto et al. (2005) depositada do GenBank e geraram uma proposta diferente da mesma com relação ao monofiletismo do gênero. Segundo Calcagnotto et al. (2005) Astyanacinus seria polifilético enquanto que Javonillo et al. (2010) propõe que o grupo é monofilético. Com relação às afinidades evolutivas com os outros Characidae, ambos os trabalhos apresentam propostas parcialmente semelhantes em que Astyanacinus seria proximamente relacionado ao gênero Inpaichthys e a algumas espécies de Astyanax.

Apesar de indicar o gênero em sua topologia, a hipótese de Mirande (2007) (figura 52) não é primeiro trabalho filogenético utilizando a metodologia cladística e a morfologia como fonte de caracteres que teve uma espécie do gênero Astyanacinus como terminal. Em seu resumo de congresso Mirande (2007) propõe que “Astyanacinus" é grupo-irmão de Oligosarcus e este clado grupo irmão de Bramocharax. No entanto, no cladograma desse trabalho o autor representa Astyanacinus entre aspas e não explica a razão, tampouco apresenta a matriz de caracteres e as sinapomorfias que sustentam a topologia da proposta.

Em Mirande (2009) o autor publica o trabalho completo, porém o táxon que apresenta a mesma posição filogenética de “Astyanacinus" na topologia de Mirande (2007) é denominado "Characidae N. Gen. N. sp.” (CI-FML 3850). Dessa forma, concluo que autor posteriormente mudou de idéia com relação à identificação do espécime e concluiu que tratava-se de um gênero ainda não descrito e não de um Astyanacinus. Reforço essa hipótese na observação de que o lote CI-FML 3850 é proveniente da Argentina, ou seja, uma localidade biogeograficamente improvável para Astyanacinus. 
Em Mirande (2010) um dos poucos gêneros que o autor não incluiu em sua análise foi Astyanacinus. Apesar disso o mesmo tece pertinentes comentários sobre a posição filogenética do grupo, especulando que este poderia estar relacionado à Astyanax bimaculatus-group com base na posse de mancha umeral redonda, circulli na porção posterior da escama e cromatóforos concentrados focus da escama ou ao clado Hyphessobrycon luetkenii com base no compartilhamento de coloração com “chevrons” laterais no corpo.

\subsection{OBJETIVOS}

Os objetivos do presente trabalho são: testar o monofiletismo do gênero com base na metodologia cladística e partir disso redefinir o mesmo. Fazer a revisão taxonômica do gênero Astyanacinus redescrevendo de forma padronizada de todas as espécies do gênero e sumarizando todo o conhecimento publicado sobre o grupo. Propor uma hipótese sobre as relações intra-específicas do grupo e estudar as relações de Astyanacinus com os outros membros de Characidae. 


\section{Materiais e Métodos}

Thomas H. Huxley

O presente trabalho foi desenvolvido, em sua maior parte, nas instalações do Laboratório de Ictiologia de Ribeirão Preto da USP (LIRP) que forneceu toda a infraestrutura necessária para a realização deste. A fim de alcançar os objetivos propostos foi empregada uma série de metodologias que são descritas a seguir.

\subsection{ANÁLISE FILOGENÉTICA}

Para a formulação de hipóteses sobre as relações de parentesco das espécies de Astyanacinus entre si e com os outros Characidae, foram utilizadas como fontes de caracteres a morfologia externa dos peixes e a estrutura osteológica destes. A preparação osteológica dos exemplares foi através do método de diafanização de Taylor \& Van Dyke (1985) com modificações. Os exemplares foram dissecados de acordo com a técnica proposta por Weitzman (1974) visando à possibilidade de observação das articulações e complexos ósseos sem serem danificados ou desestruturados (exceto sínfise do dentário). As ilustrações dos caracteres osteológicos de relevância para a análise filogenética foram feitas a partir de material diafanizado na forma de fotomicrografias a partir de uma câmera digital Leica DFC420 acoplada ao estereomicroscópio Leica MZ16. A terminologia osteológica empregada foi a proposta por Weitzman (1962) com modificações de Castro \& Vari (2004) e tradução em língua portuguesa de Castro \& Castro (1987) ainda sem alterações para as novas normas para a língua portuguesa. Os exemplares diafanizados examinados estavam conservados em glicerina $90 \%$.

A metodologia utilizada para obtenção das hipóteses filogenéticas do gênero em questão foi a cladística, pioneiramente proposta por Hennig (1950; 1966) desenvolvida e aprimorada por diversos autores como Wiley (1981), Nelson \& Platnick (1981), Forey et al. (1992), Amorim (1997), Kitching et al. (1998), entre outros. Os cladogramas mais 
parcimoniosos sobre as relações de parentesco dos peixes em questão foram obtidos através da utilização do programa computacionl TNT (Goloboff et al., 2003).

A polaridade dos caracteres examinados não foi determinada a priori sendo que esta é decorrente do grupo-externo escolhido para enraizamento da análise, seguindo assim a proposta de comparação com grupo-externo de Nixon \& Carpenter (1993). A análise foi enraizada em Chalceus, um alestídeo (segundo Zanata \& Vari, 2005), o que garante que o táxon escolhido possui posição filogenética mais plesiomórfica do que todos os outros Characidae incluídos na análise.

A otimização dos estados de caracteres utilizada foi de ACCTRAN (Accelerated Transformation optimization) (Swofford \& Maddison, 1987), que privilegia a explicação das homoplasias por reversões em detrimento das por paralelismo em casos em que ambas as possibilidades são igualmente parcimoniosas e assim preserva as hipóteses de homologia primária (de Pinna, 1991).

Ainda sobre os caracteres, na grande maioria, estes foram considerados como não-ordenados (maximamente conectados), exceto aqueles ordenados (minimamente conectados). Estados que não puderam ser determinados com exatidão foram codificados como “?” enquanto que nos casos em que os estados eram inaplicáveis, estes foram codificados como “_“. Essa distinção é meramente didática, uma vez que o programa computacional utilizado interpreta ambos caracteres (símbolos como “?” e ““) como “missing entries”.

Face à grande quantidade de terminais presentes, a busca exata (exaustiva) não foi possível já que esta se torna impraticável à medida que muitos táxons são incluídos na análise, resultado do impraticável número de combinações possíveis. Desta forma, foi necessária a utilização da busca heurística. A fim de evitar as "ilhas de árvores" sensu (Maddison, 1991) foram feitas 100.000 réplicas e cada uma destas sofreu rearranjo de ramos pelo algoritmo TBR (Tree-Bisection Reconection) para que novas combinações possíveis parcimoniosas fossem encontradas. Para aferimento de suporte de cada um dos ramos encontrados foi utilizado o índice de Bremer (Bremer, 1994) feito no programa TNT. Esse índice avalia quantos passos adicionais são necessários para colapsar cada um dos ramos da topologia. O cálculo dos índices de consistência (ic) e de retenção (ir) foi feito com programa TNT.

A matriz de caracteres utilizada como base para obtenção das topologias foi construída e editada através do programa Mesquite - A Modular System for 
Evolutionary Analysis (Maddison \& Maddison, 2005). Os caracteres usados na construção da matriz foram, em sua maior parte, propostos previamente em uma série de dezenas de artigos, dissertações e teses que versam sobre os Characiformes (e.g. Fink \& Fink (1981); Lucena (1993); Vari (1995); Fink \& Fink (1998); Buckup (1998); Zanata (2000); Malabarba \& Weitzman (2003); Moreira (2002); Bertaco (2003); Benine (2004); Zanata \& Vari (2005); Quevedo (2006); Netto-Ferreira (2006); Ferreira (2007); Moreira (2007); Bertaco (2008) e Mirande (2009; 2010). Muitos desses caracteres, entretanto, foram reinterpretados e, outros, são originalmente propostos aqui.

Além de todas as espécies de Astyanacinus, foram inseridos na análise filogenética uma série de outros táxons terminais da família Characidae objetivando-se testar o monofiletismo do gênero bem como estudar as relações deste com outros caracídeos. Os táxons que foram utilizados na análise e as razões pelas quais foram incluídos seguem abaixo:

Astyanacinus sp. nova Bolívia, Astyanacinus sp. nova Peru, Astyanacinus moorii, Astyanacinus multidens, “Astyanax” orthodus, “Astyanax” superbus

Espécies do gênero foco do presente trabalho.

Astyanax altiparanax, Astyanax fasciatus, Astyanax lineatus, Astyanax paranae

As afinidades de parentesco entre Astyanacinus e Astyanax já foram previamente sugeridas por Carl Eigemann. Somada a semelhança morfológica evidente entre os táxons e o compartilhamento de diversas características anatômicas, a inclusão de várias espécies de Astyanax faz-se necessária.

Ctenobrycon hauxwellianus, Deuterodon iguape, Gymnocorymbus ternertzi, Hyphessobrycon eques, Jupiaba anteroides, Nematocharax venustus, Oligosarcus pintoi

Caracídeos incertae sedis de corpo relativamente alto cujas afinidades são controversas e podem estar relacionados com Astyanacinus.

Agoniates anchovia, A. halecinus, Brycon pesu, Bryconops alburnoides, Clupeacharax anchoveoides, Engraulisoma taeniatum, Lignobrycon myersi, Salminus hilarii, Thoracocharax stellatus, Triportheus albus 
Caracídeos basais segundo diversos autores.

\section{Aphyocharax pusillus}

Escolhido para representar a subfamília Aphyocharacinae.

\section{Chalceus epakros}

Segundo Zanata \& Vari (2005) o gênero Chalceus pertence à família Alestidae (tipicamente africana) e é próxima aos Characidae. Dessa forma esse táxon foi o escolhido para o enraizamento da análise de parcimônia.

\section{Charax leticiae e Galeocharax knerii}

Escolhidos para representar a subfamília Characinae.

\section{Cheirodon cf. galusdae}

Escolhido para representar a subfamília Cheirodontinae.

\section{Bryconamericus exodon, Creagrutus menezesi, Knodus moenkhausii, Piabina argentea}

Gêneros escolhidos a fim de representar o clado A (sensu Malabarba \& Weitzman, 2003).

\section{Hollandichthys multifasciatus}

Segundo Mirande (2007) faz parte de um clado formado por Bramocharax, Astyanacinus, Oligosarcus, Pseudochalceus, Rhoadsia e Carlana.

\section{Mimagoniates microlepis}

Escolhido para representar a subfamília Glandulocaudinae.

\section{Moenkhausia xinguensis}

Espécie-tipo do gênero Moenkhausia que, segundo Calcagnotto (2005), é próxima filogeneticamente de Astyanacinus.

Stethaprion erythrops, Poptella paraguayensis 
Escolhidos para representar a subfamília Stethaprioninae.

\section{Markiana nigripinnis, Stichonodon insignis}

Gêneros monotípicos cujas relações de parentesco com os outros caracídeos são quase que totalmente desconhecidas.

\section{Tetragonopterus chalceus}

Escolhido para representar a subfamília Tetragonopterinae.

\section{Acestrorhynchus falcatus, Hydrolycus scomberoides}

Membros da família Characidae segundo Mirande (2010).

\subsection{MATERIAL DIAFANIZADO EXAMINADO}

Acestrorhynchus falcatus (Bloch, 1794)

LIRP 5115, 2 exemplares (128,6-135,2 mm CP), Brasil, Mato Grosso, Município de Aripuanã, Rio Aripuanã, Bacia do Rio Madeira, à montante do Salto de Dardanelos.

Agoniates anchovia Eigenmann, 1914

MZUSP 28023, 1 exemplar (104 mm CP), Brasil, Amazonas, Manaus, Arredores de Manaus, Rio Negro. 15-23.xi.1967.

Agoniates halecinus Müller \& Troschel, 1845

MZUSP 28022, 1 exemplar (127 mm CP) Brasil, Pará, Barreirinhas, Rio Tapajós, xi.1970.

MZUSP 34333, 1 exemplar (152, 1 mm CP) Brasil, Pará, Cuminá, Rio Trombetas, M. Goulding, x-xi.1983.

MZUSP 92807, 2 exemplares (106,3 mm CP) Brasil, Pará, M. Goulding, X-XI.1983.

Aphyocharax pusillus Günther, 1868

LIRP 4559, 2 exemplares (39,6-42,7 mm CP) Brasil, Amazonas, Município de Manaus, Paraná do Janauacá, entrada do Lago do Castanho. 
Astyanax altiparanae Garutti \& Britski, 2000

LIRP 6041, 2 exemplares (60,1-72,0 mm CP), Brasil, São Paulo, Pontal, Fazenda Bela Vista. 12.x.2007.

Astyanax fasciatus (Cuvier 1819)

LIRP 132, 3 exemplares (71,95-75,49 mm CP), Brasil, São Paulo, Município de Cajuru, Córrego Barro Branco, px. a desembocadura no Rio Pardo, Fz. Santa Carlota. B. Par. (S $21^{\circ} 16^{\prime} 00^{\prime \prime}$ W 47² $\left.21^{\prime} 00^{\prime \prime}\right)$.

Astyanax lineatus Perugia, 1891

LIRP 5574, 5 exemplares (59,1- 85,4 mm CP), Brasil, Mato Grosso do Sul, Bodoquena, Córrego Taquaruçu, sob ponte da vicinal MS-178, 22.viii.2004.

Brycon pesu Müller \& Troschel, 1845

LIRP 5962, 2 exemplares (73,3 e 82,9 mm CP), Venezuela, Caicara del Orinoco/Bolivar, Rio Orinoco.

Bryconamericus exodon Eigenmann, 1907

MZUSP 90275, 2 exemplares (38,9-39,2 mm CP), Brasil, Mato Grosso, Caceres, Rio Sepotuba (trecho inferior) (S 15²4'07" W 57³8'54").

Bryconops alburnoides Kner, 1858

LIRP 5116, 2 exemplares (94,0-99,8 mm CP), Brasil, Mato Grosso, Município de Aripuanã, Rio Aripuanã (bacia do Rio Madeira), a montante do Salto de Dardanelos.

Chalceus epakros Zanata \& Toledo-Piza, 2004

MZUSP 7054, 2 exemplares (93,6-95,6 mm CP), Brasil, Amazonas, Jutaí, Rio Canumã. (S 0259'00" W 6658'00").

Charax leticiae Lucena, 1987

LIRP 5998, 2 exemplares (52,1-50,4 mm CP), Brasil, Mato Grosso do Sul, Município de Coxim, Rio Taquari, pesqueiro Recanto (S $18^{\circ} 25^{\prime} 42,5^{\prime \prime}$ W $54^{\circ} 50^{\prime} 02^{\prime \prime}$ ) 
Cheirodon galusdae Eigenmann, 1928

LIRP 5968, 3 exemplares (38,7-45 mm CP), Chile, VII Region / Coronel, Estero (S $\left.36^{\circ} 57,977^{\prime} \mathrm{W} 73^{\circ} 08,494^{\prime}\right)$.

Clupeacharax anchoveoides Pearson, 1924

USNM 302225, 1 (57,3 mm CP), Peru, Departamento Madre de Dios, Provincia Manu, Rio Manu, Aprox. 3 horas a jusante de Romero.

Creagrutus menezesi Vari \& Harold, 2001

MZUSP 54093, 2 exemplares (65,2-71,6 mm CP), Brasil, Goiás, Minaçu, Rio Tocantizinho e afluentes, região da Serra da Mesa. S13³2'00"/W48¹3'00". Bacia do Rio Tocantins. Expedição MZUSP/MNRJ. 28.x-04.xi.1996.

Ctenobrycon hauxwellianus (Cope, 1870)

LIRP 5932, 2 exemplares (59,7-68,7 mm CP), Brasil, Acre, Município de Rio Branco, Igarapé São Francisco (956,271' S 6752,923”W).

Deuterodon iguape Eigenmann, 1907

LIRP 1049, 2 exemplares (83,2-86,5 mm CP), Brasil, São Paulo, Município de Ubatuba, Rio da Fazenda, Parque Estadual da Serra do Mar-Núcleo Picinguaba (23²2'0"S $\left.44^{\circ} 52^{\prime} 0 " \mathrm{~W}\right)$.

Engraulisoma taeniatum Castro, 1981

MZUSP 14705, 1 exemplar (42 mm CP), Brasil, Mato Grosso, Poconé, Rio Cuiabá, Viveiro de Pássaros. 15-16.IX.1977.

Galeocharax knerii (Steindachner, 1879)

LIRP 4081, 2 exemplares (95,2- 97,4 mm CP), Brasil, Minas Gerais, Represa de Furnas, Rio Grande.

Gymnocorymbus ternertzi (Boulenger, 1895) 
LIRP 5650, 2 exemplares (40,1-40,6 mm CP), Brasil, São Paulo, Município de Pirassununga, margem esquerda do rio Mogi-Guaçu, atrás do CEPTA, abaixo da cachoeira de Emas (2155'39"S 47²2'26"W).

Hollandichthys multifasciatus (Eigenmann \& Norris, 1900)

LIRP 5744, 2 exemplares (79,4-86,5 mm CP), Brasil, São Paulo, Município de São Sebastião, Ribeirão Guaecá, praia de Guecá.

Hydrolycus scomberoides (Cuvier, 1816)

LIRP 5943, 2 exemplares (125,5-139,4 mm CP), Brasil, Acre, Município de Rio Branco, Rio Acre $\left(10^{\circ} 03,320^{\prime} \mathrm{S} 67^{\circ} 51,450^{\prime} \mathrm{W}\right)$.

Hyphessobrycon eques (Steindachner, 1882)

LIRP 1835, 2 exemplares (29,6-30,9 mm CP), Brasil, São Paulo, Município de Teodoro Sampaio, Rio Paranapanema, próx. à foz do córrego São Carlos, P.E. Morro do Diabo (22³6' 45" S 52¹5' 19" W).

Jupiaba anteroides Géry, 1965

MZUSP 17929, 3 exemplares (63,6-74,4 mm CP), Brasil, Pará, Igarapé Caranandéua, Bacia do Rio Capim. Expedição Permanente á Amazônia 16.iix.1970.

Knodus moenkhausii (Eigenmann \& Kennedy, 1903)

LIRP 22732, 2 exemplares (38,6-39,5 mm CP), Brasil, São Paulo, Município de Nova Independência, Córrego Volta Grande, sub-bacia do Rio Aguapeí (218'20"S W $\left.51^{\circ} 24 ' 27^{\prime \prime}\right)$.

Lignobrycon myersii (Miranda Ribeiro, 1956)

LIRP 5956, 2 exemplares (102,8-104,8 mm CP), Brasil, Bahia, Município de Jequié, Prainha do Lomanto, Reservatório Barragem de Pedra, Rio de Contas.

Markiana nigripinnis (Perugia, 1891)

LIRP 5978, 2 exemplares (74,7-83,6 mm CP), Brasil, Mato Grosso do Sul, Município de Aquidauana, Rio Negro. (S 19³4'33,7" W 56¹4'49,5"). 
Mimagoniates microlepis (Steindachner, 1876)

LIRP 5942, 2 exemplares (44,3-53,5 mm CP), Brasil, São Paulo, Município de Bertioga (23ํำ $\left.57,769^{\prime} \mathrm{S} 46^{\circ} 10,625^{\prime} \mathrm{W}\right)$.

Moenkhausia xinguensis (Steindachner, 1882)

MZUSP 91690, 2 exemplares (59,8-64,6 mm CP), Brasil, Mato Grosso, Paranatinga, Rio Culuene, na futura área da PCH Paranatinga II (S 1349'00" W 53¹5'00").

Nematocharax venustus Weitzman, Menezes \& Britski, 1986

MZUSP 54797, 2 exemplares (39,0- 39,2 mm CP), Brasil, Bahia, Arataca, Rio Branco (afl. Rio Una) ma estrada BR-101, próximo à São João da Capelinha (S 15¹5'16" W $\left.39^{\circ} 27^{\prime} 07^{\prime \prime}\right)$.

Oligosarcus pintoi Campos, 1945

LIRP 300, 2 exemplares (75,2-77,9 mm CP), Brasil, São Paulo, Município de Ribeirão Preto, Campus da USP, lago Monte Alegre, Bacia do Rio Pardo.

Piabina argentea Reinhardt, 1867

LIRP 3544, 2 exemplares (74,9-79,4 mm CP), Brasil, Goiás, Município de Catalão, Ribeirão Buracão (ou Barracão), a jusante da ponte sobre o ribeirão, Bacia do Rio Paranaíba (1755'46"S 4741'1" W).

Poptella paraguayensis (Eigenmann, 1907)

LIRP 5940, 2 exemplares (38,2-39,8 mm CP), Brasil, Mato Grosso do Sul, Município de Corumbá, Rio Miranda (19³4,63' S 5701,123' W).

Rachoviscus graciliceps Weitzman \& Cruz, 1981

MZUSP 93252, 2 exemplares (26,0-26,8 mm CP), Brasil, Bahia, Canavieiras, Riacho na estrada para Santa Luzia, Canavieiras ( S 15³0'14" W 3907'08").

Salminus hilarii Valenciennes, 1850 
LIRP 369, 1 exemplares (99,0 mm CP), Brasil, São Paulo, Município de Luís Antonio, Lagoa do Diogo, Reserva Ecológica de Jataí.

Stethaprion erythrops Cope, 1870

LIRP 5967, 1 exemplares (48,4 mm CP), Brasil, Acre, Município de Manso Lima, Rio Japim. (S 07³4' 28,8" W 7255' 24,9").

Stichonodon insignis (Steindachner, 1876)

LIRP 4564, 2 exemplares (35,5-37,7 mm CP), Brasil, Amazonas, Município de Manaus, Paraná do Janauacá, entrada do Lago Castanho.

Tetragonopterus chalceus Spix \& Agassiz, 1829

LIRP 5944, 2 exemplares (86,6-71,7 mm CP), Brasil, Minas Gerais, Município de Três Marias, Represa de Três Marias (18¹3,661' S 45¹4,857' W)

Thoracocharax stellatus (Kner, 1858)

LIRP 715, 2 exemplares (40,9-44,4 mm CP), Brasil, Mato Grosso, Município de Barão de Melgaço, Rio Cuiabá, próximo ao Hotel Tuiuiu.

Triportheus albus (Günther, 1874)

LIRP 5935, 2 exemplares (69,2-75,5 mm CP), Brasil, Mato Grosso do Sul, Município de Corumbá, Rio Miranda (19³4,63' S 5701,123' W).

\subsection{TAXONOMIA}

A revisão taxonômica foi realizada com base no exame de caracteres morfométricos e merísticos obtidos a partir de exemplares, em sua maioria conservados em álcool, disponíveis em coleções ictiológicas de instituições brasileiras e estrangeiras. Uma das necessidades de se examinar o material depositado nessas coleções, incluindo material-tipo, advém da importância de se delimitar as áreas de distribuição geográfica das espécies e formular hipóteses sobre os nomes das espécies contidas no gênero Astyanacinus. O exame do material das coleções científicas deu-se através de visitas e/ou por meio de empréstimo do material. Os exemplares foram examinados por meio 
de medidas e contagens corporais seguindo basicamente as propostas por Fink \& Weitzman (1974) e que serão mais detalhadamente discutidas a seguir. No texto descritivo a freqüência de cada contagem é expressa entre parênteses e o asterisco representa a condição presente no holótipo. Os dados morfométricos foram tomados ponto a ponto através da utilização de paquímetro digital Mitutoyo com precisão de 0,01mm. Ao todo foram tomadas 22 medidas morfométricas (ver figura 48) e 14 contagens, foram elas:

\subsection{MORFOMETRIA}

Comprimento padrão (CP): medido do ponto extremo mais anterior do focinho até a base da nadadeira caudal (nas placas hipurais, antes da inserção dos raios caudais);

Altura do corpo: maior distância entre as extremidades dorsal e ventral do corpo;

Distância pré-dorsal: distância entre a extremidade anterior do focinho e a origem da nadadeira dorsal;

Distância pré-ventral: distância entre a extremidade anterior do focinho até a origem da nadadeira pélvica;

Focinho-peitoral: distância entre a extremidade anterior do focinho até a origem da nadadeira peitoral;

Focinho-anal: distância entre a extremidade anterior do focinho até a origem da nadadeira anal;

Pélvica-anal: distância entre a extremidade anterior da nadadeira pélvica até a origem da nadadeira anal;

Altura do pedúnculo caudal: menor distância entre as margens dorsal e ventral do pedúnculo;

Base da nadadeira dorsal: distância compreendida entre a inserção do primeiro e do último raio da nadadeira dorsal;

Base da nadadeira anal: distância compreendida entre a inserção do primeiro e do último raio da nadadeira anal;

Distância dorsal-caudal: distância entre a origem da nadadeira dorsal até a base da nadadeira caudal;

Maior raio da nadadeira peitoral: Comprimento do maior raio da nadadeira peitoral; Maior raio da nadadeira pélvica: Comprimento do maior raio da nadadeira pélvica; 
Maior raio da nadadeira dorsal: Comprimento do maior raio da nadadeira dorsal;

Maior raio da nadadeira anal: Comprimento do maior raio da nadadeira anal;

Comprimento da cabeça: medido da extremidade mais anterior do focinho até a porção óssea mais distal do opérculo;

Altura da cabeça: distância entre a porção dorsal da base do processo do osso occipital e o istmo (região entre as bordas inferiores das membranas branquiais);

Diâmetro da órbita ocular: distância entre as margens ósseas anterior e posterior da órbita;

Comprimento do focinho: distância entre a extremidade anterior do focinho e a extremidade anterior da órbita ocular;

Distância maxilar-pré-maxilar: distância entre a extremidade anterior do focinho até a extremidade posterior do osso maxilar;

Distância interorbital: menor distância entre as margens superiores das orbitas de ambos os lados do peixe.

Altura da cabeça: menor distância entre a extremidade posterior do espinho supraoccipital e a margem ventral da cabeça (região do istmo: entre os raios branquiostégios).

\subsection{MERÍSTICA}

Raios da nadadeira peitoral: número de raios (ramificados e não-ramificados) da nadadeira peitoral;

Raios da nadadeira pélvica: número de raios (ramificados e não-ramificados) da nadadeira pélvica;

Raios da nadadeira dorsal: número de raios (ramificados e não-ramificados) da nadadeira dorsal;

Raios da nadadeira anal: número de raios (ramificados e não-ramificados) da nadadeira anal. Os dois últimos raios da nadadeira anal são contados como se dois elementos apesar de estarem parcialmente separados (ray split to the base).

Escamas da linha lateral: número total de escamas perfuradas da escama da linha lateral, incluindo aquelas sobre a nadadeira caudal;

Escamas acima da linha lateral: séries longitudinais de escamas presentes entre a linha lateral até a nadadeira dorsal; 
Escamas abaixo da linha lateral: séries longitudinais de escamas presentes entre a linha lateral até a extremidade anterior da nadadeira anal;

Escamas do pedúnculo caudal: número de fileiras de escamas em torno do pedúnculo caudal;

Escamas pré-dorsais: escamas existentes entre a posterior ao processo supra-occipital até a origem da nadadeira dorsal;

Pré-maxilar na fileira externa: número de dentes da série externa do pré-maxilar (o pré-maxilar é um osso par e quando houver discrepância entre a quantidade de dentes presentes somente será apresentada a quantidade de dentes do lado que possuir o maior número);

Pré-maxilar na fileira interna: número de dentes da série interna do pré-maxilar (o pré-maxilar é um osso par e quando houver discrepância entre a quantidade de dentes presentes somente será apresentada a quantidade de dentes do lado que possuir o maior número);

Dentes do maxilar: número de dentes presentes no osso maxilar (o maxilar é um osso par e quando houver discrepância entre a quantidade de dentes presentes somente será apresentada a quantidade de dentes do lado que possuir o maior número);

Dentes do dentário: número de dentes presentes no osso dentário (o dentário é um osso par e quando houver discrepância entre a quantidade de dentes presentes somente será apresentada a quantidade de dentes do osso que possuir o maior número);

Vértebras: número total de vértebras dos indivíduos radiografados ou diafanizados. Todas as vértebras anteriores que formam o Complexo de Weber foram contadas como quatro elementos distintos enquanto que o PU + U1 do complexo caudal foi assumido como sendo apenas um elemento.

Tanto os dados morfométricos quanto os merísticos das espécies são apresentados sob a forma de tabelas. O comprimento padrão (medida A) é expresso em milímetros enquanto as medidas de $\mathrm{B}$ até $\mathrm{Q}$ são expressas em porcentagens obtidas em relação ao comprimento padrão, exceto diâmetro da órbita ocular (medida E), comprimento do focinho (medida F) e distância interorbital (medida G) que são expressas em relação ao comprimento da cabeça.

Os lotes examinados são listados no capítulo "Revisão Taxonômica”. As seguintes abreviações foram utilizadas: ex.: número total de exemplares do lote; mc.: indivíduos 
que foram medidos e contados; Col.: coletores. As datas apresentadas sempre seguem a formatação usualmente apresentada no Brasil na ordem DIA/MÊS/ANO.

As siglas das instituições citadas no texto seguem abaixo:

BMNH (=NHM)- Natural History Museum, London, Reino Unido.

CAS - California Academy of Sciences, San Francisco, California, EUA.

IAVHP - Instituto de Investigación de Recursos Biológicos Alexander von Humboldt, Colleción de Pecas, Villa de Leyva, Bogotá, Colombia.

LIRP - Laboratório de Ictiologia de Ribeirão Preto - Faculdade de Filosofia, Ciências e Letras de Ribeirão Preto, Universidade de São Paulo, São Paulo, Brasil.

MCP - Pontifícia Universidade Católica do Rio Grande do Sul, Museu de Ciências e Tecnologia, Rio Grande do Sul, Porto Alegre, Brasil.

MHNM - Museo Nacional de Historia Natural y Antropología, Zoologia, Seccion Ictiología, Ministerio de Educación y Cultura, Montevideo, Uruguai.

MNRJ - Museu Nacional, Departamento de Vertebrados, Setor de Ictiología, Universidade Federal do Rio de Janeiro, Rio de Janeiro, Brasil.

MUSM - Museo de Historia Natural de la Universidad Nacional Mayor de San Marcos, Lima, Peru.

MZUSP - Universidade de São Paulo, Museu de Zoologia, São Paulo, Brasil.

STRI - Smithsonian Tropical Research Institute, Balboa, Ancón, Panama.

UFRGS (=DZUFRGS) - Departamento de Zoologia, Instituto de Biociências, Universidade Federal do Rio Grande do Sul, Porto Alegre, Brasil.

USNM - Smithsonian Institution National Museum of Natural History, Department of Vertebrate Zioology, Division of Fishes, Washington D.C., EUA.

No presente trabalho são consideradas como vértebras pré-caudais todas as quatro mais anteriores que formam o aparelho de Weber e as seguintes que apresentam costelas verdadeiras. As vértebras de transição são vértebras apresentam processos ventrais bem desenvolvidos, mas que ainda não formam o arco hemal completamente nem possui o espinho hemal e que, por vezes, podem estar associados com projeções bem finas ou "falsas costelas". Vértebras caudais são todas aquelas que apresentam arco hemal completamente formado. O centro composto da última vértebra (pré-ural $1+$ ural 
1) é contado como apenas um elemento. Vértebras e supraneurais são contadas em peixes diafanizados ou em radiografias.

Os dois últimos raios da nadadeira anal, apesar de serem sustentados pelo mesmo pterigióforos e serem considerados por alguns autores como sendo um raio ramificado em sua base, são contados como dois elementos distintos.

A forma de apresentação dos resultados dar-se-á da seguinte forma: a hipótese das relações de parentesco intra-genérica de Astyanacinus e com os demais Characidae incluídos na análise será apresentada em forma de um cladograma; a partir da revisão taxonômica será criada uma chave de identificação das espécies do gênero em questão, será feita uma descrição de todos os táxons válidos do gênero, uma lista será criada contendo as sinonímias reconhecidas e serão apresentados mapas de distribuição de todas as espécies do gênero. 


\section{Resultados e Conclusões}

Neste capítulo são apresentados todos os resultados gerados a partir do presente trabalho. Alguns desses como os itens "Piscivoria em Characidae" e "Monofilia da subfamília Agoniatinae”, apesar de estarem além do escopo do trabalho, são frutos diretos da análise de diversos terminais examinados aqui.

\subsection{REVISÃO TAXONÔMICA}

\section{Astyanacinus Eigenmann, 1907}

Eigenmann (1907) pág. 769 (descrição original e ilustração), Eigenmann (1910) pág. 435 (citação e distribuição), Eigenmann (1927) pág. 338 e 339 (descrição e distribuição), Jordan (1920) pág. 522 (grafia errada como Astyacinus), Neave (1939) pág. 337 (grafia errada como Astycinus), Messner (1962) pág. 5 (espécies de Astyanacinus e a distribuição das espécies), Géry (1972) pág. 52 (citação), Géry (1977) pág. 414 e 415 (chave de identificação, ilustração e breve descrição), Eschmeyer (1998c) pág. 1851 (citação), Britski et al. (1999) pág. 37 (breve descrição e chave de identificação), Schaefer (2000) (ocorrência na Bolívia), Lima et al. (2003) em Reis et al. (2003) pág. 106 (localidade-tipo, material-tipo, distribuição), Malabarba \& Weitzman (2003) pág. 76 (presença de ganchos nas nadadeiras ainda não foi documentada para o gênero), Calcagnotto et al. (2005) pág. 139 e 145 (posição filogenética com caracteres moleculares), Abe (2007) pág. 56 (posição filogenética com caracteres moleculares), Britski et al. (2007) pág. 53 (breve descrição e chave de identificação), Mirande (2007) pág. 20 (posição filogenética: incorreto pois não é um Astyanacinus), Lima et al. (2007) em Buckup et al. (2007) pág. 44 (localidade-tipo e distribuição), Tedesco et al. (2007) pág. 8 (registro na Amazônia Boliviana, provavelmente Bacia do Alto-Rio Madeira), Bertaco et al. (2009) pág. 265-266 (reprodução da descrição de Eigenmann, composição e distribuição), Javonillo et al. (2010) pág. 505-507 (posição filogenética com caracteres moleculares), Mirande (2010) 
pág. 545 (especulações sobre a posição filogenética), Koerber \& Litz (2011) pág. 4 (transcrição do raro trabalho de Messner (1962)).

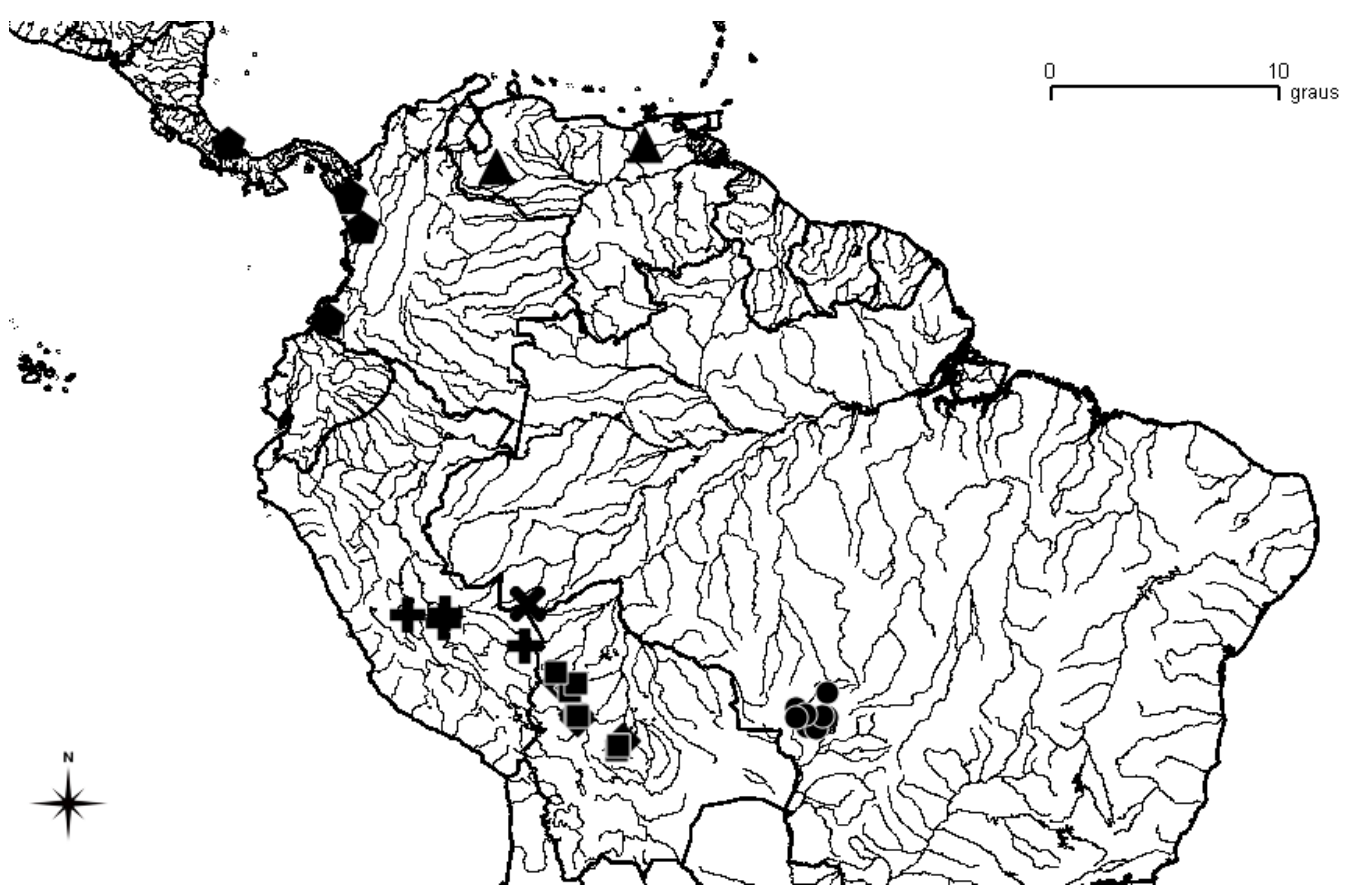

Figura 01. Distribuição geográfica do gênero Astyanacinus. Pentágono= "A." orthodus; triângulo $=$ " $A$." superbus; cruz $=A$. sp. nova Peru ; quadrado $=A$. sp. nova Bolívia; losângulo $=A$. multidens; letra $\mathrm{x}=A$. sp. nova Purus e círculo $=A$. moorii. Cada símbolo pode representar mais de um lote examinado.

O gênero Astyanacinus é aqui redefinido com base na metodologia cladística (ver item “Monofilia e redefinição do gênero Astyanacinus”) e a partir disso são descritas três novas espécies para o gênero além da alocação de duas espécies já descritas para o gênero Astyanax (“A.” orthodus e “A.” superbus). Dessa forma, Astyanacinus passa a ser composto por sete espécies. 


\section{“Astyanax” orthodus Eigenmann, 1907}

Eigenmann em Eigenmann \& Ogle (1907) pag. 27 e 28 (descrição original), Eigenmann (1910) pág. 433 (citação e distribuição), Eigenmann (1921) pág. 260-262 e prancha 42(3) (descrição, distribuição, localicade-tipo, material-tipo, ilustração), Grey (1947) pág 122 e 193* (material-tipo, localidade-tipo), Dahl (1971) pág. 142, 145 e 146 (breve descrição, chave de identificação e ilustração), Géry (1977) pág. 430 (chave de identificação), Vari \& Howe (1991) pág. 7 (material-tipo, coletor e localidade-tipo), Eschmeyer, (1998b) pág. 1255 (localidade-tipo, material-tipo), Garutti (1999) pág. 590 (comentário sobre relações de parentesco com outros Astyanax), Lima et al. (2003) em Reis et al. (2003) pág. 112, Bussing (2002) pág. 86 e 87 (breve descrição, fotografia, distribuição, nome popular e ecologia), Smith \& Bermingham (2005) pág. 1839 (registro na província biogeográfica de Bocas, Am. Central), Maldonado-Ocampo et al. (2006) pág. 146 (registro na Bacia do Rio Atrato), Maldonado-Ocampo et al. (2008) pág. 161 (registro em Bacias de Rios costeiros do Pacífico e vertente Caribenha na Colômbia), Ornelas-Garcia et al. (2008) pág. 5, 8, 10 e 13 (posição filogenética).

*Parátipos não mais citados desde então.

\section{Material-tipo}

USNM 55655 (1 ex; 90,2mm CP); Colombia, Truando. Col. Michler \& Schott.

\section{Diagnose}

Distingui-se de seus congêneres pelo autapomórfico padrão de colorido no pedúnculo caudal composto por uma mancha curta e alta (figura 54), pelo corpo mais alto 39,344,4\% no CP (vs. 29,1-40,7\%) e pela distância pré-dorsal 49,2-55\% no CP (vs. 46,352,8\%). Diferencia-se de todas as demais espécies (exceto A. sp. nova Peru ) por apresentar uma maxila superior ligeiramente mais curta 43,7-51,2\% no CC (vs. 45,954,7\%). Diferencia-se de Astyanacinus moorii, “Astyanax” superbus, Astyanacinus sp. nova Bolívia, A. sp. nova Peru por apresentar 5 ou 6 supraneurais (vs. 4 ou 5), porção postero-ventral do coracóide sem projeção (vs. presença) e canal sensorial do extraescapular com três ramos (quatro ramos). De A. multidens e A. sp. nova Peru pela origem da nadadeira anal ser anterior à vertical que passa pelo término da base da 
nadadeira dorsal (vs. posterior à vertical que passa pelo término da base da nadadeira dorsal).

Adicionalmente, é distinguida de A. multidens por menos dentes na maxila 1-4 (vs. 9-13), menos escamas pré-dorsais 11-13 (vs. 14-16), menos escamas circumpedunculares 17-18 (vs. 19-21), menos escamas na linha lateral 36-40 (vs. 3942), mais raios na nadadeira anal iii+26-31 (vs. iii+22-26), maior comprimento da cabeça 26,1-30,6\% no CP (vs. 22,4-26\%), menor diâmetro do olho 27,3-37,7\% no CC (vs. 20-29,7\%), maior raio da dorsal 23,1-32,2\% no CP (vs. 21,5-25,7\%), maior raio da peitoral 20,3-24,7\% no CP (vs. 18-20,5\%), maior base da nadadeira anal 30,7-37,9\% no CP (vs. 25-29,1\%); de “A.” superbus por menos dentes na maxila 1-4 (vs. 5-7) e ausência do padrão de colorido de faixas em zig-zag longitudinais ao corpo (vs. presença do padrão); de $\boldsymbol{A}$. sp. nova Peru pela maior distância focinho-peitoral 61,569,7\% no CP (vs. 63,3-64-4\%) e pela ausência de uma faixa prateada na lateral do corpo exatamente sobre os chevrons (vs. presença da faixa); de A. sp. nova Purus pela presença de chevrons pelo menos até a origem da nadadeira adiposa (vs. chevrons somente até o meio do corpo, não alcançando a adiposa) e maior raio da peitoral 20,324,7\% no CP (vs. 19-20,3\%); de A. sp. nova Bolívia pela ausência de ganchos nas nadadeiras anal e pélvica dos machos maduros (vs. presença de ganchos) e de A. moorii pela maior altura do corpo 36,8-44,4\% no CP (vs. 30,8-38,4\%) e por apresentar, em sua maioria, exemplares com 3-4 dentes (vs. 2-3).

\section{Descrição}

Dados merísticos e morfométricos dos exemplares examinados dessa espécie estão reunidos na tabela 01 e gráficos 01-03. O maior exemplar examinado possuia comprimento padrão de 103,5 mm enquanto que o menor tinha $42 \mathrm{~mm}$. Tem o corpo bem mais alto que as demais espécies do gênero, com a maior altura do corpo próxima à região da origem da nadadeira dorsal variando entre 36,8-44,4\% do comprimento padrão. Nadadeira peitoral alcança a base nadadeira pélvica. Nadadeira pélvica quase alcança a nadadeira anal. Perfil dorsal da cabeça (da ponta do focinho até a porção posterior do espinho supraoccipital) é côncavo, do espinho supraoccipital até a origem da nadadeira dorsal é levemente côncavo. Comparativamente com seus congêneres possui cabeça grande com comprimento que varia de $24,4-31 \%$ do comprimento padrão e altura de 98,5-118,6\% no CC. O diâmetro da órbita é relativamente grande e varia 
conforme o tamanho dos indivíduos, com menores exemplares apresentando um tamanho proporcionalmente maior em relação ao comprimento da cabeça. Em relação aos seus congêneres possui uma maxila superior mais curta variando de 43,7-51,2\% no comprimento da cabeça. A extremidade posterior do osso maxilar não alcança a vertical que passa no contato dorsal entre os infraorbitais 2 e 3, aproximadamente no centro da órbita. Margem ventral do infraorbital 1 sobrepondo a margem dorsal da maxila. Duas séries de dentes no osso pré-maxilar: a mais externa com cada lado apresentando 4(22), 5(8) ou 6(1) dentes tricuspidados e a série interna com 4(1) ou 5(29) dentes pentacuspidados. Osso maxilar com 1(1), 2(6), 3(26) ou 4(10) pequenos dentes tricuspidados. Dentário com sempre 4 dentes mais desenvolvidos e anteriores seguidos de numerosos pequenos dentículos. Nadadeira dorsal com ii+9 raios (25). A origem da nadadeira dorsal é um pouco posterior à vertical que passa pela origem da nadadeira pélvica. Nadadeira adiposa pequena com base anterior à vertical que passa pela inserção do último raio da nadadeira anal. Nadadeira peitoral com i+12(21) ou i+13(10). Nadadeira pélvica com i+7(25). Nadadeira anal com três raios não ramificados anteriores seguidos de 26(3), 27(4), 28(8), 29(11), 30(5) e 31(4) raios ramificados. Vertical que passa pela origem da nadadeira anal passando em algum ponto da base da nadadeira dorsal. Linha lateral completa com 36(4), 37(12), 38(9), 39(3) ou 40(3) escamas perfuradas. 7(27), 8(5) ou (6) séries longitudinais de escamas entre a nadadeira dorsal e a linha lateral; 7(10), 8(26) ou 9(1) séries longitudinais de escamas entre a nadadeira anal e a linha lateral. Onze (12), 12(20) ou 13(4) escamas pré-dorsais em uma série irregular e 17(9) ou 18(19) escamas ao redor do pedúnculo caudal. Apenas uma série de escamas recobrindo a base da maioria (mais da metade) dos raios da nadadeira anal. Primeiro arco branquial com 12+1+9-10 rastros. Total de 37(1)*-38(1) vértebras sendo 16(2)* pré-caudais, 2(2)* de transição e 19(1)*-20(1) caudais. Há 5(1)*-6(1) supraneurais e a nadadeira dorsal está inserida após a nona vértebra (2).

\section{Coloração em álcool}

Mancha umeral oval bem definida e distintamente mais alta de que seus congêneres ocupando área de aproximadamente 4 escamas em seu comprimento e 3 escamas em sua altura. A mancha está localizada logo acima da linha lateral ocupando a porção mais dorsal da escama que a compõem. Logo após, há uma faixa vertical com poucos cromatóforos marrons dando a impressão dá área ser despigmentada. Posterior à essa 
área existe uma segunda mancha verticalmente alongada, porém bastante difusa e fraca. Presença de estrias lateralmente dispostas no corpo formado por bandas escuras em forma de "V" deitados com seus vértices anteriormente direcionados. Nos exemplares de menor porte as bandas escuras em "V" são simples, enquanto que nos exemplares maiores as bandas são mais intrincadas e com ramificações. Quantidade variável de estrias (cerca de 12 a 16) que começam um pouco antes da manha umeral, logo atrás do opérculo, e se estendem até próximo ao pedúnculo caudal, aproximadamente na vertical que passa pela origem da nadadeira adiposa. Há uma mancha escura bastante nítida ocupando grande área da segunda metade do pedúnculo caudal. Esta mancha é tão alta quanto alongada e tem seu limite anterior nunca atingindo a vertical que passa pela inserção do último raio da nadadeira anal. A mancha prolonga-se mais difusa e muito mais afilada atingindo a região mais posterior dos raios medianos da nadadeira caudal. Corpo com coloração alaranjada ou marrom pálida. Em alguns exemplares examinados há deposito de guanina principalmente na porção ventral do corpo, abaixo da linha lateral. Corpo com muitos cromatóforos amarronzados com concentração com maiores concentrações na região dorsal. Escamas com muitos cromatóforos e com maior concentração na região periférica da escama. Nadadeiras com coloração amarelo pálido. Nadadeira adiposa com muitos cromatóforos marrons dispersos homogeneamente. Nadadeira dorsal com muitos cromatóforos marrons nas membranas inter-radiais e poucos nos raios. Peitoral e pélvica com poucos cromatóforos nos raios. Nadadeira anal repleta de cromatóforos marrons nas membranas inter-radiais e pouco sobre eles.

\section{Dimorfismo sexual}

Aparentemente a nadadeira pélvica dos machos é mais longa do que a das fêmeas, principalmente o raio mais lateral. É necessário o exame de mais lotes para confirmar o padrão que é bastante sutil.

\section{Notas sobre a espécie}

O material tipo foi coletado por Michller e Schott. Em relação aos seus congêneres “A." orthodus possui uma maxila superior mais curta variando de 43,751,2\%, porém distintamente maior que espécies do gênero Astyanax que raramente alcançam mais de $41 \%$ no comprimento da cabeça (observação pessoal) e geralmente em adultos grandes. Eigenmann (1917-1929) alerta para o grande comprimento do 
maxilar da espécie e comenta que "Astyanax" orthodus diferencia-se de exemplares de mesmo porte de Astyanax bimaculatus por apresentar um maxilar distintamente longo.

O exame de um lote proveniente do Panamá de “A.” orthodus indica que os exemplares Centro-americanos pelo menos uma escama a mais acima da linha lateral, possuem comparativamente o corpo mais alto e diâmetro orbital menor, indícios de que podem ser espécies distintas. Como a espécie tem ampla distribuição na América Central e somente 6 exemplares foram examinados é necessário que mais exemplares de diferentes localidades sejam examinados antes de que atitudes taxonômicas sejam tomadas.

Foram examinados os conteúdos estomacais de espécimes do lote CAS 68769 provenientes do Panamá e, de forma surpreendente, ao contrário do encontrado em outras espécies de Astyanacinus, foi encontrado pequenos caracídeos no estômago dos exemplares. Esse é o primeiro registro de piscivoria para o gênero, mas segundo Castro (comun. pessoal) em coletas com rotenona é comum que caracídeos de menor porte sejam os primeiros afetados pela toxina, se tornando presas fáceis para peixes maiores e a presença de peixes nos estômagos de “"Astyanax” orthodus” seria muito mais um artefato do método de coleta empregado do que um hábito comum para a espécie.

\section{Etimologia}

O epíteto “orthodus" é uma referência a disposição dos dentes da série interna do prémaxilar da espécie que, segundo Carl Eigenmann, são arranjados de forma quase reta.

\section{Distribuição geográfica}

Bacias do rio Atrato e San Juan, Colômbia. É também amplamente reportado para a América Central em rios da Costa Rica e Panamá. 


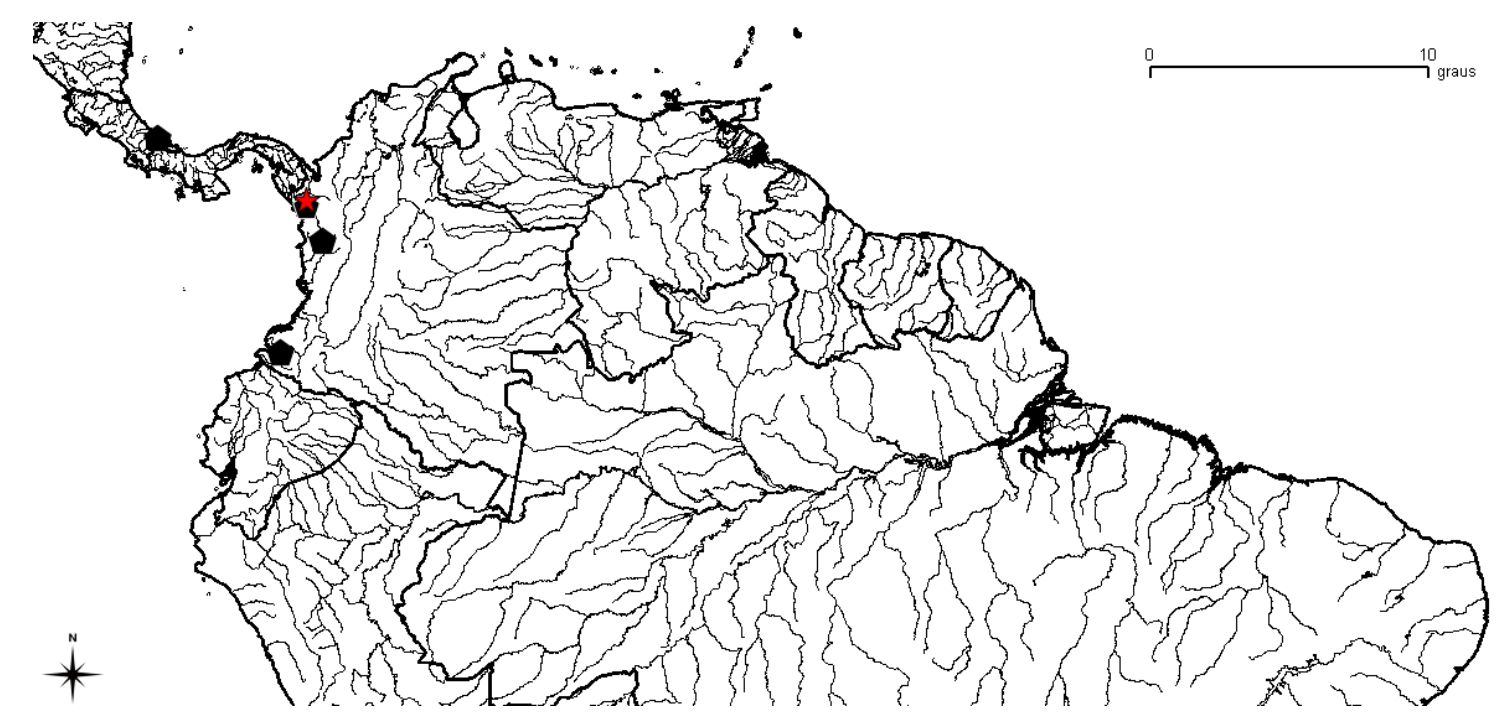

Figura 02. Mapa da distribuição geográfica de “A.” orthodus. Estrela indica a localidade-tipo.

\section{Material examinado}

\section{Colômbia}

SU 22739 (6 ex., 6 mc, 55,2-79,44 mm CP); Rio Truando. Col. C. H. Eigenmann. CAS 68770 (3 ex., 3 mc, 51,8-102,4 mm CP); Narino Dept, Drenagem do Patia. Riacho Altacar, um tributário do rio Telembi em Barbacoas. Col. C. H. Wilson, Landon-Fisher Exp. 1912. CAS 68771 (1 ex., 1 mc, 66,08 mm CP); Choco Dept, Drenagem do Atrato. Quibdo, na junção dos Rios Quito e Atrato. Col. C. H. Eigenmann. 1912. CAS 68772 (36 ex., 8 mc, 42-103,5 mm CP); Rio Truando, Drenagem do Atrato. Rio Truando, um tributário à oeste que deságua no Rio Atrato perto do Rio Sucio. Col Henn \& C. H. Wilson, Landon-Fisher Exp. 1913. CAS 70975 (83 ex., 11 mc, 47,4-70,1 mm CP); Choco Dept, Drenagem do Atrato. Rio Truando, um tributário a oeste que deságua no Rio Atrato próximo do Rio Sucio. Col. C. H. Wilson. Landon-Fisher Exp 1913.

\section{Panamá}

CAS 68769 (6 ex., 6 mc, 60,1-92,2 mm CP; 1 C\&S); Drenagem do San-San. Riacho de um tributário do Rio San-San abaixo da ponte de ferro. Col. Behre \& Chambers. 6/2/1923. 
Tabela 01. Dados merísticos e morfométricos de “A.” orthodus

\begin{tabular}{|c|c|c|c|c|c|c|c|}
\hline \multicolumn{6}{|c|}{ Astyanacinus orthodus (Drenagem Atrato e Patia) } & \multicolumn{2}{|c|}{$\begin{array}{c}\text { (Drenagem } \\
\text { San-San) }\end{array}$} \\
\hline & $\mathrm{n}$ & Mínimo & Máximo & Média & Desv. Pad. & $n$ & Média \\
\hline Comprimento Padrão & 29 & 42,03 & 103,49 & 64,54 & & 6 & 60,1 \\
\hline Altura do corpo & 29 & 36,82 & 43,68 & 41,30 & 1,56 & 6 & 39,6 \\
\hline Distância pré-dorsal & 29 & 49,22 & 55,04 & 52,94 & 1,36 & 6 & 53,3 \\
\hline Distância pré-ventral & 29 & 45,72 & 50,74 & 47,47 & 1,17 & 6 & 45,7 \\
\hline Focinho-peitoral & 29 & 26,96 & 31,38 & 28,41 & 1,11 & 6 & 28,5 \\
\hline Focinho-anal & 29 & 61,45 & 69,71 & 65,05 & 2,01 & 6 & 62,9 \\
\hline Pélvica-anal & 29 & 16,25 & 23,44 & 19,21 & 1,70 & 6 & 15,4 \\
\hline Altura do pedúnculo caudal & 29 & 11,23 & 13,65 & 12,34 & 0,57 & 6 & 11,0 \\
\hline Base da nadadeira dorsal & 29 & 12,50 & 15,68 & 14,22 & 0,76 & 6 & 13,1 \\
\hline Base da nadadeira anal & 29 & 30,67 & 37,49 & 33,44 & 1,42 & 6 & 33,2 \\
\hline Distância dorsal-caudal & 29 & 51,94 & 57,23 & 54,37 & 1,24 & 6 & 51,1 \\
\hline Maior raio da nadadeira peitoral & 29 & 21,31 & 24,72 & 22,89 & 0,94 & 6 & 20,3 \\
\hline Maior raio da nadadeira pélvica & 29 & 15,50 & 18,85 & 17,44 & 0,82 & 6 & 14,3 \\
\hline Maior raio da nadadeira dorsal & 29 & 23,10 & 32,24 & 28,38 & 2,36 & 6 & 21,8 \\
\hline Maior raio da nadadeira anal & 29 & 16,17 & 27,38 & 19,49 & 2,57 & 6 & 11,7 \\
\hline Comprimento da cabeça & 29 & 26,08 & 30,57 & 27,82 & 1,25 & 6 & 27,7 \\
\hline Comprimento do focinho & 29 & 24,41 & 30,99 & 26,88 & 1,81 & 6 & 25,1 \\
\hline Diâmetro da órbita ocular & 29 & 27,75 & 37,30 & 33,25 & 2,22 & 6 & 25,5 \\
\hline Distância maxilar-pré-maxilar & 29 & 43,68 & 51,24 & 46,61 & 1,75 & 6 & 48,0 \\
\hline Distância interorbital & 29 & 31,78 & 41,20 & 36,34 & 2,07 & 6 & 33,4 \\
\hline \multirow[t]{2}{*}{ Altura da cabeça } & 29 & 98,46 & 118,65 & 107,46 & 5,29 & 6 & 106,2 \\
\hline & $\mathrm{n}$ & Mínimo & Máximo & & Moda & $n$ & Moda \\
\hline Raios da nadadeira peitoral & 25 & $\mathrm{i}+12$ & $\mathrm{i}+13$ & & $i+12$ & 6 & $\mathrm{i}+12$ \\
\hline Raios da nadadeira pélvica & 19 & $\mathrm{i}+7$ & $\mathrm{i}+7$ & & $\mathrm{i}+7$ & 6 & $\mathrm{i}+7$ \\
\hline Raios da nadadeira dorsal & 19 & $\mathrm{ii}+9$ & $\mathrm{ii}+9$ & & $\mathrm{ii}+9$ & 6 & $\mathrm{ii}+9$ \\
\hline Raios da nadadeira anal & 28 & $\mathrm{iii}+27$ & $\mathrm{iii}+31$ & & $\mathrm{iii}+27$ & 6 & 32 \\
\hline Escamas da linha lateral & 28 & 36 & 40 & & 37 & 3 & $37-38-39$ \\
\hline Escamas acima da linha lateral & 32 & 7 & 8 & & 7 & 6 & 9 \\
\hline Escamas abaixo da linha lateral & 31 & 7 & 8 & & 8 & 6 & 8 \\
\hline Escamas do pedúnculo caudal & 26 & 17 & 18 & & 18 & 2 & $17-18$ \\
\hline Escamas pré-dorsais & 31 & 11 & 13 & & 12 & 5 & 13 \\
\hline Pré-maxilar na fileira externa & 32 & 4 & 5 & & 4 & 6 & 4 \\
\hline Pré-maxilar na fileira interna & 32 & 4 & 5 & & 5 & 6 & 5 \\
\hline Dentes do maxilar & 32 & 1 & 4 & & 3 & 6 & 4 \\
\hline Dentes do dentário & 30 & 4 & 4 & & 4 & 6 & 4 \\
\hline
\end{tabular}




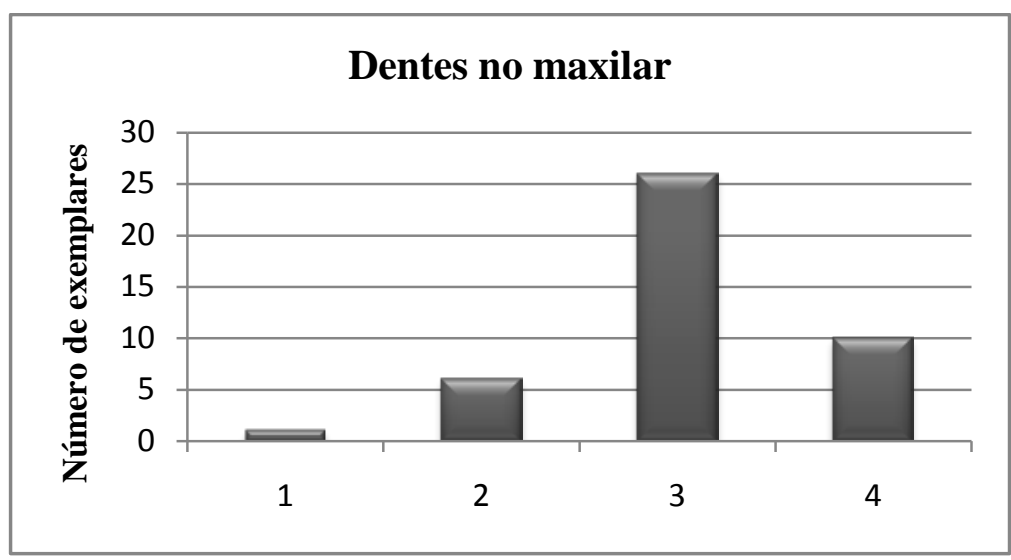

Gráfico 01. Distribuição da quantidade de dentes no maxilar dos exemplares examinados de “A.” orthodus.

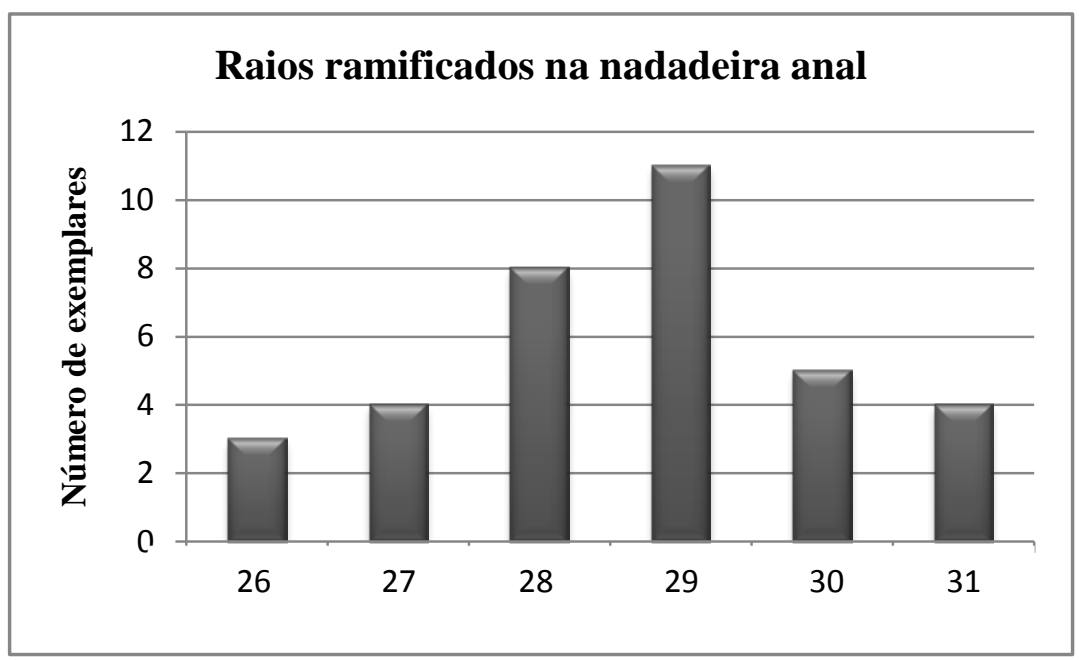

Gráfico 02. Distribuição da quantidade de raios ramificados na nadadeira anal dos exemplares examinados de “A.” orthodus.

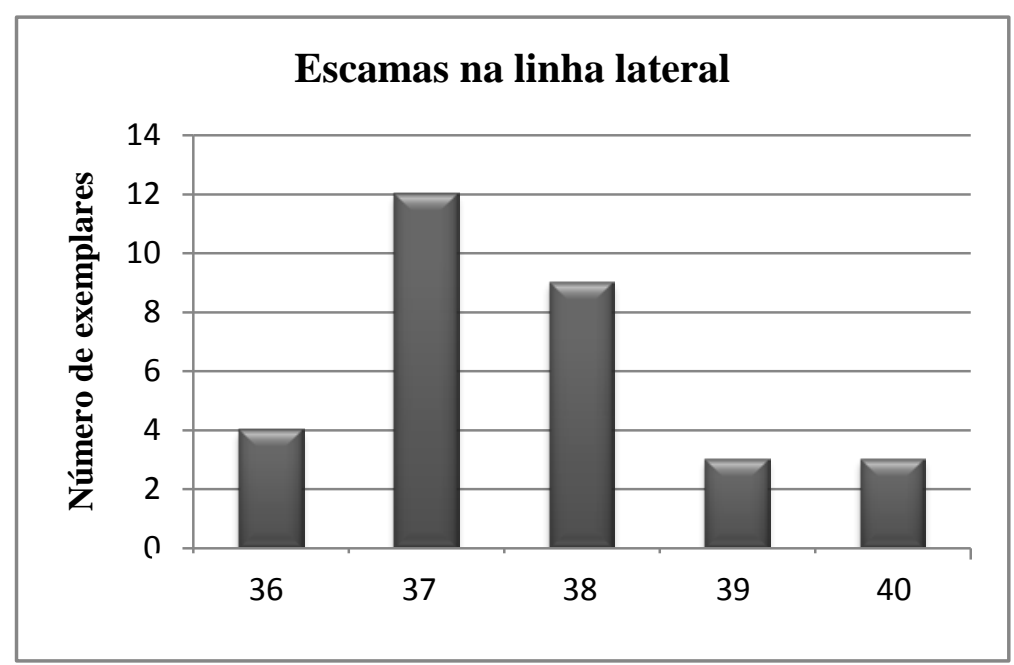

Gráfico 03. Distribuição da quantidade de escamas na linha lateral dos exemplares examinados de “A.” orthodus. 


\section{“Astyanax” superbus Myers, 1942}

Myers (1942) (descrição original), Schultz (1944) pág. 354 e 357 (chave de identificação, localidade-tipo, material-tipo, breve descrição), Böhlke (1953) pág. 22 (material-tipo, localidade-tipo), Mago-Leccia (1970) pág. 69 (registro na Venezuela e nome popular “Sardina”), Géry (1977) pág. 430 e 454 (chave de identificação, comentário sobre a coloração), Winemiller (1990) pág. 364 (registro na Bacia do Rio Apure-Orinoco), Vari \& Howe (1991) pág. 8 (catálogo de material-tipo, coletores e localidade-tipo), Eschmeyer, (1998b) pág. 1632 (localidade-tipo, material-tipo), Garutti, (1998) pág. 121 (citação), Garutti (1999) pág. 590 (comentário sobre relações de parentesco com outros Astyanax), Lima et al. (2003) em Reis et al. (2003) pág. 112 (localidade-tipo, material-tipo, distribuição), Taphorn (2003) pág. 77, 90 e 91 (chave de identificação, localidade-tipo, material-tipo, breve descrição), Lasso et al. (2003) pág. 149 (registro na Bacia do Orinoco), Lasso et al. (2004) pág. 149 (registro na Bacia do Apure, lote de referência), Hoeinghaus et al. (2004) pág. 91 (registro na Bacia do rio Portuguesa), Zarske et al. (2004) (localidade-tipo e caracteres que a separam de Moenkhausia rara), Bertaco \& Carvalho (2005) pág. 442 (comentário sobre coloração), Winemiller et al. (2008) pág. 134 (cadeia alimentar), Mirande (2010) pág. 545 (comentários sobre a coloração).

\section{Material-tipo}

SU 36489 holótipo ( 1 ex., $1 \mathrm{mc}, 84 \mathrm{~mm} \mathrm{CP}$ ); Pequeno riacho tributário do rio Tamanaco (um tributário do rio Paye; Bacia do Rio Portuguesa) em Camoruco, 20 km à nordeste de San Carlos, Estado de Cojedes, Venezuela. Bacia do rio Orinoco. Col. Bond, F. F. 9/3/1938. SU 36490 parátipos (2 ex., 2 mc, 94,9-106,2 mm CP); Pequeno riacho tributário do rio Tamanaco (um tributário do rio Paye; Bacia do Rio Portuguesa) em Camoruco, 20 km à nordeste de San Carlos, Estado de Cojedes, Venezuela. Bacia do rio Orinoco. Col. Bond, F. F. 9/3/1938. USNM 130640 parátipo (1 ex., 1 mc, 69,93 mm CP); Pequeno riacho tributário do rio Tamanaco (um tributário do rio Paye; Bacia do Rio Portuguesa) em Camoruco, 20 km à nordeste de San Carlos, Estado de Cojedes, Venezuela. Bacia do rio Orinoco. Col. Bond, F. F. 9/3/1938. 


\section{Diagnose}

Distingui-se de seus congêneres pelo autapomórfico padrão de colorido composto por faixas de pigmentação em zig-zag longitudinais ao corpo e (exceto de A. multidens) por possuir numerosos dentes na maxila 5-7 (vs. 1-5). De A. multidens e A. sp. nova Peru pela origem da nadadeira anal ser aproximadamente na vertical que passa pelo término da base da nadadeira dorsal (vs. posterior à vertical que passa pelo término da base da nadadeira dorsal). Diferencia-se de Astyanacinus moorii, "Astyanax" orthodus, Astyanacinus sp. nova Bolívia, A. sp. nova Peru por não apresentar processo posteroventral do osso orbito-esfenóide (vs. presença), primeiro dente do maxila pentacuspidado (vs. tricuspidado), forame da porção posterior do metapterigóide inserido no metapterigóide (vs. inserido entre o metapterigóide e a hiomandíbula), forame inserido na superfície dorsal do metapterigóide (vs. superfície dorsal margeando um forame). Difere ainda de "Astyanax" orthodus, Astyanacinus sp. nova Bolívia, A. sp. nova Peru por não apresentar rinosfenóide ossificado (vs. presença).

É distinguida de $\boldsymbol{A}$. multidens por menos dentes na maxila 5-7 (vs. 9-13), por mais raios na nadadeira anal iii-iv+28-32 (vs. iii+22-26), pelo comprimento do maior raio da nadadeira dorsal 22,3-28,6\% no CP (vs. 21,5-25,7\%), pelo menor diâmetro do olho 25,5-33,2\% no CC (vs. 20-29,7\%) e pela base da nadadeira anal maior 29,6-32,9\% no CP (vs. 25-29,1\%); de $\boldsymbol{A}$. sp. nova Purus pela presença de chevrons pelo menos até a origem da nadadeira adiposa (vs. chevrons somente até o meio do corpo, não alcançando a adiposa), menor distância pré-dorsal 45,1-47,2 \% no CP (vs. 47,3-49\%) e menor distância focinho-anal 59,7-62,7 \% no CP (vs. 62,8-64,3\%); de A. sp. nova Bolívia pela ausência de ganchos nas nadadeiras anal e pélvica dos machos maduros (vs. presença de ganchos); de “A.” orthodus pelo padrão de colorido no pedúnculo caudal composto por uma mancha baixa e alongada que alcança a base da nadadeira adiposa (vs. curta e alta não alcançando a base da nadadeira adiposa) e de $\boldsymbol{A}$. sp. nova Peru por apresentar uma maxila superior ligeiramente mais longa 47,8-51,3\% no CC (vs. 45-48,7\%) e pela ausência de uma faixa prateada na lateral do corpo exatamente sobre os chevrons (vs. presença da faixa).

\section{Descrição}

Dados merísticos e morfométricos dos exemplares examinados dessa espécie estão reunidos na tabela 02 e gráficos 04-06. Espécie de médio porte com o maior exemplar 
examinado apresentando o comprimento padrão de 106,89 mm enquanto que o menor possui 41,8 mm. Nadadeira peitoral quase alcança ou alcança a base nadadeira pélvica. Nadadeira pélvica quase alcança ou alcança a base da nadadeira anal. Perfil dorsal da cabeça (da ponta do focinho até a porção posterior do espinho supraoccipital) é côncavo, do espinho supraoccipital até a origem da nadadeira dorsal é marcadamente convexo. Cabeça pequena com comprimento nunca maior que 28,5\% do comprimento padrão. Maxila superior longa variando de 47,8-51,3\% no comprimento da cabeça com a extremidade posterior do osso maxilar alcançando a vertical que passa no contato dorsal entre os infraorbitais 2 e 3, aproximadamente no centro da órbita. Margem ventral do infraorbital 1 sobrepondo a margem dorsal da maxila. Duas séries de dentes no osso pré-maxilar: a mais externa com cada lado apresentando 4(13) dentes tricuspidados, geralmente com três dentes mais centralizados e um mais lateral. Série interna com 5(13) dentes pentacuspidados. Osso maxilar com 5(4), 6(7), 7(1) pequenos dentes tricuspidados. Dentário com sempre 4 dentes mais desenvolvidos pentacuspidados anteriores seguidos de numerosos pequenos dentículos. Nadadeira dorsal com ii+9 raios (13). A origem da nadadeira dorsal é um pouco posterior à vertical que passa pela origem da nadadeira pélvica. Nadadeira adiposa pequena com base anterior à vertical que passa pela inserção do último raio da nadadeira anal. Nadadeira peitoral com i+12(9) ou i+13(4). Nadadeira pélvica com i+7(12) ou i+8(1). Nadadeira anal com iii(3) ou iv(9) raios não ramificados anteriores seguidos de 28(4), 29(4), 30(3) e 32(1) raios ramificados. Origem da nadadeira anal aproximadamente na vertical que passa pelo término da base da nadadeira dorsal. Linha lateral completa pouco curvada ventralmente com 38(1), 39(1), 40(6) ou 41(4) escamas perfuradas. Sete (3) ou oito (9) séries longitudinais de escamas entre a nadadeira dorsal e a linha lateral; 7(9) ou 8(3) séries longitudinais de escamas entre a nadadeira anal e a linha lateral. Treze (9), 14(2), 15(1) ou 16(1) escamas pré-dorsais em uma série irregular e 18(10) ou 21(3) escamas ao redor do pedúnculo caudal. Apenas uma série de escamas recobrindo a base de metade dos raios da nadadeira anal. Primeiro arco branquial com $12+1+9-10$ rastros. Total de 37(1)-38(3)* sendo 15(4)* são pré-caudais, 2(4)* de transição e 20(1)-21(3)* caudais. Há 5(4)* supraneurais e a nadadeira dorsal está inserida após a nona vértebra (4)*.

\section{Coloração em álcool}

Presença de 9 a 12 faixas longitudinais em zig-zag formadas pela concentração de 
cromatóforos nas regiões superior e inferior da escama. Tal padrão é mais evidente em indivíduos maiores. Além disso, as escamas dessa espécie apresentam pigmentação na borda posterior. Mancha umeral horizontalmente alongada ocupando área de aproximadamente 4 escamas em seu comprimento e 2 escamas em sua altura. A mancha está localizada na fileira de escamas acima da linha lateral. Padrão de bandas escuras em forma de "V" lateralmente dispostas no corpo. Cerca de 11 a 16 estrias que começam um pouco antes da manha umeral, logo atrás do opérculo, e se estendem até próximo ao pedúnculo caudal. O padrão é facilmente observado em todos os exemplares analisados. Nos raios mais medianos da nadadeira caudal há uma banda escura que se distribui até a porção mais posterior destes raios e segue pelo pedúnculo caudal de maneira mais expandida e segue até aproximadamente a vertical que passa pela nadadeira adiposa. Corpo com coloração alaranjada ou marrom pálida. Não há deposito de guanina nos exemplares. Corpo com muitos cromatóforos com concentrações na base da nadadeira dorsal e na região entre o espinho supraoccipital e a margem superior do opérculo. Nadadeiras com coloração de um amarelo pálido. Nadadeira adiposa com muitos cromatóforos marrons alongados, principalmente em sua base onde há maior número destes. Nadadeiras dorsal com muitos cromatóforos marrons nas membranas inter-radiais e poucos nos raios. Peitoral e pélvica com poucos cromatóforos dispostos nos raios. Nadadeira anal repleta de cromatóforos marrons nas membranas entre os raios, porém com poucos nos raios.

\section{Dimorfismo sexual}

Segundo Taphorn (2003) há dimorfismo sexual no desenvolvimento das nadadeiras e tamanho corporal. Segundo o autor as nadadeiras pélvicas chegam a ultrapassar o ânus nos machos, mas não nas fêmeas. Quanto às nadadeiras peitorais, nos machos elas alcançam as pélvicas, porém o mesmo não ocorre em fêmeas. Com base nos poucos exemplares que pude examinar reconheço que há diferentes graus de desenvolvimento com relação ao comprimento das nadadeiras peitoral e pélvica. Há indivíduos que possuem os raios mais laterais da nadadeira pélvica mais desenvolvidos que ultrapassam o ponto de origem da nadadeira anal (figura 51 a,c), por outro lado em alguns casos esses raios ultrapassam o ânus, mas não alcançam a origem da anal (figura 51 b,d). Sobre a nadadeira peitoral, em geral, nos machos os raios mais longos ultrapassam a origem da nadadeira pélvica enquanto que o mesmo não ocorre nas fêmeas. É 
importante ressaltar que muitos exemplares possuem condições intermediárias do que foi exposto anteriormente tornando difícil o reconhecimento do sexo.

\section{Notas sobre a espécie}

A espécie em questão foi descrita por G. Myers como pertencente ao gênero Astyanax e, ironicamente, não ao gênero Astyanacinus descrito por Carl Eigenmann, mentor do próprio George Myers.

Segundo Taphorn (2003) é uma espécie pouco comum, porém o autor faz a ressalva de que esta pode ser mais encontrada em regiões ainda pouco amostradas. Segundo Winemiller \& Taphorn (1989) a espécie possui fecundidade de 800 ovos por fêmea, o diâmetro do ovo é de 0,65 mm e a reprodução ocorre no começa das chuvas, porém é possível que ocorra mais de uma vez ao ano. A espécie é onívora e se alimenta tanto de insetos alóctones quanto de pequenas sementes (obs. pessoal).

Com relação à presença de estrias longitudinais em zig-zag, esse caráter é incomum entre os caracídeos, apesar de ser encontrado em algumas espécies. Tal padrão é encontrado em Hyphessobrycon hexastichos, Astyanax lineatus, A. kullanderi, Bario steindachneri, Hollandichthys multifasciatus, Markiana nigripinnis, Moenkhausia agnesae, Moenkhausia rara, Moenkhausia simulata e Pseudochalceus lineatus e em algumas espécies de Brycon.

\section{Etimologia}

Apesar de G. Myers não explicitar qual característica encontrada na espécie foi a razão do autor designar o epíteto superbus (do inglês superb = magnífico), concordo com Taphorn (2003) em supor que tenha sido o marcante padrão de chevrons na região lateral do corpo da espécie.

\section{Distribuição geográfica}

Espécie conhecida apenas do território venezuelano que é encontrada em cursos d'água da Bacia do Apure, principalmente do Rio Portuguesa. 


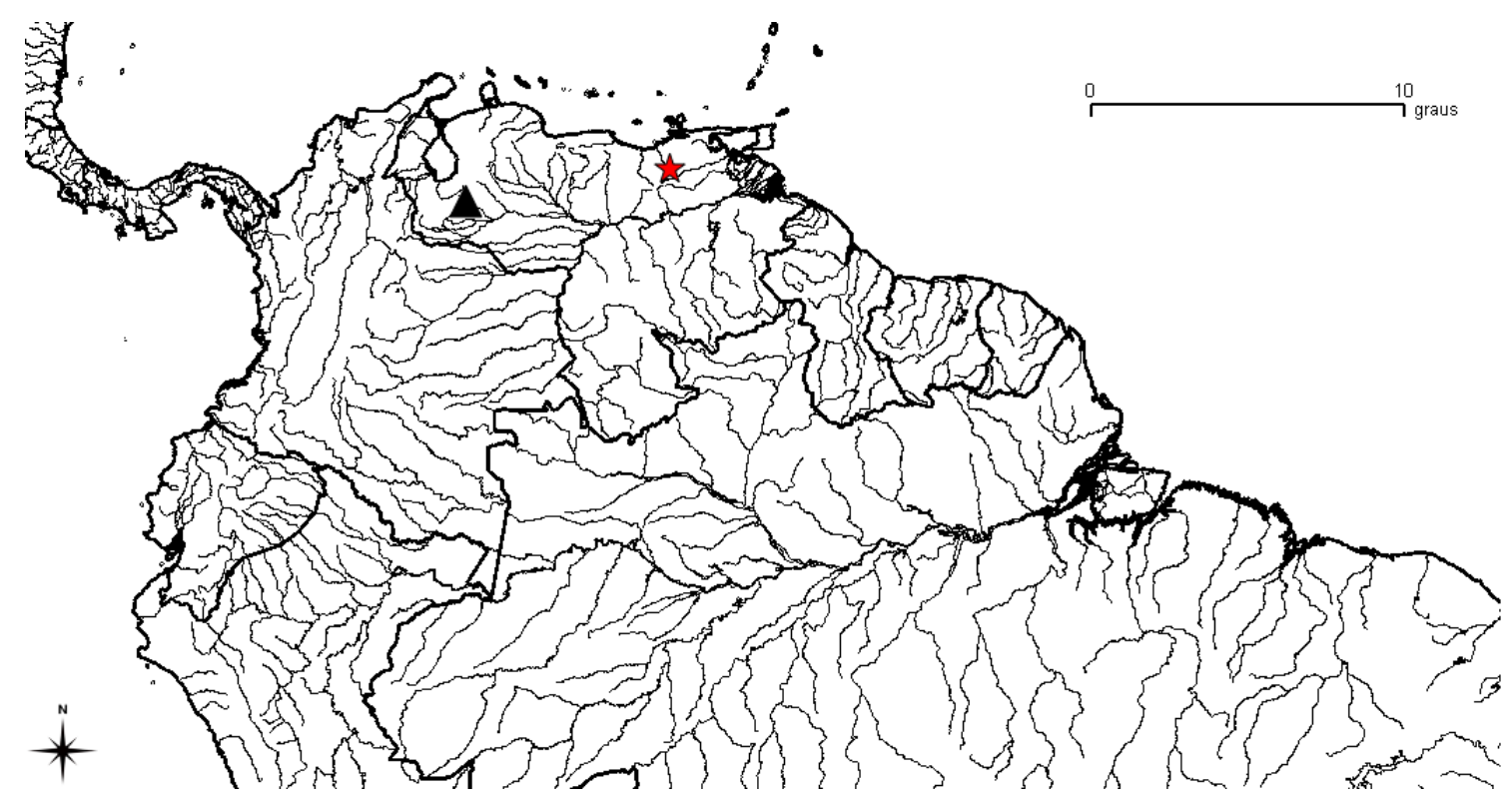

Figura 03. Mapa da distribuição geográfica de “A.” superbus. Estrela indica a localidade-tipo.

\section{Material examinado}

\section{Venezuela}

SU 36489 holótipo ( 1 ex., $1 \mathrm{mc}, 84 \mathrm{~mm} \mathrm{CP}$ ); Pequeno riacho tributário do rio Tamanaco (um tributário do rio Paye; Bacia do Rio Portuguesa) em Camoruco, 20 km à nordeste de San Carlos, Estado de Cojedes, Venezuela. Bacia do rio Orinoco. Col. Bond, F. F. 9/3/1938. SU 36490 parátipos (2 ex., 2 mc, 94,9-106,2 mm CP); Pequeno riacho tributário do rio Tamanaco (um tributário do rio Paye; Bacia do Rio Portuguesa) em Camoruco, 20 km à nordeste de San Carlos, Estado de Cojedes, Venezuela. Bacia do rio Orinoco. Col. Bond, F. F. 9/3/1938. USNM 130640 parátipo (1 ex., 1 mc, 69,93 mm CP); Pequeno riacho tributário do rio Tamanaco (um tributário do rio Paye; Bacia do Rio Portuguesa) em Camoruco, 20 km à nordeste de San Carlos, Estado de Cojedes, Venezuela. Bacia do rio Orinoco. Col. Bond, F. F. 9/3/1938. MZUSP 103071 (20 ex., 10 mc, 41,8-78,2 mm CP; 2 C\&S); Barinas, Caño, Via Ticoporo em el puente del rio

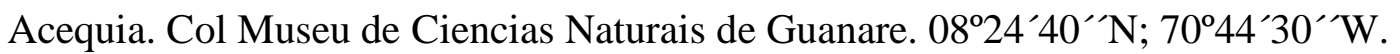


Tabela 2. Dados merísticos e morfométricos de todos os lotes examinados de “Astyanax" superbus.

Astyanacinus superbus

\begin{tabular}{|c|c|c|c|c|c|c|}
\hline & $\mathrm{n}$ & Holótipo & Mínimo & Máximo & Média & D. padrão \\
\hline Comprimento Padrão & 13 & 84,0 & 41,8 & 106,9 & 66,4 & \\
\hline Altura do corpo & 13 & 36,6 & 31,90 & 38,89 & 35,54 & 1,98 \\
\hline Distância pré-dorsal & 13 & 49,4 & 48,65 & 52,20 & 50,22 & 1,00 \\
\hline Distância pré-ventral & 13 & 45,4 & 45,10 & 47,20 & 46,05 & 0,66 \\
\hline Focinho-peitoral & 13 & 24,5 & 22,58 & 28,00 & 25,88 & 1,53 \\
\hline Focinho-anal & 13 & 59,7 & 59,70 & 62,70 & 61,68 & 0,88 \\
\hline Pélvica-anal & 13 & 16,8 & 15,00 & 18,10 & 16,76 & 1,00 \\
\hline Altura do pedúnculo caudal & 13 & 13,0 & 10,50 & 12,96 & 11,58 & 0,80 \\
\hline Base da nadadeira dorsal & 13 & 14,1 & 13,40 & 14,99 & 14,13 & 0,44 \\
\hline Base da nadadeira anal & 13 & 31,9 & 29,60 & 32,90 & 31,81 & 0,86 \\
\hline Distância dorsal-caudal & 13 & 57,9 & 53,00 & 59,11 & 56,17 & 1,84 \\
\hline Maior raio da nadadeira peitoral & 13 & 20,8 & 18,89 & 23,60 & 21,38 & 1,34 \\
\hline Maior raio da nadadeira pélvica & 13 & 15,3 & 14,44 & 17,00 & 15,63 & 0,81 \\
\hline Maior raio da nadadeira dorsal & 13 & 26,2 & 22,30 & 28,60 & 26,13 & 1,97 \\
\hline Maior raio da nadadeira anal & 13 & 13,8 & 11,74 & 17,85 & 15,61 & 1,92 \\
\hline Comprimento da cabeça & 13 & 24,6 & 22,21 & 28,47 & 25,94 & 1,78 \\
\hline Comprimento do focinho & 13 & 27,3 & 24,30 & 28,90 & 26,64 & 1,21 \\
\hline Diâmetro da órbita ocular & 13 & 27,7 & 25,53 & 33,20 & 29,85 & 2,29 \\
\hline Distância maxilar-pré-maxilar & 13 & 51,3 & 47,80 & 51,33 & 49,22 & 1,20 \\
\hline Distância interorbital & 13 & 34,5 & 28,80 & 37,45 & 31,50 & 2,93 \\
\hline \multirow[t]{2}{*}{ Altura da cabeça } & 13 & 107,6 & 95,50 & 119,08 & 104,62 & 6,40 \\
\hline & $\mathrm{n}$ & Holótipo & Mínimo & Máximo & Moda & \\
\hline Raios da nadadeira peitoral & 13 & $\mathrm{i}+13$ & $\mathrm{i}+12$ & $\mathrm{i}+13$ & $\mathrm{i}+12$ & \\
\hline Raios da nadadeira pélvica & 13 & $\mathrm{i}+7$ & $\mathrm{i}+7$ & $\mathrm{i}+8$ & $\mathrm{i}+7$ & \\
\hline Raios da nadadeira dorsal & 13 & $\mathrm{ii}+9$ & $\mathrm{ii}+9$ & $\mathrm{ii}+9$ & $\mathrm{ii}+9$ & \\
\hline Raios da nadadeira anal & 12 & $\mathrm{iii}+28$ & $\mathrm{iii}+28$ & $\mathrm{iv}+32$ & iv +29 & \\
\hline Escamas da linha lateral & 12 & 38 & 38 & 40 & 40 & \\
\hline Escamas acima da linha lateral & 12 & 8 & 8 & 8 & 8 & \\
\hline Escamas abaixo da linha lateral & 12 & 8 & 8 & 8 & 7 & \\
\hline Escamas do pedúnculo caudal & 13 & 21 & 18 & 21 & 18 & \\
\hline Escamas pré-dorsais & 13 & 16 & 13 & 16 & 13 & \\
\hline Pré-maxilar na fileira externa & 13 & 4 & 4 & 4 & 4 & \\
\hline Pré-maxilar na fileira interna & 13 & 5 & 5 & 5 & 5 & \\
\hline Dentes do maxilar & 12 & 6 & 5 & 7 & 6 & \\
\hline Dentes do dentário & 13 & 4 & 4 & 4 & 4 & \\
\hline
\end{tabular}




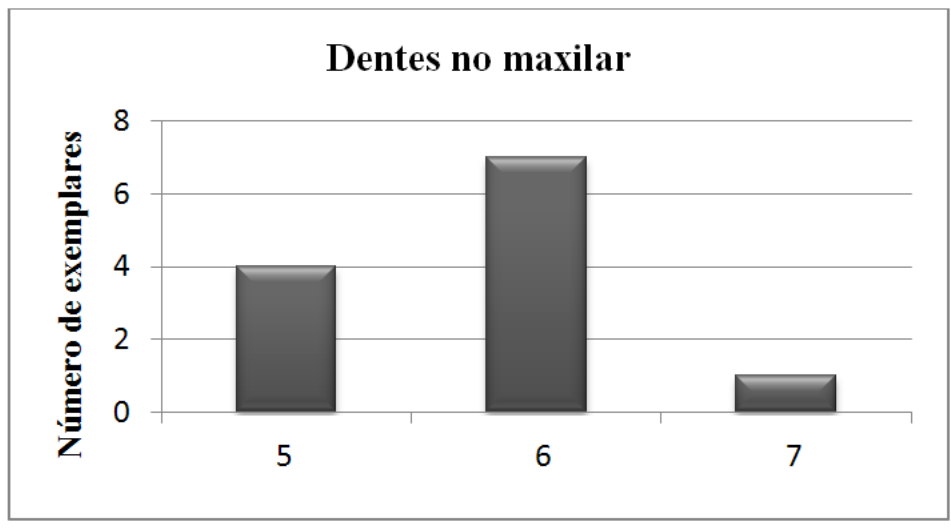

Gráfico 04. Distribuição da quantidade de dentes no maxilar dos exemplares examinados de “A.” superbus.

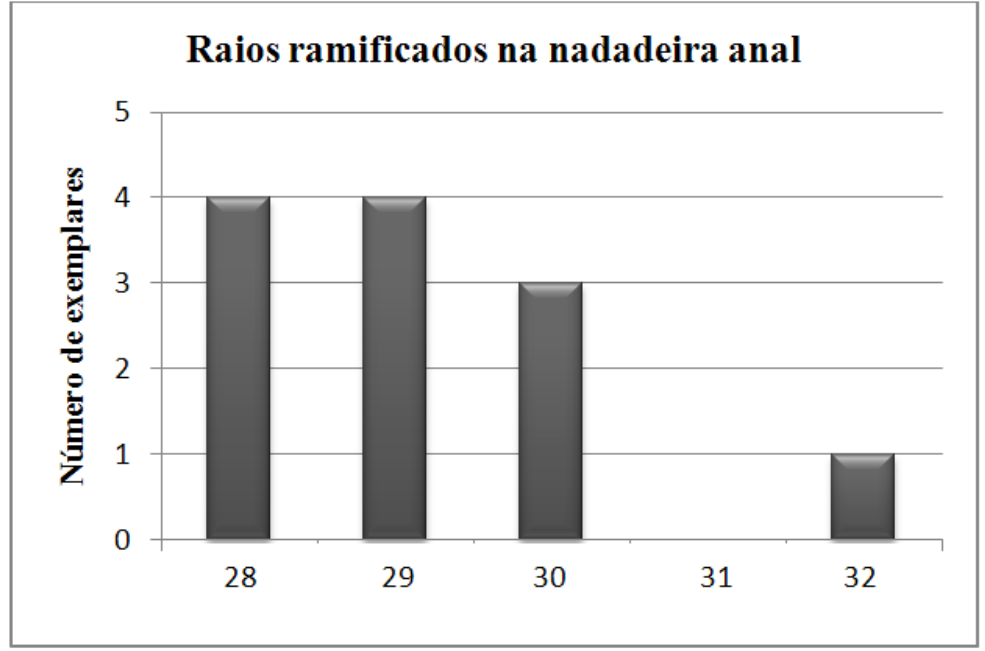

Gráfico 05. Distribuição da quantidade de raios ramificados na nadadeira anal dos exemplares examinados de “A.” superbus.

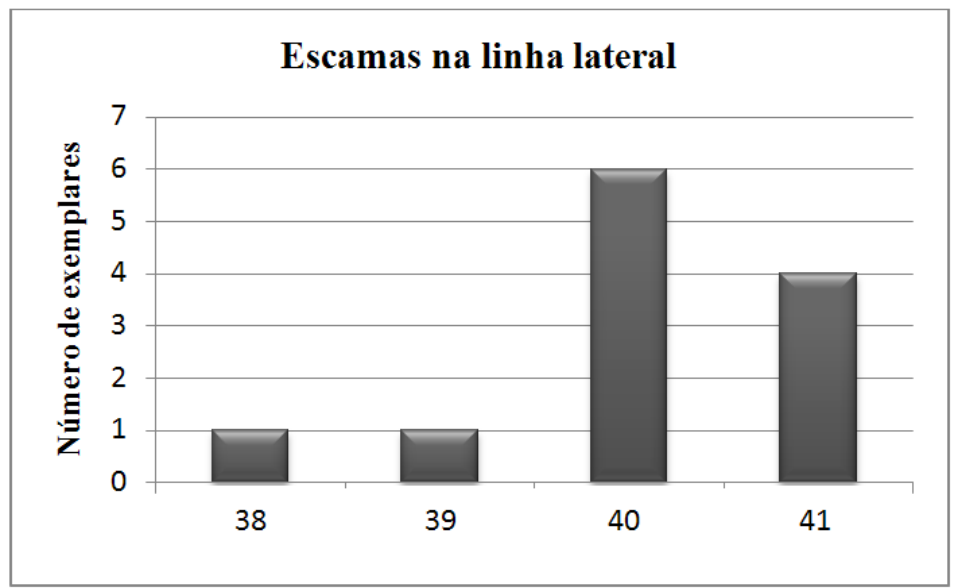

Gráfico 06. Distribuição da quantidade de escamas na linha lateral dos exemplares examinados de “A.” superbus. 


\section{Astyanacinus moorii (Boulenger, 1892)}

Tetragonopterus moorii

Boulenger (1892) pág. 11 (descrição original, ilustração), Ulrey (1895) pág 276 (citação), apud. Boulenger (1897) pág. 4 (citação).

\section{Tetragonopterus moorei}

Cope (1894) pág. 107 (coleta de exemplares nas cabeceiras do Rio Paraguai, na Chapada, Mato Grosso pelo Sr. Smith),

\section{Astyanax moorii}

Fowler (1907) pág. 432 (re-descrição)

\section{Astyanacinus moorii}

Eigenmann (1907) pág. 769 (descrição original do genro e ilustração), Pearson (1924) pág. 41 (registro na Bacia do Rio Beni), Eigenmann (1910) pág. 435 (citação e distribuição), Eigenmann (1927) pág. 339 e 340 (breve descrição, distribuição, materialtipo, localidade-tipo), Pearson (1937) pág. 108 (registro nas Bacias dos Rios Beni e Paraguai), Fowler (1940) pág. 100 (registro na Bolívia), Fowler (1948) pág. 34 e 35 (sinonímia, distribuição, ilustração, localidade-tipo), Lauzanne \& Loubens (1975) pág. 110 (registro na Bacia do Rio Mamoré), Ramlow (1989) pág. 08 (registro para o Paraguai), Ringuelet (1985) pág. 78 (registro no Alto-Paraguai), Lauzanne et al. (1991) pág. 66 (presença na região de Yucumo, tamanho e peso máximos), Eschmeyer, (1998b) pág. 1120 (localidade-tipo, material-tipo), Britski et al. (1999) pág. 37 (breve descrição e ilustração), Chernoff \& Willink (1999) pág. 97 (registro na Bacia Amazônica Boliviana), Chernoff et al. (2000) pág. 279 (registro na Bacia Amazônica Boliviana), Lima et al. (2003) em Reis et al. (2003) pág. 106 (localidade-tipo, material-tipo, distribuição), Veríssimo et al. (2005) pág. 3 (registro no Alto-Paraguai e nome popular), Rosa (2006) pág. 32, 33 e 39 (dados ecológicos, etológicos e registro no Alto-Paraguai), Britski et al. (2007) pág. 53 e 54 (breve descrição e ilustração), Lima et al. (2007) em Buckup et al. (2007) pág. 44 (localidade-tipo e distribuição), MMA (2007) pág. 221 (registro na Bacia do Alto-Paraguai), Valério et al. (2007) pág. 245 e 246 (registro no Alto Paraguai, abundância e relação com parâmetros abióticos), Bertaco et al. (2009) 
pág. 266 e 273 (distribuição e comparação com outras espécies de Astyanacinus). Lima \& Ribeiro (2011) pág. 152 (presença na Bacia Paraná-Paraguai).

\section{Material-tipo}

Síntipos BMNH 1892.4.29.50-51 (2ex.) “Chapala Plateau”. Col. Mr. Spencer Moore.

\section{Diagnose}

Diferencia-se de “Astyanax” orthodus, “Astyanax” superbus, Astyanacinus sp. nova Bolívia por não apresentar lamelas no osso nasal (presença). Difere de "Astyanax" orthodus, Astyanacinus sp. nova Bolívia e Astyanacinus sp. nova Peru pela ausência de rinosfenóide ossificado (vs. presença). Distingue-se de A. multidens e A. sp. nova Peru pela origem da nadadeira anal ser anterior à vertical que passa pelo término da base da nadadeira dorsal (vs. posterior à vertical que passa pelo término da base da nadadeira dorsal)

É distinguida ainda de $\boldsymbol{A}$. multidens por menos dentes na maxila 1-4 (vs. 9-13), menos escamas pré-dorsais 11-13 (vs. 14-16), menos escamas circumpedunculares 1618 (vs. 19-21) e por mais raios na nadadeira anal iii-iv+27-32 (vs. iii+22-26), pelo comprimento do maior raio da nadadeira dorsal 24,3-30,8\% no CP (vs. 21,5-25,7\%), pelo menor diâmetro do olho 27,1-37,4\% no CC (vs. 20-29,7\%) e pela base da nadadeira anal maior 29,6-36,3\% no CP (vs. 25-29,1\%); maior comprimento da cabeça 25,5-28,6\% no CP (vs. 22,4-26\%); de “A.” superbus por menos dentes na maxila 1-4 (vs. 5-7) e ausência do padrão de colorido de faixas em zig-zag longitudinais ao corpo (vs. presença do padrão); de A. sp. nova Purus pela presença de chevrons pelo menos até a origem da nadadeira adiposa (vs. chevrons somente até o meio do corpo, não alcançando a adiposa); de $\boldsymbol{A}$. sp. nova Bolívia pela ausência de ganchos nas nadadeiras anal e pélvica dos machos maduros (vs. presença de ganchos), pela menor altura do corpo 30,8-38,4\% no CP (vs. 31,1-40,7\%) e por apresentar, em sua maioria, exemplares com 2-3 dentes (vs. 3-4); e de “A.” orthodus pelo padrão de colorido no pedúnculo caudal composto por uma mancha baixa e alongada que alcança a base da nadadeira adiposa (vs. curta e alta não alcançando a base da nadadeira adiposa), pela menor altura do corpo 30,8-38,4\% no CP (vs. 36,8-44,4\%) e por apresentar, em sua maioria, exemplares com 2-3 dentes (vs. 3-4) e de A. sp. nova Peru por apresentar uma maxila superior ligeiramente mais longa $47,2-54,7 \%$ no CC (vs. $45-48,7 \%$ ), por uma base da 
nadadeira anal mais longa 29,6-36,3\% no CP (vs. 26,4-31,1\%) e pela ausência de uma faixa prateada na lateral do corpo exatamente sobre os chevrons (vs. presença da faixa). Adicionalmente, diferencia-se de todas as outras espécies do gênero pelo menor porte (exceto de $A$. sp. nova Purus) com até 58,07mm de CP (vs. até $124 \mathrm{~mm}$ de CP).

\section{Descrição}

Dados merísticos e morfométricos dos exemplares examinados dessa espécie estão reunidos na tabela 03 e gráficos 07-09. Espécie de pequeno porte com o maior exemplar examinado apresentando o comprimento padrão de 58,07 mm. Nadadeira peitoral quase alcança ou alcança levemente a base nadadeira pélvica. Nadadeira pélvica quase alcança ou alcança levemente a base da nadadeira anal. Perfil dorsal da cabeça (da ponta do focinho até a porção posterior do espinho supraoccipital) é sutilmente côncavo ou quase reto; do espinho supraoccipital até a origem da nadadeira dorsal é levemente convexo. Cabeça pequena com comprimento nunca maior que 28,6\% do comprimento padrão. Maxila superior longa variando de 47,2-54,7\% no comprimento da cabeça com a extremidade posterior do osso maxilar quase alcançando a vertical que passa no contato dorsal entre os infraorbitais 2 e 3, aproximadamente no centro da órbita. Margem ventral do infraorbital 1 sobrepondo a margem dorsal da maxila. Duas séries de dentes no osso pré-maxilar: a mais externa com cada lado apresentando 3(4), 4(32) ou 5(4) dentes tricuspidados, geralmente com três dentes mais centralizados e um mais lateral. Série interna com 4(2) ou 5(39) dentes pentacuspidados com a cúspide central mais desenvolvida. Osso maxilar com 1(3), 2(20), 3(11) ou 4(1) pequenos dentes tripentacuspidados. Dentário com sempre 4 dentes mais desenvolvidos pentaheptacuspidados anteriores seguidos de numerosos pequenos dentículos. Nadadeira dorsal com ii+9 raios (30). A origem da nadadeira dorsal é um pouco posterior à vertical que passa pela origem da nadadeira pélvica. Nadadeira adiposa pequena com base anterior à vertical que passa pela inserção do último raio da nadadeira anal. Nadadeira peitoral com i+12(16), i+13(24) ou i+14(1). Nadadeira pélvica com i+6(3), i+7(34) ou i+8(4). Nadadeira anal com iii(15) ou iv(26) raios não ramificados anteriores seguidos de 27( 28(4), 29(4), 30(3) e 32(1) raios ramificados. Origem da nadadeira anal anterior à vertical que passa pelo término da base da nadadeira dorsal. Linha lateral completa pouco curvada ventralmente com 36(2), 37(6), 38(13), 39(14), 40(4) ou 41(1) escamas perfuradas. Oito (25) ou 9(13) séries longitudinais de escamas entre a nadadeira dorsal e a linha lateral; 6(1), 7(20) ou 8(19) séries longitudinais de escamas entre a nadadeira 
anal e a linha lateral. Onze (1), 12(19) ou 13(18) escamas pré-dorsais em uma série irregular e 16(2), 17(17) ou 18(11) escamas ao redor do pedúnculo caudal. Apenas uma série de escamas recobrindo a base de metade dos raios da nadadeira anal. Primeiro arco branquial com 11+1+9-10 rastros. Total de 37(3)* vértebras sendo 15(2)-16(1)* précaudais, 2(3) de transição e 19(1)*-20(2) caudais. Há 4(1) ou 5(3)* supraneurais e a nadadeira dorsal está inserida após a nona vértebra (3)*.

\section{Coloração em álcool}

Mancha umeral oval bem definida ocupando área de aproximadamente 4 escamas em seu comprimento e 2 escamas em sua altura. A mancha está localizada logo acima da linha lateral ocupando a porção mais dorsal da escama que a compõem. Posteriormente, há uma faixa vertical com poucos cromatóforos marrons dando a impressão dá área ser despigmentada. Entre essa área despigmentada existem duas manchas verticalmente alongadas, porém bastante difusas e fracas. A mancha umeral está posicionada na cima da mancha vertical difusa mais anterior. Presença de estrias lateralmente dispostas no corpo formado por bandas escuras em forma de "V" deitados com seus vértices anteriormente direcionados. Os vértices encontram-se alinhados em uma faixa negra longitudinal que inicia-se logo após a mancha umeral e vai até o pedúnculo caudal. Nos exemplares de menor porte as bandas escuras em "V" são simples, enquanto que nos exemplares maiores as bandas são mais intrincadas e com ramificações. Quantidade variável de estrias (cerca de 10 a 14) que começam um pouco antes da manha umeral, logo atrás do opérculo, e se estendem até próximo ao pedúnculo caudal, aproximadamente na vertical que passa pela origem da nadadeira adiposa. Contínua com a faixa negra longitudinal do corpo há uma mancha no pedúnculo caudal mais alongada do que alta que inicia-se, aproximadamente, na vertical que passa pela origem da nadadeira adiposa e prolonga-se até a porção mais distal dos raios medianos da nadadeira caudal. Corpo com coloração amarelo-pálido sutilmente mais escuro dorsalmente. Em alguns exemplares examinados há deposito de guanina principalmente no opérculo, pré-opérculo e infra-orbital 3. Corpo com muitos cromatóforos amarronzados com maiores concentrações na região dorsal. Escamas com muitos cromatóforos e com maior concentração na região periférica da região posterior da escama. Nadadeiras com cromatóforos nas bainhas inter-radiais, mas não nos raios. 
Nadadeira adiposa com muitos cromatóforos marrons dispersos homogeneamente. Nadadeira anal com maior concentração de cromatóforos na porção distal dos raios.

\section{Dimorfismo sexual}

Nenhuma diferença foi detectada.

\section{Notas sobre a espécie}

Segundo Valério et al. (2007) a presença de Astyanacinus moorii está associada principalmente a baixas altitudes e águas rápidas com alto condutividade e profundos riachos. No mesmo trabalho o autor ainda sugere que Astyanacinus moorii foi uma das espécies mais comumente encontradas nos riachos do Alto Paraguai juntamente com Astyanax marionae e A. assuncionensis. Rosa (2006) examinou o estômago de espécimes de Astyanacinus moorii e detectou um hábito onívoro para a espécie com dieta composta de invertebrados aquáticos tais como larvas de Diptera e Plecoptera e invertebrados terrestres como indivíduos de Diptera adultos e Formicidae. O autor ainda reporta a presença de fragmentos de frutos e sementes e outros restos vegetais na espécie.

A partir da análise estomacal de 2 exemplares da espécie, de maneira geral, os dados apresentados por Rosa (2006) foram corroborados pois foram detectadas as presenças de indivíduos de Diptera e sementes de gramínea.

Segundo Rosa (2006) Astyanacinus moorii talvez tenha potencial como bioindicadores de perda de mata ciliar, uma vez que depende de alimentos diretamente influenciados pela presença deste tipo de vegetação.

\section{Etimologia}

Boulenger (1892) descreve a espécie Tetragonopterus moorii a partir de material coletado pelo botânico Spencer Le Marchant Moore na "Chapala Plateau” (=Chapada dos Guimarães?) quando este visitou o Estado do Mato Grosso em 1891. O nome do coletor gerou o epíteto específico da espécie.

\section{Distribuição geográfica}

Bacia do Alto Paraguai 


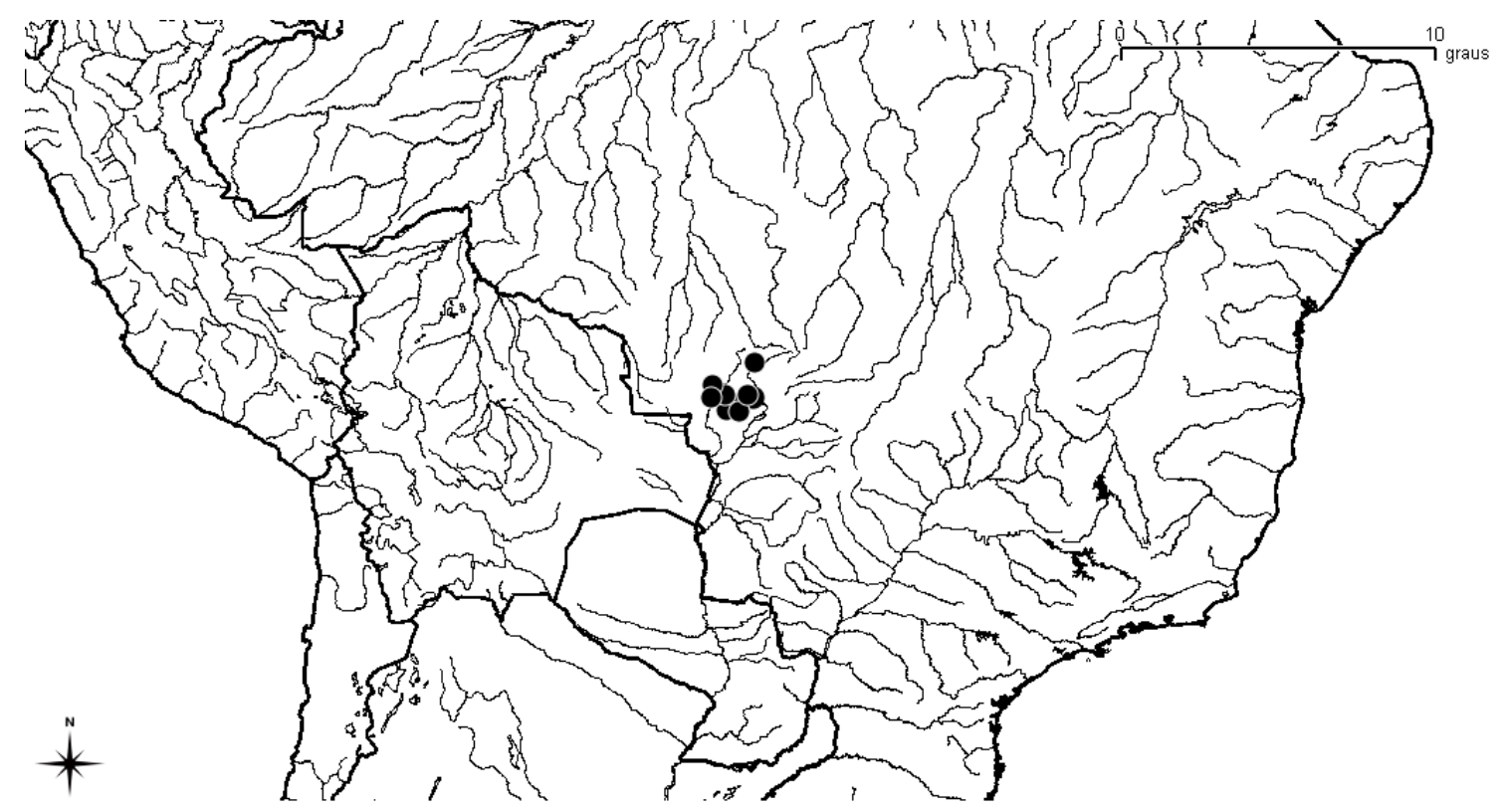

Figura 04. Mapa da distribuição geográfica de A. moorii. Localidade-tipo não é indicada porque foi muito vagamente descrita e todos os exemplares examinados são da mesma região da localidade-tipo, ou seja, topótipos. Cada símbolo pode representar mais de um lote examinado.

\section{Material examinado}

\section{Brasil}

Mato Grosso: MCP 15572 (5 ex., 2 mc, 54,95-58,07 mm CP); Arroio cruzando a estrada Cuiabá/Cáceres, $13 \mathrm{Km}$ à leste de Cáceres, afluente do Rio Paraguai, Bacia do Rio Paraguai. Município de Cáceres, Mato Grosso. Col. R. E. Reis, L. R. Malabarba, N. A. Menezes. 14/08/1991. MCP 37852 (3 ex., 3 mc, 41,34- 44,74 mm CP); Poconé, Drenagem do Paraguai. Estrada MT-060 em direção à cidade de Poconé. Col. J. Pezzi,

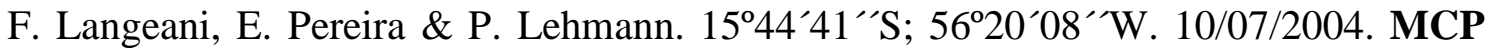
37951 (3 ex., 3 mc, 43,08-46,22 mm CP); Poconé, Drenagem do Paraguai. Ribeirão Figueira, ca de 4 km ao sul da estrada BR-070. Col R. E. Reis, P. A. Buckup, A. R. Cardoso \& E. Pereira. 1558'03”S; 5655'24”W. 10/07/2004. MCP 39751 (5 ex., 2 mc, 40,55- 41,56 mm CP); Município de Várzea Grande, Drenagem do Paraguai. Rio Pari na estrada entre a BR-070 e a Fazenda Seco Ca. De 7 km da BR-070. Col R. E.

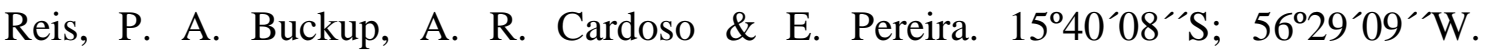
10/07/2004. MZUSP 44468 (1 ex., 1 mc, 41,51 mm CP); Cáceres, Drenagem do Paraguai. Ribeirão das Flexas na estrada Cáceres/Cuiabá, ca. 69km de Cáceres. Col. R.E.Reis, L.R. Malabarba, N.A.Meneses, M.Weitzman, F.A.Machado. 14/08/1991. MZUSP 78752 (22 ex. de 57, 20 mc, 2c\&s, 36,2-45,60mm CP); Porto Estrela, 
Drenagem do Paraguai. Rio Saloba, na estrada da estação ecológica de Serra das Araras.

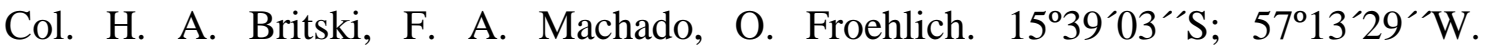
27/02/2002. MZUSP 788808 (1 ex., 1 mc, 36,59mm CP); Reserva do Cabaçal, Drenagem do Paraguai. Rio do peixe, afluente do rio Cabaçal, fazenda do Valdeci, abaixo da ponte. Col. F.C.T.Lima, G.B.Borges \& F.A.Machado. 07/03/2002. MZUSP 78820 (6 ex., 6 mc, 38,94-47,03 mm CP); Cáceres, Drenagem do Paraguai. Rio Cachoeirinha, na estrada Cáceres/Porto Estrela. Col. H.A.Britski, O. Froelich \& F.A.Machado. 27/02/2002. MZUSP 89945 (2 ex., 2 mc, 40,77- 44,7mm CP) Cáceres, Drenagem do Paraguai. Rio Sepotuba (trecho médio). Col. H.A.Britski, O. Froelich, A.C.Catella \& F. Marques. 03/2002. MZUSP 90479 (1 ex., 1 mc, 34,61 mm CP); Cáceres, Drenagem do Paraguai. Rio Sepotuba (trecho médio). MZUSP 91017 (1 ex., 1 mc, 39,49 mm CP); Barra dos Bugres, Drenagem do Paraguai. Rio Sepotuba (trecho médio). Col. H.A.Britski, O. Froelich, A.C.Catella \& F. Marques. 1506`52”S; 57³9`50”W. 03/2002. UFRGS 11969 (1 ex., 1c); Nobres, Drenagem do Paraguai. Rio serragem 2, acesso junto à ponte BR-163. Col. Almpert, V. R. \& Scherer, S. Lat 14.6321111/Long -56.2722500. 17/03/2009. 
Tabela 3. Dados merísticos e morfométricos de todos os lotes examinados de Astyanacinus moorii.

Astyanacinus moorii

\begin{tabular}{|c|c|c|c|c|c|}
\hline & $\mathrm{n}$ & Mínimo & Máximo & Média & D. padrão \\
\hline Comprimento Padrão & 41 & 34,61 & 58,07 & 41,86 & \\
\hline Altura do corpo & 41 & 30,82 & 38,42 & 33,91 & 2,03 \\
\hline Distância pré-dorsal & 41 & 47,94 & 52,63 & 49,96 & 1,14 \\
\hline Distância pré-ventral & 41 & 45,03 & 50,72 & 46,84 & 1,16 \\
\hline Focinho-peitoral & 41 & 25,98 & 29,36 & 27,91 & 0,81 \\
\hline Focinho-anal & 41 & 59,40 & 65,24 & 61,59 & 1,31 \\
\hline Pélvica-anal & 41 & 13,30 & 18,32 & 15,18 & 1,18 \\
\hline Altura do pedúnculo caudal & 41 & 10,24 & 12,14 & 11,11 & 0,54 \\
\hline Base da nadadeira dorsal & 41 & 11,58 & 15,03 & 13,73 & 0,88 \\
\hline Base da nadadeira anal & 41 & 29,57 & 36,28 & 32,81 & 1,29 \\
\hline Distância dorsal-caudal & 41 & 52,44 & 57,97 & 55,55 & 1,31 \\
\hline Maior raio da nadadeira peitoral & 41 & 19,08 & 23,00 & 20,78 & 0,84 \\
\hline Maior raio da nadadeira pélvica & 41 & 13,61 & 17,64 & 15,25 & 0,89 \\
\hline Maior raio da nadadeira dorsal & 41 & 20,43 & 30,82 & 27,64 & 1,74 \\
\hline Maior raio da nadadeira anal & 41 & 14,44 & 20,85 & 17,30 & 1,66 \\
\hline Comprimento da cabeça & 41 & 25,49 & 28,55 & 27,19 & 0,79 \\
\hline Comprimento do focinho & 41 & 22,77 & 31,35 & 27,39 & 1,64 \\
\hline Diâmetro da órbita ocular & 41 & 27,15 & 37,39 & 34,33 & 2,22 \\
\hline Distância maxilar-pré-maxilar & 41 & 47,21 & 54,70 & 50,48 & 1,86 \\
\hline Distância interorbital & 41 & 27,79 & 34,66 & 31,65 & 1,31 \\
\hline \multirow[t]{2}{*}{ Altura da cabeça } & 41 & 93,30 & 109,65 & 101,35 & 3,35 \\
\hline & $\mathrm{n}$ & Mínimo & Máximo & Moda & \\
\hline Raios da nadadeira peitoral & 41 & $\mathrm{i}+12$ & $\mathrm{i}+13$ & $\mathrm{i}+13$ & \\
\hline Raios da nadadeira pélvica & 41 & $\mathrm{i}+6$ & $\mathrm{i}+8$ & $\mathrm{i}+7$ & \\
\hline Raios da nadadeira dorsal & 30 & $\mathrm{ii}+9$ & $\mathrm{ii}+9$ & $\mathrm{ii}+9$ & \\
\hline Raios da nadadeira anal & 41 & iv ++27 & iv +32 & $\mathrm{iv}+30$ & \\
\hline Escamas da linha lateral & 40 & 36 & 41 & 39 & \\
\hline Escamas acima da linha lateral & 38 & 8 & 9 & 8 & \\
\hline Escamas abaixo da linha lateral & 40 & 6 & 8 & 8 & \\
\hline Escamas do pedúnculo caudal & 30 & 16 & 18 & 17 & \\
\hline Escamas pré-dorsais & 38 & 11 & 13 & 12 & \\
\hline Pré-maxilar na fileira externa & 40 & 3 & 5 & 4 & \\
\hline Pré-maxilar na fileira interna & 41 & 4 & 5 & 5 & \\
\hline Dentes do maxilar & 35 & 1 & 4 & 2 & \\
\hline Dentes do dentário & 41 & 4 & 4 & 4 & \\
\hline
\end{tabular}




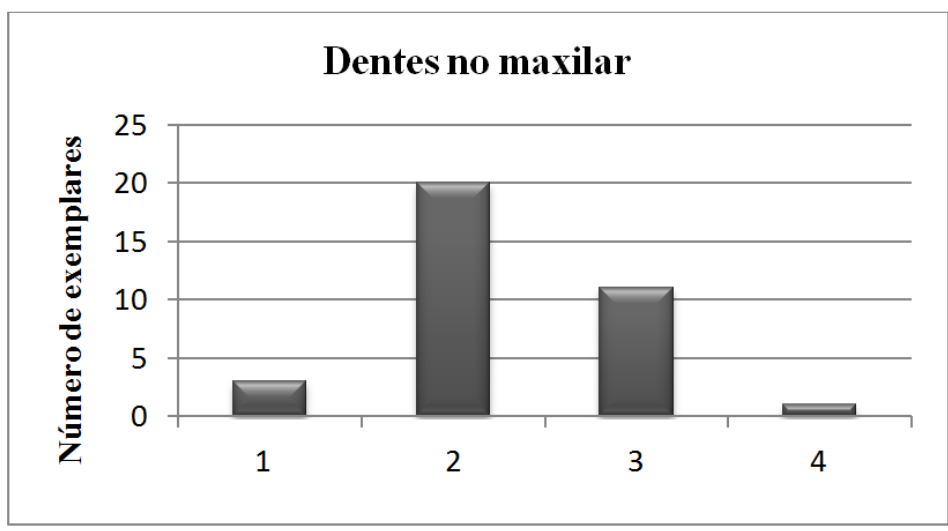

Gráfico 07. Distribuição da quantidade de dentes no maxilar dos exemplares examinados de $A$. moorii.

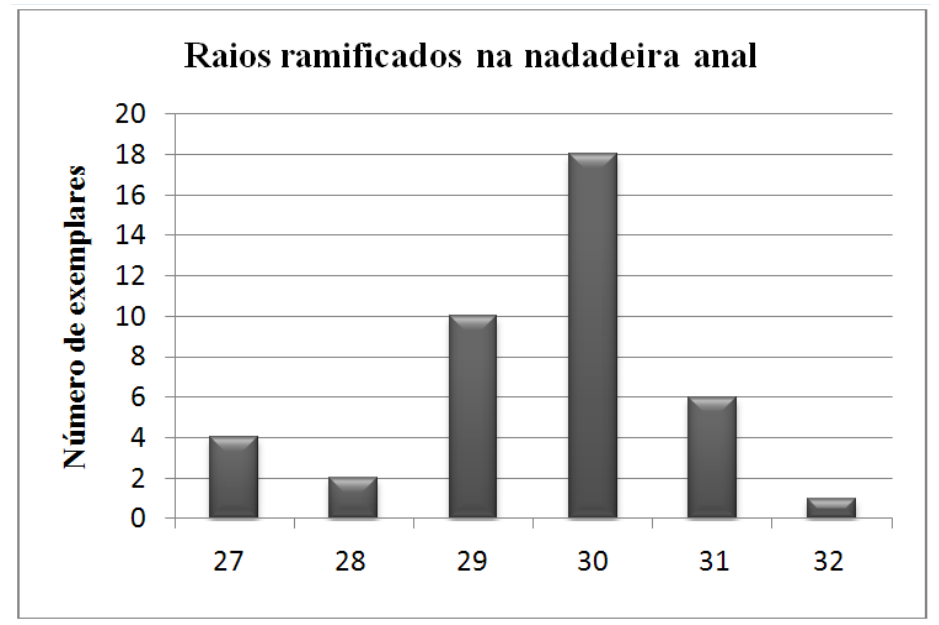

Gráfico 08. Distribuição da quantidade de raios ramificados na nadadeira anal dos exemplares examinados de A. moorii.

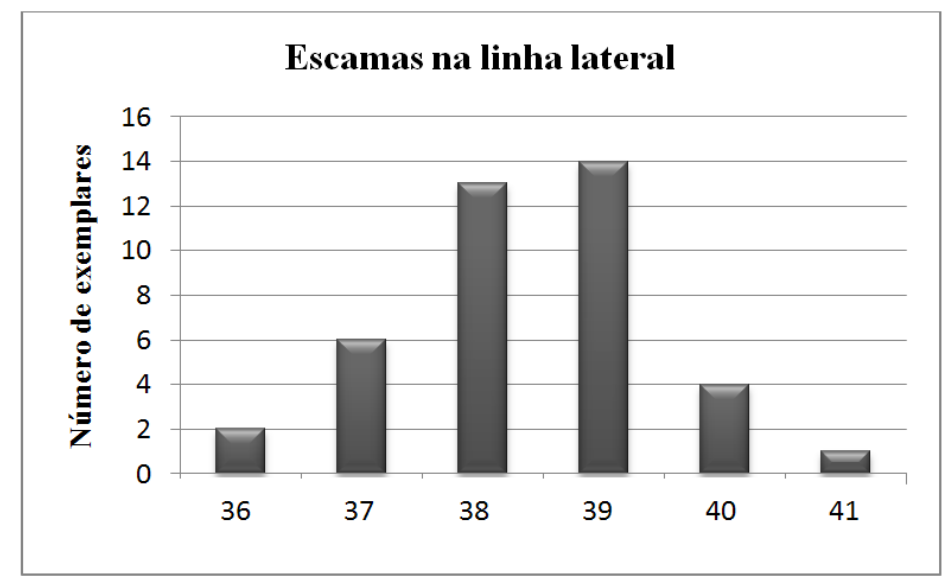

Gráfico 09. Distribuição da quantidade de escamas na linha lateral dos exemplares examinados de A. moorii. 


\section{Astyanacinus multidens Pearson, 1924}

Pearson (1924) pág. 41 e 42 (descrição original, fotografia do sintipo), Eigenmann (1927) pág. 340 e 341 (breve descrição, distribuição, material-tipo, localidade-tipo), Pearson (1937) pág. 108 (registro na Bacia do Rio Beni), Fowler (1940) pág. 100 (registro na Bolívia), Fowler (1948) pág. 35 (sinonímia, distribuição), Lauzanne \& Loubens (1985) pág. 110 (registro na Bacia do Rio Mamoré), Chang \& Ortega (1995) pág. 02 (citação), Lauzanne et al. (1991) pág. 66 (presença na região do Chapare Andino, na região de Yucumo, tamanho e peso máximos), Alonso \& Dallmeier (1998) pág. 66-68, 70 e 283 (registro na Bacia do Rio Urubamba), Chang (1998) (registro na Bacia do Rio Madre de Dios), Eschmeyer, (1998b) pág. 1130 (localidade-tipo, materialtipo), Chernoff \& Willink (1999) pág. 97 (registro na Bacia Amazônica Boliviana), Chernoff et al. (2000) pág. 279 (registro na Bacia Amazônica Boliviana), Herrera et al. (2000) pág. 144 (registro na Bacia do rio Beni), Alonso et al. (2001) pág. 146 (registro na Bacia do Rio Urubamba), Lima et al. (2003) em Reis et al. (2003) pág. 106 (localidade-tipo, material-tipo, distribuição), Bertaco et al. (2009) pág. 266 e 273 (distribuição e comparação com outras espécies de Astyanacinus).

\section{Material-tipo}

CAS 38955 Síntipos (16 ex., 9 mc, 79,78-124,30mm CP); La Paz Dept., Drenagem do Beni. Rio Colorado, tributário do baixo Rio Bopi, 10 milhas acima de San Miguel de Huachi. Col. N. E. Pearson, Expedição Mulford. 1/09/1921 - 30/09/1921.

\section{Diagnose}

Distingui-se de seus congêneres pela autapomórfica presença de numerosos dentes na maxila 9-13 (vs. 1-7), pelo menor comprimento do maior raio da nadadeira dorsal 21,5-25,7\% no CP (vs. 22,1-32,2\%), por menos raios ramificados na nadadeira anal iii+22-26 (vs. iii-iv+26-32) e pelo menor diâmetro do olho 20-29,7\% no CC (vs. $25,5-38,2 \%)$.

É distinguida ainda das outras espécies (exceto de A. sp. nova Peru ) pela origem da nadadeira anal posterior à vertical que passa pelo término da base da nadadeira dorsal (vs. origem da nadadeira anal anterior ou na vertical que passa pelo término da base da nadadeira dorsal), (exceto “A.” superbus) por ter mais escamas pré- 
dorsais 14-16 (vs. 11-13), mais escamas circumpedunculares 19-21 (vs. 17-19) e pela base da nadadeira anal menor (exceto de $\boldsymbol{A}$. sp. nova Peru ) 25-29,1\% no CP (vs. 29,6$37,9 \%)$.

Adicionalmente, é distinguida de “A.” orthodus pelo padrão de colorido no pedúnculo caudal composto por uma mancha baixa e alongada que alcança a base da nadadeira adiposa (curta e alta não alcançando a base da nadadeira adiposa), por mais dentes na maxila 9-13 (vs. 1-4), mais escamas pré-dorsais 14-16 (vs. 11-13), mais escamas circumpedunculares 19-21 (vs. 17-18), mais escamas na linha lateral 39-42 (vs. 36-40), menos raios na nadadeira anal iii+22-26 (vs. iii+26-31), menor comprimento da cabeça 22,4-26\% no CP (vs. 26,1-30,6\%), comprimento do maior raio da peitoral 1820,5\% no CP (vs. 20,3-24,7\%) e menor altura do corpo 29,1-34,7\% no CP (vs. 36,844,4\%); de “A.” superbus por mais dentes na maxila 9-13 (vs. 5-7) e ausência do padrão de colorido de faixas em zig-zag longitudinais ao corpo (vs. presença do padrão); de A. sp. nova Purus pela presença de chevrons pelo menos até a origem da nadadeira adiposa (vs. chevrons somente até o meio do corpo, não alcançando a adiposa) e menor comprimento da cabeça 22,4-26\% no CP (vs. 25,4-27,9); de A. sp. nova Bolívia pela ausência de ganchos nas nadadeiras anal e pélvica dos machos maduros (vs. presença de ganchos); de $\boldsymbol{A}$. moorii pelo menor comprimento da cabeça 22,4-26\% no CP (vs. 25,5-28,6\%) e de A. sp. nova Peru por apresentar uma maxila superior ligeiramente mais longa 47,6-53,3\% no CC (vs. 45-48,7\%) e pela ausência de uma faixa prateada na lateral do corpo exatamente sobre os chevrons (vs. presença da faixa).

\section{Descrição}

Dados merísticos e morfométricos dos exemplares examinados dessa espécie estão reunidos nas tabelas 04-05 e gráficos 10-12. Espécie de médio porte com o maior exemplar examinado apresentando o comprimento padrão de $124 \mathrm{~mm}$ enquanto que o menor apresentou $55 \mathrm{~mm}$. Corpo baixo, com a maior altura do corpo próxima à região da origem da nadadeira dorsal variando entre 29,1-34,7\% do comprimento padrão. Nadadeira peitoral nunca alcança a nadadeira pélvica. Nadadeira pélvica não alcança a nadadeira anal, porém ultrapassa o ânus. Perfil dorsal da cabeça (da ponta do focinho até a porção posterior do espinho supraoccipital) é ligeiramente convexo, do espinho supraoccipital até a origem da nadadeira dorsal é convexo. Cabeça pequena com 
comprimento que varia de 22,4-26\% do comprimento padrão e altura de 96,2-114,9\% no CC. O diâmetro da órbita é relativamente pequeno (20-39\% no CC). Maxila superior longa com comprimento variando a 47,6-53,3\% do comprimento da cabeça. A extremidade posterior do osso maxilar alcança e ultrapassa a vertical que passa pelo contato dorsal entre os infraorbitais 2 e 3, aproximadamente no centro da órbita. Margem ventral do infraorbital 1 não sobrepondo a margem dorsal da maxila ou sobrepondo muito pouco. Duas séries de dentes no osso pré-maxilar: a mais externa com cada lado apresentando 3(1), 4(13) ou 5(1) dentes tricuspidados e a série interna com 5(15) dentes pentacuspidados. Osso maxilar com 9(1), 10(4), 11(5), 12(3) ou 13(2) pequenos dentes tricuspidados ocupando grande porção da margem antero-medial do maxilar. Dentário com sempre 4 dentes pentacuspidados mais desenvolvidos e anteriores seguidos de numerosos pequenos dentículos. Nadadeira dorsal com ii+9 raios (15). A origem da nadadeira dorsal é um pouco posterior à vertical que passa pela origem da nadadeira pélvica. Nadadeira adiposa pequena com base anterior à vertical que passa pela inserção do último raio da nadadeira anal. Nadadeira peitoral com i+12(5) ou i+13(10). Nadadeira pélvica com i+7(15). Nadadeira anal com três raios não ramificados anteriores seguidos de 22(1), 23(7), 24(2), 25(4) e 26(1) raios ramificados. Origem da nadadeira anal posterior à vertical que passa pelo término da base da nadadeira dorsal. Linha lateral completa com 39(2), 40(5), 41(6) ou 42(2) escamas perfuradas. Oito (9) ou nove (6) séries longitudinais de escamas entre a nadadeira dorsal e a linha lateral; 7(6) ou 8(9) séries longitudinais de escamas entre a nadadeira anal e a linha lateral. Quatorze (1), quinze (10) ou dezesseis (4) escamas pré-dorsais em uma série irregular e 19(8), 20(6) ou 21(1) escamas ao redor do pedúnculo caudal. Apenas uma série de escamas recobrindo a base somente dos raios mais anteriores da nadadeira anal. Primeiro arco branquial com 10+1+9-10 rastros. Total de 38(1)* sendo 16(1)* são pré-caudais, 2(1)* de transição e 20(1)* caudais. Há 6(1)* supraneurais e a nadadeira dorsal está inserida após a décima vértebra (1)*.

\section{Coloração em álcool}

Mancha umeral horizontalmente alongada com não mais do que 4 escamas de comprimento e 2 escamas de altura disposta logo acima da linha lateral. Padrão de bandas escuras em forma de "V" lateralmente dispostas no corpo. Cerca de 15 estrias que começam um pouco antes da manha umeral, logo atrás do opérculo, e se estendem 
até próximo ao pendúnculo caudal. O padrão é difícil de ser observado em exemplares mal fixados (caracterizados pela coloração esbranquiçada de seus olhos). Esse é o caso dos síntipos desta espécie e dos lotes CAS 60728 e CAS 60730, porém ao examinar atentamente a região latero-dorsal desses exemplares é possível observar o referido padrão de manchas. No lote CAS 60729 da espécie o padrão de coloração é bastante evidente já que o exemplar foi bem fixado. Nos raios mais medianos da nadadeira caudal há uma banda escura que se distribui até a porção mais posterior destes raios e segue pelo pedúnculo caudal de maneira mais expandida e segue até aproximadamente a vertical que passa pela inserção do último raio da nadadeira anal. Corpo, em geral, com coloração ocre, mas principalmente na região dorsal e ventral. Região mediana do corpo com coloração prateada resultado da retenção de guanina nesse local. Série orbital e série opercular, em especial o opérculo, prateados e repletos de guanina e com cromatóforos em suas superfícies. Região dorsal do crânio com numerosos cromatóforos amarronzados. Escamas com porção posterior com cromatóforos amarronzados. Nadadeiras com coloração de um amarelo pálido. Nadadeira adiposa com cromatóforos em sua base e sua extremidade distal. Nadadeiras dorsal e peitoral com numerosos cromatóforos dispostos nos raios, porém poucos nas membranas que unem os raios. Nadadeira pélvica com raros cromatóforos nos raios. Nadadeira anal repleta de cromatóforos marrons nas membranas entre os raios, porém com poucos nos raios.

\section{Dimorfismo sexual}

Nenhuma característica que possa discriminar os sexos foi detectada

\section{Notas sobre a espécie}

Em dois lotes (CAS 60728 e CAS 38955) foram encontrados crustáceos Isopoda parasitas dentro da cavidade bucal de exemplares de Astyanacinus multidens. Os parasitas repousam no assoalho bucal e se posicionam de frente à fenda bucal de Astyanacinus. Devido ao avantajado espaço que o parasita ocupa, é bastante possível que este dificulte a alimentação dos peixes hospedeiros.

Foi descrito por Nathan Everett Pearson com base em material coletado na Bolívia em 1921 resultado da expedição Mulford (nome da expedição em referência à principal patrocinadora: H. K. Mulford Company). 


\section{Etimologia}

O nome multidens (Latin) é designado em alusão à grande quantidade de dentes no maxilar da espécie (9-13).

\section{Distribuição geográfica}

É descrito do Rio Colorado, Baixo Bopi, Bacia do Rio Beni; leste dos Andes.

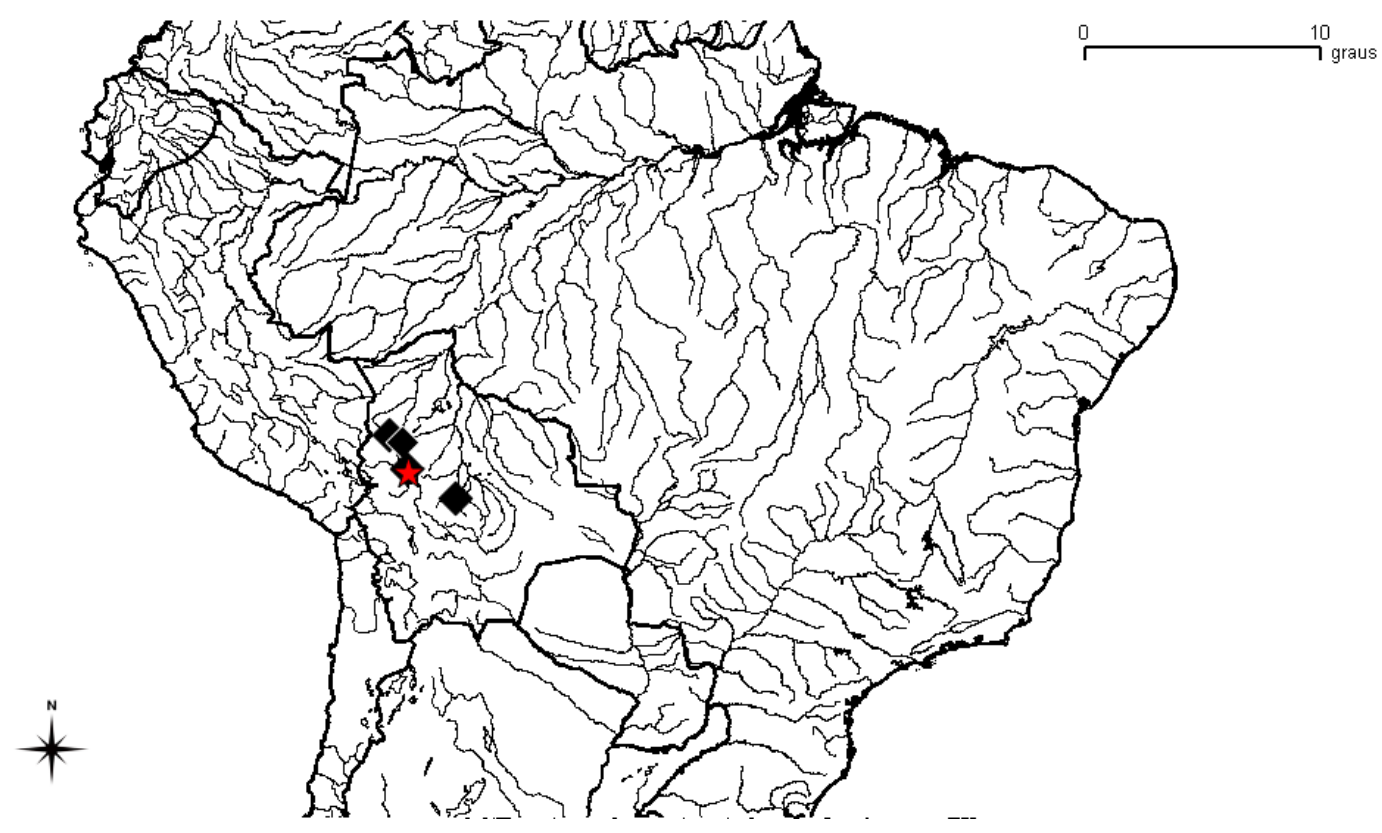

Figura 05. Mapa da distribuição geográfica de A. multidens. Estrela indica a localidade-tipo. Cada símbolo pode representar mais de um lote examinado.

\section{Material examinado}

\section{Bolívia}

CAS 38955 Síntipos (16 ex., 9 mc, 79,78-111,13 mm CP); La Paz Dept., Drenagem do Beni. Rio Colorado, tributário do baixo Rio Bopi, 10 milhas acima de San Miguel de Huachi. Col. N. E. Pearson, Expedição Mulford. 1/09/1921 - 30/09/1921. CAS 60728 (2 ex., 2 mc, 55,38-85,15 mm CP); El Beni Dept, Drenagem do Beni. Rio Popoi, Col. N. E. Pearson, Expedição Mulford. 1/9/1921 - 30/9/1921. CAS 60729 (1 ex., 1 mc, 63,24 mm CP); La Paz Dept, Drenagem do Beni. Tumupasa, 30 milhas ao norte de Rurrenabaque. Col. N. E. Pearson, Expedição Mulford. 1/12/1921 - 31/12/1921. CAS 60730 (1 ex., 1 mc, 71,28 mm CP); El Beni Dept., Drenagem do Beni. Rurrenabaque a 1500 pés de altitude. Col. N. E. Pearson, Expedição Mulford. 1/10/1921 - 31/10/1921. 
MZUSP 27829 (2 ex., 2 mc, 94-103,49 mm CP); Cristal Mayu, Drenagem do Beni. R.

Espírito Santo, acima de Villa Tunari. Col. Pisc. Orstom-UTB 24/06/1983.

Tabela 4. Dados merísticos e morfométricos de todos os lotes examinados de Astyanacinus multidens.

Astyanacinus multidens (Todo material)

\begin{tabular}{l|ccccc}
\hline \multicolumn{1}{l}{ n } & Mínimo & Máximo & Média & D. padrão \\
\hline Comprimento Padrão & 15 & 55,38 & 124,03 & 91,01 & \\
Altura do corpo & 15 & 29,07 & 34,70 & 31,94 & 1,64 \\
Distância pré-dorsal & 15 & 47,98 & 52,83 & 50,11 & 1,52 \\
Distância pré-ventral & 15 & 43,41 & 47,80 & 45,46 & 1,46 \\
Focinho-peitoral & 15 & 23,20 & 27,25 & 25,08 & 1,23 \\
Focinho-anal & 15 & 59,32 & 66,00 & 62,78 & 2,05 \\
Pélvica-anal & 15 & 16,14 & 19,54 & 17,98 & 1,04 \\
Altura do pedúnculo caudal & 15 & 11,01 & 14,10 & 12,10 & 0,82 \\
Base da nadadeira dorsal & 15 & 12,77 & 14,26 & 13,34 & 0,46 \\
Base da nadadeira anal & 15 & 24,98 & 29,11 & 27,44 & 1,27 \\
Distância dorsal-caudal & 15 & 52,79 & 57,90 & 55,14 & 1,36 \\
Maior raio da nadadeira peitoral & 15 & 17,98 & 20,51 & 18,86 & 0,67 \\
Maior raio da nadadeira pélvica & 15 & 13,83 & 18,65 & 15,23 & 1,21 \\
Maior raio da nadadeira dorsal & 15 & 21,49 & 25,65 & 23,15 & 1,38 \\
Maior raio da nadadeira anal & 15 & 13,55 & 18,36 & 15,44 & 1,60 \\
Comprimento da cabeça & 15 & 22,43 & 26,04 & 24,62 & 0,89 \\
Comprimento do focinho & 15 & 24,40 & 30,12 & 28,15 & 1,41 \\
Diâmetro da órbita ocular & 15 & 20,00 & 29,67 & 24,42 & 2,62 \\
Distância maxilar-pré-maxilar & 15 & 47,60 & 53,30 & 50,69 & 1,57 \\
Distância interorbital & 15 & 32,04 & 38,65 & 35,39 & 2,08 \\
Altura da cabeça & 15 & 96,20 & 114,87 & 102,95 & 4,47 \\
\hline & $\mathrm{n}$ & Mínimo & Máximo & Moda & \\
\cline { 1 - 4 } Raios da nadadeira peitoral & 15 & $\mathrm{i}+12$ & $\mathrm{i}+13$ & $\mathrm{i}+13$ & \\
Raios da nadadeira pélvica & 15 & $\mathrm{i}+7$ & $\mathrm{i}+7$ & $\mathrm{i}+7$ & \\
Raios da nadadeira dorsal & 15 & $\mathrm{ii}+9$ & $\mathrm{ii}+9$ & $\mathrm{ii}+9$ & \\
Raios da nadadeira anal & 15 & $\mathrm{iii}+22$ & $\mathrm{iii}+26$ & $\mathrm{iii}+23$ & \\
Escamas da linha lateral & 15 & 39 & 42 & 41 & \\
Escamas acima da linha lateral & 15 & 8 & 9 & 8 & \\
Escamas abaixo da linha lateral & 15 & 7 & 8 & 7 & \\
Escamas do pedúnculo caudal & 15 & 19 & 21 & 19 & \\
Escamas pré-dorsais & 15 & 14 & 16 & 15 & \\
Pré-maxilar na fileira externa & 15 & 4 & 4 & 4 & \\
Pré-maxilar na fileira interna & 15 & 5 & 5 & 5 & \\
Dentes do maxilar & 15 & 9 & 13 & 11 & \\
Dentes do dentário & 15 & 4 & 4 & 4 & \\
\hline
\end{tabular}


Tabela 5. Dados merísticos e morfométricos dos síntipos examinados de Astyanacinus multidens.

Astyanacinus multidens (Material-tipo)

\begin{tabular}{|c|c|c|c|c|c|}
\hline & $\mathrm{n}$ & Mínimo & Máximo & Média & D. padrão \\
\hline Comprimento Padrão & 9 & 79,78 & 124,03 & 99,17 & \\
\hline Altura do corpo & 9 & 29,07 & 33,02 & 31,34 & 1,32 \\
\hline Distância pré-dorsal & 9 & 48,32 & 51,73 & 49,96 & 1,19 \\
\hline Distância pré-ventral & 9 & 43,69 & 47,42 & 45,36 & 1,34 \\
\hline Focinho-peitoral & 9 & 23,54 & 27,25 & 25,02 & 1,20 \\
\hline Focinho-anal & 9 & 60,31 & 65,60 & 62,87 & 1,83 \\
\hline Pélvica-anal & 9 & 16,94 & 19,54 & 18,33 & 0,94 \\
\hline Altura do pedúnculo caudal & 9 & 11,16 & 12,61 & 11,84 & 0,50 \\
\hline Base da nadadeira dorsal & 9 & 12,78 & 13,94 & 13,20 & 0,39 \\
\hline Base da nadadeira anal & 9 & 24,98 & 28,23 & 26,88 & 1,28 \\
\hline Distância dorsal-caudal & 9 & 53,54 & 56,52 & 54,87 & 0,99 \\
\hline Maior raio da nadadeira peitoral & 9 & 17,98 & 20,51 & 18,89 & 0,71 \\
\hline Maior raio da nadadeira pélvica & 9 & 13,95 & 18,65 & 15,29 & 1,40 \\
\hline Maior raio da nadadeira dorsal & 9 & 21,49 & 25,65 & 22,60 & 1,30 \\
\hline Maior raio da nadadeira anal & 9 & 13,55 & 15,83 & 14,88 & 0,89 \\
\hline Comprimento da cabeça & 9 & 22,43 & 25,85 & 24,38 & 0,94 \\
\hline Comprimento do focinho & 9 & 27,28 & 30,12 & 28,68 & 1,02 \\
\hline Diâmetro da órbita ocular & 9 & 22,00 & 24,90 & 23,75 & 1,00 \\
\hline Distância maxilar-pré-maxilar & 9 & 48,33 & 53,30 & 51,27 & 1,42 \\
\hline Distância interorbital & 9 & 33,33 & 38,65 & 36,02 & 1,71 \\
\hline \multirow[t]{2}{*}{ Altura da cabeça } & 9 & 98,09 & 114,87 & 104,06 & 4,96 \\
\hline & $\mathrm{n}$ & Mínimo & Máximo & Moda & \\
\hline Raios da nadadeira peitoral & 9 & $\mathrm{i}+12$ & $\mathrm{i}+13$ & $\mathrm{i}+13$ & \\
\hline Raios da nadadeira pélvica & 9 & $\mathrm{i}+7$ & $\mathrm{i}+7$ & $\mathrm{i}+7$ & \\
\hline Raios da nadadeira dorsal & 9 & $\mathrm{ii}+9$ & $\mathrm{ii}+9$ & $\mathrm{ii}+9$ & \\
\hline Raios da nadadeira anal & 9 & $\mathrm{iii}+23$ & $\mathrm{iii}+25$ & $\mathrm{iii}+23$ & \\
\hline Escamas da linha lateral & 9 & 39 & 42 & 41 & \\
\hline Escamas acima da linha lateral & 9 & 8 & 9 & 9 & \\
\hline Escamas abaixo da linha lateral & 9 & 7 & 8 & 7 & \\
\hline Escamas do pedúnculo caudal & 9 & 19 & 20 & 19 & \\
\hline Escamas pré-dorsais & 9 & 15 & 16 & 15 & \\
\hline Pré-maxilar na fileira externa & 8 & 4 & 4 & 4 & \\
\hline Pré-maxilar na fileira interna & 8 & 5 & 5 & 5 & \\
\hline Dentes do maxilar & 9 & 10 & 12 & 10 & \\
\hline Dentes do dentário & 9 & 4 & 4 & 4 & \\
\hline
\end{tabular}




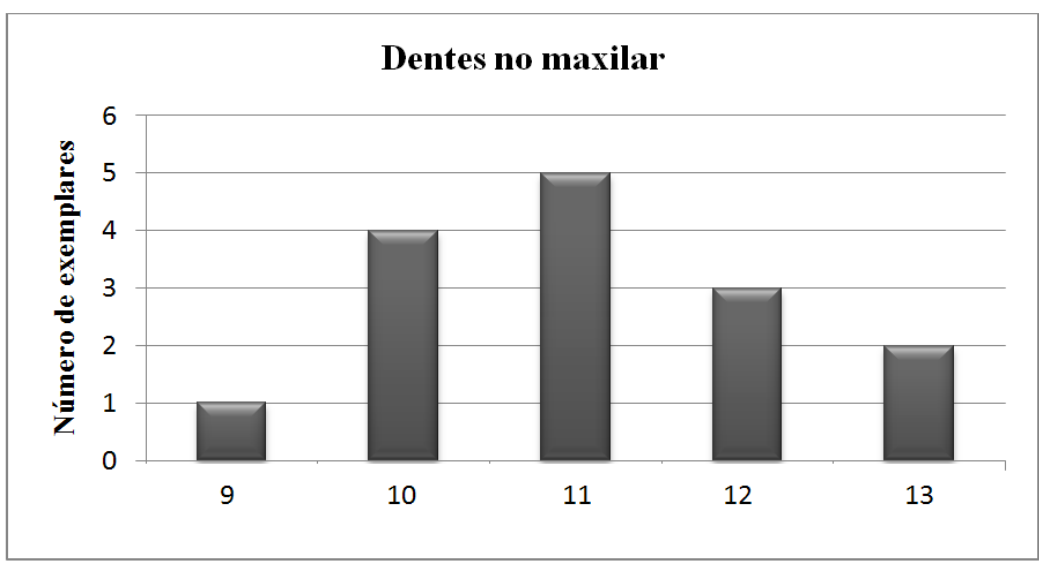

Gráfico 10. Distribuição da quantidade de dentes no maxilar dos exemplares examinados de $A$. multidens.

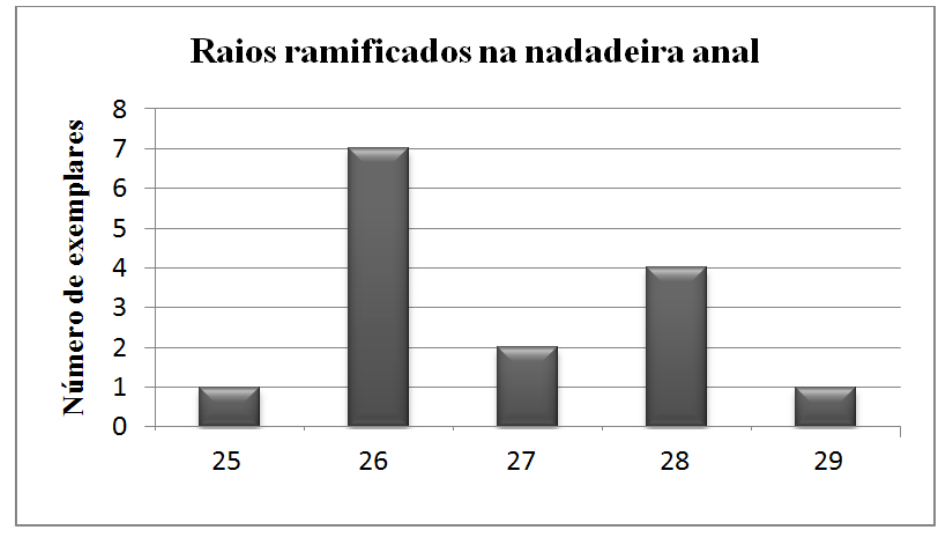

Gráfico 11. Distribuição da quantidade de raios ramificados na nadadeira anal dos exemplares examinados de A. multidens.

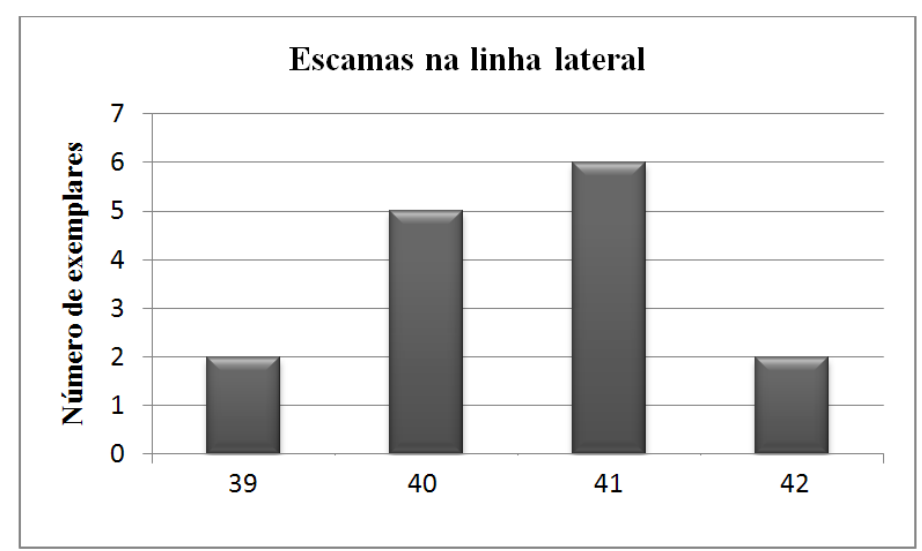

Gráfico 12. Distribuição da quantidade de escamas na linha lateral dos exemplares examinados de $A$. multidens. 


\section{Diagnose}

Distingui-se de seus congêneres pela autapomórfica condição de presença de ganchos nas nadadeiras anal e pélvica dos machos maduros (vs. ausência de ganchos). De A. multidens e A. sp. nova Peru pela origem da nadadeira anal ser aproximadamente na vertical que passa pelo término da base da nadadeira dorsal (vs. posterior à vertical que passa pelo término da base da nadadeira dorsal).

É distinguida de $\boldsymbol{A}$. multidens por menos dentes na maxila 2-5 (vs. 9-13), menos escamas pré-dorsais 11-13 (vs. 14-16), menos escamas circumpedunculares 17-20 (vs. 19-21) e por mais raios na nadadeira anal iii-iv+27-31 (vs. iii+22-26), pelo comprimento do maior raio da nadadeira dorsal 23,4-29,6\% no CP (vs. 21,5-25,7\%), pelo menor diâmetro do olho 28,1-36,7\% no CC (vs. 20-29,7\%) e pela base da nadadeira anal maior 29,8-35\% no CP (vs. 25-29,1\%); de “A.” superbus por menos dentes na maxila 2-5 (vs. 5-7) e ausência do padrão de colorido de faixas em zig-zag longitudinais ao corpo (vs. presença do padrão); de $\boldsymbol{A}$. sp. nova Purus pela presença de chevrons pelo menos até a origem da nadadeira adiposa (vs. chevrons somente até o meio do corpo, não alcançando a adiposa); de “A.” orthodus pelo padrão de colorido no pedúnculo caudal composto por uma mancha baixa e alongada que alcança a base da nadadeira adiposa (vs. curta e alta não alcançando a base da nadadeira adiposa) e de $\boldsymbol{A}$. moorii pela maior altura do corpo 31,1-40,7\% no CP (vs. 30,8-38,4\%) e por apresentar, em sua maioria, exemplares com 3-4 dentes (vs. 2-3) e de A. sp. nova Peru por apresentar uma maxila superior ligeiramente mais longa 45,9-56,8\% no CC (vs. 45$48,7 \%$ ) e pela ausência de uma faixa prateada na lateral do corpo exatamente sobre os chevrons (vs. presença da faixa).

\section{Descrição}

Dados merísticos e morfométricos dos exemplares examinados dessa espécie estão reunidos na tabela 06 e gráficos 13-15. Espécie de médio porte com o maior exemplar examinado apresentando o comprimento padrão de 85,84 mm enquanto que o menor possui 36,21 mm. Nadadeira peitoral alcança a nadadeira pélvica e nadadeira pélvica quase ou alcança a nadadeira anal. Perfil dorsal da cabeça (da ponta do focinho até a porção posterior do espinho supraoccipital) é côncavo, do espinho supraoccipital até a origem da nadadeira dorsal é marcadamente convexo. Cabeça com comprimento nunca 
maior que 29,2\% do comprimento padrão. Maxila superior longa variando de 45,956,8\% no comprimento da cabeça com a extremidade posterior do osso maxilar quase alcançando a vertical que passa no contato dorsal entre os infraorbitais 2 e 3, aproximadamente no centro da órbita. Margem ventral do infraorbital 1 sobrepondo a margem dorsal da maxila. Duas séries de dentes no osso pré-maxilar: a mais externa com cada lado apresentando 3(1), 4(37), 5(5) ou 6(1) dentes tricuspidados, geralmente com três dentes mais centralizados e um mais lateral. Série interna com 5(44) dentes pentacuspidados. Osso maxilar com 2(5), 3(37), 4(14) ou 5(1) pequenos dentes tricuspidados. Dentário com sempre 4(30) dentes mais desenvolvidos pentacuspidados anteriores seguidos de numerosos pequenos dentículos. Nadadeira dorsal com ii +9 raios (30). A origem da nadadeira dorsal é um pouco posterior à vertical que passa pela origem da nadadeira pélvica. Nadadeira adiposa pequena com base anterior à vertical que passa pela inserção do último raio da nadadeira anal. Nadadeira peitoral com i+11(3), i+12(18) ou i+13(16). Nadadeira pélvica com i+6(1), i+7(32) ou i+8(4). Nadadeira anal com iii(44) ou iv(9) raios não ramificados anteriores seguidos de 27(6), 28(18), 29(22), 30(7) e 31(1) raios ramificados. Origem da nadadeira anal anterior ou na vertical que passa pelo término da base da nadadeira dorsal. Linha lateral completa pouco curvada ventralmente com 37(1), 38(11), 39(20), 40(16) ou 41(3) escamas perfuradas. Oito (24), 9(27) ou 10(2) séries longitudinais de escamas entre a nadadeira dorsal e a linha lateral; 7(23) ou 8(30) séries longitudinais de escamas entre a nadadeira anal e a linha lateral. Onze (1), 12(21) ou 13(29) escamas pré-dorsais em uma série irregular e 17(11), 18(30), 19(5) ou 20(2) escamas ao redor do pedúnculo caudal. Apenas uma série de escamas recobrindo a base de metade dos raios da nadadeira anal. Primeiro arco branquial com 11+1+9-10 rastros. Total de 36(1) ou 38(1) vértebras sendo 15(2) pré-caudais, 2(2) de transição e 19(1) ou 21(1) caudais. Há 5(2) supraneurais e a nadadeira dorsal está inserida após a nona vértebra (2).

\section{Coloração em álcool}

Mancha umeral horizontalmente alongada ocupando área de aproximadamente 5 escamas em seu comprimento e 2 escamas em sua altura. A mancha está localizada na fileira de escamas logo acima da linha lateral. Logo após, há uma faixa vertical com pouco cromatóforos marrons dando a impressão dá área ser despigmentada. Posterior à essa área existe uma segunda mancha verticalmente alongada, porém bastante difusa e 
fraca. Marcante padrão de estrias lateralmente dispostas no corpo formado por bandas escuras em forma de "V" deitados com seus vértices anteriormente direcionados. Cerca de 10 a 14 estrias que começam um pouco antes da manha umeral, logo atrás do opérculo, e se estendem até próximo ao pendúnculo caudal, aproximadamente na vertical que passa pela origem da nadadeira adiposa. O vértice dessas estrias localizamse em uma linha escura paralela ao comprimento do peixe e que está medianamente posicionada em relação à altura do corpo. A mancha inicia-se logo após a mancha umeral de maneira menos conspícua e se intensifica posteriormente. Aproximadamente na vertical que passa pela origem da nadadeira adiposa a linha expande-se em altura formando uma marcada macha escura no pedúnculo caudal do peixe e prolonga-se, mais delgada, até a porção distal dos raios medianos da nadadeira caudal. O padrão é facilmente observado em todos os exemplares analisados. Corpo com coloração alaranjada ou marrom pálida. Em alguns exemplares examinados há deposito de guanina na séries infra-orbital e opercular. Corpo com muitos cromatóforos amarronzados com concentração em toda a região dorsal do corpo. Escamas possuem concentração de cromatóforos na borda posterior.

Nadadeiras com coloração de um amarelo pálido. Nadadeira adiposa com alguns cromatóforos marrons. Nadadeiras com cromatóforos marrons nas membranas interradiais, mas nunca nos raios. Nadadeira anal com maior concentração de cromatóforos na porção distal dos raios.

\section{Dimorfismo sexual}

Machos possuem ganchos nas nadadeiras anal e pélvica. Fêmeas são ligeiramente maiores e mais altas (lote CAS 68367) (figura 53). Fotos da nadadeira anal do lote CAS 68367 (figura 52).

\section{Notas sobre a espécie}

Espécie do complexo A. moorii. É possível que a separação desta espécie de A. moorii seja um artefato de pouco material disponível de Astyanacinus. A principal característica que distingue esta espécie de A. moorii é a presença de ganchos nas nadadeiras anal e pélvica de machos maduros, porém somente exemplares de pequeno porte (até 58,07 mm CP) de Astyanacinus moorii foram examinados o que pode ter influenciado na ausência de ganchos nesses exemplares. Apesar de considerar essa 
possibilidade, é importante ressaltar que diversos machos dotados de ganchos da espécie $A$. sp. nova Bolívia eram bastante pequenos, mas maduros, mesmo com tamanho reduzido (por exemplo, um exemplar de 43,8 mm CP do lote CAS 68369). Dessa forma, prefiro considerar que A. moorii provavelmente é uma espécie de pequeno porte e não apresenta ganchos nas nadadeiras.

\section{Distribuição geográfica}

Bacia do Alto Rio Madeira

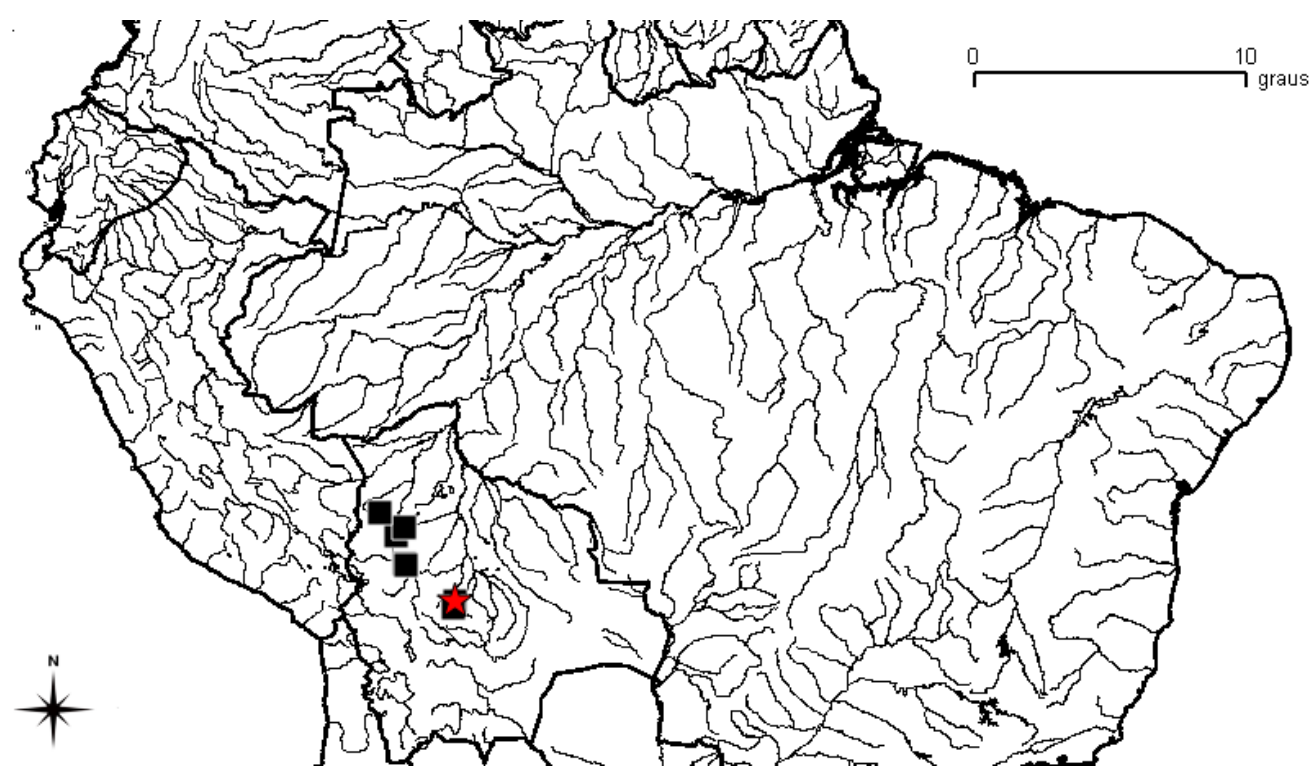

Figura 06. Mapa da distribuição geográfica de A. sp. nova Bolívia. Estrela indica a localidade-tipo.

\section{Material examinado}

\section{Bolívia}

CAS 68365 (7 ex., 7 mc, 45,35-71,58 mm CP); El Beni Dept, Drenagem do Beni. Rio Popoi, Col. N. E. Pearson, Expedição Mulford. 1/9/1921 - 30/9/1921. CAS 68367 (12 ex., 8 mc, 46-65,8 mm CP); La Paz Dept, Drenagem do Beni. Tumupasa, 30 milhas ao norte de Rurrenabaque., Col. N. E. Pearson, Expedição Mulford. 1/12/1921 31/12/1921. CAS 68368 (3 ex., 3 mc, 46,85-85,84 mm CP); La Paz Dept, Rurrenabaque, Drenagem do Beni. Rio Beni. 1500 pés de altitude. Col N. E. Pearson, Expedição Mulford. 1/1921. CAS 68369 (5 ex., 5 mc, 64,57-43,8 mm CP); La Paz Dept, Drenagem do Beni. Iximias, uma vila 60 milhas ao noroeste de Rurrenabaque. 
Col. N. E. Pearson, Expedição Mulford. CAS 68370 (13 ex., 8 mc, 37,9-59,14 mm CP); Beni Dept, Drenagem do Beni. San Miguel Del Huachi, na confluência do Rios Bopi em altitude de 2,235 pés. Col. N. E. Pearson, Expedição Mulford. MCP 35017 (14 ex., 14 mc, 2 c\&s, 48,2-65,42 mm CP); Cochabamba, Drenagem do Madeira. Arroio do Hotel El Puent, Villa Tunari, afluente do rio Chapare. Col T. Oberdorff, r. Bigorne, M.

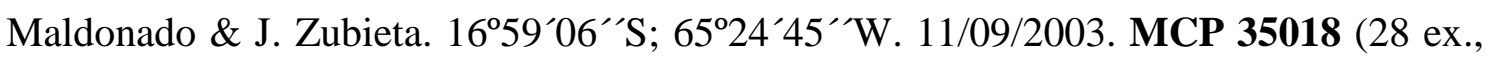
8 mc, 36,2-43,3 mm CP); Cochabamba, Drenagem do Madeira. Rio Ichoa, afluente do

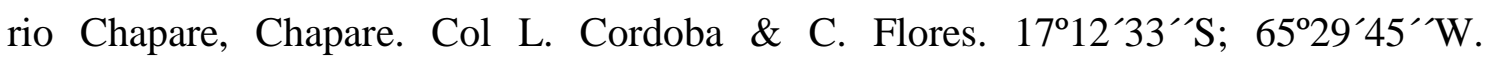
12/09/2002. MZUSP 27809 (4 ex., 4 mc, 50,16-66,86 mm CP); Villa Tunari, Rio Chapare. Col. Conv.Pisc.Orstom-Utb. 22/06/1983.

Tabela 06. Dados merísticos e morfométricos de Astyanacinus sp. nova Bolívia 


\begin{tabular}{|c|c|c|c|c|c|}
\hline \multicolumn{6}{|c|}{ Astyanacinus sp. nova Bolívia } \\
\hline & $\mathrm{n}$ & Mínimo & Máximo & Média & Desvio padrão \\
\hline Comprimento Padrão & 57 & 36,21 & 85,84 & 53,85 & \\
\hline Altura do corpo & 57 & 31,11 & 40,70 & 36,70 & 2,28 \\
\hline Distância pré-dorsal & 57 & 46,34 & 52,80 & 50,59 & 1,38 \\
\hline Distância pré-ventral & 57 & 44,29 & 49,74 & 47,38 & 1,28 \\
\hline Focinho-peitoral & 57 & 24,09 & 29,80 & 27,23 & 1,17 \\
\hline Focinho-anal & 57 & 60,20 & 65,93 & 63,06 & 1,48 \\
\hline Pélvica-anal & 57 & 13,18 & 18,91 & 16,41 & 1,36 \\
\hline Altura do pedúnculo caudal & 57 & 9,07 & 11,89 & 10,99 & 0,58 \\
\hline Base da nadadeira dorsal & 57 & 12,17 & 15,84 & 13,97 & 0,81 \\
\hline Base da nadadeira anal & 57 & 28,67 & 34,97 & 31,85 & 1,17 \\
\hline Distância dorsal-caudal & 57 & 51,33 & 58,70 & 55,79 & 1,49 \\
\hline Maior raio da nadadeira peitoral & 57 & 19,46 & 23,59 & 21,79 & 1,00 \\
\hline Maior raio da nadadeira pélvica & 57 & 14,41 & 19,44 & 16,59 & 1,23 \\
\hline Maior raio da nadadeira dorsal & 57 & 23,44 & 29,60 & 27,15 & 1,31 \\
\hline Maior raio da nadadeira anal & 57 & 14,56 & 20,13 & 17,35 & 1,24 \\
\hline Comprimento da cabeça & 57 & 24,23 & 29,17 & 26,44 & 1,06 \\
\hline Comprimento do focinho & 57 & 23,66 & 29,86 & 27,08 & 1,24 \\
\hline Diâmetro da órbita ocular & 57 & 28,13 & 36,74 & 32,64 & 2,25 \\
\hline Distância maxilar-pré-maxilar & 57 & 43,40 & 56,75 & 50,44 & 2,63 \\
\hline Distância interorbital & 57 & 27,96 & 37,40 & 33,12 & 1,95 \\
\hline \multirow[t]{2}{*}{ Altura da cabeça } & 57 & 99,43 & 122,04 & 109,35 & 5,45 \\
\hline & $\mathrm{n}$ & Mínimo & Máximo & Moda & \\
\hline Raios da nadadeira peitoral & 37 & $\mathrm{i}+11$ & $\mathrm{i}+13$ & $\mathrm{i}+12$ & \\
\hline Raios da nadadeira pélvica & 37 & $\mathrm{i}+6$ & $\mathrm{i}+8$ & $\mathrm{i}+7$ & \\
\hline Raios da nadadeira dorsal & 30 & $i i+9$ & $\mathrm{ii}+9$ & $\mathrm{ii}+9$ & \\
\hline Raios da nadadeira anal & 54 & $\mathrm{iii}+27$ & $i v+30$ & $\mathrm{iii}+29$ & \\
\hline Escamas da linha lateral & 51 & 37 & 41 & 39 & \\
\hline Escamas acima da linha lateral & 53 & 8 & 10 & 9 & \\
\hline Escamas abaixo da linha lateral & 53 & 7 & 8 & 8 & \\
\hline Escamas do pedúnculo caudal & 51 & 17 & 20 & 18 & \\
\hline Escamas pré-dorsais & 48 & 11 & 13 & 13 & \\
\hline Pré-maxilar na fileira externa & 44 & 3 & 6 & 4 & \\
\hline Pré-maxilar na fileira interna & 44 & 5 & 5 & 5 & \\
\hline Dentes do maxilar & 57 & 2 & 5 & 3 & \\
\hline Dentes do dentário & 30 & 4 & 4 & 4 & \\
\hline
\end{tabular}




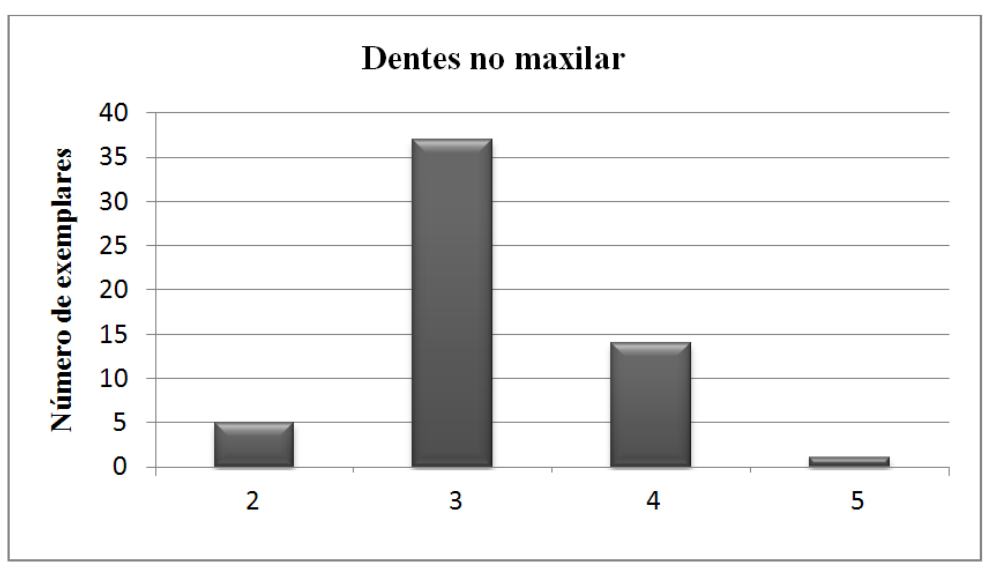

Gráfico 13. Distribuição da quantidade de dentes no maxilar dos exemplares examinados de A. sp. nova Bolívia.

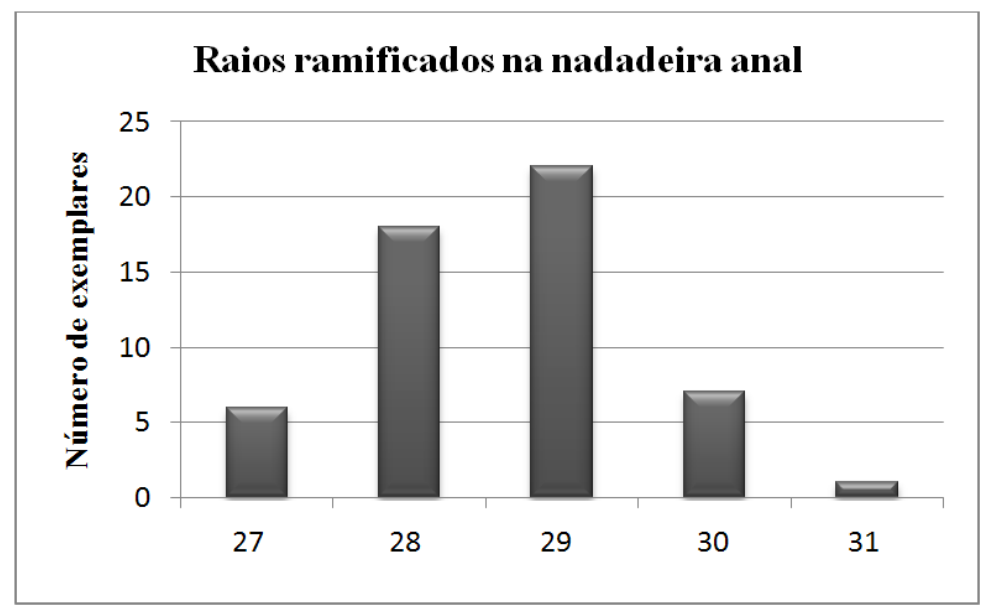

Gráfico 14. Distribuição da quantidade de raios ramificados na nadadeira anal dos exemplares examinados de A. sp. nova Bolívia.

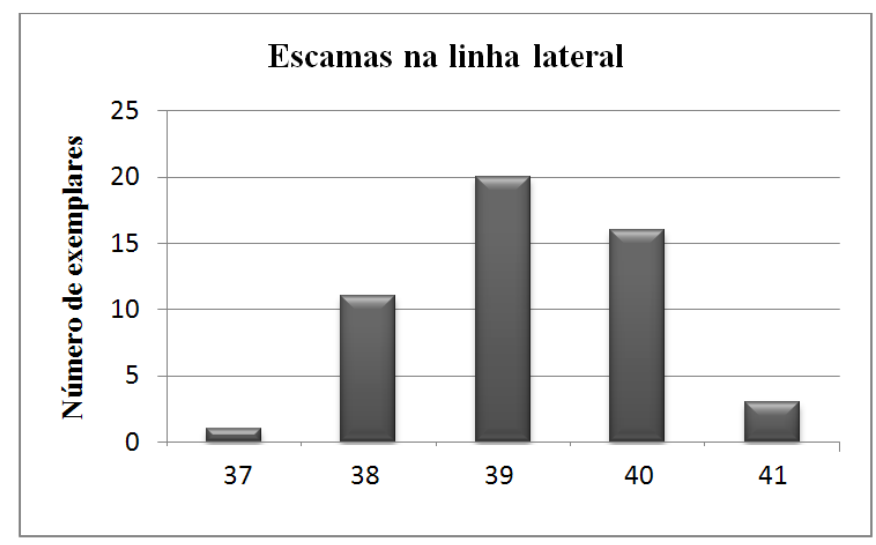

Gráfico 15. Distribuição da quantidade de escamas na linha lateral dos exemplares examinados de A. sp. nova Bolívia. 


\section{Astyanacinus sp. nova Purus}

\section{Diagnose}

Distingui-se de seus congêneres pelo autapomórfico padrão de colorido composto por de chevrons somente até o meio do corpo, não alcançando a adiposa (vs. pelo menos até a origem da nadadeira adiposa). De $A$. multidens e $A$. sp. nova Peru pela origem da nadadeira anal ser aproximadamente na vertical que passa pelo término da base da nadadeira dorsal (vs. posterior à vertical que passa pelo término da base da nadadeira dorsal).

É distinguida de $\boldsymbol{A}$. multidens por menos dentes na maxila 2-3 (vs. 9-13), menos escamas pré-dorsais 12-13 (vs. 14-16), menos escamas circumpedunculares 17 (vs. 1921) e por mais raios na nadadeira anal iii-iv+28-29 (vs. iii+22-26), pelo menor diâmetro do olho 28,7-32,6\% no CC (vs. 20-29,7\%), pela base da nadadeira anal maior 3132,16\% no CP (vs. 25-29,1\%), maior altura do corpo 35,7-37,1\% no CP (vs. 29,134,7\%), maior comprimento da cabeça 25,4-27,9\% no CP (vs. 22,4-26\%) e menor distância interorbital 29-33,4\% no CC (vs. 32-38,7\%); de “A.” superbus por menos dentes na maxila 2-3 (vs. 5-7), ausência do padrão de colorido de faixas em zig-zag longitudinais ao corpo (vs. presença do padrão), maior distância pré-dorsal 47,3-49\% no CP (vs. 45,1-47,2\%) e maior distância focinho-anal 62,8-64,3\% no CP (vs. 59,762,7\%); de $\boldsymbol{A}$. sp. nova Bolívia pela ausência de ganchos nas nadadeiras anal e pélvica dos machos maduros (presença de ganchos) e pelo menor comprimento do maior raio da nadadeira dorsal 22-24\% no CP (vs. 23,4-29,6\%); de “A.” orthodus pelo padrão de colorido no pedúnculo caudal composto por uma mancha baixa e alongada que alcança a base da nadadeira adiposa (curta e alta não alcançando a base da nadadeira adiposa), menor altura do corpo 29,1-34,7\% no CP (vs. 35,7-37,1\%) e menor comprimento do maior raio da peitoral 19-20,3\% no CP (vs. 19,5-23,6\%); de $\boldsymbol{A}$. sp. nova Peru pela ausência de uma faixa prateada na lateral do corpo exatamente sobre os chevrons (vs. presença da faixa) e acima da linha lateral que se inicia após a cabeça e prolonga-se até o pedúnculo caudal (vs. presença da faixa), maior altura do corpo 35,7-37,1\% no CP (vs. 31,7-35,9\%) e pela base da nadadeira anal maior 31-32,16\% no CP (vs. 26,4$31,1 \%)$ e $\boldsymbol{A}$. moorii pelo menor comprimento do maior raio da nadadeira dorsal $22-24 \%$ no CP (vs. 24,3-30,8\%). 


\section{Descrição}

Dados merísticos e morfométricos dos exemplares examinados dessa espécie estão reunidos na tabela 07 e gráficos 16-18. Espécie de pequeno porte com o maior exemplar examinado apresentando o comprimento padrão de 58,3 mm enquanto que o menor possui 41,16 mm. Nadadeira peitoral quase alcança a base nadadeira pélvica. Nadadeira pélvica não alcança a origem da nadadeira anal. Perfil dorsal da cabeça (da ponta do focinho até a porção posterior do espinho supraoccipital) é côncavo; do espinho supraoccipital até a origem da nadadeira dorsal é marcadamente convexo. Cabeça pequena com comprimento nunca maior que 27,9\% do comprimento padrão. Maxila superior variando de 44,2-46,6\% no comprimento da cabeça com a extremidade posterior do osso maxilar quase alcançando a vertical que passa no contato dorsal entre os infraorbitais 2 e 3, aproximadamente no centro da órbita. Margem ventral do infraorbital 1 sobrepondo a margem dorsal da maxila. Duas séries de dentes no osso pré-maxilar: a mais externa com cada lado apresentando 4(3) dentes tricuspidados, geralmente com três dentes mais centralizados e um mais lateral. Série interna com 5(3) dentes pentacuspidados. Osso maxilar com 2(1) ou 3(2) pequenos dentes tricuspidados. Dentário com sempre 4(3) dentes mais desenvolvidos pentacuspidados anteriores seguidos de numerosos pequenos dentículos. Nadadeira dorsal com ii+9 raios (3). A origem da nadadeira dorsal é um pouco posterior à vertical que passa pela origem da nadadeira pélvica. Nadadeira adiposa pequena com base anterior à vertical que passa pela inserção do último raio da nadadeira anal. Nadadeira peitoral com i+13(2) ou i+14(1). Nadadeira pélvica com i+8(3). Nadadeira anal com iii(1) ou iv(2) raios não ramificados anteriores seguidos de 28(2) ou 29(1) raios ramificados. Origem da nadadeira anal aproximadamente na vertical que passa pelo término da base da nadadeira dorsal. Linha lateral completa pouco curvada ventralmente com 39(2) ou 40(1) escamas perfuradas. Sete (3) séries longitudinais de escamas entre a nadadeira dorsal e a linha lateral; 8(3) séries longitudinais de escamas entre a nadadeira anal e a linha lateral. Doze (2) ou 13(1) escamas pré-dorsais em uma série irregular e 17(1) escamas ao redor do pedúnculo caudal. Apenas uma série de escamas recobrindo a base de, pelo menos, metade dos raios da nadadeira anal. 


\section{Coloração em álcool}

Mancha umeral oval bem definida ocupando área de aproximadamente 4 escamas em seu comprimento e 2 escamas em sua altura. A mancha está localizada logo acima da linha lateral ocupando a porção mais dorsal da escama que a compõem. Posteriormente, há uma faixa vertical com poucos cromatóforos marrons dando a impressão dá área ser despigmentada. Entre essa área despigmentada existem duas manchas verticalmente alongadas, porém bastante difusas e fracas. A mancha umeral está posicionada na cima da mancha vertical difusa mais anterior. Presença de estrias lateralmente dispostas no corpo formado por bandas escuras em forma de "V" deitados com seus vértices anteriormente direcionados. Os vértices encontram-se alinhados em uma faixa negra longitudinal que se inicia no meio do corpo, abaixo da base da nadadeira dorsal, e segue até o pedúnculo caudal. São poucas estrias (cerca de 8 ou 9) que começam depois da mancha umeral e se estendem até, aproximadamente, à vertical que passa pela porção distal do mais longo raio da nadadeira dorsal. Contínua com a faixa negra longitudinal do corpo há uma mancha no pedúnculo caudal mais alongada do que alta que se inicia, aproximadamente, na vertical que passa pela origem da nadadeira adiposa e prolonga-se até a porção mais distal dos raios medianos da nadadeira caudal. Corpo com coloração amarelo-pálido sutilmente mais escuro dorsalmente. Em nenhum dos exemplares examinados há deposito de guanina. Corpo com muitos cromatóforos amarronzados em maiores concentrações na região dorsal. Escamas com muitos cromatóforos e com maior concentração na região periférica da região posterior da escama. Nadadeiras com cromatóforos nas bainhas inter-radiais, mas não nos raios. Nadadeira adiposa com muitos cromatóforos marrons dispersos homogeneamente.

\section{Dimorfismo sexual}

Nenhuma característica que possa discriminar os sexos foi encontrada.

\section{Distribuição geográfica}

Bacia do Rio Purus 


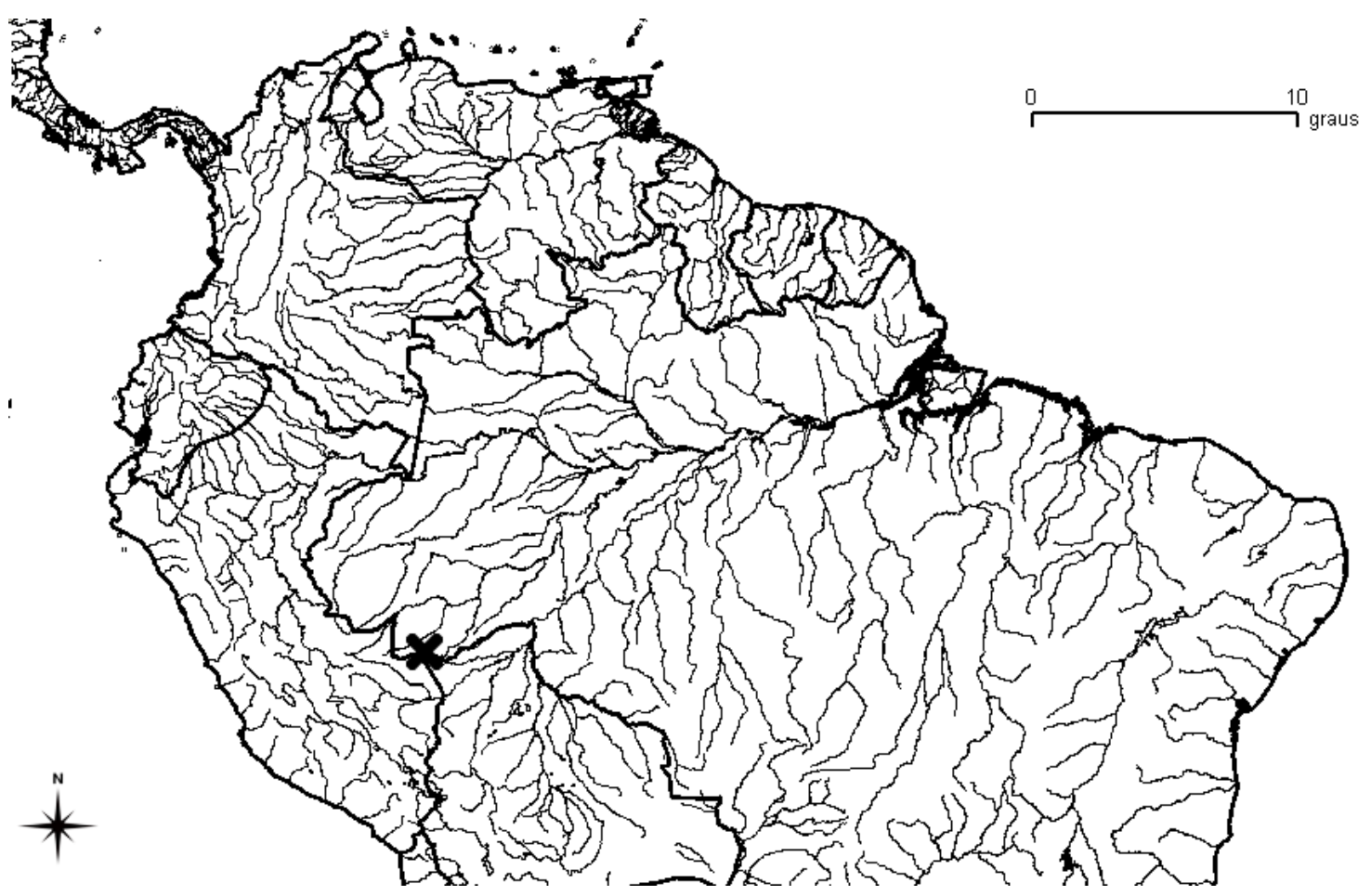

Figura 07. Mapa da distribuição geográfica de A. sp. nova Purus.

\section{Material examinado}

Acre: MCP 39773 (3 ex., 3 mc, 41,16-58,3 mm CP); Brasiléia, Drenagem do Purus. Pequeno igarapé no ramal Oitenta e Oito, ca. De 1,2 km ao N da BR-317, e a NE de Assis Brasil. Col R. E. Reis, F. C. T. Lima, P. Lehmann \& E. Pereira. 1047’50”'S; 69²4’36”W. 23/07/2004. 
Tabela 7. Dados merísticos e morfométricos de Astyanacinus sp. nova Purus

\begin{tabular}{|c|c|c|c|c|c|c|}
\hline \multicolumn{7}{|c|}{ A. sp. nova Purus } \\
\hline & $\mathrm{n}$ & Holótipo & Mínimo & Máximo & Média & D. padrão \\
\hline Comprimento Padrão & 3 & 58,3 & 41,2 & 58,3 & 47,1 & \\
\hline Altura do corpo & 3 & 37,1 & 35,74 & 37,10 & 36,56 & 0,63 \\
\hline Distância pré-dorsal & 3 & 53,2 & 50,57 & 53,21 & 51,96 & 1,18 \\
\hline Distância pré-ventral & 3 & 49,0 & 47,29 & 48,98 & 48,39 & 0,81 \\
\hline Focinho-peitoral & 3 & 28,0 & 26,05 & 27,99 & 27,09 & 0,87 \\
\hline Focinho-anal & 3 & 64,3 & 62,80 & 64,26 & 63,60 & 0,66 \\
\hline Pélvica-anal & 3 & 17,4 & 15,60 & 17,36 & 16,25 & 0,83 \\
\hline Altura do pedúnculo caudal & 3 & 12,5 & 11,37 & 12,49 & 11,94 & 0,50 \\
\hline Base da nadadeira dorsal & 3 & 13,7 & 12,88 & 13,68 & 13,36 & 0,37 \\
\hline Base da nadadeira anal & 3 & 32,2 & 30,95 & 32,16 & 31,49 & 0,55 \\
\hline Distância dorsal-caudal & 3 & 56,6 & 53,32 & 56,55 & 54,51 & 1,53 \\
\hline Maior raio da nadadeira peitoral & 3 & 20,3 & 18,99 & 20,34 & 19,48 & 0,64 \\
\hline Maior raio da nadadeira pélvica & 3 & 15,2 & 14,12 & 15,15 & 14,58 & 0,47 \\
\hline Maior raio da nadadeira dorsal & 3 & 24,0 & 22,04 & 24,04 & 22,97 & 0,90 \\
\hline Maior raio da nadadeira anal & 3 & 14,9 & 12,30 & 14,94 & 13,74 & 1,19 \\
\hline Comprimento da cabeça & 3 & 27,9 & 25,39 & 27,92 & 26,83 & 1,15 \\
\hline Comprimento do focinho & 3 & 28,4 & 26,14 & 28,38 & 27,46 & 1,03 \\
\hline Diâmetro da órbita ocular & 3 & 32,6 & 28,72 & 32,55 & 30,84 & 1,73 \\
\hline Distância maxilar-pré-maxilar & 3 & 46,6 & 44,19 & 46,62 & 45,24 & 1,11 \\
\hline Distância interorbital & 3 & 33,4 & 29,05 & 33,45 & 30,93 & 2,00 \\
\hline \multirow[t]{2}{*}{ Altura da cabeça } & 3 & 114,4 & 104,18 & 114,39 & 108,07 & 4,80 \\
\hline & $\mathrm{n}$ & Holótipo & Mínimo & Máximo & Moda & \\
\hline Raios da nadadeira peitoral & 3 & $\mathrm{i}+14$ & $\mathrm{i}+13$ & $\mathrm{i}+14$ & $\mathrm{i}+14$ & \\
\hline Raios da nadadeira pélvica & 3 & $\mathrm{i}+8$ & $\mathrm{i}+8$ & $\mathrm{i}+8$ & $\mathrm{i}+8$ & \\
\hline Raios da nadadeira dorsal & 3 & $\mathrm{ii}+9$ & $\mathrm{ii}+9$ & $\mathrm{ii}+9$ & $\mathrm{ii}+9$ & \\
\hline Raios da nadadeira anal & 3 & $\mathrm{iiii}+29$ & $\mathrm{iii}+28$ & $\mathrm{iiii}+29$ & $\mathrm{iiii}+28-29$ & \\
\hline Escamas da linha lateral & 3 & 39 & 39 & 40 & 39 & \\
\hline Escamas acima da linha lateral & 3 & 7 & 7 & 7 & 7 & \\
\hline Escamas abaixo da linha lateral & 3 & 8 & 8 & 8 & 8 & \\
\hline Escamas do pedúnculo caudal & 1 & - & 17 & 17 & 17 & \\
\hline Escamas pré-dorsais & 3 & 12 & 12 & 13 & 12 & \\
\hline Pré-maxilar na fileira externa & 3 & 4 & 4 & 4 & 4 & \\
\hline Pré-maxilar na fileira interna & 3 & 5 & 5 & 5 & 5 & \\
\hline Dentes do maxilar & 3 & 3 & 2 & 3 & 3 & \\
\hline Dentes do dentário & 3 & 4 & 4 & 4 & 4 & \\
\hline
\end{tabular}




\section{Diagnose}

Distingui-se de seus congêneres pela autapomórfica presença de uma faixa prateada na lateral do corpo exatamente sobre os chevrons e acima da linha lateral que se inicia após a cabeça e prolonga-se até o pedúnculo caudal. Diferencia-se ainda de todas as demais espécies (exceto “A.” orthodus) por apresentar uma maxila superior ligeiramente mais curta 45-48,7\% no CC (vs. 45,9-54,7\%), por menos raios ramificados na nadadeira anal (exceto de A. multidens) iii+26-29 (vs. iii-iv+27-32), por uma base da nadadeira anal mais curta (exceto de A. multidens) 26,4-31,1\% no CP (vs. 29,6-37,9\%), origem da nadadeira anal posterior à vertical que passa pelo término da base da nadadeira dorsal (exceto de A. multidens) (vs. origem da nadadeira anal anterior ou na vertical que passa pelo término da base da nadadeira dorsal) e por uma distância focinho-anal maior (exceto “A.” orthodus) 63,3-68,4\% no CP (vs. 59,4-66\%). Distingue-se ainda de “A.” orthodus, “A.” superbus e A. sp. nova Bolívia pelo corpo mais baixo 31,7-35,9\% no CP (vs. 31,1-44,4\%). Diferencia-se de “Astyanax" orthodus, “Astyanax" superbus, Astyanacinus sp. nova Bolívia por não apresentar lamelas no osso nasal (presença). Difere de Astyanacinus moorii, “Astyanax” superbus”, “Astyanax” orthodus e Astyanacinus sp. nova Bolívia pelo primeiro radial proximal da nadadeira anal que é inclinado anteriormente (vs. direcionado dorsalmente).

É distinguida de $\boldsymbol{A}$. multidens por menos dentes na maxila 1-3 (vs. 9-13), menos escamas pré-dorsais 12-13 (vs. 14-16), menos escamas circumpedunculares 17-18 (vs. 19-21), pelo comprimento do maior raio da nadadeira dorsal 22,1-28,7\% no CP (vs. 21,5-25,7\%), pelo menor diâmetro do olho 27,4-38,2\% no CC (vs. 20-29,7\%); de “A.” superbus por menos dentes na maxila 1-3 (vs. 5-7) e ausência do padrão de colorido de faixas em zig-zag longitudinais ao corpo (vs. presença do padrão); de A. sp. nova Purus por menos raios ramificados na nadadeira pélvica 7 (vs. 8) e pela presença de chevrons pelo menos até a origem da nadadeira adiposa (vs. chevrons somente até o meio do corpo, não alcançando a adiposa); de $\boldsymbol{A}$. sp. nova Bolívia pela ausência de ganchos nas nadadeiras anal e pélvica dos machos maduros (vs. presença de ganchos), de “A.” orthodus pelo padrão de colorido no pedúnculo caudal composto por uma mancha baixa e alongada que alcança a base da nadadeira adiposa (vs. curta e alta não alcançando a 
base da nadadeira adiposa); de $\boldsymbol{A}$. moorii pelo maior porte com até $106,7 \mathrm{~mm}$ de CP (vs. até $58,07 \mathrm{~mm}$ de $\mathrm{CP}$ ).

\section{Descrição}

Dados merísticos e morfométricos dos exemplares examinados dessa espécie estão reunidos na tabela 08 e gráficos 19-21. Espécie de médio porte com o maior exemplar examinado apresentando o comprimento padrão de 106,69 mm enquanto que o menor possui 36,89 mm. Nadadeira peitoral quase alcança ou alcança levemente a base nadadeira pélvica. Nadadeira pélvica quase alcança ou alcança levemente a base da nadadeira anal. Perfil dorsal da cabeça (da ponta do focinho até a porção posterior do espinho supraoccipital) é sutilmente côncavo; do espinho supraoccipital até a origem da nadadeira dorsal é levemente convexo. Cabeça pequena com comprimento nunca maior que 28,8\% do comprimento padrão. Maxila superior, comparada com seus congêneres, é mais curta variando de $45-48,7 \%$ no comprimento da cabeça com a extremidade posterior do osso maxilar quase alcançando a vertical que passa no contato dorsal entre os infraorbitais 2 e 3, aproximadamente no centro da órbita. Margem ventral do infraorbital 1 sobrepondo a margem dorsal da maxila. Duas séries de dentes no osso pré-maxilar: a mais externa com cada lado apresentando 3(1), 4(15) ou 5(3) dentes tricuspidados, geralmente com três dentes mais centralizados e um mais lateral. Série interna com 4(1) ou 5(18) dentes pentacuspidados. Osso maxilar com 1(1), 2(7), 3(7), 4(3) ou 5(1) pequenos dentes tricuspidados. Dentário com sempre 4(19) dentes mais desenvolvidos pentacuspidados anteriores seguidos de numerosos pequenos dentículos. Nadadeira dorsal com ii+9 raios (19). A origem da nadadeira dorsal é um pouco posterior à vertical que passa pela origem da nadadeira pélvica. Nadadeira adiposa pequena com base anterior à vertical que passa pela inserção do último raio da nadadeira anal. Nadadeira peitoral com i+11(1), i+12(12) ou i+13(6). Nadadeira pélvica com $i+6(1)$, $i+7(13)$ ou $i+8(5)$. Nadadeira anal com iii(19) raios não ramificados anteriores seguidos de 26(3), 27(8), 28(4) ou 29(4) raios ramificados. Origem da nadadeira anal posterior à vertical que passa pelo término da base da nadadeira dorsal. Linha lateral completa pouco curvada ventralmente com 3(1), 38(5), 39(3), 40(5) ou 41(1) escamas perfuradas. Oito (19) séries longitudinais de escamas entre a nadadeira dorsal e a linha lateral; 7(6) ou 8(13) séries longitudinais de escamas entre a nadadeira anal e a linha lateral. Doze (12) ou 13(7) escamas pré-dorsais em uma série irregular e 
17(3), 18(4) ou 19(2) escamas ao redor do pedúnculo caudal. Apenas uma série de escamas recobrindo a base dos primeiros raios da nadadeira anal. Primeiro arco branquial com 12+1+9-10 rastros. Total de 37(1) ou 38(1) vértebras sendo 16(2) précaudais, 2(2) de transição e 19(1) ou 20(1) caudais. Há 5(2) supraneurais e a nadadeira dorsal está inserida após a nona vértebra (2).

\section{Coloração em álcool}

Mancha umeral oval bastante alongada horizontalmente ocupando área de aproximadamente 4 escamas em seu comprimento e 2 escamas em sua altura. A mancha está localizada logo acima da linha lateral não alcançando nenhuma escama da linha lateral. Posteriormente, há uma faixa vertical com poucos cromatóforos marrons dando a impressão dá área ser despigmentada. Entre essa área despigmentada existem duas manchas verticalmente alongadas, porém bastante difusas e fracas. A mancha umeral está posicionada em cima da mancha vertical difusa mais anterior. Presença de estrias lateralmente dispostas no corpo formado por bandas escuras em forma de "V" deitados com seus vértices anteriormente direcionados e que geralmente estão encobertos por uma faixa longitudinal acinzentada (como em Astyanax fasciatus). Essa faixa se estende da região pós-opercular até o pedúnculo caudal ocupando aproximadamente 4 escamas de altura e nela há intensa concentração de cromatóforos escuros. Mancha no pedúnculo caudal mais alongada do que alta que inicia-se, aproximadamente, na vertical que passa pela origem da nadadeira adiposa e prolonga-se até a porção mais distal dos raios medianos da nadadeira caudal. Corpo com coloração amarelo-pálido sutilmente mais escuro dorsalmente. Há deposito de guanina na faixa lateral do corpo e principalmente nas séries opercular e infra-orbital. Corpo com muitos cromatóforos amarronzados densamente concentrados na região dorsal e menos na região ventral. Escamas com muitos cromatóforos e com maior concentração na região periférica da região posterior da escama. Nadadeira anal com pouquíssimos cromatóforos que, quando presentes, estão situados na periferia da bainha inter-radial em contato com os raios. Nadadeira adiposa com muitos cromatóforos marrons dispersos homogeneamente. Nadadeiras peitoral e dorsal com alguns cromatóforos nas margens dos raios.

\section{Dimorfismo sexual}

Nenhuma característica que possa discriminar os sexos foi encontrada. 


\section{Notas sobre a espécie}

Grande parte dos exemplares estava misturado em lotes com exemplares de Astyanax aff. bimaculatus. Quando a espécie era corretamente triada era quase sempre identificada como A. multidens. A análise estomacal de exemplares revelou que estes se alimentam principalmente de insetos alóctones. Foi detectada também a presença de pequenos fragmentos de origem vegetal.

\section{Distribuição geográfica}

Bacias do Alto Rio Ucayali e Alto Rio Madeira

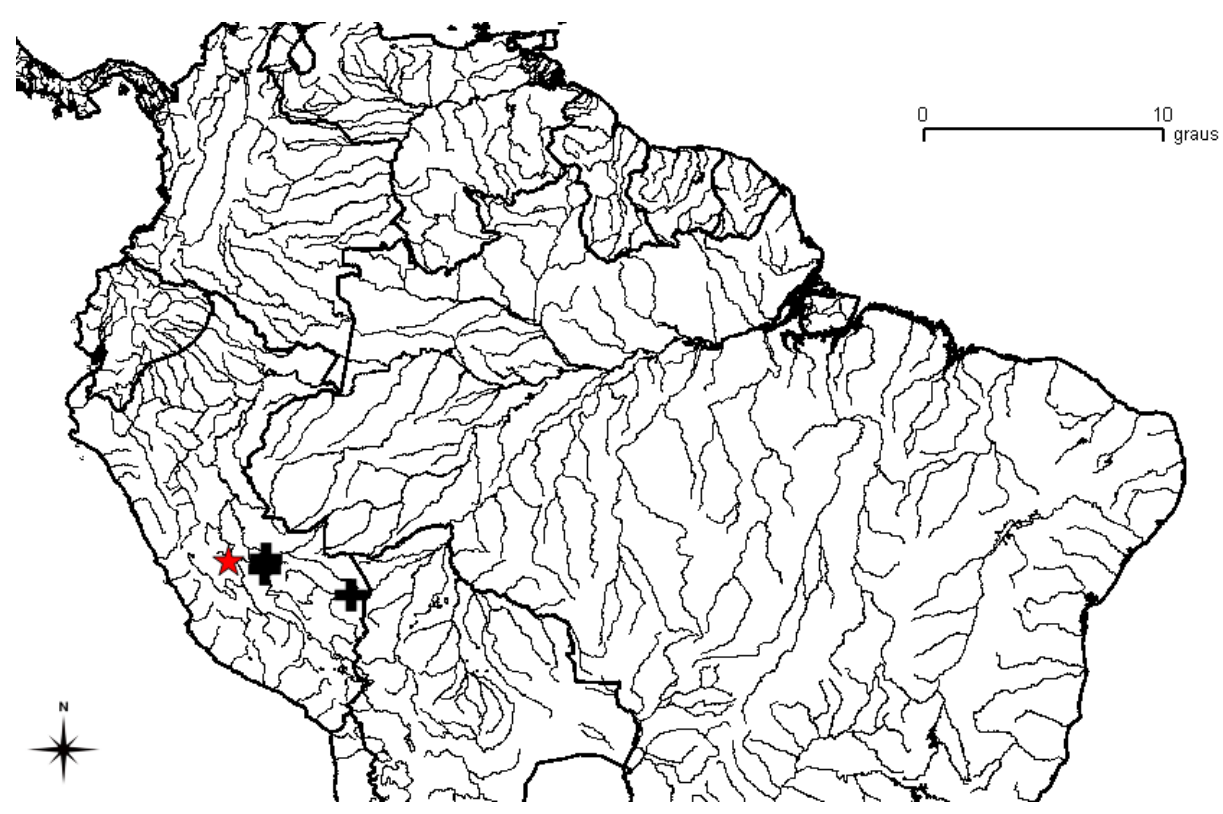

Figura 08. Mapa da distribuição geográfica de $A$. sp. nova Peru . Estrela indica a localidade-tipo. Cada símbolo pode representar mais de um lote examinado.

\section{Material examinado}

MUSM 13101 (6 ex., 6 mc, 41,4-56,4 mm CP; 1 c\&s); Departamento de UC, Província de Atalaya, Cidade de Sepahua, Braço do Rio Urubamba. Bacia do Alto Rio Ucayali. Col. Hernán Ortega. 06/06/1998. MUSM 21160 (6 ex., 6 mc, 36,6-40,61 mm CP); Departamento de Cusco, Província de La Convención, Departamento de Cuzco, Cidade de Kirigueti, Qda. Pitomiari. Baixo Rio Urubamba. Bacia do Alto Rio Ucayali. Col. Hernán Ortega et al. 09/09/2003. MUSM 23863 (1 ex., 1 mc, 67,13 mm CP); Departamento de Madre de Dios, Província de Tambopata, Distrito de Laberinto, Rio 
Madre de Dios, Playa Esperenza. Bacia do Alto Rio Madeira. Col. Hernán Ortega et al. 18/08/2004. MUSM 37878 (6 ex., 6 mc, 96,4-106,7 mm CP; 1 c\&s); Departamento de Junin, Cidade de Satipo, Mashira, cca. Rio Tambo, Qda. Capirosantiari. Bacia do Alto Rio Ucayali. Col. G. Trevejo et al. 07/06/2009. 
Tabela 08. Dados merísticos e morfométricos de Astyanacinus sp. nova Peru

\begin{tabular}{|c|c|c|c|c|c|}
\hline \multicolumn{6}{|c|}{ A. sp. nova Peru } \\
\hline & $\mathrm{n}$ & Mínimo & Máximo & Média & Desvio padrão \\
\hline Comprimento Padrão & 19 & 36,59 & 106,69 & 60,97 & \\
\hline Altura do corpo & 19 & 31,74 & 35,87 & 33,82 & 1,14 \\
\hline Distância pré-dorsal & 19 & 48,76 & 52,43 & 50,61 & 1,26 \\
\hline Distância pré-ventral & 19 & 46,45 & 50,20 & 48,46 & 1,07 \\
\hline Focinho-peitoral & 19 & 25,71 & 29,50 & 27,35 & 1,15 \\
\hline Focinho-anal & 19 & 63,30 & 68,40 & 64,42 & 1,15 \\
\hline Pélvica-anal & 19 & 14,09 & 21,10 & 17,56 & 1,74 \\
\hline Altura do pedúnculo caudal & 19 & 10,39 & 12,71 & 11,52 & 0,69 \\
\hline Base da nadadeira dorsal & 19 & 11,97 & 14,64 & 13,11 & 0,84 \\
\hline Base da nadadeira anal & 19 & 26,35 & 30,74 & 29,05 & 1,11 \\
\hline Distância dorsal-caudal & 19 & 52,62 & 58,74 & 55,43 & 1,48 \\
\hline Maior raio da nadadeira peitoral & 19 & 19,57 & 23,23 & 21,16 & 1,08 \\
\hline Maior raio da nadadeira pélvica & 19 & 13,10 & 20,20 & 16,68 & 1,85 \\
\hline Maior raio da nadadeira dorsal & 19 & 22,10 & 28,70 & 26,50 & 1,76 \\
\hline Maior raio da nadadeira anal & 19 & 11,90 & 19,90 & 15,49 & 2,34 \\
\hline Comprimento da cabeça & 19 & 24,10 & 28,83 & 26,61 & 1,45 \\
\hline Comprimento do focinho & 19 & 26,36 & 30,90 & 27,75 & 1,10 \\
\hline Diâmetro da órbita ocular & 19 & 27,40 & 38,24 & 33,63 & 3,37 \\
\hline Distância maxilar-pré-maxilar & 19 & 45,01 & 50,57 & 47,04 & 1,35 \\
\hline Distância interorbital & 19 & 31,07 & 37,50 & 33,79 & 1,91 \\
\hline \multirow[t]{2}{*}{ Altura da cabeça } & 19 & 97,91 & 113,90 & 104,50 & 4,34 \\
\hline & $\mathrm{n}$ & Mínimo & Máximo & Moda & \\
\hline Raios da nadadeira peitoral & 19 & $\mathrm{i}+11$ & $\mathrm{i}+13$ & $\mathrm{i}+12$ & \\
\hline Raios da nadadeira pélvica & 19 & $\mathrm{i}+6$ & $\mathrm{i}+8$ & $\mathrm{i}+7$ & \\
\hline Raios da nadadeira dorsal & 19 & $\mathrm{ii}+9$ & $\mathrm{ii}+9$ & $\mathrm{ii}+9$ & \\
\hline Raios da nadadeira anal & 19 & $\mathrm{iii}+26$ & $\mathrm{iii}+29$ & $\mathrm{iii}+27$ & \\
\hline Escamas da linha lateral & 15 & 37 & 41 & 38 & \\
\hline Escamas acima da linha lateral & 19 & 8 & 8 & 8 & \\
\hline Escamas abaixo da linha lateral & 19 & 7 & 8 & 8 & \\
\hline Escamas do pedúnculo caudal & 9 & 17 & 19 & 18 & \\
\hline Escamas pré-dorsais & 19 & 12 & 13 & 12 & \\
\hline Pré-maxilar na fileira externa & 19 & 3 & 5 & 4 & \\
\hline Pré-maxilar na fileira interna & 19 & 4 & 5 & 5 & \\
\hline Dentes do maxilar & 19 & 1 & 5 & 2 ou 3 & \\
\hline Dentes do dentário & 19 & 4 & 4 & 4 & \\
\hline
\end{tabular}




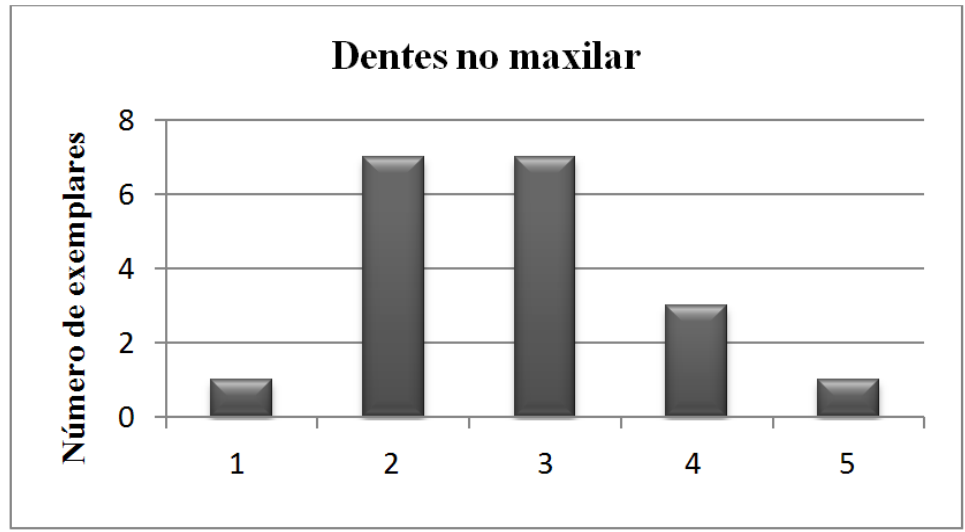

Gráfico 16. Distribuição da quantidade de dentes no maxilar dos exemplares examinados de $A$. sp. nova Peru .

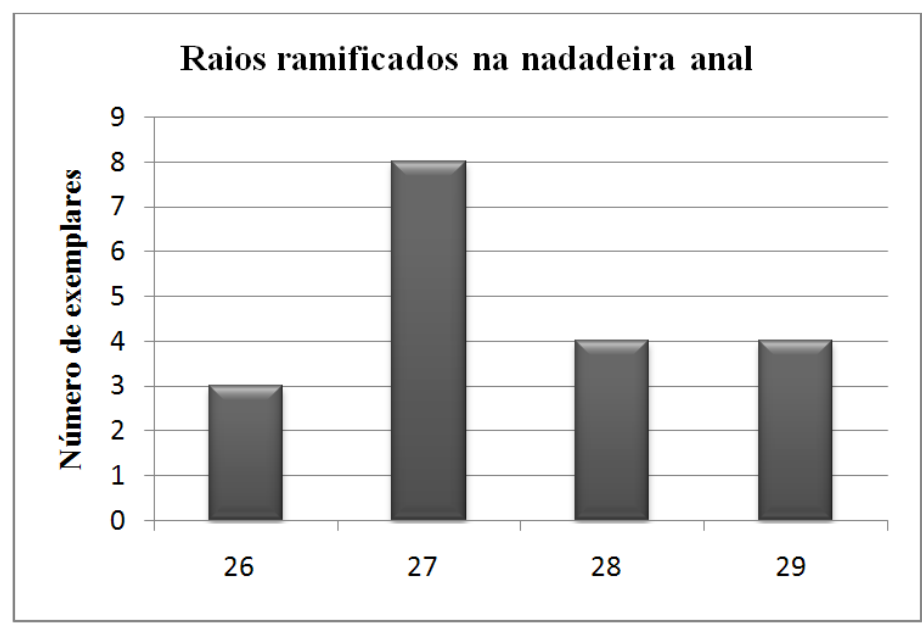

Gráfico 17. Distribuição da quantidade de raios ramificados na nadadeira anal dos exemplares examinados de $A$. sp. nova Peru.

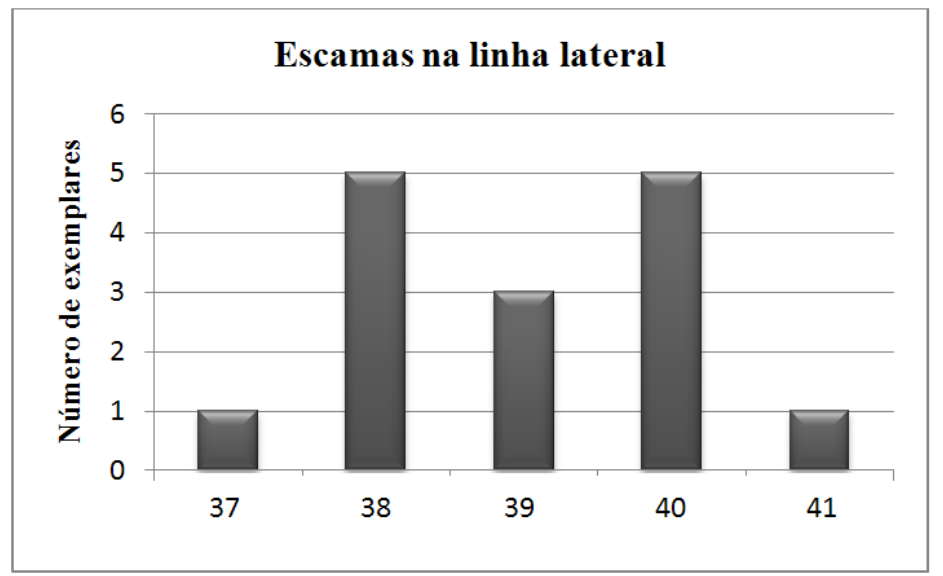


Gráfico 18. Distribuição da quantidade de escamas na linha lateral dos exemplares examinados de A. sp. nova Peru .

\section{“Astyanacinus” platensis Messner, 1962}

Messner (1962) pág. 5 (descrição original), Olazarri et al. (1970) pág. 3 (localidade-tipo e material-tipo), Nión et al. (2002) pág. 11 (registro e nome popular), Malabarba et al., 2004 pág. 100 (comentário sobre a validade do táxon), Bertaco et al. (2009) pág. 266 e 273 (distribuição e comparação com outras espécies de Astyanacinus), Koerber \& Litz (2011) pág. 4 (transcrição da descrição original da espécie).

\section{Material-tipo}

CL 762 Holótipo fêmea (96,75mm CP), Canelones, Laguna Tropa Vieja, Uruguai. E. Messner.

\section{Diagnose}

Difere de Astyanacinus por não apresentar o padrão de colorido lateral composto por estrias de chevrons dispostas lateralmente (vs. presença do padrão); mancha umeral verticalmente alongada (vs. horizontalmente alongada) e ausência de duas barras verticais escuras na região umeral (presença das barras); mais raios ramificados na nadadeira peitoral i+14 (vs. maioria com i+12-13, um exemplar de $A$. sp. nova Purus e um exemplar de A. moorii com i+14); mais escamas pré-dorsais 18 (vs. 12-16); mais dentes no maxilar 14-15 (vs. 1-13). É também distinguida de todos os Astyanacinus por dados morfométricos por apresentar distância pré-dorsal maior 53,85\% no CP (exceto de “A.” orthodus) (vs. 46,3-53,2\%); distância pré-ventral menor 43,66\% no CP (exceto de A. multidens) (vs. 44,3-51,3); distância dorsal-caudal menor 49,46\% no CP (vs. 51,159,1\%) e distância interorbital menor 27,7\% no CC (vs. 27,8-41,2\%).

\section{Descrição}

Dados merísticos e morfométricos do exemplar examinado estão reunidos na tabela 09. Espécie de médio porte com o exemplar examinado apresentando o comprimento padrão de 96,75 mm. Nadadeira peitoral alcança a base nadadeira pélvica. Nadadeira pélvica não alcança a base da nadadeira anal. Perfil dorsal da cabeça (da ponta do focinho até a porção posterior do espinho supraoccipital) é marcadamente côncavo, do 
espinho supraoccipital até a origem da nadadeira dorsal é levemente convexo, quase reto. Cabeça pequena com comprimento $25,7 \%$ do comprimento padrão. Maxila superior longa com 49,1\% no comprimento da cabeça. Duas séries de dentes no osso pré-maxilar: a mais externa com cada lado apresentando 4 dentes. Série interna com 5 dentes multicuspidados. Osso maxilar com muitos dentes, 14 de um lado e 15 do outro e com área com dentes maior que a área edentelosa. Dentário com sempre 4 dentes mais desenvolvidos anteriores seguidos de numerosos 10 pequenos dentículos. Nadadeira dorsal com ii+9 raios. A origem da nadadeira dorsal é bem posterior à vertical que passa pela origem da nadadeira pélvica. Nadadeira adiposa pequena com base anterior à vertical que passa pela inserção do último raio da nadadeira anal. Nadadeira peitoral com i+14. Nadadeira pélvica com i+7. Nadadeira anal com iv+28. Origem da nadadeira anal aproximadamente na vertical que passa pelo término da base da nadadeira dorsal. Linha lateral completa pouco curvada ventralmente com 42 ou 43 escamas perfuradas dependendo do lado. Sete séries longitudinais de escamas entre a nadadeira dorsal e a linha lateral; 8 séries longitudinais de escamas entre a nadadeira anal e a linha lateral. Dezoito escamas pré-dorsais e 20 séries de escamas ao redor do pedúnculo caudal.

\section{Coloração em álcool}

Corpo com coloração amarelo-pálido, com região dorsal mais escura. Mancha umeral verticalmente alongada bem definida localizada acima da linha lateral. Presença de uma faixa longitudinal bem definida a partir da metade do corpo alcançando o pedúnculo caudal e a porção mais distal dos raios medianos da nadadeira caudal. Mancha no pedúnculo caudal tem formato losangular com região mais anterior afilada e posterior mais expandida. Raios da nadadeira caudal com coloração alaranjada.

\section{Notas sobre a espécie}

Emil Messner, um alemão radicado no Uruguai, por muitos anos estudou temas relacionados à fisiologia animal, principalmente aqueles ligados à Medicina Veterinária. Nos últimos anos de sua vida dedicou-se ao estudo dos peixes e publicou dois trabalhos sobre o assunto: o primeiro, Messner (1962), é uma lista dos Tetragonopterinae do Uruguai e o segundo, Messner (1962), é a descrição da nova espécie Acestrorhamphus purpureus (sinônimo-júnior de Oligosarcus jenynsii). 
Em Messner (1962) há uma breve descrição de duas novas espécies de Characidae para o Uruguai: Astyanacinus platensis e Astyanax stenohalinus. Ambas as espécies até Malabarba et al. (2004) não tinham sido incluídas nos registros de dados da Zoological Record e não foram mencionadas em importantes catálogos ictiológicos como Eschmeyer (1998) e Reis et al. (2003), e não foram relatadas como descritas por Messner na "Bio-bibliografia” (disponível online no site do Museo Nacional de Historia Natural y Antropología) do próprio autor que foi escrita por Álvaro Mones, sendo que neste trabalho consta apenas a descrição de Acestrorhamphus purpureus.

Por outro lado, Nion et al. (2002) lista Astyanacinus platensis e Astyanax stenohalinus como sendo parte da ictiofauna uruguaia e em Olazarri et al. (1970) os autores reportam que os tipos de ambas espécies (Holótipo de Astyanacinus platensis e Síntipos de Astyanax stenohalinus) estão depositadas no Museo Nacional de Historia Natural de Montevideo . Já Reichert-Lang (2002) cita em “Atlas Ilustrado de los Peces de água dulce del Uruguay” apenas Astyanax stenohalinus e na "Corrigenda for CLOFFSCA” de Reis et al. (2005), novamente, apenas Astyanax stenohalinus é citado e nada é dito sobre Astyanacinus platensis que foi descrito exatamente no mesmo trabalho da descrição da espécies de Astyanax em questão.

Segundo Malabarba et al. (2004) a razão da omissão dessas espécies na grande maioria da literatura ictiológica advém da limitada distribuição do veículo em que Emil Messner publicou as espécies, o mimeografado Boletin de la Associacíon Latino Americanade Ictíologos y Herpetologos (BALAIH). A publicação de Messner (1962) apesar de mimeografada é válida, como acertadamente apontam Malabarba et al. (2004), e os novos nomes de espécies publicados nela também. Esses autores baseiam sua afirmação em um trecho do artigo 8.4 do ICZN (1999) em que é dito que um trabalho produzido antes de 1986 deve ser produzido em papel por método de impressão e, nesta definição, o método de mimeografia pode ser incluído.

Ao entrar em contato com o curador da coleção do Museo Nacional de Historia Natural de Montevideo constatei que o Holótipo da espécie encontra-se na PUC-RS onde prof. Dr. Luiz Malabarba prepara um trabalho sobre a espécie. De qualquer maneira, examinei o exemplar e concluo que o mesmo não se trata de um Astyanacinus.

A única característica de Astyanacinus presente em “Astyanacinus platensis” é a presença de uma superior maxila longa com comprimento quase igual à metade da cabeça, porém a posse dessa característica é bastante comum entre os Characidae, 
principalmente predadores. Com base no exame do Holótipo de "Astyanacinus platensis” é possível inferior que a presença de muitos dentes na maxila, presença de um maxilar bastante longo, presença de uma mancha umeral verticalmente alongada e grande quantidade de escamas pré-dorsais são indícios de que a espécie em questão pertença ao gênero Oligosarcus, provavelmente uma espécie já descrita.

\section{Etimologia}

Em referência à Bacia hidrográfica onde o exemplar foi coletado.

\section{Distribuição geográfica}

Conhecido apenas da localidade-tipo.

\section{Material examinado}

\section{Uruguai}

CL 762 Holótipo fêmea (96,75mm CP), Canelones, Laguna Tropa Vieja, Uruguai. E. Messner. 
Tabela 09. Dados merísticos e morfométricos de "Astyanacinus" platensis.

\begin{tabular}{|c|c|}
\hline \multicolumn{2}{|c|}{ "Astyanacinus" platensis Holótipo } \\
\hline Comprimento Padrão & 96,75 \\
\hline Altura do corpo & 32,99 \\
\hline Distância pré-dorsal & 53,85 \\
\hline Distância pré-ventral & 43,66 \\
\hline Focinho-peitoral & 26,59 \\
\hline Focinho-anal & 63,73 \\
\hline Pélvica-anal & 18,71 \\
\hline Altura do pedúnculo caudal & 11,12 \\
\hline Base da nadadeira dorsal & 11,71 \\
\hline Base da nadadeira anal & 31,70 \\
\hline Distância dorsal-caudal & 49,46 \\
\hline Maior raio da nadadeira peitoral & 23,48 \\
\hline Maior raio da nadadeira pélvica & 16,67 \\
\hline Maior raio da nadadeira dorsal & 23,47 \\
\hline Maior raio da nadadeira anal & 16,81 \\
\hline Comprimento da cabeça & 25,71 \\
\hline Comprimento do focinho & 24,05 \\
\hline Diâmetro da órbita ocular & 29,43 \\
\hline Distância maxilar-pré-maxilar & 49,10 \\
\hline Distância interorbital & 27,74 \\
\hline Altura da cabeça & 96,30 \\
\hline Raios da nadadeira peitoral & $\mathrm{i}+14$ \\
\hline Raios da nadadeira pélvica & $\mathrm{i}+7$ \\
\hline Raios da nadadeira dorsal & $\mathrm{ii}+9$ \\
\hline Raios da nadadeira anal & iiii +28 \\
\hline Escamas da linha lateral & $42-43$ \\
\hline Escamas acima da linha lateral & 7 \\
\hline Escamas abaixo da linha lateral & 8 \\
\hline Escamas do pedúnculo caudal & 20 \\
\hline Escamas pré-dorsais & 18 \\
\hline Pré-maxilar na fileira externa & 4 \\
\hline Pré-maxilar na fileira interna & 4 \\
\hline Dentes do maxilar & 14 e 15 \\
\hline Dentes do dentário & 4 \\
\hline
\end{tabular}




\section{“Astyanacinus” goyanensis Miranda-Ribeiro, 1944}

Astyanacinus goyanensis

Miranda-Ribeiro (1944) pág. 1-3 (descrição original, fotografia do holótipo), Fowler (1948) pág. 34 (distribuição), Eschmeyer, (1998a) pág. 662 (localidade-tipo, materialtipo), Lima et al. (2003) em Reis et al. (2003) pág. 106 (localidade-tipo, material-tipo, distribuição), Lima et al. (2007) em Buckup et al. (2007) pág. 44 (localidade-tipo e distribuição), MMA (2007) pág. 221 (registro na Bacia do Tocantins).

Astyanax goyanensis

Bertaco et al. (2009) pág. 265-275 (redescrição, realocação em Astyanax, material-tipo, fotografia).

\section{Material-tipo}

MNRJ 4129 Holótipo (82,2 mm CP), rio dos Couros, Chapada dos Veadeiros, Estado de Goiás, Brasil, 1929.

MNRJ 2843 Parátipos (7 ex., 59,4-84,8 mm CP), rio dos Couros, Chapada dos Veadeiros, Estado de Goiás, Brasil, 1929.

\section{Diagnose}

É distinguida de Astyanacinus (exceto de “A.” orthodus) por apresentar distância prédorsal maior 55,3-56,8\% no CP (vs. 46,3-53,2\%); menor base da nadadeira anal 18,921,8\% no CP (vs. 25-37,9\%); distância dorsal-caudal menor 48,9-50,5\% no CP (vs. 51,1-59,1\%); maxila superior menor 40,8-42,5\% no CC (vs. 43,7-56,8\%); menos raios ramificados na nadadeira peitoral i+10-12 (vs. maioria com i+12-13, um exemplar de $A$. sp. nova Peru e três exemplares de $A$. sp. nova Bolívia com i+11); menos raios ramificados na nadadeira anal 15-17 (vs. 22-32); menos escamas na linha lateral 32-34 (vs. 36-42); menos fileiras de escamas acima da linha lateral 6 (vs. 7-9); menos fileiras de escamas abaixo da linha lateral 4 (vs. 6-9); menos escamas circumpedunculares 14 (vs. 16-21); ausência de padrão de chevrons na lateral do corpo (vs. presença do padrão); mancha umeral verticalmente alongada (vs. horizontalmente alongada); 
ausência de duas barras verticais escuras na região umeral (presença das barras) e menos vértebras 35 (vs. 37-38).

Para diagnose das outras espécies de Astyanax veja Bertaco et al. (2010).

\section{Descrição}

Dados merísticos e morfométricos dos exemplares examinados dessa espécie estão reunidos na tabela 10. Espécie de pequeno porte com o maior exemplar examinado apresentando o comprimento padrão de $62,27 \mathrm{~mm}$. Nadadeira peitoral não alcança a base nadadeira pélvica. Nadadeira pélvica não alcança a base da nadadeira anal. Perfil dorsal da cabeça (da ponta do focinho até a porção posterior do espinho supraoccipital) é levemente convexo, do espinho supraoccipital até a origem da nadadeira dorsal é marcadamente convexo. Cabeça grande com comprimento nunca menor que 28,9\% do comprimento padrão. Maxila superior curta variando de 40,8-42,5\% no comprimento da cabeça com a extremidade posterior do osso maxilar não alcançando a vertical que passa no contato dorsal entre os infraorbitais 2 e 3, aproximadamente no centro da órbita. Duas séries de dentes no osso pré-maxilar: a mais externa com cada lado apresentando 3(1) ou 4(5) dentes tricuspidados. Série interna com 5(5) dentes pentacuspidados. Osso maxilar com 2(3) ou 3(2) dentes tricuspidados. Dentário com 4(5) dentes mais desenvolvidos pentacuspidados anteriores seguidos de numerosos pequenos dentículos. Nadadeira dorsal com ii+9 raios (5). A origem da nadadeira dorsal é um pouco posterior à vertical que passa pela origem da nadadeira pélvica. Nadadeira adiposa pequena com base anterior à vertical que passa pela inserção do último raio da nadadeira anal. Nadadeira peitoral com poucos raios ramificados i+10(1), 11(3) ou 12(1). Nadadeira pélvica com i+6(4) ou i+7(1). Nadadeira anal curta com iii(4) ou iv(1) raios não ramificados anteriores seguidos de 15(2), 16(2) ou 17(1) raios ramificados. Origem da nadadeira anal aproximadamente na vertical que passa pelo término da base da nadadeira dorsal. Linha lateral completa pouco curvada ventralmente com 32(1), 33(1) ou 34(4) escamas perfuradas. Seis (5) séries longitudinais de escamas entre a nadadeira dorsal e a linha lateral; 4(5) séries longitudinais de escamas entre a nadadeira anal e a linha lateral. Doze (4), 13(1) ou 14(1) escamas pré-dorsais em uma série regular e 14(5) escamas ao redor do pedúnculo caudal. Apenas uma série de escamas recobrindo a base dos raios mais anteriores da nadadeira anal.

\section{Coloração em álcool}


Veja Bertaco et al. (2010).

\section{Dimorfismo sexual}

Segundo Bertaco et al. (2010) os machos apresentam ganchos na nadadeira anal, além disso, os machos apresentam a porção distal da nadadeira anal mais reta enquanto que nas fêmeas é côncava.

\section{Notas sobre a espécie}

Foi descrito por Paulo de Miranda Ribeiro em 1944 a partir de material coletado pelo Dr. Rudolf Pfrimmer em 1929 no Rio do Couro, Chapada dos Veadeiros, estado de Goiás.

Recentemente, foi redescrito e re-alocado em Astyanax. Segundo os autores essa atitude deveu-se ao fato de Astyanacinus goyanensis diferir de Astyanacinus moorii e A. multidens por apresentar menos escamas na linha lateral 35-37 (vs. 39-40), menos escamas ao redor do pedúnculo caudal 14 (vs. 18), menor número de série de escamas transversais no corpo 12-13 (vs. 15-16), menos raios ramificados na nadadeira anal 1314 (vs. 25-31), menos raios na nadadeira pélvica 8* (vs. 7*), formato da mancha umeral e coloração em padrão de "V" ausente em A. goyanensis.

* é provável que os autores tenham invertido incorretamente os números apresentados no artigo.

\section{Etimologia}

Em referência a localidade-tipo da espécie (Chapada dos Veadeiros) localizada no Estado de Goiás, Brasil.

\section{Distribuição geográfica}

Conhecido de tributários do rio dos Couros, afluente do rio Tocantinzinho e do rio Paranã, Bacia do Alto Rio Tocantins (Bertaco et al., 2010).

\section{Material examinado}

\section{Brasil}

MCP 44402 Topótipos (20 ex., 5 m.c., 26.9-63.9 mm CP) Riacho afluente do rio dos 
Couros, Bacia do Rio Tocantinzinho, Parque Estadual Portal da Chapada, Estado de Goiás, Brasil. Muncípio de Alto Paraíso. 10/09/2009.

Tabela 10. Dados merísticos e morfométricos de topotipos de Astyanax goyanensis.

\begin{tabular}{|c|c|c|c|c|c|}
\hline \multicolumn{6}{|c|}{ Astyanax goyanensis } \\
\hline & $\mathrm{n}$ & Mínimo & Máximo & Média & Desvio padrão \\
\hline Comprimento Padrão & 5 & 30,50 & 35,50 & 32,51 & \\
\hline Altura do corpo & 5 & 55,31 & 56,80 & 56,10 & 0,57 \\
\hline Distância pré-dorsal & 5 & 50,90 & 52,20 & 51,46 & 0,49 \\
\hline Distância pré-ventral & 5 & 28,10 & 30,60 & 29,08 & 1,07 \\
\hline Focinho-peitoral & 5 & 68,00 & 69,30 & 68,60 & 0,58 \\
\hline Focinho-anal & 5 & 17,20 & 18,00 & 17,57 & 0,36 \\
\hline Pélvica-anal & 5 & 11,50 & 12,70 & 11,99 & 0,46 \\
\hline Altura do pedúnculo caudal & 5 & 10,10 & 12,00 & 11,02 & 0,74 \\
\hline Base da nadadeira dorsal & 5 & 18,90 & 21,80 & 20,03 & 1,07 \\
\hline Base da nadadeira anal & 5 & 48,90 & 50,50 & 49,72 & 0,72 \\
\hline Distância dorsal-caudal & 5 & 18,10 & 20,96 & 19,61 & 1,10 \\
\hline Maior raio da nadadeira peitoral & 5 & 13,80 & 14,79 & 14,36 & 0,41 \\
\hline Maior raio da nadadeira pélvica & 5 & 20,20 & 23,06 & 21,73 & 1,13 \\
\hline Maior raio da nadadeira dorsal & 5 & 14,80 & 17,94 & 16,51 & 1,38 \\
\hline Maior raio da nadadeira anal & 5 & 28,80 & 30,78 & 29,54 & 0,92 \\
\hline Comprimento da cabeça & 5 & 24,80 & 29,50 & 26,46 & 1,88 \\
\hline Comprimento do focinho & 5 & 25,00 & 28,30 & 27,00 & 1,31 \\
\hline Diâmetro da órbita ocular & 5 & 40,80 & 42,50 & 41,82 & 0,73 \\
\hline Distância maxilar-pré-maxilar & 5 & 31,10 & 32,70 & 31,82 & 0,69 \\
\hline Distância interorbital & 5 & 94,20 & 100,10 & 96,44 & 2,48 \\
\hline \multirow[t]{2}{*}{ Altura da cabeça } & 5 & 99,43 & 122,04 & 110,95 & 6,08 \\
\hline & $\mathrm{n}$ & Mínimo & Máximo & Moda & \\
\hline Raios da nadadeira peitoral & 5 & $\mathrm{i}+10$ & $\mathrm{i}+12$ & $\mathrm{i}+11$ & \\
\hline Raios da nadadeira pélvica & 5 & $\mathrm{i}+6$ & $\mathrm{i}+7$ & $\mathrm{i}+6$ & \\
\hline Raios da nadadeira dorsal & 5 & $\mathrm{ii}+9$ & $\mathrm{ii}+9$ & $\mathrm{ii}+9$ & \\
\hline Raios ramificados da nadadeira anal & 5 & 15 & 17 & $15-16$ & \\
\hline Escamas da linha lateral & 5 & 32 & 34 & 34 & \\
\hline Escamas acima da linha lateral & 5 & 6 & 6 & 6 & \\
\hline Escamas abaixo da linha lateral & 5 & 4 & 4 & 4 & \\
\hline Escamas do pedúnculo caudal & 5 & 14 & 14 & 14 & \\
\hline Escamas pré-dorsais & 5 & 12 & 14 & 12 & \\
\hline Pré-maxilar na fileira externa & 5 & 3 & 4 & 4 & \\
\hline Pré-maxilar na fileira interna & 5 & 5 & 5 & 5 & \\
\hline Dentes do maxilar & 5 & 2 & 3 & 2 & \\
\hline Dentes do dentário & 5 & 4 & 4 & 4 & \\
\hline
\end{tabular}




\section{Chave de identificação das espécies de Astyanacinus}

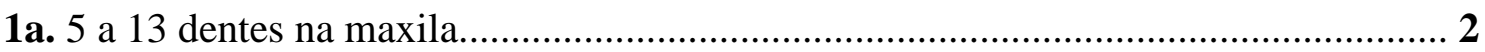

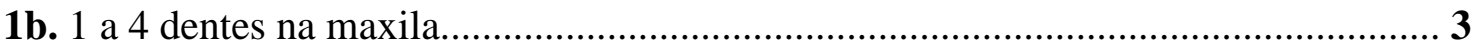

2a. 5-7 dentes na maxila, padrão de colorido de faixas em zig-zag longitudinais ao corpo, comprimento do maior raio da nadadeira dorsal 22,3-28,6\% no CP e raios ramificados na nadadeira anal 28-32, margem ventral do infraorbital 1 sobrepondo a margem dorsal da maxila. “A.” superbus (Bacia do Rio Orinoco).

2b. 9-13 dentes na maxila e ausência de faixas em zig-zag longitudinais ao corpo, comprimento do maior raio da nadadeira dorsal $21,5-25,7 \%$ no CP e por menos raios ramificados na nadadeira anal 22-26, margem ventral do infraorbital 1 não sobrepondo a margem dorsal da maxila. A. multidens (Bacia do Alto Rio Madeira). 3a. Padrão de colorido no pedúnculo caudal composto por uma mancha curta e alta que não alcança a vertical que passa pela base da nadadeira adiposa (figura 75 a) “A." orthodus (Bacias do

Atrato e San Juan, Colômbia; e diversos rios na Costa Rica e Panamá).

3b. Padrão de colorido no pedúnculo caudal composto por uma mancha baixa e alongada que alcança a vertical que passa pela base da nadadeira adiposa (figura 75 b). 4 (complexo A. moorii)

4a. Chevrons somente até o meio do corpo, não alcançando a vertical que passa pela origem da adiposa. A. sp nov Purus (Bacia do Purus).

4b. Chevrons até o início do pedúnculo caudal, alcançando a vertical que passa pela origem da adiposa.

5a. Presença de uma faixa prateada na lateral do corpo exatamente sobre os chevrons e acima da linha lateral que se inicia após a cabeça e prolonga-se até o pedúnculo caudal; mancha umeral relativamente baixa, não muito mais alta do que a maior altura do infraorbital 4; origem da nadadeira anal posterior à vertical que passa pelo término da base da nadadeira dorsal; maxila superior ligeiramente mais curta 45-48,7\% no CC; raios ramificados na nadadeira anal 26-28 e base da nadadeira anal curta 26,4-31,1\% no 
CP A. sp. nova Peru (Bacias do

Ucayali, Madre de Dios e Rio de las Piedras).

5b. Ausência de uma faixa prateada na lateral do corpo exatamente sobre os chevrons e acima da linha lateral que se inicia após a cabeça e prolonga-se até o pedúnculo caudal; mancha umeral relativamente alta, bem mais alta do que a maior altura do infraorbital 4; origem da nadadeira anal anterior ou na vertical que passa pelo término da base da nadadeira dorsal; maxila superior ligeiramente mais longa 45,9-56,8\% no CC; raios ramificados na nadadeira anal 27-32 e base da nadadeira anal mais longa 29,6$36,3 \%$ 6

6a. Presença de ganchos nas nadadeiras pélvica e anal de machos maduros, maior altura do corpo 31,1-40,7\% no CP (média 36,7) e por apresentar, em sua maioria, exemplares com 3-4 dentes, porte médio até $85 \mathrm{~mm}$, presença de rinosfenóide ossificado.

A. sp. nova Bolívia (Bacia do Alto Rio Madeira).

6b. Ausência de ganchos nas nadadeiras pélvica e anal de machos maduros, menor altura do corpo 30,8-38,4\% (média 33,9) no CP e por apresentar, em sua maioria, exemplares com 2-3 dentes, porte pequeno até 58mm, ausência de rinosfenóide ossificado

A. moorii (Bacia do Alto Paraguai). 


\subsection{ANÁLISE FILOGENÉTICA}

Todos os caracteres apresentados na presente análise são morfológicos. A grande maioria desses se referem à osteologia dos peixes enquanto que outros são provenientes de outras estruturas como, por exemplo, a coloração do corpo.

A osteologia dos peixes actinopterigianos é uma das estruturas mais complexas dentre os vertebrados (Tetrápodes em geral apresentam menos ossos nas cinturas peitorais e pélvicas e, principalmente, no crânio) apresentando uma série modificações entre as diversas linhagens de peixes. Assim, a osteologia fornece um arcabouço intricado de informações acerca da evolução dos peixes, uma das razões pelas qual há ampla utilização da osteologia como fonte de caracteres em estudos filogenéticos.

Os caracteres analisados serão apresentados a seguir divididos em duas categorias: em crânio e pós-crânio. Para que os caracteres analisados sejam apresentados de forma anatomicamente organizada as categorias crânio e póscrânio são divididas em complexos fundamentados em parâmetros embriológicos. É importante ressaltar que os comentários embriológicos que serão feitos a seguir, tanto das cápsulas cartilaginosas do neurocrânio quanto dos arcos do esplancnocrânio e os ossos que eles originam, são generalizações e simplificações do intrincado padrão que ocorre em peixes. O autor é ciente da enorme complexidade e diversidade de exemplos de peixes que não seguem o padrão apresentado (e.g. perdas, fusões, ossos laminares, ossos membranosos) e tece tais comentários pretendendo somente explicar a razão pela qual dividiu as estruturas anatômicas dessa maneira.

Grande parte dos caracteres analisados já foram descritos e discutidos anteriormente por outros autores e, em respeito aos trabalhos anteriores e a fim de dar os devidos créditos aos autores, sempre que possível são citados os trabalhos em que os caracteres já foram apresentados. É importante ressaltar também que os estados dos caracteres e a polarização destes na maioria das vezes são reinterpretados no presente trabalho. Em todos os caracteres a distribuição dos estados nos peixes analisados é apresentada assim como uma breve discussão 
da importância do caráter na análise de outros autores e , quando relevante, a interpretação do caráter em relação ao resultado final da análise. Os índices de retenção e de consistência são apresentados no quadro 3. A lista das transições apresentadas por cada um dos caracteres é apresentada no apêndice 01.

Apesar de alguns caracteres terem sido observados em Astyanacinus multidens através do exame de radiografias, o número foi insuficiente e causou bastante ruído na análise, pois gerou 26 árvores igualmente parcimoniosas. Assim, a fim de permitir discussões mais aprofundadas preferiu-se descartar a utilização desta espécie. A presente análise utilizou 46 táxons e 136 caracteres morfológicos e obteve 6 árvores igualmente parcimoniosas com 918 passos e a árvore consenso de todas essas tem 922 passos. O índice de consistência da árvore consenso é 0.228 e o índice de retenção 0.502.

\section{Crânio}

O crânio é a parte do esqueleto axial do vertebrado que envolve e protege o cérebro e os órgãos sensitivos (Helfman et al., 2009). Por razões embriológicas o crânio divide-se em neurocrânio e branquiocrânio, sendo que este último também é chamado de crânio visceral ou esplancnocrânio. O neurocrânio é muito complexo e é formado tanto por ossos pré-formados em cartilagem que são posteriormente ossificadas (ossos endocondrais) quanto por ossos dermais. Os ossos endocondrais do neurocrânio formam o condrocrânio e os ossos dermais, o dermatocrânio. Ainda na fase embrionária cápsulas de cartilagem formadas próximas aos órgãos sensoriais dos peixes dão origem ao condrocrânio, são as cartilagens das regiões etmóide, orbital, ótica e basicranial. No presente trabalho a região onde se desenvolvem essas cartilagens servirão de landmarks para a divisão didática dos ossos cranianos. A partir da cartilagem da região etmóide se desenvolve os ossos mesetmóide, etmóide lateral e vomer. O osso nasal é um osso dermal, porém como fica situado próximo (lateralmente) ao mesetmóide será tratado aqui como da região etmóide. Da cartilagem da região orbital desenvolve-se o pteroesfenóide e basiesfenóide. Ossos dermais que fazem parte 
da região orbital são os frontais e ossos que compõem a série circum-orbital. A região ótica é a mais complexa e formada embiologicamente por cinco cartilagens (Helfman et al., 2009) que originam o esfenótico, pterótico, proótico, epoccipital, pós-temporal e intercalar. O único osso dérmico desta região é o parietal. A região basicranial é formada por três cartilagens e formam o exoccipital, basioccipital e supraoccipital. O único osso dermal da região basicranial é o paraesfenóide.

\section{Região etmóide}

\section{Caráter 00. Lamelas no osso nasal}

Lucena (1993) caráter 31, Vari (1995) caráter 17, Oyakawa (1998) caráter 3, Moreira (2002) caráter 48, Netto-Ferreira (2005) caráter 22, Lima (2006) caráter 7, Moreira (2007) caráter 175, Toledo-Pìza (2007) caráter 10, Mirande (2010) caráter 34

Estado 0 - Presentes (figura 83a)

Acestrorhynchus falcatus, Aphyocharax pusillus, Astyanacinus sp. nova Bolivia, “Astyanax” superbus, "Astyanax" orthodus, Astyanax altiparanae, Astyanax lineatus, Astyanax paranae, Brycon pesu, Bryconops alburnoides, Chalceus epakros, Creagrutus menezesi, Ctenobrycon hauxwellianus, Deuterodon iguape, Galeocharax knerii, Hollandichthys multifasciatus, Hydrolycus scomberoides, Hyphessobrycon eques, Jupiaba anteroides, Knodus moenkhausii, Lignobrycon myersii, Markiana nigripinnis, Mimagoniates microlepis, Piabina argentea, Poptella paraguayensis, Rachoviscus graciliceps, Salminus hilarii, Stethaprion erythrops, Stichonodon insignis, Tetragonopterus chalceus, Thoracocharax stellatus, Triportheus albus

Estado 1 - Ausentes (figura 83c)

Agoniates anchovia, Agoniates halecinus, Astyanacinus moorii, Astyanacinus sp. nova Peru, Astyanax fasciatus, Bryconamericus exodon, Charax leticiae, Cheirodon galusdae, Clupeacharax anchoveoides, Engraulisoma taeniatum, Gymnocorymbus ternertzi, Moenkhausia xinguensis, Nematocharax venustus, Oligosarcus pintoi

Em Characiformes o osso nasal apresenta-se como um tubo simples posicionado lateralmente ao mesetmóide e à frente do frontal. Roberts (1966) e Zatana \& Vari (2005) reportam a ausência do osso no alestídeo Lepidarchus. Essa ossificação é responsável pela interligação entre as extremidades anteriores dos ramos dos canais látero-sensoriais cefálicos dos ramos supra-orbitais aos 
ramos das pré-maxilas. Em caracóideos há ampla variação com relação à presença ou não de uma lamela óssea com diferentes graus de desenvolvimento no eixo longitudinal deste osso. Toledo-Piza (2007) reporta a lamela para espécies de Acestrorhynchidae. Segundo Vari (1995) a presença dessa lamela é sinapomórfica para o clado Ctenoluciidae + Erythrinidae + Hepsetidae + Lebiasinidae, hipótese semelhante à obtida por Oyakawa (1998).

\section{Região orbital}

\section{Caráter 01. Aba óssea na porção anterior da margem ventral do primeiro infra-orbital}

Lucena (1993) caráter 29, Oyakawa (1998) caráter 30, Zanata (2000) caráter 6, Zanata \& Vari (2005) caráter 9, Moreira (2007) caráter 136, Mirande (2010) caráter 58

Estado 0 - Aba óssea presente não expondo o canal sensorial (figura 79a) Acestrorhynchus falcatus, Aphyocharax pusillus, Astyanacinus moorii, Astyanacinus sp. nova Bolivia, Astyanacinus sp. nova Peru, "Astyanax" superbus, "Astyanax" orthodus, Astyanax altiparanae, Brycon pesu, Bryconamericus exodon, Chalceus epakros, Cheirodon galusdae, Creagrutus menezesi, Ctenobrycon hauxwellianus, Engraulisoma taeniatum, Galeocharax knerii, Gymnocorymbus ternertzi, Hollandichthys multifasciatus, Hyphessobrycon eques, Jupiaba anteroides, Markiana nigripinnis, Mimagoniates microlepis, Moenkhausia xinguensis, Nematocharax venustus, Oligosarcus pintoi, Piabina argentea, Poptella paraguayensis, Rachoviscus graciliceps, Salminus hilarii, Stethaprion erythrops, Stichonodon insignis, Tetragonopterus chalceus

Estado 1 - Com aba óssea reduzida ou ausente

Agoniates halecinus, Agoniates anchovia, Astyanax fasciatus, Astyanax lineatus, Astyanax paranae, Bryconops alburnoides, Charax leticiae, Clupeacharax anchoveoides, Deuterodon iguape, Hydrolycus scomberoides, Knodus moenkhausii, Lignobrycon myersii, Triportheus albus

\section{Indeterminado}

Thoracocharax stellatus

Tipicamente o primeiro infra-orbital em Characiformes apresenta uma lamela óssea ventral margeando ventralmente o canal sensorial (Zanata \& Vari, 2005). Em alguns Characiformes esta aba ventral é ausente ou muito reduzida deixando a margem ventral do canal sensorial exposta. Esse estado está presente em Alestidae (Zanata \& Vari, 2005) e alguns Serrasalminae como Serrasalmus 
(Zanata \& Vari, 2005) enquanto que, em relação aos Characidae, este estado surgiu independentemente em diferentes linhagens.

\section{Caráter 02. Área de contato entre os infra-orbitais 1 e 2}

Estado 0 - Menor que a área de participação do infra-orbital 1 na órbita (figura 79a)

Aphyocharax pusillus, Brycon pesu, Bryconamericus exodon, Bryconops alburnoides, Chalceus epakros, Charax leticiae, Cheirodon galusdae, Ctenobrycon hauxwellianus, Deuterodon iguape, Galeocharax knerii, Gymnocorymbus ternertzi, ollandichthys multifasciatus, Hydrolycus scomberoides, Hyphessobrycon eques, Jupiaba anteroides, Knodus moenkhausii, Markiana nigripinnis, Mimagoniates microlepis, Moenkhausia xinguensis, Nematocharax venustus, Oligosarcus pintoi, Poptella paraguayensis, Rachoviscus graciliceps, Salminus hilarii, Stethaprion erythrops, Stichonodon insignis

Estado 1 - Maior que a área de participação do infra-orbital 1 na órbita Acestrorhynchus falcatus, Agoniates anchovia, Agoniates halecinus, Clupeacharax anchoveoides, Engraulisoma taeniatum, Lignobrycon myersii, Piabina argentea, Triportheus albus

Estado 2 - Semelhante à área de participação do infra-orbital 1 na órbita (figura 79b)

Astyanacinus moorii, Astyanacinus sp. nova Bolivia, Astyanacinus sp. nova Peru, "Astyanax" superbus, "Astyanax" orthodus, Astyanax altiparanae, Astyanax fasciatus, Astyanax lineatus, Astyanax paranae, Creagrutus menezesi, Tetragonopterus chalceus,

\section{Indeterminado}

Thoracocharax stellatus

A porção posterior do infra-orbital 1 contacta a porção anterior da infraorbital 2 sendo que nesse contato pode haver uma sobreposição lateral do segundo infra-orbital sobre primeiro. Em algumas espécies a contato entre esses infra-orbitais é maior e, em outras, é reduzido. Geralmente, nas espécies com amplo contato entre esses ossos o infra-orbital o primeiro infra-orbital apresenta pequena participação na margem orbital, um exemplo extremo disso é observado Engraulisoma como ilustrado em Castro (1983). Na maioria dos Characiformes, o contato entre os infra-orbitais 1 e 2 é restrito e menor que a participação do primeiro infra-orbital na margem orbital.

\section{Caráter 03. Tamanho da margem anterior do quarto infra-orbital}

Zanata (2000) caráter 8, Piton-Serra (2003) caráter 25, Benine (2004) caráter 2, Netto-Ferreira (2005) caracteres 10 e 11, Zanata \& Vari (2005) caráter 13, 
Buhrnhein (2006) caráter 20, Moreira (2007) caráter 155, Mirande (2010) caráter 67

Estado 0 - Margem pequena, menor que o comprimento do osso (figura 79b)

Acestrorhynchus falcatus, Agoniates anchovia, Agoniates halecinus, Astyanacinus moorii, Astyanacinus sp. nova Bolivia, Astyanacinus sp. nova Peru, "Astyanax" superbus, "Astyanax" orthodus, Astyanax altiparanae, Astyanax lineatus, Astyanax paranae, Brycon pesu, Chalceus epakros, Creagrutus menezesi, Deuterodon iguape, Galeocharax knerii, Hydrolycus scomberoides, Lignobrycon myersii, Oligosarcus pintoi, Piabina argentea, Salminus hilarii

Estado 1 - Margem ampla, maior que o comprimento do osso

Aphyocharax pusillus, Astyanax fasciatus, Bryconops alburnoides, Cheirodon galusdae, Ctenobrycon hauxwellianus, Gymnocorymbus ternertzi, Hyphessobrycon eques, Jupiaba anteroides, Moenkhausia xinguensis, Mimagoniates microlepis, Poptella paraguayensis, Stethaprion erythrops, Stichonodon insignis, Tetragonopterus chalceus, Triportheus albus

Estado 2 - Igual ao comprimento do osso

Nematocharax venustus, Markiana nigripinnis, Knodus moenkhausii, Bryconamericus exodon

Indeterminado

Charax leticiae, Thoracocharax stellatus

\section{Inaplicável}

Clupeacharax anchoveoides, Engraulisoma taeniatum, Hollandichthys multifasciatus, Rachoviscus graciliceps

A forma do quarto infra-orbital é bastante variável entre os Characiformes e essa variação tem sido freqüentemente utilizada como diversos caracteres em filogenias. A variação ocorre tanto nas margens anteriores e posteriores quanto na altura do osso que pode ser mais largo do que alto ou o inverso. Dos peixes examinados, a condição mais comum foi um infra-orbital 4 com margem anterior menor que o comprimento do osso e maior que a margem posterior.

\section{Caráter 04. Grau de fusão dos infra-orbitais 3 e 4}

Zanata \& Vari (2005) caráter 12, Mirande (2010) caráter 66

\section{Estado 0 - Separados (figura 79b)}

Acestrorhynchus falcatus, Agoniates anchovia, Agoniates halecinus, Aphyocharax pusillus, Astyanacinus moorii, Astyanacinus sp. nova Bolivia, Astyanacinus sp. nova Peru, "Astyanax" superbus, "Astyanax" orthodus, Astyanax altiparanae, Astyanax fasciatus, Astyanax lineatus, Astyanax paranae, Brycon pesu, Bryconamericus exodon, Bryconops alburnoides, Chalceus epakros, Charax leticiae, Cheirodon galusdae, Creagrutus menezesi, Ctenobrycon hauxwellianus, Deuterodon iguape, Galeocharax knerii, Gymnocorymbus ternertzi, Hydrolycus scomberoides, Hyphessobrycon eques, Jupiaba anteroides, Knodus moenkhausii, Lignobrycon myersii, Markiana nigripinnis, Mimagoniates microlepis, Moenkhausia xinguensis, Nematocharax venustus, Oligosarcus pintoi, Piabina argentea, Poptella 
paraguayensis, Salminus hilarii, Stethaprion erythrops, Stichonodon insignis, Tetragonopterus chalceus, Triportheus albus

Estado 1 - Fundidos

Hollandichthys multifasciatus, Rachoviscus graciliceps, Engraulisoma taeniatum, Clupeacharax anchoveoides,

\section{Indeterminado}

Thoracocharax stellatus

Como salienta Mirande (2010) a maioria dos Characiformes apresentam seis infra-orbitais, porém reduções nesse número surge em diversos grupos com perdas e fusões em diversos ossos dá série sendo o quarto infra-orbital é o mais freqüentemente envolvido com modificações. Uj (1990) propõe que a redução ou perda desse osso é sinapomórfica para Aphyocharacidae (Aphyocharax + Prionobrama), Vari (1995) infere a mesma característica como uma sinapomorfia de Ctenoluciidae. Castro (1983) sugere a fusão entre os infraorbitais 3 e 4 como uma sinapomorfia de Clupeacharax e Engraulisoma. Segundo Zanata \& Vari (2005) algumas espécies de Alestidae não apresentam o quarto infra-orbital e essa condição derivada estaria relacionada à redução corporal das espécies. Vari (1979) reporta a perda do osso em Nannocharax, Weitzman (1954) em Carnegiella e Weitzman \& Malabarba (1999) em Spintherobolus. A espécie Charax leticiae apresenta uma condição intermediária, com o canal sensorial desenvolvido, porém com as lamelas não ossificadas e a priori a espécie é codificada como estado indeterminado. Zanata \& Vari (2005) e Mirande (2010) também reportam que Charax apresenta uma condição diferente dos demais peixes.

\section{Caráter 05. Tamanho da margem posterior do quarto infra-orbital}

Estado 0 - Maior ou do mesmo tamanho que a margem anterior (figura 79a)

Acestrorhynchus falcatus, Agoniates anchovia, Agoniates halecinus, Brycon pesu, Bryconops alburnoides, Cheirodon galusdae, Galeocharax knerii, Hydrolycus scomberoides, Markiana nigripinnis, Moenkhausia xinguensis, Nematocharax venustus, Oligosarcus pintoi, Triportheus albus, Stichonodon insignis

Estado 1 - Menor que a margem anterior (figura 79b)

Astyanacinus moorii, Astyanacinus sp. nova Bolivia, Astyanacinus sp. nova Peru, "Astyanax" superbus, "Astyanax" orthodus, Astyanax altiparanae, Astyanax fasciatus, Astyanax lineatus, Astyanax paranae, 
Bryconamericus exodon, Chalceus epakros, Creagrutus menezesi, Ctenobrycon hauxwellianus, Deuterodon iguape, Gymnocorymbus ternertzi, Hyphessobrycon eques, Jupiaba anteroides, Knodus moenkhausii, Lignobrycon myersii, Piabina argentea, Poptella paraguayensis, Salminus hilarii, Stethaprion erythrops, Tetragonopterus chalceus

\section{Indeterminado}

Aphyocharax pusillus, Charax leticiae, Mimagoniates microlepis, Thoracocharax stellatus

\section{Inaplicável}

Clupeacharax anchoveoides, Engraulisoma taeniatum, Hollandichthys multifasciatus, Rachoviscus graciliceps

Mesma discussão do caráter 04.

\section{Caráter 06. Comprimento do ramo posterior do canal sensorial no infra- orbital 4}

Benine (2004) caráter 3, Zanata \& Vari (2005) caráter 151, Lima (2006) caráter 53, Toledo-Piza (2007) caráter 92, Moreira (2007) caráter 157, Mirande (2010) caráter 74

Estado 0 - Bem desenvolvido alcançando quase metade do osso (figura 79a)

Agoniates anchovia, Agoniates halecinus, Astyanacinus moorii, Astyanacinus sp. nova Bolivia, Astyanacinus sp. nova Peru, "Astyanax" superbus, "Astyanax" orthodus, Astyanax altiparanae, Astyanax fasciatus, Astyanax lineatus, Brycon pesu, Bryconops alburnoides, Chalceus epakros, Charax leticiae, Deuterodon iguape, Galeocharax knerii, Gymnocorymbus ternertzi, Jupiaba anteroides, Lignobrycon myersii, Markiana nigripinnis, Moenkhausia xinguensis, Oligosarcus pintoi, Poptella paraguayensis, Salminus hilarii

Estado 1 - Muito curto ou ausente

Acestrorhynchus falcatus, Astyanax paranae, Bryconamericus exodon, Cheirodon galusdae, Ctenobrycon hauxwellianus, Creagrutus menezesi, Hydrolycus scomberoides, Hyphessobrycon eques, Knodus moenkhausii, Mimagoniates microlepis, Nematocharax venustus, Piabina argentea, Stethaprion erythrops, Stichonodon insignis, Tetragonopterus chalceus, Triportheus albus

\section{Indeterminado}

Thoracocharax stellatus, Aphyocharax pusillus

\section{Inaplicável}

Engraulisoma taeniatum, Clupeacharax anchoveoides, Hollandichthys multifasciatus, Rachoviscus graciliceps

$\mathrm{Na}$ grande maioria dos Characiformes o infra-orbital 4 possui uma ramificação posterior do canal sensorial e que apresenta diferentes graus de desenvolvimento. Em alguns táxons examinados a canal se prolonga 
posteriormente ao quarto infra-orbital alcançando a lateral do opérculo, mas esse prolongamento do canal não é ossificado.

\section{Caráter 07. Grau de ramificação do canal sensorial do infra-orbital 6}

Moreira (2002) caráter 46, Zanata \& Vari (2005) caráter 153, Toledo-Piza (2007) caráter 93, Mirande (2010) caráter 76

\section{Estado 0 - Com ramificação conspícua (figura 79a)}

Brycon pesu, Bryconops alburnoides, Chalceus epakros, Clupeacharax anchoveoides, Galeocharax knerii, Hollandichthys multifasciatus, Hydrolycus scomberoides, Markiana nigripinnis, Salminus hilarii, Triportheus albus, Tetragonopterus chalceus

\section{Estado 1 - Sem ramificação (figura 79b)}

Acestrorhynchus falcatus, Agoniates anchovia, Agoniates halecinus, Aphyocharax pusillus, Astyanacinus moorii, Astyanacinus sp. nova Bolivia, Astyanacinus sp. nova Peru, "Astyanax" superbus, "Astyanax" orthodus, Astyanax altiparanae, Astyanax fasciatus, Astyanax lineatus, Astyanax paranae, Bryconamericus exodon, Charax leticiae, Cheirodon galusdae, Creagrutus menezesi, Ctenobrycon hauxwellianus, Deuterodon iguape, Engraulisoma taeniatum, Gymnocorymbus ternertzi, Hyphessobrycon eques, Jupiaba anteroides, Knodus moenkhausii, Lignobrycon myersii, Mimagoniates microlepis, Moenkhausia xinguensis, Nematocharax venustus, Oligosarcus pintoi, Piabina argentea, Poptella paraguayensis, Stethaprion erythrops, Stichonodon insignis

\section{Indeterminado}

Thoracocharax stellatus, Rachoviscus graciliceps

Apesar de existirem exceções, nos Characiformes o infra-orbital 6 apresenta o ramo do canal sensorial que conecta o sistema infra-orbital com crânio através de ligação com o ramo supra-orbital. Em alguns táxons esse canal é simples enquanto que em outros ele é ramificado. Zanata \& Vari (2005) denominam de tripartido o estado do caráter que considero aqui como ramificado.

\section{Caráter 08. Tamanho da margem inferior do antorbital}

Estado 0 - Menor que a altura do osso

Acestrorhynchus falcatus, Aphyocharax pusillus, Astyanacinus moorii, Astyanacinus sp. nova Bolivia, Astyanacinus sp. nova Peru, "Astyanax" superbus, "Astyanax" orthodus, Astyanax altiparanae, Astyanax lineatus, Astyanax paranae, Bryconamericus exodon, Bryconops alburnoides, Charax leticiae, Clupeacharax anchoveoides, Ctenobrycon hauxwellianus, Deuterodon iguape, Engraulisoma taeniatum, Galeocharax knerii, Gymnocorymbus ternertzi, Hollandichthys multifasciatus, Hydrolycus scomberoides, Hyphessobrycon eques, Jupiaba anteroides, Knodus moenkhausii, Lignobrycon myersii, Markiana nigripinnis, Mimagoniates microlepis, Moenkhausia xinguensis, Nematocharax venustus, Oligosarcus 
pintoi, Piabina argentea, Poptella paraguayensis, Rachoviscus graciliceps, Salminus hilarii, Stethaprion erythrops, Stichonodon insignis, Tetragonopterus chalceus, Thoracocharax stellatus

Estado 1 - Maior ou semelhante à altura do osso (figura 79a)

Agoniates anchovia, Agoniates halecinus, Astyanax fasciatus, Brycon pesu, Chalceus epakros, Cheirodon galusdae, Creagrutus menezesi, Triportheus albus

O antorbital é um osso posicionado na margem antero-ventral da margem orbital. Está presente na grande maioria dos Characiformes, porém a perda desta ossificação parece ter ocorrido em algumas linhagens independentemente. Oyakawa (1998) reporta a ausência em Hoplias, Vari (1995) em Ctenoluciidae, Zanata \& Vari (2005) em Lepidarchus, Moreira (2007) em Glandulocauda, Mirande (2010) em Inpaichthys. Quando presente, essa ossificação apresenta quase sempre a margem inferior mais ampla que a superior.

\section{Caráter 09. Formato do antorbital}

Estado 0 - Margem superior ampla, mas menor que a inferior (figura 79a) Agoniates anchovia, Agoniates halecinus, Aphyocharax pusillus, Brycon pesu, Bryconops alburnoides, Chalceus epakros, Charax leticiae, Engraulisoma taeniatum, Hydrolycus scomberoides, Lignobrycon myersii, Poptella paraguayensis, Salminus hilarii, Stethaprion erythrops, Thoracocharax stellatus, Triportheus albus

Estado 1 - Forma de triângulo com margem superior muito afilada Acestrorhynchus falcatus, Astyanacinus moorii, Astyanacinus sp. nova Bolivia, Astyanacinus sp. nova Peru, "Astyanax" superbus, "Astyanax" orthodus, Astyanax altiparanae, Astyanax fasciatus, Astyanax lineatus, Astyanax paranae, Bryconamericus exodon, Cheirodon galusdae, Clupeacharax anchoveoides, Creagrutus menezesi, Ctenobrycon hauxwellianus, Deuterodon iguape, Gymnocorymbus ternertzi, Hyphessobrycon eques, Knodus moenkhausii, Markiana nigripinnis, Mimagoniates microlepis, Moenkhausia xinguensis, Piabina argentea, Stichonodon insignis, Tetragonopterus chalceus

Estado 2 - Margem superior mais a larga que a inferior Galeocharax knerii

Estado 3 - Margens superior e inferior semelhantes

Hollandichthys multifasciatus, Jupiaba anteroides, Nematocharax venustus, Rachoviscus graciliceps

\section{Polimórfico}

Oligosarcus pintoi

Mesma discussão do caráter anterior

\section{Caráter 10. Posição do antorbital}

Toledo-Piza (2000) caráter 2, Mirande (2010) caráter 56 
Estado 0 - Lateralmente sobreposto ao etmóide lateral

Agoniates anchovia, Agoniates halecinus, Chalceus epakros, Clupeacharax anchoveoides, Engraulisoma taeniatum, Hydrolycus scomberoides, Mimagoniates microlepis, Triportheus albus, Thoracocharax stellatus

Estado 1 - Sem contato com o etmóide lateral (figura 82a)

Acestrorhynchus falcatus, Aphyocharax pusillus, Astyanacinus moorii, Astyanacinus sp. nova Bolivia, Astyanacinus sp. nova Peru, "Astyanax" superbus, "Astyanax" orthodus, Astyanax altiparanae, Astyanax fasciatus, Astyanax lineatus, Astyanax paranae, Brycon pesu, Bryconamericus exodon, Bryconops alburnoides, Charax leticiae, Cheirodon galusdae, Creagrutus menezesi, Ctenobrycon hauxwellianus, Deuterodon iguape, Galeocharax knerii, Gymnocorymbus ternertzi, Hollandichthys multifasciatus, Hyphessobrycon eques, Jupiaba anteroides, Knodus moenkhausii, Lignobrycon myersii, Markiana nigripinnis, Moenkhausia xinguensis, Nematocharax venustus, Oligosarcus pintoi, Piabina argentea, Poptella paraguayensis, Rachoviscus graciliceps, Salminus hilarii, Stethaprion erythrops, Stichonodon insignis, Tetragonopterus chalceus

Na grande maioria dos Characiformes o osso antorbital está posicionado anteriormente à asa do etmóide lateral. Por outro lado, em alguns táxons o antorbital está posicionado lateralmente à ao etmóide lateral contactando-o medialmente. Segundo Toledo-Piza (2000) todos os Cynodontinae possuem esse contato e a autora considera essa característica como sinapomórfica para o clado. Mirande (2010) considera que esse estado seja uma sinapomorfia para o clado Triportheus + Lignobrycon e para Gasteropelecidae (Carnegiella, Engraulisoma, Gasteropelecus e Thoracocharax; Clupeacharax?). Castro (1983) diz que o contato entre esses ossos é uma possível sinapomorfia para Clupeacharax e Engraulisoma.

\section{Caráter 11. Contato entre o primeiro infra-orbital e o antorbital}

Estado 0 - Restrito, bem menor que o contato entre o quinto e o sexto-infraorbital ou sem contato (figura 79b)

Astyanacinus moorii, Astyanacinus sp. nova Bolivia, Astyanacinus sp. nova Peru, "Astyanax” superbus, "Astyanax" orthodus, Astyanax altiparanae, Astyanax fasciatus, Astyanax lineatus, Astyanax paranae, Brycon pesu, Chalceus epakros, Cheirodon galusdae, Clupeacharax anchoveoides, Creagrutus menezesi, Ctenobrycon hauxwellianus, Engraulisoma taeniatum, Galeocharax knerii, Gymnocorymbus ternertzi, Hollandichthys multifasciatus, Hyphessobrycon eques, Jupiaba anteroides, Knodus moenkhausii, Markiana nigripinnis, Mimagoniates microlepis, Piabina argentea, Rachoviscus graciliceps, Stethaprion erythrops, Stichonodon insignis

Estado 1 - igual ou quase tão extenso quanto o contato entre o quinto e o sextoinfra-orbital

Acestrorhynchus falcatus, Agoniates anchovia, Agoniates halecinus, Aphyocharax pusillus, Bryconamericus exodon, Bryconops alburnoides, Charax leticiae, Deuterodon iguape, Hydrolycus 
scomberoides, Lignobrycon myersii, Moenkhausia xinguensis, Nematocharax venustus, Oligosarcus pintoi, Poptella paraguayensis, Salminus hilarii, Tetragonopterus chalceus, Triportheus albus

\section{Indeterminado}

Thoracocharax stellatus

Quando presente, nos Characiformes a margem ventral do osso antorbital contacta a margem antero-dorsal do infra-orbital 1. Esse contato pode ser amplo, restrito ou ausente. Há uma direta correlação entre um extenso contato entre esses ossos e o grau de desenvolvimento da margem inferior do antorbital.

\section{Caráter 12. Alinhamento das margens anteriores do antorbital e do primeiro infra-orbital}

Estado 0 - Margem anterior do antorbital anterior a do primeiro infra-orbital Acestrorhynchus falcatus, Aphyocharax pusillus, Astyanacinus moorii, Astyanacinus sp. nova Bolivia, Astyanacinus sp. nova Peru, "Astyanax" superbus, "Astyanax" orthodus, Astyanax altiparanae, Astyanax fasciatus, Astyanax lineatus, Astyanax paranae, Brycon pesu, Bryconamericus exodon, Bryconops alburnoides, Charax leticiae, Cheirodon galusdae, Creagrutus menezesi, Ctenobrycon hauxwellianus, Deuterodon iguape, Engraulisoma taeniatum, Gymnocorymbus ternertzi, Hollandichthys multifasciatus, Hydrolycus scomberoides, Hyphessobrycon eques, Jupiaba anteroides, Knodus moenkhausii, Lignobrycon myersii, Markiana nigripinnis, Mimagoniates microlepis, Moenkhausia xinguensis, Nematocharax venustus, Oligosarcus pintoi, Piabina argentea, Poptella paraguayensis, Rachoviscus graciliceps, Salminus hilarii, Stethaprion erythrops, Stichonodon insignis, Tetragonopterus chalceus, Triportheus albus

Estado 1 - Margem anterior do antorbital posterior a do primeiro infra-orbital Galeocharax knerii

Estado 2 - Margens anterior do antorbital e do primeiro infra-orbital alinhadas Agoniates anchovia, Agoniates halecinus, Chalceus epakros, Clupeacharax anchoveoides, Thoracocharax stellatus

Nos Characiformes que apresentam antorbital esse osso geralmente tem sua margem ventral em contato com a margem antero-dorsal do infra-orbital 1. A posição entre esses ossos é variável, porém a maioria dos peixes examinados apresentam a margem do anterior do antorbital anteriormente posicionada à margem do infra-orbital 1.

\section{Caráter 13. Gau de contato entre o infra-orbital 6 e o supra-orbital}


Lucena (1993) caráter 27, Moreira (2002) caráter 40, Zanata \& Vari (2005) caráter 5, Moreira (2007) caráter 174, Mirande (2010) caráter 71

Estado 0 - Grande espaço entre o supra-orbital e o sexto infra-orbital Acestrorhynchus falcatus, Agoniates anchovia, Agoniates halecinus, Chalceus epakros, Bryconops alburnoides, Clupeacharax anchoveoides, Engraulisoma taeniatum

Estado 1 - Contato entre o supra-orbital e o sexto infra-orbital (figura 79a) Brycon pesu, Hydrolycus scomberoides, Lignobrycon myersii, Salminus hilarii, Triportheus albus

\section{Inaplicável}

Aphyocharax pusillus, Astyanacinus moorii, Astyanacinus sp. nova Bolivia, Astyanacinus sp. nova Peru, "Astyanax" superbus, "Astyanax" orthodus, Astyanax altiparanae, Astyanax fasciatus, Astyanax lineatus, Astyanax paranae, Bryconamericus exodon, Charax leticiae, Cheirodon galusdae, Creagrutus menezesi, Ctenobrycon hauxwellianus, Deuterodon iguape, Galeocharax knerii, Gymnocorymbus ternertzi, Hollandichthys multifasciatus, Hyphessobrycon eques, Jupiaba anteroides, Knodus moenkhausii, Markiana nigripinnis, Mimagoniates microlepis, Moenkhausia xinguensis, Nematocharax venustus, Oligosarcus pintoi, Piabina argentea, Poptella paraguayensis, Rachoviscus graciliceps, Stethaprion erythrops, Stichonodon insignis, Tetragonopterus chalceus, Thoracocharax stellatus

Quando presente o supra-orbital é um osso que faz parte de série orbital e situa-se entre o antorbital e o sexto infra-orbital. Em alguns Characiformes há grande desenvolvimento do osso supra-orbital fazendo com que haja contato entre esse o sexto infra-orbital tornando a série infra-orbital fechada, ou seja, sem a participação do frontal na órbita. É necessário dizer que, como salienta Zanata \& Vari (2005), entre os Characiformes não existe uma relação direta entre o desenvolvimento de supra-orbital e o desenvolvimento do corpo, uma vez que, por exemplo, espécies de Erythrinidae de grande porte não possuem tal ossificação ao passo que espécies de Characidae de pequeno porte como Engraulisoma tem supra-orbital.

\section{Caráter 14. Supra-orbital}

Uj (1990) caráter 48, Lucena (1993) caráter 26, Vari (1995) caráter 09, Buckup (1998) caráter 21, Oyakawa (1998) caráter 07, Moreira (2002) caráter 39, Benine (2004) caráter 5, Zanata \& Vari (2005) caráter 02, Netto-Ferreira (2005) caráter 18, Lima (2006) caráter 6, Toledo-Piza (2007) caráter 37, Mirande (2010) caráter 
Estado 0 - Presente (figura 79a)

Acestrorhynchus falcatus, Agoniates anchovia, Agoniates halecinus, Brycon pesu, Bryconops alburnoides, Chalceus epakros, Clupeacharax anchoveoides, Engraulisoma taeniatum, Lignobrycon myersii, Hydrolycus scomberoides, Salminus hilarii, Triportheus albus

\section{Estado 1 - Ausente}

Aphyocharax pusillus, Astyanacinus moorii, Astyanacinus sp. nova Bolivia, Astyanacinus sp. nova Peru, "Astyanax" superbus, "Astyanax" orthodus, Astyanax altiparanae, Astyanax fasciatus, Astyanax lineatus, Astyanax paranae, Bryconamericus exodon, Charax leticiae, Cheirodon galusdae, Creagrutus menezesi, Ctenobrycon hauxwellianus, Deuterodon iguape, Galeocharax knerii, Gymnocorymbus ternertzi, Hollandichthys multifasciatus, Hyphessobrycon eques, Jupiaba anteroides, Knodus moenkhausii, Markiana nigripinnis, Mimagoniates microlepis, Moenkhausia xinguensis, Nematocharax venustus, Oligosarcus pintoi, Piabina argentea, Poptella paraguayensis, Rachoviscus graciliceps, Stethaprion erythrops, Stichonodon insignis, Tetragonopterus chalceus, Thoracocharax stellatus

Como sugerido em Roberts (1969), os Characiformes primitivamente possuem um anel orbital com um osso supra-orbital e essa hipótese vem sendo seguida por diversos autores há anos. Além de estar presente nos grupos mais basais de caracóideos, tal ossificação está presente em Gonorhynchiformes e Cypriniformes (Fink \& Fink, 1981), além de ser encontrada na grande maioria dos Characiformes. No entanto, entre esses últimos há eventos secundários de perda de tal. Essa perda ocorre em Lebiasinidae, Erythrinidae, Crenuchinae, em alguns Alestidae e em diversos Characidae. Segundo Vari (1995) a perda do supra-orbital teria ocorrido independentemente em Erythrinidae e em Lebiasinidae, proposta esta diferente do sugerido por Oyakawa (1998) e NettoFerreira (2010) em que a perda seria sinapomórfica para um clado composto por essas duas famílias. Buckup (1998) considera a perda do supra-orbital sinapomórfica para os Crenuchinae. Zanata \& Vari (2005) consideram a perda da ossificação como sinapomórfica para um clado composto por alguns gêneros de Alestidae. Com relação aos Characidae, Malabarba \& Weitzman (2003) propõem que a ausência deste osso seria sinapomórfica para um clado contendo os Aphyocharacinae, Characinae, Cheirodontinae, Glandulocaudinae, Paragoniatinae, Rhoadsiinae, Stethaprioninae e Tetragonopterinae, além de todos os gêneros incertae sedis sensu Lima et. al (2003). 


\section{Caráter 15. Rinosfenóide}

Lucena (1993) caráter 08, Buckup (1998) caráter 07, Toledo-Piza (2000) caráter 16, Zanata (2000) caráter 16, Benine (2004) caráter 20, Netto-Ferreira (2005) caráter 44, Zanata \& Vari (2005) caráter 31, Moreira (2007) caráter 101, ToledoPiza 2007 caráter 13, Mirande (2010) caráter 47

Estado 0 - Presente (figura 80a)

Acestrorhynchus falcatus, Agoniates anchovia, Agoniates halecinus, Aphyocharax pusillus, Astyanacinus sp. nova Bolivia, Astyanacinus sp. nova Peru, "Astyanax" orthodus, Astyanax fasciatus, Astyanax paranae, Bryconamericus exodon, Bryconops alburnoides, Cheirodon galusdae, Clupeacharax anchoveoides, Creagrutus menezesi, Ctenobrycon hauxwellianus, Gymnocorymbus ternertzi, Hydrolycus scomberoides, Hyphessobrycon eques, Jupiaba anteroides, Knodus moenkhausii, Lignobrycon myersii, Mimagoniates microlepis, Nematocharax venustus, Oligosarcus pintoi, Piabina argentea, Poptella paraguayensis, Stethaprion erythrops, Stichonodon insignis, Tetragonopterus chalceus, Triportheus albus

Estado 1 - Ausente ou cartilaginoso

Astyanacinus moorii, “Astyanax" superbus, Astyanax lineatus, Astyanax altiparanae, Brycon pesu, Chalceus epakros, Charax leticiae, Deuterodon iguape, Engraulisoma taeniatum, Galeocharax knerii, Hollandichthys multifasciatus, Markiana nigripinnis, Rachoviscus graciliceps, Salminus hilarii, Thoracocharax stellatus

\section{Indeterminado}

Moenkhausia xinguensis

O rinosfenóide é um osso ímpar situado no plano sagital craniano situado anteriormente ao orbitoesfenóide com o qual geralmente liga-se por intermédio de uma cartilagem. Esse osso projeta-se por entre e por baixo das abas dos etmóides laterais e sua porção anterior liga-se na junção sincondral que há entre os etmóides laterais.

O osso rinosfenóide não é encontrado em nenhum outro grupo de Ostariophysi além dos peixes da ordem Characiformes (Toledo-Piza, 2000). Dentro dessa ordem é encontrado nos Hemiodontidae (Roberts, 1974), Cynodontidae (Toledo-Piza, 2000); Acestrorhynchidae (Menezes, 1969: Roberts, 1969; Toledo-Piza, 2007) e Characidae (Mirande, 2010). Campanário (2002) reporta a presença de rinosfenóide em Crenuchidae enquanto que segundo Moreira (2007) não há rinosfenóide em Characidium bahiensis e Crenuchus spilurus. Para Roberts (1973) a distribuição da presença ou ausência desse osso entre os Characiformes Sul-americanos parece ser em mosaico. 
Entre os Characidae, a presença desse osso é bastante variável, estando presente em algumas linhagens e ausentes em outras, além disso, a presença dessa ossificação é variável intra-genericamente como reportado por Roberts (1973) em que o autor cita que Astyanax fasciatus apresenta rinosfenóide e Astyanas festae não. No presente trabalho as observações de Tyson Roberts são parcialmente corroboradas, pois é detectada a variação intra-genérica em Astyanax. Mirande (2010) reporta ainda que a variação na presença ou ausência desse osso pode ser intraespecífica, ou seja, um polimorfismo.

\section{Caráter 16. Processo dorsal do rinosfenóide}

Lucena \& Menezes (1998) caráter 33, Toledo-Piza (2000) caráter 16, Piton-Serra (2003) caráter 17, Benine (2004) caráter 21, Ferreira (2007) caráter 30, Mirande (2010) caráter 48

\section{Estado 0 - Ausente (figura 80b)}

Acestrorhynchus falcatus, Agoniates anchovia, Agoniates halecinus, Aphyocharax pusillus, Astyanacinus sp. nova Bolivia, Astyanacinus sp. nova Peru, "Astyanax" orthodus, Astyanax paranae, Bryconamericus exodon, Bryconops alburnoides, Cheirodon galusdae, Creagrutus menezesi, Hydrolycus scomberoides, Knodus moenkhausii, Lignobrycon myersii, Mimagoniates microlepis, Oligosarcus pintoi, Triportheus albus, Piabina argentea

\section{Estado 1 - Presente}

Astyanax fasciatus, Clupeacharax anchoveoides, Ctenobrycon hauxwellianus, Gymnocorymbus ternertzi, Jupiaba anteroides, Nematocharax venustus, Poptella paraguayensis, Stethaprion erythrops, Stichonodon insignis, Tetragonopterus chalceus

\section{Inaplicável}

Astyanacinus moorii, "Astyanax" superbus, Astyanax lineatus, Astyanax altiparanae, Brycon pesu, Chalceus epakros, Charax leticiae, Deuterodon iguape, Engraulisoma taeniatum, Galeocharax knerii, Hollandichthys multifasciatus, Markiana nigripinnis, Rachoviscus graciliceps, Salminus hilarii, Thoracocharax stellatus

A forma do osso rinosfenóide é variável entre os Characiformes e esse osso geralmente está tem seu eixo principal inclinado para trás, ficando aproximadamente na diagonal do paraesfenóide. Em alguns táxons a porção posterior do rinosfenóide que contata a porção anterior do orbitosfenóide possui um processo dorsalmente desenvolvido. 


\section{Caráter 17. Margem ventral do rinoesfenóide}

Toledo-Piza (2007) caráter 14, Mirande (2010) caráter 50

Estado 0 - Distante da borda dorsal do paraesfenóide (figura 82a)

Agoniates anchovia, Agoniates halecinus, Astyanacinus sp. nova Bolivia, Astyanacinus sp. nova Peru, "Astyanax" orthodus, Astyanax fasciatus, Astyanax paranae, Bryconamericus exodon, Bryconops alburnoides, Cheirodon galusdae, Clupeacharax anchoveoides, Creagrutus menezesi, Ctenobrycon hauxwellianus, Gymnocorymbus ternertzi, Hyphessobrycon eques, Jupiaba anteroides, Knodus moenkhausii, Lignobrycon myersii, Mimagoniates microlepis, Nematocharax venustus, Oligosarcus pintoi, Piabina argentea, Poptella paraguayensis, Stethaprion erythrops, Stichonodon insignis, Tetragonopterus chalceus, Triportheus albus

Estado 1 - Muito próxima e paralela à borda dorsal do paraesfenóide Acestrorhynchus falcatus, Aphyocharax pusillus, Hydrolycus scomberoides,

\section{Inaplicável}

Astyanacinus moorii, “Astyanax" superbus, Astyanax lineatus, Astyanax altiparanae, Brycon pesu, Chalceus epakros, Charax leticiae, Deuterodon iguape, Engraulisoma taeniatum, Galeocharax knerii, Hollandichthys multifasciatus, Markiana nigripinnis, Rachoviscus graciliceps, Salminus hilarii, Thoracocharax stellatus

Segundo Toledo-Piza (2007) o osso rinosfenóide das espécies de Acestrorhynchus é bastante desenvolvido e trata essa característica como sendo uma sinapomorfia da família. Entretanto, Mirande (2010) considera que condição semelhante é encontrada em Rhapiodon e sugere que seja uma sinapomorfia unindo Acestrorhynchinae e Cynodontinae.

\section{Caráter 18. Comprimento da porção anterior da fontanela frontal}

Lucena (1993) caráter 7, Vari (1995) caráter 26, Buckup (1998) caráter 9, Oyakawa (1998) caráter 21, Zanata (2000) caráter 20, Vari \& Harold (2001) caráter 37, Moreira (2002) caráter 35, Benine (2004) caráter 9, Zanata \& Vari (2005) caráter 36, Mirande (2010) caráter 21

Estado 0 - Margem anterior alcança a porção posterior do mesetmóide Acestrorhynchus falcatus, Agoniates anchovia, Agoniates halecinus, Aphyocharax pusillus, Astyanacinus moorii, Astyanacinus sp. nova Bolivia, Astyanacinus sp. nova Peru, "Astyanax" superbus, "Astyanax" orthodus, Astyanax fasciatus, Astyanax lineatus, Bryconamericus exodon, Ctenobrycon hauxwellianus, Gymnocorymbus ternertzi, Hollandichthys multifasciatus, Lignobrycon myersii, Markiana nigripinnis, Mimagoniates microlepis, Poptella paraguayensis, Salminus hilarii, Stethaprion erythrops, Stichonodon insignis, Tetragonopterus chalceus

Estado 1 - Margem anterior não alcança a porção posterior do mesetmóide 
Astyanax altiparanae, Astyanax paranae, Brycon pesu, Bryconops alburnoides, Chalceus epakros, Charax leticiae, Cheirodon galusdae, Clupeacharax anchoveoides, Creagrutus menezesi, Deuterodon iguape, Engraulisoma taeniatum, Galeocharax knerii, Hydrolycus scomberoides, Hyphessobrycon eques, Jupiaba anteroides, Moenkhausia xinguensis, Nematocharax venustus, Piabina argentea, Rachoviscus graciliceps, Triportheus albus

\section{Indeterminado}

Knodus moenkhausii, Oligosarcus pintoi, Thoracocharax stellatus

A maioria dos Characiformes possui os ossos frontais e parietais separados pelas fontanelas medianos frontais e parietais. Essas aberturas estão presentes também em representantes de Ostariophysi não- Characiformes (Vari, 1995), tais como Cypriniformes e Siluriformes.

A fontanela do osso frontal é variável em Characiformes sendo que Vari (1995) e Zanata \& Vari (2005) afirmam que esta se apresenta em diferentes graus de desenvolvimento no grupo, além disso, o primeiro sugere a ausência desta como sendo derivada para a ordem e teria surgido homoplasticamente várias vezes no clado. Dentre os caracóideos, a fontanela está ausente em diversos grupos como Ctenoluciidae, Erythrinidae e Hepsetidae (cf. Weitzman, 1964); Parodontidae (cf. Roberts, 1974); alguns Alestidae (Zanata \& Vari, 2005) e outros. Oyakawa (1998) considera a ausência da fontanela como sendo uma sinapormorfia para o clado Ctenoluciidae, Erythrinidae, Hepsetidae, Lebiasinidae, Phyrrhulinidae, resultado semelhante ao obtido nas duas hipóteses mais parcimoniosas de Buckup (1998).

Zanata \& Vari (2005) alertam para o fato de a fontanela ser variável conforme o estágio de vida do peixe, com indivíduos juvenis apresentando fontanelas mais desenvolvidas. Uma vez que no método de diafanização peixes menores (com até $10 \mathrm{~cm}$ ) são preferidos em detrimento de indivíduos maiores, espécies com adultos grandes podem apresentar problemas com a codificação deste caráter.

Além do desenvolvimento da fontanela, há também diferenças com relação à margem anterior desta que pode apresentar contato medial entre os ossos frontais fazendo que a margem posterior do mesetmóide não tenha 
participação na fontanela ou ausência de contato entre os frontais e o mesetmóide delimitando anteriormente a fontanela.

\section{Caráter 19. Processo postero-ventral do osso orbito-esfenóide}

Lucena (1993) caráter 9, Benine (2004) caráter 22, Ferreira (2007) caráter 31

\section{Estado 0 - Ausente (figura 82a)}

Acestrorhynchus falcatus, Agoniates anchovia, Agoniates halecinus, Aphyocharax pusillus, Astyanacinus sp. nova Bolivia, “Astyanax" superbus, Astyanax altiparanae, Astyanax fasciatus, Astyanax lineatus, Astyanax paranae, Brycon pesu, Bryconops alburnoides, Chalceus epakros, Clupeacharax anchoveoides, Creagrutus menezesi, Ctenobrycon hauxwellianus, Deuterodon iguape, Engraulisoma taeniatum, Galeocharax knerii, Gymnocorymbus ternertzi, Jupiaba anteroides, Markiana nigripinnis, Moenkhausia xinguensis, Nematocharax venustus, Piabina argentea, Salminus hilarii, Stethaprion erythrops, Triportheus albus

\section{Estado 1 - Presente}

Astyanacinus moorii, Astyanacinus sp. nova Peru, "Astyanax" orthodus, Bryconamericus exodon, Charax leticiae, Cheirodon galusdae, Hollandichthys multifasciatus, Hydrolycus scomberoides, Hyphessobrycon eques, Knodus moenkhausii, Lignobrycon myersii, Mimagoniates microlepis, Oligosarcus pintoi, Poptella paraguayensis, Rachoviscus graciliceps, Stichonodon insignis, Tetragonopterus chalceus, Thoracocharax stellatus

O orbito-esfenóide é um osso par formado por duas lâminas ósseas que se contactam medialmente. Sua margem posterior articula com o pterosfenóide e sua margem ventral pode ou não apresentar uma projeção em forma de ponta direcionada postero-ventralmente.

\section{Caráter 20. Distância entre os ossos órbito-esfenóide e paraesfenóide}

Toledo-Piza (2000) caráter 18, Zanata (2000) caráter 18, Benine (2004) caráter 25, Netto-Ferreira (2005) caráter 48, Moreira (2007) caráter 104

\section{Estado 0 - Ossos distantes}

Agoniates anchovia, Agoniates halecinus, Astyanacinus moorii, Astyanacinus sp. nova Bolivia, Astyanacinus sp. nova Peru, "Astyanax" superbus, “Astyanax" orthodus, Astyanax altiparanae, Astyanax fasciatus, Astyanax lineatus, Astyanax paranae, Brycon pesu, Bryconops alburnoides, Clupeacharax anchoveoides, Deuterodon iguape, Hyphessobrycon eques, Jupiaba anteroides, Knodus moenkhausii, Lignobrycon myersii, Mimagoniates microlepis, Moenkhausia xinguensis, Nematocharax venustus, Oligosarcus pintoi, Piabina argentea, Poptella paraguayensis, Rachoviscus graciliceps, Stethaprion erythrops, Stichonodon insignis, Tetragonopterus chalceus, Triportheus albus

Estado 1 - Ossos em contato ou bem próximos 
Acestrorhynchus falcatus, Aphyocharax pusillus, Bryconamericus exodon, Chalceus epakros, Charax leticiae, Cheirodon galusdae, Creagrutus menezesi, Ctenobrycon hauxwellianus, Engraulisoma taeniatum, Galeocharax knerii, Gymnocorymbus ternertzi, Hollandichthys multifasciatus, Hydrolycus scomberoides, Markiana nigripinnis, Salminus hilarii, Thoracocharax stellatus

A distância entre os ossos órbito-esfenóide e paraesfenóide é variável entre os Characiformes. Por exemplo, segundo Toledo-Piza (2000) todos os Cynodontinae apresentam o órbito-esfenóide em contato direto com o paraesfenóide e segundo a autora está uma sinapomorfia para do clado Cynodon + Rhaphiodon. Outros Characiformes que apresentam esses ossos próximos entre si são espécies Ctenoluciidae, Erythrinidae e Lebiasinidae. Por outro lado, como ilustrado em Weitzman (1962) Brycon meekii apresenta esses ossos distantes.

\section{Região ótica}

\section{Caráter 21. Processo da margem posterior do epoccipital}

Lucena (1993) caráter 21, Netto-Ferreira (2005) caráter 67, Moreira (2007) caráter 113, Mirande (2010) caráter 7

\section{Estado 0 - Lisa (figura 80a)}

Acestrorhynchus falcatus, Aphyocharax pusillus, Astyanacinus moorii, Astyanacinus sp. nova Bolivia, Astyanacinus sp. nova Peru, "Astyanax" superbus, "Astyanax" orthodus, Astyanax altiparanae, Astyanax fasciatus, Astyanax lineatus, Astyanax paranae, Brycon pesu, Bryconamericus exodon, Bryconops alburnoides, Chalceus epakros, Charax leticiae, Cheirodon galusdae, Clupeacharax anchoveoides, Engraulisoma taeniatum, Galeocharax knerii, Gymnocorymbus ternertzi, Hydrolycus scomberoides, Hyphessobrycon eques, Jupiaba anteroides, Knodus moenkhausii, Moenkhausia xinguensis, Nematocharax venustus, Poptella paraguayensis, Rachoviscus graciliceps, Stethaprion erythrops, Stichonodon insignis, Tetragonopterus chalceus, Thoracocharax stellatus

Estado 1 - Com processo posterior (figura 80b)

Agoniates anchovia, Agoniates halecinus, Creagrutus menezesi, Ctenobrycon hauxwellianus, Deuterodon iguape, Hollandichthys multifasciatus, Lignobrycon myersii, Markiana nigripinnis, Mimagoniates microlepis, Piabina argentea, Salminus hilarii, Triportheus albus

\section{Indeterminado}

Oligosarcus pintoi

O osso epoccipital é um osso com formato complexo que está em contato com diversos ossos da parte posterior do neurocrânio. Esse osso também compõe a borda posterior da fossa pós-temporal e em sua margem posterior pode 
apresentar ou não uma projeção óssea conspícua que serve para a fixação de músculos epaxiais. Weitzman (1962) ilustra essa estrutura em Brycon meeki.

\section{Caráter 22. Tamanho da cápsula lagenar}

Fink \& Fink (1981) caráter 15

Estado 0 - Pequena (bem menor que o proótico) (figura 80b)

Acestrorhynchus falcatus, Agoniates anchovia, Agoniates halecinus, Brycon pesu, Bryconops alburnoides, Clupeacharax anchoveoides, Creagrutus menezesi, Engraulisoma taeniatum, Hydrolycus scomberoides, Lignobrycon myersii, Salminus hilarii

Estado 1 - Grande (quase do mesmo tamanho do proótico) (figura 80a)

Aphyocharax pusillus, Astyanacinus moorii, Astyanacinus sp. nova Bolivia, Astyanacinus sp. nova Peru, "Astyanax" superbus, "Astyanax" orthodus, Astyanax altiparanae, Astyanax fasciatus, Astyanax lineatus, Astyanax paranae, Bryconamericus exodon, Chalceus epakros, Charax leticiae, Cheirodon galusdae, Ctenobrycon hauxwellianus, Deuterodon iguape, Galeocharax knerii, Gymnocorymbus ternertzi, Hollandichthys multifasciatus, Hyphessobrycon eques, Jupiaba anteroides, Knodus moenkhausii, Markiana nigripinnis, Mimagoniates microlepis, Moenkhausia xinguensis, Nematocharax venustus, Piabina argentea, Poptella paraguayensis, Rachoviscus graciliceps, Stethaprion erythrops, Stichonodon insignis, Tetragonopterus chalceus, Thoracocharax stellatus, Triportheus albus

\section{Indeterminado}

Oligosarcus pintoi

A cápsula lagenar é formada pelos ossos exoccipital e basioccipital e encontra-se na porção postero-inferior do neurocrânio. Uma cápsula lagenar bem desenvolvida é característica dos Characiformes, porém o tamanho relativo dessa estrutura é variável entre os eles e alguns táxons apresentam cápsulas tão desenvolvidas que podem ser tão grandes quanto o osso proótico.

\section{Caráter 23. Comprimento do espinho do pterótico}

Lucena (1993) caráter 17, Netto-Ferreira (2005) caráter 62, Mirande (2010) caráter 46

Estado 0 - Curto (não alcança a margem posterior do epoccipital) (figura 80a) Aphyocharax pusillus, Astyanacinus moorii, Astyanacinus sp. nova Bolivia, Astyanacinus sp. nova Peru, "Astyanax" superbus, "Astyanax" orthodus, Astyanax altiparanae, Astyanax fasciatus, Astyanax lineatus, Astyanax paranae, Bryconamericus exodon, Bryconops alburnoides, Chalceus epakros, Charax leticiae, Cheirodon galusdae, Creagrutus menezesi, Ctenobrycon hauxwellianus, Deuterodon iguape, Galeocharax knerii, Gymnocorymbus ternertzi, Hollandichthys multifasciatus, Hydrolycus scomberoides, Hyphessobrycon eques, Jupiaba anteroides, Knodus moenkhausii, Markiana nigripinnis, Mimagoniates 
microlepis, Moenkhausia xinguensis, Nematocharax venustus, Piabina argentea, Poptella paraguayensis, Rachoviscus graciliceps, Stethaprion erythrops, Stichonodon insignis, Tetragonopterus chalceus

Estado 1 - Longo (ultrapassa a margem posterior do epoccipital) (figura 80b)

Acestrorhynchus falcatus, Agoniates anchovia, Agoniates halecinus, Brycon pesu, Clupeacharax anchoveoides, Engraulisoma taeniatum, Lignobrycon myersii, Salminus hilarii, Thoracocharax stellatus, Triportheus albus

\section{Indeterminado}

Oligosarcus pintoi

O pterótico é um osso posicionado na porção postero-lateral craniana. Sua porção mais distal prolonga-se como uma projeção óssea, o espinho do pterótico.

O grau de desenvolvimento desse espinho é bastante variável entre os Characiformes. Segundo Mirande (2010) um espinho pouco desenvolvido é sinapomórfico para um grande clado de Characidae contendo Characinae, Cheirodontinae, Gymnocharacinae, Heterocharacinae, Rhoadsiinae, Stethaprioninae, Stevardiinae, and Tetragonopterinae; Astyanax clade, Astyanax paris clade, Bramocharax clade, Bryconamericus scleroparius clade, Hyphessobrycon anisitsi clade e Pseudochalceus clade.

\section{Caráter 24. Formato do proótico}

Malabarba (1998) caráter 14

\section{Estado 0 - Alto e curto (figura 80a)}

Astyanacinus moorii, Astyanacinus sp. nova Bolivia, Astyanacinus sp. nova Peru, "Astyanax" superbus, "Astyanax" orthodus, Astyanax altiparanae, Astyanax fasciatus, Astyanax lineatus, Astyanax paranae, Brycon pesu, Bryconops alburnoides, Cheirodon galusdae, Clupeacharax anchoveoides, Creagrutus menezesi, Deuterodon iguape, Galeocharax knerii, Gymnocorymbus ternertzi, Hollandichthys multifasciatus, Hydrolycus scomberoides, Hyphessobrycon eques, Jupiaba anteroides, Lignobrycon myersii, Markiana nigripinnis, Mimagoniates microlepis, Moenkhausia xinguensis, Nematocharax venustus, Piabina argentea, Poptella paraguayensis, Rachoviscus graciliceps, Stethaprion erythrops, Stichonodon insignis, Tetragonopterus chalceus

Estado 1 - Baixo e mais extenso horizontalmente (figura 80b)

Acestrorhynchus falcatus, Agoniates anchovia, Agoniates halecinus, Aphyocharax pusillus, Bryconamericus exodon, Chalceus epakros, Charax leticiae, Ctenobrycon hauxwellianus, Engraulisoma taeniatum, Knodus moenkhausii, Salminus hilarii, Thoracocharax stellatus, Triportheus albus

\section{Indeterminado}

Oligosarcus pintoi 
A proótico é um osso grande da porção postero-inferior do neurocrânio. Entre os peixes examinados ficou evidente uma variação no formato desse osso. Peixes com crânio cabeça mais alongada possui um proótico alongado enquanto que táxons com cabeça ligeiramente mais curta há um proótico mais curto e alto. Segundo Malabarba (1998) um formato mais alongado do proótico é uma sinapomorfia entre Triportheus e Lignobrycon. A autora comenta a presença de condição semelhante em Thoracocharax, porém comenta que a condição não deve ser homóloga.

\section{Região basicranial}

\section{Caráter 25. Porção posterior do paraesfenóide}

Estado 0 - Afilando-se gradualmente (figura 80b)

Acestrorhynchus falcatus, Agoniates anchovia, Agoniates halecinus, Aphyocharax pusillus, Chalceus epakros, Clupeacharax anchoveoides, Engraulisoma taeniatum, Galeocharax knerii, Hydrolycus scomberoides, Lignobrycon myersii, Rachoviscus graciliceps, Salminus hilarii

Estado 1 - Terminando abruptamente (figura 80a)

Astyanacinus moorii, Astyanacinus sp. nova Bolivia, Astyanacinus sp. nova Peru, "Astyanax" superbus, "Astyanax" orthodus, Astyanax altiparanae, Astyanax fasciatus, Astyanax lineatus, Astyanax paranae, Brycon pesu, Bryconamericus exodon, Bryconops alburnoides, Charax leticiae, Cheirodon galusdae, Creagrutus menezesi, Ctenobrycon hauxwellianus, Deuterodon iguape, Gymnocorymbus ternertzi, Hollandichthys multifasciatus, Hyphessobrycon eques, Jupiaba anteroides, Knodus moenkhausii, Markiana nigripinnis, Mimagoniates microlepis, Moenkhausia xinguensis, Nematocharax venustus, Piabina argentea, Poptella paraguayensis, Stethaprion erythrops, Stichonodon insignis, Tetragonopterus chalceus, Thoracocharax stellatus, Triportheus albus

\section{Indeterminado}

Oligosarcus pintoi

O paraesfenóide é maior osso do crânio e estende-se ventralmente desde a porção mais anterior até a mais posterior deste. Em sua porção posterior o paraesfenóide apresenta uma lamela óssea que pode diminuir gradualmente até a porção sua porção mais posterior ou terminar abruptamente e com formato côncavo posteriormente. A ilustração do neurocrânio de Brycon meeki de Weitzman (1962) em vista lateral esquerda é um exemplo da porção posterior do 
osso paraesfenóide terminando abruptamente e formando uma concavidade posterior.

\section{Esplancnocrânio}

Já o esplancnocrânio é formado por uma série de sete arcos que estariam presentes em sua forma plesiomórfica no ancestral dos gnatostomados, e que neles se modificaram para formar a parte visceral do esqueleto de um gnatostomado (Liem \& Walker, 2003).

\section{Arco mandibular}

O mais anterior e mais modificado arco de um peixe é o arco mandibular que forma as maxilas superior e inferior e compõem a região dorsal ("teto") da cavidade bucal. Plesiomorficamente é composto por duas cartilagens: dorsalmente pelo elemento palato-quadrado e ventralmente pela cartilagem de Meckel ou mandibular. A maxila superior é formada somente pelos ossos dermais pré-maxila e maxila enquanto que a maxila inferior é formada pelos ossos dermais dentário e retroarticular, e pelo angular que é endocondral. A região dorsal da cavidade bucal é formada por quatro ossos sendo que desses, são pré-formados em cartilagem o palatino e o metapterigóide enquanto que o endopterigóide e o ectopterigóide são dermais.

\section{Caráter 26. Número de séries de dentes no dentário}

Uj (1990) caráter 50, Lucena (1993) caráter 49, Buckup (1998) caráter 36, Malabarba (1998) caráter 41, Oyakawa (1998) caráter 61, Zanata (2000) caráter 55 e 56, Moreira (2002) caráter 10, Zanata \& Vari (2005) caráter 88, Lima (2006) caráter 13, Moreira (2007) caráter, Mirande (2010) caráter 143

Estado 0 - Duas séries (figura 81b)

Agoniates anchovia, Agoniates halecinus, Brycon pesu, Chalceus epakros, Galeocharax knerii, Nematocharax venustus, Salminus hilarii, Triportheus albus

Estado 1 - Uma série 
Acestrorhynchus falcatus, Aphyocharax pusillus, Astyanacinus moorii, Astyanacinus sp. nova Bolivia, Astyanacinus sp. nova Peru, "Astyanax" superbus, "Astyanax" orthodus, Astyanax altiparanae, Astyanax fasciatus, Astyanax lineatus, Astyanax paranae, Bryconamericus exodon, Bryconops alburnoides, Charax leticiae, Cheirodon galusdae, Clupeacharax anchoveoides, Creagrutus menezesi, Ctenobrycon hauxwellianus, Deuterodon iguape, Engraulisoma taeniatum, Gymnocorymbus ternertzi, Hollandichthys multifasciatus, Hydrolycus scomberoides, Hyphessobrycon eques, Jupiaba anteroides, Knodus moenkhausii, Lignobrycon myersii, Markiana nigripinnis, Mimagoniates microlepis, Moenkhausia xinguensis, Oligosarcus pintoi, Piabina argentea, Poptella paraguayensis, Rachoviscus graciliceps, Stethaprion erythrops, Stichonodon insignis, Tetragonopterus chalceus, Thoracocharax stellatus

Characiformes podem apresentar uma ou duas séries de dentes na mandíbula. A série interna, quando presente, pode ser representada por um par de dentes posicionados próximos à porção sinfisiana do dentário (dentes sinfisianos) ou ser formada por uma série completa de dentes posicionados posteriormente à fossa dos dentes de reposição. Zanata \& Vari (2005) reportam a variação intraespecífica da presença de uma ou duas séries no dentário.

A segunda série de dentes no dentário parece ter surgido independentemente em diversas linhagens de Characiformes, mas dentre os Characidae ela é incomum estando presente somente em alguns táxons como, por exemplo, Agoniates, Brycon, Salminus, Triportheus e alguns outros. Além dos Characidae, podem apresentar série interna dentes no dentário: Lebiasinidae (Weitzman, 1964), Alestidae (Zanata \& Vari, 2005), Distichodontidae (Vari, 1979), Hepsetidae (Oyakawa, 1998), Erythrinidae (Oyakawa, 1998) entre outros.

\section{Caráter 27. Segunda série de dentes no dentário}

Uj (1990) caráter 50, Lucena (1993) caráter 49, Buckup (1998) caráter 36, Malabarba (1998) caráter 41, Oyakawa (1998) caráter 61, Zanata (2000) caráter 55 e 56, Moreira (2002) caráter 10, Zanata \& Vari (2005) caráter 88, Lima (2006) caráter 13, Moreira (2007) caráter, Mirande (2010) caráter 143

Estado 0 - Presente como um dente sinfisiano (figura 81b)

Agoniates anchovia, Agoniates halecinus, Brycon pesu, Chalceus epakros, Triportheus albus

Estado 1 - Segunda série completa

Galeocharax knerii, Nematocharax venustus, Salminus hilarii

\section{Inaplicável}


Acestrorhynchus falcatus, Aphyocharax pusillus, Astyanacinus moorii, Astyanacinus sp. nova Bolivia, Astyanacinus sp. nova Peru, "Astyanax" superbus, "Astyanax" orthodus, Astyanax altiparanae, Astyanax fasciatus, Astyanax lineatus, Astyanax paranae, Bryconamericus exodon, Bryconops alburnoides, Charax leticiae, Cheirodon galusdae, Clupeacharax anchoveoides, Creagrutus menezesi, Ctenobrycon hauxwellianus, Deuterodon iguape, Engraulisoma taeniatum, Gymnocorymbus ternertzi, Hollandichthys multifasciatus, Hydrolycus scomberoides, Hyphessobrycon eques, Jupiaba anteroides, Knodus moenkhausii, Lignobrycon myersii, Markiana nigripinnis, Mimagoniates microlepis, Moenkhausia xinguensis, Oligosarcus pintoi, Piabina argentea, Poptella paraguayensis, Rachoviscus graciliceps, Stethaprion erythrops, Stichonodon insignis, Tetragonopterus chalceus, Thoracocharax stellatus

Mesma discussão do caráter anterior

\section{Caráter 28. Número de cúspides do maior dente do dentário}

Vari \& Harold (2001) caráter 18, Ferreira (2007) caráter 55, Bertaco (2008) caráter 20

\section{Estado 0 - 7 cúspides}

Astyanax altiparanae, Astyanax fasciatus, Astyanax lineatus, Astyanax paranae, Brycon pesu, Bryconops alburnoides, Clupeacharax anchoveoides, Ctenobrycon hauxwellianus, Deuterodon iguape, Engraulisoma taeniatum, Knodus moenkhausii, Lignobrycon myersii, Markiana nigripinnis, Stethaprion erythrops, Triportheus albus

\section{Estado 1 - 5 cúspides}

Astyanacinus moorii, Astyanacinus sp. nova Bolivia, Astyanacinus sp. nova Peru, "Astyanax" orthodus, “Astyanax" superbus, Bryconamericus exodon, Chalceus epakros, Cheirodon galusdae, Gymnocorymbus ternertzi, Hollandichthys multifasciatus, Hyphessobrycon eques, Jupiaba anteroides, Mimagoniates microlepis, Moenkhausia xinguensis, Nematocharax venustus, Oligosarcus pintoi, Poptella paraguayensis, Tetragonopterus chalceus

Estado 2 - 3 cúspides

Aphyocharax pusillus, Creagrutus menezesi, Piabina argentea, Rachoviscus graciliceps, Stichonodon insignis, Thoracocharax stellatus

\section{Estado 3 - Cônicos}

Acestrorhynchus falcatus, Agoniates anchovia, Agoniates halecinus, Charax leticiae, Galeocharax knerii, Hydrolycus scomberoides, Salminus hilarii

A maioria dos Characidae apresenta os dentes mais anteriores do dentário mais desenvolvidos e com mais cúspides que os posteriores. Entretanto, o número de cúspides é bastante variável variando de dentes cônicos até espécies com 7 cúspides. Segundo Vari \& Harold (2001) a maioria dos Tetragonopterinae apresentam mais do que três cúspides no maior dente no dentário.

\section{Caráter 29. Quarto dente mais anterior do dentário}


Estado 0 - Semelhante aos demais

Acestrorhynchus falcatus, Aphyocharax pusillus, Astyanacinus moorii, Astyanacinus sp. nova Bolivia, Astyanacinus sp. nova Peru, “Astyanax" superbus, “Astyanax" orthodus, Astyanax altiparanae, Astyanax fasciatus, Astyanax lineatus, Astyanax paranae, Brycon pesu, Bryconamericus exodon, Bryconops alburnoides, Chalceus epakros, Charax leticiae, Cheirodon galusdae, Clupeacharax anchoveoides, Creagrutus menezesi, Ctenobrycon hauxwellianus, Deuterodon iguape, Engraulisoma taeniatum, Galeocharax knerii, Gymnocorymbus ternertzi, Hollandichthys multifasciatus, Hydrolycus scomberoides, Hyphessobrycon eques, Jupiaba anteroides, Knodus moenkhausii, Lignobrycon myersii, Markiana nigripinnis, Mimagoniates microlepis, Moenkhausia xinguensis, Nematocharax venustus, Oligosarcus pintoi, Piabina argentea, Poptella paraguayensis, Rachoviscus graciliceps, Salminus hilarii, Stethaprion erythrops, Stichonodon insignis, Tetragonopterus chalceus, Thoracocharax stellatus, Triportheus albus

Estado 1 - Bem mais desenvolvido

Agoniates halecinus, Agoniates anchovia

A maioria dos Characidae apresenta os dentes mais anteriores do dentário mais desenvolvidos que os posteriores, porém outro padrão recorrente principalmente entre os piscívoros é o desenvolvimento de dentes caninos bem mais desenvolvidos que os demais. Somente Agoniates apresenta o quarto dente mais anterior da mandíbula como sendo o mais desenvolvido.

\section{Caráter 30. Margem dorsal do dentário}

Moreira (2002) caráter 36, Ferreira (2007) caráter 51, Moreira (2007) caráter 38

Estado 0 - Com área edentelosa menor que área com dentes (figura 81a)

Acestrorhynchus falcatus, Agoniates anchovia, Agoniates halecinus, Astyanacinus moorii, Astyanacinus sp. nova Peru, "Astyanax" superbus, “Astyanax" orthodus, Brycon pesu, Charax leticiae, Galeocharax knerii, Hollandichthys multifasciatus, Hydrolycus scomberoides, Knodus moenkhausii, Oligosarcus pintoi, Piabina argentea, Rachoviscus graciliceps, Salminus hilarii, Thoracocharax stellatus

Estado 1 - Com área edentelosa maior que área com dentes

Bryconops alburnoides, Cheirodon galusdae, Clupeacharax anchoveoides, Creagrutus menezesi, Ctenobrycon hauxwellianus, Engraulisoma taeniatum, Hyphessobrycon eques, Gymnocorymbus ternertzi, Nematocharax venustus, Poptella paraguayensis, Stichonodon insignis

Estado 2 - Área com dentes e edentelosa de tamanhos semelhantes (figura 81b) Aphyocharax pusillus, Astyanacinus sp. nova Bolivia, Astyanax altiparanae, Astyanax fasciatus, Astyanax lineatus, Astyanax paranae, Bryconamericus exodon, Chalceus epakros, Deuterodon iguape, Jupiaba anteroides, Lignobrycon myersii, Markiana nigripinnis, Mimagoniates microlepis, Moenkhausia xinguensis, Stethaprion erythrops, Tetragonopterus chalceus, Triportheus albus 
É na margem dorsal do dentário que estão fixados os dentes da mandíbula. A porção mais posterior do dentário não apresenta dentes (edentelosa) e a extensão desta área é bastante variável entre os Characiformes.

\section{Caráter 31. Forma dos dentes mais anteriores do dentário}

Moreira (2002) caráter 13, Ferreira (2007) caráter 54

Estado 0 - Coroa menor que a base

Acestrorhynchus falcatus, Agoniates anchovia, Agoniates halecinus, Charax leticiae, Galeocharax knerii, Hollandichthys multifasciatus, Hydrolycus scomberoides, Mimagoniates microlepis, Oligosarcus pintoi, Rachoviscus graciliceps, Salminus hilarii, Stichonodon insignis, Thoracocharax stellatus

Estado 1 - Coroa maior que a base

Cheirodon galusdae, Hyphessobrycon eques

Estado 2 - Coroa e base semelhantes

Aphyocharax pusillus, Astyanacinus moorii, Astyanacinus sp. nova Bolivia, Astyanacinus sp. nova Peru, "Astyanax" superbus, "Astyanax" orthodus, Astyanax altiparanae, Astyanax fasciatus, Astyanax lineatus, Astyanax paranae, Brycon pesu, Bryconamericus exodon, Bryconops alburnoides, Chalceus epakros, Clupeacharax anchoveoides, Creagrutus menezesi, Ctenobrycon hauxwellianus, Deuterodon iguape, Engraulisoma taeniatum, Gymnocorymbus ternertzi, Jupiaba anteroides, Knodus moenkhausii, Lignobrycon myersii, Markiana nigripinnis, Moenkhausia xinguensis, Nematocharax venustus, Piabina argentea, Poptella paraguayensis, Stethaprion erythrops, Tetragonopterus chalceus, Triportheus albus

O formato dos dentes em Characiformes é bastante variável e está diretamente relacionado ao hábito alimentar dos peixes como discutido no item "Piscivoria em Characidae”. Entre os Characidae a dentição é muito importante como caráater diagnósticos para diversos gêneros e a dentição é bastante diferente entre diferentes linhagens. Por exemplo, Malabarba (1998) considera sinapomórfico para a subfamília Cheirodontinae a posse de dentes pedicelados, com coroa com muitas cúspides e base mais estreita que a base.

\section{Caráter 32. Número de dentes mais desenvolvidos do dentário}

Zanata \& Vari (2005) caráter 82, Mirande (2010) caráter 142

Estado 0 - 6 dentes

Bryconops alburnoides, Charax leticiae, Nematocharax venustus, Tetragonopterus chalceus

Estado 1 - 5 dentes 
Cheirodon galusdae, Deuterodon iguape, Galeocharax knerii, Rachoviscus graciliceps, Thoracocharax stellatus

Estado 2 - 4 dentes (figura 81b)

Acestrorhynchus falcatus, Astyanacinus moorii, Astyanacinus sp. nova Bolivia, Astyanacinus sp. nova Peru, "Astyanax" superbus, "Astyanax" orthodus, Astyanax altiparanae, Astyanax fasciatus, Astyanax lineatus, Astyanax paranae, Brycon pesu, Creagrutus menezesi, Ctenobrycon hauxwellianus, Gymnocorymbus ternertzi, Hyphessobrycon eques, Knodus moenkhausii, Lignobrycon myersii, Markiana nigripinnis, Mimagoniates microlepis, Moenkhausia xinguensis, Piabina argentea, Poptella paraguayensis, Stethaprion erythrops, Triportheus albus

Estado 3 - 3 dentes

Bryconamericus exodon, Clupeacharax anchoveoides, Engraulisoma taeniatum, Hollandichthys multifasciatus, Jupiaba anteroides, Oligosarcus pintoi

Estado 4 - 2 dentes

Stichonodon insignis

Indeterminado

Agoniates anchovia, Agoniates halecinus, Aphyocharax pusillus, Chalceus epakros, Hydrolycus scomberoides, Salminus hilarii

A maioria dos Characidae apresenta os dentes mais anteriores do dentário mais desenvolvidos e com mais cúspides que os posteriores. Entretanto, o número de dentes anteriores mais desenvolvidos é variável sendo que a maioria deles, principalmente entre os Tetragonopterinae, apresenta 4 dentes assim como o inferido por Zanata \& Vari (2005) para os Alestidae.

\title{
Caráter 33. Disposição dos dentes do dentário
}

\author{
Zanata \& Vari (2005) caráter 85
}

Estado 0 - Heterogênea com dentes anteriores maiores e posteriores menores Astyanacinus moorii, Astyanacinus sp. nova Bolivia, Astyanacinus sp. nova Peru, "Astyanax" superbus, "Astyanax" orthodus, Astyanax altiparanae, Astyanax fasciatus, Astyanax lineatus, Astyanax paranae, Brycon pesu, Bryconamericus exodon, Bryconops alburnoides, Charax leticiae, Cheirodon galusdae, Ctenobrycon hauxwellianus, Engraulisoma taeniatum, Gymnocorymbus ternertzi, Hollandichthys multifasciatus, Hyphessobrycon eques, Jupiaba anteroides, Knodus moenkhausii, Lignobrycon myersii, Markiana nigripinnis, Mimagoniates microlepis, Moenkhausia xinguensis, Nematocharax venustus, Oligosarcus pintoi, Piabina argentea, Poptella paraguayensis, Rachoviscus graciliceps, Stethaprion erythrops, Stichonodon insignis, Tetragonopterus chalceus, Thoracocharax stellatus, Triportheus albus

Estado 1 - Heterogênea com pequenos dentes entre os maiores anteriores (figura 81a)

Agoniates halecinus, Acestrorhynchus falcatus, Agoniates anchovia, Galeocharax knerii, Hydrolycus scomberoides

Estado 2 - Homogênea (dentes diminuem progressivamente) 
Aphyocharax pusillus, Chalceus epakros, Deuterodon iguape, Salminus hilarii

Estado 3 - Somente com dentes desenvolvidos anteriores

Clupeacharax anchoveoides, Creagrutus menezesi

O formato entre os dentes do dentário é bastante variável entre os Characidae. O estado mais comumente encontrado é a presença de dentes mais anteriores mais desenvolvidos e com mais cúspides e os posteriores menores e com menos cúspides. Entre os peixes examinados por Zanata \& Vari (2005) somente Astyanax, Charax, Brycon, Bryconops, Tetragonopterus e Triportheus apresentaram essa condição, sendo assim essa condição ausente em Alestidae. Além disso, pelo menos outras três condições estão presente entre os caracídeos examinados.

\section{Caráter 34. Fossa na face medial do mandibular}

Vari (1995) caráter 42, Netto-Ferreira (2005) caráter 98, Moreira (2007) caráter 33

\section{Estado 0 - Aberta (figura 81a)}

Agoniates anchovia, Agoniates halecinus, Aphyocharax pusillus, Astyanacinus moorii, Astyanacinus sp. nova Bolivia, Astyanacinus sp. nova Peru, "Astyanax" superbus, "Astyanax" orthodus, Astyanax altiparanae, Astyanax fasciatus, Astyanax lineatus, Astyanax paranae, Bryconamericus exodon, Bryconops alburnoides, Chalceus epakros, Cheirodon galusdae, Clupeacharax anchoveoides, Creagrutus menezesi, Ctenobrycon hauxwellianus, Deuterodon iguape, Engraulisoma taeniatum, Gymnocorymbus ternertzi, Hollandichthys multifasciatus, Hyphessobrycon eques, Jupiaba anteroides, Knodus moenkhausii, Lignobrycon myersii, Markiana nigripinnis, Mimagoniates microlepis, Moenkhausia xinguensis, Nematocharax venustus, Oligosarcus pintoi, Piabina argentea, Poptella paraguayensis, Rachoviscus graciliceps, Stethaprion erythrops, Stichonodon insignis, Tetragonopterus chalceus, Thoracocharax stellatus, Triportheus albus

Estado 1 - Com leve expansão do dentário que se projeta e cobre a região anterodorsal da fossa (figura 81b)

Acestrorhynchus falcatus, Brycon pesu, Charax leticiae, Galeocharax knerii, Hydrolycus scomberoides, Salminus hilarii,

Segundo Vari (1995) há uma fossa na face medial do dentário que é ocupada amplamente pela seção $\mathrm{A}_{\mathrm{w}}$ do músculo adductor mandibulae. Ainda segundo o autor, a porção do dentário, particularmente em peixes com dentição bastante desenvolvida, é relativamente mais desenvolvida tanto para fixação dos dentes bem desenvolvidos quanto para acomodar os dentes de reposição, porém 
essa região expandida não cobre dorsalmente a fossa mandibular. Para Vari (1995) somente em Boulengerella e Ctenolucius a fossa mandibular está dorsalmente coberta por uma expansão óssea e indica essa característica como sinapomórfica para os Ctenoluciidae. Apesar de concordar com o autor e compreender que tal grau de desenvolvimento dorsal ósseo na margem dorsal da fossa mandibular só é encontrado em Ctenoluciidae, alguns táxons como espécies de Acestrorhynchus, Brycon, Salminus apresentam uma condição semelhante, porém menos desenvolvida.

\section{Caráter 35. Comprimento da mandíbula}

Vari (1983) caráter 30, Moreira (2007) caráter 32

Estado 0 - Maior que a órbita (figura 82b)

Acestrorhynchus falcatus, Agoniates anchovia, Agoniates halecinus, Astyanacinus sp. nova Peru, Astyanacinus sp. nova Bolivia, "Astyanax" superbus, Astyanacinus moorii, "Astyanax" orthodus, Astyanax altiparanae, Bryconops alburnoides, Charax leticiae, Clupeacharax anchoveoides, Galeocharax knerii, Hollandichthys multifasciatus, Hydrolycus scomberoides, Lignobrycon myersii, Mimagoniates microlepis, Oligosarcus pintoi, Salminus hilarii, Thoracocharax stellatus

Estado 1 - Aproximadamente igual ao diâmetro da órbita (figura 82a)

Aphyocharax pusillus, Astyanax fasciatus, Astyanax lineatus, Astyanax paranae, Brycon pesu, Bryconamericus exodon, Chalceus epakros, Cheirodon galusdae, Ctenobrycon hauxwellianus, Deuterodon iguape, Engraulisoma taeniatum, Gymnocorymbus ternertzi, Hyphessobrycon eques, Jupiaba anteroides, Knodus moenkhausii, Markiana nigripinnis, Moenkhausia xinguensis, Nematocharax venustus, Poptella paraguayensis, Rachoviscus graciliceps, Stethaprion erythrops, Stichonodon insignis, Tetragonopterus chalceus, Triportheus albus

Estado 2 - Muito curta, aproximadamente do tamanho do metapterigóide Creagrutus menezesi, Piabina argentea

O dentário é o principal osso que compõe a mandíbula. O comprimento deste é altamente variado entre os Characiformes e como discutido no item “Piscivoria em Characidae” muitas dessas modificações podem refletir nichos ecológicos. Segundo Vari (1983) um dentário muito curto é sinapomórfico para os Prochilodontidae. Entre os Characidae a variação é mais sutil, porém quando o comprimento da mandíbula é comparado com outras estruturas, e não julgado subjetivamente, diferenças no comprimento desta estrutura são bastante reveladoras para a evolução dos caracídeos. 


\section{Caráter 36. Articulação entre o articular e o quadrado}

Lucena (1993) caráter 62, Moreira (2002) caráter 68, Bertaco (2003) caráter 7, Zanata \& Vari (2005) caráter 93, Moreira (2007) caráter 68, Mirande (2010) caracteres 153 e 154

Estado 0 - Na vertical que passa pelo centro da órbita (figura 82b)

Astyanacinus moorii, Astyanacinus sp. nova Bolivia, Astyanacinus sp. nova Peru, "Astyanax" superbus, "Astyanax" orthodus, Astyanax paranae, Creagrutus menezesi, Hollandichthys multifasciatus, Jupiaba anteroides, Oligosarcus pintoi, Piabina argentea, Rachoviscus graciliceps

Estado 1 - Anterior a vertical que passa pelo centro da órbita (figura 82a) Aphyocharax pusillus, Astyanax altiparanae, Astyanax fasciatus, Astyanax lineatus, Bryconamericus exodon, Chalceus epakros, Cheirodon galusdae, Clupeacharax anchoveoides, Deuterodon iguape, Engraulisoma taeniatum, Hyphessobrycon eques, Knodus moenkhausii, Lignobrycon myersii, Moenkhausia xinguensis, Nematocharax venustus, Tetragonopterus chalceus

Estado 2 - Posterior a vertical que passa pelo centro da órbita

Agoniates anchovia, Agoniates halecinus, Brycon pesu, Bryconops alburnoides, Charax leticiae, Galeocharax knerii, Hydrolycus scomberoides, Salminus hilarii, Thoracocharax stellatus

Estado 3 - Posterior a órbita

Acestrorhynchus falcatus

Estado 4 - Na vertical da margem anterior da órbita

Ctenobrycon hauxwellianus, Gymnocorymbus ternertzi, Markiana nigripinnis, Mimagoniates microlepis, Poptella paraguayensis, Stethaprion erythrops, Stichonodon insignis, Triportheus albus

A variação na posição relativa da articulação entre o articular e o quadrado é mais uma modificação que pode estar atrelada aos hábitos alimentares como é discutido no item "Piscivoria em Characidae”. Entre os Characiformes a posição dessa articulação é variável com uma localização tipicamente relacionada com o comprimento da mandíbula e a posição da boca (Zanata \& Vari, 2005). Grupos mais basais dentro da ordem apresentam essa articulação situada posterior à vertical que passa pela ponta do processo do etmóide lateral. Segundo Zanata \& Vari (2005) a maioria dos Alestidae apresentam essa articulação situada entre as verticais que passam anteriormente ou na ponta do processo do etmóide lateral. Mirande (2010) considera que a articulação articular-quadrado posteriormente situada à vertical que passa no meio do olho é sinapomórfica do clado 
Acestrorhynchinae, Agoniatinae + Cynodontidae + Salmininae. Considera também que é sinapomorfia da subfamília Iguanodectinae a articulação posicionada na vertical passando anterior ou sobre o etmóide lateral.

\section{Caráter 37. Formato do retro-articular}

Estado 0 - Ossso alongado, bem mais comprido do que alto e com região anterior afilada

Acestrorhynchus falcatus, Agoniates anchovia, Agoniates halecinus, Brycon pesu, Bryconamericus exodon, Bryconops alburnoides, Chalceus epakros, Clupeacharax anchoveoides, Ctenobrycon hauxwellianus, Galeocharax knerii, Hydrolycus scomberoides, Lignobrycon myersii, Piabina argentea, Salminus hilarii, Stichonodon insignis, Triportheus albus

Estado 1 - Ossso curto, bem mais alto do que longo

Aphyocharax pusillus, Astyanacinus moorii, Astyanacinus sp. nova Bolivia, Astyanacinus sp. nova Peru, "Astyanax" superbus, "Astyanax" orthodus, Astyanax altiparanae, Astyanax fasciatus, Astyanax lineatus, Astyanax paranae, Charax leticiae, Cheirodon galusdae, Creagrutus menezesi, Deuterodon iguape, Engraulisoma taeniatum, Gymnocorymbus ternertzi, Hollandichthys multifasciatus, Hyphessobrycon eques, Jupiaba anteroides, Knodus moenkhausii, Markiana nigripinnis, Mimagoniates microlepis, Moenkhausia xinguensis, Nematocharax venustus, Oligosarcus pintoi, Poptella paraguayensis, Rachoviscus graciliceps, Stethaprion erythrops, Tetragonopterus chalceus, Thoracocharax stellatus

O osso retro-articular é uma pequena ossificação situada na porção postero-ventral do dentário e é um dos ossos em que menos caracteres são atribuídos em filogenias. Apesar disso, entre diversos grupos de Characiformes essa estrutura apresenta certo grau de variação principalmente com relação ao seu tamanho relativo e a seu formato. Pelo menos dois estados podem ser atribuídos: peixes geralmente com dentário mais alongado apresentam retro-articular longo e menos alto ao passo que táxons com mandíbula alongada tem, geralmente, a ossificação relativamente mais curta e alta.

\section{Caráter 38. Número de cavidades nas interdigitações na porção anterior dos} dentários

Ferreira (2007) caráter 50

Estado 0 - Duas a quatro cavidades

Acestrorhynchus falcatus, Agoniates halecinus, Aphyocharax pusillus, Astyanacinus moorii, Astyanacinus sp. nova Bolivia, Astyanacinus sp. nova Peru, "Astyanax" superbus, "Astyanax" orthodus, Astyanax altiparanae, Astyanax fasciatus, Astyanax lineatus, Astyanax paranae, Brycon pesu, Bryconamericus exodon, Bryconops alburnoides, Charax leticiae, Cheirodon galusdae, Ctenobrycon hauxwellianus, 
Galeocharax knerii, Gymnocorymbus ternertzi, Hyphessobrycon eques, Knodus moenkhausii, Lignobrycon myersii, Markiana nigripinnis, Mimagoniates microlepis, Moenkhausia xinguensis, Nematocharax venustus, Piabina argentea, Poptella paraguayensis, Rachoviscus graciliceps, Salminus hilarii, Stethaprion erythrops, Stichonodon insignis, Tetragonopterus chalceus, Thoracocharax stellatus, Triportheus albus

Estado 1 - Cinco ou seis cavidades

Agoniates anchovia, Chalceus epakros, Clupeacharax anchoveoides, Creagrutus menezesi, Engraulisoma taeniatum, Hollandichthys multifasciatus, Hydrolycus scomberoides

\section{Indeterminado}

Deuterodon iguape, Jupiaba anteroides, Oligosarcus pintoi,

Segundo Vari (1979) os Citharinoidei são os Characiformes mais basais e não apresentam interdigitação mediana entre os dentários sendo estes conectados somente por tecido conjuntivo assim como em Curimatidae, Hemiodontidae, Prochilodontidae, Anostomidae, Chilodontidae e Parodontidae. Os Cypriniformes também não apresentam dentários interdigitados. É importante, porém, ressaltar que esse estado não é exclusivo dos Characiformes, estando presente também em alguns outros grupos de peixes não-relacionados como, por exemplo, Tetraodontidae. Por essa razão Newbrey et al. (2009) devem ter se enganado ao atribuírem à um Characiforme o registro fóssil de uma sínfise dentária interdigitada datando do Cretáceo no norte América do Norte. Caso os autores estivessem corretos (e provavelmente não estão, pois o dentário não necessariamente pertence à um Characiforme) este seria absolutamente um dos registros mais antigos da ordem e adicionaria enorme grau de incerteza quando à biogeografia do grupo que de certa forma é bem esclarecido e, ao que tudo indica, obedece ao padrão de Gondwana.

Entre os Characidae, a ausência de interdigitações no dentário foi proposta como sinapomórfica para o clado Amazonspinther + Spintherobolus por Bührnheim et al. (2008). Nos Characiformes que os apresenta, as interdigitações no dentário podem apresentar variação quanto ao número de cavidades que a compõe.

\section{Caráter 39. Número de séries de dentes no pré-maxilar}


Lucena (1993) caracteres 38 e 39, Buckup (1998) caráter 32, Malabarba (1998) caráter 55, Oyakawa (1998) caráter 60, Zanata (2000) caráter 42, Moreira (2002) caráter 3, Bertaco (2003) caráter 75, Benine (2004) caráter 27, Zanata \& Vari (2005) caráter 57, Netto-Ferreira (2005) caráter 83, Buhrnheim (2006) caráter 35, Lima (2006) caráter 11, Moreira (2007) caráter 6, Mirande (2010) caracteres 122 e 123

Estado 0 - Duas séries (figura 83d)

Agoniates anchovia, Agoniates halecinus, Astyanacinus moorii, Astyanacinus sp. nova Bolivia, Astyanacinus sp. nova Peru, "Astyanax" superbus, "Astyanax" orthodus, Astyanax altiparanae, Astyanax fasciatus, Astyanax lineatus, Astyanax paranae, Bryconamericus exodon, Clupeacharax anchoveoides, Ctenobrycon hauxwellianus, Deuterodon iguape, Engraulisoma taeniatum, Galeocharax knerii, Gymnocorymbus ternertzi, Hollandichthys multifasciatus, Jupiaba anteroides, Knodus moenkhausii, Lignobrycon myersii, Markiana nigripinnis, Moenkhausia xinguensis, Nematocharax venustus, Poptella paraguayensis, Rachoviscus graciliceps, Salminus hilarii, Stethaprion erythrops, Stichonodon insignis, Tetragonopterus chalceus, Thoracocharax stellatus

Estado 1 - Três séries

Brycon pesu, Bryconops alburnoides, Chalceus epakros, Creagrutus menezesi, Piabina argentea, Triportheus albus

Estado 2 - Uma série

Acestrorhynchus falcatus, Aphyocharax pusillus, Charax leticiae, Cheirodon galusdae, Hydrolycus scomberoides, Hyphessobrycon eques, Oligosarcus pintoi

\section{Indeterminado}

Mimagoniates microlepis

O número de séries de dentes presentes no pré-maxilar é variável entre os Characiformes e os Characidae podendo ser variável até intra-especificamente como no caso de Inpaichthys, reportado por Géry \& Junk (1977). A quantidade de séries de dentes no pré-maxilar tem sido historicamente importante na definição de grupos menos inclusivos dentro da família Characidae e, como será apresentado a seguir, tem sido amplamente utilizada como sinapomorfia de diversos grupos de Characiformes. Apesar disso, como ressalta Mirande (2010) a homologia entre as séries de dentes pré-maxilares entre diferentes linhagens de peixes nem sempre é fácil de ser traçada, especialmente quando séries inteiras estão ausentes ou quando há intercalação de dentes de diferentes séries. 
Segundo Lucena (1993) a presença de duas séries de dentes pré-maxilaes é sinapomórfica para um clado correspondente à família Characidae e a presença de três séries é sinapomórfica para o clado Creagrutus + Piabina e, paralelamente, para Brycon + Chalceus. Zanata (2000) comenta que a terceira série de dentes entre esses dois últimos gêneros não é homóloga. Para Buckup (1998) duas ou três séries de dentes é sinapomorfia de um grande grupo de Characiformes composto por Alestidae, Characidae, Ctenoluciidae, Hepsetidae, Lebiasinidae, Erythrinidae e Acestrorhynchidae; apesar de sofrer reversão nas últimas cinco famílias. Malabarba (1998) sugere que a presença de apenas uma série de dentes na pré-maxila é sinapomórfica de Cheirodontinae, porém Mirande (2010) infere que essa característica sinapomórfica entre as subfamílias Aphyocharacinae, Aphyoditeinae e Cheirodontinae. Mirande (2010) considera que três séries de dentes é uma sinapomorfia da subfamília Bryconinae.

\section{Caráter 40. Números de dentes na fileira mais interna do pré-maxilar}

Bertaco (2003) caráter 76, Benine (2004) caráter 29, Zanata \& Vari (2005) caráter 61, Mirande (2010) caráter 129 e 130

Estado 0 - Mais de cinco

Lignobrycon myersii, Poptella paraguayensis, Salminus hilarii, Thoracocharax stellatus

\section{Estado 1 - Cinco}

Aphyocharax pusillus, Astyanacinus moorii, "Astyanax" superbus, Astyanax altiparanae, "Astyanax" orthodus, Astyanacinus sp. nova Bolivia, Astyanacinus sp. nova Peru, Astyanax fasciatus, Astyanax lineatus, Astyanax paranae, Ctenobrycon hauxwellianus, Deuterodon iguape, Gymnocorymbus ternertzi, Jupiaba anteroides, Moenkhausia xinguensis, Nematocharax venustus, Rachoviscus graciliceps, Stethaprion erythrops, Tetragonopterus chalceus

Estado 2 - Quatro (figura 83d)

Agoniates anchovia, Bryconamericus exodon, Creagrutus menezesi, Engraulisoma taeniatum, Galeocharax knerii, Knodus moenkhausii, Markiana nigripinnis, Piabina argentea

\section{Polimórfico}

Agoniates halecinus, Clupeacharax anchoveoides

\section{Indeterminado}

Mimagoniates microlepis, Stichonodon insignis

\section{Inaplicável}


Acestrorhynchus falcatus, Aphyocharax pusillus, Brycon pesu, Bryconops alburnoides, Chalceus epakros, Charax leticiae, Cheirodon galusdae, Creagrutus menezesi, Hydrolycus scomberoides, Hyphessobrycon eques, Oligosarcus pintoi, Piabina argentea, Triportheus albus

Quando presente, a série interna de dentes na pré-maxila apresenta variável número de dentes entre as diferentes linhagens de Characidae. De acordo com Malabarba \& Weitzman (2003) a presença de quatro dentes na série interna de dentes no pré-maxilar é sinapomórfica para o Clado A. Já em Mirande (2010) o autor sugere que a condição é uma sinapomorfia do clado Aphyocharacinae, Aphyoditeinae, Cheirodontinae, Gymnocharacinae, Stevardiinae e Bryconamericus scleroparius clade. O autor ainda considera que 8 ou mais dentes na série interna da pré-maxila é sinapomórfica para os Aphyoditeinae. Géry (1977) considerou a presença de quatro dentes na série interna da prémaxila como uma característica do grupo "genus Hemibrycon and allied genera" composto por Boehlkea, Bryconacidnus, Bryconamericus, Carlastyanax, Ceratobranchia, Coptobrycon, Creagrudite, Hemibrycon, Knodus, Microgenys, Nematobrycon, Piabarchus, Rhinobrycon e Rhinopetitia.

\section{Caráter 41. Organização da terceira série de dentes do pré-maxilar}

Moreira (2007) caráter 9

Estado 0 - Séries mais externa e interna com mais dentes

Bryconops alburnoides, Chalceus epakros, Creagrutus menezesi, Piabina argentea, Triportheus albus

Estado 1 - As duas séries mais externas com mais dentes Brycon pesu

\section{Inaplicável}

Acestrorhynchus falcatus, Agoniates anchovia, Agoniates halecinus, Aphyocharax pusillus, Astyanacinus moorii, Astyanacinus sp. nova Bolivia, Astyanacinus sp. nova Peru, "Astyanax" superbus, "Astyanax" orthodus, Astyanax altiparanae, Astyanax fasciatus, Astyanax lineatus, Astyanax paranae, Bryconamericus exodon, Charax leticiae, Cheirodon galusdae, Clupeacharax anchoveoides, Ctenobrycon hauxwellianus, Deuterodon iguape, Engraulisoma taeniatum, Galeocharax knerii, Gymnocorymbus ternertzi, Hollandichthys multifasciatus, Hydrolycus scomberoides, Hyphessobrycon eques, Jupiaba anteroides, Knodus moenkhausii, Lignobrycon myersii, Markiana nigripinnis, Mimagoniates microlepis, Moenkhausia xinguensis, Nematocharax venustus, Oligosarcus pintoi, Poptella paraguayensis, Rachoviscus graciliceps, Salminus hilarii, Stethaprion erythrops, Stichonodon insignis, Tetragonopterus chalceus, Thoracocharax stellatus

\section{Indeterminado}


Mimagoniates microlepis, Stichonodon insignis

A terceira série de dentes na pré-maxila é incomum entre os Characiformes e quando presente pode ser composta por diferentes arranjos. Zanata (2000) comenta que a terceira série de dentes presente nos gêneros Brycon e Chalceus não é homóloga.

\section{Caráter 42. Dentes caninos na pré-maxila}

Lucena (1993) caráter 40, Mirande (2010) caráter 121

\section{Estado 0 - Ausente}

Agoniates anchovia, Agoniates halecinus, Aphyocharax pusillus, Astyanacinus moorii, Astyanacinus sp. nova Bolivia, Astyanacinus sp. nova Peru, "Astyanax" superbus, "Astyanax" orthodus, Astyanax altiparanae, Astyanax fasciatus, Astyanax lineatus, Astyanax paranae, Brycon pesu, Bryconamericus exodon, Bryconops alburnoides, Chalceus epakros, Cheirodon galusdae, Clupeacharax anchoveoides, Creagrutus menezesi, Ctenobrycon hauxwellianus, Deuterodon iguape, Engraulisoma taeniatum, Gymnocorymbus ternertzi, Hollandichthys multifasciatus, Hyphessobrycon eques, Jupiaba anteroides, Knodus moenkhausii, Lignobrycon myersii, Markiana nigripinnis, Mimagoniates microlepis, Moenkhausia xinguensis, Nematocharax venustus, Oligosarcus pintoi, Piabina argentea, Poptella paraguayensis, Rachoviscus graciliceps, Salminus hilarii, Stethaprion erythrops, Stichonodon insignis, Tetragonopterus chalceus, Thoracocharax stellatus, Triportheus albus

Estado 1 - Presente, com um mais anterior e outro mais posterior e dentes menos desenvolvidos entre eles (figura 83a)

Acestrorhynchus falcatus, Charax leticiae, Galeocharax knerii, Hydrolycus scomberoides

Como discutido no item "Piscivoria em Characidae" a presença de dentes caninos ou com cúspides laterais reduzidas está relacionada ao hábito piscívoro. Mirande (2010) considera que a presença de dois pares de dentes caninos bem desenvolvidos na pré-maxila e dentes menores entre eles é uma sinapomorfia de Acestrorhynchinae + Cynodontinae.

\section{Caráter 43. Comprimento do pré-maxilar}

Vari (1995) caráter 37

Estado 0 - Maior que o comprimento do processo ascendente da maxila

Acestrorhynchus falcatus, Aphyocharax pusillus, Astyanacinus moorii, Astyanacinus sp. nova Bolivia, Astyanacinus sp. nova Peru, "Astyanax" superbus, "Astyanax" orthodus, Astyanax altiparanae, Astyanax fasciatus, Astyanax lineatus, Astyanax paranae, Brycon pesu, Bryconamericus exodon, Bryconops alburnoides, Chalceus epakros, Charax leticiae, Cheirodon galusdae, Clupeacharax 
anchoveoides, Creagrutus menezesi, Ctenobrycon hauxwellianus, Deuterodon iguape, Engraulisoma taeniatum, Galeocharax knerii, Gymnocorymbus ternertzi, Hollandichthys multifasciatus, Hydrolycus scomberoides, Hyphessobrycon eques, Jupiaba anteroides, Knodus moenkhausii, Lignobrycon myersii, Markiana nigripinnis, Mimagoniates microlepis, Moenkhausia xinguensis, Nematocharax venustus, Oligosarcus pintoi, Piabina argentea, Poptella paraguayensis, Rachoviscus graciliceps, Salminus hilarii, Stethaprion erythrops, Stichonodon insignis, Tetragonopterus chalceus, Thoracocharax stellatus, Triportheus albus

Estado 1 - Menor que o comprimento do processo ascendente da maxila Agoniates anchovia, Agoniates halecinus

O comprimento horizontal do pré-maxilar é variável entre os Characiformes, sendo que peixes com focinho mais pronunciado como, por exemplo, Acestrorhynchus e alguns Characinae apresentam esse osso mais alongado. Contrariamente, em Agoniatinae o pré-maxilar é bastante reduzido em seu eixo antero-posterior com seu processo ascendente sendo mais longo que o comprimento horizontal do osso.

\section{Caráter 44. Suturas na face medial do pré-maxilar}

Lucena (1993) caráter 37, Zanata \& Vari (2005) caráter 55, Mirande (2010) caráter 103

Estado 0 - Com suturas

Brycon pesu, Chalceus epakros, Triportheus albus

\section{Estado 1 - Sem suturas}

Acestrorhynchus falcatus, Agoniates anchovia, Agoniates halecinus, Aphyocharax pusillus, Astyanacinus moorii, Astyanacinus sp. nova Bolivia, Astyanacinus sp. nova Peru, "Astyanax" superbus, "Astyanax" orthodus, Astyanax altiparanae, Astyanax fasciatus, Astyanax lineatus, Astyanax paranae, Bryconamericus exodon, Bryconops alburnoides, Charax leticiae, Cheirodon galusdae, Clupeacharax anchoveoides, Creagrutus menezesi, Ctenobrycon hauxwellianus, Deuterodon iguape, Engraulisoma taeniatum, Galeocharax knerii, Gymnocorymbus ternertzi, Hollandichthys multifasciatus, Hydrolycus scomberoides, Hyphessobrycon eques, Jupiaba anteroides, Knodus moenkhausii, Lignobrycon myersii, Markiana nigripinnis, Mimagoniates microlepis, Moenkhausia xinguensis, Nematocharax venustus, Oligosarcus pintoi, Piabina argentea, Poptella paraguayensis, Rachoviscus graciliceps, Salminus hilarii, Stethaprion erythrops, Stichonodon insignis, Tetragonopterus chalceus, Thoracocharax stellatus

$\mathrm{Na}$ grande maioria dos Characiformes as pré-maxilas são separadas medialmente pela porção mais anterior do mesetmóide e se conectam entre si apenas por tecido conjuntivo. Em alguns grupos, entretanto, há projeções lamelares ósseas na porção mediana da pré-maxila que faz com que esses ossos sejam interdigitados. Weitzman (1962) ilustra essa condição em Brycon meeki. 
Mirande (2010) infere que interdigitações entre as pré-maxilas é uma sinapomorfia de Bryconinae (Brycon, Chilobrycon, Henochilus, Lignobrycon e Triportheus). Vari (1979) considera a característica uma sinapomorfia de Citharinoidei. De acordo com Zanata \& Vari (2005) essa característica também está presente em alguns Alestidae enquanto que outros não apresentam.

\section{Caráter 45. Lateral da porção posterior do maxilar}

Lucena \& Menezes (1998) caráter 13 e 14, Zanata (2000) caráter 51, NettoFerreira (2005) caráter 90, Moreira (2007) caráter 26

Estado 0 - Sem elaborações (figura 83d)

Agoniates anchovia, Agoniates halecinus, Aphyocharax pusillus, Astyanacinus moorii, Astyanacinus sp. nova Bolivia, Astyanacinus sp. nova Peru, "Astyanax" superbus, "Astyanax" orthodus, Astyanax altiparanae, Astyanax fasciatus, Astyanax lineatus, Astyanax paranae, Brycon pesu, Bryconamericus exodon, Bryconops alburnoides, Chalceus epakros, Charax leticiae, Cheirodon galusdae, Clupeacharax anchoveoides, Creagrutus menezesi, Ctenobrycon hauxwellianus, Deuterodon iguape, Engraulisoma taeniatum, Galeocharax knerii, Gymnocorymbus ternertzi, Hollandichthys multifasciatus, Hyphessobrycon eques, Jupiaba anteroides, Knodus moenkhausii, Lignobrycon myersii, Markiana nigripinnis, Mimagoniates microlepis, Moenkhausia xinguensis, Nematocharax venustus, Oligosarcus pintoi, Piabina argentea, Poptella paraguayensis, Rachoviscus graciliceps, Stethaprion erythrops, Stichonodon insignis, Tetragonopterus chalceus, Thoracocharax stellatus, Triportheus albus

Estado 1 - Repleta de ramificações do canal sensorial dando o aspecto de estrias Acestrorhynchus falcatus, Hydrolycus scomberoides, Salminus hilarii

Os Characiformes apresentam um canal que, às vezes é bastante ramificado, no osso maxilar. A maioria dos Characidae apresenta a superfície lateral da maxila lisa (Lucena \& Menezes, 1998). Segundo esses mesmos autores a presença de uma maxila com sua porção mais distal rugosa devido à complexa ramificação de canais é sinapormórfica entre as famílias Acestrorhynchidae e Cynodontidae.

\section{Caráter 46. Extensão do canal no osso maxilar}

Zanata \& Vari (2005) caráter 75, Mirande (2010) caráter 98

Estado 0 - Presente até a metade posterior do osso

Acestrorhynchus falcatus, Agoniates anchovia, Agoniates halecinus, Aphyocharax pusillus, Astyanacinus moorii, Astyanacinus sp. nova Bolivia, Astyanacinus sp. nova Peru, "Astyanax" superbus, "Astyanax" 
orthodus, Astyanax altiparanae, Astyanax lineatus, Astyanax paranae, Brycon pesu, Chalceus epakros, Charax leticiae, Creagrutus menezesi, Deuterodon iguape, Galeocharax knerii, Hollandichthys multifasciatus, Hydrolycus scomberoides, Lignobrycon myersii, Markiana nigripinnis, Nematocharax venustus, Oligosarcus pintoi, Piabina argentea, Poptella paraguayensis, Rachoviscus graciliceps, Salminus hilarii, Stethaprion erythrops, Stichonodon insignis, Thoracocharax stellatus, Triportheus albus

Estado 1 - Presente até a metade anterior do osso

Astyanax fasciatus, Bryconamericus exodon, Bryconops alburnoides, Cheirodon galusdae, Clupeacharax anchoveoides, Ctenobrycon hauxwellianus, Engraulisoma taeniatum, Gymnocorymbus ternertzi, Hyphessobrycon eques, Jupiaba anteroides, Knodus moenkhausii, Mimagoniates microlepis, Moenkhausia xinguensis, Tetragonopterus chalceus

Menezes (1976) comenta que segundo Stanley Weitzman o canal presente no osso maxilar não faz parte do sistema lateral sensorial dos peixes, mas serve para passagem de nervos ou vasos sanguíneos. As observações do presente estudo confirmam essa hipótese. Além disso, Nelson (1972) ilustra todas as ramificações dos canais latero-sensoriais cefálicos em diversos grupos de peixes e em nenhum deles reporta a presença de um canal sensorial no osso maxilar. A porção do osso maxilar na qual este canal ocupa e o grau de desenvolvimento de suas ramificações são variáveis entre os Characiformes. Em alguns táxons o canal está ausente, e quando presente, pode alcançar até a porção mais distal do maxilar ou ser restrito até porção mais anterior do osso. Como reportado por Zanata \& Vari (2005) alguns Alestidae o canal maxilar até a porção posterior do osso. Mirande (2010) considera que a presença intricada ramificação (anastomosed tubules) de canais no osso maxilar é sinapomorfia de um grande clado composto pelas famílias Alestidae, Characidae e Serrasalmidae enquanto que a presença do canal sem ramificação seria uma sinapomorfia das subfamílias Aphyocharacinae, Aphyoditeinae, Cheirodontinae, Gymnocharacinae e Stevardiinae.

\section{Caráter 47. Número de dentes maxilares}

Lucena (1993) caráter 45, Zanata (2000) caracteres 52 e 53, Vari \& Harold (2001) caráter 7, Moreira (2002) caráter 38, Benine (2004) caráter 34, NettoFerreira (2005) caracteres 92 e 93, Zanata \& Vari (2005) caráter 78, Moreira (2007) caráter 28, Mirande (2010) caracteres 135 e 136 
Estado 0 - 2 ou mais (figura 82b)

Acestrorhynchus falcatus, Agoniates anchovia, Agoniates halecinus, Aphyocharax pusillus, Astyanacinus moorii, Astyanacinus sp. nova Bolivia, Astyanacinus sp. nova Peru, "Astyanax" superbus, "Astyanax" orthodus, Brycon pesu, Bryconamericus exodon, Bryconops alburnoides, Chalceus epakros, Charax leticiae, Creagrutus menezesi, Deuterodon iguape, Galeocharax knerii, Hollandichthys multifasciatus, Hydrolycus scomberoides, Hyphessobrycon eques, Jupiaba anteroides, Knodus moenkhausii, Lignobrycon myersii, Mimagoniates microlepis, Moenkhausia xinguensis, Nematocharax venustus, Oligosarcus pintoi, Piabina argentea, Poptella paraguayensis, Rachoviscus graciliceps, Salminus hilarii, Tetragonopterus chalceus, Thoracocharax stellatus

Estado 1 - Ausente ou somente 1 (figura 82a)

Astyanax altiparanae, Astyanax fasciatus, Astyanax lineatus, Cheirodon galusdae, Clupeacharax anchoveoides, Ctenobrycon hauxwellianus, Engraulisoma taeniatum, Gymnocorymbus ternertzi, Markiana nigripinnis, Stethaprion erythrops, Stichonodon insignis, Triportheus albus

\section{Polimórfico}

Astyanax paranae

A maioria dos Characiformes apresenta dentes maxilares, porém a quantidade desses é enormemente variável dentro da família Characidae o que pode dificultar a interpretação do sinal filogenético presente neste caráter. Segundo Zanata \& Vari (2005) a posse de um ou mais dentes maxilares é uma característica comum entre os Characiformes, apesar da maioria dos Alestidae apresentar maxila edentelosa, exceção feita à Chalceus que é o mais basal da família. Segundo Castro \& Vari (2004) a ausência de dentes maxilares é sinapomórfica para o clado formado por Anostomidae, Chilodontidae, Curimatidae e Prochilodontidae.

\section{Caráter 48. Quantidade de dentes maxilares}

Lucena (1993) caráter 45, Zanata (2000) caracteres 52 e 53, Vari \& Harold (2001) caráter 7, Moreira (2002) caráter 38, Benine (2004) caráter 34, NettoFerreira (2005) caracteres 92 e 93, Zanata \& Vari (2005) caráter 78, Moreira (2007) caráter 28, Mirande (2010) caracteres 135 e 136

\section{Estado 0 - 2}

Bryconamericus exodon, Bryconops alburnoides, Deuterodon iguape, Hyphessobrycon eques, Jupiaba anteroides, Knodus moenkhausii, Moenkhausia xinguensis, Poptella paraguayensis, Tetragonopterus chalceus

Estado 1 - 3

Creagrutus menezesi, Piabina argentea, Thoracocharax stellatus, 


\section{Estado 2 - 4}

\section{Estado 3 - 5}

\section{Estado 4 - 6}

\section{Estado 5 - 7 ou mais}

Acestrorhynchus falcatus, Agoniates anchovia, Agoniates halecinus, Aphyocharax pusillus, Brycon pesu, Chalceus epakros, Charax leticiae, Galeocharax knerii, Hollandichthys multifasciatus, Hydrolycus scomberoides, Lignobrycon myersii, Mimagoniates microlepis, Nematocharax venustus, Oligosarcus pintoi, Rachoviscus graciliceps, Salminus hilarii

\section{Polimórfico}

Astyanacinus moorii, Astyanacinus sp. nova Bolivia, Astyanacinus sp. nova Peru, “Astyanax" superbus, "Astyanax" orthodus

\section{Inaplicável}

Astyanax altiparanae, Astyanax fasciatus, Astyanax lineatus, Cheirodon galusdae, Clupeacharax anchoveoides, Ctenobrycon hauxwellianus, Engraulisoma taeniatum, Gymnocorymbus ternertzi, Markiana nigripinnis, Stethaprion erythrops, Stichonodon insignis, Triportheus albus

Mesmoa discussão do caráter anterior

\section{Caráter 49. Relação da área com dentes do maxilar}

Lucena (1993) caráter 44, Moreira (2002) caráter 6, Bertaco (2003) caráter 79, Mirande (2010) caráter 137

\section{Estado 0 - Área edentelosa menor que a porção com dentes (figura 83b)}

Acestrorhynchus falcatus, Agoniates anchovia, Agoniates halecinus, Aphyocharax pusillus, Brycon pesu, Chalceus epakros, Charax leticiae, Galeocharax knerii, Hydrolycus scomberoides, Hollandichthys multifasciatus, Lignobrycon myersii, Nematocharax venustus, Oligosarcus pintoi, Salminus hilarii, Thoracocharax stellatus

Estado 1 - Área edentelosa maior que a porção com dentes (figura 83d)

Astyanacinus moorii, Astyanacinus sp. nova Bolivia, Astyanacinus sp. nova Peru, "Astyanax" superbus, "Astyanax" orthodus, Astyanax fasciatus, Astyanax lineatus, Astyanax paranae, Bryconamericus exodon, Bryconops alburnoides, Cheirodon galusdae, Clupeacharax anchoveoides, Creagrutus menezesi, Ctenobrycon hauxwellianus, Deuterodon iguape, Gymnocorymbus ternertzi, Hyphessobrycon eques, Jupiaba anteroides, Knodus moenkhausii, Markiana nigripinnis, Mimagoniates microlepis, Moenkhausia xinguensis, Piabina argentea, Poptella paraguayensis, Rachoviscus graciliceps, Stethaprion erythrops, Tetragonopterus chalceus, Triportheus albus

\section{Inaplicável}

Astyanax altiparanae, Engraulisoma taeniatum, Stichonodon insignis 
A maxila dos Characiformes pode ou não apresentar dentes. Na maioria deles há dentes, porém a quantidade desses é bastante variável dentro da ordem. Em alguns grupos os dentes são bastante numerosos e estão implantados em quase toda a margem anterior da maxila. Historicamente essa variação de dentes no maxilar dos Characidae tem sido bastante utilizada e tem grande importância para a diagnose de gêneros da família. Para Mirande (2010) uma maxila com margem anterior com dentes em quase toda a sua extensão é uma sinapomorfia do clado Acestrorhynchinae + Agoniatinae + Bryconinae + Cynodontinae + Salmininae e, paralelamente de outro formado por Aphyocharacinae, Aphyoditeinae, Characinae, Cheirodontinae, Gymnocharacinae, Heterocharacinae, Rhoadsiinae, Stethaprioninae, Stevardiinae, Tetragonopterinae; Astyanax clade, Astyanax paris clade, Bramocharax clade, Bryconamericus scleroparius clade, Hyphessobrycon anisitsi clade e Pseudochalceus clade.

\section{Caráter 50. Cúspides do primeiro dente maxilar}

Lucena (1993) caráter 43, Moreira (2002) caráter 7, Bertaco (2003) caráter 81, Benine (2004) caráter 35, Mirande (2010) caracteres 138 e 139

\section{Estado 0 - Tricuspidado}

Aphyocharax pusillus, Astyanacinus moorii, Astyanacinus sp. nova Bolivia, Astyanacinus sp. nova Peru, "Astyanax" orthodus, Astyanax lineatus, Astyanax paranae, Brycon pesu, Bryconamericus exodon, Bryconops alburnoides, Chalceus epakros, Creagrutus menezesi, Gymnocorymbus ternertzi, Hollandichthys multifasciatus, Jupiaba anteroides, Lignobrycon myersii, Mimagoniates microlepis, Nematocharax venustus, Piabina argentea, Poptella paraguayensis

Estado 1 - Pentacuspidado (figura 83c)

"Astyanax" superbus, Astyanax fasciatus, Cheirodon galusdae, Clupeacharax anchoveoides, Ctenobrycon hauxwellianus, Hyphessobrycon eques, Moenkhausia xinguensis, Oligosarcus pintoi, Stethaprion erythrops, Tetragonopterus chalceus, Triportheus albus

Estado 2 - Unicuspidado (figura 83a)

Acestrorhynchus falcatus, Agoniates anchovia, Agoniates halecinus, Charax leticiae, Galeocharax knerii, Hydrolycus scomberoides, Rachoviscus graciliceps, Salminus hilarii, Thoracocharax stellatus

Estado 3 - Heptacuspidado

Deuterodon iguape, Knodus moenkhausii

\section{Indeterminado}


Markiana nigripinnis

\section{Inaplicável}

Astyanax altiparanae, Engraulisoma taeniatum, Stichonodon insignis

Segundo Mirande (2010) usualmente apresentam os dentes maxilares com morfologia similar aos dentes presentes em outros ossos da mandíbula. Com base nos peixes examinados é possível concluir que essa afirmação não é verdadeira. Dentes maxilares são quase sempre menores que os dentes presentes na prémaxila e no dentário, na maioria das vezes eles apresentam menos cúspides, de maneira geral, não há tanta variação de tamanho entre os dentes quanto há nos outros ossos e a variação entre a quantidade de cúspides é mais restrita nos dentes maxilares.

O número de cúspides nos dentes maxilares, assim como é em dentes de outros ossos, é bastante variável em Characidae.

\section{Caráter 51. Posição relativa da margem posterior da maxila}

Buckup (1998) caracteres 33 e 34, Bertaco (2003) caráter 5, Zanata \& Vari (2005) caráter 72, Bührnheim (2006) caráter 53, Mirande (2010) caracteres 99 e 100

Estado 0 - Margem posterior da maxila bem posterior a vertical que passa pela asa do etmóide lateral (figura 82b)

Acestrorhynchus falcatus, Agoniates anchovia, Agoniates halecinus, Astyanacinus moorii, Astyanacinus sp. nova Bolivia, Astyanacinus sp. nova Peru, “Astyanax" superbus, "Astyanax" orthodus, Astyanax paranae, Brycon pesu, Bryconops alburnoides, Charax leticiae, Deuterodon iguape, Galeocharax knerii, Gymnocorymbus ternertzi, Hollandichthys multifasciatus, Hydrolycus scomberoides, Hyphessobrycon eques, Nematocharax venustus, Oligosarcus pintoi, Rachoviscus graciliceps, Salminus hilarii

Estado 1 - Margem posterior da maxila não muito posterior a vertical que passa pela asa do etmóide lateral (figura 82a)

Astyanax altiparanae, Astyanax fasciatus, Astyanax lineatus, Bryconamericus exodon, Cheirodon galusdae, Creagrutus menezesi, Clupeacharax anchoveoides, Engraulisoma taeniatum, Jupiaba anteroides, Knodus moenkhausii, Mimagoniates microlepis, Moenkhausia xinguensis

Estado 2 - Margem posterior da maxila anterior a vertical que passa pela asa do etmóide lateral

Aphyocharax pusillus, Chalceus epakros, Ctenobrycon hauxwellianus, Lignobrycon myersii, Markiana nigripinnis, Piabina argentea, Poptella paraguayensis, Stethaprion erythrops, Stichonodon insignis, Tetragonopterus chalceus, Thoracocharax stellatus, Triportheus albus 
O comprimento da maxila é bastante variável entre os Characiformes e os Characidae. Como discutido no item "Piscivoria em Characidae" uma maxila mais alongada pode estar relacionada ao hábito piscívoro. Segundo Mirande (2010) a maioria dos Characidae a maxila ultrapassa o segundo infra-orbital enquanto que algumas espécies possuem maxila relativamente mais curta.

\section{Caráter 52. Constrição na porção posterior da maxila}

Estado 0 - Ausente (figura 83b)

Acestrorhynchus falcatus, Aphyocharax pusillus, Astyanacinus moorii, Astyanacinus sp. nova Bolivia, Astyanacinus sp. nova Peru, "Astyanax" superbus, "Astyanax" orthodus, Astyanax altiparanae, Astyanax fasciatus, Astyanax lineatus, Astyanax paranae, Brycon pesu, Bryconamericus exodon, Bryconops alburnoides, Charax leticiae, Cheirodon galusdae, Clupeacharax anchoveoides, Creagrutus menezesi, Ctenobrycon hauxwellianus, Deuterodon iguape, Engraulisoma taeniatum, Galeocharax knerii, Gymnocorymbus ternertzi, Hollandichthys multifasciatus, Hydrolycus scomberoides, Hyphessobrycon eques, Jupiaba anteroides, Knodus moenkhausii, Lignobrycon myersii, Markiana nigripinnis, Mimagoniates microlepis, Moenkhausia xinguensis, Nematocharax venustus, Oligosarcus pintoi, Piabina argentea, Poptella paraguayensis, Rachoviscus graciliceps, Salminus hilarii, Stethaprion erythrops, Stichonodon insignis, Tetragonopterus chalceus, Thoracocharax stellatus, Triportheus albus

Estado 1 - Pouco pronunciada

Chalceus epakros

Estado 2 - Bastante pronunciada

Agoniates anchovia, Agoniates halecinus

A porção posterior da margem dorsal da maxila nos Characiformes é quase sempre reta, sem a formação de entalhes definidos. Entre os peixes examinados somente os Agoniatinae e Chalceus apresentaram o entalhe. Considerando as propostas previamente apresentadas sobre a posição filogenética de Chalceus, este seria mais proximamente relacionado aos Alestidae e posse dessa característica nesses dois grupos deve ser interpretada como um paralelismo. Além disso, Chalceus apresenta uma ossificação autógena situada na região posterior da margem dorsal da maxila, exatamente próximo ao local onde há o entalhe na maxila. É bastante provável que em Chalceus esse entalhe seja uma depressão onde se encaixa a supra-maxila.

De acordo com Fink \& Fink (1996) a ausência dessa ossificação é uma sinapomorfia de Ostariophysi e a presença dela em Characiformes é bastante 
rara. Apesar de alguns autores (cf. Géry, 1962: fig. 7) citarem a presença dessa estrutura em Agoniatinae nenhum dos exemplares apresentaram esse estado.

\section{Caráter 53. Posição relativa do dentário e pré-maxila em vista lateral}

Ferreira (2007) caráter 32, Bertaco (2008) caráter 25

Estado 0 - Pré-maxilar anterior ao dentário

Acestrorhynchus falcatus, Brycon pesu, Bryconamericus exodon, Chalceus epakros, Charax leticiae, Creagrutus menezesi, Engraulisoma taeniatum, Galeocharax knerii, Knodus moenkhausii, Markiana nigripinnis, Piabina argentea, Salminus hilarii

Estado 1 - Pré-maxilar e dentário alinhados

Astyanacinus moorii, Astyanacinus sp. nova Bolivia, Astyanacinus sp. nova Peru, "Astyanax" superbus, "Astyanax" orthodus, Astyanax altiparanae, Astyanax fasciatus, Astyanax lineatus, Astyanax paranae, Bryconops alburnoides, Cheirodon galusdae, Clupeacharax anchoveoides, Ctenobrycon hauxwellianus, Deuterodon iguape, Gymnocorymbus ternertzi, Jupiaba anteroides, Mimagoniates microlepis, Nematocharax venustus, Stethaprion erythrops

Estado 2 - Dentário anterior ao pré-maxilar

Agoniates anchovia, Aphyocharax pusillus, Agoniates halecinus, Hollandichthys multifasciatus, Hydrolycus scomberoides, Hyphessobrycon eques, Lignobrycon myersii, Moenkhausia xinguensis, Oligosarcus pintoi, Poptella paraguayensis, Rachoviscus graciliceps, Stichonodon insignis, Tetragonopterus chalceus, Thoracocharax stellatus, Triportheus albus

Em vista lateral a região do focinho dos Characidae apresenta variação com relação ao desenvolvimento das maxilas superior e inferior. Diversos grupos como, por exemplo, Creagrutus e Piabina apresentam a maxila superior mais proeminente do que o dentário. Myers (1944) utiliza essa característica para diagnosticar Rhinobrycon de todos os outros Characidae.

\section{Caráter 54. Distância entre o ectopterigóide e dentário}

Estado 0 - Em contato ou próximos (figura 81b)

Acestrorhynchus falcatus, Aphyocharax pusillus, Astyanacinus moorii, Astyanacinus sp. nova Bolivia, Astyanacinus sp. nova Peru, "Astyanax" superbus, "Astyanax" orthodus, Astyanax altiparanae, Astyanax fasciatus, Astyanax lineatus, Astyanax paranae, Brycon pesu, Bryconamericus exodon, Bryconops alburnoides, Chalceus epakros, Charax leticiae, Cheirodon galusdae, Clupeacharax anchoveoides, Creagrutus menezesi, Ctenobrycon hauxwellianus, Deuterodon iguape, Engraulisoma taeniatum, Galeocharax knerii, Gymnocorymbus ternertzi, Hollandichthys multifasciatus, Hydrolycus scomberoides, Hyphessobrycon eques, Jupiaba anteroides, Knodus moenkhausii, Lignobrycon myersii, Markiana nigripinnis, Mimagoniates microlepis, Moenkhausia xinguensis, Nematocharax venustus, Oligosarcus pintoi, Piabina argentea, Poptella paraguayensis, Rachoviscus graciliceps, Salminus hilarii, Stethaprion erythrops, Stichonodon insignis, Tetragonopterus chalceus, Thoracocharax stellatus, Triportheus albus 
Estado 1 - Distantes (equivalente a maior altura do dentário)

Agoniates anchovia, Agoniates halecinus,

Exceto nos Agoniatinae, em todos os peixes examinados o ectopterigóide encontra-se em contato ou próximo da superfície postero-dorsal do dentário. Na referida subfamília esses ossos estão distantes por um espaço tanto grande quanto a maior altura do dentário.

\section{Caráter 55. Contato ectopterigóide-quadrado}

Zanata (2000) caráter 59, Vari \& Harold (2001) caráter 21, Moreira (2002) caráter 15, Benine (2004) caráter 42, Netto-Ferreira (2006) caráter 123, Ferreira (2007) caráter 59, Moreira (2007) caráter 53, Mirande (2010) caráter 162

Estado 0 - Presente (figura 81a)

Acestrorhynchus falcatus, Agoniates anchovia, Agoniates halecinus, Aphyocharax pusillus, "Astyanax" orthodus, Astyanax altiparanae, Astyanax fasciatus, Astyanax lineatus, Astyanax paranae, Brycon pesu, Bryconops alburnoides, Chalceus epakros, Charax leticiae, Clupeacharax anchoveoides, Ctenobrycon hauxwellianus, Deuterodon iguape, Galeocharax knerii, Gymnocorymbus ternertzi, Hydrolycus scomberoides, Hyphessobrycon eques, Jupiaba anteroides, Lignobrycon myersii, Markiana nigripinnis, Moenkhausia xinguensis, Nematocharax venustus, Oligosarcus pintoi, Salminus hilarii, Stethaprion erythrops, Stichonodon insignis, Tetragonopterus chalceus, Thoracocharax stellatus, Triportheus albus

\section{Estado 1 - Ausente}

Astyanacinus sp. nova Bolivia, Astyanacinus moorii, Bryconamericus exodon, Cheirodon galusdae, Creagrutus menezesi, Engraulisoma taeniatum, Hollandichthys multifasciatus, Knodus moenkhausii, Mimagoniates microlepis, Piabina argentea, Poptella paraguayensis, Rachoviscus graciliceps,

\section{Polifmórfico}

Astyanacinus sp. nova Peru, “Astyanax” superbus

Na maioria dos Characiformes o ectopterígoide é um osso alongado situado ventralmente ao endopterigóide. Sua porção mais posterior pode ou não alcançar a região antero-dorsal do braço vertical do quadrado, sendo que a condição mais comumente encontra é da ocorrência desse contato. Segundo Vari \& Harold (2001) poucos Characiformes não apresentam contato entre o ectopterigóide e o quadrado. De acordo com o autor o contato está ausente em Anodus (Hemiodontidae) e Parodon (Parodontidae). Vari \& Harold (2001) comenta que a única espécie de Creagrutus a apresentar contato entre esses ossos 
é Creagrutus тисipu, além de estar ausente também em Piabina argentea e esta característica é sinapomórfica para o clado que agrupa os dois gêneros.

\section{Caráter 56. Dentição no ectopterigóide}

Lucena (1993) caráter 56, Buckup (1998) caráter 22, Moreira (2002) caráter 16, Benine (2004) caráter 41, Lima (2006) caráter 19, Toledo-Piza (2007) caráter 50, Mirande (2010) caracteres 159 e 160

\section{Estado 0 - Ausente}

Agoniates anchovia, Agoniates halecinus, Aphyocharax pusillus, Astyanacinus moorii, Astyanacinus sp. nova Bolivia, Astyanacinus sp. nova Peru, "Astyanax" superbus, "Astyanax" orthodus, Astyanax altiparanae, Astyanax fasciatus, Astyanax lineatus, Astyanax paranae, Brycon pesu, Bryconamericus exodon, Bryconops alburnoides, Chalceus epakros, Charax leticiae, Cheirodon galusdae, Clupeacharax anchoveoides, Creagrutus menezesi, Ctenobrycon hauxwellianus, Deuterodon iguape, Engraulisoma taeniatum, Galeocharax knerii, Gymnocorymbus ternertzi, Hollandichthys multifasciatus, Hyphessobrycon eques, Jupiaba anteroides, Knodus moenkhausii, Lignobrycon myersii, Markiana nigripinnis, Mimagoniates microlepis, Moenkhausia xinguensis, Nematocharax venustus, Piabina argentea, Poptella paraguayensis, Rachoviscus graciliceps, Salminus hilarii, Stethaprion erythrops, Stichonodon insignis, Tetragonopterus chalceus, Thoracocharax stellatus, Triportheus albus

Estado 1 - Presente na forma de fileiras ou dentículos Acestrorhynchus falcatus, Hydrolycus scomberoides, Oligosarcus pintoi

A presença de dentes no ectopterigóide é relativamente comum entre os Characiformes (Toledo-Piza, 2007), mas o padrão de distribuição e o tamanho relativo desses dentes variam entre os grupos. Toledo-Piza (2007) comenta que todas as espécies Acestrorhynchus apresentam dentes no ectopterigóide arranjados em uma única série, Ctenoluciidae e Cynodontinae apresentam agrupamentos de dentículos e Erythrinidae apresenta uma combinação das duas condições anteriores. Mirande (2010) sugere que a presença desses dentes é uma sinapomorfia de Oligosarcus.

\section{Caráter 57. Dentição no endopterigóide}

Uj (1990) caráter 68, Lucena (1993) caráter 55, Vari (1995) caráter 54, Buckup (1998) caráter 23, Toledo-Piza (20000 caráter 29, Moreira (2002) caráter 17, Toledo-Piza (2007) caráter 51, Mirande (2010) caráter 165 


\section{Estado 0 - Ausente}

Agoniates anchovia, Agoniates halecinus, Aphyocharax pusillus, Astyanacinus moorii, Astyanacinus sp. nova Bolivia, Astyanacinus sp. nova Peru, "Astyanax" superbus, "Astyanax" orthodus, Astyanax altiparanae, Astyanax fasciatus, Astyanax lineatus, Astyanax paranae, Brycon pesu, Bryconamericus exodon, Bryconops alburnoides, Chalceus epakros, Charax leticiae, Cheirodon galusdae, Clupeacharax anchoveoides, Creagrutus menezesi, Ctenobrycon hauxwellianus, Deuterodon iguape, Engraulisoma taeniatum, Galeocharax knerii, Gymnocorymbus ternertzi, Hollandichthys multifasciatus, Hyphessobrycon eques, Jupiaba anteroides, Knodus moenkhausii, Lignobrycon myersii, Markiana nigripinnis, Mimagoniates microlepis, Moenkhausia xinguensis, Nematocharax venustus, Oligosarcus pintoi, Piabina argentea, Poptella paraguayensis, Rachoviscus graciliceps, Salminus hilarii, Stethaprion erythrops, Stichonodon insignis, Tetragonopterus chalceus, Thoracocharax stellatus, Triportheus albus

Estado 1 - Presença de dentículos

Acestrorhynchus falcatus, Hydrolycus scomberoides

Segundo Toledo-Piza (2000) dentes no osso endopterigóide são raros entre os Characiformes, mas apesar disso todas as espécies de Acestrorhynchus (A. falcirostris) apresentam essas estruturas (Toledo-Piza, 2007). Esses dentes ainda estão presentes nas espécies de Cynodontinae e no Erythrinidae (Hoplerythrinus unitaeniatus). De acordo com Lucena \& Menezes (1998) a presença desses dentes foi ambígua na análise filogenética, podendo tanto ser uma sinapomorfia das famílias Cynodontidae + Acestrorhynchidae com perda secundária em Roestinae como uma sinapomorfia de Cynodontinae e, paralelamente, de Acestrorhynchidae.

\section{Caráter 58. Formato da fenestra entre o quadrado e o metapterigóide}

Lucena (1993) caráter 60, Vari (1995) caráter 55, Buckup (1998) caráter 25, Lucena \& Menezes (1998) caráter 26, Oyakawa (1998) caráter 44, Zanata (2000) caráter 66, Moreira (2002) caráter 28, Benine (2004) caráter 94, Zanata \& Vari (2005) caráter 102, Netto-Ferreira (2006) caracteres 124 e 125, Ferreira (2007) caráter 70, Moreira (2007) caráter 69, Bertaco (2008) caráter 52, Sidlauskas \& Vari (2008) caráter 79

Estado 0 - Mais comprida do que alta (figura 82a)

Aphyocharax pusillus, Astyanacinus moorii, Astyanacinus sp. nova Bolivia, Astyanax altiparanae, Astyanax fasciatus, Astyanax lineatus, Astyanax paranae, Bryconamericus exodon, Chalceus epakros, Cheirodon galusdae, Ctenobrycon hauxwellianus, Deuterodon iguape, Engraulisoma taeniatum, Gymnocorymbus ternertzi, Hyphessobrycon eques, Jupiaba anteroides, Knodus moenkhausii, 
Lignobrycon myersii, Markiana nigripinnis, Mimagoniates microlepis, Moenkhausia xinguensis, Nematocharax venustus, Piabina argentea, Poptella paraguayensis, Rachoviscus graciliceps, Stethaprion erythrops, Stichonodon insignis, Tetragonopterus chalceus, Thoracocharax stellatus, Triportheus albus

Estado 1 - Mais alta que comprida

Acestrorhynchus falcatus, Agoniates anchovia, Brycon pesu, Charax leticiae, Creagrutus menezesi, Galeocharax knerii, Hydrolycus scomberoides, Salminus hilarii

Estado 2 - Tão alta quanto comprida

Agoniates halecinus, Astyanacinus sp. nova Peru, "Astyanax" superbus, "Astyanax" orthodus, Bryconops alburnoides, Clupeacharax anchoveoides, Hollandichthys multifasciatus, Oligosarcus pintoi

Na grande maioria dos Characiformes há uma grande fenestra na porção central do suspensório formada antero-ventralmente pelo quadrado e posterodorsalmente pelo metapterigóide. Ao que tudo indica a fenestra não é atravessada nem por músculos, vasos ou nervos. O formato dessa fenestra é variável dentro das diversas linhagens de caracóideos podendo ser mais alongada anteroposteroirmente ou dorso-ventralmente.

Segundo Zanata \& Vari (2005) com exceção feita à Chalceus e Hydrocynus, todos os Alestidae apresentam a fenestra mais alongada anteroposteriormente. Para Sidlauskas \& Vari (2008) o formato da fenestra de Anostomus, Gnathodolus, Petulanos, Pseudanos, Sartor e Synaptolaemus é sinapomórfico para o grupo.

\section{Caráter 59. Forame na porção posterior do metapterigóide}

Lucena (1993) caráter 57, Zanata (2000) caráter 63, Vari \& Harold (2001) caráter 23, Moreira (2002) caráter 23, Benine (2004) caráter 43, Lima (2006) caráter 22, Netto-Ferreira (2006) caráteres 128, Ferreira (2007) caráter 67, Moreira (2007) caráter 65, Bertaco (2008) caráter 44, Marinho (2009) caráter 42; Mirande (2009) caráter 168, Mirande (2010) caráter 168, Netto-Ferreira (2010) caráter 71

Estado 0 - entre o hiomandibular e o metapterigóide (figura 81b)

Acestrorhynchus falcatus, Agoniates anchovia, Agoniates halecinus, "Astyanax" superbus, Brycon pesu, Bryconops alburnoides, Chalceus epakros, Clupeacharax anchoveoides, Engraulisoma taeniatum, Hydrolycus scomberoides, Lignobrycon myersii, Mimagoniates microlepis, Rachoviscus graciliceps, Salminus hilarii, Thoracocharax stellatus, Triportheus albus 
Estado 1 - incluso no metapterigóide (figura 81a)

Aphyocharax pusillus, Astyanacinus moorii, Astyanacinus sp. nova Bolivia, Astyanacinus sp. nova Peru, "Astyanax" orthodus, Astyanax altiparanae, Astyanax fasciatus, Astyanax lineatus, Astyanax paranae, Bryconamericus exodon, Charax leticiae, Cheirodon galusdae, Creagrutus menezesi, Ctenobrycon hauxwellianus, Deuterodon iguape, Galeocharax knerii, Gymnocorymbus ternertzi, Hollandichthys multifasciatus, Hyphessobrycon eques, Jupiaba anteroides, Knodus moenkhausii, Markiana nigripinnis, Moenkhausia xinguensis, Nematocharax venustus, Oligosarcus pintoi, Piabina argentea, Poptella paraguayensis, Stethaprion erythrops, Stichonodon insignis, Tetragonopterus chalceus

Nos Characiformes o osso metapterigóide apresenta um forame em sua porção posterior que pode estar totalmente incluso nesse osso ou entre o metapterigóide e o hiomandibular. Segundo Moreira (2007) e Mirande (2010) tal forame é a passagem do ramo mandibularis do nervo trigêmeo enquanto que, segundo Vari \& Harold (2001) e Netto-Ferreira (2010), o mesmo serve para passagem de um vaso sanguíneo. Datovo (2011) vai além e sugere que o forame é atravessado por um vaso que se liga à pseudobrânquia (estrutura formada pelo primeiro arco branquial reduzido, próxima a superfície medial do opérculo que está relacionada com a oxigenação de vasos que irrigam o olho).

De acordo com Lucena (1993) a presença desse forame é uma sinapomorfia de Alestidae, Serrasalmidae e Characidae. Segundo Mirande (2010) o forame inserido no metapterigóide e sem participação da hiomandíbula é sinapomórfico do clado formado por Aphyocharacinae, Aphyoditeinae, Characinae, Cheirodontinae, Gymnocharacinae, Heterocharacinae, Rhoadsiinae, Stethaprioninae, Stevardiinae e Tetragonopterinae; Astyanax clade, Astyanax paris clade, Bramocharax clade, Bryconamericus scleroparius clade, Hyphessobrycon anisitsi clade e Pseudochalceus clade.

\section{Caráter 60. Superfície pôstero-superior do metapterigóide}

Estado 0 - Lisa (figura 81b)

Agoniates anchovia, Agoniates halecinus, Bryconops alburnoides, Clupeacharax anchoveoides, Hydrolycus scomberoides, Hyphessobrycon eques, Knodus moenkhausii, Lignobrycon myersii, Mimagoniates microlepis, Piabina argentea, Salminus hilarii, Thoracocharax stellatus, Triportheus albus

Estado 1 - Modificada para a passagem de um canal (figura 81a)

Aphyocharax pusillus, Astyanacinus moorii, Astyanacinus sp. nova Bolivia, Astyanacinus sp. nova Peru, "Astyanax" orthodus, Astyanax altiparanae, Astyanax fasciatus, Astyanax lineatus, Astyanax paranae, Brycon pesu, Bryconamericus exodon, Chalceus epakros, Charax leticiae, Cheirodon galusdae, Creagrutus menezesi, Ctenobrycon hauxwellianus, Deuterodon iguape, Engraulisoma taeniatum, Galeocharax knerii, Gymnocorymbus ternertzi, Hollandichthys multifasciatus, Jupiaba anteroides, 
Markiana nigripinnis, Moenkhausia xinguensis, Nematocharax venustus, Oligosarcus pintoi, Poptella paraguayensis, Rachoviscus graciliceps, Stethaprion erythrops, Stichonodon insignis, Tetragonopterus chalceus

Estado 2 - Canal inserido no metapterigóide Acestrorhynchus falcatus, "Astyanax" superbus

Nos peixes examinados a superfície pôstero-dorsal do metapterigóide em diversos táxons apresenta uma projeção lamelar dorsal que parece formar a borda de um canal juntamente com a margem anterior da hiomandíbula. Em outros táxons a margem dorsal do metapterigóide é lisa.

\section{Série Opercular}

Ainda no crânio há uma série de ossos (série ou aparato opercular) que não faz parte nem do neurocrânio e nem do esplancnocrânio. São todos ossos laminares com origem dermal que cobrem lateralmente a câmara branquial. É formada pelos ossos opérculo, subopérculo, preopérculo e interopérculo.

\section{Caráter 61. Bordas dorsais do hiomandibular e do opérculo}

Bertaco (2008) caráter 54

Estado 0 - Borda dosal do opérculo mais elevada do que a do hiomandibular (figura 81b)

Acestrorhynchus falcatus, Agoniates anchovia, Agoniates halecinus, Aphyocharax pusillus, Astyanacinus moorii, Astyanacinus sp. nova Bolivia, Astyanacinus sp. nova Peru, "Astyanax" superbus, "Astyanax" orthodus, Astyanax altiparanae, Astyanax fasciatus, Astyanax lineatus, Astyanax paranae, Brycon pesu, Bryconops alburnoides, Chalceus epakros, Cheirodon galusdae, Clupeacharax anchoveoides, Ctenobrycon hauxwellianus, Deuterodon iguape, Engraulisoma taeniatum, Gymnocorymbus ternertzi, Hollandichthys multifasciatus, Hyphessobrycon eques, Jupiaba anteroides, Knodus moenkhausii, Lignobrycon myersii, Markiana nigripinnis, Mimagoniates microlepis, Moenkhausia xinguensis, Nematocharax venustus, Oligosarcus pintoi, Poptella paraguayensis, Rachoviscus graciliceps, Salminus hilarii, Stethaprion erythrops, Stichonodon insignis, Tetragonopterus chalceus, Thoracocharax stellatus, Triportheus albus

Estado 1 - Bordas dosais do opérculo e do hiomandibular alinhadas

Bryconamericus exodon, Galeocharax knerii, Piabina argêntea 
Estado 2 - Borda dosal do hiomandibular mais elevada do que a do opérculo (figura 81a)

Charax leticiae, Creagrutus menezesi, Hydrolycus scomberoides

Na maioria dos Characidae a borda dorsal do opérculo é mais alta que a borda dorsal da hiomandíbula. Entretanto, há alguns grupos de peixes em que condições diferentes estão presentes.

Bertaco (2008) considera que as margens dorsais do hiomandibular e do opérculo alinhadas é sinapomórfica para um clado composto por Nematobrycon, Pseudochalceus, Charax, Hollandichthys, Rachoviscus, Nematocharax, Odontostilbe e Rhoadsia, e para outro formado por Bryconamericus, Knodus, Landonia, Othonocheirodus, Bryconadenos, Piabina, Aphyocharax e Carlastyanax.

\section{Arco hióide e suspensório}

O arco hióide, que diferentemente do que é mais comumente dito, não é formado somente pelos hipohiais ventral e dorsal (endocondrais), ceratohiais anterior e posterior (endocondrais), inter-hial (endocondral) e raios branquiostégios (dermais). Por razões embriológicas, três ossos endocondrais que unem a maxila inferior (ou mandíbula) ao crânio (hiomandíbula, simplético e quadrado) devem ser discutidos separadamente e não como complexos distintos.

\section{Caráter 62. Número de raios branquiostégios}

Vari (1995) caráter 61, Lucena (1993) caráter 70, Lucena \& Menezes (1998) caráter 33, Toledo-Piza (2000) caráter 33, Zanata \& Vari (2005) caráter 112, Lima (2006) caráter 39, Toledo-Piza (2007) caráter 57, Mirande (2010) caracteres 212 e 213

Estado 0 - Quatro ou cinco

Acestrorhynchus falcatus, Agoniates anchovia, Agoniates halecinus, Aphyocharax pusillus, Astyanacinus moorii, Astyanacinus sp. nova Bolivia, Astyanacinus sp. nova Peru, "Astyanax" superbus, "Astyanax" orthodus, Astyanax altiparanae, Astyanax fasciatus, Astyanax lineatus, Astyanax paranae, Brycon pesu, Bryconamericus exodon, Bryconops alburnoides, Chalceus epakros, Charax leticiae, Cheirodon 
galusdae, Creagrutus menezesi, Ctenobrycon hauxwellianus, Deuterodon iguape, Galeocharax knerii, Gymnocorymbus ternertzi, Hollandichthys multifasciatus, Hydrolycus scomberoides, Hyphessobrycon eques, Jupiaba anteroides, Knodus moenkhausii, Lignobrycon myersii, Markiana nigripinnis, Mimagoniates microlepis, Moenkhausia xinguensis, Nematocharax venustus, Oligosarcus pintoi, Piabina argentea, Poptella paraguayensis, Rachoviscus graciliceps, Salminus hilarii, Stethaprion erythrops, Stichonodon insignis, Tetragonopterus chalceus, Thoracocharax stellatus, Triportheus albus

Estado 1 - Três

Clupeacharax anchoveoides, Engraulisoma taeniatum

Raios branquiostégios são ossos laminares alongados que se inserem na face medial dos cerato-hiais . No clássico trabalho sobre os raios branquiostégios dos peixes, McAllister (1968) sugere que entre os Characiformes a quantidade de raios varia entre três e cinco. Segundo Roberts (1969) a maioria dos Characiformes apresentam quatro raios branquiostégios, percepção confirmada através do exame de vários táxons. Há, entretanto, alguns táxons que apresentam cinco raios como representantes das famílias Ctenoluciidae, Cynodontidae, Erytrhrinidae, Gasteropelecidae, Hemiodontidae e Hepsetidae. Em Characidae, assim como em Characiformes, a maioria das espécies apresenta quatro raios branquiostégios, dentre eles os táxons aparentemente mais basais dos caracídeos indicando que essa quantidade seja plesiomórfica tanto para a ordem quanto para a família.

Para Vari (1995) a presença de cinco raios branquiostégios é uma sinapomorfia da família Erythrinidae e para Lucena \& Menezes (1998) para Cynodontinae. Os Cypriniformes possuem três raios branquiostégios e tanto Gymnotiformes quando Siluriformes apresentam mais do que cinco (Mirande, 2010). Castro (1984) propôs que a presença de tês raios é uma sinapomorfia de Clupeacharax + Engraulisoma.

\section{Caráter 63. Número de raios branquiostégios no cerato-hial posterior}

Lucena (1993) caráter 69, Vari (1995) caráter 60, Lucena \& Menezes (1998) caráter 34, Toledo-Piza (2000) caráter 34, Toledo-Piza (2007) caráter 58, Mirande (2010) caráter 217

Estado 0 - Um raio (figura 84a) 
Agoniates anchovia, Agoniates halecinus, Aphyocharax pusillus, Astyanacinus moorii, Astyanacinus sp. nova Bolivia, Astyanacinus sp. nova Peru, "Astyanax" superbus, "Astyanax" orthodus, Astyanax altiparanae, Astyanax fasciatus, Astyanax lineatus, Astyanax paranae, Brycon pesu, Bryconamericus exodon, Bryconops alburnoides, Chalceus epakros, Charax leticiae, Cheirodon galusdae, Clupeacharax anchoveoides, Creagrutus menezesi, Ctenobrycon hauxwellianus, Deuterodon iguape, Engraulisoma taeniatum, Galeocharax knerii, Gymnocorymbus ternertzi, Hollandichthys multifasciatus, Hyphessobrycon eques, Jupiaba anteroides, Knodus moenkhausii, Lignobrycon myersii, Markiana nigripinnis, Mimagoniates microlepis, Moenkhausia xinguensis, Nematocharax venustus, Oligosarcus pintoi, Piabina argentea, Poptella paraguayensis, Rachoviscus graciliceps, Salminus hilarii, Stethaprion erythrops, Stichonodon insignis, Tetragonopterus chalceus, Thoracocharax stellatus, Triportheus albus

Estado 1 - Dois raios (figura 84b)

Acestrorhynchus falcatus, Hydrolycus scomberoides

A maioria dos Characiformes e dos Characidae apresenta apenas um raio branquiostégio articulando com o cerato-hial posterior. Lucena (1993) considera a presença de dois raios branquiostégios articulando com cerato-hial posterior como uma sinapomorfia de um clado composto Acestrorhynchus, Cynodon e Rhaphiodon e ocorrência paralela em Ctenolucius. Na análise de Lucena \& Menezes (1998) essa característica mostrou-se ambígua e tanto pode ser considerada uma sinapomorfia das famílias Acestrorhynchidae + Cynodontidae e reversão em Roestinae como sinapomorfias independentes para Acestrorhynchidae e Cynodontinae. Mirande (2010) recobra a primeira hipótese de Lucena \& Menezes (1998).

\section{Caráter 64. Abertura da artéria hióide aferente}

Castro (1984), Buckup (1998) caráter 25, Zanata (2000) caráter 71, Benine (2004) caráter 103, Zanata \& Vari (2005) caráter 111, Ferreira (2007) caráter 78, Moreira (2007) caráter 189, Mirande (2009) caráter 178, Mirande (2010) caráter 178

Estado 0 - delimitada pelos ossos ceratohial anterior e hipohial dorsal

Acestrorhynchus falcatus, Agoniates anchovia, Agoniates halecinus, Brycon pesu, Bryconops alburnoides, Chalceus epakros, Clupeacharax anchoveoides, Engraulisoma taeniatum, Hydrolycus scomberoides, Lignobrycon myersii, Salminus hilarii, Thoracocharax stellatus, Triportheus albus

Estado 1 - Porção dorsal do ceratohial anterior

Aphyocharax pusillus, Astyanacinus moorii, Astyanacinus sp. nova Bolivia, Astyanacinus sp. nova Peru, "Astyanax" superbus, "Astyanax" orthodus, Astyanax altiparanae, Astyanax fasciatus, Astyanax lineatus, Astyanax paranae, Bryconamericus exodon, Charax leticiae, Cheirodon galusdae, Creagrutus menezesi, Ctenobrycon hauxwellianus, Deuterodon iguape, Galeocharax knerii, Gymnocorymbus 
ternertzi, Hollandichthys multifasciatus, Hyphessobrycon eques, Jupiaba anteroides, Knodus moenkhausii, Markiana nigripinnis, Mimagoniates microlepis, Moenkhausia xinguensis, Nematocharax venustus, Oligosarcus pintoi, Piabina argentea, Poptella paraguayensis, Rachoviscus graciliceps, Stethaprion erythrops, Stichonodon insignis, Tetragonopterus chalceus

O primeiro a reportar esse caráter, embora com interpretação diferente, foi Castro (1984). Nele, o autor sugeriu que o "canal sensorial” do cerato-hial termina anteriormente num orifício situado na borda dorsal do cerato-hial anterior e, segundo o mesmo autor, essa característica configurava-se em uma sinapomorfia de Astyanax, Bryconamericus, Piabina e Creagrutus enquanto que em outros peixes o canal abria-se abruptamente e anteriormente num grande forame delimitado pelo hipi-hial dorsal e posteriormente pelo cerato-hial anterior. Grosso modo, Castro (1984) estava correto em tecer tal afirmação, porém algumas considerações sobre esse caráter são necessárias. A primeira delas é que o referido "canal sensorial" não de um canal sensorial e sim de um canal onde passa a artéria hióide aferente.

Em actinopterigianos basais a artéria hióide aferente passa lateralmente pela margem do cerato-hial sem passar por entre os ossos hipi-hiais (de Pinna, 1996). Nos Teleostei a artéria hióide aferente também percorre lateral os ceratohiais, porém, diferentemente dos actinopterigianos basais, atravessa os hipi-hiais de diversas maneiras distintas como ilustrado em Arratia \& Schultze (1990). Essa condição, apesar de ser variável entre os teleósteos, é considerada como uma sinapomorfia do grupo (de Pinna, 1996). Entre os Characidae condição semelhante pode ser observada, embora haja variação na forma como a artéria hióide passa entre aos cerato-hiais antes de atravessar os hipi-hiais. Aparentemente, a artéria hióide aferente passa por dentro do cerato-hial, porém visto que esta não é a condição comum entre os Teleostei talvez essa ossificação seja tardia, ou seja, uma lamela óssea que se projete cobrindo lateralmente a artéria.

Nos Characiformes há dois estados para a abertura da artéria hióide aferente: um deles é a abertura lateral entre os hipiais e o outro é a abertura na porção dorsal do certaohial anterior. Nos dois estados de aberturas a artéria 
posteriormente entra por uma abertura na face medial dos hipi-hiais. Para Mirande (2010) a abertura na porção postero-dorsal do cerato-hial é uma sinapomorfia de um grande agrupamento formado por Aphyocharacinae, Aphyoditeinae, Characinae, Cheirodontinae, Gymnocharacinae, Rhoadsiinae, Stethaprioninae, Stevardiinae e Tetragonopterinae; Astyanax clade, Astyanax paris clade, Bramocharax clade, Bryconamericus scleroparius clade, Hyphessobrycon anisitsi clade e Pseudochalceus clade. Esse clado corresponde, basicamente, ao que representa a família Characidae sensu Reis et al. (2003).

\section{Caráter 65. Margem ventral do ceratohial anterior}

Lucena (1993) caráter 68, Bührnheim caráter 79, Mirande (2010) caráter 179

Estado 0 - sem reentrâncias para inserção dos dois raios branquioestégios mais anteriores (figura 84b)

Acestrorhynchus falcatus, Agoniates anchovia, Agoniates halecinus, Brycon pesu, Charax leticiae, Clupeacharax anchoveoides, Creagrutus menezesi, Engraulisoma taeniatum, Galeocharax knerii, Hydrolycus scomberoides, Triportheus albus, Thoracocharax stellatus

Estado 1 - com reentrâncias para inserção dos dois raios branquioestégios mais anteriores (figura 84a)

Aphyocharax pusillus, Astyanacinus moorii, Astyanacinus sp. nova Bolivia, Astyanacinus sp. nova Peru, "Astyanax" superbus, "Astyanax" orthodus, Astyanax altiparanae, Astyanax fasciatus, Astyanax lineatus, Astyanax paranae, Bryconamericus exodon, Bryconops alburnoides, Chalceus epakros, Cheirodon galusdae, Ctenobrycon hauxwellianus, Deuterodon iguape, Gymnocorymbus ternertzi, Hollandichthys multifasciatus, Hyphessobrycon eques, Jupiaba anteroides, Knodus moenkhausii, Lignobrycon myersii, Markiana nigripinnis, Mimagoniates microlepis, Moenkhausia xinguensis, Nematocharax venustus, Oligosarcus pintoi, Piabina argentea, Poptella paraguayensis, Rachoviscus graciliceps, Salminus hilarii, Stethaprion erythrops, Stichonodon insignis, Tetragonopterus chalceus

Os raios branquiostégios estão fixados na porção mais ventral dos ceratohiais. Em alguns táxons os dois raios branquiostégios mais anteriores estão fixados próximos à entalhes na margem ventral do cerato-hial anterior em quanto que em outros a margem é ventral do cerato-hial é lisa e sem entalhes.

\section{Caráter 66. Articulação entre os cerato-hiais}

Vari (1995) caráter 57, Netto-Ferreira (2005) caráter 144, Lima (2006) caráter 37, Moreira (2007) caráter 185, Mirande (2010) caráter 181 
Estado 0 - Sem interdigitações

Acestrorhynchus falcatus, Agoniates anchovia, Agoniates halecinus, Aphyocharax pusillus, Astyanacinus moorii, Astyanacinus sp. nova Bolivia, Astyanacinus sp. nova Peru, "Astyanax" superbus, "Astyanax" orthodus, Astyanax altiparanae, Astyanax fasciatus, Astyanax lineatus, Astyanax paranae, Brycon pesu, Bryconamericus exodon, Bryconops alburnoides, Chalceus epakros, Cheirodon galusdae, Clupeacharax anchoveoides, Creagrutus menezesi, Ctenobrycon hauxwellianus, Deuterodon iguape, Engraulisoma taeniatum, Gymnocorymbus ternertzi, Hollandichthys multifasciatus, Hydrolycus scomberoides, Hyphessobrycon eques, Jupiaba anteroides, Knodus moenkhausii, Lignobrycon myersii, Markiana nigripinnis, Mimagoniates microlepis, Moenkhausia xinguensis, Nematocharax venustus, Oligosarcus pintoi, Piabina argentea, Poptella paraguayensis, Rachoviscus graciliceps, Salminus hilarii, Stethaprion erythrops, Stichonodon insignis, Tetragonopterus chalceus, Thoracocharax stellatus, Triportheus albus

Estado 1 - Com interdigitações

Charax leticiae, Galeocharax knerii

Os cerato-hiais anterior e posterior dos Characiformes estão em contato através de uma junção sincondral. Em alguns grupos, há uma derivação que consiste na formação de interdigitações ósseas entre esses ossos. Uj (1990) mencionado que a presença dessa estrutura é sinapomórfica para os Cynopotaminae (= parte dos Characinae), hipótese semelhante à de Mirande (2010). Já Vari (1995) considera esse estado como sendo sinapomórfico de um clado formado pelas famílias Ctenoluciidae e Erythrinidae.

\section{Caráter 67. Margem inferior do uro-hial}

\section{Estado 0 - Reta}

Aphyocharax pusillus, Astyanacinus moorii, Astyanacinus sp. nova Bolivia, Astyanacinus sp. nova Peru, "Astyanax" superbus, “Astyanax" orthodus, Astyanax altiparanae, Astyanax fasciatus, Astyanax lineatus, Astyanax paranae, Brycon pesu, Bryconamericus exodon, Bryconops alburnoides, Chalceus epakros, Charax leticiae, Cheirodon galusdae, Clupeacharax anchoveoides, Creagrutus menezesi, Ctenobrycon hauxwellianus, Deuterodon iguape, Engraulisoma taeniatum, Galeocharax knerii, Gymnocorymbus ternertzi, Hollandichthys multifasciatus, Hydrolycus scomberoides, Hyphessobrycon eques, Jupiaba anteroides, Knodus moenkhausii, Lignobrycon myersii, Markiana nigripinnis, Mimagoniates microlepis, Moenkhausia xinguensis, Nematocharax venustus, Oligosarcus pintoi, Piabina argentea, Poptella paraguayensis, Rachoviscus graciliceps, Salminus hilarii, Stethaprion erythrops, Stichonodon insignis, Tetragonopterus chalceus, Thoracocharax stellatus, Triportheus albus

Estado 1 - Bastante convexa

Agoniates halecinus, Agoniates anchovia

\section{Indeterminado}

Acestrorhynchus falcatus 
A margem do uro-hial que apresenta as lamelas divergentes laterais é quase sempre reta dentre os peixes examinados. Em Agoniatinae ela é marcadamente convexa e é considerada uma sinapomorfia da subfamília.

\section{Caráter 68. Porção anterior do uro-hial}

Moreira (2002) caráter 52, Netto-Ferreira (2005) caráter 151, Moreira (2007) caráter 196

\section{Estado 0 - Com bifurcação}

Agoniates anchovia, Agoniates halecinus, Aphyocharax pusillus, Astyanacinus moorii, Astyanacinus sp. nova Bolivia, Astyanax altiparanae, Brycon pesu, Bryconamericus exodon, Bryconops alburnoides, Chalceus epakros, Charax leticiae, Cheirodon galusdae, Clupeacharax anchoveoides, Deuterodon iguape, Engraulisoma taeniatum, Galeocharax knerii, Gymnocorymbus ternertzi, Hollandichthys multifasciatus, Hyphessobrycon eques, Jupiaba anteroides, Lignobrycon myersii, Mimagoniates microlepis, Nematocharax venustus, Oligosarcus pintoi, Piabina argentea, Poptella paraguayensis, Rachoviscus graciliceps, Salminus hilarii, Stethaprion erythrops, Stichonodon insignis, Triportheus albus

Estado 1 - Lisa

Creagrutus menezesi, Hydrolycus scomberoides, Thoracocharax stellatus

Estado 2 - Lisa com orifício centralizado

Astyanacinus sp. nova Peru, “Astyanax” superbus, “Astyanax” orthodus, Astyanax fasciatus, Astyanax lineatus, Astyanax paranae, Ctenobrycon hauxwellianus, Knodus moenkhausii, Markiana nigripinnis, Moenkhausia xinguensis, Tetragonopterus chalceus

\section{Indeterminado}

Acestrorhynchus falcatus

O uro-hial é um osso formado por eixo principal lamelar e com abas laterais na porção ventral. A porção anterior do osso é formada por duas projeções medianas que podem se contatar medialmente e formar um orifício ou estarem separadas. Há táxons em que essas projeções medianas não estão presentes.

Caráter 69. Forame inserido anteriormente ao simplético e no quadrado, logo após ao côndilo do quadrado

Lucena (1993) caráter 59, Mirande (2010) caráter 149

Estado 0 - Ausente (figura 81b) 
Acestrorhynchus falcatus, Agoniates anchovia, Agoniates halecinus, Aphyocharax pusillus, Astyanacinus moorii, Astyanacinus sp. nova Bolivia, Astyanacinus sp. nova Peru, "Astyanax" superbus, "Astyanax" orthodus, Astyanax altiparanae, Astyanax fasciatus, Astyanax lineatus, Astyanax paranae, Brycon pesu, Bryconamericus exodon, Bryconops alburnoides, Chalceus epakros, Cheirodon galusdae, Clupeacharax anchoveoides, Creagrutus menezesi, Ctenobrycon hauxwellianus, Deuterodon iguape, Engraulisoma taeniatum, Gymnocorymbus ternertzi, Hollandichthys multifasciatus, Hydrolycus scomberoides, Hyphessobrycon eques, Jupiaba anteroides, Knodus moenkhausii, Lignobrycon myersii, Markiana nigripinnis, Mimagoniates microlepis, Moenkhausia xinguensis, Nematocharax venustus, Oligosarcus pintoi, Piabina argentea, Poptella paraguayensis, Rachoviscus graciliceps, Salminus hilarii, Stethaprion erythrops, Stichonodon insignis, Tetragonopterus chalceus, Thoracocharax stellatus, Triportheus albus

Estado 1 - Presente (figura 81a)

Charax leticiae, Galeocharax knerii

Logo posteriormente ao côndilo de articulação do quadrado com o articular há um forame. Mirande (2010) considera esse estado como uma sinapomorfia do clado (Acanthocharax?, Acestrocephalus, Charax, Cynopotamus, Galeocharax e Roeboides).

\section{Caráter 70. Posição relativa da porção anterior do simplético}

Estado 0 - Situado na vertical que passa pelo centro da fenestra metapterigóidequadrado

Agoniates anchovia, Agoniates halecinus, Bryconops alburnoides, Oligosarcus pintoi

Estado 1 - Situado na vertical que passa pelo terço anterior da fenestra metapterigóide-quadrado (figura 81b)

Aphyocharax pusillus, Astyanacinus moorii, Astyanacinus sp. nova Bolivia, Astyanacinus sp. nova Peru, "Astyanax" superbus, "Astyanax" orthodus, Astyanax altiparanae, Astyanax fasciatus, Astyanax lineatus, Astyanax paranae, Brycon pesu, Bryconamericus exodon, Chalceus epakros, Cheirodon galusdae, Clupeacharax anchoveoides, Ctenobrycon hauxwellianus, Deuterodon iguape, Gymnocorymbus ternertzi, Hollandichthys multifasciatus, Hyphessobrycon eques, Jupiaba anteroides, Knodus moenkhausii, Lignobrycon myersii, Markiana nigripinnis, Mimagoniates microlepis, Moenkhausia xinguensis, Nematocharax venustus, Piabina argentea, Poptella paraguayensis, Rachoviscus graciliceps, Salminus hilarii, Stethaprion erythrops, Stichonodon insignis, Tetragonopterus chalceus, Triportheus albus

Estado 2 - Situado na vertical anterior a fenestra metapterigóide-quadrado Creagrutus menezesi, Engraulisoma taeniatum, Thoracocharax stellatus

Estado 3 - Situado na vertical que passa pelo terço posterior da fenestra metapterigóide-quadrado (figura 81a)

Acestrorhynchus falcatus, Charax leticiae, Galeocharax knerii, Hydrolycus scomberoides,

A posição relativa do osso simplético apresenta variação entre os

Characiformes. A fim de evitar subjetivismo no estabelecimento dos estados, a 
posição desse osso é sempre relativizada quanto a posição da sua porção mais anterior com relação à fenestra metapterigóide-quadrado.

\section{Caráter 71. Comprimento do braço vertical do quadrado}

Estado 0 - Curto, não ultrapassando a borda dorsal do dentário

Aphyocharax pusillus, Astyanacinus moorii, Astyanacinus sp. nova Bolivia, Astyanacinus sp. nova Peru, "Astyanax" superbus, "Astyanax" orthodus, Astyanax altiparanae, Astyanax fasciatus, Astyanax lineatus, Astyanax paranae, Brycon pesu, Bryconamericus exodon, Bryconops alburnoides, Chalceus epakros, Cheirodon galusdae, Creagrutus menezesi, Ctenobrycon hauxwellianus, Deuterodon iguape, Engraulisoma taeniatum, Hollandichthys multifasciatus, Hyphessobrycon eques, Jupiaba anteroides, Knodus moenkhausii, Lignobrycon myersii, Markiana nigripinnis, Mimagoniates microlepis, Moenkhausia xinguensis, Nematocharax venustus, Piabina argentea, Rachoviscus graciliceps, Stethaprion erythrops, Stichonodon insignis, Tetragonopterus chalceus, Triportheus albus

Estado 1 - Muito longo, ultrapassando bastante a borda dorsal do dentário Agoniates halecinus, Agoniates anchovia, Hydrolycus scomberoides

Estado 2 - Longo, ultrapassando um pouco a borda dorsal do dentário (figura 81a)

Acestrorhynchus falcatus, Charax leticiae, Clupeacharax anchoveoides, Galeocharax knerii, Gymnocorymbus ternertzi, Oligosarcus pintoi, Poptella paraguayensis, Salminus hilarii, Thoracocharax stellatus

Entre os peixes examinados o braço vertical do quadrado apresentou variação em seu comprimento. Em alguns táxons ele é mais curto, em outros táxons como nos Agoniatinae é bastante longo e ultrapassa bastante a borda dorsal do dentário.

\section{Caráter 72. Inclinação do braço vertical do quadrado}

Estado 0 - Sem inclinação ou inclinado anteriormente (figura 81a)

Acestrorhynchus falcatus, Agoniates anchovia, Agoniates halecinus, Aphyocharax pusillus, Astyanacinus moorii, Astyanacinus sp. nova Bolivia, Astyanacinus sp. nova Peru, "Astyanax" superbus, "Astyanax" orthodus, Astyanax altiparanae, Astyanax fasciatus, Astyanax lineatus, Astyanax paranae, Brycon pesu, Bryconops alburnoides, Chalceus epakros, Charax leticiae, Cheirodon galusdae, Clupeacharax anchoveoides, Creagrutus menezesi, Deuterodon iguape, Engraulisoma taeniatum, Galeocharax knerii, Gymnocorymbus ternertzi, Hollandichthys multifasciatus, Hydrolycus scomberoides, Hyphessobrycon eques, Jupiaba anteroides, Lignobrycon myersii, Markiana nigripinnis, Mimagoniates microlepis, Moenkhausia xinguensis, Nematocharax venustus, Oligosarcus pintoi, Piabina argentea, Poptella paraguayensis, Rachoviscus graciliceps, Salminus hilarii, Stethaprion erythrops, Stichonodon insignis, Tetragonopterus chalceus

Estado 1 - Inclinado posteriormente (figura 81b)

Bryconamericus exodon, Ctenobrycon hauxwellianus, Knodus moenkhausii, Thoracocharax stellatus, Triportheus albus 
Na grande maioria dos Characiformes e dos Characidae o braço vertical do quadrado está anteriormente inclinado ou sem inclinação. Em alguns táxons, porém, o osso é inclinado posteriormente e talvez esta característica esteja diretamente relacionada à boca voltada para cima.

\section{Caráter 73. Formato da região posterior do hiomandibular (entre a porção dorsal e o côndilo de articulação com o opérculo)}

Estado 0 - Reta ou convexa

Astyanacinus moorii, Astyanacinus sp. nova Peru, “Astyanax” orthodus, Astyanax altiparanae, Astyanax fasciatus, Astyanax lineatus, Astyanax paranae, Bryconamericus exodon, Bryconops alburnoides, Chalceus epakros, Creagrutus menezesi, Deuterodon iguape, Hollandichthys multifasciatus, Hyphessobrycon eques, Jupiaba anteroides, Knodus moenkhausii, Moenkhausia xinguensis, Oligosarcus pintoi, Piabina argentea, Stethaprion erythrops, Tetragonopterus chalceus

Estado 1 - Levemente côncava (figura 81b)

Acestrorhynchus falcatus, Astyanacinus sp. nova Bolivia, “Astyanax" superbus, Brycon pesu, Cheirodon galusdae, Galeocharax knerii, Lignobrycon myersii, Markiana nigripinnis, Mimagoniates microlepis, Nematocharax venustus, Poptella paraguayensis, Rachoviscus graciliceps, Salminus hilarii, Stichonodon insignis, Thoracocharax stellatus, Triportheus albus

Estado 2 - Bastante côncava (figura 81a)

Agoniates anchovia, Agoniates halecinus, Aphyocharax pusillus, Charax leticiae, Clupeacharax anchoveoides, Ctenobrycon hauxwellianus, Engraulisoma taeniatum, Gymnocorymbus ternertzi, Hydrolycus scomberoides,

A margem posterior da hiomandíbula (entre a porção dorsal e o côndilo de articulação com o opérculo) tem formato variável entre os Characiformes. A delimitação de estados com base na forma é, de certa forma, subjetiva, porém a grande variação o formato dessa região permite que sejam estabelecidos pelo menos três estados diferentes.

\section{Caráter 74. Ângulo pôstero-dorsal do hiomandibular}

Estado 0 - Sem processo afilado (figura 81b)

Acestrorhynchus falcatus, Astyanacinus moorii, Astyanacinus sp. nova Bolivia, Astyanacinus sp. nova Peru, "Astyanax" superbus, "Astyanax" orthodus, Astyanax altiparanae, Astyanax fasciatus, Astyanax lineatus, Astyanax paranae, Brycon pesu, Bryconamericus exodon, Bryconops alburnoides, Chalceus epakros, Cheirodon galusdae, Creagrutus menezesi, Ctenobrycon hauxwellianus, Deuterodon iguape, Engraulisoma taeniatum, Galeocharax knerii, Gymnocorymbus ternertzi, Hollandichthys multifasciatus, Hydrolycus scomberoides, Hyphessobrycon eques, Jupiaba anteroides, Knodus moenkhausii, Lignobrycon myersii, Markiana nigripinnis, Mimagoniates microlepis, Moenkhausia xinguensis, Nematocharax venustus, Oligosarcus pintoi, Piabina argentea, Poptella paraguayensis, Rachoviscus 
graciliceps, Salminus hilarii, Stethaprion erythrops, Tetragonopterus chalceus, Thoracocharax stellatus, Triportheus albus

Estado 1 - Com processo afilado e voltado posteriormente que acompanha a curvatura do osso (figura 81a)

Agoniates anchovia, Agoniates halecinus, Charax leticiae, Clupeacharax anchoveoides, Stichonodon insignis

\section{Indeterminado}

Aphyocharax pusillus

Um processo afilado posteriormente direcionado está associado à uma margem posterior da hiomandíbula bastante côncava e acompanha a curvatura do osso. Em alguns casos o processo alcança o opérculo.

\section{Caráter 75. Formato da margem anterior e antero-dorsal do hiomandibular}

Estado 0 - Reta ou côncava (figura 81b)

Acestrorhynchus falcatus, Aphyocharax pusillus, Astyanacinus moorii, Astyanacinus sp. nova Bolivia, Astyanacinus sp. nova Peru, "Astyanax" superbus, "Astyanax" orthodus, Astyanax altiparanae, Astyanax fasciatus, Astyanax lineatus, Astyanax paranae, Brycon pesu, Bryconamericus exodon, Bryconops alburnoides, Cheirodon galusdae, Ctenobrycon hauxwellianus, Deuterodon iguape, Engraulisoma taeniatum, Gymnocorymbus ternertzi, Hollandichthys multifasciatus, Hydrolycus scomberoides, Hyphessobrycon eques, Jupiaba anteroides, Knodus moenkhausii, Lignobrycon myersii, Markiana nigripinnis, Mimagoniates microlepis, Moenkhausia xinguensis, Nematocharax venustus, Oligosarcus pintoi, Poptella paraguayensis, Rachoviscus graciliceps, Salminus hilarii, Stethaprion erythrops, Stichonodon insignis, Tetragonopterus chalceus, Thoracocharax stellatus, Triportheus albus

\section{Estado 1 - Convexa}

Agoniates anchovia, Agoniates halecinus, Chalceus epakros, Charax leticiae, Clupeacharax anchoveoides, Creagrutus menezesi, Galeocharax knerii, Piabina argentea

Outra variação no formato da hiomandíbula que pode ocorrer entre os Characiformes é da margem anterior. Na maioria dos peixes examinados a margem anterior é reta ou côncava enquanto que em outros é convexa.

\section{Arcos branquiais}

O arco branquial é formado não por um, mas por cinco arcos que apresentam diferenças na composição de uma série de elementos endocondrais: basibranquial, hipobranquial, ceratobranquial, epibranquial e faringobranquial.

\section{Caráter 76. Dentição no basibranquial 4}


Lucena \& Menezes (1998) caráter 36, Zanata (2000) caráter 79, Netto-Ferreira (2005) caráter 159, Toledo-Piza (2007) caráter 68, Mirande (2010) caráter 187

\section{Estado 0 - Sem dentes}

Agoniates anchovia, Aphyocharax pusillus, Astyanacinus moorii, Astyanacinus sp. nova Bolivia, Astyanacinus sp. nova Peru, "Astyanax" superbus, "Astyanax" orthodus, Astyanax altiparanae, Astyanax fasciatus, Astyanax lineatus, Astyanax paranae, Brycon pesu, Bryconamericus exodon, Bryconops alburnoides, Chalceus epakros, Charax leticiae, Cheirodon galusdae, Clupeacharax anchoveoides, Creagrutus menezesi, Ctenobrycon hauxwellianus, Deuterodon iguape, Engraulisoma taeniatum, Galeocharax knerii, Gymnocorymbus ternertzi, Hollandichthys multifasciatus, Hydrolycus scomberoides, Hyphessobrycon eques, Jupiaba anteroides, Knodus moenkhausii, Lignobrycon myersii, Markiana nigripinnis, Mimagoniates microlepis, Moenkhausia xinguensis, Nematocharax venustus, Oligosarcus pintoi, Piabina argentea, Poptella paraguayensis, Rachoviscus graciliceps, Salminus hilarii, Stethaprion erythrops, Stichonodon insignis, Tetragonopterus chalceus, Thoracocharax stellatus, Triportheus albus

Estado 1 - Com dentes (figura 85a)

Acestrorhynchus falcatus, Agoniates halecinus

A presença de uma placa dentígera autógena associada com a borda dorsal do quarto basi-branquial é bastante rara entre os Characiformes. A característica só é reportada para os táxons Acestrorhynchus (Lucena, 1993), Agoniates (Lucena, 1993) e Crenuchus spilurus (Moreira, 2007). Com base nas observações deste trabalho, somente uma espécie de Agoniates apresenta a placa dentígera, $A$. halecinus.

A interpretação de Lucena (1993) para este caráter foi que este teria ocorrido independentemente tanto em Acestrorhynchus quanto em Agoniates, a mesma interpretação de Lucena \& Menezes (1998). Para Toledo-Piza (2007) a dentição está presente em algumas espécies de Acestrorhynchus como $A$. pantaneiro, A. abbreviatus, A. altus, A. britskii, A. falcatus, A. lacustris, A. minimus e A. nasutus.

\section{Caráter 77. Basibranquial 4}

Lucena (1993) caráter 74, Vari \& Harold (2001) caráter 32, Moreira (2002) caráter 56, Benine (2004) caráter 53, Lima (2006) caráter 43, Toledo-Piza (2007) caráter 67, Mirande (2010) caráter 185

Estado 0 - Sem ossificação (figura 85b) 
Brycon pesu, Bryconamericus exodon, Bryconops alburnoides, Chalceus epakros, Charax leticiae, Creagrutus menezesi, Engraulisoma taeniatum, Galeocharax knerii, Hydrolycus scomberoides, Hyphessobrycon eques, Mimagoniates microlepis, Moenkhausia xinguensis, Salminus hilarii, Stichonodon insignis

\section{Estado 1 - Com ossificação (figura 85a)}

Acestrorhynchus falcatus, Agoniates anchovia, Agoniates halecinus, Aphyocharax pusillus, Astyanacinus moorii, Astyanacinus sp. nova Bolivia, Astyanacinus sp. nova Peru, "Astyanax" superbus, "Astyanax" orthodus, Astyanax altiparanae, Astyanax fasciatus, Astyanax lineatus, Astyanax paranae, Cheirodon galusdae, Clupeacharax anchoveoides, Ctenobrycon hauxwellianus, Deuterodon iguape, Gymnocorymbus ternertzi, Hollandichthys multifasciatus, Jupiaba anteroides, Knodus moenkhausii, Lignobrycon myersii, Markiana nigripinnis, Nematocharax venustus, Oligosarcus pintoi, Piabina argentea, Poptella paraguayensis, Rachoviscus graciliceps, Stethaprion erythrops, Tetragonopterus chalceus, Thoracocharax stellatus, Triportheus albus

A ossificação do basi-branquial 4 é variável entre os Characiformes. Em grande parte dos Characidae ocorre ossificação dessa estrutura. Segundo Lucena (1993) a presença de basi-branquial 4 ossificado é uma sinapomorfia de um clado que inclui grande parte dos Characidae. De acordo com Toledo-Piza (2007) todas as espécies de Acestrorhynchus, exceto A. falcirostris, apresentam o basibranquial 4 ossificado.

Mirande (2010) considera a ossificação como sinapomorfia paralelas de diversos grupos como: Gasteropelecidae, Lignobrycon + Triportheus e de um clado formado por Aphyocharacinae, Aphyoditeinae, Cheirodontinae, Gymnocharacinae, Rhoadsiinae, Stethaprioninae, Stevardiinae e Tetragonopterinae; Astyanax clade, Astyanax paris clade, Bramocharax clade, Bryconamericus scleroparius clade, Hyphessobrycon anisitsi clade e Pseudochalceus clade.

\section{Caráter 78. Cartilagem do basi-hial}

Estado 0 - Porção posterior (resultado da divisão transversal desta em duas porções) restrita a margem anterior do basi-hial (figura 85b)

Acestrorhynchus falcatus, Aphyocharax pusillus, Astyanacinus moorii, Astyanacinus sp. nova Bolivia, Astyanax altiparanae, Astyanax fasciatus, Astyanax lineatus, Astyanax paranae, Brycon pesu, Bryconamericus exodon, Bryconops alburnoides, Chalceus epakros, Charax leticiae, Cheirodon galusdae, Clupeacharax anchoveoides, Creagrutus menezesi, Ctenobrycon hauxwellianus, Galeocharax knerii, Gymnocorymbus ternertzi, Hollandichthys multifasciatus, Hyphessobrycon eques, Jupiaba anteroides, Knodus moenkhausii, Markiana nigripinnis, Moenkhausia xinguensis, Nematocharax venustus, Oligosarcus pintoi, Piabina argentea, Poptella paraguayensis, Rachoviscus graciliceps, Salminus hilarii, Stethaprion erythrops, Stichonodon insignis, Tetragonopterus chalceus 
Estado 1 - 1 Porção posterior presente também nas laterais do basi-hial (figura 85a)

Agoniates anchovia, Agoniates halecinus, Deuterodon iguape, Hydrolycus scomberoides, Mimagoniates microlepis, Triportheus albus

Estado 2 - 2 Com a cartilagem dorsalmente ao basi-hial

Lignobrycon myersii

\section{Indeterminado}

Astyanacinus sp. nova Peru, "Astyanax" superbus, "Astyanax" orthodus, Engraulisoma taeniatum, Thoracocharax stellatus

Segundo Vari (1995) na porção anterior do ao basi-hial está uma cartilagem. Com base nos peixes examinados da presente análise é possível inferir que o formato dessa cartilagem é variável entre os Characiformes sendo que ela pode estar somente restrita a borda anterior do basi-hial ao estar presente também nas laterais do osso. Vari (1995) informa que uma composição específica da cartilagem do basi-hial formada por duas cartilagens alongadas horizontalmente é sinapomórfica para a família Erythrinidae.

\section{Caráter 79. Formato da margem anterior da porção ossificada do basi-hial}

\section{Estado 0 - Reta (figura 85b)}

Aphyocharax pusillus, Astyanacinus moorii, Astyanacinus sp. nova Bolivia, Astyanacinus sp. nova Peru, “Astyanax" superbus, “Astyanax" orthodus, Astyanax altiparanae, Astyanax fasciatus, Astyanax lineatus, Astyanax paranae, Brycon pesu, Bryconops alburnoides, Charax leticiae, Cheirodon galusdae, Clupeacharax anchoveoides, Creagrutus menezesi, Ctenobrycon hauxwellianus, Deuterodon iguape, Engraulisoma taeniatum, Galeocharax knerii, Gymnocorymbus ternertzi, Hollandichthys multifasciatus, Jupiaba anteroides, Knodus moenkhausii, Markiana nigripinnis, Moenkhausia xinguensis, Nematocharax venustus, Oligosarcus pintoi, Piabina argentea, Poptella paraguayensis, Rachoviscus graciliceps, Salminus hilarii, Stichonodon insignis, Tetragonopterus chalceus

\section{Estado 1 - Convexa (figura 85a)}

Bryconamericus exodon, Acestrorhynchus falcatus, Agoniates anchovia, Agoniates halecinus, Chalceus epakros, Hydrolycus scomberoides, Hyphessobrycon eques, Mimagoniates microlepis, Stethaprion erythrops, Triportheus albus

\section{Indeterminado}

Lignobrycon myersii, Thoracocharax stellatus

O basi-hial é osso mais anterior da cesta branquial, é impar e é o principal elemento que sustenta a língua nos Characiformes, além de outros grupos. Seu 
formato é enormemente variável entre as diversas linhagens da ordem e há diferenças quanto ao seu comprimento longitudinal, formato de sua margem anterior e seu formato como um todo.

\section{Caráter 80. Formato do basi-hial}

Oyakawa (1998) caráter 51, Piton-Serra (2003) caráter 76, Castro \& Vari (2004) caráter 14, Netto-Ferreira (2005) caráter 141, Moreira (2007) caráter 183, Mirande (2010) caráter 191

Estado 0 - Com mesma largura que porção posterior (figura 85a)

Acestrorhynchus falcatus, Agoniates anchovia, Agoniates halecinus, Hydrolycus scomberoides, Stichonodon insignis

Estado 1 - Com porção anterior mais larga que a posterior (figura 85b)

Aphyocharax pusillus, Astyanacinus moorii, Astyanacinus sp. nova Bolivia, Astyanacinus sp. nova Peru, "Astyanax" superbus, "Astyanax" orthodus, Astyanax altiparanae, Astyanax fasciatus, Astyanax lineatus, Astyanax paranae, Brycon pesu, Bryconamericus exodon, Bryconops alburnoides, Chalceus epakros, Charax leticiae, Cheirodon galusdae, Clupeacharax anchoveoides, Creagrutus menezesi, Ctenobrycon hauxwellianus, Deuterodon iguape, Engraulisoma taeniatum, Galeocharax knerii, Gymnocorymbus ternertzi, Hollandichthys multifasciatus, Hyphessobrycon eques, Jupiaba anteroides, Knodus moenkhausii, Markiana nigripinnis, Mimagoniates microlepis, Moenkhausia xinguensis, Nematocharax venustus, Oligosarcus pintoi, Piabina argentea, Poptella paraguayensis, Rachoviscus graciliceps, Salminus hilarii, Stethaprion erythrops, Tetragonopterus chalceus, Triportheus albus

\section{Indeterminado}

Lignobrycon myersii, Thoracocharax stellatus

Mesma discussão do caráter anterior

\section{Caráter 81. Comprimento do basi-hial}

Piton-Serra (2003) caráter 76, Oyakawa (1998) caráter 50, Netto-Ferreira (2005) caráter 140, Moreira (20070 caráter 184, Mirande (2010) caráter 191

Estado 0 - Curto (menor que o dobro do comprimento do primeiro basibranquial (figura 85b)

Acestrorhynchus falcatus, Agoniates anchovia, Astyanacinus sp. nova Peru, “Astyanax" superbus, "Astyanax" orthodus, Astyanax altiparanae, Astyanax fasciatus, Brycon pesu, Bryconamericus exodon, Bryconops alburnoides, Clupeacharax anchoveoides, Deuterodon iguape, Engraulisoma taeniatum, Hollandichthys multifasciatus, Hydrolycus scomberoides, Knodus moenkhausii, Lignobrycon myersii, Markiana nigripinnis, Mimagoniates microlepis, Moenkhausia xinguensis, Piabina argentea, Triportheus albus 
Estado 1 - Longo (maior que o dobro do comprimento do primeiro basibranquial) (figura 85a)

Agoniates halecinus, Aphyocharax pusillus, Astyanacinus moorii, Astyanacinus sp. nova Bolivia, Astyanax lineatus, Astyanax paranae, Chalceus epakros, Charax leticiae, Cheirodon galusdae, Creagrutus menezesi, Ctenobrycon hauxwellianus, Galeocharax knerii, Gymnocorymbus ternertzi, Hyphessobrycon eques, Jupiaba anteroides, Nematocharax venustus, Poptella paraguayensis, Rachoviscus graciliceps, Salminus hilarii, Stethaprion erythrops, Stichonodon insignis, Tetragonopterus chalceus

\section{Polimórfico}

Oligosarcus pintoi

\section{Indeterminado}

Thoracocharax stellatus

Mesma discussão do caráter 79

\section{Caráter 82. Dentição no faringo-branquial 2}

Lucena (1993) caráter 72, Moreira (2002) caráter 57, Netto-Ferreira (2005) caráter 155, Moreira (2007) caráter 207

\section{Estado 0 - Presente (figura 85b)}

Acestrorhynchus falcatus, Agoniates anchovia, Agoniates halecinus, Aphyocharax pusillus, Astyanacinus moorii, Astyanacinus sp. nova Bolivia, Astyanacinus sp. nova Peru, "Astyanax" superbus, "Astyanax" orthodus, Astyanax altiparanae, Astyanax fasciatus, Astyanax lineatus, Brycon pesu, Bryconamericus exodon, Bryconops alburnoides, Chalceus epakros, Charax leticiae, Cheirodon galusdae, Ctenobrycon hauxwellianus, Deuterodon iguape, Galeocharax knerii, Gymnocorymbus ternertzi, Hollandichthys multifasciatus, Hydrolycus scomberoides, Hyphessobrycon eques, Jupiaba anteroides, Knodus moenkhausii, Lignobrycon myersii, Markiana nigripinnis, Mimagoniates microlepis, Nematocharax venustus, Oligosarcus pintoi, Piabina argentea, Poptella paraguayensis, Rachoviscus graciliceps, Salminus hilarii, Stethaprion erythrops, Stichonodon insignis, Tetragonopterus chalceus, Triportheus albus

Estado 1 - Ausente

Astyanax paranae, Clupeacharax anchoveoides, Creagrutus menezesi, Engraulisoma taeniatum, Thoracocharax stellatus

\section{Indeterminado}

Moenkhausia xinguensis

Como ilustrado por Weitzman (1962) cada um dos três primeiros arcos branquiais apresentam elementos faringo-branquiais. Ainda segundo o autor, esses ossos curtos formam a parte óssea que suspende a cesta branquial ligando-a com a base craniana. Há certa confusão na literatura sobre a numeração desses 
elementos e somente três faringo-branquiais estão presente entre os Characidae. No ramo superior do quarto arco branquial há, entretanto, placas dentígeras autógenas associadas ao quarto faringo-branquial que é cartilaginoso, porém a porção superior do quinto arco branquial nunca está presente e muito menos o faringo-branquial associado com ele. As duas placas dentígeras autógenas associadas a cartilagem posterior do último arco, não devem ser chamadas de faringo-branquiais 4 e 5 uma vez que a homologia não com esses elementos não é comprovada.

\section{Caráter 83. Rastros branquiais do primeiro hipo-branquial}

Uj (1990) caráter 70, Lucena (1993) caráter 71, Lucena \& Menezes (1998) caráter 35, Toledo-Piza (2000) caráter 38, Moreira (2007) caráter 217, ToledoPiza (2007) caráter 65, Mirande (2010) caráter 197

\section{Estado 0 - Alongados}

Aphyocharax pusillus, Astyanacinus moorii, Astyanacinus sp. nova Bolivia, Astyanacinus sp. nova Peru, "Astyanax" superbus, "Astyanax" orthodus, Astyanax altiparanae, Astyanax fasciatus, Astyanax lineatus, Astyanax paranae, Brycon pesu, Bryconamericus exodon, Bryconops alburnoides, Chalceus epakros, Charax leticiae, Cheirodon galusdae, Clupeacharax anchoveoides, Creagrutus menezesi, Ctenobrycon hauxwellianus, Deuterodon iguape, Engraulisoma taeniatum, Gymnocorymbus ternertzi, Hollandichthys multifasciatus, Hyphessobrycon eques, Jupiaba anteroides, Knodus moenkhausii, Lignobrycon myersii, Markiana nigripinnis, Mimagoniates microlepis, Moenkhausia xinguensis, Nematocharax venustus, Oligosarcus pintoi, Piabina argentea, Poptella paraguayensis, Rachoviscus graciliceps, Salminus hilarii, Stethaprion erythrops, Stichonodon insignis, Tetragonopterus chalceus, Thoracocharax stellatus, Triportheus albus

Estado 1 - Em forma de placas

Acestrorhynchus falcatus, Agoniates anchovia, Agoniates halecinus, Galeocharax knerii, Hydrolycus scomberoides

Como dito em Mirande (2010) o formato dos rastros branquiais é quase homogêneo entre os Characiformes, com uma região proximal larga que articula com o cerato-branquial e progressivamente mais fino distalmente. Apesar disso, a quantidade e o desenvolvimento dos rastros branquiais entre os Characiformes e os Characidae são bastante variáveis.

Lucena (1993) considera a presença de rastros branquiais curtos e largos portando dentículos em sua superfície dorsal como uma sinapomorfia de 
Acestrorhynchus, Cynodon e Rhaphiodon, sendo que em Lucena \& Menezes (1998) essa característica é ambígua para o clado. Para Toledo-Piza (2007) essa característica é sinapomorfia do clado Acestrorhynchidae + Cynodontinae (Cynodon, Hydrolycus e Rhaphiodon), interpretação semelhante à Mirande (2010).

Formato semelhante dos primeiros rastros branquiais estão presente em outros peixes piscívoros como Erythrinidae, Ctenoluciidae e Hepsetidae (cf. Roberts, 1969) e Agoniatinae. Como discutido no item "Piscivoria em Characidae” essa característica pode estar diretamente relacionada com a adaptação desses peixes ao hábito piscívoro fazendo que possa uma homoplasia e sua

\section{Caráter 84. Comprimento dos rastros branquiais do primeiro arco branquial}

Uj (1990) caráter 70, Lucena (1993) caráter 71, Lucena \& Menezes (1998) caráter 35, Toledo-Piza (2000) caráter 38, Moreira (2007) caráter 217, ToledoPiza (2007) caráter 65, Mirande (2010) caráter 197

Estado 0 - Longos (quando deprimidos alcançam a base dos dois adjacentes) Agoniates anchovia, Agoniates halecinus, Aphyocharax pusillus, Astyanacinus moorii, Astyanacinus sp. nova Bolivia, Astyanacinus sp. nova Peru, "Astyanax" superbus, "Astyanax" orthodus, Astyanax altiparanae, Astyanax fasciatus, Astyanax paranae, Bryconops alburnoides, Charax leticiae, Creagrutus menezesi, Ctenobrycon hauxwellianus, Deuterodon iguape, Galeocharax knerii, Markiana nigripinnis, Moenkhausia xinguensis, Nematocharax venustus, Oligosarcus pintoi, Rachoviscus graciliceps, Stethaprion erythrops

Estado 1 - Muito longos (quando deprimidos alcançam a base dos três adjacentes)

Astyanax lineatus, Bryconamericus exodon, Gymnocorymbus ternertzi, Hyphessobrycon eques, Jupiaba anteroides, Lignobrycon myersii, Poptella paraguayensis, Stichonodon insignis, Tetragonopterus chalceus, Triportheus albus

Estado 2 - Curtos (quando deprimidos alcançam a base do adjacente) (figura 85b)

Brycon pesu, Chalceus epakros, Cheirodon galusdae, Clupeacharax anchoveoides, Engraulisoma taeniatum, Hollandichthys multifasciatus, Knodus moenkhausii, Mimagoniates microlepis, Piabina argentea, Salminus hilarii, Thoracocharax stellatus

Estado 3 - Mais anteriores são curtos e os posteriores são muito longos Acestrorhynchus falcatus, Hydrolycus scomberoides 
Mesma discussão do caráter anterior

\section{Caráter 85. Número de rastros branquiais da porção superior do primeiro arco branquial}

Estado 0 - 10 a 14

Astyanacinus moorii, Astyanacinus sp. nova Bolivia, "Astyanax" orthodus, Astyanax fasciatus, Brycon pesu, Cheirodon galusdae, Creagrutus menezesi, Jupiaba anteroides, Markiana nigripinnis, Poptella paraguayensis, Salminus hilarii, Stichonodon insignis, Tetragonopterus chalceus

Estado 1 - 6 a 9 (figura 85b)

Agoniates anchovia, Agoniates halecinus, Aphyocharax pusillus, styanacinus sp. nova Peru, "Astyanax" superbus, Astyanax altiparanae, Astyanax lineatus, Astyanax paranae, Bryconamericus exodon, Bryconops alburnoides, Chalceus epakros, Charax leticiae, Ctenobrycon hauxwellianus, Deuterodon iguape, Engraulisoma taeniatum, Galeocharax knerii, Gymnocorymbus ternertzi, Hollandichthys multifasciatus, Hyphessobrycon eques, Knodus moenkhausii, Mimagoniates microlepis, Moenkhausia xinguensis, Nematocharax venustus, Piabina argentea, Stethaprion erythrops

Estado 2 - 4 a 5

Clupeacharax anchoveoides, Rachoviscus graciliceps, Thoracocharax stellatus,

Estado 3 - 15 ou mais

Acestrorhynchus falcatus, Hydrolycus scomberoides, Lignobrycon myersii, Triportheus albus

\section{Polimórfico}

Oligosarcus pintoi

Mesma discussão do caráter 86

\section{Caráter 86. Número de rastros branquiais da porção inferior do primeiro arco branquial}

Malabarba (1998) caracteres 15 e 16, Piton-Serra (2003) caráter 82, Bührnheim (2006) caráter 90, Mirande (2010) caracteres 195 e 196

\section{Estado 0 - 12 a 16 (figura 85b)}

Agoniates anchovia, Agoniates halecinus, Astyanacinus moorii, Astyanacinus sp. nova Bolivia, Astyanacinus sp. nova Peru, "Astyanax" superbus, “Astyanax" orthodus, Astyanax altiparanae, Astyanax fasciatus, Astyanax lineatus, Astyanax paranae, Bryconamericus exodon, Bryconops alburnoides, Chalceus epakros, Cheirodon galusdae, Creagrutus menezesi, Ctenobrycon hauxwellianus, Deuterodon iguape, Gymnocorymbus ternertzi, Hyphessobrycon eques, Jupiaba anteroides, Mimagoniates microlepis, Moenkhausia xinguensis, Oligosarcus pintoi, Poptella paraguayensis, Salminus hilarii, Stethaprion erythrops, Tetragonopterus chalceus, Thoracocharax stellatus

Estado 1-8 a 11 
Aphyocharax pusillus, Brycon pesu, Charax leticiae, Clupeacharax anchoveoides, Engraulisoma taeniatum, Galeocharax knerii, Hollandichthys multifasciatus, Knodus moenkhausii, Nematocharax venustus, Piabina argentea, Rachoviscus graciliceps

Estado 2 - 17 ou mais

Acestrorhynchus falcatus, Hydrolycus scomberoides, Lignobrycon myersii, Markiana nigripinnis, Stichonodon insignis, Triportheus albus

Segundo Mirande (2010) a posse de poucos (10 ou menos) rastros branquiais no ramo inferior do primeiro arco branquial é uma sinapomorfia de Characinae e, paralelamente, do clado composto por Aphyocharacinae, Aphyoditeinae, Cheirodontinae e Stevardiinae. Além disso, propõe a presença de muitos (16 ou mais) rastros é uma sinapomorfia do clado Acestrorhynchinae + Agoniatinae + Bryconinae + Cynodontinae + Salmininae. Já Malabarba (1998) considera que mais de 20 rastros é uma sinapomorfia de Lignobrycon + Triportheus.

\section{Pós-Crânio}

O pós-crânio, como o nome já informa, é formado por ossos situados posteriormente ao crânio. São eles: vértebras; aparelho de Weber; costelas; ossos intermusculares; nadadeiras caudal, dorsal e anal; cinturas escapular e pélvica e supraneurais.

\section{Vértebras}

As vértebras são ossos endocondrais e na maioria dos Actinopterygii há uma delas por segmento muscular. As vértebras são dividas em pré-caudais, transição e caudais com base nas estruturas que apresentam tais como costelas e espinho hemal.

\section{Caráter 87. Número de vértebras pré-caudais}

Estado 0 - 12 ou menos

Poptella paraguayensis, Stichonodon insignis, Thoracocharax stellatus

Estado 1 - 13 ou 14 
Astyanax altiparanae, Bryconamericus exodon, Charax leticiae, Ctenobrycon hauxwellianus, Deuterodon iguape, Gymnocorymbus ternertzi, Hyphessobrycon eques, Knodus moenkhausii, Markiana nigripinnis, Mimagoniates microlepis, Moenkhausia xinguensis, Nematocharax venustus, Stethaprion erythrops, Tetragonopterus chalceus, Triportheus albus

\section{Estado 2 - 15 ou 16}

Agoniates halecinus, Astyanacinus moorii, Astyanacinus sp. nova Bolivia, Astyanacinus sp. nova Peru, "Astyanax" superbus, “Astyanax" orthodus, Astyanax fasciatus, Astyanax lineatus, Astyanax paranae, Clupeacharax anchoveoides, Creagrutus menezesi, Galeocharax knerii, Hollandichthys multifasciatus, Jupiaba anteroides, Oligosarcus pintoi, Piabina argentea, Rachoviscus graciliceps

Estado 3 - 17 ou 18

Aphyocharax pusillus, Brycon pesu, Bryconops alburnoides, Cheirodon galusdae, Lignobrycon myersii

Estado 4 - 19 ou mais

Acestrorhynchus falcatus, Chalceus epakros, Engraulisoma taeniatum, Hydrolycus scomberoides, Salminus hilarii

\section{Indeterminado}

Agoniates anchovia

\section{Mesma discussão do caráter 90}

\section{Caráter 88. Vértebras de transição}

\section{Estado 0 - 1 ou 2}

Aphyocharax pusillus, Astyanacinus moorii, Astyanacinus sp. nova Bolivia, Astyanacinus sp. nova Peru, "Astyanax" superbus, “Astyanax" orthodus, Astyanax altiparanae, Astyanax fasciatus, Astyanax paranae, Bryconamericus exodon, Bryconops alburnoides, Charax leticiae, Cheirodon galusdae, Clupeacharax anchoveoides, Creagrutus menezesi, Ctenobrycon hauxwellianus, Deuterodon iguape, Engraulisoma taeniatum, Galeocharax knerii, Gymnocorymbus ternertzi, Hollandichthys multifasciatus, Hyphessobrycon eques, Jupiaba anteroides, Knodus moenkhausii, Lignobrycon myersii, Markiana nigripinnis, Mimagoniates microlepis, Moenkhausia xinguensis, Nematocharax venustus, Oligosarcus pintoi, Piabina argentea, Poptella paraguayensis, Rachoviscus graciliceps, Stethaprion erythrops, Stichonodon insignis, Tetragonopterus chalceus, Thoracocharax stellatus

Estado $1-3$ ou 4

Acestrorhynchus falcatus, Agoniates halecinus, Astyanax lineatus, Brycon pesu, Hydrolycus scomberoides, Triportheus albus

Estado 2 - 5 ou mais

Chalceus epakros, Salminus hilarii

\section{Indeterminado}

Agoniates anchovia

\section{Mesma discussão do caráter 90}




\section{Caráter 89. Vértebras caudais}

Estado 0 - 16 ou menos

Astyanax paranae, Chalceus epakros,

\section{Estado 1 - 17 ou 18}

Aphyocharax pusillus, Astyanax fasciatus, Astyanax lineatus, Cheirodon galusdae, Deuterodon iguape, Engraulisoma taeniatum, Gymnocorymbus ternertzi, Moenkhausia xinguensis, Nematocharax venustus

\section{Estado 2 - 19 ou 20}

Acestrorhynchus falcatus, Astyanacinus moorii, Astyanacinus sp. nova Peru, "Astyanax" orthodus, Astyanax altiparanae, Brycon pesu, Hollandichthys multifasciatus, Hyphessobrycon eques, Jupiaba anteroides, Oligosarcus pintoi, Poptella paraguayensis, Rachoviscus graciliceps, Salminus hilarii, Stethaprion erythrops, Stichonodon insignis, Triportheus albus

Estado 3 - 21 ou 22

Agoniates halecinus, Bryconamericus exodon, Creagrutus menezesi, Ctenobrycon hauxwellianus, Knodus moenkhausii, Markiana nigripinnis, Piabina argentea, Thoracocharax stellatus

Estado 4 - 23 ou mais

Bryconops alburnoides, Charax leticiae, Clupeacharax anchoveoides, Galeocharax knerii, Hydrolycus scomberoides, Lignobrycon myersii, Mimagoniates microlepis, Tetragonopterus chalceus

\section{Polimórfico}

Astyanacinus sp. nova Bolivia, “Astyanax” superbus

\section{Indeterminado}

Agoniates anchovia

Mesma discussão do caráter 90

\section{Caráter 90. Número total de vértebras}

Benine (2004) caráter 57, Ferreira (2007) caráter 100, Mirande (2010) caráter 227

Estado 0 - 32 ou menos

Astyanax paranae, Gymnocorymbus ternertzi

Estado 1 - 33 ou 34

Deuterodon iguape, Hyphessobrycon eques, Moenkhausia xinguensis, Nematocharax venustus, Poptella paraguayensis, Stichonodon insignis, Thoracocharax stellatus

Estado 2 - 35 ou 36

Astyanax altiparanae, Astyanax fasciatus, Astyanax lineatus, Cheirodon galusdae, Oligosarcus pintoi, Rachoviscus graciliceps, Stethaprion erythrops

Estado 3 - 37 ou 38 
Aphyocharax pusillus, Astyanacinus moorii, Astyanacinus sp. nova Peru, "Astyanax" superbus, "Astyanax" orthodus, Bryconamericus exodon, Chalceus epakros, Creagrutus menezesi, Ctenobrycon hauxwellianus, Hollandichthys multifasciatus, Jupiaba anteroides, Knodus moenkhausii, Markiana nigripinnis, Tetragonopterus chalceus, Triportheus albus

Estado 4 - 39 ou 40

Charax leticiae, Clupeacharax anchoveoides, Engraulisoma taeniatum, Mimagoniates microlepis, Piabina argentea

Estado 5 - 41 ou 42

Agoniates halecinus, Brycon pesu, Bryconops alburnoides, Galeocharax knerii, Lignobrycon myersii

Estado 6 - 43 ou mais

Acestrorhynchus falcatus, Hydrolycus scomberoides, Salminus hilarii

\section{Polimórfico}

Astyanacinus sp. nova Bolivia

\section{Indeterminado}

Agoniates anchovia

O número total de vértebras é bastante variável entre as linhagens de Characidae. Intra-especificamente a variação é, geralmente, de uma ou duas vértebras. Apesar do número de vértebras, aparentemente, ser uma informação desconexa para fins evolutivos devido ao alto grau de variação, quando analisado com critério revela padrões implícitos sobre a história natural dos grupos.

Se considerarmos, por exemplo, que Astyanax é um gênero com mais de uma centena de espécies que podem apresentam de 30-38 vértebras, a amplitude desse intervalo com certeza suplantará as possíveis inferências filogenéticas sobre a quantidade de vértebras de um grupo relacionado. No presente trabalho Astyanacinus é obtido como um grupo proximamente relacionado à Astyanax, porém apesar de o intervalo de vértebras do primeiro gênero estar totalmente contido dentro do intervalo do segundo, é possível concluir que a posse de 37-38 vértebras em Astyanacinus é bastante relevante uma vez que a grande maioria dos Astyanax apresentam 34-36 vértebras (quadro 02).

Mirande (2010) considera que a posse de 40 ou menos vértebras é uma sinapomorfia do clado formado por Aphyocharacinae, Aphyoditeinae, Characinae, Cheirodontinae, Gymnocharacinae, Heterocharacinae, Rhoadsiinae, Stethaprioninae, Stevardiinae e Tetragonopterinae; Astyanax clade, Astyanax 
paris clade, Bramocharax clade, Bryconamericus scleroparius clade, Hyphessobrycon anisitsi clade e Pseudochalceus clade.

\section{Caráter 91. Zigapófises dorsais das vértebras caudais}

Moreira (2007) caráter 341

Estado 0 - Pré-zigapófises mais desenvolvidas que as pós-zigapófises

Acestrorhynchus falcatus, Agoniates halecinus, Astyanax paranae, Bryconops alburnoides, Ctenobrycon hauxwellianus, Hollandichthys multifasciatus, Lignobrycon myersii, Markiana nigripinnis, Mimagoniates microlepis, Poptella paraguayensis, Stethaprion erythrops, Triportheus albus

Estado 1 - Pré-zigapófises menos desenvolvidas que as pós-zigapófises Hydrolycus scomberoides

Estado 2 - Pré e Pós-zigapófises de tamanhos semelhantes

Aphyocharax pusillus, Astyanacinus moorii, Astyanacinus sp. nova Bolivia, Astyanacinus sp. nova Peru, "Astyanax" superbus, "Astyanax" orthodus, Astyanax altiparanae, Astyanax fasciatus, Astyanax lineatus, Brycon pesu, Bryconamericus exodon, Chalceus epakros, Charax leticiae, Cheirodon galusdae, Clupeacharax anchoveoides, Creagrutus menezesi, Deuterodon iguape, Engraulisoma taeniatum, Galeocharax knerii, Gymnocorymbus ternertzi, Hyphessobrycon eques, Jupiaba anteroides, Knodus moenkhausii, Moenkhausia xinguensis, Nematocharax venustus, Oligosarcus pintoi, Piabina argentea, Rachoviscus graciliceps, Salminus hilarii, Stichonodon insignis, Tetragonopterus chalceus

\section{Indeterminado}

Agoniates anchovia, Thoracocharax stellatus

As pré-zigapófises e pós-zigapófises dorsais das vértebras caudais dos peixes examinados apresentaram variações com relação ao seu grau de desenvolvimento. Moreira (2007) propõe que a presença de pré-zigapófises mais desenvolvidas que as pós-zigapófises é sinapomorfia de dois clados: o primeiro formado por Bryconops, Iguanodectes, Agoniates, Triportheus, Clupeacharax, Gasteropelecidae e outro por Odontostilbe, Compsura e Rhoadsia.

\section{Caráter 92. Inclinação das pré-zigapófises dorsais das vértebras caudais}

Moreira (2007) caráter 342

Estado 0 - Não sobrepondo a vértebra anterior

Aphyocharax pusillus, Astyanacinus moorii, Astyanacinus sp. nova Bolivia, Astyanacinus sp. nova Peru, "Astyanax" superbus, "Astyanax" orthodus, Astyanax altiparanae, Astyanax fasciatus, Astyanax lineatus, Astyanax paranae, Brycon pesu, Bryconamericus exodon, Chalceus epakros, Charax leticiae, 
Cheirodon galusdae, Clupeacharax anchoveoides, Creagrutus menezesi, Ctenobrycon hauxwellianus, Deuterodon iguape, Engraulisoma taeniatum, Galeocharax knerii, Gymnocorymbus ternertzi, Hollandichthys multifasciatus, Hydrolycus scomberoides, Hyphessobrycon eques, Jupiaba anteroides, Knodus moenkhausii, Lignobrycon myersii, Markiana nigripinnis, Mimagoniates microlepis, Moenkhausia xinguensis, Nematocharax venustus, Oligosarcus pintoi, Piabina argentea, Rachoviscus graciliceps, Salminus hilarii, Stichonodon insignis, Tetragonopterus chalceus

Estado 1 - Sobrepondo a vértebra anterior

Acestrorhynchus falcatus, Agoniates halecinus, Bryconops alburnoides, Poptella paraguayensis, Stethaprion erythrops, Triportheus albus

\section{Indeterminado}

Agoniates anchovia, Thoracocharax stellatus

As pré-zigapófises dorsais das vértebras caudais dos peixes examinados apresentaram variações com relação ao seu grau de desenvolvimento e inclinação. Moreira (2007) considerou que a presença de pré-zigapófises dorsais inclinadas anteriormente, mas não sobrepondo a vértebra anterior é sinapomorfia do clado Hemiodontidae + Anostomoidea e, paralelamente, outro formado pelas famílias Lebiasinidae, Erythrinidae, Alestidae e Serrasalmidae. Ainda segundo esse autor, pronunciada inclinação das pré-zigapófises dorsais sobrepondo a vértebra anterior é sinapomorfia do clado Ctenoluciidae + Hepsetidae + Cynodontidae + Brycon .

\section{Supraneurais}

Os supraneurais são ossificações em forma de bastão presentes entre o crânio e a nadadeira dorsal, entre ou acima dos espinhos neurais (Mabee, 1988). Weitzman (1962) comenta que tais estruturas apresentam forma similar aos radiais proximais da nadadeira dorsal e possuem as extremidades mais proximais projetadas entre os espinhos neurais das vértebras.

\section{Caráter 93. Número de supraneurais}

Moreira (2002) caráter 76, Benine (2004) caráter 61, Lima (2006) caráter 46, Moreira (2007) caráter 340, Mirande (2010) caracteres 280 e 281 
Estado 0 - Numerosos (6 ou mais)

Acestrorhynchus falcatus, Agoniates anchovia, Agoniates halecinus, Aphyocharax pusillus, "Astyanax" orthodus, Brycon pesu, Bryconops alburnoides, Chalceus epakros, Cheirodon galusdae, Clupeacharax anchoveoides, Engraulisoma taeniatum, Hollandichthys multifasciatus, Hydrolycus scomberoides, Lignobrycon myersii, Mimagoniates microlepis, Rachoviscus graciliceps, Salminus hilarii, Thoracocharax stellatus, Triportheus albus

Estado 1 - Poucos (6 ou menos)

Astyanacinus moorii, Astyanacinus sp. nova Bolivia, Astyanacinus sp. nova Peru, "Astyanax" superbus, Astyanax altiparanae, Astyanax paranae, Bryconamericus exodon, Charax leticiae, Creagrutus menezesi, Ctenobrycon hauxwellianus, Deuterodon iguape, Galeocharax knerii, Gymnocorymbus ternertzi, Hyphessobrycon eques, Jupiaba anteroides, Markiana nigripinnis, Moenkhausia xinguensis, Nematocharax venustus, Poptella paraguayensis, Stethaprion erythrops, Stichonodon insignis, Tetragonopterus chalceus

\section{Indeterminado}

Astyanax fasciatus, Astyanax lineatus, Knodus moenkhausii, Oligosarcus pintoi, Piabina argentea

Nos Characiformes, assim como em diversos grupos de Teleostei, há grande variação na quantidade e formato dessas ossificações. É provável que a quantidade de supraneurais esteja relacionada ao alongamento do corpo e como cita Mirande (2010) é relacionado também com a posição da nadadeira dorsal e pelo número de vértebras. Na família Characidae, é bastante notável o padrão de que a maioria dos caracídeos incertae sedis possuem poucos supraneurais, aproximadamente até seis ossificações. Um maior número de supraneurais é encontrado em boa parte dos caracídeos previamente propostos como sendo basais como Brycon, Salminus, Triportheus, Agoniates e outros mais. Lima (2006) ressalta que os Tetragonopterinae (sensu Géry, 1977), apesar de aparentemente não formarem um grupo monofilético, possuem de três a oito supraneurais.

Mirande (2010) considera que quatro ou menos supraneurais é uma sinapomorfia de um grande grupo de Characidae (Bario, Brachychalcinus, Deuterodon, Gymnocorymbus, Hasemania, Hemigrammus, Hyphessobrycon, Jupiaba, Moenkhausia, Myxiops?, Paracheirodon, Orthospinus, Petitella, Poptella, Pristella, Stethaprion, Stichonodon, Tetragonopterus e Thayeria) e, paralelamente, da subfamília Aphyoditeinae. O mesmo autor ainda propõe que oito ou mais elementos é sinapomórfico da família Gasteropelecidae sensu Reis et al. (2003) (Carnegiella, Gasteropelecus e Thoracocharax). 


\section{Caráter 94. Supraneural antecedendo o espinho neural da quarta vértebra}

Lucena (1993) caráter 96, Buckup (1998) caráter 47, Zanata (2000) caráter 94, Moreira (2002) caráter 74, Benine (2004) caráter 63, Zanata \& Vari (2005) caráter 122, Netto-Ferreira (2006) caráter 214, Lima (2006) caráter 45, Ferreira (2007) caráter 109, Moreira (2007) caráter 335, Toledo-Piza (2007) caráter 76, Mirande (2010) caráter 279

Estado 0 - Presente

Acestrorhynchus falcatus, Agoniates anchovia, Agoniates halecinus, Brycon pesu, Bryconops alburnoides, Chalceus epakros, Clupeacharax anchoveoides, Engraulisoma taeniatum, Hydrolycus scomberoides, Lignobrycon myersii, Salminus hilarii, Triportheus albus

Estado 1 - Ausente

Aphyocharax pusillus, Astyanacinus moorii, Astyanacinus sp. nova Bolivia, Astyanacinus sp. nova Peru, "Astyanax" superbus, "Astyanax" orthodus, Astyanax fasciatus, Astyanax lineatus, Astyanax paranae, Bryconamericus exodon, Charax leticiae, Cheirodon galusdae, Creagrutus menezesi, Ctenobrycon hauxwellianus, Deuterodon iguape, Galeocharax knerii, Gymnocorymbus ternertzi, Hollandichthys multifasciatus, Hyphessobrycon eques, Jupiaba anteroides, Knodus moenkhausii, Markiana nigripinnis, Mimagoniates microlepis, Moenkhausia xinguensis, Nematocharax venustus, Oligosarcus pintoi, Piabina argentea, Poptella paraguayensis, Rachoviscus graciliceps, Stethaprion erythrops, Stichonodon insignis, Tetragonopterus chalceus, Thoracocharax stellatus

\section{Indeterminado}

Astyanax altiparanae

Como é explicitado pela série de trabalhos anteriores que utilizam esse caráter, esta característica vem sendo largamente utilizada no estudo das relações dos Characiformes e dos Characidae. Entre os Characidae há ou não um supraneural situado antes do espinho neural da quarta. Segundo Buckup (1998) a perda desse elemento seria sinapomórfica para um clado composto por Oligosarcus, Tetragonopterus, Phenacogaster, Charax e Cynopotamus. Para Zanata \& Vari (2005) a perda dessa ossificação estaria relacionada a eventos de miniturização, mas não invariavelmente. Mirande (2010) propõe que a presença dessa ossificação seria uma sinapomorfia que uniria as famílias Alestidae, Characidae e Serrasalmidae enquanto que a ausência dela é sinapomórfica de Aphyocharacinae, Aphyoditeinae, Characinae, Cheirodontinae, Gymnocharacinae, Rhoadsiinae, Stethaprioninae, Stevardiinae e 
Tetragonopterinae; Astyanax clade, Astyanax paris clade, Bramocharax clade, Bryconamericus scleroparius clade, Hyphessobrycon anisitsi clade e Pseudochalceus clade.

\section{Nadadeira dorsal}

A nadadeira dorsal é composta pelos ossos radiais proximais, medianos e distais, pela peça terminal e pelos raios. De maneira geral, a nadadeira dorsal dos Characiformes apresenta poucas modificações em relação ao estado plesiomórfico dessa estrutura encontrado em grupos mais basais relacionados (e.g. Clupeiformes e Cypriniformes) sendo formada, nesse caso, por raios ramificados e não-ramificados sustentados por radiais proximais, mediais e distais. Outras ordens como Siluriformes e Gymnotiformes apresentam algumas derivações, tais como a ausência de radiais medianos na primeira e ausência da estrutura como um todo na segunda que, segundo Fink \& Fink (1981, 1996), configuram sinapomorfias desses clados. Por outro lado, algumas derivações em relação à nadadeira dorsal são encontradas nos Characiformes.

\section{Caráter 95. Perfil posterior da nadadeira dorsal}

Bertaco (2003) caráter 35, Quevedo (2006) caráter 39

Estado 0 - Não-arredondado, formato aproximadamente triangular (figura 91a) Acestrorhynchus falcatus, Agoniates anchovia, Agoniates halecinus, Aphyocharax pusillus, Astyanacinus moorii, Astyanacinus sp. nova Bolivia, Astyanacinus sp. nova Peru, "Astyanax" superbus, "Astyanax" orthodus, Astyanax altiparanae, Astyanax fasciatus, Astyanax lineatus, Astyanax paranae, Brycon pesu, Bryconamericus exodon, Bryconops alburnoides, Chalceus epakros, Charax leticiae, Cheirodon galusdae, Clupeacharax anchoveoides, Creagrutus menezesi, Ctenobrycon hauxwellianus, Deuterodon iguape, Engraulisoma taeniatum, Galeocharax knerii, Gymnocorymbus ternertzi, Hydrolycus scomberoides, Jupiaba anteroides, Knodus moenkhausii, Lignobrycon myersii, Markiana nigripinnis, Mimagoniates microlepis, Moenkhausia xinguensis, Nematocharax venustus, Oligosarcus pintoi, Piabina argentea, Poptella paraguayensis, Salminus hilarii, Stethaprion erythrops, Stichonodon insignis, Tetragonopterus chalceus, Thoracocharax stellatus, Triportheus albus

Estado 1 - Arredondado, porção distal dos raios formando um semicírculo (figura 91b)

Hollandichthys multifasciatus, Hyphessobrycon eques, Rachoviscus graciliceps

A presença de uma nadadeira dorsal com perfil posterior aproximadamente triangular é a mais comumente encontrada entre os 
Characiformes e nos Characidae e é interpretada como o estado plesiomórfico dentro da família. Dos peixes analisados somente Hyphessobrycon eques, Hollandichthys multifasciatus e Rachoviscus graciliceps apresentaram nadadeira dorsal com perfil arredondado com a porção distal dos raios formando um semicírculo. Bertaco (2003) propõe que a presença de uma nadadeira dorsal com esse formato arredondado é sinapomórfica para o gênero Hollandichthys.

\section{Caráter 96. Posição relativa da nadadeira dorsal}

Vari (1995) caráter 80, Malabarba (1998) caráter 29, Zanata (2000) caráter 98, Moreira (2002) caráter 77, Moreira (2007) caráter 274, Benine (2004) caráter 65, Netto-Ferreira (2006) caráter 239, Ferreira (2007) caracteres 92 e 93, Mirande (2010) caráter 265

Estado 0 - Final da base da nadadeira dorsal bem próxima à linha que passa pela origem da nadadeira anal (figura 92a)

Acestrorhynchus falcatus, Aphyocharax pusillus, Astyanacinus moorii, Astyanacinus sp. nova Bolivia, Astyanacinus sp. nova Peru, "Astyanax" superbus, "Astyanax" orthodus, Astyanax altiparanae, Astyanax fasciatus, Astyanax lineatus, Astyanax paranae, Brycon pesu, Bryconops alburnoides, Cheirodon galusdae, Creagrutus menezesi, Ctenobrycon hauxwellianus, Deuterodon iguape, Jupiaba anteroides, Knodus moenkhausii, Moenkhausia xinguensis, Nematocharax venustus, Piabina argentea, Poptella paraguayensis, Salminus hilarii, Stichonodon insignis, Tetragonopterus chalceus

Estado 1 - Origem da nadadeira anal passando em algum ponto da nadadeira dorsal (figura 92b)

Agoniates anchovia, Agoniates halecinus, Bryconamericus exodon, Charax leticiae, Galeocharax knerii, Gymnocorymbus ternertzi, Hollandichthys multifasciatus, Hyphessobrycon eques, Markiana nigripinnis, Oligosarcus pintoi, Rachoviscus graciliceps, Stethaprion erythrops, Triportheus albus

Estado 2 - Origem da nadadeira dorsal passando posterior à linha que passa pela origem da nadadeira anal (figura 92c)

Lignobrycon myersii, Mimagoniates microlepis, Thoracocharax stellatus,

Estado 3 - Toda a base da nadadeira dorsal bem anterior à linha que passa pela origem da nadadeira anal (figura 92d)

Chalceus epakros, Clupeacharax anchoveoides, Engraulisoma taeniatum, Hydrolycus scomberoides

Para todos os autores que utilizaram esse caráter em filogenias envolvendo Characiformes o estado plesiomórfico proposto foi a nadadeira dorsal ter sua origem passando anteriormente à linha que passa pela origem da nadadeira anal, porém, nesse caso, outro estado deve ser distinguido. Grande parte dos 
Characidae apresentam a linha vertical que passa pela origem da nadadeira anal passando em algum ponto da base nadadeira dorsal como em Agoniates halecinus, Galecharax kneri, Hollandichthys multifasciatus, Hyphessobrycon eques e Lonchogenys ilisha (obs. pessoal).

Segundo Vari (1995) a maioria dos Characiformes apresentam uma nadadeira dorsal posicionada aproximadamente dorsal à inserção da nadadeira pélvica e antes da vertical que passa pela origem do primeiro raio da nadadeira anal e este padrão está presente no caracóideo tido como o mais basal, Xenocharax. Vari (1995) comenta que entre os Characidae há vários caracídeos com corpo alto e nadadeira anal longa, como Gymnocorymbus, que possuem a nadadeira dorsal posicionada próxima à vertical da origem da nadadeira anal.

\section{Caráter 97. Radiais medianos da nadadeira dorsal}

Netto-Ferreira (2005) caráter 234, Moreira (2007) caráter 280

\section{Estado 0 - Presentes (figura 86b)}

Acestrorhynchus falcatus, Agoniates anchovia, Agoniates halecinus, Aphyocharax pusillus, Astyanacinus moorii, Astyanacinus sp. nova Bolivia, Astyanacinus sp. nova Peru, "Astyanax" superbus, "Astyanax" orthodus, Astyanax altiparanae, Astyanax fasciatus, Astyanax lineatus, Astyanax paranae, Brycon pesu, Bryconamericus exodon, Bryconops alburnoides, Chalceus epakros, Cheirodon galusdae, Clupeacharax anchoveoides, Creagrutus menezesi, Deuterodon iguape, Engraulisoma taeniatum, Galeocharax knerii, Hollandichthys multifasciatus, Hydrolycus scomberoides, Jupiaba anteroides, Knodus moenkhausii, Lignobrycon myersii, Markiana nigripinnis, Mimagoniates microlepis, Nematocharax venustus, Oligosarcus pintoi, Piabina argentea, Poptella paraguayensis, Salminus hilarii, Stethaprion erythrops, Stichonodon insignis, Tetragonopterus chalceus, Triportheus albus

Estado 1 - Ausentes (figura 86a)

Charax leticiae, Ctenobrycon hauxwellianus, Gymnocorymbus ternertzi, Hyphessobrycon eques, Rachoviscus graciliceps, Thoracocharax stellatus,

\section{Indeterminado}

Moenkhausia xinguensis

Assim como pode ocorrer na nadadeira anal, em alguns caracídeos os radiais medianos da nadadeira dorsal não estão presentes como ossificações independentes.

\section{Caráter 98. Número de raios ramificados na nadadeira dorsal}


Zanata (2000) caráter 102, Bertaco (2003) caráter 38, Benine (2004) caráter 64, Netto-Ferreira (2005) caráter 232, Quevedo (2006) caráter 38, Ferreira (2007) caráter 91, Moreira (2007) caráter 278, Bertaco (2008) caráter 67, Mirande (2010) caráter 270

\section{Estado 0 - Nove ou mais (figura 86a)}

Acestrorhynchus falcatus, Agoniates anchovia, Agoniates halecinus, Aphyocharax pusillus, Astyanacinus moorii, Astyanacinus sp. nova Bolivia, Astyanacinus sp. nova Peru, "Astyanax" superbus, "Astyanax" orthodus, Astyanax altiparanae, Astyanax fasciatus, Astyanax lineatus, Astyanax paranae, Brycon pesu, Bryconops alburnoides, Chalceus epakros, Charax leticiae, Cheirodon galusdae, Ctenobrycon hauxwellianus, Deuterodon iguape, Galeocharax knerii, Hollandichthys multifasciatus, Hydrolycus scomberoides, Hyphessobrycon eques, Jupiaba anteroides, Lignobrycon myersii, Markiana nigripinnis, Moenkhausia xinguensis, Nematocharax venustus, Oligosarcus pintoi, Poptella paraguayensis, Rachoviscus graciliceps, Salminus hilarii, Stethaprion erythrops, Stichonodon insignis, Tetragonopterus chalceus, Thoracocharax stellatus, Triportheus albus

Estado 1 - Oito

Bryconamericus exodon, Clupeacharax anchoveoides, Creagrutus menezesi, Engraulisoma taeniatum, Knodus moenkhausii, Mimagoniates microlepis, Piabina argentea,

\section{Polimórfico}

Gymnocorymbus ternertzi

De acordo com Malabarba \& Weitzman (2003) o número de elementos no esqueleto da nadadeira dorsal de caracídeos raramente varia. A condição mais amplamente encontrada entre os caracídeos é a presença de nove raios ramificados na nadadeira dorsal precedida de dois raios não-ramificados. Tal condição aparenta ser plesiomórfica e é encontra em peixes comumente propostos como sendo basais dentro da família Characidae como, por exemplo, Agoniates, Triportheus, Brycon, Salminus e outros. Ainda segundo Malabarba \& Weitzman (2003) a condição derivada seria a presença de dois raios anteriores não-ramificados e oito raios ramificados posteriores sendo que esta condição configuraria uma sinapomorfia para uma unidade monofilético dentro de Characidae, o "clado A".

\section{Caráter 99. Número de pterigióforos na nadadeira dorsal}

Lucena (1993) caráter 97, Zanata (2000) caráter 99, Netto-Ferreira (2005) caráter 233, Zanata \& Vari (2005) caráter 125, Moreira (2007) caráter 279 
Estado 0 - Mais de 10 (figura 86b)

Chalceus epakros, Hydrolycus scomberoides, Stethaprion erythrops, Stichonodon insignis, Thoracocharax stellatus

Estado 1 - 10 (figura 86a)

Acestrorhynchus falcatus, Agoniates anchovia, Agoniates halecinus, Aphyocharax pusillus, Astyanacinus moorii, Astyanacinus sp. nova Bolivia, Astyanacinus sp. nova Peru, "Astyanax" superbus, "Astyanax" orthodus, Astyanax altiparanae, Astyanax fasciatus, Astyanax lineatus, Astyanax paranae, Brycon pesu, Bryconops alburnoides, Charax leticiae, Cheirodon galusdae, Ctenobrycon hauxwellianus, Deuterodon iguape, Galeocharax knerii, Hollandichthys multifasciatus, Hyphessobrycon eques, Jupiaba anteroides, Lignobrycon myersii, Markiana nigripinnis, Moenkhausia xinguensis, Nematocharax venustus, Oligosarcus pintoi, Poptella paraguayensis, Salminus hilarii, Tetragonopterus chalceus, Triportheus albus

\section{Estado 2 - 9}

Bryconamericus exodon, Clupeacharax anchoveoides, Creagrutus menezesi, Engraulisoma taeniatum, Knodus moenkhausii, Mimagoniates microlepis, Piabina argentea

\section{Polimórfico}

Gymnocorymbus ternertzi, Rachoviscus graciliceps

A quantidade de pterigióforos está direamente relacionada com a quantidade de raios presentes. De forma geral, o número de pterigióforos é sempre um a menos do que o de raios da nadadeira dorsal e, assim, variações na quantidade de raios significa alterações também no número de pterigióforos associados. A grande maioria dos Characidae apresenta ii+9 e dez pterigióforos na nadadeira dorsal, inclusive alguns táxons considerados previamente por outros autores como sendo formas plesiomórficas da família tais como Agoniates, Brycon, Bryconops, Salminus e Triportheus. Assim, a presença de uma dezena de pterigióforos na nadadeira dorsal deve representar o estado plesiomórfico, pelo menos para os Characidae, enquanto que reduções ou adições nessa quantidade devem ser interpretadas como derivações. Em caracídeos como Poptella que possuem uma dorsal mais longa (ii+10), apresentam também maior número de pterigióforos (11).

\section{Caráter 100. Espinho precedendo a nadadeira dorsal}

Zanata \& Vari (2005) caráter 124, Moreira (2007) caráter 276, Netto-Ferreira (2005) caráter 233 
Estado 0 - Ausente

Acestrorhynchus falcatus, Agoniates anchovia, Agoniates halecinus, Aphyocharax pusillus, Brycon pesu, Bryconamericus exodon, Bryconops alburnoides, Chalceus epakros, Charax leticiae, Cheirodon galusdae, Clupeacharax anchoveoides, Creagrutus menezesi, Engraulisoma taeniatum, Galeocharax knerii, Hydrolycus scomberoides, Knodus moenkhausii, Lignobrycon myersii, Markiana nigripinnis, Oligosarcus pintoi, Piabina argentea, Rachoviscus graciliceps, Thoracocharax stellatus, Triportheus albus

Estado 1 - Presente (figura 86a)

Astyanacinus moorii, Astyanacinus sp. nova Bolivia, Astyanacinus sp. nova Peru, "Astyanax" superbus, "Astyanax" orthodus, Astyanax altiparanae, Astyanax fasciatus, Astyanax lineatus, Astyanax paranae, Ctenobrycon hauxwellianus, Deuterodon iguape, Gymnocorymbus ternertzi, Hyphessobrycon eques, Jupiaba anteroides, Mimagoniates microlepis, Moenkhausia xinguensis, Nematocharax venustus, Salminus hilarii, Stichonodon insignis, Tetragonopterus chalceus

Estado 2 - Muito desenvolvido e com lamela anterior na região pré-dorsal (figura 86b)

Poptella paraguayensis, Stethaprion erythrops,

\section{Polimórfico}

Hollandichthys multifasciatus

Uma estrutura óssea posteriormente direcionada associada ao primeiro pterigióforo da nadadeira dorsal é encontrada em diversos grupos de Characiformes como, por exemplo, em Stethaprioninae (Reis, 1989), Curimatidae (1992) e Prochilodontidae (Castro \& Vari, 2004). Como salienta Zanata \& Vari (2005) a presença dessa estrutura é condição mais amplamente encontrada entre os caracóideos neotropicais. Há, porém, diversos registros de taxas de diferentes clados que perderam tal ossificação e com base nas propostas filogenéticas previamente propostas envolvendo esses peixes é possível inferir que a perda dessa característica ocorreu mais de uma vez entre os Characiformes.

Segundo Zanata \& Vari (2005) essa ossificação está ausente em Alestidae e é uma sinapomorfia da família. Com relação aos Characidae, diversos táxons previamente considerados por diversos autores como formas plesiomórficas de caracídeos como Agoniates, Brycon, Bryconops e Triportheus não possuem uma ossificação autógena precedendo a nadadeira dorsal.

\section{Nadadeira anal}


De maneira geral, a estrutura da nadadeira anal dos Characiformes apresenta poucas modificações, principalmente entre os Characidae, e até o momento, poucos são os caracteres descritos para a referida estrutura. Há, apesar disso, variações em relação ao comprimento da nadadeira anal (quantidade de raios e pterigióforos presentes na nadadeira) e a posição dessa estrutura em relação a nadadeira dorsal.

\section{Caráter 101. Radial distal da nadadeira anal}

Moreira (2002) caráter 84, Benine (2004) caráter 84, Ferreira (2007) caráter 98 modificado, Moreira (2007) caráter 290

Estado 0 - Sem processo pareado ventral

Acestrorhynchus falcatus, Agoniates anchovia, Agoniates halecinus, Aphyocharax pusillus, Brycon pesu, Chalceus epakros, Clupeacharax anchoveoides, Engraulisoma taeniatum, Lignobrycon myersii, Salminus hilarii, Thoracocharax stellatus

Estado 1 - Com processo pareado ventral (figura 87a)

Astyanacinus moorii, Astyanacinus sp. nova Bolivia, Astyanacinus sp. nova Peru, "Astyanax" superbus, "Astyanax" orthodus, Astyanax altiparanae, Astyanax fasciatus, Astyanax lineatus, Astyanax paranae, Bryconamericus exodon, Bryconops alburnoides, Charax leticiae, Cheirodon galusdae, Creagrutus menezesi, Ctenobrycon hauxwellianus, Deuterodon iguape, Galeocharax knerii, Gymnocorymbus ternertzi, Hollandichthys multifasciatus, Hydrolycus scomberoides, Hyphessobrycon eques, Jupiaba anteroides, Knodus moenkhausii, Markiana nigripinnis, Mimagoniates microlepis, Moenkhausia xinguensis, Nematocharax venustus, Oligosarcus pintoi, Piabina argentea, Poptella paraguayensis, Rachoviscus graciliceps, Stethaprion erythrops, Stichonodon insignis, Tetragonopterus chalceus, Triportheus albus

Na porção ventral do radial distal de alguns Characidae é possível observar um processo pareado espiniforme direcionado ventralmente. O grau de desenvolvimento desses processos é variável sendo que no mesmo indivíduo o grau de desenvolvimento varia de forma crescente na direção ântero-posterior. É notável o fato de que em alguns exemplares juvenis é possível observar a ossificação desses elementos em um estado mais avançado do que a dos próprios radiais distais que os sustentam trazendo dúvidas sobre a origem da ossificação desses elementos. Dentro dos Characiformes e, mais especificamente nos Characidae, há variação quanto à presença ou ausência desses processos. Ao constatar a presença desses processos em várias famílias de Characiformes, 
corroborando assim as observações de Moreira (2007), é possível inferir que a presença dessas estruturas pode ser plesiomórfica para os Characidae apesar de que em observações pessoais ficou evidente que táxons provavelmente basais dentro da família como Salminus, Brycon, Agoniates e outros, provavelmente relacionados como os caracídeos como Chalceus, não apresentam o processo ventral.

\section{Caráter 102. Radiais medianos da nadadeira anal}

Fink \& Fink (1996) caráter 106, Benine (2004) caráter 82, Netto-Ferreira (2005) caráter 245, Zanata \& Vari (2005) caráter 191, Moreira (2007) caráter 291, Mirande (2010) caráter 294

\section{Estado 0 - Presentes (figura 87a)}

Acestrorhynchus falcatus, Agoniates anchovia, Agoniates halecinus, Aphyocharax pusillus, Astyanacinus moorii, Astyanacinus sp. nova Bolivia, Astyanacinus sp. nova Peru, "Astyanax" superbus, "Astyanax" orthodus, Astyanax altiparanae, Astyanax fasciatus, Astyanax paranae, Brycon pesu, Bryconamericus exodon, Bryconops alburnoides, Chalceus epakros, Cheirodon galusdae, Clupeacharax anchoveoides, Creagrutus menezesi, Deuterodon iguape, Engraulisoma taeniatum, Hollandichthys multifasciatus, Hyphessobrycon eques, Jupiaba anteroides, Knodus moenkhausii, Lignobrycon myersii, Markiana nigripinnis, Mimagoniates microlepis, Oligosarcus pintoi, Piabina argentea, Salminus hilarii, Tetragonopterus chalceus, Triportheus albus

Estado 1 - Ausentes (figura 87b)

Astyanax lineatus, Ctenobrycon hauxwellianus, Gymnocorymbus ternertzi, Hydrolycus scomberoides, Nematocharax venustus, Poptella paraguayensis, Rachoviscus graciliceps, Stethaprion erythrops, Stichonodon insignis, Thoracocharax stellatus

Estado 2 - Parcialmente presentes; os mais anteriores fundidos aos radiais proximais

Charax leticiae, Galeocharax knerii

\section{Indeterminado}

Moenkhausia xinguensis

A presença de radiais medianos na nadadeira dorsal e anal dos Otophysi é considerada plesiomórfica (Fink \& Fink, 1981, 1996) enquanto que a ausência destes é sinapomórfica para o clado Siluriphysi (Siluriformes + Gymnotiformes). Entre os Characidae muitas vezes é comum a ausência dessa estrutura devido à fusão destes com o radial proximal. Na realidade, essas duas estruturas não se fundem; a união dessas duas peças é um provável resultado de processos de 
truncamentos no desenvolvimento quando essas estruturas pré-formadas por uma única cartilagem não se dividem com o desenvolvimento ontogenético e algumas vezes nem se ossificam dando a impressão de fusão entre os elementos proximais e medianos.

Zanata \& Vari (2005) reportam a ausência de radiais medianos em Hoplias e nos Serrasalmíneos Catoprion, Piaractus e Serrasalmus. Mirande (2010) considera que a fusão entre os cinco primeiros radiais medianos e distais da nadadeira anal é uma sinapomorfia que une as famílias Alestidae e Characidae enquanto que a fusão da maioria deles é uma sinapomorfia de um clado composto por Brachychalcinus, Gymnocorymbus, Orthospinus, Poptella, Stethaprion, Stichonodon e Tetragonopterus e, paralelamente, de outro formado por Leptagoniates?, Paragoniates, Phenagoniates, Prionobrama e Xenagoniates.

\section{Caráter 103. Número de raios não-ramificados anteriores na nadadeira anal} Zanata \& Vari (2005) caráter 142, Lima (2006) caráter 51, Mirande (2010) caráter 285

\section{Estado 0 - Três ou menos}

Acestrorhynchus falcatus, Agoniates anchovia, Agoniates halecinus, Chalceus epakros, Clupeacharax anchoveoides, Creagrutus menezesi, Engraulisoma taeniatum, Hydrolycus scomberoides, Mimagoniates microlepis, Moenkhausia xinguensis, Thoracocharax stellatus

Estado 1 - Quatro ou mais (figura 87b)

Aphyocharax pusillus, Astyanacinus moorii, Astyanacinus sp. nova Bolivia, Astyanacinus sp. nova Peru, "Astyanax" orthodus, "Astyanax" superbus, Astyanax altiparanae, Astyanax fasciatus, Astyanax lineatus, Astyanax paranae, Brycon pesu, Bryconamericus exodon, Bryconops alburnoides, Charax leticiae, Cheirodon galusdae, Ctenobrycon hauxwellianus, Deuterodon iguape, Galeocharax knerii, Gymnocorymbus ternertzi, Hollandichthys multifasciatus, Hyphessobrycon eques, Jupiaba anteroides, Knodus moenkhausii, Lignobrycon myersii, Markiana nigripinnis, Nematocharax venustus, Oligosarcus pintoi, Piabina argentea, Poptella paraguayensis, Rachoviscus graciliceps, Salminus hilarii, Stethaprion erythrops, Stichonodon insignis, Tetragonopterus chalceus, Triportheus albus

Nos Characiformes e nos Characidae, os primeiros raios da nadadeira anal não são ramificados sendo que a quantidade desses é variável nesses grupos. Segundo Zanata \& Vari (2005) a maioria dos Alestidae apresentam apenas três raios não-ramificados na nadadeira anal, uma condição compartilhada com 
Crenuchus, Hepsetus e Hoplias. Ainda para os autores, os Tetragonopterinae e os Cheirodontinae apresentam 4 ou 5. Para Mirande (2010) a presença de três ou menos raios não-ramificados seria uma sinapomorfia do gênero Creagrutus.

\section{Caráter 104. Número de raios ramificados na nadadeira anal}

Uj (1990) caráter 76, Lucena (1993) caracteres 103 e 104, Buckup (1998) caracteres 65 e 66, Weitzman \& Menezes (1998) caráter 35, Zanata (2000) caráter 112, Netto-ferreira (2006) caráter 247, Moreira (2002) caráter 80, Benine (2004) caráter 78, Lima (2006) caráter 52, Moreira (2007) caráter 292, Mirande (2010) caracteres 286 a 289

Estado 0 - Até 19 raios

Aphyocharax pusillus, Astyanax lineatus, Chalceus epakros, Creagrutus menezesi, Knodus moenkhausii

Estado 1 - 19 até 29 raios

Acestrorhynchus falcatus, Agoniates halecinus, Astyanax altiparanae, Astyanax fasciatus, Astyanax paranae, Brycon pesu, Bryconamericus exodon, Bryconops alburnoides, Cheirodon galusdae, Deuterodon iguape, Engraulisoma taeniatum, Hyphessobrycon eques, Jupiaba anteroides, Mimagoniates microlepis, Moenkhausia xinguensis, Nematocharax venustus, Oligosarcus pintoi, Rachoviscus graciliceps, Salminus hilarii

Estado 2 - 29 ou mais raios (figura 87b)

Agoniates anchovia, Charax leticiae, Clupeacharax anchoveoides, Ctenobrycon hauxwellianus, Galeocharax knerii, Gymnocorymbus ternertzi, Hollandichthys multifasciatus, Hydrolycus scomberoides, Lignobrycon myersii, Markiana nigripinnis, Poptella paraguayensis, Stethaprion erythrops, Stichonodon insignis, Tetragonopterus chalceus, Thoracocharax stellatus, Triportheus albus

\section{Polimórfico}

Astyanacinus moorii, Astyanacinus sp. nova Bolivia, Astyanacinus sp. nova Peru, "Astyanax" superbus, "Astyanax" orthodus, Piabina argentea

O número de raios na nadadeira anal tem sido amplamente utilizado como caráter diagnóstico das espécies de Characidae (Mirande, 2010). Mirande (2010) afirma que Cypriniformes basais, Siluriformes e a maioria dos Characiformes não-caracídeos apresentam poucos raios não-ramificados enquanto que a maioria dos Characidae apresentam mais do que 15 raios.Diversos autores como, por exemplo, Weitzman (1964) e Buckup (1998) consideraram uma nadadeira anal curta (contendo poucos raios ramificados) como sendo o padrão plesiomórfico para os Characiformes. Nessa mesma ordem há uma grande variação desse 
caráter e, assim como assinalado por Moreira (2002), essas variações parecem ter distribuição em mosaico entre as diversas linhagens, podendo ter surgido diversas vezes independentemente.

Segundo Buckup (1998) é possível observar um intervalo entre 13 e 19 raios ramificados na nadadeira anal, por outro lado diversos autores propuseram vários intervalos distintos codificando o mesmo caráter e, ao que tudo indica, nenhum desses intervalos é consenso entre os pesquisadores. Assim, adoto uma posição mais conservadora e proponho que para os Characidae uma nadadeira anal contendo uma quantidade mediana de raios (entre 15 e 30) seja o estado plesiomórfico e variações desse número sejam interpretadas como derivações. O intervalo entre 15 e 30 raios ramificados na nadadeira anal compreende a maioria dos Characidae sendo que variações desse padrão provavelmente são derivadas, como no caso de uma quantidade maior que 30 raios geralmente relacionada a um formato corporal arredondado presente em Gymnocorymbus, Markiana, Metynnis, Myleus, Poptella, Tetragonopterus e outros. Outro exemplo de derivação é a pouca quantidade de raios ramificados em Spintherobolus configurando uma sinapomorfia do gênero (Weitzman \& Malabarba, 1999).

Buckup (1998) propôes que a presence de 19 ou mais raios totais era uma sinapomorfia incluindo as famílias Alestidae, Characidae, Acestrorhynchidae, Erythrinidae, Lebiasinidae, Hepsetidae e Ctenoluciidae, com uma reversão nessas quatro últimas. Por outro lado, Lucena (1993) infere que 14 ou mais raios na nadadeira anal é uma sinapomorfia do clado composto pelas famílias Acestrorhynchidae, Alestidae, Characidae, Cynodontidae e Serrasalmidae. Para Mirande (2010) a presença de 11 ou mais raios ramificados é uma sinapomorfia de Characoidea, 17 ou menos raios de Alestidae e do clado Coptobrycon + Grundulus + Gymnocharacinus, 25 ou mais da família Characidae sensu Mirande (2010), 24 ou menos do clado dos lepidofágicos Bryconexodon, Exodon e Roeboexodon e do clado composto por Aphyocharacinae, Aphyoditeinae, Cheirodontinae, Gymnocharacinae e Stevardiinae; Astyanax clade, Astyanax paris clade e Bryconamericus scleroparius clade e, 35 ou mais raios como uma 
sinapomorfia entre Leptagoniates?, Paragoniates, Phenagoniates e Xenagoniates.

\section{Caráter 105. Forma dos radiais medianos da nadadeira anal}

Benine (2004) caráter 145, Ferreira (2007) caráter 97

Estado 0 - Alongado, ligeiramente retangular (figura 87a)

Acestrorhynchus falcatus, Agoniates anchovia, Agoniates halecinus, Aphyocharax pusillus, Astyanax fasciatus, Astyanax paranae, Brycon pesu, Bryconamericus exodon, Bryconops alburnoides, Chalceus epakros, Charax leticiae, Cheirodon galusdae, Clupeacharax anchoveoides, Creagrutus menezesi, Deuterodon iguape, Engraulisoma taeniatum, Galeocharax knerii, Jupiaba anteroides, Knodus moenkhausii, Lignobrycon myersii, Mimagoniates microlepis, Moenkhausia xinguensis, Oligosarcus pintoi, Piabina argentea, Salminus hilarii, Triportheus albus

Estado 1 - Curto, aproximadamente quadrangular

Astyanacinus moorii, Astyanacinus sp. nova Bolivia, Astyanacinus sp. nova Peru, “Astyanax” superbus, "Astyanax" orthodus, Astyanax altiparanae, Hollandichthys multifasciatus, Markiana nigripinnis

Estado 2 - Bastante comprimido antero-posteriormente

Tetragonopterus chalceus

\section{Indeterminado}

Hyphessobrycon eques

\section{Inaplicável}

Astyanax lineatus, Ctenobrycon hauxwellianus, Gymnocorymbus ternertzi, Hydrolycus scomberoides, Nematocharax venustus, Poptella paraguayensis, Rachoviscus graciliceps, Stethaprion erythrops, Stichonodon insignis, Thoracocharax stellatus

A maioria dos Characidae apresenta os radiais medianos da nadadeira anal com formato alongado e aproximadamente retangular apesar de que há variações com relação ao seu formato.

\section{Caráter 106. Inclinação do primeiro radial proximal da nadadeira anal}

Lucena (1993) caráter 102, Moreira (2007) caráter 285

Estado 0 - Inclinado anteriormente (figura 87a)

Acestrorhynchus falcatus, Agoniates anchovia, Agoniates halecinus, Aphyocharax pusillus, Astyanacinus sp. nova Bolivia, Astyanacinus sp. nova Peru, Astyanax altiparanae, Astyanax lineatus, Astyanax paranae, Brycon pesu, Bryconamericus exodon, Bryconops alburnoides, Chalceus epakros, Cheirodon galusdae, Clupeacharax anchoveoides, Creagrutus menezesi, Deuterodon iguape, Engraulisoma taeniatum, Galeocharax knerii, Hydrolycus scomberoides, Jupiaba anteroides, Knodus moenkhausii, 
Lignobrycon myersii, Moenkhausia xinguensis, Nematocharax venustus, Oligosarcus pintoi, Piabina argentea, Salminus hilarii, Stichonodon insignis, Triportheus albus

Estado 1 - Direcionado posteriormente (figura 87b)

Charax leticiae, Gymnocorymbus ternertzi, Thoracocharax stellatus

Estado 2 - Direcionado dorsalmente

Astyanacinus moorii, "Astyanax" superbus, "Astyanax" orthodus, Astyanax fasciatus, Ctenobrycon hauxwellianus, Hollandichthys multifasciatus, Hyphessobrycon eques, Markiana nigripinnis, Mimagoniates microlepis, Poptella paraguayensis, Rachoviscus graciliceps, Stethaprion erythrops, Tetragonopterus chalceus

A maioria dos Characidae apresenta o primeiro radial proximal da nadadeira anal ligeiramente inclinado anteriormente ou sem inclinação. Em alguns taxós, entretanto, esse elemento é inclinado posteriormente.

\section{Caráter 107. Associação entre os primeiros pterigióforos da nadadeira anal}

Netto-ferreira (2006) caráter 243 modificado

Estado 0 - Primeiros radiais proximais não associados entre si (sem contato) (figura 87a)

Acestrorhynchus falcatus, Agoniates anchovia, Agoniates halecinus, Aphyocharax pusillus, Astyanacinus moorii, Astyanacinus sp. nova Peru, "Astyanax" superbus, "Astyanax" orthodus, Astyanax lineatus, Brycon pesu, Bryconamericus exodon, Bryconops alburnoides, Chalceus epakros, Cheirodon galusdae, Clupeacharax anchoveoides, Creagrutus menezesi, Engraulisoma taeniatum, Galeocharax knerii, Hollandichthys multifasciatus, Knodus moenkhausii, Lignobrycon myersii, Mimagoniates microlepis, Piabina argentea, Rachoviscus graciliceps, Salminus hilarii, Triportheus albus

Estado 1 - Primeiros radiais proximais associados entre si (com contato ou muito próximos) (figura 87b)

Astyanacinus sp. nova Bolivia, Astyanax altiparanae, Astyanax fasciatus, Astyanax paranae, Charax leticiae, Ctenobrycon hauxwellianus, Deuterodon iguape, Gymnocorymbus ternertzi, Hydrolycus scomberoides, Hyphessobrycon eques, Jupiaba anteroides, Markiana nigripinnis, Moenkhausia xinguensis, Nematocharax venustus, Oligosarcus pintoi, Poptella paraguayensis, Stethaprion erythrops, Stichonodon insignis, Tetragonopterus chalceus, Thoracocharax stellatus

A ausência de associação entre os primeiros radiais proximais da nadadeira anal é o estado mais comumente encontrado entre os componentes da família e, além disso, é encontrado em outras famílias de Characiformes como Alestidae, Acestrorhynchidae e Cynodontidae.

A associação entre os primeiros radiais proximais da nadadeira anal nos Characidae através de contato de suas porções mais proximais pode estar 
relacionada com o achatamento lateral do corpo, ou melhor, do aumento da altura corporal que, por conseqüência, teria influência no rearranjo espacial da cavidade abdominal dos peixes. Tal inferência é possível pela observação de que concomitante ao estado de associação dos primeiros radiais proximais há também, na maioria dos casos, um deslocamento desses em direção posterior de forma a liberar espaço na cavidade abdominal que abriga os órgãos. Um clássico exemplo do padrão é a ocorrência deste na grande maioria dos Serrasalminae que sempre apresentam corpo alto e achatamento lateral.

\section{Nadadeira peitoral e cintura escapular}

Diferentemente dos Tetrápodas, os Actinopterygii aprensentam a cintura pélvica livre de coneções com o esqueleto axial. Nos Actinopterygii ela é ligada à região posterior do crânio pelo osso pós-temporal. Os ossos pós-temporal, extraescapular e supra-cleitro são dermais enquanto que todos os outros ossos da peitoral são de origem endocondral.

\section{Caráter 108. Pós-cleitro 2}

Lucena (1993) caráter 89, Buckup (1998) caráter 58, Lucena \& Menezes (1998) caráter 30, Toledo-Piza (2000) caráter 55, Moreira (2002) caráter 60, Zanata \& Vari (2005) caráter 133, Moreira (2007) caráter 225, Mirande (2010) caráter 248

Estado 0 - Presente (figura 88b)

Acestrorhynchus falcatus, Agoniates anchovia, Agoniates halecinus, Aphyocharax pusillus, Astyanacinus moorii, Astyanacinus sp. nova Bolivia, Astyanacinus sp. nova Peru, "Astyanax" superbus, "Astyanax" orthodus, Astyanax altiparanae, Astyanax fasciatus, Astyanax lineatus, Astyanax paranae, Brycon pesu, Bryconamericus exodon, Bryconops alburnoides, Chalceus epakros, Charax leticiae, Cheirodon galusdae, Creagrutus menezesi, Ctenobrycon hauxwellianus, Deuterodon iguape, Galeocharax knerii, Gymnocorymbus ternertzi, Hollandichthys multifasciatus, Hyphessobrycon eques, Jupiaba anteroides, Knodus moenkhausii, Markiana nigripinnis, Mimagoniates microlepis, Moenkhausia xinguensis, Nematocharax venustus, Oligosarcus pintoi, Piabina argentea, Poptella paraguayensis, Rachoviscus graciliceps, Salminus hilarii, Stethaprion erythrops, Stichonodon insignis, Tetragonopterus chalceus

Estado 1 - Ausente

Clupeacharax anchoveoides, Engraulisoma taeniatum, Hydrolycus scomberoides, Lignobrycon myersii, Thoracocharax stellatus, Triportheus albus 
A presença de três ossos pós-cleitros na margem posterior da nadadeira peitoral é a condição plesiomórfica dos Characiformes (Roberts, 1969; Vari, 1983, 1995; Toledo-Piza, 2000) com modificações nesse padrão consideradas como apomórficas.

O pós-cleitro 2 está ausente em diversos grupos de Characiformes e essa condição derivada surgiu independentemente em diversas linhagens do clado. Zanata \& Vari (2005) reportam a ausência do mesmo no alestídeo Rhabdalestes rhodesiensis, Vari (1995) em Ctenoluciidae, Roberts (1969) em Hepsetidae, Weitzman (1960) em Gasteropelecidae e Toledo-Piza (2000) em Cynodontinae. Entre os Characidae essa perda ocorreu ainda com mais freqüência, pois está presente em diversos gêneros como Clupeacharax, Engraulisoma, Clupeacharax, Engraulisoma, Pseudocorynopoma, Triportheus e Lignobrycon.

Para Mirande (2010) a ausência desse osso é uma sinapomorfia de um clado formado por Carnegiella, Engraulisoma, Gasteropelecus, Thoracocharax e Clupeacharax?, além de uma sinapomorfia Triportheus + Lignobrycon. Castro (1984) considera a presença de apenas um pós-cleitro como uma sinapomorfia de Clupeacharax + Engraulisoma.

\section{Caráter 109. Póscleitro 3}

Lucena (1993) caráter 90, Vari (1995) caráter 64, Buckup (1998) caráter 59, Lucena \& Menezes (1998) caráter 31, Toledo-Piza (2000) caráter 56, Moreira (2002) caráter 61, Zanata \& Vari (2005) caráter 134, Moreira (2007) caráter 228, Mirande (2010) caráter 249

Estado 0 - Presente (figura 88b)

Acestrorhynchus falcatus, Agoniates anchovia, Agoniates halecinus, Aphyocharax pusillus, Astyanacinus moorii, Astyanacinus sp. nova Bolivia, Astyanacinus sp. nova Peru, "Astyanax" superbus, "Astyanax" orthodus, Astyanax altiparanae, Astyanax fasciatus, Astyanax lineatus, Astyanax paranae, Brycon pesu, Bryconamericus exodon, Bryconops alburnoides, Chalceus epakros, Charax leticiae, Cheirodon galusdae, Creagrutus menezesi, Ctenobrycon hauxwellianus, Deuterodon iguape, Galeocharax knerii, Gymnocorymbus ternertzi, Hollandichthys multifasciatus, Hyphessobrycon eques, Jupiaba anteroides, Knodus moenkhausii, Markiana nigripinnis, Mimagoniates microlepis, Moenkhausia xinguensis, Nematocharax venustus, Oligosarcus pintoi, Piabina argentea, Poptella paraguayensis, Rachoviscus graciliceps, Salminus hilarii, Stethaprion erythrops, Stichonodon insignis, Tetragonopterus chalceus

Estado 1 - Ausente 
Clupeacharax anchoveoides, Engraulisoma taeniatum, Hydrolycus scomberoides, Lignobrycon myersii, Thoracocharax stellatus, Triportheus albus

Como exposto na discussão do caráter anterior, a presença de três ossos pós-cleitros é a condição plesiomórfica dos Characiformes. Como ocorre com o pós-cleitro 2, o pós-cleitro 3 está ausente em diversos grupos de caracóideos e essa condição derivada surgiu independentemente em diversas linhagens de Characiformes. Como ilustram os casos de Acestrorhynchus falcirostris, Chilodus e Roestes é válido notar que a perda do pós-cleitro 2 é sempre acompanhada da perda do pós-cleitro 3 e o mesmo não ocorre com a perda do pós-cleitro 3, ou seja, nenhum caracóideo que apresenta pós-cleitro 3 carece de um pós-cleitro 2.

Zanata \& Vari (2005) reportam a ausência do pós-cleitro 3 em alguns Alestidae, Vari (1995) em Ctenoluciidae, Roberts (1969) em Hepsetidae, Weitzman (1960) em Gasteropelecidae, Toledo-Piza (2000) em Cynodontinae, Toledo-Piza (2007) em Acestrorhynchidae (A. falcirostris) e Vari et al. (1995), Vari (1995) em Chilodontidae (Chilodus). A ausência do pós-cleitro 3 foi sugerida por Lucena \& Menezes (1998) como sinapomórfica a família Cynodontidae, na visão dos autores composta pelas submfaílias Cynodontinae e Roestinae.

Entre os Characidae, essa ossificação não está presente em Clupeacharax, Engraulisoma, Piabucus, Xenagoniates, Paragoniates, Triportheus e Lignobrycon. Para Mirande (2010) a ausência dessa ossificação é uma sinapomorfia do clado Carnegiella, Engraulisoma, Gasteropelecus, Thoracocharax e Clupeacharax?, e paralelamente, Triportheus + Lignobrycon.

\section{Caráter 110. Pós-cleitro 3}

Bertaco (2003) caráter 42, Benine (2004) caráter 69, Zanata \& Vari (2005) caráter 135, Ferreira (2007) caráter 86, Toledo-Piza (2007) caráter 76, Mirande (2010) caráter 250

Estado 0 - Sem aba óssea (figura 88a) 
Acestrorhynchus falcatus, Aphyocharax pusillus, Brycon pesu, Bryconamericus exodon, Bryconops alburnoides, Creagrutus menezesi, Hyphessobrycon eques, Knodus moenkhausii, Mimagoniates microlepis, Moenkhausia xinguensis, Piabina argentea, Salminus hilarii

Estado 1 - Com ába óssea (figura 88b)

Astyanacinus moorii, Astyanacinus sp. nova Bolivia, Astyanacinus sp. nova Peru, "Astyanax" superbus, "Astyanax" orthodus, Astyanax altiparanae, Astyanax fasciatus, Astyanax lineatus, Astyanax paranae, Chalceus epakros, Charax leticiae, Cheirodon galusdae, Ctenobrycon hauxwellianus, Deuterodon iguape, Galeocharax knerii, Gymnocorymbus ternertzi, Hollandichthys multifasciatus, Jupiaba anteroides, Markiana nigripinnis, Nematocharax venustus, Oligosarcus pintoi, Poptella paraguayensis, Rachoviscus graciliceps, Stethaprion erythrops, Stichonodon insignis, Tetragonopterus chalceus

Estado 2 - Paralelo aos raios e com região anterior desenvolvida Agoniates anchovia, Agoniates halecinus

\section{Inaplicável}

Clupeacharax anchoveoides, Engraulisoma taeniatum, Hydrolycus scomberoides, Lignobrycon myersii, Thoracocharax stellatus, Triportheus albus

Weitzman (1962) descreve o terceiro pós-cleitro como um osso em forma de espinho. Segundo Toledo-Piza (2007) todas as espécies de Acestrorhynchus apresentam o pós-cleitro 3 sem lamelas. Mirande (2010) considera a presença desta lamela como uma sinapomorfia de um clado composto po Aphyocharacinae, Aphyoditeinae, Characinae, Cheirodontinae, Gymnocharacinae, Rhoadsiinae, Stethaprioninae, Stevardiinae e Tetragonopterinae; Astyanax clade, Astyanax paris clade, Bramocharax clade, Bryconamericus scleroparius clade, Hyphessobrycon anisitsi clade e Pseudochalceus clade.

\section{Caráter 111. Distância entre os pós-cleitros 1 e 2}

Oyakawa (1998) caráter 86, Moreira (2002) caráter 58, Netto-Ferreira (2005) caráter 170, Ferreira (2007) caráter 84, Moreira (2007) caráter 226

Estado 0 - Distantes (espaço entre eles maior ou do tamanho da altura do póscleitro 1 (figura 88a)

Aphyocharax pusillus, Astyanax altiparanae, Astyanax lineatus, Charax leticiae, Cheirodon galusdae, Creagrutus menezesi, Ctenobrycon hauxwellianus, Galeocharax knerii, Gymnocorymbus ternertzi, Jupiaba anteroides, Mimagoniates microlepis, Moenkhausia xinguensis, Oligosarcus pintoi, Poptella paraguayensis, Salminus hilarii, Stichonodon insignis, Tetragonopterus chalceus

Estado 1 - Próximos (espaço entre eles menor que a altura do pós-cleitro 1) (figura 88b) 
Acestrorhynchus falcatus, Agoniates anchovia, Agoniates halecinus, Astyanacinus moorii, Astyanacinus sp. nova Bolivia, Astyanacinus sp. nova Peru, "Astyanax" superbus, "Astyanax" orthodus, Astyanax fasciatus, Astyanax paranae, Brycon pesu, Bryconamericus exodon, Bryconops alburnoides, Chalceus epakros, Deuterodon iguape, Hollandichthys multifasciatus, Hyphessobrycon eques, Knodus moenkhausii, Markiana nigripinnis, Nematocharax venustus, Piabina argentea, Rachoviscus graciliceps, Stethaprion erythrops

\section{Inaplicável}

Clupeacharax anchoveoides, Engraulisoma taeniatum, Hydrolycus scomberoides, Lignobrycon myersii, Thoracocharax stellatus, Triportheus albus

O primeiro é o mais dorsal dos pós-cleitros e está situado na margem posterior do cleitro. Abaixo dele, quando presente, situa-se o pós-cleitro 2 e a distância entre essas duas variações é variável entre os Characidae. Para Moreira (2007) pós-cleitros separados é uma sinapomorfia para o clado Bryconops e Iguanodectes.

\section{Caráter 112. Porção ventral-posterior do osso coracóide}

Moreira (2002) caráter 66, Netto-Ferreira (2005) caráter 174, Moreira (2007) caráter 244

\section{Estado 0 - Com expansão posterior em forma de uma ponta (figura 88b)}

Acestrorhynchus falcatus, Agoniates anchovia, Agoniates halecinus, Astyanacinus moorii, Astyanacinus sp. nova Bolivia, Astyanacinus sp. nova Peru, “Astyanax" superbus, Astyanax altiparanae, Astyanax lineatus, Brycon pesu, Bryconops alburnoides, Chalceus epakros, Charax leticiae, Cheirodon galusdae, Clupeacharax anchoveoides, Creagrutus menezesi, Engraulisoma taeniatum, Galeocharax knerii, Hollandichthys multifasciatus, Jupiaba anteroides, Markiana nigripinnis, Mimagoniates microlepis, Rachoviscus graciliceps

\section{Estado 1 - Sem expansão (figura 88a)}

Aphyocharax pusillus, “Astyanax” orthodus, Astyanax fasciatus, Astyanax paranae, Bryconamericus exodon, Ctenobrycon hauxwellianus, Deuterodon iguape, Gymnocorymbus ternertzi, Hydrolycus scomberoides, Hyphessobrycon eques, Knodus moenkhausii, Lignobrycon myersii, Moenkhausia xinguensis, Nematocharax venustus, Oligosarcus pintoi, Piabina argentea, Poptella paraguayensis, Salminus hilarii, Stethaprion erythrops, Stichonodon insignis, Tetragonopterus chalceus, Thoracocharax stellatus, Triportheus albus

A porção postero-ventral do coracóide da maioria dos Characidae apresenta um processo. Moreira (2007) reporta a presença dessa estrutura para outras famílias de Characiformes como Distichodontidae, Citharhinidae, Parodontidae, Anostomidae, Alestidae, além de outras. 


\section{Caráter 113. Expansão ventral do coracóide}

Malabarba (1998) caráter 21, Toledo-Piza (2000) caráter 58, Zanata (2000) caráter 106, Moreira (2002) caráter 63, Moreira (2007) caráter 235, Mirande (2010) caráter 238

\section{Estado 0 - Ausente (figura 88b)}

Acestrorhynchus falcatus, Agoniates halecinus, Aphyocharax pusillus, Astyanacinus moorii, Astyanacinus sp. nova Bolivia, Astyanacinus sp. nova Peru, "Astyanax" superbus, "Astyanax” orthodus, Astyanax altiparanae, Astyanax fasciatus, Astyanax lineatus, Astyanax paranae, Brycon pesu, Bryconamericus exodon, Bryconops alburnoides, Chalceus epakros, Charax leticiae, Cheirodon galusdae, Creagrutus menezesi, Ctenobrycon hauxwellianus, Deuterodon iguape, Engraulisoma taeniatum, Galeocharax knerii, Gymnocorymbus ternertzi, Hollandichthys multifasciatus, Hyphessobrycon eques, Jupiaba anteroides, Knodus moenkhausii, Markiana nigripinnis, Mimagoniates microlepis, Moenkhausia xinguensis, Nematocharax venustus, Oligosarcus pintoi, Piabina argentea, Rachoviscus graciliceps, Salminus hilarii, Tetragonopterus chalceus

\section{Estado 1 - Presente}

Agoniates anchovia, Clupeacharax anchoveoides, Hydrolycus scomberoides, Lignobrycon myersii, Poptella paraguayensis, Stethaprion erythrops, Stichonodon insignis, Thoracocharax stellatus, Triportheus albus

Segundo Weitzman (1954) um coracóide expandido ventralmente surgiu independentemente diversas vezes entre os Characiformes. Castro \& Vari (1990) propoem que um coracóide expandido ventralmente formando uma quilha é uma sinapomorfia do clado Triportheus + Lignobrycon assim como proposto por Malabarba (1998) e Mirande (2010).

Toledo-Piza (2000) reporta um coracóide expandido para os Cynodontinae e considera isso como uma sinapomorfia do grupo. Mirande (2010) propõe a expansão do coracóide como uma sinapomorfia da família Gasteropelecidae sensu Reis et al. (2003). Castro \& Vari (1990) promovem uma detalhada discussão sobre a presença de coracóides expandidos entre os Characiformes e os autores sugerem que essa característica tenha surgindo independentemente na maioria dos grupos. Outros caracídeos apresentam coracóide ventralmente expandido como Paragoniates, Piabucus, Gnathocharax, Pseudocorynopoma, Clupeacharax e Agoniates. 


\section{Caráter 114. Grau de expansão ventral do coracóide}

Malabarba (1998) caráter 21, Toledo-Piza (2000) caráter 58, Zanata (2000)

caráter 106, Moreira (2002) caráter 63, Moreira (2007) caráter 235, Mirande (2010) caráter 238

Estado 0 - Pequena, comprimento do osso ainda é maior que a altura Agoniates anchovia, Clupeacharax anchoveoides, Hydrolycus scomberoides, Lignobrycon myersii

Estado 1 - Grande, comprimento do osso é menor ou igual a altura Poptella paraguayensis, Stethaprion erythrops, Stichonodon insignis, Thoracocharax stellatus, Triportheus albus

\section{Inaplicável}

Acestrorhynchus falcatus, Agoniates halecinus, Aphyocharax pusillus, Astyanacinus moorii, Astyanacinus sp. nova Bolivia, Astyanacinus sp. nova Peru, "Astyanax" superbus, "Astyanax" orthodus, Astyanax altiparanae, Astyanax fasciatus, Astyanax lineatus, Astyanax paranae, Brycon pesu, Bryconamericus exodon, Bryconops alburnoides, Chalceus epakros, Charax leticiae, Cheirodon galusdae, Creagrutus menezesi, Ctenobrycon hauxwellianus, Deuterodon iguape, Engraulisoma taeniatum, Galeocharax knerii, Gymnocorymbus ternertzi, Hollandichthys multifasciatus, Hyphessobrycon eques, Jupiaba anteroides, Knodus moenkhausii, Markiana nigripinnis, Mimagoniates microlepis, Moenkhausia xinguensis, Nematocharax venustus, Oligosarcus pintoi, Piabina argentea, Rachoviscus graciliceps, Salminus hilarii, Tetragonopterus chalceus

Mesma discussão do caráter anterior

\section{Caráter 115. Margem postero-ventral do cleitro}

Lucena (1993) caráter 88, Buckup (1998) caráter 57, Oyakawa (1998) caráter 81, Moreira (2002) caráter 65, Benine (2004) caráter 68, Netto-Ferreira (2005) caráter 165, Ferreira (2007) caráter 83, Moreira (2007) caráter 240, Mirande (2010) caracteres 234 e 235

\section{Estado 0 - Abruptamente côncava (figura 88a)}

Aphyocharax pusillus, Bryconamericus exodon, Creagrutus menezesi, Engraulisoma taeniatum, Knodus moenkhausii, Mimagoniates microlepis, Piabina argentea

\section{Estado 1 - Suavemente côncava}

Acestrorhynchus falcatus, Agoniates anchovia, Agoniates halecinus, Astyanacinus moorii, Astyanacinus sp. nova Bolivia, Astyanacinus sp. nova Peru, “Astyanax” superbus, “Astyanax” orthodus, Astyanax altiparanae, Astyanax fasciatus, Astyanax lineatus, Astyanax paranae, Brycon pesu, Bryconops alburnoides, Chalceus epakros, Charax leticiae, Cheirodon galusdae, Clupeacharax anchoveoides, Ctenobrycon hauxwellianus, Deuterodon iguape, Galeocharax knerii, Gymnocorymbus ternertzi, Hollandichthys multifasciatus, Hydrolycus scomberoides, Hyphessobrycon eques, Jupiaba anteroides, Lignobrycon myersii, Markiana nigripinnis, Moenkhausia xinguensis, Nematocharax venustus, Oligosarcus pintoi, Poptella paraguayensis, Rachoviscus graciliceps, Salminus hilarii, Stethaprion erythrops, Stichonodon insignis, Tetragonopterus chalceus, Thoracocharax stellatus, Triportheus albus 
O cleitro é o maior osso da cintura peitoral e na maioria dos Characidae a margem posterior desse osso é suavemente côncava, porém há táxons em que esta região apresenta marcada concavidade posterior. Mirande (2010) propõe que a presença de uma concavidade na região posterior do cleitro ventralmente ao primeiro pós-cleitro sofre várias reversões dentro de Characidae e que é uma sinapomorfia do clado formado por Aphyocharacinae, Aphyoditeinae, Cheirodontinae e Stevardiinae.

\section{Caráter 116. Forame anterior entre o cleitro e o coracóide}

Estado 0 - Não inclinado (figura 88b)

Acestrorhynchus falcatus, Agoniates anchovia, Agoniates halecinus, Aphyocharax pusillus, Astyanacinus moorii, Astyanacinus sp. nova Bolivia, Astyanacinus sp. nova Peru, "Astyanax" superbus, "Astyanax" orthodus, Astyanax altiparanae, Astyanax fasciatus, Astyanax lineatus, Astyanax paranae, Brycon pesu, Bryconamericus exodon, Bryconops alburnoides, Chalceus epakros, Charax leticiae, Cheirodon galusdae, Clupeacharax anchoveoides, Creagrutus menezesi, Ctenobrycon hauxwellianus, Deuterodon iguape, Engraulisoma taeniatum, Galeocharax knerii, Gymnocorymbus ternertzi, Hollandichthys multifasciatus, Hydrolycus scomberoides, Hyphessobrycon eques, Jupiaba anteroides, Knodus moenkhausii, Lignobrycon myersii, Markiana nigripinnis, Mimagoniates microlepis, Moenkhausia xinguensis, Nematocharax venustus, Oligosarcus pintoi, Piabina argentea, Poptella paraguayensis, Salminus hilarii, Stethaprion erythrops, Stichonodon insignis, Tetragonopterus chalceus

Estado 1 - Inclinado e quase diagonal ao comprimento do peixe Rachoviscus graciliceps, Thoracocharax stellatus, Triportheus albus

As faces antero-medial do cleitro e antero-lateral do coracóide se contactam formando um grande forame na porção anterior da cintura peitoral. Em alguns táxons esse forame é inclinado e situado quase na diagonal ao comprimento do peixe.

\section{Caráter 117. Forame do coracóide (próximo a região ventral do mesocoracóide)}

Lucena (1993) caráter 119, Moreira (2002) caráter 20, Bertaco (2003) caráter 46, Toledo-Piza (2007) caráter 79, Mirande (2010) caráter 243

Estado 0 - Bem desenvolvido (figura 88b) 
Acestrorhynchus falcatus, Agoniates anchovia, Agoniates halecinus, Astyanacinus sp. nova Peru, "Astyanax" superbus, "Astyanax" orthodus, Astyanax lineatus, Brycon pesu, Bryconops alburnoides, Chalceus epakros, Clupeacharax anchoveoides, Hydrolycus scomberoides, Lignobrycon myersii, Markiana nigripinnis, Salminus hilarii, Stethaprion erythrops, Stichonodon insignis

Estado 1 - Desenvolvido

Astyanacinus moorii, Astyanacinus sp. nova Bolivia, Astyanax altiparanae, Astyanax fasciatus, Astyanax paranae, Bryconamericus exodon, Charax leticiae, Creagrutus menezesi, Ctenobrycon hauxwellianus, Engraulisoma taeniatum, Jupiaba anteroides, Knodus moenkhausii, Mimagoniates microlepis, Nematocharax venustus, Oligosarcus pintoi, Piabina argentea, Poptella paraguayensis, Rachoviscus graciliceps

Estado 2 - Muito reduzido ou ausente

Aphyocharax pusillus, Cheirodon galusdae, Galeocharax knerii, Gymnocorymbus ternertzi, Hollandichthys multifasciatus, Hyphessobrycon eques, Moenkhausia xinguensis, Tetragonopterus chalceus, Triportheus albus

\section{Indeterminado}

Deuterodon iguape, Thoracocharax stellatus

O forame do coracóide é uma abertura arredondada situada ventralmente à região inferior do mesocoracóide. Como ressalta Toeldo-Piza (2007) essa abertura é variável entre os Characiformes e em alguns táxons ela está ausente ou reduzida. Segundo Lucena \& Menezes (1998) a presença de uma abertura bem desenvolvida é ambígua e pode ser sinapmórfica para o clado Cynodontinae + Roestinae, ou uma sinapomorfias da subfamília Cynodontinae e do gênero Gilbertolus enquanto que Roestes teria a perda do forame como sinapomorfia. Para Mirande (2010) o grande desenvolvimento dessa estrutura é uma sinapomorfia que sustenta a união entre as famílias Alestidae e Characidae. O autor considera ainda que a redução ou ausência do forame é um sinapomorfia de Triportheus + Lignobrycon e, paralelamente, para o clado formado por Aphyocharacinae, Aphyoditeinae, Characinae, Cheirodontinae, Gymnocharacinae, Heterocharacinae, Rhoadsiinae, Stethaprioninae, Stevardiinae e Tetragonopterinae; Astyanax clade, Astyanax paris clade, Bramocharax clade, Bryconamericus scleroparius clade, Hyphessobrycon anisitsi clade e Pseudochalceus clade.

\section{Caráter 118. Número total de raios da nadadeira peitoral}

Estado 0 - 13 ou mais 
Acestrorhynchus falcatus, Agoniates anchovia, Agoniates halecinus, Astyanacinus moorii, Astyanacinus sp. nova Peru, "Astyanax" superbus, "Astyanax" orthodus, Astyanax fasciatus, Astyanax paranae, Brycon pesu, Chalceus epakros, Charax leticiae, Creagrutus menezesi, Ctenobrycon hauxwellianus, Deuterodon iguape, Galeocharax knerii, Gymnocorymbus ternertzi, Hollandichthys multifasciatus, Hydrolycus scomberoides, Jupiaba anteroides, Markiana nigripinnis, Moenkhausia xinguensis, Nematocharax venustus, Oligosarcus pintoi, Piabina argentea, Rachoviscus graciliceps, Tetragonopterus chalceus

Estado 1 - 10 a 12

Aphyocharax pusillus, Astyanax altiparanae, Astyanax lineatus, Bryconamericus exodon, Bryconops alburnoides, Cheirodon galusdae, Engraulisoma taeniatum, Hyphessobrycon eques, Knodus moenkhausii, Lignobrycon myersii, Mimagoniates microlepis, Poptella paraguayensis, Salminus hilarii, Stethaprion erythrops, Stichonodon insignis, Thoracocharax stellatus, Triportheus albus

Estado 2 - Menos de 10

Clupeacharax anchoveoides

\section{Indeterminado}

Astyanacinus sp. nova Bolivia

A grande maioria dos Characiformes apresenta apenas um raio nãoramificao na nadadeira peitoral, porém alguns Crenuchidae podem apresentar dois ou mais. O número de raios ramificados também é bastante variável, porém a grande maioria apresenta entre 9 e 15.

\section{Caráter 119. Ramificações no canal sensorial no extra-escapular}

Vari (1983) caráter 67, Moreira (2007) caráter 234

\section{Estado 0 - Com três ramos}

"Astyanax" orthodus, Clupeacharax anchoveoides, Deuterodon iguape, Engraulisoma taeniatum, Mimagoniates microlepis, Nematocharax venustus, Stethaprion erythrops, Thoracocharax stellatus

\section{Estado 1 - Com quatro ramos (figura 82a)}

Acestrorhynchus falcatus, Agoniates anchovia, Agoniates halecinus, Aphyocharax pusillus, Astyanacinus moorii, Astyanacinus sp. nova Bolivia, Astyanacinus sp. nova Peru, "Astyanax" superbus, Astyanax altiparanae, Astyanax fasciatus, Astyanax lineatus, Astyanax paranae, Brycon pesu, Bryconamericus exodon, Bryconops alburnoides, Chalceus epakros, Cheirodon galusdae, Creagrutus menezesi, Ctenobrycon hauxwellianus, Galeocharax knerii, Gymnocorymbus ternertzi, Hollandichthys multifasciatus, Hydrolycus scomberoides, Hyphessobrycon eques, Jupiaba anteroides, Knodus moenkhausii, Lignobrycon myersii, Markiana nigripinnis, Moenkhausia xinguensis, Oligosarcus pintoi, Piabina argentea, Poptella paraguayensis, Salminus hilarii, Stichonodon insignis, Tetragonopterus chalceus, Triportheus albus

\section{Indeterminado}

Charax leticiae, Rachoviscus graciliceps 
Segundo Vari (1983) o sistema latero-sensorial contindo no osso extraescapular dos Characiformes é tipicamente tripartido, com uma simples abertura posterior que se comunica com o canal sensorial do supra-cleitro. O mesmo autor considera que um extra-escapular com quatro ramos do canal sensorial é uma sinapomorfia de Anostomidae.

\section{Caráter 120. Forame escapular}

Lucena (1993) caráter 87, Vari \& Harold (2001) caráter 48, Zanata \& Vari (2005) caráter 136, Mirande (2010) caráter 244

\section{Estado 0 - Entre a escápula e o cleitro (figura 88a)}

Aphyocharax pusillus, Astyanacinus moorii, Astyanacinus sp. nova Bolivia, Astyanacinus sp. nova Peru, "Astyanax" superbus, "Astyanax" orthodus, Astyanax altiparanae, Astyanax fasciatus, Astyanax paranae, Bryconamericus exodon, Bryconops alburnoides, Charax leticiae, Creagrutus menezesi, Ctenobrycon hauxwellianus, Deuterodon iguape, Engraulisoma taeniatum, Gymnocorymbus ternertzi, Hollandichthys multifasciatus, Hyphessobrycon eques, Jupiaba anteroides, Knodus moenkhausii, Markiana nigripinnis, Mimagoniates microlepis, Moenkhausia xinguensis, Oligosarcus pintoi, Piabina argentea, Poptella paraguayensis, Salminus hilarii, Tetragonopterus chalceus

Estado 1 - Incluso na escápula (figura 88b)

Acestrorhynchus falcatus, Agoniates anchovia, Agoniates halecinus, Brycon pesu, Chalceus epakros, Cheirodon galusdae, Clupeacharax anchoveoides, Hydrolycus scomberoides, Lignobrycon myersii, Rachoviscus graciliceps, Stethaprion erythrops, Stichonodon insignis, Thoracocharax stellatus, Triportheus albus

Estado 2 - Entre a escápula e uma cartilagem

Astyanax lineatus, Galeocharax knerii, Nematocharax venustus

O forame escapular é delimitado por diferentes formas entre os Characiformes. Ele pode estar totalmente incluso na escápula, delimitado entre o cleitro e a escápula ou entre o cleitro e o coracóide ou delimitado entre a escápula e uma cartilagem. Na maioria dos peixes examinados o forame escapular é posteriormente delimitado pela escapula, antero-ventralmente é delimitado por um processo ósseo bastante fino em forma de anel da escápula, mas esse anel não é totalmente fechado fazendo com que a borda do forame tenha participação do cleitro. Apesar disso, em alguns peixes o forame é claramente delimitado somente pela escápula. Para Mirande (2010) um forame escapular não totalmente incluso na escápula é uma sinapomorfia do clado formado por Aphyocharax, 
Leptagoniates?, Paragoniates, Phenagoniates, Prionobrama, Rachoviscus?, e Xenagoniates.

\section{Nadadeira pélvica e cintura pélvica}

Assim como ocorre com a cintura peitoral, a cintura pélvica dos Actinopterygii difere dos Tetrápodas em não aprensentar coneções com o esqueleto axial. Na grande maiore deles ela está inserida na musculatura ventral do peixe e por isso às vezes recebe o nome de nadadeira ventral. Diversos grupos de Actinopterygii perderam de forma paralela todos os ossos dessa nadadeira como nos casos de Anguiliformes, Belonídeos, Tetraodontiformes e até Trichomycterídeos.

\section{Caráter 121. Número total de raios da nadadeira pélvica}

Lucena (1993) caráter 95, Buckup (1998) caráter 63, Zanata (2000) caráter 108, Moreira (2002) caráter 68, Bertaco (2003) caráter 57, Benine (2004) caráter 70, Zanata \& Vari (2005) caráter 138, Ferreira (2007) caráter 88, Moreira (2007) caráter 254, Mirande (2010) caracteres 258 e 259

Estado 0 - 9 ou 8

Acestrorhynchus falcatus, Agoniates halecinus, Aphyocharax pusillus, Astyanacinus moorii, Astyanacinus sp. nova Bolivia, Astyanacinus sp. nova Peru, "Astyanax" superbus, "Astyanax" orthodus, Astyanax altiparanae, Astyanax fasciatus, Astyanax lineatus, Astyanax paranae, Brycon pesu, Bryconamericus exodon, Bryconops alburnoides, Chalceus epakros, Charax leticiae, Creagrutus menezesi, Ctenobrycon hauxwellianus, Deuterodon iguape, Galeocharax knerii, Hydrolycus scomberoides, Hyphessobrycon eques, Jupiaba anteroides, Knodus moenkhausii, Markiana nigripinnis, Moenkhausia xinguensis, Nematocharax venustus, Oligosarcus pintoi, Piabina argentea, Poptella paraguayensis, Salminus hilarii, Tetragonopterus chalceus

\section{Estado 1 - 7}

Agoniates anchovia, Cheirodon galusdae, Clupeacharax anchoveoides, Engraulisoma taeniatum, Gymnocorymbus ternertzi, Hollandichthys multifasciatus, Lignobrycon myersii, Mimagoniates microlepis, Stichonodon insignis, Triportheus albus

Estado 2 - 6

Rachoviscus graciliceps, Stethaprion erythrops, Thoracocharax stellatus

A grande maioria dos Characiformes apresentam um raio não-ramificado e diversos raios ramificados na nadadeira pélvica, entretanto há diversas variações nesse padrão coom em Hollandichthys em que todos os raios são ramificados (Bertaco, 2003) ou em Leptocharacidium (Buckup, 1993) em que há dois raios 
não-ramificados. O número de raios na nadadeira pélvica varia entre os Characiformes e os Characidae, que segundo os peixes examinados por Zanata \& Vari (2005), varia entre 7 à 11. De acordo com Weitzman (1962) a maioria dos caracídeos apresenta 8 raios e alguns possuem menos, o mesmo padrão encontrado por Mirande (2010). Buckup (1998) reporta a presença de oito ou mais raios em membros das famílias Citharinidae, Crenuchidae, Distichodontidae e Hemiodontidae. Malabarba \& Weitzman (2003) consideram que a presença de apenas 6 raios ramificados é diagnóstico de Cyanocharax. Mirande (2010) considera a posse de 6 ou menos raios ramificados como uma sinapomorfias de diversos clados: Aphyocharacinae; Triportheus + Lignobrycon; Brachychalcinus + Gymnocorymbus + algumas Moenkhausia? + Orthospinus + Poptella + Stethaprion + Stichonodon; Coptobrycon + Grundulus + Gymnocharacinus.

\section{Caráter 122. Posição da crista óssea longitudinal na superfície dorsal do osso pélvico}

Benine (2004) caráter 71, Ferreira (2007) caráter 89

Estado 0 - Situada bem lateralmente (figura 89b)

Acestrorhynchus falcatus, Agoniates anchovia, Agoniates halecinus, Aphyocharax pusillus, Astyanacinus moorii, Astyanacinus sp. nova Bolivia, Astyanacinus sp. nova Peru, "Astyanax" superbus, "Astyanax" orthodus, Astyanax altiparanae, Astyanax fasciatus, Astyanax lineatus, Astyanax paranae, Brycon pesu, Bryconamericus exodon, Bryconops alburnoides, Chalceus epakros, Cheirodon galusdae, Creagrutus menezesi, Deuterodon iguape, Galeocharax knerii, Hollandichthys multifasciatus, Hydrolycus scomberoides, Hyphessobrycon eques, Knodus moenkhausii, Lignobrycon myersii, Markiana nigripinnis, Mimagoniates microlepis, Nematocharax venustus, Oligosarcus pintoi, Piabina argentea, Rachoviscus graciliceps, Salminus hilarii, Stethaprion erythrops, Triportheus albus

Estado 1 - Situada mais medianamente

Clupeacharax anchoveoides, Ctenobrycon hauxwellianus, Engraulisoma taeniatum, Jupiaba anteroides, Moenkhausia xinguensis, Poptella paraguayensis, Stichonodon insignis, Tetragonopterus chalceus, Thoracocharax stellatus

Estado 2 - Situada bem no meio do osso (figura 89a)

Charax leticiae, Gymnocorymbus ternertzi

Na superfície dorsal do osso pélvico dos Characidae há uma crista óssea longitudinal onde há inserção de musculatura associada. A posição dessa crista é 
variável entre os caracídeos, sendo posicionada mais lateralmente ou mais medianamente no osso.

\section{Caráter 123. Articulação mediana entre os processos isquiáticos}

Castro (1984), Mirande (2010) caráter 261

Na maioria dos Characidae os ossos pélvicos são ligados entre si por ligamentos. Há, entretanto, casos em que esses ossos são articulados medialmente por interidigitações ósseas dos processos isquiáticos. Castro (1984) considera que essa condição é uma sinapomorfia de um clado formado pelos gêneros Clupeacharax + Engraulisoma ao considerar a condição presente em Agoniates e em Pseudanos (Winterbotton, 1980) como não homóloga.

Estado 0 - Ausente (figura 89b)

Acestrorhynchus falcatus, Aphyocharax pusillus, Astyanacinus moorii, Astyanacinus sp. nova Bolivia, Astyanacinus sp. nova Peru, "Astyanax" superbus, "Astyanax" orthodus, Astyanax altiparanae, Astyanax fasciatus, Astyanax lineatus, Astyanax paranae, Brycon pesu, Bryconamericus exodon, Bryconops alburnoides, Chalceus epakros, Charax leticiae, Cheirodon galusdae, Creagrutus menezesi, Ctenobrycon hauxwellianus, Deuterodon iguape, Galeocharax knerii, Gymnocorymbus ternertzi, Hollandichthys multifasciatus, Hydrolycus scomberoides, Hyphessobrycon eques, Jupiaba anteroides, Knodus moenkhausii, Markiana nigripinnis, Mimagoniates microlepis, Moenkhausia xinguensis, Nematocharax venustus, Oligosarcus pintoi, Piabina argentea, Poptella paraguayensis, Rachoviscus graciliceps, Salminus hilarii, Stethaprion erythrops, Stichonodon insignis, Tetragonopterus chalceus, Thoracocharax stellatus

Estado 1 - Presente

Agoniates anchovia, Agoniates halecinus, Clupeacharax anchoveoides, Engraulisoma taeniatum, Lignobrycon myersii, Triportheus albus

\section{Nadadeira caudal}

Historicamente o esqueleto caudal é considerado como uma das estruturas anatômicas mais informativas sobre a evolução dos Teleostei e fonte de muitos caracteres utilizados para o estudo da evolução destes peixes (Monod, 1968; Patterson \& Rosen, 1977). Uma série de trabalhos de Schultze \& Arratia (1986, 1988, 1989) descreve e comenta os esqueletos caudais de diversos actinopterigianos basais o que, sem dúvida, contribuiu muito para a compreensão da evolução desse complexo. Entre os Characiformes, entretanto, o complexo 
caudal não foi utilizado extensivamente como fonte de caracteres, o que pode ser reflexo da pouca variação presente nesses peixes, mesma opinião de Roberts (1973) que diz que nos Characiformes o esqueleto caudal é generalizado e notavelmente conservativo. Entre os Characidae, há uma série de modificações no esqueleto caudal dos Serrasalminae.

\section{Caráter 124. Pares de uroneurais}

Uj(1990) caráter 54, Lucena (1993) caráter 108, Buckup (1998) caráter 70, Oyakawa (1998) caráter 89, Zanata (2000) caráter 116, Moreira (2002) caráter 145, Benine (2004) caráter 85, Netto-Ferreira (2005) caráter 258, Zanata \& Vari (2005) caráter 149, Ferreira (2007) caráter 112, Moreira (2007) caráter 301, Mirande (2010) caráter 306

\section{Estado 0 - Dois (figura 90a)}

Acestrorhynchus falcatus, Agoniates anchovia, Agoniates halecinus, Brycon pesu, Bryconops alburnoides, Chalceus epakros, Ctenobrycon hauxwellianus, Hydrolycus scomberoides, Jupiaba anteroides, Lignobrycon myersii, Moenkhausia xinguensis, Poptella paraguayensis, Salminus hilarii, Stethaprion erythrops, Stichonodon insignis, Tetragonopterus chalceus, Triportheus albus

\section{Estado 1 - Um (figura 90b)}

Aphyocharax pusillus, Astyanacinus moorii, Astyanacinus sp. nova Bolivia, Astyanacinus sp. nova Peru, "Astyanax" superbus, "Astyanax" orthodus, Astyanax altiparanae, Astyanax fasciatus, Astyanax lineatus, Astyanax paranae, Bryconamericus exodon, Charax leticiae, Cheirodon galusdae, Clupeacharax anchoveoides, Creagrutus menezesi, Deuterodon iguape, Engraulisoma taeniatum, Galeocharax knerii, Gymnocorymbus ternertzi, Hollandichthys multifasciatus, Hyphessobrycon eques, Knodus moenkhausii, Mimagoniates microlepis, Nematocharax venustus, Oligosarcus pintoi, Piabina argentea, Rachoviscus graciliceps, Thoracocharax stellatus

\section{Polimórfico}

Markiana nigripinnis

Uroneurais são ossos pares alongados localizados bilateralmente ao longo da região dorsal do esqueleto caudal (de Pinna, 1996) e são derivados ontogeneticamente dos arcos neurais do centro ural. A presença desses ossos é sinapomórfica para os Teleostei e o número de pares destes varia amplamente dentro deste grupo havendo um padrão de redução na quantidade destes nos clados mais derivados (Patterson, 1968). Um exemplo desse padrão é a presença 
de 7 pares em †Leptolepis, representante da ordem Leptolepidiformes (uma das ordens mais basais entre os Teleostei). Dentro da ordem Characiformes a variação é menor e a evolução do caráter na família Characidae, aparentemente, segue o padrão de redução de Patterson (1968) já que a posse de dois pares é comum entre táxons tipicamente basais como Agoniates, Brycon, Bryconops, Salminus e Triportheus. Dessa forma, é possível inferir que o padrão plesiomórfica é a presença de dois pares.

Para Mirande (2010) a posse de dois pares de uroneurais é uma sinapomorfia que une as famílias Alestidae, Characidae e Serrasalmidae, e paralelamente, uma sinapomorfia dos Tetragonopterinae. Já a posse de apenas um par é sinapomorfia do clado formado por Subfamilies Aphyocharacinae, Aphyoditeinae, Characinae, Cheirodontinae, Gymnocharacinae, Heterocharacinae, Rhoadsiinae, Stethaprioninae, Stevardiinae e Tetragonopterinae; Astyanax clade, Astyanax paris clade, Bramocharax clade, Bryconamericus scleroparius clade, Hyphessobrycon anisitsi clade e Pseudochalceus clade.

\section{Caráter 125. Epurais}

Lucena (1993) caráter 106, Buckup (1998) caráter 68 e 69, Oyakawa (1998) caráter 88, Zanata (2000) caráter 115, Zanata \& Vari (2005) caráter 148, NettoFerreira (2006) caráter 256, Ferreira (2007) caráter 112, Moreira (2007) caráter 298, Toledo-Piza (2007) caráter 90, Mirande (2010) caracteres 296 e 297

\section{Estado 0 - Dois (figura 90b)}

Acestrorhynchus falcatus, Agoniates anchovia, Agoniates halecinus, Aphyocharax pusillus, Astyanacinus moorii, Astyanacinus sp. nova Bolivia, "Astyanax" superbus, "Astyanax" orthodus, Astyanax altiparanae, Astyanax fasciatus, Astyanax lineatus, Astyanax paranae, Brycon pesu, Bryconamericus exodon, Bryconops alburnoides, Charax leticiae, Cheirodon galusdae, Clupeacharax anchoveoides, Creagrutus menezesi, Ctenobrycon hauxwellianus, Deuterodon iguape, Galeocharax knerii, Gymnocorymbus ternertzi, Hollandichthys multifasciatus, Hydrolycus scomberoides, Hyphessobrycon eques, Jupiaba anteroides, Knodus moenkhausii, Lignobrycon myersii, Markiana nigripinnis, Mimagoniates microlepis, Moenkhausia xinguensis, Nematocharax venustus, Oligosarcus pintoi, Piabina argentea, Poptella paraguayensis, Rachoviscus graciliceps, Salminus hilarii, Stethaprion erythrops, Stichonodon insignis, Tetragonopterus chalceus, Triportheus albus

Estado 1 - Um

Engraulisoma taeniatum, Thoracocharax stellatus 
Estado 2 - Três

Chalceus epakros

\section{Polimórfico}

Astyanacinus sp. nova Peru

Epurais são ossos laminares ímpares presentes na porção dorsal do esqueleto caudal, mais especificamente acima do centro da última vértebra, embora haja controversas sobre sua homologia nas diversas linhagens de Actinopterygii (Schultze \& Arratia, 1989). Nos Teleostei tais ossificações variam grandemente em número e um padrão de redução na quantidade desses ossos está presente dentre os teleósteos (Patterson, 1973) assim como no caso dos pares de uroneurais.

Já entre os Characiformes a variação é menor (presença de uma, duas ou três ossificações). Do universo analisado a grande maioria dos exemplares possuem dois epurais assim como na literatura consultada sobre os Characidae e, aparentemente, esta é a condição plesiomórfica. Por outro lado, para Roberts (1969) a plesiomórfica para os Characiformes é a presença de três epurais. Para Mirande (2010) a presença de três epurais é uma sinapomorfia da família Alestidae.

\section{Caráter 126. Grau de fusão entre o hipural 2 e o centro composto da última vértebra}

Estado 0 - Ausente

Acestrorhynchus falcatus, Hydrolycus scomberoides

Estado 1 - Presente (figura 90a)

Agoniates anchovia, Agoniates halecinus, Aphyocharax pusillus, Astyanacinus moorii, Astyanacinus sp. nova Bolivia, Astyanacinus sp. nova Peru, "Astyanax" superbus, "Astyanax" orthodus, Astyanax altiparanae, Astyanax fasciatus, Astyanax lineatus, Astyanax paranae, Brycon pesu, Bryconamericus exodon, Bryconops alburnoides, Chalceus epakros, Charax leticiae, Cheirodon galusdae, Clupeacharax anchoveoides, Creagrutus menezesi, Ctenobrycon hauxwellianus, Deuterodon iguape, Engraulisoma taeniatum, Galeocharax knerii, Gymnocorymbus ternertzi, Hollandichthys multifasciatus, Hyphessobrycon eques, Jupiaba anteroides, Knodus moenkhausii, Lignobrycon myersii, Markiana nigripinnis, Mimagoniates microlepis, Moenkhausia xinguensis, Nematocharax venustus, Oligosarcus pintoi, Piabina argentea, Poptella paraguayensis, Rachoviscus graciliceps, Salminus hilarii, Stethaprion erythrops, Stichonodon insignis, Tetragonopterus chalceus, Thoracocharax stellatus, Triportheus albus 
Segundo Fink \& Fink (1981, 1996) a fusão da placa hipural 2 ao centro composto é uma sinapomorfia de Otophysi. Zanata \& Vari (2005) comentam que essa é a condição mais comum entre os Characiformes e a separação seria uma derivação secundária nos peixes que apresentam as placas hipurais 1 e 2 fundidas. A ausência da fusão entre o centro composto e a placa hipural 2 é, para Mirande (2010) uma sinapomorfia do clado Acestrorhynchinae e Cynodontinae. Outros Characiformes que apresentam tal condição são: Hepsetus, Erythrinidae e Ctenoluciidae (cf. Roberts, 1969). Toledo-Piza (2007) comenta que a maioria das espécies de Acestrorhynchus apresenta essa condição.

\section{Caráter 127. Base do único raio associado ao segundo hipural}

Estado 0 - Base não-modificada (figura 90b)

Acestrorhynchus falcatus, Aphyocharax pusillus, Astyanacinus moorii, Astyanacinus sp. nova Bolivia, Astyanacinus sp. nova Peru, "Astyanax" superbus, "Astyanax" orthodus, Astyanax altiparanae, Astyanax fasciatus, Astyanax lineatus, Astyanax paranae, Brycon pesu, Bryconamericus exodon, Bryconops alburnoides, Chalceus epakros, Charax leticiae, Cheirodon galusdae, Clupeacharax anchoveoides, Creagrutus menezesi, Ctenobrycon hauxwellianus, Deuterodon iguape, Engraulisoma taeniatum, Galeocharax knerii, Gymnocorymbus ternertzi, Hollandichthys multifasciatus, Hydrolycus scomberoides, Hyphessobrycon eques, Jupiaba anteroides, Knodus moenkhausii, Lignobrycon myersii, Markiana nigripinnis, Mimagoniates microlepis, Moenkhausia xinguensis, Nematocharax venustus, Oligosarcus pintoi, Piabina argentea, Poptella paraguayensis, Rachoviscus graciliceps, Salminus hilarii, Stethaprion erythrops, Stichonodon insignis, Tetragonopterus chalceus, Thoracocharax stellatus, Triportheus albus

Estado 1 - Com base expandida (figura 90a)

Agoniates anchovia, Agoniates halecinus

A base do raio caudal associado à segunda placa hipural de todos táxons examinados não apresenta modificações, exceto em Agoniatinae em que ambas as espécies possuem uma expansão bastante desenvolvida que é similar, em tamanho, à maior altura da segunda placa hipural. Essa base expandida pode estar relacionada com a fixação de músculos na base dos raios caudais, uma condição muito comum entre os Teleostei (cf. Winterbottom, 1974).

\section{Caráter 128. Número de raios pró-correntes ventrais}


Bertaco (2003) caráter 74, Bührnheim (2006) caráter 124, Mirande (2010) caráter 302

Estado 0 - 7 ou menos (figura 90a)

Agoniates anchovia, Agoniates halecinus, Bryconamericus exodon, Clupeacharax anchoveoides, Engraulisoma taeniatum, Markiana nigripinnis, Rachoviscus graciliceps, Thoracocharax stellatus

Estado 1 - 8 a 11 (figura 90b)

Acestrorhynchus falcatus, Astyanacinus moorii, Astyanacinus sp. nova Bolivia, Astyanacinus sp. nova Peru, “Astyanax" superbus, “Astyanax” orthodus, Astyanax altiparanae, Astyanax fasciatus, Astyanax lineatus, Astyanax paranae, Brycon pesu, Chalceus epakros, Charax leticiae, Ctenobrycon hauxwellianus, Deuterodon iguape, Gymnocorymbus ternertzi, Hollandichthys multifasciatus, Hydrolycus scomberoides, Hyphessobrycon eques, Jupiaba anteroides, Lignobrycon myersii, Mimagoniates microlepis, Moenkhausia xinguensis, Nematocharax venustus, Oligosarcus pintoi, Poptella paraguayensis, Stethaprion erythrops, Stichonodon insignis, Tetragonopterus chalceus, Triportheus albus

Estado 2 - 12 a 19

Aphyocharax pusillus, Bryconops alburnoides, Creagrutus menezesi, Galeocharax knerii, Knodus moenkhausii, Piabina argentea, Salminus hilarii

Estado 3 - 20 ou mais

Cheirodon galusdae

O número de raios pró-correntes ventrais é bastante variável entre os Characiformes. Segundo Mirande (2010) a maioria dos Characidae tem 11 ou menos raios pró-correntes ventrais. Malabarba (1998) considerou a presença de mais de 11 raios como uma sinapomorfia da tribo Cheirodontini. De acordo com Mirande (2010) 12 ou mais raios pró-correntes é sinapomorfias de Bryconops, de Creagrutus e de um clado formado por alguns Cheirodontinae.

\section{Miscelânea}

\section{Caráter 129. Mancha no pedúnculo caudal}

Estado 0 - Ausente ou pequena (origem depois da base da adiposa) (figura 75a) Acestrorhynchus falcatus, Agoniates anchovia, Agoniates halecinus, Aphyocharax pusillus, "Astyanax" orthodus, Brycon pesu, Bryconamericus exodon, Bryconops alburnoides, Chalceus epakros, Charax leticiae, Cheirodon galusdae, Clupeacharax anchoveoides, Creagrutus menezesi, Ctenobrycon hauxwellianus, Deuterodon iguape, Engraulisoma taeniatum, Galeocharax knerii, Gymnocorymbus ternertzi, Hollandichthys multifasciatus, Hydrolycus scomberoides, Hyphessobrycon eques, Jupiaba anteroides, Knodus moenkhausii, Lignobrycon myersii, Markiana nigripinnis, Mimagoniates microlepis, Moenkhausia xinguensis, Piabina argentea, Poptella paraguayensis, Rachoviscus graciliceps, Salminus hilarii, Stethaprion erythrops, Stichonodon insignis, Tetragonopterus chalceus, Thoracocharax stellatus, Triportheus albus 
Estado 1 - Grande (origem na vertical da adiposa) (figura 75b)

Astyanacinus moorii, Astyanacinus sp. nova Bolivia, Astyanacinus sp. nova Peru, “Astyanax” superbus, Astyanax altiparanae, Astyanax fasciatus, Astyanax lineatus, Astyanax paranae, Nematocharax venustus, Oligosarcus pintoi

A maioria dos Characidae apresenta uma mancha no pedúnculo caudal, porém alguns não apresentam nenhum tipo de pigmentação na região como, por exemplo, Agoniates. O formato desta mancha é bastante variável entre os diferentes grupos de caracídeos, sendo diagnóstica para diversos grupos deles como no grupo Moenkhausia oligolepis em que é uma barra vertical bastante definida, ou uma mancha horizontalmente mais alongada como a que Garutti (1999) descreve para o grupo Astyanax bimaculatus (mancha losangular no pedúnculo caudal, estendendo-se à extremidade dos raios caudais medianos).

\section{Caráter 130. Escamação na nadadeira anal}

Piton-Serra (2003) caráter 93, Benine (2004) caráter 93, Mirande (2010) caráter 327

Estado 0 - Uma ou duas séries de escamas na base da nadadeira

Acestrorhynchus falcatus, Agoniates anchovia, Agoniates halecinus, Aphyocharax pusillus, Astyanacinus moorii, Astyanacinus sp. nova Bolivia, Astyanacinus sp. nova Peru, "Astyanax" superbus, "Astyanax" orthodus, Astyanax altiparanae, Astyanax fasciatus, Astyanax lineatus, Astyanax paranae, Brycon pesu, Bryconamericus exodon, Bryconops alburnoides, Chalceus epakros, Charax leticiae, Cheirodon galusdae, Clupeacharax anchoveoides, Creagrutus menezesi, Ctenobrycon hauxwellianus, Deuterodon iguape, Engraulisoma taeniatum, Hollandichthys multifasciatus, Hydrolycus scomberoides, Hyphessobrycon eques, Jupiaba anteroides, Knodus moenkhausii, Lignobrycon myersii, Mimagoniates microlepis, Moenkhausia xinguensis, Nematocharax venustus, Oligosarcus pintoi, Piabina argentea, Rachoviscus graciliceps, Salminus hilarii, Triportheus albus

Estado 1 - Várias séries de pequenas escamas recobrindo a base da nadadeira Galeocharax knerii, Gymnocorymbus ternertzi, Markiana nigripinnis, Poptella paraguayensis, Stethaprion erythrops, Stichonodon insignis, Tetragonopterus chalceus, Thoracocharax stellatus

A maioria dos Characidae apresenta somente uma ou duas séries de escams recobrindo a base dos raios da nadadeira anal. Há, entretanto, táxons em que essa escamação é bem mais desenvolvida sendo que existem várias séries de pequenas escamas na base da nadadeira. Essa diferença é um importante caráter diagnóstico para alguns grupos de caracídeos. Para Mirande (2010) a presença deste caráter é uma sinapomorfia da família Serrasalmidae e, paralelamente, de 
outro clado formado por Brachychalcinus + Gymnocorymbus + Orthospinus + Poptella + Stethaprion + Stichonodon + Tetragonopterus.

\section{Caráter 131. Ganchos nas nadadeiras}

Malabarba (1998) caráter 35, Bertaco (2003) caráter 58, Lima (2006) caráter 60, Mirande (2010) caráter 307

Estado 0 - Ausente (figura 89a)

Acestrorhynchus falcatus, Agoniates anchovia, Agoniates halecinus, Astyanacinus moorii, Astyanacinus sp. nova Peru, "Astyanax" superbus, "Astyanax" orthodus, Chalceus epakros, Clupeacharax anchoveoides, Deuterodon iguape, Engraulisoma taeniatum, Hydrolycus scomberoides

Estado 1 - Presente (figura 89b)

Aphyocharax pusillus, Astyanacinus sp. nova Bolivia, Astyanax altiparanae, Astyanax fasciatus, Astyanax lineatus, Astyanax paranae, Brycon pesu, Bryconamericus exodon, Bryconops alburnoides, Charax leticiae, Cheirodon galusdae, Creagrutus menezesi, Ctenobrycon hauxwellianus, Galeocharax knerii, Gymnocorymbus ternertzi, Hollandichthys multifasciatus, Hyphessobrycon eques, Jupiaba anteroides, Knodus moenkhausii, Lignobrycon myersii, Markiana nigripinnis, Mimagoniates microlepis, Moenkhausia xinguensis, Nematocharax venustus, Oligosarcus pintoi, Piabina argentea, Poptella paraguayensis, Rachoviscus graciliceps, Salminus hilarii, Stethaprion erythrops, Stichonodon insignis, Tetragonopterus chalceus, Thoracocharax stellatus, Triportheus albus

Segundo Malabarba \& Weitzman (2003) a presença de ganchos nas nadadeiras anal e pélvicas de machos, às vezes na nadadeira caudal e raramente na dorsal e na peitoral, tem sido descrita para as famílias Gasteropelecidae, Characidae e Cynodontidae (Rosteinae). Ainda segundo os autores, apesar dos ganchos nas nadadeiras serem quase sempre um caráter sexual secundário de machos eles podem ter variação em sua forma, posição e talvez na função entre os diferentes grupos em que estão presentes.

Malabarba \& Weitzman (2003) reportam a presença dos ganchos para a grande maioria de gêneros de Characidae, porém lista alguns nos quais não há registros. Um desses é Astyanacinus e o presente trabalho é o primeiro a reportar a presença dessas estruturas no gênero. Considera também que pelo menos lnpaichthys, Hypobrycon e Triportheus são gêneros em que os ganchos estariam ausentes.

Malabarba \& Weitzman (2003) propõem que a presença de ganchos nas nadadeiras de adultos é uma sinapomorfia de um clado formado pelos 
Gasteropelecidae, Serrasalmidae e Characidae, exceto Agoniates, Clupeacharax, e Engraulisoma. Mirande (2010) considera a ausência de ganchos como uma sinapomorfia que une diversos pequenos grupos de caracídeos como (Deuterodon + Jupiaba + Myxiops?); (Coptobrycon + Grundulus + Gymnocharacinus + Nematobrycon) e (Leptagoniates?, Paragoniates, Phenagoniates e Xenagoniates).

\section{Caráter 132. Mancha umeral}

Malabarba (1998) caráter 64, Vari \& Harold (2001) caráter 53, Mirande (2010) caráter 341

\section{Estado 0 - Presente}

Acestrorhynchus falcatus, Aphyocharax pusillus, Astyanacinus moorii, Astyanacinus sp. nova Bolivia, Astyanacinus sp. nova Peru, "Astyanax" superbus, "Astyanax" orthodus, Astyanax altiparanae, Astyanax fasciatus, Astyanax lineatus, Astyanax paranae, Brycon pesu, Bryconamericus exodon, Chalceus epakros, Charax leticiae, Creagrutus menezesi, Ctenobrycon hauxwellianus, Deuterodon iguape, Galeocharax knerii, Gymnocorymbus ternertzi, Hydrolycus scomberoides, Hyphessobrycon eques, Jupiaba anteroides, Knodus moenkhausii, Moenkhausia xinguensis, Nematocharax venustus, Oligosarcus pintoi, Piabina argentea, Poptella paraguayensis, Rachoviscus graciliceps, Stethaprion erythrops, Stichonodon insignis, Tetragonopterus chalceus,

\section{Estado 1 - Ausente}

Agoniates anchovia, Agoniates halecinus, Bryconops alburnoides, Cheirodon galusdae, Clupeacharax anchoveoides, Engraulisoma taeniatum, Hollandichthys multifasciatus, Lignobrycon myersii, Markiana nigripinnis, Mimagoniates microlepis, Salminus hilarii, Thoracocharax stellatus, Triportheus albus

De acordo com Malabarba (1998) a presença de uma mancha umeral é amplamente distribuída entre os Characidae e, de alguma forma, entre os Characiformes. Ainda segundo o autor, ela é formada por uma densa concentração de cromatóforos, usualmente próxima à linha mediana do corpo e próxima da cabeça. A mancha umeral apesar de variável entre as espécies quase nunca varia entre as espécies e tem sido largamente utilizada como caráter diagnóstico para diversas espécies de peixes. Vari \& Harold (2001) comentam que a mancha é altamente variável em Creagrutus, com a maioria dos membros apresentando uma mancha redonda ou uma mancha vertical. 
Segundo Malabarba (1998) a ausência dessa mancha é uma sinapomorfia da subfamília Cheirodontinae. Além desses, outros Characidae que não apresentam mancha umeral são Aphyocharax, Microschemobrycon e Aphyodite.

\section{Caráter 133. Composição da mancha umeral}

Estado 0 - Uma barra difusa verticalmente alongada

Acestrorhynchus falcatus, Aphyocharax pusillus, Bryconamericus exodon, Chalceus epakros, Charax leticiae, Creagrutus menezesi, Ctenobrycon hauxwellianus, Deuterodon iguape, Galeocharax knerii, Hyphessobrycon eques, Knodus moenkhausii, Moenkhausia xinguensis, Piabina argentea, Stethaprion erythrops, Stichonodon insignis

Estado 1 - Duas barras difusas verticalmente alongadas

Astyanax fasciatus, Astyanax lineatus, Astyanax paranae, Gymnocorymbus ternertzi, Nematocharax venustus, Oligosarcus pintoi, Poptella paraguayensis, Tetragonopterus chalceus

Estado 2 - Duas barras difusas verticalmente alongadas e uma mancha horizontalmente alongada sobre a primeira barra

Astyanacinus moorii, Astyanacinus sp. nova Bolivia, Astyanacinus sp. nova Peru, “Astyanax” superbus, "Astyanax" orthodus, Astyanax altiparanae, Jupiaba anteroides

Estado 3 - Uma mancha difusa ovalada

Brycon pesu, Hydrolycus scomberoides

\section{Indeterminado}

Rachoviscus graciliceps

\section{Inaplicável}

Agoniates anchovia, Agoniates halecinus, Bryconops alburnoides, Cheirodon galusdae, Clupeacharax anchoveoides, Engraulisoma taeniatum, Hollandichthys multifasciatus, Lignobrycon myersii, Markiana nigripinnis, Mimagoniates microlepis, Salminus hilarii, Thoracocharax stellatus, Triportheus albus

Como dito em Malabarba (1998) o formato, o número de manchas, a intensidade delas e a cor é variável entre as espécies. Mirande (2010) sugere que a presença de uma mancha umeral horizontalmente ovalada é uma sinapomorfia de um grande grupo de Astyanax composto por Astyanax abramis, A. argyrimarginatus Garutti?, A. asuncionensis, A. bimaculatus?, A. goyacensis?, A. lacustris?, A. maculisquamis?, A. orthodus?, A. paraguayensis?, A. saltor?, A. superbus?, A. validus?, outros Astyanax?, com uma aquisição independente em Jupiaba mucronata. Esse clado de Mirande (2010) corresponde ao grupo A. bimaculatus proposto por Garutii (1999) que é caracterizado por uma mancha umeral ovalada horizontalmente, mancha losangular no pedúnculo caudal, 
estendendo-se à extremidade dos raios caudais medianos, e duas barras verticais na região umeral. Outros Characidae que compartilham a presença de desse padrão de mancha umeral são todos os Astyanacinus e algumas Jupiabas.

\section{Caráter 134. Pseudotímpano}

Malabarba (1998) caráter 1, Zanata \& Vari (2005) caráter 199, Bührnheim (2006) caráter 163, Mirande (2010) caráter 339

\section{Estado 0 - Ausente}

Acestrorhynchus falcatus, Agoniates anchovia, Agoniates halecinus, Astyanacinus moorii, Astyanacinus sp. nova Bolivia, Astyanacinus sp. nova Peru, “Astyanax" superbus, “Astyanax” orthodus, Astyanax altiparanae, Astyanax fasciatus, Astyanax lineatus, Astyanax paranae, Brycon pesu, Bryconamericus exodon, Bryconops alburnoides, Chalceus epakros, Clupeacharax anchoveoides, Creagrutus menezesi, Deuterodon iguape, Engraulisoma taeniatum, Gymnocorymbus ternertzi, Hollandichthys multifasciatus, Hydrolycus scomberoides, Jupiaba anteroides, Knodus moenkhausii, Lignobrycon myersii, Markiana nigripinnis, Moenkhausia xinguensis, Nematocharax venustus, Oligosarcus pintoi, Piabina argentea, Poptella paraguayensis, Salminus hilarii, Stethaprion erythrops, Stichonodon insignis, Triportheus albus

Estado 1 - Presente como uma redução da musculatura

Aphyocharax pusillus, Ctenobrycon hauxwellianus, Hyphessobrycon eques, Rachoviscus graciliceps, Tetragonopterus chalceus, Thoracocharax stellatus,

Estado 2 - Presente como um hiato muscular

Charax leticiae, Cheirodon galusdae, Galeocharax knerii

Indeterminado

Mimagoniates microlepis

Malabarba (1998) comenta que o pseudotímpano é caracterizado por um espaço ou uma grande redução dos músculos que cobrem a porção anterior da bexiga natatória. Segundo ele, essa redução seria para facilitar a transmissão de vibrações exteriores para a parede da bexiga natatória, que ao vibrar, transmitiria para o aparelho de Weber. Ainda para o autor, é necessário que sejam distinguidos diferentes estados com relação a essa característica e a redução muscular nessa região estaria presente em diversos grupos de Characidae como Tetragonopterus, Microschemobrycon, Paracbasis, Aphyocharax e outros, porém uma condição diferente do grande hiato muscular presente entre a primeira e a segunda costela dos Cheirodontinae. Somente alguns Characinae como Charax e Phenacogaster apresentariam condição similar, mas na ausência 
de sinapomorfias entre essas duas subfamílias, Malabarba (1998) decide considerar as condições semelhantes encontradas em ambas como paralelismos.

Mirande (2010) sugere que um pseudotímpano limitado pela primeira costela, pelo lateralis superficialis, segunda costela, obliquus inferioris e obliquus superioris é uma sinapomorfia que une Aphyoditeinae e Cheirodontinae.

\section{Caráter 135. Padrão de coloração na lateral do corpo}

Estado 0 - Ausência de "chevrons"

Acestrorhynchus falcatus, Agoniates anchovia, Agoniates halecinus, Aphyocharax pusillus, Astyanax altiparanae, Astyanax fasciatus, Astyanax lineatus, Astyanax paranae, Brycon pesu, Bryconamericus exodon, Bryconops alburnoides, Chalceus epakros, Charax leticiae, Cheirodon galusdae, Clupeacharax anchoveoides, Creagrutus menezesi, Ctenobrycon hauxwellianus, Deuterodon iguape, Engraulisoma taeniatum, Galeocharax knerii, Gymnocorymbus ternertzi, Hollandichthys multifasciatus, Hydrolycus scomberoides, Hyphessobrycon eques, Jupiaba anteroides, Knodus moenkhausii, Lignobrycon myersii, Markiana nigripinnis, Mimagoniates microlepis, Moenkhausia xinguensis, Oligosarcus pintoi, Piabina argentea, Poptella paraguayensis, Rachoviscus graciliceps, Salminus hilarii, Stethaprion erythrops, Stichonodon insignis, Tetragonopterus chalceus, Thoracocharax stellatus, Triportheus albus

Estado 1 - Presença de “chevrons”

Astyanacinus moorii, Astyanacinus sp. nova Bolivia, Astyanacinus sp. nova Peru, “Astyanax” superbus, "Astyanax" orthodus, Nematocharax venustus

Os “chevrons” são estrias com em formato de letras “v” deitadas com o vértice direcionado anteriormente (“<”) e lateralmente dispostas no corpo do peixe. Essas marcas não são simplesmente pigmentação e estão relacionadas com o sistema vascular do peixe. A musculatura dos peixes é irrigada por artérias e veias que estão distribuídas de acordo com o padrão da segmentação corporal do animal. Segundo Iwamizu \& Itazawa (1991) nos Teleostei há menor variação no arranjo dos vasos somáticos e estes estão, em geral, atrelados à presença de artérias e veias presentes alternadamente no corpo. Os “chevros” presentes em Astyanacinus e em alguns outros Characidae são os segmentos laterais da artéria (ou veia) que vasculariza a porção mais lateral da musculatura do corpo e que apresentam dois ramos, um dorsal e outro ventral denominados ramos intersegmentais (ver figura 95) bem desenvolvidos e, algumas vezes, dotados de pigmentação. 
Apesar de essa irrigação ser parte do plano básico dos peixes e estar presente em quase todos os grupos sem modificações, em Astyanacinus esses vasos são altamente desenvolvidos e repletos de ramificações. Alguns outros caracídeos também apresentam característica similar. Esse padrão já foi descrito para Astyanax leopoldi, Creagrutus mucipu, Hyphessobrycon bifasciatus, Hyphessobrycon heliacus, Jupiaba keithi, Jupiaba maroniensis, Jupiaba meunieri, Jupiaba pinnata, Moenkhausia pittieri, Nematocharax venustus e Pseudochalceus lineatus. Com relação às espécies de Jupiaba que possuem essa característica, estas espécies compartilham também dentes com cúspides aproximadamente do mesmo tamanho (Zanata, 1997) e dentes do dentário decrescendo gradualmente em tamanho (Géry et al., 1996; Zanata, 1997) e segundo Zanata (1997) essas espécies fazem parte de um mesmo grupo dentro do gênero o que provavelmente reflete uma origem única para essa característica em Jupiaba. Quanto às espécies de Hyphessobrycon com os “chevrons” Moreira et al. (2002) não tecem nenhum comentário filogenético sobre essas estrias nas espécies de Hyphessobrycon e somente comentam a distribuição desse padrão em outros caracídeos. Dada a distribuição dessa característica nos caracídeos, e mesmo entre os Characiformes, e considerando hipóteses prévias sobre as relações entre os gêneros de Characidae é possível afirmar com segurança que a presença desse estado é uma derivação e ocorreu repetidas vezes dentro do grupo. Alguns Cheirodontinae e Characinae apresenta chevrons bem pequenos. 


\section{POSIÇÃO FILOGENÉTICA DE ASTYANACINUS EM CHARACIDAE}

Este estudo, de certa maneira, falha ao não indicar à qual grupo de Characidae o gênero Astyanacinus estaria mais proximamente relacionado. A principal razão disto ter ocorrido reside na incompleta análise da estrutura morfológica das espécies do gênero, uma vez que duas das espécies não puderam ser diafanizadas. A primeira delas, Astyanacinus sp. nova Purus, é extremamente rara, contando com apenas 3 exemplares conhecidos e o autor considerou prudente, em um primeiro momento, não utilizar um dos exemplares para tal estudo e nem incluí-la na análise. A outra espécie, Astyanacinus multidens, não é tão rara, porém o autor não teve autorização para diafanizar exemplares de instituições brasileiras nem internacionais.

Kitching et al. (1998) alertam que a inclusão de “missing datas" (dados desconhecidos) na análise podem conduzir à geração de múltiplos cladogramas igualmente parcimoniosos, teorias espúrias de evolução de caracteres e diminuição da resolução ao mascarar o sinal filogenético presente nos dados observados. Devido à ausência de material disponível para diafanização da espécie Astyanacinus multidens, o autor pode incluir essa espécie em sua análise apenas através das informações disponíveis em um exame de raio-x. Desta forma, apenas 61 dos 136 caracteres puderam ser analisados para a espécie. O restrito número de caracteres analisados na espécie foi suficiente para confirmar o posicionamento da espécie dentro do gênero Astyanacinus, porém insuficiente para definir as relações internas do grupo e, pior, trouxe um sério questionamento sobre qual a posição do gênero dentro de Characidae.

A análise filogenética do presente trabalho sem a inclusão de Astyanacinus multidens gera 6 árvores mais parcimoniosas (figura 13) sendo que em todas elas o gênero Astyanacinus seria um agrupamento monofilético grupo-irmão de Astyanax e a espécie mais basal de Astyanacinus seria A. sp. nova Bolívia. Com a inclusão de Astyanacinus multidens o número de árvores mais parcimoniosas salta para 26, sendo que destas, 18 apresentam topologia bastante semelhante àquelas (figura 10) 6 obtidas sem a presença de $A$. sp. nova Bolívia. Por outro lado, as 8 (figura 09) restantes apresentam um cenário bastante diferente para a evolução de Astyanacinus. De acordo com essas árvores, o gênero não estaria relacionado à Astyanax e sim com um grupo formado por Oligosarcus, Hollandichthys e Rachoviscus (composição semelhante ao clado 228 de Mirande (2010)) e, além disso, a espécie mais basal de Astyanacinus seria 
A. multidens e não $A$. sp. nova Bolívia. Essa diferente interpretação está alicerçada no compartilhamento de A. multidens com Oligosarcus, Hollandichthys e Rachoviscus de uma maxila com mais de 7 dentes e com área com dentes maior que a área edentelosa. Dessa forma, apesar de ter incluído táxons de quase todos os grandes grupos de Characidae na análise, o posicionamento do gênero Astyanacinus na família ainda é incerto e a hipótese de uma proximidade evolutiva com o clado 228 de Mirande (2010) não deve ser ignorada e depende, acima de tudo, da obtenção da informação completa das espécies Astyanacinus sp. nova Purus e Astyanacinus multidens.

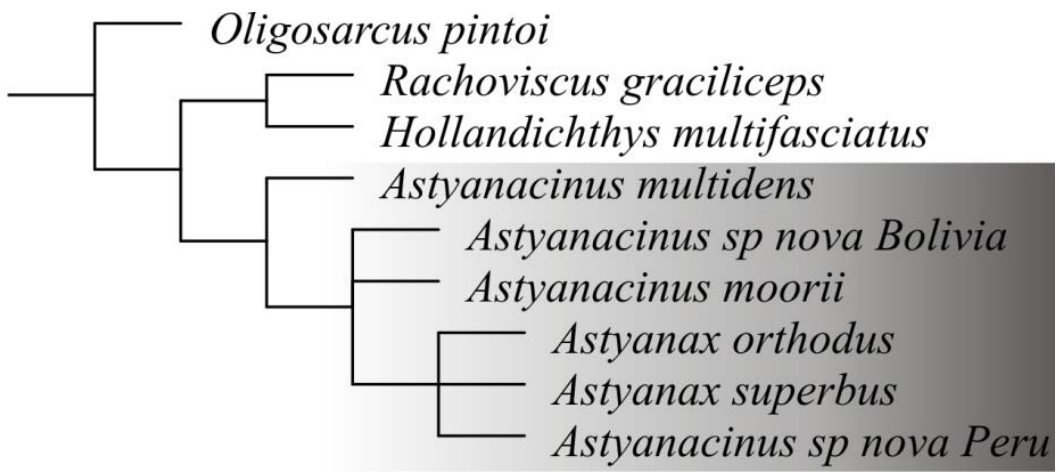

Figura 09. Parte da árvore de consenso entre 8 das 26 árvores obtidas com a inclusão de Astyanacinus multidens que indicam um estreito relacionamento entre Astyanacinus e o clado 228 de Mirande (2010).

\section{ASTYANACINUS COMO GRUPO-IRMÃO DE ASTYANAX}

Eigenmann (1927) foi o primeiro a tecer comentários sobre as relações de parentesco do gênero Astyanacinus em que indica uma proximidade entre o gênero e Astyanax ao dizer "Closely allied to Astyanax" p.338 e "This genus grades into Astyanax” p.339. Apesar de Astyanacinus ser morfologicamente bastante semelhante ao gênero Astyanax compartilhando com este inúmeras características bastantes comuns entre os Characidae, Eigenmann (1921 pag. 338) considera que eles se diferenciam entre si por características referentes ao formato da boca: maxila longa formando com o pré-maxilar, metade do comprimento da cabeça e ausência de um ângulo distinto entre os ossos maxilar e pré-maxilar.

No presente estudo, após examinar diversas espécies de Astyanacinus e Astyanax é possível concluir que ambos os gêneros realmente apresentam diferenças com relação à maxila superior, principalmente com relação ao comprimento do osso maxilar, porém 
as considerações de Eigenmann (1921) sobre o formato da maxila não se mostraram tão verdadeiras. O caráter utilizado por Eigenmann é muito subjetivo e quando examinado em diversos táxons de ambos os gêneros se mostra ineficiente para abarcar toda a diversidade. A figura 10 indica uma ligeira menor angulação na maxila superior de Astyanacinus em relação à Astyanax. Mesmo sem ter dissecado um Astyanacinus, Mirande (2010) comenta que o estado descrito por Eigenmann (1921) para a maxila superior do gênero está presente também em outros gêneros de Characidae como Dectobrycon, Hollandichthys, Oligosarcus e Pseudochalceus.

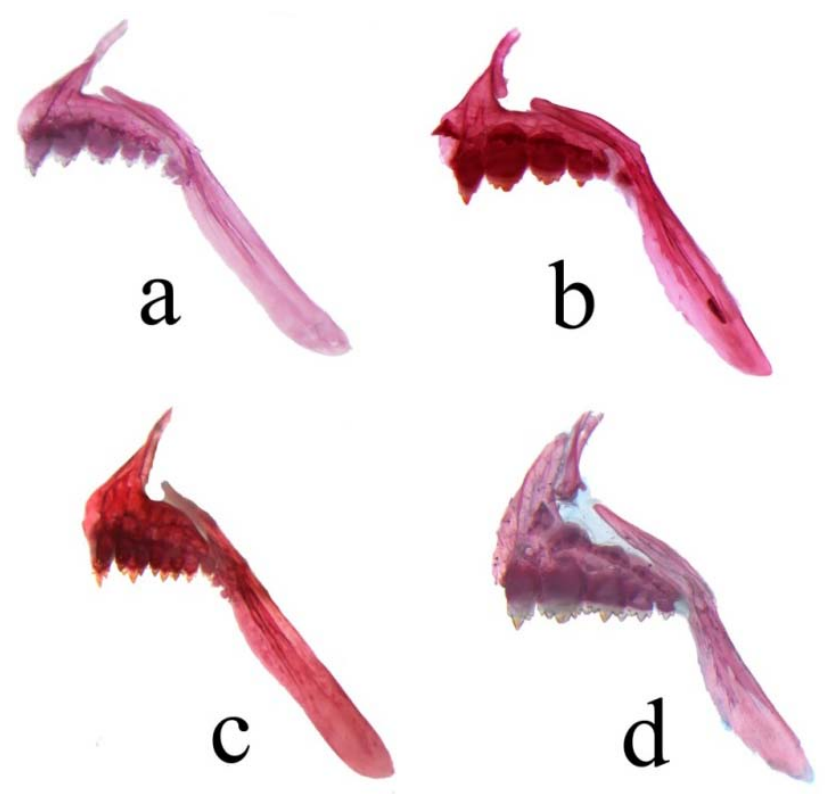

Figura 10. Maxila superior de a. Astyanacinus moorii MZUSP 78752 (43,3 mm CP) b. Astyanax fasciatus LIRP 132 (75,3 mm CP) c. Astyanacinus sp. nova Bolívia MCP 35017 (60 mm CP) d. Astyanax altiparanae LIRP 6041 (54,2 mm CP).

Os gêneros Astyanacinus e Astyanax são morfologicamente bastante semelhantes tanto externamente quando internamente. Compartilham, por exemplo, prémaxilar com duas séries de dentes com quatro dentes na série mais externa do e cinco dentes na série mais interna, linha lateral completa, presença de nadadeira adiposa, nadadeiras anal e caudal nuas, nadadeira dorsal ii+9, entre outros caracteres. Na presente análise os dois gêneros formariam um grupo monofilético com base no compartilhamento de: 
- Área de contato entre os infra-orbitais 1 e 2 semelhante à área de participação do infraorbital 1 na órbita ocular

- Margem anterior do quarto infra-orbital pequena, menos extensa que o comprimento do osso

- Canal no osso maxilar presente até a metade posterior do osso

- Mancha no pedúnculo caudal alongada horizontalmente com origem na vertical da nadadeira adiposa

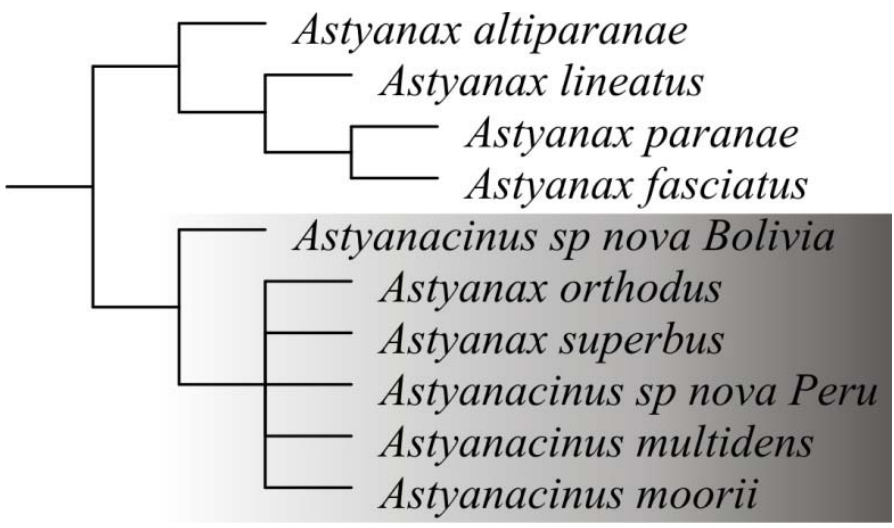

Figura 11. Parte da árvore de consenso estrito entre as outras 18 das 26 árvores obtidas com a inclusão de Astyanacinus multidens que indicam um estreito relacionamento entre Astyanacinus e o gênero Astyanax.

Conforme comentado anteriormente, segundo a presente análise Mirande (2010) pode estar correto ao dizer que Astyanacinus talvez esteja relacionado ao Astyanax clade de sua análise. Entretanto, é possível que ao se incluir todas as espécies de Astyanax e de Astyanacinus em uma análise filogenética a proximidade evolutiva entre essas duas entidades não seja recobrada como no presente trabalho. O gênero Astyanax é extremamente complexo e diverso e a pequena representatividade deste na presente análise (A. altiparanae, A. fasciatus, A. lineatus, A. paranae) é um problema. Dada a complexidade desse gênero é impossível afirmar que em uma análise mais completa e com a maioria das espécies, Astyanacinus possa ser obtido como um agrupamento monofilético e grupo-irmão de Astyanax ou dentro deste. Essas conjecturas ainda são muito prematuras, até porque só poderão ser testadas com segurança quando a definição do que é Astyanax for melhor estabelecida.

Dessa forma, o presente trabalho é o primeiro com base na metodologia cladística e utilizando caracteres morfológicos a propor hipóteses sobre as relações de Astyanacinus com os outros caracídeos. Aqui, é fornecida a hipótese de que o gênero 
Astyanacinus é um agrupamento proximamente relacionado à Astyanax além de indicar que a relação desse gênero com o nó 228 de Mirande (2010) não deve ser descartada.

\section{MONOFILIA E REDEFINIĈ̃̃O DO GÊNERO ASTYANACINUS}

Contrariamente ao proposto por Calcagnotto et al. (2005) que com base em caracteres moleculares propõe que Astyanacinus moorii e A. multidens não formam um agrupamento monofilético, o presente estudo, apesar de não ter incluído todas as espécies de Astyanacinus (ausência de $A$. sp. nova Purus na análise) sugere a monofilia do gênero com a inclusão de duas espécies de Astyanax (A. superbus e A. orthodus). Já o trabalho de Javonillo et al. (2010) também através da utilização de bases nucleares, e utilizando os dados sequenciados de Calcagnotto et al. (2005), sugerem que Astyanacinus é monofilético, proposta essa recobrada aqui.

O presente trabalho é primeiro a sustentar com base em caracteres morfológicos o monofiletismo do gênero Astyanacinus. As sete sinapomorfias (nenhuma exclusiva) responsáveis pelo agrupamento são:

- Caráter 35 estado 0: Mandíbula longa, maior que a órbita

- Caráter 49 estado 1: Três dentes no osso maxilar

- Caráter 52 estado 0: Margem posterior da maxila bem posterior a vertical que passa pela asa do etmóide lateral

- Caráter 107 estado 2: Primeiro radial proximal da nadadeira anal direcionado dorsalmente

- Caráter 112 estado 1: Pós-cleitros 1 e 2 próximos (espaço entre eles menor que a altura do pós-cleitro 1)

- Caráter 135 estado 1: Presença de chevrons

Além das sinapomorfias listadas acima, diversas características são compartilhadas entre as espécies de Astyanacinus e são úteis na identificação do gênero. Algumas delas são até sugeridas como sinapomórficas para o gênero nas topologias em que este é interpretado como relacionado o clado composto Oligosarcus, Hollandichthys e Rachoviscus. Além das sinapomorfias listadas acima, as espécies de Astyanacinus podem ser diagnosticadas dos demais caracídeos com base na combinação 
de uma série de caracteres, são eles: linha lateral completa; nadadeiras anal e caudal nuas; duas séries de dentes na pré-maxila; série de dentes mais externa da pré-maxila com quatro dentes multicuspidados e série interna com cinco; quatro dentes mais anteriores do dentários são mais desenvolvidos e seguidos por números dentes menores; presença de duas barras verticais difusas e uma mancha bem delimitada e horizontalmente ovalada posicionada sobre a barra vertical difusa mais anterior na região umeral; uma mancha escura horizontalmente alongada no pedúnculo caudal que se estende até a porção mais distal dos raios medianos da nadadeira caudal (reversão em A. orthodus), nadadeira anal com 25-36 raios totais, dorsal com ii+9, ausência de ganchos nas nadadeiras (exceto em $A$. sp. nova Bolívia) e peitoral com i+11-13. 


\section{RELAÇÕES ENTRE AS ESPÉCIES DE ASTYANACINUS}

Osteologicamente as espécies de Astyanacinus apresentam pouquíssimas variações significativas entre si, sendo que em sua maioria as diferenças são polimorfismos e/ou alterações em formato que não são informativas quando analisadas em um universo mais amplo. Apesar disso, algumas poucas diferenças entre as espécies estão presentes e, dentre essas, é possível destacar algumas características que dispensam subjetivismos e certamente trazem luz à história evolutiva do grupo. Alguns exemplos dessas características são: presença ou não de um rinosfenóide ossificado, quantidade de dentes no maxilar, lamelas ósseas no osso nasal e outros. Somado a pouca variação morfológica entre as espécies, a impossibilidade de se examinar a estrutura morfológica completa das espécies Astyanacinus sp nova Purus e A. multidens (como discutido no item "Posição filogenética de Astyanacinus em Characidae”) prejudicou consistentemente as discussões sobre as relações internas do grupo.

Em A. multidens somente parte dos caracteres puderam ser observados e quando a espécie é incluída na análise gera 26 árvores mais parcimoniosas que deixam Astyanacinus em uma completa politomia, atrapalhando assim a discussão sobre as relações entre as espécies do grupo. Apesar disso, analisando atentamente as 26 árvores (figura 12c) geradas depreende-se dois padrões de árvores: em 8 delas A. multidens é irmão de todos outros Astyanacinus (figura 12a) ao passo que nas outras 18 a espécie mais basal é Astyanacinus sp nova Bolivia (figura 12b).
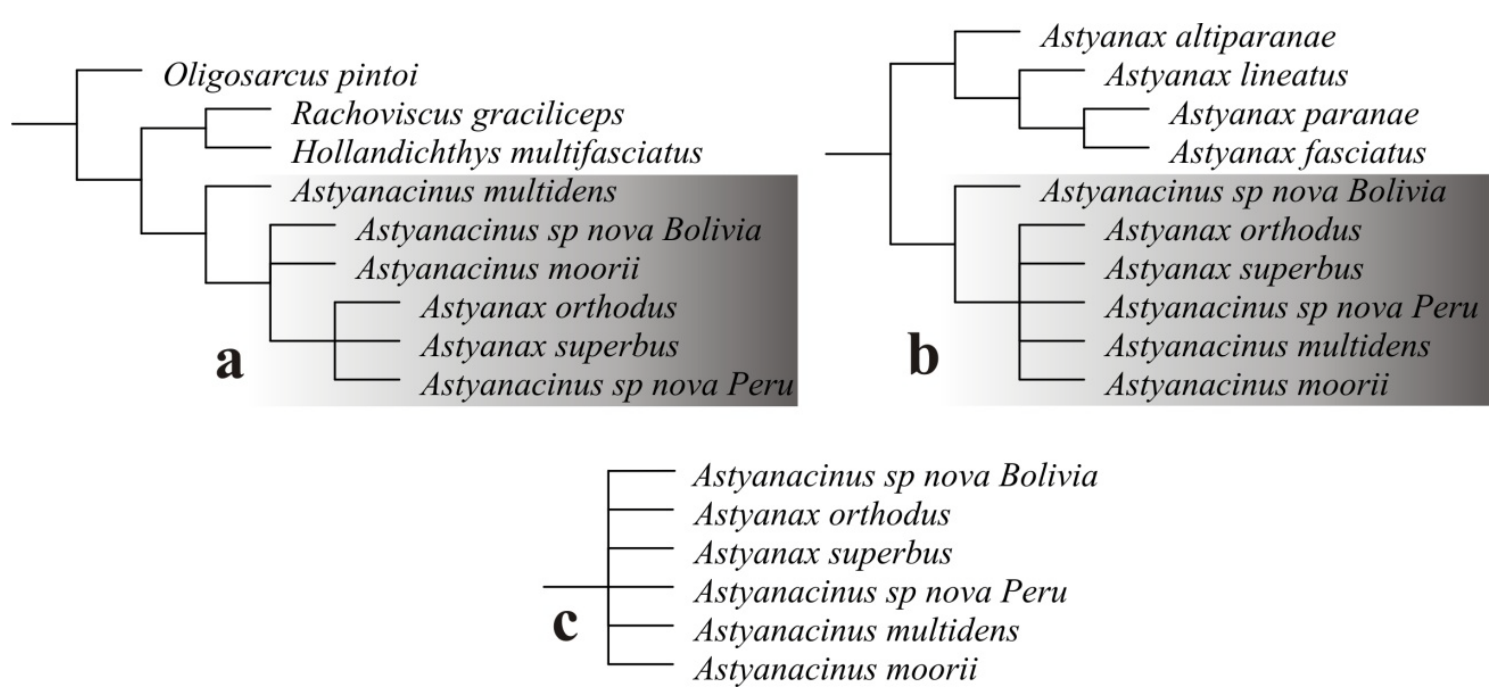

Figura 12. a. Consenso estrito entre as 8 árvores mais parcimoniosas em que Astyanacinus é relacionado ao clado 228 de Mirande (2010) b. Consenso estrito entre as 
18 árvores em que Astyanacinus é grupo-irmão de Astyanax c. Consenso estrito entre as 26 árvores mais parcimoniosas.

Por outro lado, quando a espécie $A$. multidens não é incluída na análise a resolução é melhor e somente 6 árvores mais parcimoniosas são encontradas (figura 13). Dessa forma, até que toda a informação morfológica de A. multidens esteja disponível, a fim de propiciar maiores inferências serão discutidas aqui as relações internas de Astyanacinus a partir da análise filogenética sem A. multidens.

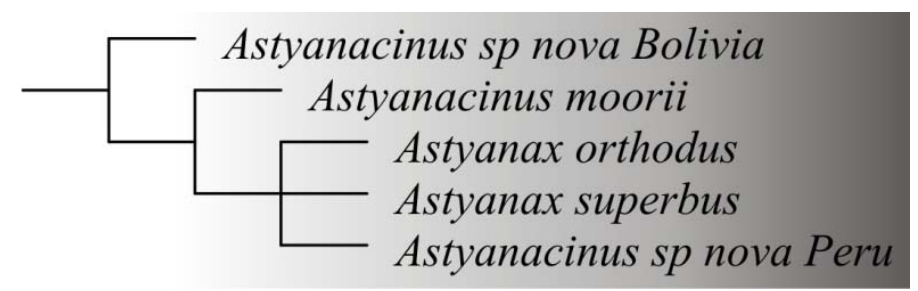

Figura 13. Consenso estrito entre as 6 árvores mais parcimoniosas obtidas sem a inclusão de Astyanacinus multidens.

O posicionamento basal de Astyanacinus sp nova Bolívia é sustentado pela retenção de plesiomorfias compartilhadas, dentre outros, com os Astyanax. Dentre essas características destaca-se a presença de ganchos nas nadadeiras. Essa característica está presente em quase todos os Characidae e a ausência dela em todas as outras espécies de Astyanacinus, mesmo após o exame de dezenas de indivíduos, é um forte indício de uma relação de parentesco próxima entre elas. A monofilia de um clado composto por Astyanacinus moorii + Astyanax orthodus + Astyanax superbus + Astyanacinus sp nova Peru é sustentado pelas seguintes sinapomorfias:

- Presença de processo postero-ventral do osso orbito-esfenóide

- Margem dorsal do dentário com área com dentes maior que a área edentelosa

- Ausência de contato entre os primeiros radiais proximais da anal

- Ausência de ganchos nas nadadeiras de machos maduros

Já Astyanacinus moorii seria grupo-irmão de um clado formado por "Astyanax" orthodus + “Astyanax superbus” + Astyanacinus sp nova Peru que é sustentado por quatro sinapomorfias, são elas: 
- Formato da fenestra entre o quadrado e o metapterigóide tão alta quando comprida

- Porção anterior do uro-hial lisa com orifício centralizado

- Basi-hial curto (menor que o com o dobro do comprimento do primeiro basibranquial)

- Forame do coracóide desenvolvido

Autapomorfias das espécies de Astyanacinus:

Astyanacinus sp nova Bolívia - sem autapomorfias

Astyanacinus moorii - ausência de lamelas no osso nasal, ausência de rinosfenóide ossificado

"Astyanax" orthodus - seis ou mais supraneurais, porção postero-ventral do coracóide sem projeção, canal sensorial do extra-escapular com três ramos, mancha no pedúnculo caudal curta com origem na depois da base da nadadeira adiposa

“Astyanax” superbus - ausência de rinosfenóide ossificado, ausência de processo postero-ventral do osso orbito-esfenóide, 5 ou 6 dentes maxilares, primeiro dente do maxila pentacuspidado, forame da porção posterior do metapterigóide inserido no metapterigóide, forame inserido na superfície dorsal do metapterigóide

Astyanacinus sp nova Peru - ausência de lamelas no osso nasal, primeiro radial proximal da nadadeira anal inclinado anteriormente 


\section{BIOGEOGRAFIA}

A história geológica das bacias hidrográficas do Continente Sul-americano é bastante complexa e ainda não é totalmente compreendida, porém alguns processos geológicos (e.g. quebra de Gondwanna, formação dos Andes e estabelecimento do Ístmo do Panamá) tiveram clara influência na diversificação da ictiofauna Neotropical. Fósseis de invertebrados marinhos indicam a presença de um mar entre os Continentes Africano e Sul-Americano no Cretáceo Inferior (112 Ma) (Lundberg, et al., 1998), evento esse que teve grande influência na diversificação alopátrica de grandes grupos (high-ranks) de peixes Neotropicais como famílias de Characiformes e Siluriformes, dentro muitos outros exemplos.

A formação dos Andes teve enorme influência na evolução das Drenagens Sulamericanas e, conseqüentemente, nos peixes que as habitam. Tal influência tem sido amplamente reportada por diversos autores especialistas em vários grupos de peixes Neotropicais de água doce. Albert et al. (2006) apresentam uma lista com 123 gêneros que tem representantes Cis e Trans-andinos. A formação da cadeia de Montanhas Andinas é bastante complexa e inicou-se à 90 Ma por meio de forças de compressão tectônicas da Placa de Nazca na placa Sul-americana (Lundberg, 1998). A partir de evidências de diversas naturezas (e.g. sedimentológicos Piper et al., 1997; fissões geológicas Shagam et al., (1983); paleontológicas Lundberg, 1998; Vonhorf et al., (1998; 2003)) sugere-se que até o Mioceno Médio (Lundberg et al., 1998); 16 Ma Albert et al., 2006) os cursos d'água da região Noroeste do Continente Sul-americano, em geral, eram drenados em direção ao norte para um delta localizado na região onde atualmente encontra-se a Bacia do Rio Maracaibo; o chamado Paleo-AmazonasOrinoco. Com o surgimento dos Andes o Paleo-Amazonas-Orinoco se transformou de forma gradativa em um lago gigante “Lago Pebas” com 1 milhão de km² (Wesselingh et al., 2002) há aproximadamente 20-10 Ma (Lundberg et al., 1998). Figueiredo et al. (2009) com base em evidências sedimentológicas e paleontológicas sugerem que o rio Amazonas somente tornou-se um rio transcontinental com corrente em direção ao leste há 11 milhões de anos atrás.

Aproximadamente no Mioceno Médio ( 12-10 Ma) ocorre o surgimento da Cordilheira Oriental (parte da porção Norte da Cordilheira dos Andes) que dividiu os rios da região Noroeste do Continente Sul-americano (Lundberg et al. 1998, Albert et 
al., 2006). A oeste da Cordilheira Oriental situa-se a Bacia do Rio Magdalena e Drenagens do Pacífico enquanto que a leste ficam os rios Cis-Andinos (Bacias Amazonas Ocidental e Orinoco).

O gênero Astyanacinus possui ampla distribuição nos Continentes Central e Sulamericano e com espécies distribuídas por diferentes drenagens, inclusive com espécies Cis e Trans-andinas (ver figura 14). Apesar disso, nenhuma das espécies de Astyanacinus ocorre em rios efetivamente da planície Amazônica, isso porque esses peixes estão presentes apenas na Bacia do Rio Atrato a oeste dos Andes e em rios que drenam a face leste Andina e em rios dos Escudos Cristalinos da Guiana e do Brasil nas bordas, respectivamente, ao norte e ao sul da Planície Amazônica. Como pode ser observado na figura 14, aparentemente, a distribuição do grupo é fortemente influenciada pela altitude. Seis das espécies são Cis-andinas: a espécie-tipo Astyanacinus moorii é encontrada na Bacia do Alto Rio Paraguai, mas restrita a Chapada dos Guimarães e rios próximos; Astyanacinus multidens, Astyanacinus sp nova Bolivia, Astyanacinus sp nova Peru e Astyanacinus sp nova Purus ocorrem em diversos tributários do Alto Amazonas que drenam a leste dos Andes quase sempre em grandes altitudes; "Astyanax” superbus é restrito a Bacia do Rio Apure que é um dos grandes afluentes do Orinoco. A espécie Trans-andina é “Astyanax” orthodus que é da Bacia do Rio Atrato e San Juan além de estar presente também em rios centro-americanos, no Panamá.

Com base na distribuição atual do gênero é possível tecer hipóteses sobre a evolução do grupo e os eventos vicariantes responsáveis pela diversificação do gênero. Partindo-se da premissa que o gênero é uma unidade monofilética e distribui-se por diferentes Bacias hidrográficas da América do Sul supõe-se que este se dispersou por outras drenagens a partir de eventos vicariantes. 


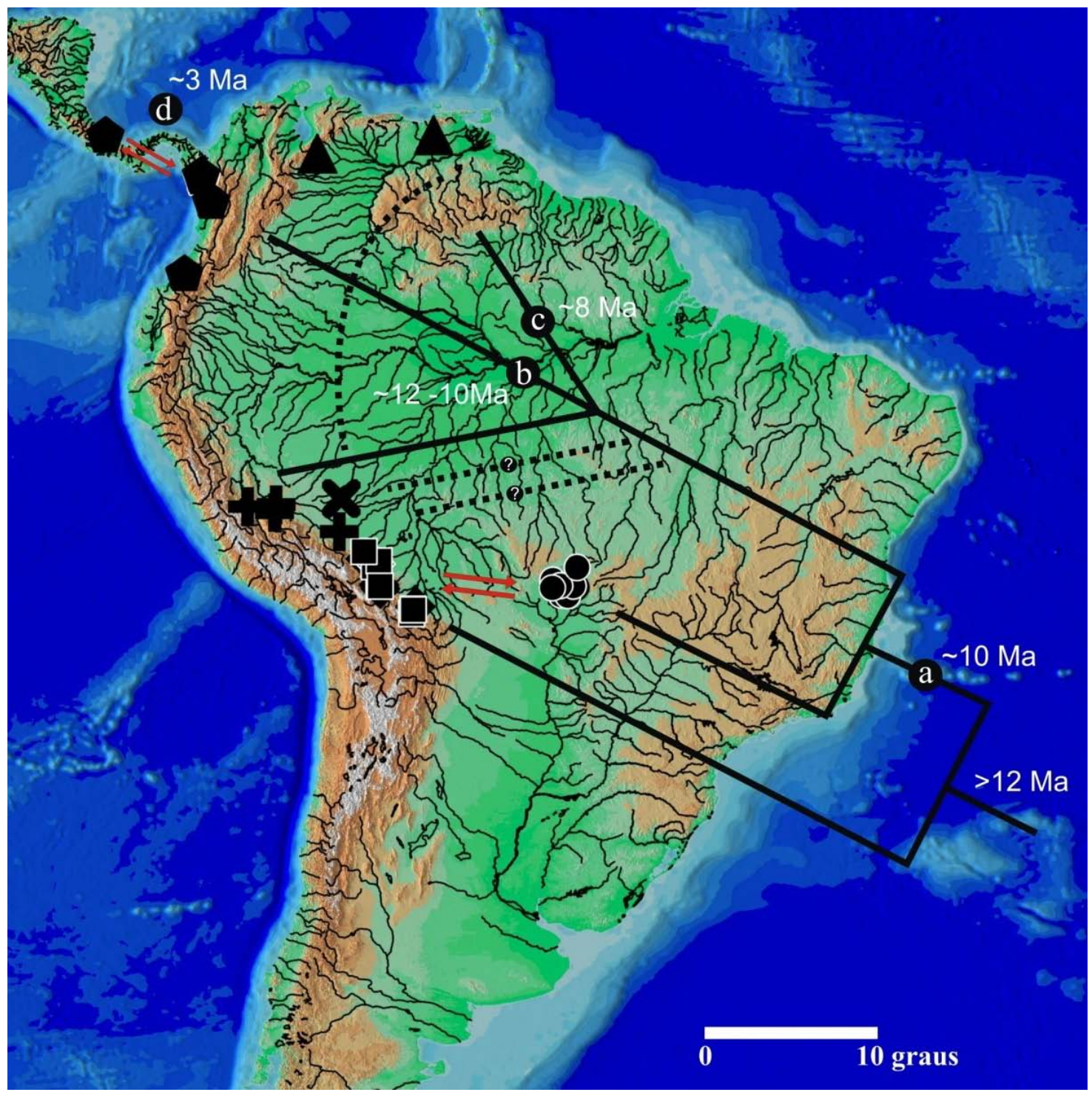

Figura 14. Mapa da distribuição geográfica do gênero Astyanacinus e a relação com os eventos geológicos. Pentágono $=A$. orthodus; triângulo $=A$. superbus; $c r u z=A$. sp nova Peru ; quadrado $=A$. sp nova Bolívia; losângulo $=A$. multidens; letra $\mathrm{x}=A$. sp nova Purus e círculo $=A$. moorii. Cada símbolo pode representar mais de um lote examinado. a. intercâmbio faunístico entre o Alto Madeira e Alto Paraguai; b. formação da Cordilheira Oriental; c. formação do Arco Vaupes; d. conexão entre o Ístmo do Panamá e América do Sul. 


\section{Biogeografia de “Astyanax" orthodus}

Uma vez que existe uma espécie Trans-andina é mais parcimonioso conjecturar uma origem para o gênero mais antiga do que o isolamento geográfico entre as regiões Cis e Trans-Andina do que supor que uma espécie de peixe de pequeno porte como Astyanacinus conseguiu transpor uma barreira geográfica tão conspícua quanto a Cordilheira dos Andes. Apesar disso, não é possível afirmar que essa espécie Transandina deva ser grupo-irmão de todos os Astyanacinus Cis-andinos. Afirmar isso seria extremamente simplista ao não considerar o lento e complexo soerguimento andino e a heterogenidade espacial e temporal da formação da cadeia Andina, além de descartar outros padrões geológicos que talvez tenham influenciado eventos cladogenéticos no gênero antes do soerguimento Andino.

Os Andes além de não terem se formado a partir de um evento único e, muito menos abrupto, foram influenciados por vários fatores desde o Cretáceo, e é difícil estabelecer qual data estes estariam formados o suficiente para isolar populações de Astyanacinus. Somente na região Noroeste Sul-Americana há Astyanacinus isolados pelas montanhas Andinas e esta região é bastante complexa geologicamente, sendo formada por três cadeias de montanhas e, além disso, ao que tudo indica, esta foi a última porção da cadeia a ser formada. Dessa forma, somado aos resultados filogenéticos apresentados neste trabalho, é possível questionar a pronta idéia de que a espécie Trans-andina de Astyanacinus seria obrigatoriamente a mais antiga e grupoirmão de todas as outras espécies do gênero. A presença de uma espécie Trans-andina fornece com certeza, no máximo, uma data mínima para o grupo, mas não necessariamente representa o Astyanacinus mais basal. Outros autores também fornecem hipóteses em que a espécie Trans-andina não é, necessariamente, a mais basal do grupo. Por exemplo, Ribeiro (2004) considera Creagrutus varii, conhecido de afluentes do Rio São Marcos na Bacia do Alto Rio Paranaíba, como o grupo-irmão de todas as demais espécies do gênero (espécies Trans e Cis-Andina). Em Bertaco (2008) a espécie mais basal do gênero é do Rio Ucayali e não alguma das muitas espécies Transandinas do grupo. Em Vari (1991) resultado semelhante é encontrado em Steindachnerina e Lima (2006) para Salminus. Castro \& Vari (2004) inferem que o gênero estritamente Trans-andino Ichthyoelephas é grupo-irmão de Semaprochilodus e não grupo-irmão de Semaprochilodus + Prochilodus. Esses são alguns exemplos de 
propostas em que a clássica hipótese de uma espécie Trans-andina ser grupo-irmão das outras Cis-andinas muitas vezes pode não corresponder ao obtido na análise.

Com relação à Astyanacinus, se consideradas as possíveis datas dos eventos geológicos atrelados a diversificação do gênero, talvez o primeiro evento cladogenético seja a separação Trans-andina (“Astyanax” orthodus) - Cis-andina (demais espécies do gênero) há 12-10 Ma, mas a data é imprecisa e muito próxima do evento de trocas faunísticas entre o Alto Madeira e o Alto Paraguai ( 10 Ma). Sendo assim, aliado à evidência filogenética contrária à hipótese, não há nenhuma evidência clara (nem morfológica, nem biogeográfica) para se esperar que “Astyanax" orthodus fosse a espécie mais basal do gênero Astyanacinus.

\section{Presença de “Astyanax” orthodus na América Central}

A data do soerguimento do Ístmo do Panamá é bastante controversa na literatura. Há evidências de possíveis conexões terrestres entre as Américas Central e do Sul entre o Paleoceno Tardio e o Eoceno Médio (60-43 Ma) com base em possíveis eventos de dispersão de mamíferos e aves neste período (Marshall et al., 1997) e, além disso, para Bussing (1985) a grande diversidade e a ampla distribuição de certos grupos de peixes, anfíbios e répteis na América Central é outro indício de conexões entre as Américas Central e Sul antes do Plioceno. Contudo, para a maioria dos autores o evento teria ocorrido há aproximadamente 3 Ma durante o Plioceno (Coney, 1982; Keller et al., 1989; Coates et al., 1992; Coates \& Obando, 1996; Albert et al., 2006). Na verdade, o soerguimento do Ístmo panamenho que separou os Oceanos Pacífico Leste e Atlântico Norte e uniu as Américas Central e Sul ocorreu não como um evento único e sim como uma série de eventos que se iniciaram há aproximadamente 15 Ma quando a Placa Tectônica Sul-Americana começou a se mover na direção noroeste e colidiu com a América Central (Duque, 1990; Coates \& Obando, 1996; Cobbold et al., 1996; Collins, 1996; Lundberg et al., 1998). Para Lundberg et al. (1998) e Marshall \& Sempere (1993) a formação de uma completa conexão terrestre entre as Américas Central e Sul com provável início de rotas de dispersão e intercâmbio de faunas de água doce entre essas regiões ocorreu há 2.5 Ma. Lundberg et al. (1998) ainda comentam que a grande similaridade biótica entre os rios Atrato (Am. do Sul) e Tuyra (Am. Central) é talvez um claro exemplo de rotas de dispersão de água doce entre esses continentes. 
Já que a história evolutiva dos caracídeos está ligada aos fragmentos de Gondwana e não com os da Laurásia é óbvio concluir que a origem do gênero Astyanacinus ocorreu em solos do Continente Sul-americano, e assim, pode-se admitir que as populações de Astyanacinus que ocorrem na América Central colonizaram essa região a partir de ancestrais que viviam na região Noroeste do Continente Sulamericano há não mais do que 3 milhões de anos atrás (data do estabelecimento da conexão terrestre entre as Américas Central e Sul pelo Ístmo do Panamá). Essa inferência é possível uma vez que o contato do Ístmo do Panamá com a América do Sul ocorreu há oeste da Cordilheira Oriental Andina e como esta se formou há aproximadamente 12-10 Ma, portanto, bem antes do contato entre as Américas Central e do Sul (3 Ma), é provável que a população ancestral que colonizou cursos d'água da Costa Rica, Panamá e Nicarágua advenha de população(s) provindas à oeste da Cordilheira Oriental. Outra evidência que corrobora a hipótese de colonização de Astyanacinus para a região é a grande similaridade biótica entre os rios Atrato (Am. do Sul) e Tuyra (Am. Central) (Lundberg et al., 1998) que, por sua vez, indica intercâmbio faunístico entre as drenagens dos dois continentes.

Com relação às outras espécies de peixes, a distribuição de Astyanax orthodus pode ser comparada com a de Ctenolucius beani (cf. Vari, 1995) que está restrita aos Rios do Panamá e Bacias dos Rios Atrato e San Juan no noroeste da Colômbia. Outros peixes apresentam distribuição semelhante como Hemibrycon dariensis Bertaco (2008) (Panamá, Atrato e Sinú) e Roeboides occidentalis (Lucena, 2000).

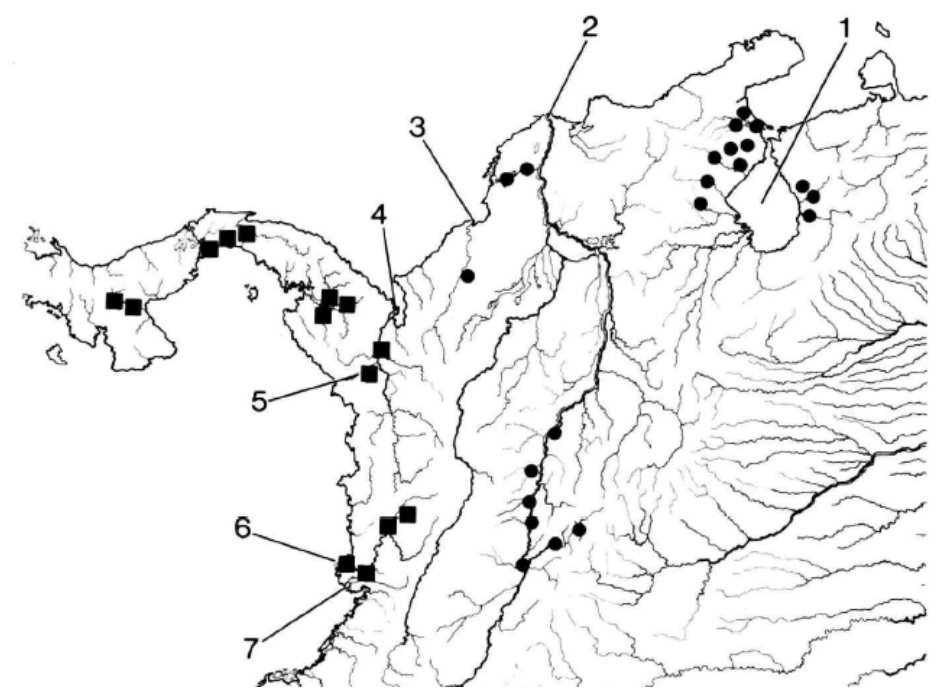

Figura 15. Distribuição das espécies de Ctenolucius (modificado de Vari, 1995). Quadrado representa C. beani e círculo C. hujeta. 


\section{Biogeografia de Astyanacinus moorii}

Para Lundberg et al. (1998) o divisor moderno entre as drenagens do Paraná e Amazonas (Paleoarco Michicola) foi estabelecido há aproximadamente 30 Ma com o início de um episódio tectônico e um período de inclinação da oroclinal Boliviana. Já Hubert \& Renno (2006) inferem que a bacia do Paraná-Paraguai separou-se da Protoamazônica por volta de 10 Ma, porém há evidências de eventos de captura de cabeceiras do Paraná por parte da drenagem amazônica nos últimos 10 Ma (Räsänem et al., 1995; Lundberg et al., 1998; Hubert \& Renno, 2006).

Com base nas evidências hidrogeológicas é possível inferir dois cenários acerca da presença de uma espécie de Astyanacinus na Drenagem do Alto-Paraguai. O primeiro é que o gênero Astyanacinus seria bastante antigo e teve origem em algum momento quando as atuais Drenagens do Amazonas, Orinoco e Paraná-Paraguai ainda formavam uma unidade. O gênero seria amplamente distribuído pela Bacia e quando as drenagens do Paraná e Amazonas foram separadas pelo Paleoarco Michicola há 30 Ma (Lundberg et al., 1998) ou a 10 Ma (Hubert \& Renno, 2006) e este evento seria o responsável pela especiação alopátrica da referida espécie.

No outro, e mais plausível cenário, o gênero não seria tão antigo e teria surgido no Paleo-Amazonas-Orinoco. Somente mais recentemente, através de capturas de cabeceira, houve intercâmbio de fauna entre as Drenagens do Paraguai e Madeira, criando uma possível rota de dispersão da espécie para a Drenagem do Paraná. Essa rota de dispersão foi sugerida por Hubert \& Renno (2006). Como infere Lima (2006) a ocorrência de Salminus brasiliensis no sistema do Alto Rio Madeira na Bolívia e Peru é um possível remanescente do intercâmbio faunístico entre uma porção da Bacia do Paraguai e a Bacia do paleo-Amazonas subsequente ao estabelecimento do arco de Michicola como divisor de águas entre estas bacias, no Mioceno tardio. Outros peixes restritos às Bacias do Alto Amazonas e Bacia do Paraguai são os gêneros monoespecíficos de caracídeos Clupeacharax e Engraulisoma, as espécies Piabarchus analis, Piabucus melanostomus, Potamotrygon castexi, Anchoviella carrikeri, Potamorrhaphis eigenmanni, Pseudotylosurus angusticeps e outros. 


\section{Biogeografia de “Astyanax" superbus}

Como Astyanacinus está atualmente presente nas Bacias do Orinoco e Amazonas é possível inferir que estava preteritamente distribuído no Paleo-AmazonasOrinoco antes que este se dividisse e formasse as Drenagens do Amazonas e Orinoco que hoje são independentes (exceto canal do Cassiquiare que conecta as Bacias do Orinoco e Rio Negro).

Como o gênero Astyanacinus seria distribuído preteritamente na Drenagem do Paleo-Amazonas-Orinoco é possível sugerir que a separação da Drenagem do Orinoco (onde ocorre “Astyanax" superbus) da Drenagem do Alto Amazonas pela formação do Palearco Vaupes entre 8 e 5 milhoes de anos atrás (Hoorn, 1993; Hoorn et al., 1995) foi o evento responsável pela cladogênese que deu origem ao táxon. A partir desses dados geológicos é também possível inferir que a provável espécie-irmã de “Astyanax" superbus é uma espécie da região do Alto Amazonas.

Lima (2006) lista alguns peixes que apresentam o padrão de distribuição Alto Amazonas/Rio Orinoco (Steindachnerina guentheri, Otocinclus huaorani e o gênero Aphanotolurus). Pode-se adicionar à lista Rineloricaria formosa e Ageneiosus vittatus. É possível inferir que essas espécies deveriam estar presentes quando ocorreu a separação das Bacias doAlto Amazonas/Rio Orinoco causou a distribuição alopátrica dessas.

\section{Biogeografia de Astyanacinus sp. nova Peru}

A espécie de Astyanacinus com distribuição mais ampla é $A$. sp. nova Peru que está presente nas Bacias do Urubamba, Ucayali, Madre de Dios e Rio de las Piedras. Essa distribuição por diversos tributários do Alto Amazonas é concordante com o padrão encontrado em dezenas de espécies de peixes neotropicais. Lima (2006) lista alguns desses, entre os quais estão Salminus iquitensis (Lima, 2006), curimatídeos (Vari 1991,1992), Creagrutus (Vari \& Harold, 2001). 


\section{Biogeografia de Astyanacinus sp. nova Bolívia, A. multidens}

Ambas as espécies possuem distribuição restritas, sendo registradas apenas para o Alto Madeira (Alto Beni para A. multidens e Alto Beni e Chapare para A. sp. nova Bolívia). Estão restritas aos rios de água mais fria que vertem pela face oriental Andina. Segundo a presente análise Astyanacinus sp. nova Bolívia é a espécie mais basal do gênero.

\section{Biogeografia de Astyanacinus sp. nova Purus}

A espécie é conhecida de apenas um lote com três exemplares. Apesar de ser o suficiente para reconhecer a validade como uma espécie nova a restrita distribuição e a impossibilidade de incluí-la na análise filogenética inviabiliza maiores comentários sobre sua biogeografia. O único comentário possível é que a espécie está registrada no Alto Purus seguindo assim o padrão das outras espécies de Astyanacinus de não estarem distribuídas no Baixo e Médio Amazonas.

\section{Considerações sobre a distribuição do gênero Astyanacinus}

Apesar de o gênero ter ampla distribuição nos continentes Central e Sulamericano e, provavelmente ter surgido durante o Paleo-Amazonas-Orinoco, nenhuma das espécies de Astyanacinus ocorre em rios efetivamente da planície Amazônica (figura 14). A partir disso é possível formular duas hipóteses acerca dessa distribuição. Na primeira, o grupo seria fortemente influenciado pela altitude e não ocorreria na Planície Amazônica por fatores que dificultariam sua adaptação. Como exposto em Castro (1999) peixes de cabeceiras de rios possuem elevados requisitos ecológicos e baixa capacidade de deslocamento ativo, talvez a grande turbidez e a menor oxigenação da água sejam fatores importantes na limitação da distribuição de Astyanacinus. Entretanto, essas correlações fornecem evidências que podem circunstanciais e não necessariamente indicariam relações causais diretas. Seguindo o moderno conceito de nicho multidimensional de Hutchinson (1957), a restrita distribuição de Astyanacinus às regiões altas-cisandinas pode ser, acima de tudo, resultado de variáveis múltiplas e interativas bastante complexas. 
Na segunda, a distribuição atual de Astyanacinus seria explicada pela teoria de refúgios. Ela sugere que transgressões marinhas pretéritas teriam extinguido as populações de peixes de água doce que ocorriam nas regiões mais baixas e somente as populações que ocorriam em regiões com maior altitude e, por isso não eram afetadas pela influência marinha, sobreviveram. Com isso, as regiões altas funcionariam como uma espécie de refúgio. Uma evidência em favor dessa hipótese é o registro de uma grande transgressão marinha no Mioceno (Hoorn, 1993; Räsänen et al., 1995; Monsch, 1998) exatamente no região de alta diversidade de Astyanacinus, os sistemas fluviais do Alto Amazonas.

Por fim, a configuração geral da distribuição do gênero Astyanacinus, até onde foi possível estudar, é única. Como discutido acima, isoladamente cada uma das espécies do gênero apresenta distribuição correspondente em diversos outros grupos de peixes, porém quando considerado como um todo, a distribuição do gênero é singular. Essa singularidade é baseada na combinação padrões de distribuição comuns, porém não no mesmo grupo de peixes. Os padrões foram: ausência de espécies na Planície Amazônica com espécies restritas ao Alto Amazonas, espécie restrita às cabeceiras do Rio Paraguai, espécie restrita à Bacia do Rio Orinoco e espécie com distribuição TransAndina Atrato-San Juan + rios do Panamá.

Apesar da pouca informação disponível sobre a distribuição de peixes Neotropicais, o gênero que apresentou distribuição mais semelhante de Astyanacinus foi Aphanotorulus (Loricariidae). Como demonstrado na figura 16, esses gêneros compartilham os padrões: ausência de espécies na Planície Amazônica com espécies restritas ao Alto Amazonas e espécie restrita à Bacia do Rio Orinoco. Diferenciam-se pela ausência de uma espécie restrita às cabeceiras do Rio Paraguai e de uma com distribuição Trans-Andina Atrato-San Juan + rios do Panamá em Aphanotorulus. 


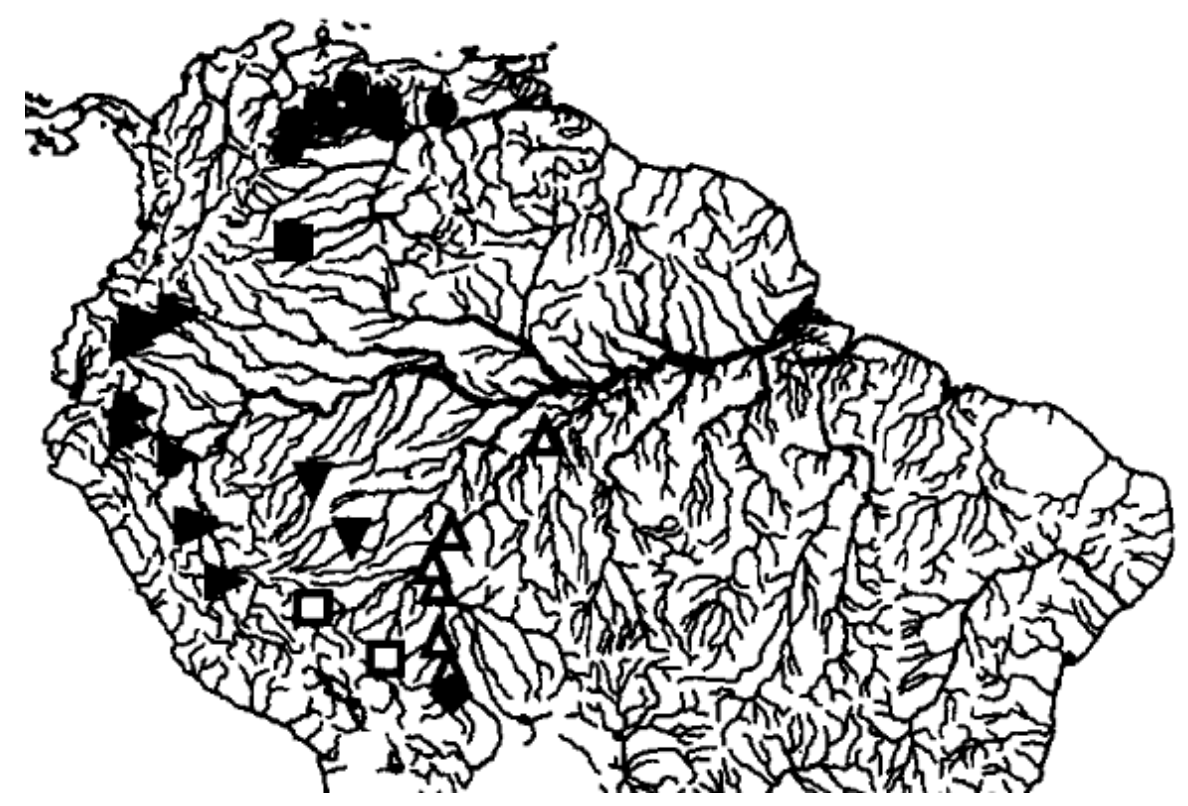

Figura 16. Distribuição das espécies de Aphanotorulus (retirado de Armbruster \& Page, 1996).

\section{Diferenciação de Astyanacinus}

Embora as idades dos eventos geológicos responsáveis pela cladogênese de Astyanacinus moorii (captura da cabeceiras 10 Ma), “Astyanax” orthodus (formação da Cordilheira Oriental 12-10 Ma) e “Astyanax" superbus (Arco Vaupes 8 Ma) pareçam ser muito antigas para o estabelecimento da disjunção geográfica das espécies a presença de um evento geográfico por volta de somente 3 Ma (intercâmbio faunístico entre o Oeste Sul-americano e Ístmo do Panamá) não foi suficientemente antiga para que as populações desses dois continentes acumulassem diferenças de forma significativa para serem consideradas espécies diferentes. Assim como ocorre em “Astyanax” orthodus em que há enorme congruência morfológica entre as populações centro-americanas e do Rio Atrato, Vari (1995) (em Ctenolucius beani), Lucena (2000) (em Roeboides ocidentalis) e Bertaco (2008) (em Hemibrycon dariensis) também consideraram que as populações dessas espécies nesses dois continentes não são espécies diferentes e sim somente populações distintas.

Assim como reportado para vários grupos de peixes Neotropicais, as espécies do gênero Astyanacinus devem ter experimentado pouca diferenciação morfológica durante os últimos milhões de anos. A pouca diferenciação morfológica dos fósseis apresentados por Lundberg (1998) com relação à ictiofauna neontológica, a pouca 
diferenciação de Salminus (Lima, 2006) e a discussão de Castro \& Vari (2004) sobre a estase em Prochilodontidae são alguns exemplos de que talvez essa pouca diferenciação tenha sido bastante comum em certos períodos da história evolutiva da ictiofauna Neotropical. 


\section{COMENTÁRIOS SOBRE OS OUTROS CLADO OBTIDOS NA FILOGENIA}

Na presente análise a família Characidae é recobrada como monofilética se incluir as famílias Acestrorhyncidae, Cynodontidae e Gasteropelecidae, resultado semelhante ao proposto por Moreira (2007) e Mirande (2010). Segundo o segundo autor as duas primeiras famílias seriam inclusas em Characidae enquanto que Gasteropelecidae seria parte de Characoidea, mas não um Characidae.

Assim como em diversos trabalhos lidando com a filogenia dos caracídeos, Brycon é obtido como um táxon basal, talvez a mais plesiomórfica forma da família. Outros táxons previamente propostos como basais em Characidae como Bryconops e Salminus também tem sua posição plesiomórfica confirmada.

Da mesma forma como proposto aqui, Lucena (1993), Lucena \& Menezes (1998), Moreira (2007) e Mirande (2007) propõem as famílias Acestrorhyncidae e Cynodontidae como sendo irmãs. A posição basal de Agoniatinae em Characidae é recobrada assim como em Uj (1990), Lucena (1993) e Mirande (2010). No presente trabalho a estreita relação de parentesco entre Agoniatinae e Acestrorhyncidae + Cynodontidae é proposta assim como em Mirande (2009; 2010).

A hipótese de Castro \& Vari (1990) e Malabarba (1998) de uma proximidade filogenética entre Triportheus e Lignobrycon também é recobrada. Diferentemente do proposto por Mirande (2010), no presente trabalho esse clado seria mais proximamente relacionado à Gasteropelecidae e Engraulisoma + Clupeacharax. A hipótese de Castro (1984) da relação entre Engraulisoma + Clupeacharax é corroborada com sinapomorfias adicionais. A proximidade evolutiva entre Gasteropelecidae e Engraulisoma + Clupeacharax proposta por Mirande (2010) é confirmada.

A monofilia dos Tetragonopterinae sensu Géry (1977) que corresponde ao clado sem supra-orbital de Malabarba \& Weitzman (2003) e clado 205 de Mirande (2010) é corroborada. A monofilia da subfamília Characinae bem como sua posição basal dentro dos caracídeos sem supra-orbital é recobrada. A hipótese de Quevedo (2006) e Thomaz et al. (2010) sobre a afinidade de parentesco entre Rachoviscus e Hollandicthys é confirmada.

A composição da subfamília Tetragonopterinae proposta por Mirande (2010) com base na posse de dois pares de uroneurais não é confirmada. No presente trabalho a subfamília apresenta extensa polifilia, apesar de que a monofilia de algumas das suas 
subunidades é confirmada. Por exemplo, o clado 221de Mirande (2010) correspondente ao grupo dos caracídeos de corpo alto e, segundo o autor, incluso na subfamília Tetragonopterinae, é recobrado com algumas diferenças como, por exemplo, a inclusão de Markiana e Ctenobrycon.

Apesar de próximos na filogenia, Aphyocharacinae e Cheirodontinae não são recobrados como relacionados ao Clado A de Malabarba \& Weitzman (2003) (=Stevardiinae de Mirande (2010)), mas apresentam uma posição relativamente basal entre os caracídeos sem supra-orbital, resultado semelhante ao proposto por Moreira (2007). Apesar do baixo de suporte, o gênero Astyanax é obtido como uma unidade monofilética e proximamente relacionada à Astyanacinus. O clado A de Malabarba \& Weitzman (2003) ou Stevardiinae de Mirande (2010) é recobrado como uma unidade monofilética. A clado Piabina + Creagrutus é corroborado conforme proposta prévia de Vari \& Harold (2001). 


\section{PISCIVORIA EM CHARACIDAE}

Segundo Lauder (1981) três principais fatores devem ser considerados para se explicar a forma de uma dada estrutura: como ela é produzida, sua função e sua história evolutiva. Ainda segundo o autor é necessário testar a hipótese de morfologia funcional reconhecendo que todas as hipóteses morfológicas são históricas e devem estar inseridas no contexto evolutivo; a importância da organização hierarquizada para compreender os padrões de altercações estruturais e funcionais durante o curso do tempo; e compreender o papel crucial de filogenias corroboradas para permitir o teste de hipóteses históricas.

A morfologia funcional da alimentação merece detalhado interesse porque está intimamente ligada a todos os aspectos da evolução e biologia dos peixes (Helfman et al., 1997; 2009). Adaptações relacionadas à alimentação claramente envolvem estruturas envolvidas na aquisição e processamento de alimentos como modificações em ossos das maxilas, músculos, dentes, rastros branquiais e no trato digestório (Helfman et al., 1997; 2009) e com os Characidae não é diferente.

Estudos versando sobre convergência adaptativa tendo a alimentação como plano de fundo não são comuns, mas existem alguns exemplos como, por exemplo, trabalhos sobre ocorrência de zooplanctívoros em Acanthuroidei (Winterbottom \& McLennan, 1993); piscívoros de Ciclídeos e Centrarquídeos (Norton, 1993) e durofagia em Carangidae, Scienidae e Haemulidae (Grubich, 2003).

Neste capítulo serão abordadas a convergência adaptativa e as modificações morfológicas que as diferentes linhagens piscívoras de Characidae adquiriram.

Em geral, estudos envolvendo ecologia trófica de peixes buscam identificar os hábitos alimentares através da análise dos principais itens consumidos pelas espécies (Bennemann et al., 2006). Muitas vezes a definição dessas guildas em peixes Neotropicais de água doce é bastante complexa uma vez que esses peixes podem sofrer alterações de dieta sazonais, ontogenéticas e além de, muitas vezes, apresentar um amplo espectro alimentar composto por matéria orgânica advinda de diversas origens. Soma-se a isso o fato de que o conjunto mais acessível de informações alimentares de peixes é obtido de forma indireta através do exame de conteúdos gástricos (Windell \& Bown, 1978; Bennemann et al., 2006), havendo problemas na quantificação dos itens devido ao estado de digestão. Assim, a fim de simplificar as dificuldades e discussões atreladas à complexidade das guildas é necessário que seja feita uma aproximação das 
guildas dos Characidae. Assim, para esta discussão atribuirei três guildas aos Characidae: piscívoros especializados e.g. Acestrorhynchus (peixes com especializações à piscivoria e que se alimentam primordialmente de peixes), generalistas e.g. Brycon (alimentam-se de invertebrados, matéria vegetal e pequenos peixes) e invertívoros e.g. Astyanax (alimentam-se essencialmente de invertebrados e, em menor escala, de matéria vegetal). Tais agrupamentos tróficos são obviamente insuficientes para abarcar toda a complexidade de guildas dos caracídeos, mas para que informações filogenéticas sejam extraídas e relacionadas aos níveis tróficos essa aproximação e simplificação das guildas, quando criteriosa, é extremamente útil e necessária.

A partir da hipótese de Mirande (2010) (figura 17) é possível tecer algumas hipóteses acerca da evolução do hábito piscívoro em Characidae. Segundo o mesmo, Characidae é um agrupamento monofilético com a inclusão de Cynodontidae e Acestrorhynchidae, além da exclusão de Gasteropelecidae e Serrasalmidae. Na topologia de consenso os caracídeos são recobrados como grupo-irmão de Alestidae. Zanata \& Vari (2005) propõem o monofiletismo da família africana Alestidae com a inclusão do gênero sul-americano Chalceus. Na topologia obtida por Mirande (2010) Characidae é composta por dois clados: o primeiro formado pelas subfamílias Bryconinae, Salmininae, Agoniatinae, Cynodontinae e Acestrorhynchinae; o segundo por todas as outras linhagens de caracídeos.

Antes de tecer hipóteses sobre o surgimento do hábito piscívoro em Characidae é preciso discutir a polarização deste caráter comportamental na família. Como dito anteriormente, segundo Mirande (2010) a família Characidae é obtida como grupo-irmã de Alestidae e, sendo assim, antes de considerar o hábito piscívoro em Characidae apomórfico ou plesiomórfico faz-se necessário examinar os hábitos alimentares dos alestídeos mais plesiomórficos. Para Zanata \& Vari (2005) todos alestídeos-africanos são grupo-irmão de Chalceus, um grupo de peixes generalistas que se alimentam essencialmente de invertebrados e matéria vegetal, mas que eventualmente pode ter pequenos peixes em sua dieta. Dos alestídeos africanos, o mais plesiomórfico é o gênero Arnoldichthys que apresenta hábito alimentar bastante similar ao de Chalceus. Os grupos mais plesiomórficos dentro dos dois clados de Characidae de Mirande (2010) possuem hábitos generalistas muito semelhantes ao encontrado nas formas mais plesiomórficas de Alestidae. Dessa forma, é razoável supor que o ancestral comum de 
Alestidae e Characidae tinha hábito generalista e a aquisição de adaptações à piscivoria deve ser interpretada como uma derivação em ambas as famílias.

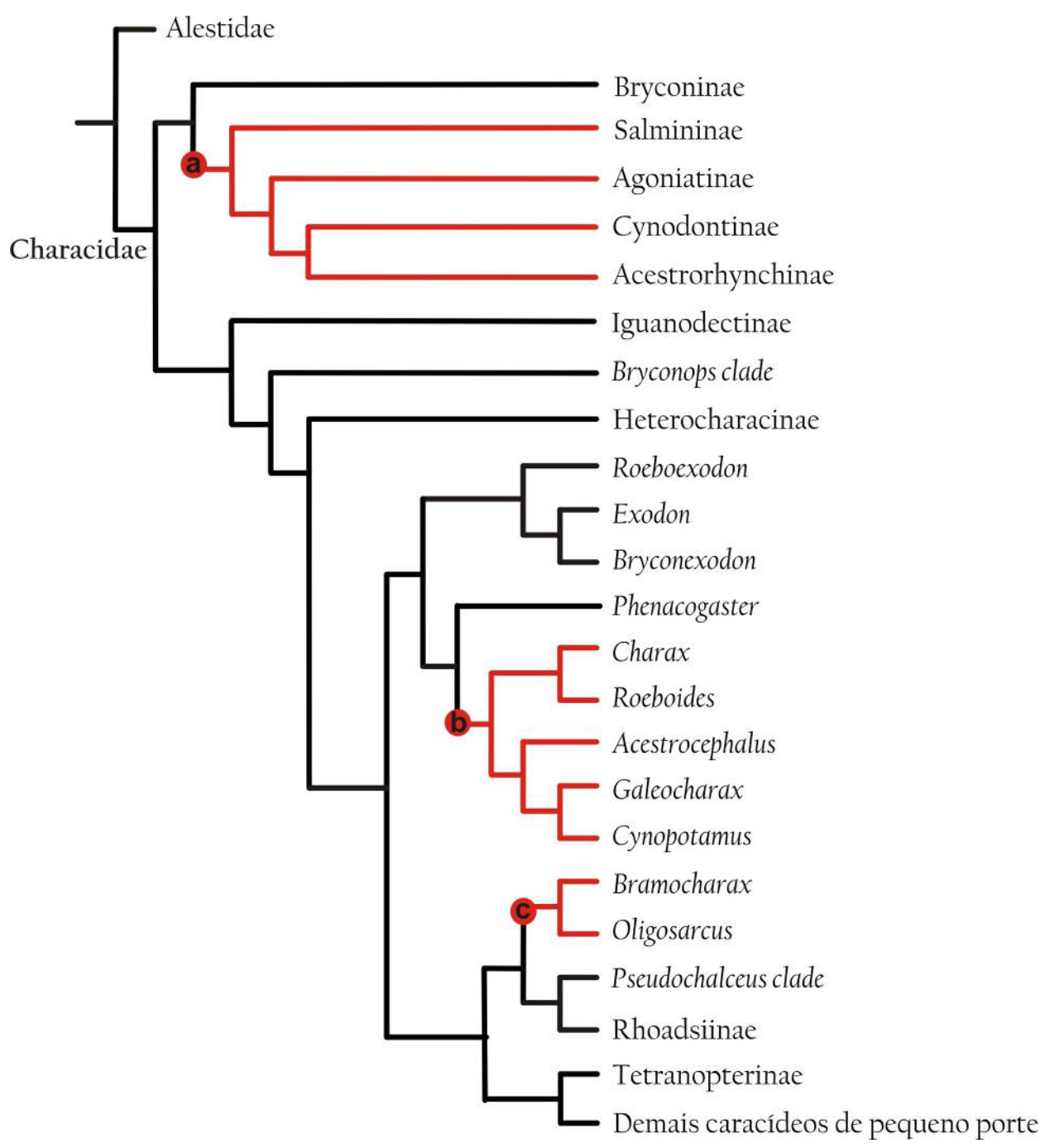

Figura 17. Hipótese resumida de Mirande (2010) sobre as relações evolutivas entre os Characidae.

Examinando a topologia de Characidae de Mirande (2010) é possível interpretar que a especialização à piscivoria teria ocorrido em três clados independentemente. $\mathrm{O}$ primeiro (clado a figura 17) formado por Salmininae - Agoniatinae - Cynodontinae Acestrorhynchinae. Todos os membros deste clado são piscívoros especializados, exceto Agoniates que possui dieta essencialmente composta por pequenos peixes, mas também pode se alimentar de invertebrados (cf. Camargo et al., 2005). O outro clado (clado b figura 17) é composto pelos Characinae piscívoros (clado 211 de Mirande, 2010) e formado pelos gêneros Acestrocephalus, Charax, Cynopotamus, Galeocharax e Roeboides. Todas as espécies deste clado são piscívoros especializados, exceto algumas 
espécies de Roeboides que se alimentam também de insetos, crustáceos e escamas (cf. Novakowski et al., 2004). O último (clado c figura 17) é o clado 275 (Bramocharax clade) de Mirande (2010) composto pelos gêneros Bramocharax e Oligosarcus. De maneira geral, as espécies desses dois gêneros são piscívoras, porém não exclusivamente sendo que algumas delas também podem se alimentar de insetos e crustáceos (cf. Gealh \& Hahn, 1998; Hermes-Silva et al., 2004; Nunes \& Hartz, 2006). É necessário dizer que algumas espécies de caracídeos não pertencentes a esses três clados também podem eventualmente se alimentar de peixes, porém não de forma essencial como os que denominei de piscívoros. Há, por exemplo, registros de espécies de Astyanacinus e Hollandichthys se alimentando de peixes, porém essa ingestão é ocasional sendo que a dieta dessas espécies é essencialmente constituída de insetos. Por outro lado, há o caso de algumas espécies Brycon que apesar de também se alimentarem de peixes, são a mais clara representação do termo generalista. Até agora nenhuma das espécies de Brycon é reconhecida como exclusivamente piscívora e todas as que possuem registros de peixes em sua alimentação também apresentam frutos e insetos em sua dieta e por isso devem ser consideradas como generalistas e não piscívoras.

Dessa forma, a partir da análise do cladograma proposto por Mirande (2010) é possível propor a ocorrência da piscivoria somente em três clados e é mais parcimonioso conjecturar que adaptações ao este comportamento tenham surgido de forma independente nos três clados de Characidae anteriormente elencados do que por outro cenário diferente. Apesar de o hábito piscívoro ter surgido independentemente nas três linhagens listadas anteriormente e, segundo Mirande (2010), não haver relação de parentesco tão próxima entre elas, há congruências morfológicas entre os peixes que as compõem.

Tais congruências são adaptações ao modo de vida piscívoro e consistem basicamente em especializações anatômicas para captura de presas. Tal como esperado, essas adaptações morfológicas à alimentação envolvem principalmente alterações na morfologia bucal e estruturas relacionadas.

\section{Modificações na amplitude de abertura bucal}

Um recorrente padrão entre diversas linhagens de teleósteos piscívoros é o desenvolvimento de uma ampla abertura bucal que favorece a captura de presas inteiras. Nas três linhagens piscívoras de Characidae há modificações semelhantes que permitem 
ao peixe uma maior amplitude de abertura bucal, são elas: alongamento dos ossos dentário e maxila, e articulação quadrado-articular mais posteriormente ao corpo. Tais características permitem ao peixe uma maior amplitude de abertura bucal sem aumentar o ângulo de abertura da boca (figura 18).
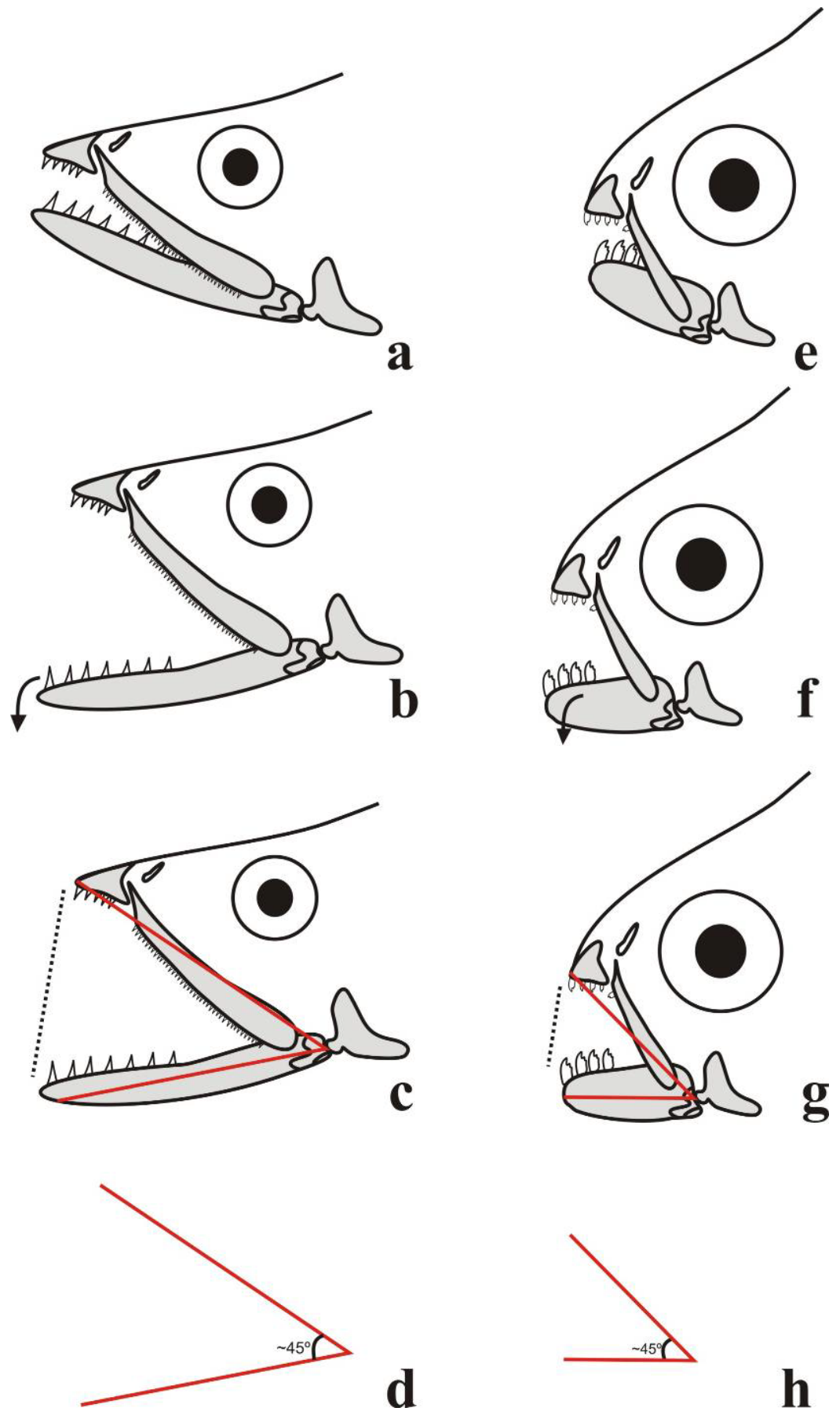

Figura 18. a-c Abertura bucal de um Characidae piscívoro generalizado. e-g Abertura bucal de um Characidae invertívoro generalizado. d,h mesmo ângulo de abertura bucal para os dois morfótipos. 

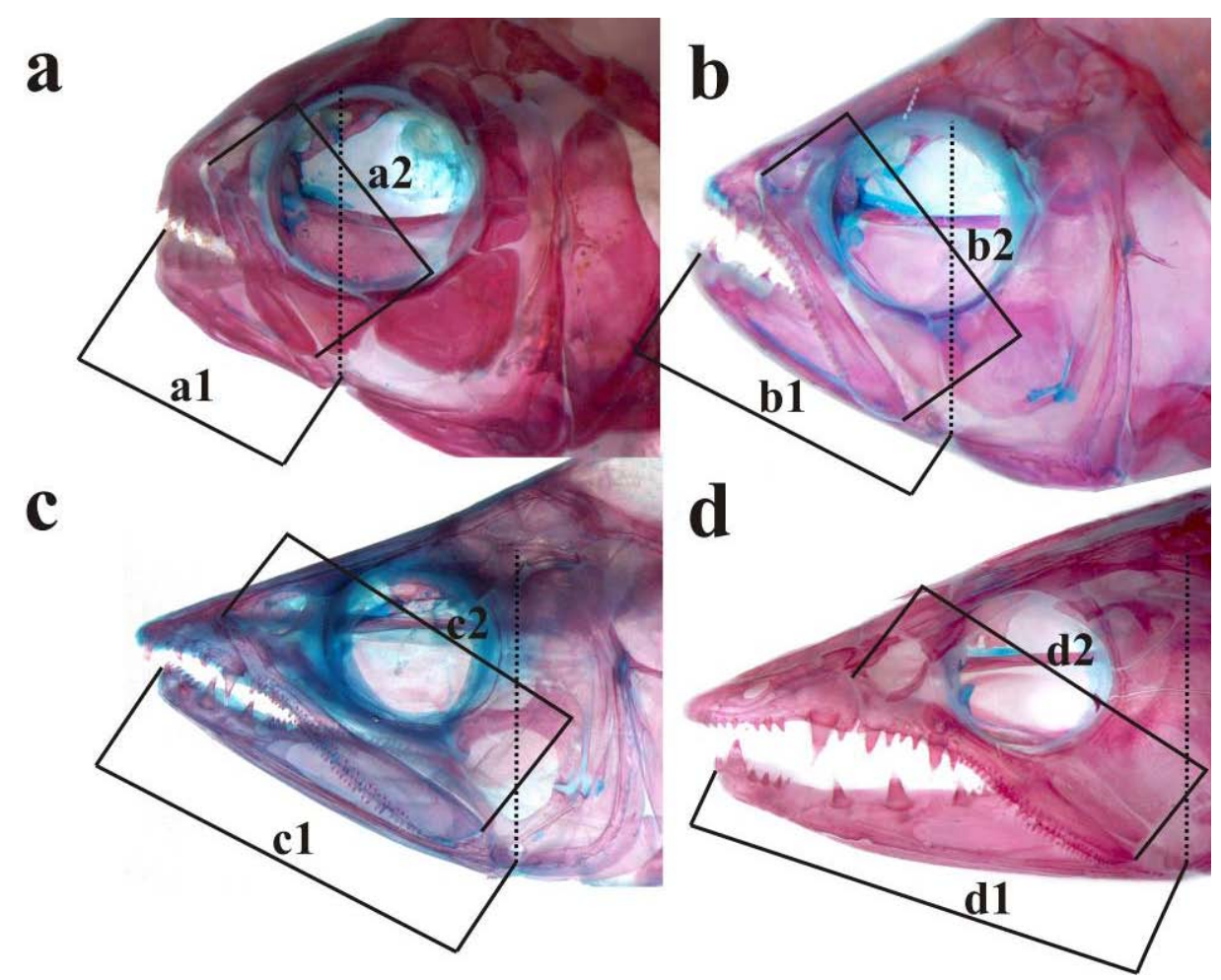

Figura 19. Vista lateral esquerda de: a. Deuterodon iguape LIRP 1049 (66,67 mm CP); b. Oligosarcus pintoi LIRP 300 (82,06 mm CP); c. Galecharax knerii LIRP 4081 (137 mm CP); d. Acestrorhynchus falcatus LIRP 5115 (128,6mm CP). Número 1 representa comprimento do dentário e 2 comprimento da maxila.

Caracídeos piscívoros apresentam, proporcionalmente, os ossos dentário e maxila mais longos do que a grande maioria das outras linhagens de Characidae. Como pode depreender-se da figura 19, nos piscívoros o dentário é sempre maior que o diâmetro da órbita ao passo que nos outros caracídeos o dentário é quase sempre aproximadamente do mesmo diâmetro. Com relação à maxila o mesmo padrão é encontrado, porém é necessário ressaltar que o alongamento do osso maxilar também ocorre em linhagens não-piscívoras de Characidae como Astyanacinus, Pseudochalceus, Hollandichthys, Nematocharax, Rhoadsia e Paragoniates.

\section{Dentição}

Como ressaltam Helfman et al. $(1997 ; 2009)$ a presa que um peixe come e como essa presa é capturada são previstas a partir do tipo de dente que um peixe possui. Um padrão óbvio, mas também presente nas três linhagens piscívoras de Characidae é o 
desenvolvimento de dentes puntiformes e cônicos. O grau de desenvolvimento desses dentes é variável dentro dos grupos de caracídeos piscívoros, com casos como os de membros de Acestrorhynchinae e Cynodontinae que apresentam extremo desenvolvimento de dentes cônicos, dentes caniniformes. Os membros de Agoniatinae apresentam enormes caninos no dentário e na pré-maxila possuem dentes puntiformes quase cônicos, não fosse pela presença de uma pequena cúspide posterior. Em Salmininae tanto na pré-maxila quanto no dentário a dentição é formada por unidades alongadas e puntiformes que, como descreve Lima \& Britski (2007), possuem cúspides laterais reduzidas quase indiferenciáveis. Semelhante é o padrão encontrado nos gêneros Bramocharax e Oligosarcus do clado Bramocharax de Mirande (2010). Neles estão presentes dentes multicuspidados (geralmente pentacuspidados), porém diferentemente da grande maioria dos Characidae, há severa atrofia das cúspides laterais sendo a cúspide central muito mais desenvolvida e puntiforme do que as mais laterais. Dessa forma, apesar de apresentar ligeiras diferenças com relação ao formato e ao grau de desenvolvimento dos dentes é latente que entre os caracídeos piscívoros há um padrão de redução das cúspides laterais em oposição ao desenvolvimento da cúspide central além do alongamento da base do dente.

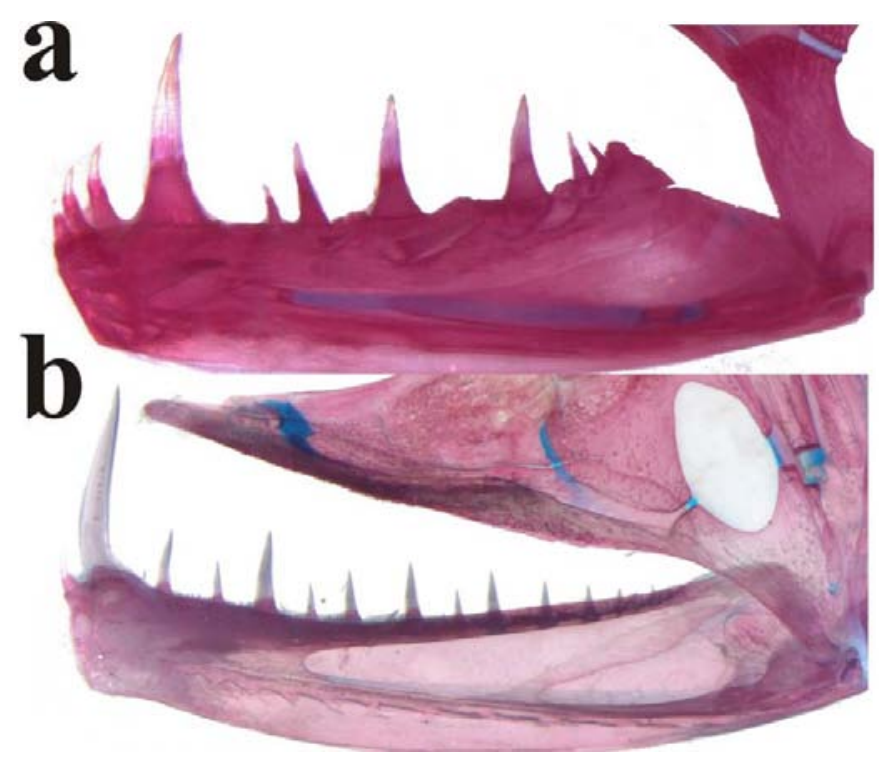




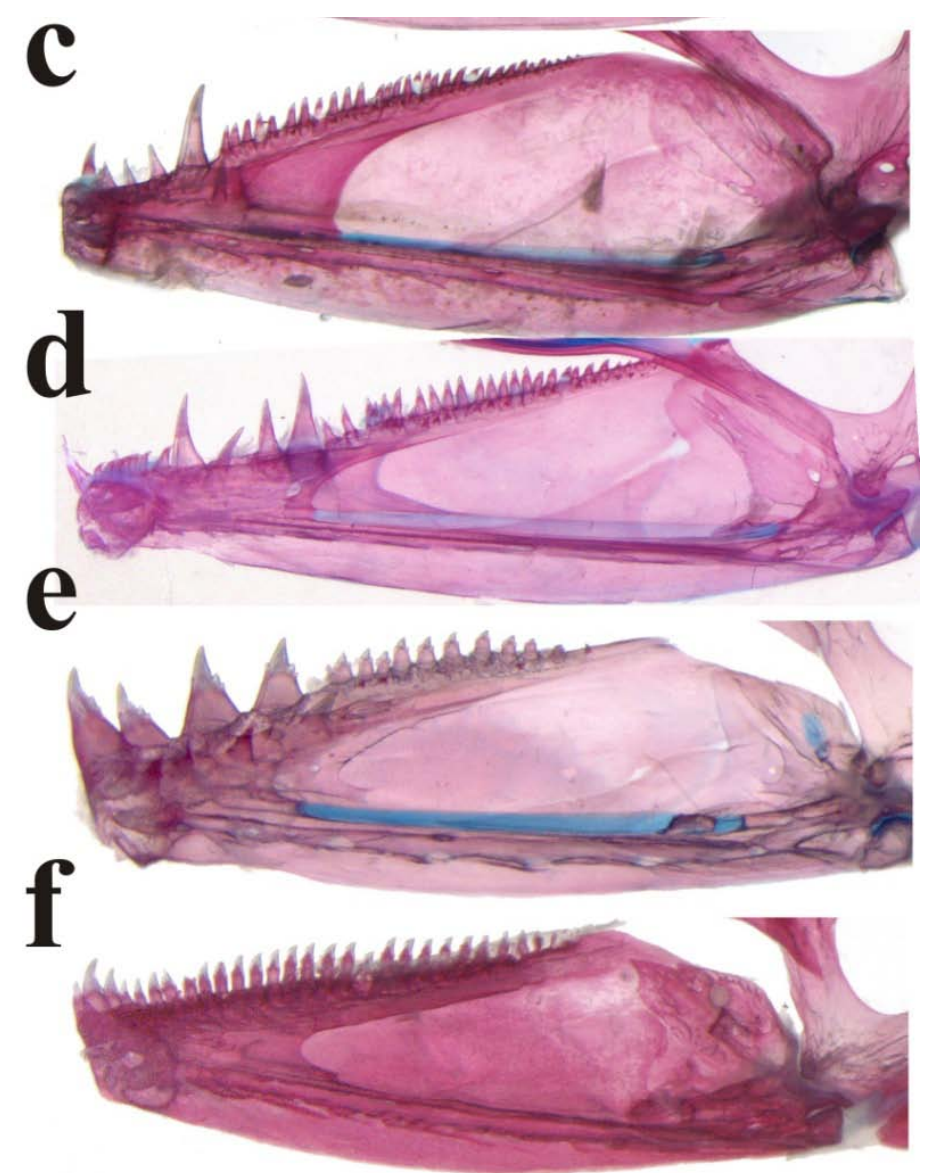

Figura 20. Vista medial da mandíbula de: a. Agoniates halecinus MZUSP 92807 (104,8mm CP); b. Hydrolycus scomberoides LIRP 5943 (133,23 mm CP); c. Charax leticiae LIRP 5998 (67,8mm CP); d. Galecharax knerii LIRP 4081 (137 mm CP); e. Oligosarcus pintoi LIRP 300 (82,06 mm CP); f. Salminus hilarii LIRP 369 (122,87 mm $\mathrm{CP})$.

Como dito anteriormente o desenvolvimento de um maxilar alongado é um dos padrões encontrados em todos os caracídeos piscívoros. Além disso, a maxila desses caracídeos apresentam quase toda sua margem anterior cravada por dentes que, acompanhando o padrão da dentição de piscívoros anteriormente discutido, são cônicos ou com cúspides laterais reduzidas como no caso dos gêneros do clado Bramocharax+Oligosarcus. 


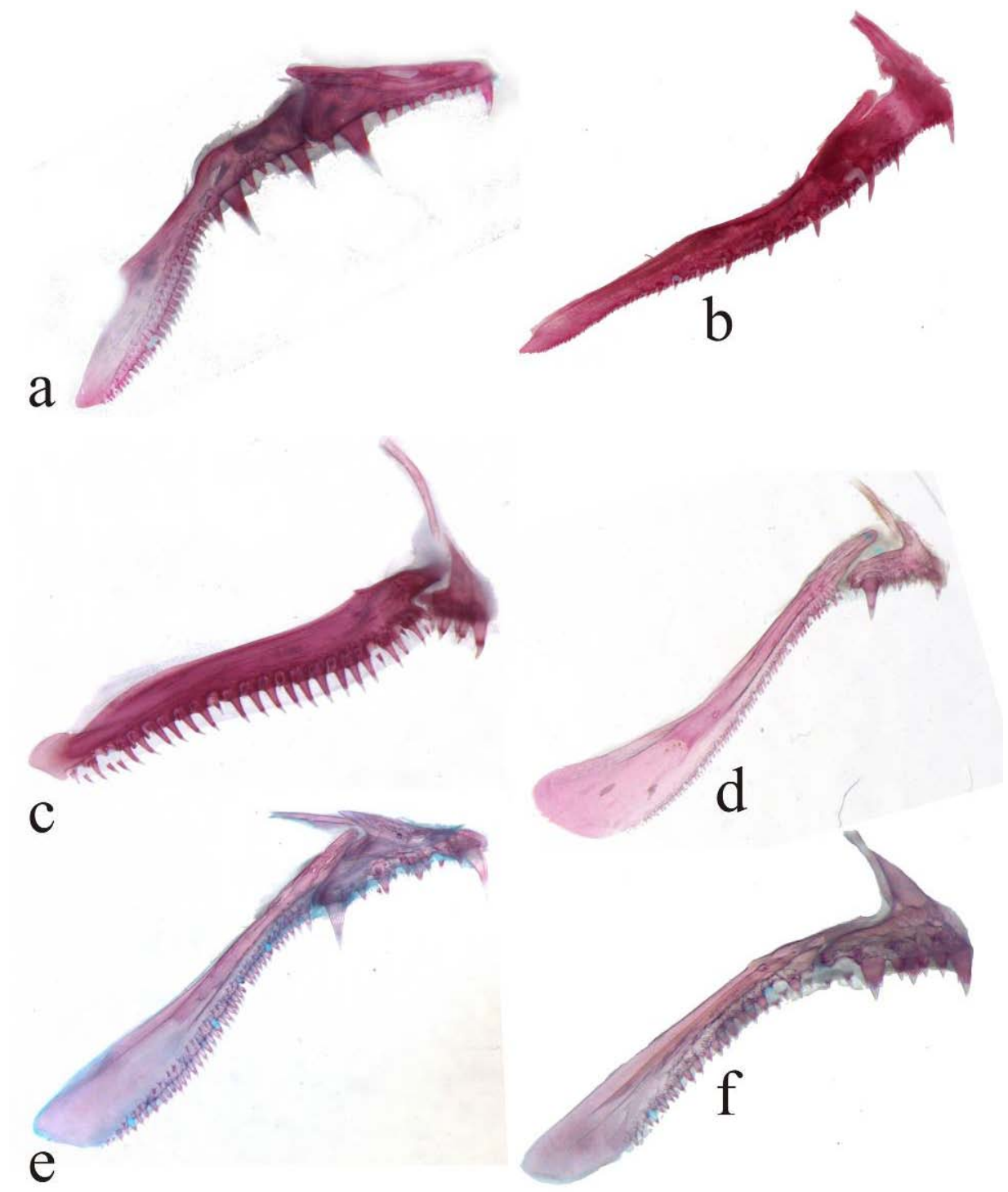

Figura 21. Vista lateral da maxila superior de: a. Acestrorhynchus falcatus LIRP 5115 (128,6mm CP); b. Hydrolycus scomberoides LIRP 5943 (133,23 mm CP); c. Agoniates halecinus MZUSP 92807 (104,8mm CP); d. Charax leticiae LIRP 5998 (67,8mm CP); e. Galecharax knerii LIRP 4081 (137 mm CP); f. Oligosarcus pintoi LIRP 300 (82,06 mm CP).

\section{Rastros branquiais}

Outro padrão encontrado nos caracídeos piscívoros são modificações no número, no grau de desenvolvimento e na robustez dos rastros branquiais. Exceto em casos de especializações, essas estruturas tem como função evitar que fragmentos de alimentos causem danos físicos aos frágeis filamentos branquiais, posteriormente dispostos às séries de rastros. Diferentemente da maioria dos outros Characidae, nas distintas linhagens de piscívoros da família é recorrente o aumento no grau de robustez destes. 
No clado Salmininae -Agoniatinae - Cynodontinae - Acestrorhynchinae os rastros branquiais mais anteriores do primeiro arco branquial são robustos, largos e repletos de dentículos. Segundo Mirande (2010) a presença dessa forma de rastros é sinapormórfica para Acestrorhynchinae+Cynodontinae, porém exemplares de Agoniatinae e Salmininae examinados no presente trabalho também apresentam tal condição. Pelo menos em Galeocharax, é encontrada condição semelhante nos rastros mais anteriores. Mirande (2010) utiliza esta condição como sinapomórfica para o clado Cynopotamus+Galeocharax. De forma geral os outros Characinae examinados e os membros do clado Bramocharax apresentam rastros branquiais bastante robustos, em menor número e alongados. Apesar das diferentes linhagens de Characidae piscívoros apresentarem condições distintas para as modificações nos rastros branquiais, elas estão, ao que tudo indica, relacionadas ao hábito piscívoro.

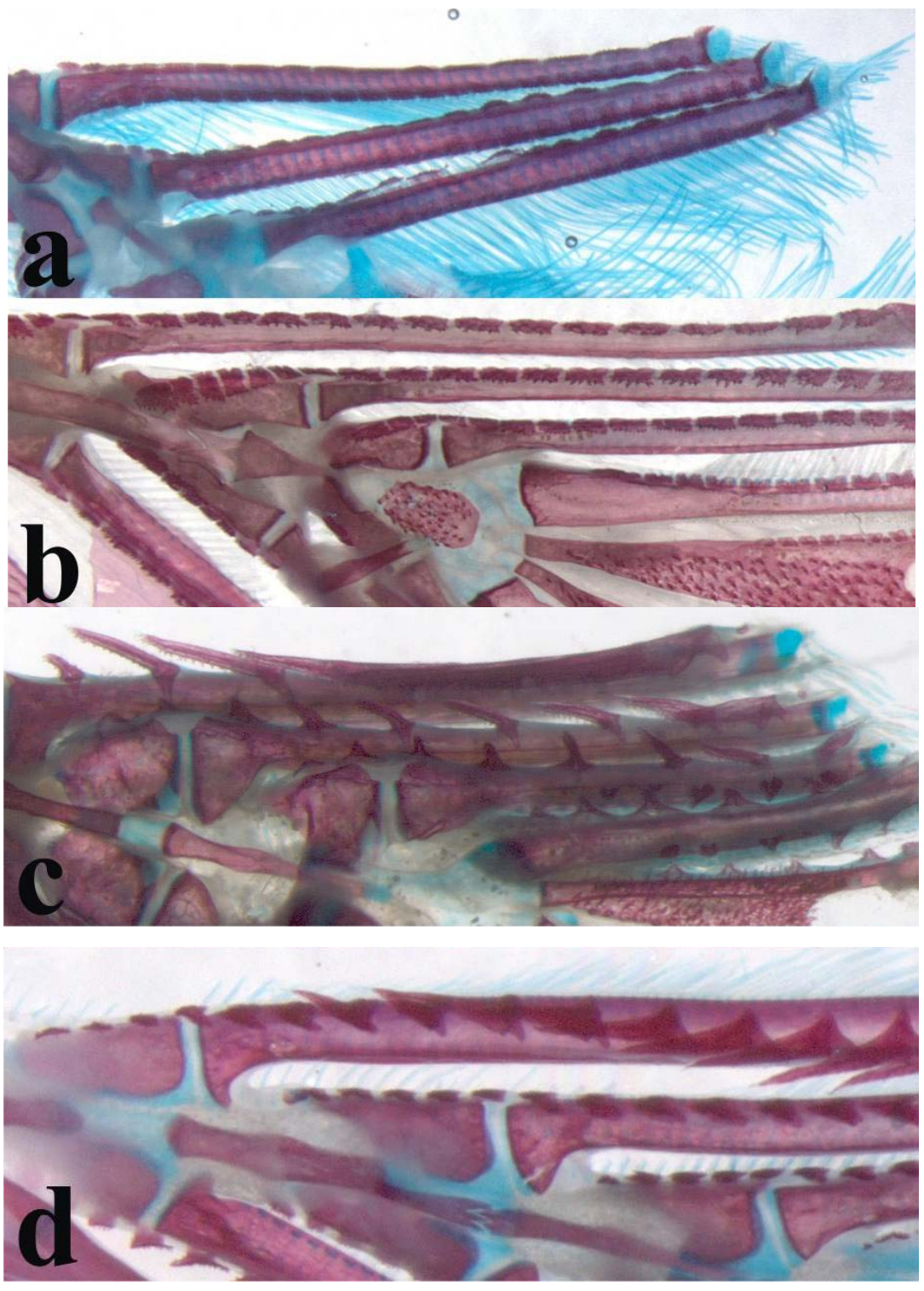


Figura 22. Vista dorsal da porção direita da cesta branquial de: a. Hydrolycus scomberoides LIRP 5943 (133,23 mm CP); b. Acestrorhynchus falcatus LIRP 5115 (128,6mm CP); c. Charax leticiae LIRP 5998 (67,8mm CP); d. Agoniates halecinus MZUSP 92807 (104,8mm CP).

\section{Conclusões}

Com base no cladograma proposto por Mirande (2010) as adaptações ao comportamento piscívoro surgiram de forma independente em três clados de Characidae. Algumas adaptações ao modo de vida piscívoro são compartilhadas por todos os três clados e essas características são paralelismos, ou seja, adaptações convergentes entre essas diferentes linhagens. Algumas dessas modificações são: alongamento dos ossos dentário e maxila, articulação quadrado-articular mais posteriormente ao corpo, dentição com redução das cúspides laterais e rastros branquiais robustos.

Como dito anteriormente o clado Bramocharax é composto por espécies que, de maneira geral, não são exclusivamente dependentes da piscivoria, mas que apresentam algumas adaptações à este modo de vida. Este estudo comprova que esse menor grau de especialização à predação de peixes é refletido em menor especialização morfológica das espécies se comparadas com os outros clados de Characidae piscívoros. Alguns exemplos de estruturas morfológicas não radicalmente adaptados à piscivoria como em outros clados são: presença de cúspides nos dentes do dentário desenvolvidas, menor maxila, articulação articular-quadrado mais anteriormente. 


\section{MONOFILIA E POSIÇÃO FILOGENÉTICA DA SUBFAMÍLIA AGONIATINAE}

Agoniatinae é uma subfamília de Characidae muito pouco conhecida composta somente pelo gênero Agoniates com duas espécies descritas válidas (A. halecinus e $A$. anchovia) (Zarske \& Géry, 1997; Lima \& Zanata, 2003; Lima, 2007; Eschmeyer \& Fong, 2011). Ambas as espécies possuem tamanho médio (cerca de $20 \mathrm{~cm} \mathrm{CP}$ ) e ocorrem primariamente na Bacia (Lima \& Zanata, 2003). Diferentemente de outros caracídeos, assemelha-se bastante externamente aos Clupeiformes por apresentar corpo alongado e prateado. De acordo com Zarske \& Géry (1997) e considerando o baixo número de espécimes depositados em coleções ictiológicas, as espécies de Agoniates aparentam serem táxons raros. A ecologia e o comportamento de ambas as espécies são quase desconhecidas e nenhum trabalho explora esses tópicos exclusivamente para alguma espécie do gênero. Ambas as espécies compartilham uma dentição distinta composta por dentes caniniformes bastante desenvolvidos (mais uma característica incomum entre os caracídeos) o que reflete um hábito de carnívoro (Goulding et al., 1988; de Mérona et al., 2001; Camargo et al., 2005).

A relação filogenética entre Agoniatinae e os outros Characidae é bastante controversa. Apesar de diversos pós-graduandos (e.g. Uj, 1990, Lucena, 1993; Zanata, 2000; Moreira, 2007; Cavallaro, 2010; Datovo, 2010) terem incluídos espécimes de Agoniates em suas análises filogenéticas nenhum desses trabalhos foram publicados ainda. Apesar disso, há quatro trabalhos publicados que apresentam diferentes hipóteses para as relações de parentesco entre Agoniatinae e os Characidae (Géry, 1962 figura 23.a; Malabarba \& Weiztman, 2003 figura 23b; Mirande, 2009, 2010 figura 23c).

Em um contexto pré-cladístico, Géry (1962) sugeriu que Agoniates era proximamente relacionado com Clupeacharax, Triportheus e Moojenichthys (= Lignobrycon). Com base em duas plesiomorfias (posse do osso supra-orbital e ausência de ganchos nas nadadeiras) Malabarba \& Weiztman (2003) concluíram que Agoniates é possivelmente mais relacionado com Chalceus, Clupeacharax e Engraulisoma. Por outro lado, segundo o mais completo estudo filogenético da família Characidae, Mirande (2009; 2010) sugere que Agoniates anchovia é grupo-irmão de um clado composto por Acestrorhynchus pantaneiro e Rhaphiodon vulpinus. 

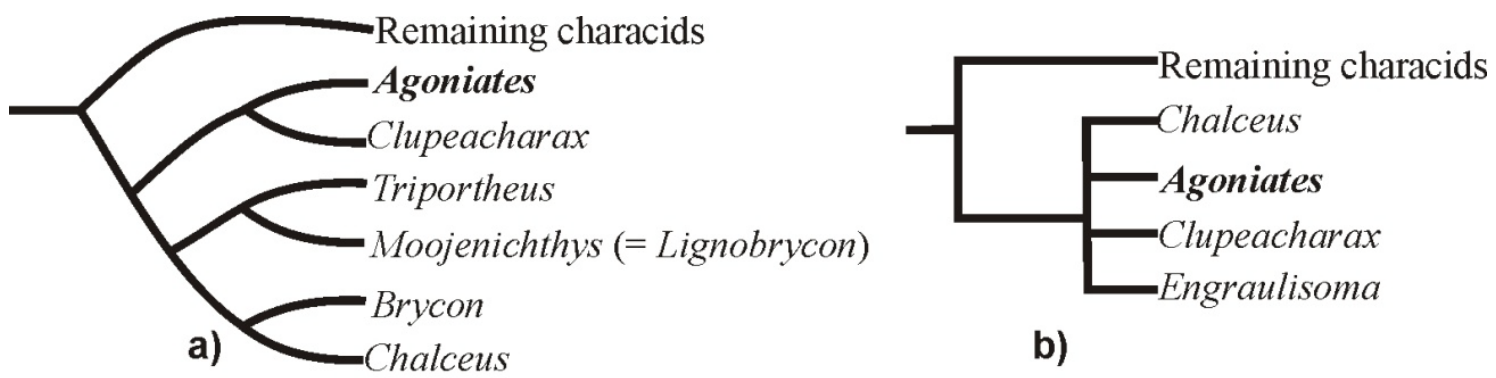

b)

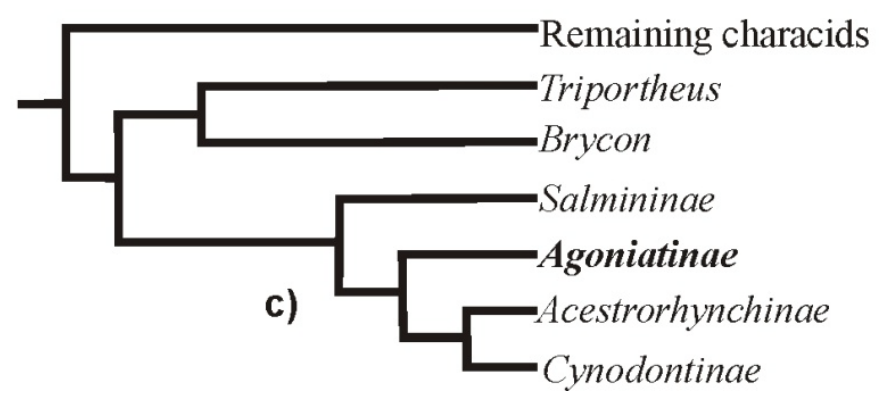

Figure 23. a) Dendograma modificado de Géry (1962); b) hipótese resumida de Malabarba \& Weiztman (2003); c) parte da topologia de Mirande (2009, 2010).

A partir da análise filogenética obtida no presente trabalho a monofilia de Agoniatinae é corroborada e as hipóteses de relações do grupo os outros caracídeos são discutidas.

\section{Monofilia de Agonitinae}

Segundo a proposta do presente trabalho a subfamília Agoniatinae tem sua monofilia corroborada com base em 15 sinapomorfias, sendo 7 delas exclusivas para o clado. A seguir são listadas e discutidas as 7 sinapomorfias exclusivas para a subfamília:

\section{Constrição na região posterior da maxila}

Agoniates apresenta uma marcante constrição na região postero-dorsal da maxila formando um entalhe na margem dorsal do osso. Aparentemente essa característica está relacionada com o contato entre a porção posterior da maxila e a superfície ventral do segundo infra-orbital. Em nenhum dos outros caracídeos examinados há condição similar, exceto em Chalceus epakros que possui um entalhe pouco desenvolvido, além disso, esse entalhe é parte de uma pequena depressão na maxila onde a supra-maxila se encaixa. Uma vez que ambas as espécies de Agoniates não apresentam supra-maxila e considerando-se trabalhos prévios indicando um posicionamento de Chalceus 
relacionado aos Alestidae (Zanata \& Vari, 2005) é possível concluir que os entalhes encontrados em Agoniatinae e Chalceus são condições diferentes.

\section{Comprimento da pré-maxila}

A pré-maxila de Agoniates é marcadamente reduzida com o comprimento de seu eixo horizontal similar à metade do comprimento do eixo vertical do osso nasal e menor que o processo ascendente da pré-maxila. A redução na pré-maxila já foi registrada em alguns grupos de Otophysi (e.g. Bivibranchia Hemiodontidae em Roberts, 1974; Corydoras em Huysentruyt \& Adriaens, 2005), mas entre os caracídeos essas condição é bastante incomum e nenhum dos peixes examinados apresentou condição similar tamanho o grau de redução apresentado pelas espécies de Agoniates. A condição mais amplamente encontrada entre os outros peixes examinados foi uma pré-maxila com comprimento maior que seu processo ascendente.

3. Quarto dente da série externa do dentário bastante desenvolvido

A presence de dentes cônicos é bastante homoplástica e é encontrada em diversos grupos não relacionados de peixes piscívoros. Entre os caracóideos Sul-Americanos essa condicao é compartilhada por Acestrorhynchidae (Roberts, 1969; Toledo-Piza, 2007), Characidae (Characinae and Agoniatinae), Cynodontidae (Toledo-Piza, 2000), Erythrinidae (Roberts, 1969) entre outros. Apesar desses peixes apresentarem os dentes mais desenvolvidos na porção anterior do dentário há diferentes padrões de arranjo na dentição. A presença de três pequenos dentes tricuspidados precedendo um dente cônico bastante desenvolvido é exclusiva das espécies de Agoniates.

4. Base do raio caudal associado à segunda placa hipural é expandida

A base do raio caudal associado à segunda placa hipural de ambas as espécies de Agoniatinae possuem uma expansão bastante desenvolvida que é similar, em tamanho, à maior altura da segunda placa hipural. Essa base expandida pode estar relacionada com a fixação de músculos na base dos raios caudais, uma condição muito comum entre os Teleostei (cf. Winterbottom, 1974). Nenhum dos outros peixes examinados apresentaram uma base expandida como reportado para Agoniates.

5. Margem ventral do uro-hial bastante convexa 
Em todos os táxons examinados o uro-hial é composto por uma lamela medial que se expande dorsalmente e ventralmente é formado por duas abas laterais. O grau de desenvolvimento dessas lamelas varia entre os Characiformes (cf. Toledo-Piza, 2007; Zanata \& Vari, 2005), mas em vista lateral a margem ventral deste osso é quase sempre reta ou ligeiramente côncava entre os caracídeos. A condição encontrada em Agoniates com a margem ventral do uro-hial marcadamente convexa é exclusiva, somente Rachoviscus apresenta condição semelhante, mas diferente do encontrado em Agoniatinae.

6. Ramo vertical do quadrado longo e grande distância entre ectopterigóide e dentário Em todos os Characidae o osso quadrado é composto por dois ramos (um vertical e um horizontal). Em Agoniates o ramo vertical é bastante longo e ultrapassa o nível da margem dorsal do dentário. Entre os caracídeos, há diferentes graus de desenvolvimento nessa estrutura, mas a condição mais comumente encontrada é a do ramo vertical quase alcançando o nível da margem dorsal do dentário. Dos peixes examinados somente as species de Acestrorhynchus e Salminus apresentaram condição semelhante, mas não tão desenvolvida como em Agoniates. Como conseqüência do alongamento do ramo vertical do quadrado os ossos ectopterigóide e dentário tornam-se bastante afastados um do outro. Em Agoniates a distância entre esses ossos é quase igual à maior altura do dentário. Com base na condição presente em todos os outros caracídeos examinados que possuem ectoperigóide e dentário em contato ou próximos é possível concluir que a condição apresentada por Agoniatinae é exclusiva.

7. Pós-cleitro 3 alongado, laminar e paralelo aos raios da nadadeira peitoral

A ausência do pós-cleitro 3 em Characidae é reportada em Engraulisoma e Clupeacharax (Castro, 1984; obs. pessoal), Triportheus e Lignobrycon (Malabarba \& Malabarba, 1998; obs. pessoal) e Xenagoniates, Leptagoniates e Gnathocharax (obs. pessoal), mas a presença de uma ossificação é a mais comumente encontrada entre os caracídeos. Quando presente o pós-cleitro é um osso com formato vermiforme geralmente posicionado quase perpendicular aos raios da nadadeira peitoral e que pode ou não apresentar uma lamela óssea posteriormente ao seu eixo vertical. A presença de um osso laminar alongado posicionado paralelamente aos raios da nadadeira peitoral é única e somente encontrada nas espécies de Agoniates. 


\section{Posição filogenética de Agonitinae}

Segundo a proposta do presente trabalho a família Characidae é formada por dois grandes clados: um deles é composto por Bryconops, Salminus, Acestrorhynchus, Agoniates, Lignobrycon, Triportheus, Thoracocharax, Engraulisoma e Clupeacharax e outro formado por diversos caracídeos de menor porte. Essa proposta é semelhante em alguns aspectos à proposta de Mirande (2010) em que Characidae é composta também por dois clados: o primeiro formado pelas subfamílias Bryconinae, Salmininae, Agoniatinae, Cynodontinae e Acestrorhynchinae; o segundo por todas as outras linhagens de caracídeos. Basicamente, as diferenças nas topologias residem na posição filogenética de Bryconops que para Mirande (2010) é parte do clado que contém a maior diversidade de Characidae e na posição dos Gasteropelecidae (sensu Mirande, 2010) que é recobrado no presente trabalho, porém como sendo parte da família Characidae e não fora da família como propõe Mirande (2010). Além disso, segundo a proposta de Mirande Gasteropelecidae é o clado mais basal de Characoidea.

Tanto o presente trabalho quanto a proposta de Mirande (2010) sugerem que Agoniatinae é grupo-irmão de Acestrorhynchinae + Cynodontinae. Esse clado é aqui sustentado por 6 sinapormorfias: disposição dos dentes heterogênea, com pequenos dentes entre os maiores anteriores caniniformes; braço vertical do quadrado muito longo, ultrapassando a borda dorsal do dentário; porção anterior do basi-hial com a mesma largura que porção posterior; rastros branquiais do primeiro hipo-branquial em forma de placas; 3 ou 4 vértebras de transição e ausência de ganchos nas nadadeiras.

Das seis sinapomorfias listadas anteriormente é importante notar que, pelo menos, duas dessas são características diretamente relacionadas ao hábito alimentar piscívoro, são elas: pequenos dentes entre os mais anteriores caniniformes e mais desenvolvidos dentes e rastros branquiais do primeiro hipo-branquial em forma de placas. Detalhes sobre a evolução dessas características são apresentados no item “Piscivoria em Characidae”, mas o agrupamento de táxons com comportamentos alimentares semelhantes tanto na presente proposta como na de Mirande (2010) chama a atenção. Como parcimoniosamente é sugerido pelas de Mirande (2010) e a do presente trabalho, tais características relacionadas à piscivoria são interpretadas como sinapomórficas para o clado Agoniatinae + Acestrorhynchinae + Cynodontinae e o texto do "Piscivoria em Characidae" utiliza essa interpretação como arcabouço para uma discussão mais aprofundada. 
Entretanto, é importante salientar que talvez em um contexto filogenético ainda mais abrangente do que o de Mirande (2010) essas características sejam re-interpretadas e todo o panorama sobre a evolução de Agoniatinae possa ser modificado. É notável o fato de Agoniatinae ser grupo-irmão de Acestrorhynchinae + Cynodontinae, porém não compartilhar com eles nenhuma característica exclusiva (exceto caráter 60, com reversão em Acestrorhynchus), ao passo que compartilha com Clupeacharax + Engraulisoma a exclusiva presença de sobreposição lateral do antorbital sobre a asa lateral do etmóide. Compartilha também com Clupeacharax + Engraulisoma e com Lignobrycon + Triportheus a rara presença de uma interdigitação mediana entre os ossos pélvicos. Além disso, compartilha com Clupeacharax + Engraulisoma diversas características que, apesar de não exclusivas, são bastante incomuns entre os caracídeos como nadadeira pélvica i+6; margem dorsal do antorbital ampla; formato do infraorbital 1 característico, com margem dorsal com menor participação na órbita que o contato entre os infra-orbitais 1 e 2 (compartilhada com Triportheus e Lignobrycon); ausência de ganchos nas nadadeiras (únicos gêneros de Characidae sensu Lima et al., 2003); ausência de lamela no osso nasal; poucos raios pró-correntes ventrais e poucos raios supranumerários na nadadeira anal. Agoniatinae ainda compartilha com Clupeacharax algumas características bastante raras como: margens anterior e dorsal da hiomandíbula convexas, presença de uma projeção afilada posterior na região dorsal da hiomandíbula e alinhamento das margens anteriores do antorbital e infra-orbital 1.

Pelas razões discutidas anteriormente, uma possível proximidade de parentesco entre Agoniatinae e o clado Clupeacharax + Engraulisoma e provavelmente com Triportheus e Lignobrycon não deve ser descartada e estudos posteriores que incluam mais táxons terminais e, principalmente, mais caracteres de outras fontes poderão trazer nova luz sobre a problemática e colocam dúvida sobre a relação de Agoniatinae com o clado Acestrorhynchinae + Cynodontinae. 
"Mais da metade do conhecimento reside em saber onde ele está.”

Anônimo

\section{Referências Bibliográficas}

ALBERT, J. S.; LOVEJOY, N. R.; CRAMPTON, W. G. R. 2006. Miocene tectonism and the separation of cis- and trans-Andean river basins: Evidence from Neotropical fishes. Journal of South American Earth Sciences, 21: 14-27.

ALONSO, A., \& DALLMEIER, F. (eds). 1998. Biodiversity Assessment of the Lower Urubamba Region, Perú: Cashiriari 3-Well Site and the Camisea and Urubamba Rivers. Smithsonian Institution/MAB Series n2. Smithsonian Institution/MAB Biodiversity Program, Washington, DC, 345pp.

ALONSO, A.; DALlMEIER, F. \& CAMPBELL, P. (eds.) 2001. Urubamba: The Biodiversity of a Peruvian Rainforest, Smithsonian Institution/MAB Biodiversity Program Series n7. Smithsonian Institution, Washington, DC, 216pp.

BENINE, R. C. 2004. Análise filogenética do gênero Moenkausia Eigenamnn, 1903 (Characiformes: Characidae) com uma revisão dos táxons do alto rio Paraná. Tese de Doutorado não publicada, Botucatu, Universidade Estadual Paulista.

BERTACO, V. A. \& CARVALHO, T. P. 2005. A new characid fish, Hyphessobrycon hexastichos (Characiformes Characidae) from Chapada dos Parecis, Mato Grosso, Brazil. Neotropical Ichthyology, 3(3):439-443p.

BERTACO, V. A.; CARVALHO, F. R. \& JEREP, F. C. 2009. Astyanax goyanensis (Miranda-Ribeiro, 1944), new combination and Astyanax courensis, new species (Ostariophysi: Characiformes): two Characidae from the upper rio Tocantins basin, Central Brazil. Neotropical Ichthyology, 8(2):265-275p.

BOULENGER, G. A. 1892. On some new or little-known fishes obtained by Dr. J. W. Evans and Mr. Spencer Moore during their recent expedition to the Province of Mato Grosso, Brazil. Annals and Magazine of Natural History (Series 6) 10(55): 9-12, Pls. $1-2$.

BOULENGER, G. A. 1897. Viaggio del Dott. Alfredo Borelli nel Chaco boliviano e nella Repubblica Argentina. III. Poissons. Bollettino dei Musei di Zoologia ed Anatomia Comparata della R. Università di Torino, 12 (279):1-4p. 
BREMER, K. 1994. Branch support and tree stability. Cladistics,10: 295-304p.

BUCKUP, P. A., 1991. The Characidiinae: a phylogenetic study of the South American darters and their relationships with other characiform fishes. Tese de Doutorado não publicada, University of Michigan, Ann Arbor. 391 p.

BUCKUP, P. A. 1993. Review of the characidiin fishes (Teleostei: Characiformes), with descriptions of four new genera and ten new species. Ichthyological Exploration of Freshwaters, 4(2): 97-154p.

BUCKUP, P. A., 1998. Relationships of the Characidiinae and phylogeny of characiform fishes (Teleostei: Ostariophysi). Pp: 123-144. Em: Phylogeny and Classification of the Neotropical Fishes. Eds: L. R. Malabarba, R. E Reis, R. P. Vari, Z. M. S. Lucena e C. A. S. Lucena. Edipucrs, Porto Alegre.

BUCKUP, P. A.; MENEZES, N. A. \& GHAZZI, M. S. 2007. Introdução, 11-16. In: Buckup, P. A.; Menezes, N. A. \& Ghazzi, M. S. Catálogo das Espécies de Peixes de Água Doce do Brasil. Rio de Janeiro, Museu Nacional, 195p.

BÜHRNHEIM, C. M.; CARVALHO, T. P.; MALABARBA, L. R. \& WEITZMAN, S. W. 2008. A new genus and species of characid fish from the Amazon basin: the recognition of a relictual lineage of characid fishes (Ostariophysi: Cheirodontinae: Cheirodontini). Neotropical Ichthyology, 6(4): 663-678.

BUSSING, W. A. 1985. Patterns of distribution of the Central American ichthyofauna. Pp. 453-473 in: F. G. Stehli \& S. D. Webb (eds.), The Great American Interchange. Plenum Publ. Corp New York.

BRITSKI H.A.; SILIMON, K. Z. \& LOPES B. S. 1999. Peixes do Pantanal: manual de identificação. EMBRAPA, Brasília, 184pp.

BRITSKI H.A.; SILIMON, K. Z. \& LOPES B. S. 2007. Peixes do Pantanal: manual de identificação. EMBRAPA, Brasília, 227pp.

CALCAGNOTTO, D.; SCHAEFER, S. A. \& DESALLE, R. 2005. Relationships among characiform fishes inferred from analysis of nuclear and mitochondrial gene sequences. Molecular Phylogenetics and Evolution, 36:135-153.

CAMPANARIO, C. M. 2002. Revisão taxonômica do gênero Crenuchus Günther (1863), com uma hipótese sobre a filogenia de Crenuchinae (Characiformes Ostariophysi). Dissertação de Mestrado, não publicada. Instituto de Biociências, Universidade de São Paulo, 205p. 
CASTRO, R. M. C. \& CASTRO, M. M. C. 1987. Proposta de uma nomenclatura osteológica para Characiformes (Pisces: Ostariophysi). Boletins do Museu Paraense Emílio Goeldi, série Zoológica 3(1):25-32.

CASTRO, R. M. C. \& R. P. VARI. 1990. Moojenichthys Miranda-Ribeiro (Pisces: Ostariophysi: Characidae), a phylogenetic reappraisal and redescription. Proceedings of the Biological Society of Washington, 103(3): 525-542.

CASTRO, R. M. C. \& R. P. VARI. 2004. Detritivores of the South American fish family Prochilodontidae (Teleostei: Ostariophysi: Characiformes): a phylogenetic and revisionary study. Smithsonian Contributions to Zoology, 622: 1-189.

CASTRO, R. M. C. \& VARI, R. P. 2007. New species of Astyanax (Ostariophysi: Characiformes: Characidae) from the upper Rio Paraná System, Brazil. Copeia, v. 1, p. $150-162$.

CASTRO, R. M. C. 1984. Osteologia e relações filogenéticas de Engraulisoma taeniatum Castro 1981 (Ostariophysi, Characiformes, Characidae). Dissertação de Mestrado não-publicada, São Paulo, Universidade de São Paulo.

CHANG, F. 1998. Fishes of the Tambopata-Candamo Reserved Zone, southeastern Peru. Revista Peruana de Biologia, 5(1): 15-26p.

CHANG, F. \& H. ORTEGA. 1995. Additions and corrections to the list of freshwater fishes of Peru. Publicaciones del Museo de Historia Natural, Universidad Nacional Mayor de San Marcos. Serie A, 50: 1-11p.

CHERNOFF, B. \& WILLINK, P. W. (eds.) 1999. A Biological Assessment of the Aquatic Ecosystems of the Upper Río Orthon Basin, Pando, Bolivia. Conservation International, Washington DC, Bulletin of Biological Assessment (15), 145pp.

CHERNOFF, B.; MACHADO-ALLISON, A.; WILLINK, P.; SARMIENTO, J.; BARRERA, S.; MENEZES, N. \& ORTEGA, N. 2000. Fishes of three bolivian Rivers; diversity, distribution and conservation. Interciencia, 5(6): 273-383p.

COATES, A. G. \& OBANDO, J. A. 1996. The geologic evolution of the Central American isthmus. Pp. 21 -56 in: Jackson, J. B. C.; Budd, J. B. C.; Coates, A. G. (eds.), Evolution and Environment in Tropical America. University of Chicago Press.

COATES, A. G., JACKSON, J. B. C., COLLINS, L. S., CRONIN, T. M., DOWSETT, H. J., BYBELL, L. M., JUNG, P. J.;OBANDO, J. A. 1992. Closure 
of the Isthmus of Panama: The nearshore record of Costa Rica and western Panama. Geol. Soc. Am. Bull. 104, 814-828.

COBBOLD, P. R.; SZATMARI, P.; LIMA, C.; ROSSELLO, E. A. 1996. Cenozoic deformation across South America: continent-wide data and analogue models. Trosiéme Symposium International sur la Géodynamique Andine, Saint-Malo, p. 21 -24 .

COLLINS, L. S. 1996. Environmental changes in Caribbean shallow waters relative to closing of the Tropical American Seaway. Pp.130-167 in: Jackson, J. B. C.; Budd, A. F.; Coates, A. G. (eds.), Evolution and Environment in Tropical America. University of Chicago Press.

CONEY, P. J, 1982. Plate tectonic constraints on the biogeography of Middle America and the Caribbean region. Annals Missouri Botanical Garden 69, 432-443.

COPE, E. D. 1894. On the fishes obtained by the Naturalist Expedition in Rio Grande do Sul. Proceedings of the American Philosophical Society, 33: 84-108p.

DAGET, J. 1960. Le genre Xenocharax (Poissons, Characiformes). Revue de Zoologie et de Botanique Africaines, 61(1-2):35-48.

DAHL, G. 1971. Los peces del norte de Colombia. Inderena, Bogata. Los peces del norte de Colombia, $391 \mathrm{pp}$.

DE PINNA, M. C. C. 1991. Concepts and tests of homology in the cladistic paradigm. Cladistics 7: 367-394p.

DE PINNA, M. C. C. 1993. A new subfamily of Trichomycteridae (Teleostei, Siluriformes), lower loricarioid relationships and a discussion on the impact of additional taxa for phylogenetic analysis. Zoological Journal of the Linnean Society 106:175-229p.

DUQUE, H. 1990. Estratigrafía, Paleoceanografía y Paleobiogeografia de la Cuenca deI Atrato y la Evolución de Panama. Bol Geol. Ingeominas 31 (1):1-45.

EIGENMANN, C. H. 1907. Fowler's "Heterognathus Fishes" with a note on the Stethaprioninae. American Naturalist 41 (492): 767-772p.

EIGENMANN, C. H. 1910. Catalogue of the fresh-water fishes of tropical and south temperate America. In: Reports of the Princeton University expeditions to Patagonia 1896-1899. Zoology. Catalogue of the fresh-water fishes of tropical and south temperate America. 3 (4): 375-511p. 
EIGENMANN, C. H. 1917. The American Characidae [Parte 1]. Memoirs of the Museum of Comparative Zoology 43 (1): 1-102p.

EIGENMANN, C. H. 1918. The American Characidae [Parte 2]. Memoirs of the Museum of Comparative Zoology 43 (2): 103-208p.

EIGENMANN, C. H. 1921. The American Characidae [Parte 3]. Memoirs of the Museum of Comparative Zoology 43 (3): 209-310p.

EIGENMANN, C. H. 1927. The American Characidae [Parte 4]. Memoirs of the Museum of Comparative Zoology v. 43 (4): 311-428p.

EIGENMANN, C. H. \& MYERS, G. S. 1929. The American Characidae [Parte 5, e suplemento de G. S. Myers, pp. 516-550]. Memoirs of the Museum of Comparative Zoology v. 43 (5): 429-558p.

ESCHMEYER, W. N. 1998a. (Editor) Catalog of Fishes A-L. Center for Biodiversity Research and Information, Spec. Publ. 1. California Academy of Sciences. vol. 2: 958p.

ESCHMEYER, W. N. 1998b. (Editor) Catalog of Fishes M-Z. Center for Biodiversity Research and Information, Spec. Publ. 1. California Academy of Sciences. vol. 2: 959-1820p.

ESCHMEYER, W. N. 1998c. (Editor) Catalog of Fishes: Species and Genera in classification, Literature cited and Appendices. Center for Biodiversity Research and Information, Spec. Publ. 1. California Academy of Sciences. vol. 3: 1821-2905p.

ESCHMEYER, W. N. 2010. (ed.) Catalog of Fishes electronic version http://research.calacademy.org/ichthyology/catalog/fishcatmain.asp (30 Novembro 2010).

FERREIRA, K. M. 2007. Análise filogenética e revisão taxonômica do gênero Knodus Eigenmann, 1911 (Characiformes: Characidae). Tese de doutorado nãopublicada, Ribeirão Preto, Universidade de São Paulo.

FIGUEIREDO, J.; HOORN, C.; VAN DER VEN, P.; SOARES, E. 2009. Late Miocene onset of the Amazon River and the Amazon deep-sea fan: Evidence from the Foz do Amazonas Basin. Geology, 37, 619-622.

FINK, S. V. \& W. L. FINK, 1981. Interrelationships of Ostariophysan Eishes (Teleostei). Zoological Journal of the Linnean Society, 72:297-53. 
FINK, S. V. \& W. L. FINK. 1996. Interrelationships of Ostariophysan Eishes (Teleostei) . Pp. 209-249. Em: Interrelationships of Fishes. M. L. J. Stiassny, L. R. Parenti, \& G. D. Johnson (Eds.). Academic Press, San Diego.

FINK, W. L. \& WEITZMAN, S. H. 1974. The so-called cheirodontin fishes of Central America with description of two new species (Pisces, Characidae). Smithsonian Contributions to Zoology, 172: 1—46.

FOWLER, H. W. 1907. Further knowledge of some heterognathous fishes. Part II. Proceedings of the Academy of Natural Sciences of Philadelphia, 58: 431-483p.

FOWLER, H. W. 1940. Zoological results of the second Bolivian expedition for the Academy of Natural Sciences of Philadelphia, 1936-1937. Part I.--The fishes. Proceedings of the Academy of Natural Sciences of Philadelphia, 92: 43-103p.

FOWLER, H. W. 1948. Os peixes de água doce do Brasil. Arquivos de Zoologia do Estado de São Paulo (1 ${ }^{\mathrm{a}}$ entrega), 6: 1-204p.

GARUTTI, V. 1998. Descrição de uma espécie nova de Astyanax (Teleostei, Characidae) da Bacia do Tocantins, Brazil. Iheringia, Série Zoologia (Porto Alegre) 85: 115-122p.

GARUTTI, V. 1999. Descrição de Astyanax argyrimarginatus sp. n. (Characiformes, Characidae) procedente da bacia do Rio Araguaia, Brasil. Revista Brasileira de Biologia, 59(4): 585-591p.

GÉRY, J. 1972. Poissons characoïdes des Guyanes. I. Généralités. II. Famille des Serrasalmidae. Zoologische Verhandelingen, 122: 1-250p.

GÉRY, J., 1977. Characoids of the World T. E. H. Publications, Neptune City, New Jersey 672p.

GREENWOOD, P. H.; ROSEN, D. E.; WEITZMAN, S. H. \& MYERS, G. S. 1966. Phyletic studies of teleostean fishes with a provisional classification of living forms. Bulletin of the American Museum of Natural History, 131: 339—456p.

GREGORY, W. K. \& CONRAD, G. M. 1938. The phylogeny of the characin fishes. Zoologica (N.Y.), 23(17): 319-360p.

GREY, M. 1947. Catalogue of type specimens of fishes in Chicago Natural History Museum. Fieldiana Zoology 32(3): 109-205p. 
HENNIG, W. 1966. Phylogenetic Systematics. University of Illinois Press, Urbana, $263 \mathrm{p}$.

HERRERA-MACBRYDE, O.; DALLMEIER, F.; MACBRYDE, B., COMISKEY, J. A. \& MIRANDA, C. (eds.) 2000. Biodiversity, Conservation and Management in the Region of the Beni Biological Station Biosphere Reserve, Bolivia. Smithsonian Institution/MAB Series No. 4, Smithsonian Institution, Washington, D.C, 419pp.

HOEINGHAUS, D. J.; WINEMILLER, K. O. \& TAPHORN, D. C. 2004. Compositional change in fish assemblages along the Andean piedmont - Llanos floodplain gradient of the río Portuguesa, Venezuela. Neotropical Ichthyology, 2(2):85-92p.

HOORN, C. 1993. Marine incursion and the influence of Andean tectonics on the Miocene depositional history of northwestern Amazonia: results of a palynostratigraphical study. Palaeogeography, Palaeoclimatology, Palaeoecology, 105: 267-309.

HOORN, E. ; GUERRERO, I.; SARMIENTO, G. A.; LORENTE, M. A. 1995. Andean tectonics as a cause for changing drainage patterns in Miocene northern South America. Geology, 23:237-240.

HUTCHINSON, G. E. 1957. Concluding remarks. Cold Spring Harbour Symposium on Quantitative Biology, 22:415-427.

JAVONILLO, R.; MALABARBA, L. R.; WEITZMAN, S. H. \& BURNS, J. R. 2010. Relationships among major lineages of characid fishes (Teleostei: Ostariophysi: Characiformes), based on molecular sequence data. Molecular Phylogenetics and Evolution, 54: 498-511p.

JORDAN, D. S. 1920. The genera of fishes, part IV, from 1881 to 1920, thirty-nine years, with the accepted type of each. A contribution to the stability of scientific nomenclature. Leland Stanford Jr. University Publications, University Series 43: 411-576p.

KELLER, G.; ZENKER, C. E.; STOKES, S. M. 1989. Late Neogene history of the Pacific-Caribbean gateway. J. South Am. Earth Sci. 2, 73-108.

KOEBER, S. \& LITZ, T. 2011. Transcription and copy of Emil Messner's list of Tetragonopterinae from Uruguay published in 1962. Ichthyological Contributions of PecesCriollos, 21: 1-8. 
LAUZANE, L. \& LOUBENS, G. 1985. Peces Del rio Mamore. Ed. Orstom Cordebeni - Utb, Paris. 113pp.

LAUZANNE, L.; LOUBENS, G.; LE GUENNEEC, B. 1991. Liste commentée des poissons de l'Amazonie bolivienne. Revue de Hydrobiolgie Tropical, 24(1): 61-76p.

LASSO, C. A.; LEW, D.; TAPHORN, D.; DONASCIMIENTO, C.; LASSOAlCAlÁ, O.; PROVEnZANO, F. \& MACHADO-AllisON, A. 2004. Biodiversidad ictiológica continental de Venezuela. Parte I. Lista de especies y distribución por cuencas. Memoria de la Fundación La Salle de Ciencias Naturales, 159-160: 105-195p.

LASSO, C. A.; MOJICA, J. I.; USMA, J. S.; MALDONADO, J. A.; DONASCIMIENTO, C.; TAPHORN, D.; PROVENZANO, F.; LASSOALCALÁ, O. M.; GALVIS, G.; VÁSQUEZ, L.; LUGO, M.; MACHADOALLISON, A.; ROYERO, R.; SUÁREZ, C. \& ORTEGA-LARA, A. 2004. Peces de la cuenca del río Orinoco. Parte I: lista de especies y distribución por subcuencas. Biota Colombiana, 5(2):95-158p.

LIMA, E. C. T. 2006. Revisão taxonômica e relações filogenéticas do gênero Salminus (Teleostei: Ostariophysi: Characiformes: Characidae). Tese de Doutorado não publicada, 253 pp. Universidade de São Paulo, São Paulo.

LIMA, F.C.T., MALABARBA, L.R., BUCKUP, P.A., PEZZI DA SILVA, J.F., VARI, R.P.; HAROLD, A., BENINE, R., OYAKAWA, O.T., PAVANELLI, C.S., MENEZES, N.A., LUCENA, C.A.S., MALABARBA, M.C.S. L., LUCENA, Z.M.S., REIS, R.E., LANGEANI, F., CASATTI, L., BERTACO, V.A., MOREIRA, C., \& LUCINDA, P.H.F. 2003. Genera Incertae Sedis in Characidae. Pp. 106-169. In: Reis, R. E., Kullander, S. O., \& Ferraris, C. J. (Eds.). Check list of the freshwater fishes of South and Central America (CLOFFSCA). Porto Alegre, EDIPUCRS, 729 p.

LIMA, F. C. T. \& RIBEIRO, A. C. 2011. Continental-scale tectonic controls of biogeography and ecology in Alberts, J. S. \& Reis, R. E. (Eds). Historical Biogeographical of Neotropical Freshwater Fishes. Berkeley and Los Angeles, University of California Press, 388 p.

LUCENA, C. A. S. \& MENEZES, N. A. 1998. A phylogenetic analysis of the Roestes Gunther and Gilbertolus Eigenmann, with a hypothesis on the relationships of the Cynodontidae and Acestrorhynchidae (Teleostei: Ostariophysi: Characiformes). Pp. 261-278. in: Phylogeny and Classification of the Neotropical Fishes. 
LUCENA, C. A. S. 1993. Estudo filogenético da família Characidae com uma discussão dos grupos naturais propostos (Teleostei, Ostariophysi, Characiformes). Tese de Doutorado não-publicada. São Paulo, Universidade de São Paulo.

LUCENA, C. A. S. 2000. Revisão taxonômica e filogenia das espécies transandinas do gênero Roeboides Günther (Teleostei: Ostariophysi: Characiformes). Comunicações do Museu de Ciências e Tecnologia da PUCRS, Sér. Zoologia. 13(3): 3-63.

LUNDBERG, J. G.; MARSHALL, L. G.; GUERRERO, J.; HORTON, B.; MALABARBA, M. C. S.; WESSELINGH, F. 1998. The Stage for Neotropical Fish Diversification: A History of Tropical South American Rivers. Phylogeny and Classification of Neotropical Fishes. 1998. Malabarba, L.R., R.E. Reis, R.P. Vari, Z.M. Lucena \& C.A.S. Lucena, (eds). Porto Alegre, Edipucrs, 603p.

MABEE, P.M. 1988. Supraneurals and predorsal bones in fishes: development and homologies. Copeia, 1988(4): 827-838p.

MACHADO-ALLISON, A. 1986. Osteología comparada del neurocráneo y branquicráneo en los géneros de la subfamilia Serrasalminae (Teleostei Characidae). Acta Biologica Venezuelica 12 (2) Suppl.: 1-75.

MACHADO-ALLISON, A. 1982a. Studies on the systematics of the subfamily Serrasalminae (Pisces-Characidae). Ph. D. Thesis, The George Washington University, 267 pp.

MACHADO-ALLISON, A. 1982b. Estudios sobre la Subfamilia Serrasalminae (Teleostei-Charac idae). Parte I. Estudio comparado de los juveniles de las "cachama" de Venezuela (Generos Colossoma y Piaractus). Acta Biologica Venezuelica, 11 (3): 1-102.

MACHADO-ALLISON, A. 1985. Estudios sobre la Subfamilia Serrasalminae. Parte III: Sobre el estatus generico y relaciones filogeneticas de los generos Pygopristis. Pygocentrus, Pristobrycon y Serrasalmus (Teleostei - Characidae - Serrasalminae). Acta Biologica Venezuelica, 12(1) : 19-42.

MADDISON, D.R. 1991. The discovery and importance of multiple islands of mostparsimonious trees. Systematic Biology, 40: 315-328p.

MAGO-LECCIA, F. 1970. Lista de los peces de Venezuela. MAC, Oficina Nac. de Pesca, Caracas, 238p. 
MALABARBA, L. R., 1998. Monophyly of the Cheirodontinae, characters and major clades (Ostariophysi: Characida. Pp: 193-233 in: Phylogeny and Classification of neotropical fishes. MALABARBA, L. R., R. E. REIS, R. P. VARI, Z. M. S. LUCENA \& C. A. LUCENA (eds.). EDIPUCRS. Porto Alegre.

MALABARBA, L.R. \& WEITZMAN, S.H. 2003. Description of a new genus with six new species from southern Brazil, Uruguay and Argentina, with a discussion of a putative characid clade (Teleostei: Characiformes: Characidae). Comunicações do Museu de Ciência e Tecnologia da PUCRS, Sér. Zool., 16 (1): 67-151p.

MALABARBA, L. R.; WEITZMAN, S. H. \& LITZ, T. 2004. Hyphessobrycon melanopleurus uruguayensis Messner, 1962, an available name and a senior synonym of Cyanocharax macropinna Malabarba \& Weitzman, 2003 (Ostariophysi: Characidae). Neotropical Ichthyology, 2(2):99-102p.

MALDONADO-OCAMPO, J. A.; VILLA-NAVARRO, F. A.; ORTEGA-LARA, A.; PRADA-PEDREROS, S.; VILLA, U. J.; CLARO, A.; USMA, J. S.; LARA, T. S. R.; SALAZAR, C.; BARRIOS, J. F. C. \& GÁRCIA-MELO, J. E. 2006. Peces del río Atrato, zona hidrogeografica del caribe, Colombia. Biota Colombiana, 7(1): 141 - 152p.

MALDONADO-OCAMPO, J. A.; VARI, R. P. \& USMA, J. S. 2008. Checklist of the Freshwater Fishes of Colombia. Biota Colombiana, 9(2):143-237p.

MARSHALL, L. G. \& T. SEMPERE. 1993. Evolution of the Neotropical Cenozoic Land Mammal Fauna in its geochronologic, straligraphic and tectonic context. Pp 329-392 in: Goldblatt, P. (ed.), Biological Relationships between Africa and South America. Yale University Press. New Haven.

MARSHALL, L. G.; SEMPERE, T.; BUTLER, R. F. 1997. Chronostratigraphy of the mammal-bearing Paleocene of South America, S. Am. Earth Sci., 10: 49-70.

MCALLISTER, D. E. 1968. The evolution of branchiostegals and the classification of teleostome fishes, living and fossil. Bulletin of National Museum of Canada, 221: 1239p.

MENEZES, N. A. 1976. On the Cynopotaminae, a new subfamily of Characidae (Osteichthyes, Ostariophysi, Characoidei). Arquivos de Zoologia (São Paulo), 28 (2): 1-91p.

MESSNER, E. 1962. Lista de los peces Tetragonopterinae (fam. Characidae) del Uruguay, Boletin de la Associason Latino Americana de Ictiologos y Herpetologos, 2(1): 4-5. 
MIRANDA, R. P. 1944. Nova espécie para o gênero Astyanacinus Eigenmann, 1907 (Pisces - Characinidae). Boletim do Museu Nacional do Rio de Janeiro, Nova Série. Zoologia 29: 1-3.

MIRANDE, J. M. 2007. Filogenia de Characidae (Teleostei, Characiformes) y optimizacíon autopesada. VII Reunión Argentina de Cladística y Biogeografia: Darwiniana, 45:19-23p.

MIRANDE, J. M. 2009. Weighted parsimony phylogeny of the family Characidae (Teleostei: Characiformes). Cladistics, 25:1-40p.

MIRANDE, J. M. 2010. Phylogeny of the family Characidae (Teleostei: Characiformes): from characters to taxonomy. Neotropical Ichthyology, 8(3):385$568 p$.

MINISTÉRIO DO MEIO AMBIENTE, 2007. Biodiversidade do Cerrado e Pantanal: áreas e ações prioritárias para conservação. Ministério do Meio Ambiente, Brasília. (Série Biodiversidade 17): 397pp.

MONOD, T. 1968. Le complexe urophore des poisons teleosteens. Afrique Noire: Mem Inst Fond 81: 705p.

MONSCH, K. A. 1998. Miocene fish faunas from the northwestern Amazonia basin (Colombia, Peru, Brazil) with evidence of marine incursions. Palaeogeography, Palaeoclimatology, Palaeoecology, 143: 31-50.

MOREIRA, C. R. 2002. Relações Filogenéticas em Iguanodectinae (Characidae: Characiformes: Teleostei). Dissertação de Mestrado não-publicada, Universidade de São Paulo.

MOREIRA, C. R. 2007. Relações filogenéticas na ordem Characiformes (Teleostei: Ostariophysi). Tese de Doutorado não-publicada. São Paulo, Universidade de São Paulo.

MURRAY, A. M. 2004. Osteology and morphology of the characiform fish Alestes stuhlmannii Pfeffer, 1896 (Alestidae) from the Rufiji River basin, East Africa. Journal of Fish Biology, 65: 1412-1430p.

MYERS, G. S. 1944. Rhinobrycon negrensis, a new genus and species of characid fishes from the Rio Negro, Brazil. Proceedings of the California Academy of Sciences, 23(39): 587-590p. 
NELSON, G. J. 1972. Cephalic Sensory Canals, Pitlines, and the Classification of Esocoid Fishes, with Notes on Galaxiids and Other Teleosts. American Museum Novitates, 2492: 1-49p.

NELSON, J. 2006. Fishes of the World. 4th ed. John Wiley \& Sons Inc., N.Y., 600p.

NETTO_FERREIRA, A. L. 2006. Relações filogenéticas dos gêneros de Lebiasinidae (Ostariophysi, Characiformes). Dissertação de Mestrado nãopublicada, Universidade Federal do Rio de Janeiro.

NION, H.; RÍOS, C. \& MENESES, P. 2002. Peces del Uruguay: Lista Sistemática y Nombres Comunes. Montevideo, Dirección Nacional de Recursos Acuáticos / INFOPESCA, 105pp.

OLAZARRI, J.; MONES, A.; XIMÉNEZ, A. \& PHILIPPI, M. E. 1970. Lista de los ejemplares-tipo depositados en el Museo Nacional de Historia Natural de Montevideo, Uruguay. Comunicaciones Zoologicas del Museo de Historia Natural de Montevideo 10(131): 1-12.

ORNELAS-GARCÍA, C. P., DOMÍNGUEZ-DOMÍNGUEZ, O. \& DOADRIO, I. 2008. Evolutionary history of the fish genus Astyanax Baird \& Girard (1854) (Actinopterygii, Characidae) in Mesoamerica reveals multiple morphological homoplasies. BMC Evolutionary Biology, 8(340):1-17p.

ORTI, G. \& MEYER, A. 1997. The radiation of characiform fishes and the limits of the resolution of mitochondrial ribosomal DNA sequences. Systematic Biology, 46(1):75-100.

PATTERSON, C. \& G.D. JOHNSON. 1995. The intermuscular bones and ligaments of Teleostean fishes. Smithsonian Contributions to Zoology, 559: 83p.

PATTERSON, C. 1968. The caudal skeleton in Lower Liassic pholidophorid fishes. Bull. Br. Mus. (Nat. Hist.), Geol. 16, 201-239.

PATTERSON, C. 1973. Interrelationships of holosteans. In Interrelationships of Fishes P. H. Greenwood, R. S. Miles, C. Patterson (eds.), pp. 233-305. Academic Press, London.

PATTERSON. C. \& ROSEN, D. E. 1977. Review of Ichthyodectiform and Other Mesozoic Teleost Fishes and the Theory and Practice of Classifying Fossils. Systematic Zoology, 26(3): 358-359p. 
PEARSON, N. E. 1924. The fishes of the eastern slope of the Andes. I. The fishes of the Rio Beni basin, Bolivia, collected by the Mulford expedition. Indiana University Studies 11(64): 1-83, Pls. 1-12.

PEARSON, N. E. 1937. The fishes of the Beni-Mamore and Paraguay basins, and a discussion of the origin of the Paraguayan fauna. Proceedings of the California Academy of Sciences 23(8) 99-114p.

PIPER, D.J., PIRMEZ, W.C., MANLEY, P.L., LONG, D., FLOOD, R.D., NORMARK, W.R., SHOWERS, W., 1997. Mass transport deposits of Amazon Fan, pp. 109-146. In: Flood, R.D., Piper, D.J.W., Klaus, A., Peterson, L.C. (Eds.), Proceedings Ocean Drilling Program Scientific Results, College Station.

QUEVEDO, R. 2006. Estudo taxonômico e filogenéticos da subfamília Paragoniatinae Géry (Characiformes: Characidae). Tese de doutorado não publicada, 288 pp. Universidade Federal do Rio Grande do Sul, Porto Alegre.

RAMLOW, J. M. 1989. Lista de peces y sitios de colección de la Seccion de Ictiología del Inventario Biológico Nacional/Museo Nacional de Historia Natural del Paraguay. Boletín del Inventario Biologico Nacional del Paraguay, 9: 1-40p.

RASANEN, M. E.; LINNA, A. M.; SANTOS, J. C. R.; NEGRI, F. R. 1995. Late Miocene tidal deposits in the Amazonian foreland basin. Science, 269: 386-390.

REGAN, C.T. 1911. The classification of the Teleostean fishes of the Order Ostariophysi. - 1. Cyprinoidea. Annals and Magazine of Natural History, 8(8): 1332, 1 pr.

REIS, R. 1989. Systematic revision of the neotropical characid subfamily Stethaprioninae (Pisces, Characiformes). Comunicações do Museu de Ciências da PUCRS, 2(6-11): 03-86p.

REIS, R. E., KULLANDER, S. O. \& FERRARIS, C. J. 2003. Check List of the Freshwater Fishes of South and Central America. Porto Alegre, EDIPUCRS. 729p.

RIBEIRO, A. C. 2007. Filogenia e Biogeografia do gênero Oligosarcus Günther, 1864 (Characiformes: Characidae). Tese de Doutorado não- publicada, Universidade Estadual Paulista, Botucatu.

RINGUELET, R. A. 1975. Zoogeografía y ecología de los peces de águas continentales de la Argentina y consideraciones sobre las áreas ictiológicas de América del Sur. Ecosur, 2(3):122pp. 
ROBERTS, T. R. 1966. Description and osteology of Lepidarchus adonis, a remarkable new characid fish from West Africa. Stanford Ichthyological Bulletin, 8(3): 209-227p.

ROBERTS T. R. 1969. Osteology and relationships of characoid fishes, particularly the genera Hepsetus, Salminus, Hoplias, Ctenolucius and Acestrorhynchus. Proceedings of the Californian Academy of Sciences, 4, 36 (15) : 391-500.

ROBERTS, T. R. 1966. Description and osteology of Lepidarchus adonis, a remarkable new characid fish from West Africa. Stanford Ichthyological Bulletin 8(3): 209-227.

ROBERTS, T. R. 1973. Osteology and relationships of the Prochilodontidae, a South American family of characoid fishes. Bulletin of the Museum of Comparative Zoology 145 (no. 4): 213-235.

ROBERTS, T. R. 1973. The glandulocaudine characid fishes of the Guayas Basin in western Ecuador. Bulletin of the Museum of Comparative Zoology 144 (no. 8): 489514.

ROBERTS, T. R. 1974. Osteology and classification of the noetropical characoid fishes of the families Hemiodontidae (including Anodontinae) and Parodontidae. Bulletin of the Museum of Comparative Zoology 146 (no. 9): 411-472, Pl. 1.

ROSA, F. R. 2006. Ictiofauna e assoreamento em dois córregos da Chapada dos Guimarães: comparações entre o íntegro e o degradado. Dissertação de Mestrado não-publicada. Cuiabá, Universidade Federal de Mato Grosso.

ROSEN, D. E. 1972. Origin of the characid fish genus Bramocharax and a description of a second, more primitive, species in Guatemala. Amererican Museum Novitates, 2500: 1-21p.

SCHAEFER, S. 2000. Fishes of innundated tropical savannas: diversity and endemism in the Serrania Huanchaca of eastern Bolivia. Final Report of a project sponsored by The American Museum Center for Biodiversity and Conservation, Curator Research Grants Program, 1-25p.

SCHULTZ, L. P. 1944. The fishes of the family Characinidae from Venezuela, with descriptions of seventeen new forms. Proceedings of the United States National Museum, 95(3181): 235-367p. 
SCHULTZE, H. P., \& ARRATIA, G. 1986. Reevaluation of the caudal skeleton of actinopterygian fishes: I. Lepisosteus and Amia. J. Morphol. 190, 215-241.

SCHULTZE, H. P., \& ARRATIA, G. 1988. Reevaluation of the caudal skeleton of some actinopterygian fishes: II. Hiodon, Elops, and Albula. J. Morphol. 195, 257303.

SCHULTZE, H. P., \& ARRATIA, G. 1989. The composition of the caudal skeleton of teleosts (Actinopterygii: Osteichthyes). Zool. J. Linn. Soc. 97, 189-231.

SHAGAM, R.; KOHN, B. P.; BANKS, P. O.; DASCH, L. E.; VARGAS, R.; RODRIGUES, G. I.; PIMENTEL, N. 1983. Tectonic implications of CetaceousPliocene fissiontrack ages from rocks of the circum Maracaibo basin region of western Venezuela and eastern Colombia. pp. 385-412. In: Bonini, W. E.; Hargraves, R. B.; Shagam, R. (eds.), The Caribbean-South America Plate Boundary and Regional Tectonics.

SMITH, S. A. \& BERMINGHAM, E. 2005. The biogeography of lower Mesoamerican freshwater fishes. Journal of Biogeography, 32:1835-1854p.

TAYLOR, W. R. \& G. C. VAN DYKE. 1985. Revised procedures for staining and clearing small fishes and other vertebrates for bone and cartilage study. Cybium, 9(2): 107-119p.

TEDESCO, P. A.; IBAÑEZ, C.; MOYA, N.; BIRGORNE, R.; CAMACHO, J.; GOITIA, E.; HUGUENY, B.; MALDONADO, M.; RIVERO, M.; TOMANOVÁ, S.; ZUBIETA, J. P. \& OBERDORFF, T. 2007. Local-scale species-energy relationships in fish assemblages of some forested streams of the Bolivian Amazon. Comptes Rendus Biologies, 330(3): 255-264p.

THOMAZ, A. T.; MALABARBA, L. R. \& BONATTO, S. L. 2010. The phylogenetic placement of Hollandichthys Eigenmann 1909 (Teleostei: Characidae) and related genera. Molecular Phylogenetics and Evolution, 57(3): 1347-1352.

TOLEDO-PIZA, M. 2000. The neotropical fish subfamily Cynodontinae (Teleostei: Ostariophysi: Characiformes): a phylogenetic study and a revision of Cynodon and Raphiodon. American Museum Novitates, 3286:1-88p.

TOLEDO-PIZA, M. 2007. Phylogenetic relationships among Acestrorhynchus species (Ostariophysi: Characiformes: Acestrorhynchidae). Zoological Journal of the Linnean Society, p. 691-757. 
UJ, A. 1990. Etude comparative de l'osteologie cranienne des poisson de la familie des Characidae et son importance phylogenetique. Tese de Doutorado nãopublicada, Universite de Geneve, 191 p.

ULREY, A. B. 1895. The South American Characinidae collected by Charles Frederick Hartt. Annals of the New York Academy of Sciences 8: 257-300p.

VARI, R. P. \& A. S. HAROLD, 2001. Neotropical fishes of the genus Creagrutus (Teleostei: Ostariophysi: Characiformes): a phylogenetic study and a revision of the species east of the Andes. Smithsonian Contributions to Zoology, 612:1-239p.

VARI, R. P. 1979. Anatomy, relationships and classification of the families Citharinidae and Distichodontidae (Pisces, Characoidea). Bulletin of the British Museum (Natural History — Zoological Series) 36(5): 261-344p.

VARI, R. P. 1982. Systematics of the neotropical characoid genus Curimatopsis (Pisces: Characoidei). Smithsonian Contributions to Zoology 373: i-iii + 1-28.

VARI, R. P. 1983. Phylogenetic relationships of the families Curimatidae, Prochilodontidae, Anostomidae, and Chilodontidae (Pisces: Characiformes). Smithsonian Contributions to Zoology, 378: i-iii + 1-60.

VARI, R. P. 1984. Systematics of the neotropical characiform genus Potamorhina (Pisces: Characiformes). Smithsonian Contributions to Zoology, 400: 1-36.

VARI, R. P. 1988. The curimatidae, a lowland neotropical fish family (Pisces: Characiformes); distribution, endemism, and phylogenetic biogeography. Proceedings of a workshop on Neotropical distribution patterns, 343-377.

VARI, R. P. 1989a. Systematics of the neotropical characiform genus Pseudocurimata Fernández-Yépez (Pisces: Ostariophysi). Smithsonian Contributions to Zoology, 490: i-iii + 1-26.

VARI, R. P. 1989b. Systematics of the neotropical characiform genus Curimata Bosc (Pisces: Characiformes). Smithsonian Contributions to Zoology, 474: i-iii + 1-63.

VARI, R. P. 1989c. Systematics of the neotropical characiform genus Psectrogaster Eigenmann and Eigenmann (Pisces: Characiformes). Smithsonian Contributions to Zoology, 481: i-iii + 1-43.

VARI, R. P. 1989d. A phylogenetic study of the neotropical characiform family Curimatidae (Pisces: Ostariophysi). Smithsonian Contributions to Zoology, 471: i-iv $+1-71$. 
VARI, R. P. 1991. Systematics of the neotropical characiform genus Steindachnerina Fowler (Pisces, Ostariophysi). Smithsonian Contributions to Zoology, 507: 1-118.

VARI, R. P. 1992. Systematics of the neotropical Characiform genus Cyphocharax Fowler (Pisces, Ostariophysi). Smithsonian Contributions to Zoology, 529: i-iv + 1137.

VARI, R. P. 1992. Systematics of the neotropical characiform genus Curimatella Eigenmann and Eigenmann (Pisces, Ostariophysi), with summary comments on the Curimatidae. Smithsonian Contributions to Zoology, 533: i-iii + 1-48.

VALÉRIO, S.; SUÁREZ, Y. R.; FELIPE, T. R. A.; TONDATO, K. K. \& XIMENES, L. Q. L. 2007. Organization patterns of headwater-stream fish communities in the Upper Paraguay-Paraná basins. Hydrobiologia 583:241-250p.

VERISSIMO, S. PAVANELLI, C. S.; BRITSKI, H. A. \& MOREIRA, M. M. M. 2005. Fish, Manso Reservoir region of influence, Rio Paraguai basin, Mato Grosso. Check List 1(1):1-9p.

VONHOF, H. B.; WESSELINGH, F. P.; GANSSEN, G. M. 1998. Reconstruction of the Miocene western Amazonian aquatic system using molluscan isotopic signatures. Palaeogeography, Palaeoclimatology, Palaeoecology 141, 85-93.

VONHOF, H. B.; WESSELINGH, F. P.; KAANDORP, R. J. G.; DAVIES, G. R.; VAN HINTE, J. E.; GUERRERO, J.; RASANEN, M.; ROMERO-PITTMAN, L.; RANZI, A. 2003. Paleogeography of Miocene Western Amazonia: Isotopic composition of molluscan shells constrains the influence of marine incursions. Geological Society of America Bulletin 115, 983-993.

WEITZMAN, S. H. \& L. R. MALABARBA. 1998. Perspectives about the phylogeny and classification of the Characidae (Teleostei: Characiformes) Pp. 161-170. in: Phylogeny and Classification of neotropical fishes. Malabarba, L. R., R. E. Reis, R. P. Vari, Z. M. S. Lucena \&C. A. Lucena (eds.), EDIPUCRS. Porto Alegre.

WEITZMAN, S. H. \& R. P. VARI, 1988. Miniaturization in South American freshwater fishes; an overview and discussion. Proceedings of the Biological Society of Washington, 101(2): 444-465p.

WEITZMAN, S. H. \& W. L. FINK. 1983. Relationships of the neon tetras, a group of South American freshwater fishes (Teleostei, Characidae), with comments on the phylogeny of New World characiforms. Bull. Mus. Comp. Zool., 150: 339-395p. 
WEITZMAN, S. H. 1962. The osteology of Brycon meeki, a generalized characid fish, with na osteological definition of the family. Stanford Ichthyological Bulletin, 8(1):1-77p.

WEITZMAN, S. H. 1964. Osteology and relationships of South American characid fishes of subfamilies Lebiasininae and Erythrininae with special reference to subtribe Nannostomina. Proceedings of the United States Museum, 116 (3499): 127-169p.

WEITZMAN, S. H. 1974. Osteology and evolutionary relationships of the Sternoptychidae, with a new classification of Stomiatoid families. Bulletin of American Museum (Natural History), 153(3):327-478p.

WEITZMAN, S. H., 1954. The osteology and relationships of the South American characid fishes of the subfamily Gasteropelecinae. Amererican Museum Novitates, 4(1): 212-263p.

WEITZMAN, S. H.; MENEZES, N. A.; EVERS, H. G. \& BURNS; J. R. 2005. Putative relationships among inseminating and externally fertilizing characids, with a description of a new genus and species of Brazilian inseminating fish bearing an anal—fin gland in males (Characiformes: Characidae). Neotropical Ichthyology, 3(3):329-360p.

WESSELINGH, F.P., RÄSÄNEN, M.E., IRION, G., VONHOF, H.B., KAANDORP, R., RENEMA, W., ROMERO PITTMAN L. \& GINGRAS, M. 2002. Lake Pebas: a palaeoecological reconstruction of a Miocene, long-lived lake complex in western Amazonia. Cenozoic Research, 1: 35-81.

WINEMILLER, K. O. 1990. Spatial and temporal variation in tropical fish trophic networks. Ecological Monographs, 60(3):331-367p.

WINEMILLER, K. \& D. C. TAPHORN. 1989. La evolución de las estrategias de vida en los peces de los llanos occidentales de Venezuela. BioLlania 6:77-122.

WINEMILLER, K. O; AGOSTINHO, A. A. \& CARAMASCHI, E. P. 2008. Fish Ecology in Tropical Streams. Pp. 107-146. In: Dudgeon, D. (ed.). Tropical Stream Ecology. Amsterdam, Elselvier Press, 370p.

WINTERBOTTOM, R. 1980. Systematics, osteology and phylogenetic relationships of fishes of the Ostariophysan subfamily Anostominae (Characoidei, Anostomidae). Life Sciences Contribution, Royal Ontario Museum, 123: 112p.

ZANATA, A. M. \& TOLEDO-PIZA, M. 2004. Taxonomic revision of the South American fish genus Chalceus Cuvier (Teleostei:Ostariophysi: Characiformes) with 
the description of three new species. Zoological Journal of Linnean Society, 140:103-135p.

ZANATA, A. M. \& VARI, R. P. 2005. The family Alestidae (Ostariophysi, Characiformes): a phylogenetic analysis of a trans-Atlantic clade. Zoological Journal of Linnean Society, 145:1-144p.

ZANATA, A. M. 2000. Estudo das relações filogenéticas do gênero Brycon Müller and Troschel, 1844 (Characidae; Characiformes). Tese de Doutorado nãopublicada. São Paulo, Universidade de São Paulo.

ZARSKE, A.; GÉRY, J. \& ISBRÜCKER, I. 2004. Moenkhausia rara sp. n. - eine neue, bereits bestandsgefährdete Salmler-Art (Teleostei: Characiformes: Characidae) aus Surinam und Französisch Guayana mit einer ergänzenden Beschreibung von $M$. simulata (Eigenmann in Pearson, 1924). Zoologische Abhandlungen (Dresden) 54: 19-30p.

ZARSKE, A. 2010. Der Kolibrisalmler Trochilocharax ornatus gen. et spec. nov. ein neuer Salmler aus Peru (Teleostei: Characiformes: Characidae). Vertebrate Zoology 60(2): 75-98p. 


\section{Apêndice 1}

Sinapomorfias e lista transições 
Acestrorhynchus falcatus:

Todas as árvores:

Caráter - 1: $1 \rightarrow 0$

Caráter - 9: $0 \rightarrow 1$

Caráter - 10: $0 \rightarrow 1$

Caráter - 36: $2 \rightarrow 3$

Caráter - 53: $2 \rightarrow 0$

Caráter - 60: $0 \rightarrow 2$

Caráter - 71: $1 \rightarrow 2$

Caráter - 76: $0 \rightarrow 1$

Caráter - 89: $4 \rightarrow 2$

Agoniates anchovia:

Todas as árvores:

Caráter - 38: $0 \rightarrow 1$

Caráter - 40: $0 \rightarrow 2$

Agoniates halecinus:

Todas as árvores:

Caráter - 58: $1 \rightarrow 2$

Caráter - 76: $0 \rightarrow 1$

Caráter - 81: $0 \rightarrow 1$

Aphyocharax pusillus:

Todas as árvores:

Caráter - 17: $0 \rightarrow 1$

Caráter - 18: $1 \rightarrow 0$

Caráter - 24: $0 \rightarrow 1$

Caráter - 28: $1 \rightarrow 2$

Caráter - 33: $0 \rightarrow 2$

Caráter - 50: $1 \rightarrow 0$

Caráter - 73: $01 \rightarrow 2$

Caráter - 90: $2 \rightarrow 3$

Caráter - 101: $1 \rightarrow 0$

Caráter - 110: $1 \rightarrow 0$

Caráter - 115: $1 \rightarrow 0$

Caráter - 128: $1 \rightarrow 2$

Astyanacinus moorii:

Todas as árvores:

Caráter - 0: $0 \rightarrow 1$

Caráter - 15: $0 \rightarrow 1$

Astyanacinus sp nova Bolivia:

Todas as árvores:

Sem autapomorfias:

Astyanacinus sp nova Peru:

Todas as árvores:

Caráter - 0: $0 \rightarrow 1$

Caráter - 106: $2 \rightarrow 0$

“Astyanax" superbus:

Todas as árvores:

Caráter - 15: $0 \rightarrow 1$

Caráter - 19: $1 \rightarrow 0$

Caráter - 48: $1 \rightarrow 34$
Caráter - 50: $0 \rightarrow 1$

Caráter - 59: $1 \rightarrow 0$

Caráter - 60: $1 \rightarrow 2$

“Astyanax” orthodus:

Todas as árvores:

Caráter - 93: $1 \rightarrow 0$

Caráter - 112: $0 \rightarrow 1$

Caráter - 119: $1 \rightarrow 0$

Caráter - 129: $1 \rightarrow 0$

Astyanax altiparanae:

Todas as árvores:

Caráter - 81: $1 \rightarrow 0$

Caráter - 87: $2 \rightarrow 1$

Astyanax fasciatus:

Todas as árvores:

Caráter - 0: $0 \rightarrow 1$

Caráter - 3: $0 \rightarrow 2$

Caráter - 8: $0 \rightarrow 1$

Caráter - 46: $0 \rightarrow 1$

Caráter - 50: $0 \rightarrow 1$

Caráter - 81: $1 \rightarrow 0$

Caráter - 85: $1 \rightarrow 0$

Caráter - 106: $0 \rightarrow 2$

Astyanax lineatus:

Todas as árvores:

Caráter - 84: $0 \rightarrow 1$

Caráter - 88: $0 \rightarrow 1$

Caráter - 102: $0 \rightarrow 1$

Caráter - 107: $1 \rightarrow 0$

Caráter - 117: $1 \rightarrow 0$

Caráter - 120: $0 \rightarrow 2$

Astyanax paranae:

Todas as árvores:

Caráter - 6: $0 \rightarrow 1$

Caráter - 36: $1 \rightarrow 0$

Caráter - 51: $1 \rightarrow 0$

Caráter - 82: $0 \rightarrow 1$

Caráter - 89: $1 \rightarrow 0$

Caráter - 90: $2 \rightarrow 0$

Caráter - 91: $2 \rightarrow 0$

Caráter - 104: $1 \rightarrow 0$

Brycon pesu :

Todas as árvores:

Caráter - 20: $1 \rightarrow 0$

Caráter - 25: $0 \rightarrow 1$

Caráter - 41: $0 \rightarrow 1$

Caráter - 65: $1 \rightarrow 0$

Caráter - 81: $1 \rightarrow 0$

Caráter - 85: $1 \rightarrow 0$

Caráter - 86: $0 \rightarrow 1$

Caráter - 87: $4 \rightarrow 3$ 
Caráter - 133: $0 \rightarrow 3$

Bryconamericus exodon:

Todas as árvores:

Caráter - 0: $0 \rightarrow 1$

Caráter - 11: $0 \rightarrow 1$

Caráter - 20: $0 \rightarrow 1$

Caráter - 32: $2 \rightarrow 3$

Caráter - 37: $1 \rightarrow 0$

Caráter - 60: $0 \rightarrow 1$

Bryconops alburnoides:

Todas as árvores:

Caráter - 3: $0 \rightarrow 1$

Caráter - 25: $0 \rightarrow 1$

Caráter - 30: $0 \rightarrow 1$

Caráter - 32: $2 \rightarrow 0$

Caráter - 39: $0 \rightarrow 1$

Caráter - 46: $0 \rightarrow 1$

Caráter - 48: $5 \rightarrow 0$

Caráter - 49: $0 \rightarrow 1$

Caráter - 50: $2 \rightarrow 0$

Caráter - 58: $1 \rightarrow 2$

Caráter - 73: $1 \rightarrow 0$

Caráter - 87: $4 \rightarrow 3$

Caráter - 101: $0 \rightarrow 1$

Caráter - 128: $1 \rightarrow 2$

Chalceus epakros:

Todas as árvores:

Sem autapomorfias:

\section{Charax leticiae:}

Todas as árvores:

Caráter - 0: $0 \rightarrow 1$

Caráter - 1: $0 \rightarrow 1$

Caráter - 7: $0 \rightarrow 1$

Caráter - 25: $0 \rightarrow 1$

Caráter - 32: $1 \rightarrow 0$

Caráter - 39: $0 \rightarrow 2$

Caráter - 73: $1 \rightarrow 2$

Caráter - 74: $0 \rightarrow 1$

Caráter - 87: $2 \rightarrow 1$

Caráter - 90: $5 \rightarrow 4$

Caráter - 97: $0 \rightarrow 1$

Caráter - 106: $0 \rightarrow 1$

Caráter - 107: $0 \rightarrow 1$

Caráter - 122: $0 \rightarrow 2$

Cheirodon galusdae:

Todas as árvores:

Caráter - 6: $0 \rightarrow 1$

Caráter - 8: $0 \rightarrow 1$

Caráter - 11: $1 \rightarrow 0$

Caráter - 30: $2 \rightarrow 1$

Caráter - 31: $2 \rightarrow 1$

Caráter - 47: $0 \rightarrow 1$

Caráter - 55: $0 \rightarrow 1$

Caráter - 84: $0 \rightarrow 2$

Caráter - 85: $1 \rightarrow 0$
Caráter - 112: $1 \rightarrow 0$

Caráter - 120: $0 \rightarrow 1$

Caráter - 121: $0 \rightarrow 1$

Caráter - 128: $1 \rightarrow 3$

Caráter - 132: $0 \rightarrow 1$

Clupeacharax anchoveoides:

Todas as árvores:

Caráter - 33: $0 \rightarrow 3$

Caráter - 58: $0 \rightarrow 2$

Caráter - 74: $0 \rightarrow 1$

Caráter - 75: $0 \rightarrow 1$

Caráter - 87: $4 \rightarrow 2$

Caráter - 118: $1 \rightarrow 2$

Creagrutus menezesi :

Todas as árvores:

Caráter - 8: $0 \rightarrow 1$

Caráter - 20: $0 \rightarrow 1$

Caráter - 22: $1 \rightarrow 0$

Caráter - 30: $0 \rightarrow 1$

Caráter - 33: $0 \rightarrow 3$

Caráter - 38: $0 \rightarrow 1$

Caráter - 52: $0 \rightarrow 1$

Caráter - 58: $0 \rightarrow 1$

Caráter - 60: $0 \rightarrow 1$

Caráter - 65: $1 \rightarrow 0$

Caráter - 68: $0 \rightarrow 1$

Caráter - 70: $1 \rightarrow 2$

Caráter - 81: $0 \rightarrow 1$

Caráter - 82: $0 \rightarrow 1$

Caráter - 84: $2 \rightarrow 0$

Caráter - 85: $1 \rightarrow 0$

Caráter - 103: $1 \rightarrow 0$

Caráter - 111: $1 \rightarrow 0$

Caráter - 112: $1 \rightarrow 0$

Ctenobrycon hauxwellianus:

Todas as árvores:

Caráter - 24: $0 \rightarrow 1$

Caráter - 37: $1 \rightarrow 0$

Caráter - 72: $0 \rightarrow 1$

Caráter - 130: $1 \rightarrow 0$

Caráter - 134: $0 \rightarrow 1$

Deuterodon iguape:

Todas as árvores:

Caráter - 1: $0 \rightarrow 1$

Caráter - 15: $0 \rightarrow 1$

Caráter - 21: $0 \rightarrow 1$

Caráter - 28: $1 \rightarrow 0$

Caráter - 33: $0 \rightarrow 2$

Caráter - 50: $0 \rightarrow 3$

Caráter - 78: $0 \rightarrow 1$

Caráter - 81: $1 \rightarrow 0$

Caráter - 131: $1 \rightarrow 0$

Engraulisoma taeniatum:

Todas as árvores:

Caráter - 1: $1 \rightarrow 0$ 
Caráter - 35: $0 \rightarrow 1$

Caráter - 40: $0 \rightarrow 2$

Caráter - 55: $0 \rightarrow 1$

Caráter - 60: $0 \rightarrow 1$

Caráter - 77: $1 \rightarrow 0$

Caráter - 89: $4 \rightarrow 1$

Caráter - 104: $2 \rightarrow 1$

Caráter - 113: $1 \rightarrow 0$

Caráter - 115: $1 \rightarrow 0$

Caráter - 117: $0 \rightarrow 1$

Caráter - 120: $1 \rightarrow 0$

Galeocharax knerii :

Todas as árvores:

Caráter - 9: $0 \rightarrow 2$

Caráter - 11: $1 \rightarrow 0$

Caráter - 12: $0 \rightarrow 1$

Caráter - 33: $0 \rightarrow 1$

Caráter - 83: $0 \rightarrow 1$

Caráter - 112: $0 \rightarrow 1$

Caráter - 120: $0 \rightarrow 2$

Caráter - 128: $01 \rightarrow 2$

Caráter - 130: $0 \rightarrow 1$

Gymnocorymbus ternertzi:

Todas as árvores:

Caráter - 0: $0 \rightarrow 1$

Caráter - 6: $1 \rightarrow 0$

Caráter - 51: $2 \rightarrow 0$

Caráter - 71: $0 \rightarrow 2$

Caráter - 90: $3 \rightarrow 0$

Caráter - 106: $2 \rightarrow 1$

Caráter - 117: $1 \rightarrow 2$

Caráter - 121: $0 \rightarrow 1$

Caráter - 122: $1 \rightarrow 2$

Caráter - 124: $0 \rightarrow 1$

Caráter - 133: $0 \rightarrow 1$

Hollandichthys multifasciatus:

Todas as árvores:

Caráter - 18: $1 \rightarrow 0$

Caráter - 21: $0 \rightarrow 1$

Caráter - 25: $0 \rightarrow 1$

Caráter - 32: $1 \rightarrow 3$

Caráter - 38: $0 \rightarrow 1$

Caráter - 50: $2 \rightarrow 0$

Caráter - 81: $1 \rightarrow 0$

Caráter - 84: $0 \rightarrow 2$

Caráter - 90: $2 \rightarrow 3$

Caráter - 91: $2 \rightarrow 0$

Caráter - 104: $1 \rightarrow 2$

Hydrolycus scomberoides:

Todas as árvores:

Caráter - 2: $1 \rightarrow 0$

Caráter - 13: $0 \rightarrow 01$

Caráter - 19: $0 \rightarrow 1$

Caráter - 23: $1 \rightarrow 0$

Caráter - 24: $1 \rightarrow 0$

Caráter - 38: $0 \rightarrow 1$
Caráter - 61: $0 \rightarrow 2$

Caráter - 77: $1 \rightarrow 0$

Caráter - 91: $0 \rightarrow 1$

Caráter - 96: $0 \rightarrow 3$

Caráter - 99: $1 \rightarrow 0$

Caráter - 101: $0 \rightarrow 1$

Caráter - 102: $0 \rightarrow 1$

Caráter - 107: $0 \rightarrow 1$

Caráter - 108: $0 \rightarrow 1$

Caráter - 109: $0 \rightarrow 1$

Caráter - 112: $0 \rightarrow 1$

Caráter - 133: $0 \rightarrow 3$

Hyphessobrycon eques:

Todas as árvores:

Caráter - 30: $2 \rightarrow 1$

Caráter - 31: $2 \rightarrow 01$

Caráter - 39: $0 \rightarrow 12$

Caráter - 50: $0 \rightarrow 1$

Caráter - 90: $3 \rightarrow 1$

Caráter - 95: $0 \rightarrow 1$

Caráter - 97: $0 \rightarrow 1$

Caráter - 117: $1 \rightarrow 2$

Caráter - 134: $0 \rightarrow 1$

Jupiaba anteroides:

Todas as árvores:

Caráter - 9: $1 \rightarrow 3$

Caráter - 32: $2 \rightarrow 3$

Caráter - 122: $0 \rightarrow 1$

Caráter - 124: $1 \rightarrow 0$

Knodus moenkhausii:

Todas as árvores:

Caráter - 1: $0 \rightarrow 1$

Caráter - 50: $0 \rightarrow 3$

Caráter - 68: $0 \rightarrow 2$

Lignobrycon myersii:

Todas as árvores:

Caráter - 5: $0 \rightarrow 1$

Caráter - 10: $0 \rightarrow 1$

Caráter - 18: $1 \rightarrow 0$

Caráter - 19: $0 \rightarrow 1$

Caráter - 24: $1 \rightarrow 0$

Caráter - 65: $0 \rightarrow 1$

Markiana nigripinnis:

Todas as árvores:

Caráter - 1: $0 \rightarrow 1$

Caráter - 3: $1 \rightarrow 2$

Caráter - 5: $1 \rightarrow 0$

Caráter - 6: $1 \rightarrow 0$

Caráter - 7: $1 \rightarrow 0$

Caráter - 15: $0 \rightarrow 1$

Caráter - 40: $1 \rightarrow 2$

Caráter - 53: $1 \rightarrow 0$

Caráter - 81: $1 \rightarrow 0$

Caráter - 85: $1 \rightarrow 0$

Caráter - 86: $0 \rightarrow 2$ 
Caráter - 102: $1 \rightarrow 0$

Caráter - 112: $1 \rightarrow 0$

Caráter - 128: $1 \rightarrow 0$

Caráter - 132: $0 \rightarrow 1$

Mimagoniates microlepis:

Todas as árvores:

Caráter - 10: $1 \rightarrow 0$

Caráter - 21: $0 \rightarrow 1$

Caráter - 31: $2 \rightarrow 0$

Caráter - 35: $1 \rightarrow 0$

Caráter - 36: $1 \rightarrow 4$

Caráter - 48: $0 \rightarrow 5$

Caráter - 59: $1 \rightarrow 0$

Caráter - 73: $0 \rightarrow 1$

Caráter - 78: $0 \rightarrow 1$

Caráter - 90: $3 \rightarrow 4$

Caráter - 91: $2 \rightarrow 0$

Caráter - 93: $1 \rightarrow 0$

Caráter - 96: $01 \rightarrow 2$

Caráter - 103: $1 \rightarrow 0$

Caráter - 112: $1 \rightarrow 0$

Caráter - 119: $1 \rightarrow 0$

Caráter - 121: $0 \rightarrow 1$

Caráter - 132: $0 \rightarrow 1$

Moenkhausia xinguensis:

Todas as árvores:

Caráter - 68: $0 \rightarrow 2$

Caráter - 77: $1 \rightarrow 0$

Caráter - 81: $1 \rightarrow 0$

Caráter - 103: $1 \rightarrow 0$

Caráter - 110: $1 \rightarrow 0$

Caráter - 122: $0 \rightarrow 1$

Caráter - 124: $1 \rightarrow 0$

Nematocharax venustus:

Todas as árvores:

Caráter - 6: $0 \rightarrow 1$

Caráter - 9: $1 \rightarrow 03$

Caráter - 26: $1 \rightarrow 0$

Caráter - 30: $2 \rightarrow 1$

Caráter - 48: $0 \rightarrow 5$

Caráter - 49: $1 \rightarrow 0$

Caráter - 73: $0 \rightarrow 1$

Caráter - 86: $01 \rightarrow 1$

Caráter - 102: $0 \rightarrow 1$

Caráter - 120: $0 \rightarrow 2$

Caráter - 133: $0 \rightarrow 1$

Caráter - 135: $0 \rightarrow 1$

Oligosarcus pintoi :

Todas as árvores:

Caráter - 20: $1 \rightarrow 0$

Caráter - 32: $1 \rightarrow 3$

Caráter - 56: $0 \rightarrow 1$

Caráter - 70: $1 \rightarrow 0$

Caráter - 71: $0 \rightarrow 2$

Caráter - 107: $0 \rightarrow 1$

Caráter - 129: $0 \rightarrow 1$
Caráter - 133: $0 \rightarrow 1$

Piabina argentea:

Todas as árvores:

Caráter - 37: $1 \rightarrow 0$

Caráter - 51: $1 \rightarrow 2$

Caráter - 90: $3 \rightarrow 4$

Poptella paraguayensis:

Todas as árvores:

Caráter - 6: $1 \rightarrow 0$

Caráter - 9: $1 \rightarrow 0$

Caráter - 11: $0 \rightarrow 1$

Caráter - 55: $0 \rightarrow 1$

Caráter - 71: $0 \rightarrow 2$

Caráter - 91: $2 \rightarrow 0$

Caráter - 92: $0 \rightarrow 1$

Caráter - 100: $1 \rightarrow 2$

Rachoviscus graciliceps:

Todas as árvores:

Caráter - 20: $1 \rightarrow 0$

Caráter - 28: $1 \rightarrow 2$

Caráter - 35: $0 \rightarrow 1$

Caráter - 49: $0 \rightarrow 1$

Caráter - 59: $1 \rightarrow 0$

Caráter - 67: $0 \rightarrow 1$

Caráter - 85: $1 \rightarrow 2$

Caráter - 97: $0 \rightarrow 1$

Caráter - 102: $0 \rightarrow 1$

Caráter - 116: $0 \rightarrow 1$

Caráter - 120: $0 \rightarrow 1$

Caráter - 128: $1 \rightarrow 0$

Salminus hilarii:

Todas as árvores:

Caráter - 5: $0 \rightarrow 1$

Caráter - 21: $0 \rightarrow 1$

Caráter - 33: $0 \rightarrow 2$

Caráter - 45: $0 \rightarrow 1$

Caráter - 71: $0 \rightarrow 2$

Caráter - 85: $1 \rightarrow 0$

Caráter - 90: $5 \rightarrow 6$

Caráter - 100: $0 \rightarrow 1$

Caráter - 112: $0 \rightarrow 1$

Caráter - 128: $1 \rightarrow 2$

Stethaprion erythrops:

Todas as árvores:

Caráter - 9: $1 \rightarrow 0$

Caráter - 20: $1 \rightarrow 0$

Caráter - 79: $0 \rightarrow 1$

Caráter - 90: $3 \rightarrow 2$

Caráter - 92: $0 \rightarrow 1$

Caráter - 99: $1 \rightarrow 0$

Caráter - 113: $0 \rightarrow 1$

Caráter - 118: $0 \rightarrow 1$

Caráter - 119: $1 \rightarrow 0$

Caráter - 120: $0 \rightarrow 1$

Caráter - 121: $0 \rightarrow 2$ 
Stichonodon insignis:

Todas as árvores:

Caráter - 5: $1 \rightarrow 0$

Caráter - 28: $1 \rightarrow 2$

Caráter - 31: $12 \rightarrow 0$

Caráter - 32: $2 \rightarrow 4$

Caráter - 37: $1 \rightarrow 0$

Caráter - 74: $0 \rightarrow 1$

Caráter - 77: $1 \rightarrow 0$

Caráter - 80: $1 \rightarrow 0$

Caráter - 86: $0 \rightarrow 2$

Caráter - 99: $1 \rightarrow 0$

Caráter - 106: $2 \rightarrow 0$

Caráter - 117: $1 \rightarrow 0$

Caráter - 120: $0 \rightarrow 1$

Caráter - 121: $0 \rightarrow 1$

Tetragonopterus chalceus:

Todas as árvores:

Caráter - 2: $0 \rightarrow 2$

Caráter - 7: $1 \rightarrow 0$

Caráter - 11: $0 \rightarrow 1$

Caráter - 32: $2 \rightarrow 0$

Caráter - 50: $0 \rightarrow 1$

Caráter - 68: $0 \rightarrow 2$

Caráter - 89: $02 \rightarrow 4$

Caráter - 117: $1 \rightarrow 2$

Caráter - 133: $0 \rightarrow 1$

Caráter - 134: $0 \rightarrow 1$

Thoracocharax stellatus:

Todas as árvores:

Caráter - 14: $0 \rightarrow 1$

Caráter - 19: $04 \rightarrow 1$

Caráter - 22: $0 \rightarrow 1$

Caráter - 25: $0 \rightarrow 1$

Caráter - 28: $0 \rightarrow 2$

Caráter - 68: $0 \rightarrow 1$

Caráter - 72: $0 \rightarrow 1$

Caráter - 87: $4 \rightarrow 0$

Caráter - 89: $4 \rightarrow 3$

Caráter - 94: $0 \rightarrow 1$

Caráter - 97: $0 \rightarrow 1$

Caráter - 102: $0 \rightarrow 1$

Caráter - 106: $0 \rightarrow 1$

Caráter - 107: $0 \rightarrow 1$

Caráter - 116: $0 \rightarrow 1$

Caráter - 121: $1 \rightarrow 2$

Caráter - 130: $0 \rightarrow 1$

Caráter - 134: $0 \rightarrow 1$

Triportheus albus :

Todas as árvores:

Caráter - 3: $0 \rightarrow 1$

Caráter - 6: $0 \rightarrow 1$

Caráter - 8: $0 \rightarrow 1$

Caráter - 22: $02 \rightarrow 1$

Caráter - 25: $0 \rightarrow 1$

Caráter - 26: $1 \rightarrow 01$
Caráter - 35: $0 \rightarrow 1$

Caráter - 39: $0 \rightarrow 1$

Caráter - 44: $1 \rightarrow 0$

Caráter - 47: $0 \rightarrow 1$

Caráter - 49: $0 \rightarrow 1$

Caráter - 72: $0 \rightarrow 1$

Caráter - 88: $01 \rightarrow 1$

Caráter - 89: $4 \rightarrow 2$

Caráter - 90: $5 \rightarrow 3$

Caráter - 96: $2 \rightarrow 1$

Caráter - 101: $0 \rightarrow 1$

Caráter - 116: $0 \rightarrow 1$

Caráter - 117: $0 \rightarrow 2$

Clado 48:

Todas as árvores:

Caráter - 6: $0 \rightarrow 1$

Caráter - 17: $0 \rightarrow 1$

Caráter - 34: $0 \rightarrow 1$

Caráter - 39: $0 \rightarrow 2$

Caráter - 42: $0 \rightarrow 1$

Caráter - 45: $0 \rightarrow 1$

Caráter - 56: $0 \rightarrow 1$

Caráter - 57: $0 \rightarrow 1$

Caráter - 63: $0 \rightarrow 1$

Caráter - 86: $0 \rightarrow 2$

Caráter - 90: $5 \rightarrow 6$

Caráter - 126: $0 \rightarrow 1$

Caráter - 132: $1 \rightarrow 0$

Clado 49:

Todas as árvores:

Caráter - 33: $0 \rightarrow 1$

Caráter - 71: $0 \rightarrow 1$

Caráter - 80: $1 \rightarrow 0$

Caráter - 83: $0 \rightarrow 1$

Caráter - 88: $0 \rightarrow 1$

Caráter - 131: $1 \rightarrow 0$

Clado 50:

Todas as árvores:

Caráter - 2: $0 \rightarrow 1$

Caráter - 10: $1 \rightarrow 0$

Caráter - 65: $1 \rightarrow 0$

Caráter - 77: $0 \rightarrow 1$

Caráter - 120: $0 \rightarrow 1$

Clado 51:

Todas as árvores:

Caráter - 1: $0 \rightarrow 1$

Caráter - 15: $1 \rightarrow 0$

Caráter - 81: $1 \rightarrow 0$

Caráter - 89: $2 \rightarrow 04$

Caráter - 91: $2 \rightarrow 0$

Caráter - 111: $0 \rightarrow 1$

Clado 52:

Todas as árvores:

Caráter - 8: $1 \rightarrow 0$

Caráter - 11: $0 \rightarrow 1$ 
Caráter - 35: $1 \rightarrow 0$

Caráter - 39: $1 \rightarrow 0$

Caráter - 44: $0 \rightarrow 1$

Caráter - 50: $0 \rightarrow 2$

Caráter - 120: $1 \rightarrow 0$

Clado 53:

Todas as árvores:

No synapomorphies

Clado 54:

Todas as árvores:

Caráter - 0: $0 \rightarrow 1$

Caráter - 8: $0 \rightarrow 1$

Caráter - 12: $0 \rightarrow 2$

Caráter - 21: $04 \rightarrow 1$

Caráter - 26: $1 \rightarrow 0$

Caráter - 29: $0 \rightarrow 1$

Caráter - 43: $0 \rightarrow 1$

Caráter - 52: $0 \rightarrow 12$

Caráter - 54: $0 \rightarrow 1$

Caráter - 67: $0 \rightarrow 1$

Caráter - 74: $0 \rightarrow 1$

Caráter - 75: $0 \rightarrow 1$

Caráter - 96: $0 \rightarrow 1$

Caráter - 110: $0 \rightarrow 2$

Caráter - 127: $0 \rightarrow 1$

Caráter - 128: $1 \rightarrow 0$

Clado 55:

Todas as árvores:

Caráter - 30: $0 \rightarrow 2$

Caráter - 31: $0 \rightarrow 2$

Caráter - 35: $0 \rightarrow 1$

Caráter - 36: $0 \rightarrow 1$

Caráter - 87: $2 \rightarrow 3$

Caráter - 89: $2 \rightarrow 1$

Caráter - 96: $1 \rightarrow 0$

\section{Clado 56:}

Todas as árvores:

Caráter - 7: $0 \rightarrow 1$

Caráter - 15: $1 \rightarrow 0$

Caráter - 39: $0 \rightarrow 2$

Caráter - 50: $2 \rightarrow 1$

Caráter - 112: $0 \rightarrow 1$

\section{Clado 57:}

Todas as árvores:

Caráter - 36: $2 \rightarrow 0$

Caráter - 53: $0 \rightarrow 2$

Caráter - 58: $1 \rightarrow 02$

Caráter - 77: $0 \rightarrow 1$

Caráter - 90: $5 \rightarrow 2$

\section{Clado 58:}

Todas as árvores:

Caráter - 14: $0 \rightarrow 1$

Caráter - 22: $0 \rightarrow 12$

Caráter - 32: $2 \rightarrow 1$
Caráter - 59: $0 \rightarrow 1$

Caráter - 64: $0 \rightarrow 1$

Caráter - 87: $4 \rightarrow 2$

Caráter - 94: $0 \rightarrow 1$

Caráter - 96: $0 \rightarrow 1$

Caráter - 101: $0 \rightarrow 1$

Caráter - 110: $0 \rightarrow 1$

Caráter - 117: $0 \rightarrow 12$

Caráter - 124: $0 \rightarrow 1$

Clado 59:

Todas as árvores:

Caráter - 19: $0 \rightarrow 1$

Caráter - 30: $2 \rightarrow 0$

Caráter - 107: $1 \rightarrow 0$

Caráter - 131: $1 \rightarrow 0$

Clado 60:

Todas as árvores:

Caráter - 35: $1 \rightarrow 0$

Caráter - 48: $0 \rightarrow 1$

Caráter - 51: $1 \rightarrow 0$

Caráter - 106: $0 \rightarrow 2$

Caráter - 111: $0 \rightarrow 1$

Caráter - 135: $0 \rightarrow 1$

Clado 61:

Todas as árvores:

Caráter - 2: $0 \rightarrow 2$

Caráter - 3: $1 \rightarrow 0$

Caráter - 46: $1 \rightarrow 0$

Caráter - 129: $0 \rightarrow 1$

Clado 62:

Todas as árvores:

Caráter - 87: $1 \rightarrow 2$

Caráter - 112: $1 \rightarrow 0$

Caráter - 133: $0 \rightarrow 2$

Clado 63:

Todas as árvores:

Caráter - 11: $1 \rightarrow 0$

Caráter - 89: $1 \rightarrow 2$

Caráter - 90: $1 \rightarrow 3$

Clado 64:

Todas as árvores:

Caráter - 50: $1 \rightarrow 0$

Caráter - 117: $2 \rightarrow 1$

Clado 65:

Todas as árvores:

Caráter - 20: $1 \rightarrow 0$

Caráter - 39: $12 \rightarrow 0$

Caráter - 87: $13 \rightarrow 1$

Caráter - 90: $2 \rightarrow 1$

Caráter - 93: $0 \rightarrow 1$

Caráter - 100: $0 \rightarrow 1$

Caráter - 107: $0 \rightarrow 12$ 
Clado 66:

Todas as árvores:

Caráter - 9: $0 \rightarrow 1$

Caráter - 25: $0 \rightarrow 1$

Caráter - 46: $0 \rightarrow 1$

Caráter - 49: $0 \rightarrow 12$

Caráter - 53: $2 \rightarrow 1$

\section{Clado 67:}

Todas as árvores:

Caráter - 58: $0 \rightarrow 2$

Caráter - 68: $0 \rightarrow 2$

Caráter - 81: $1 \rightarrow 0$

Caráter - 117: $1 \rightarrow 0$

Clado 68:

Todas as árvores:

Caráter - 28: $1 \rightarrow 0$

Caráter - 47: $0 \rightarrow 1$

Caráter - 90: $3 \rightarrow 2$

Clado 69:

Todas as árvores:

Caráter - 111: $0 \rightarrow 1$

Caráter - 112: $0 \rightarrow 1$

Clado 70:

Todas as árvores:

Caráter - 1: $0 \rightarrow 1$

Caráter - 68: $0 \rightarrow 02$

Caráter - 89: $2 \rightarrow 1$

Caráter - 133: $2 \rightarrow 1$

Clado 71:

Todas as árvores:

Caráter - 3: $1 \rightarrow 2$

Caráter - 53: $2 \rightarrow 0$

Caráter - 100: $1 \rightarrow 0$

Caráter - 106: $2 \rightarrow 0$

\section{Clado 72:}

Todas as árvores:

Caráter - 16: $1 \rightarrow 0$

Caráter - 55: $0 \rightarrow 1$

Caráter - 81: $1 \rightarrow 0$

Caráter - 98: $0 \rightarrow 12$

Caráter - 99: $1 \rightarrow 2$

Caráter - 107: $1 \rightarrow 0$

Caráter - 115: $1 \rightarrow 0$

Clado 73:

Todas as árvores:

Caráter - 60: $1 \rightarrow 0$

Caráter - 77: $01 \rightarrow 0$

Caráter - 79: $01 \rightarrow 1$

Caráter - 110: $1 \rightarrow 0$

Caráter - 118: $0 \rightarrow 1$

Clado 74:

Todas as árvores:
Caráter - 6: $0 \rightarrow 1$

Caráter - 19: $02 \rightarrow 1$

Caráter - 53: $1 \rightarrow 2$

Caráter - 106: $0 \rightarrow 2$

Clado 75:

Todas as árvores:

Caráter - 42: $0 \rightarrow 1$

Caráter - 65: $1 \rightarrow 0$

Caráter - 66: $0 \rightarrow 1$

Caráter - 69: $0 \rightarrow 1$

Caráter - 70: $1 \rightarrow 3$

Caráter - 71: $0 \rightarrow 2$

Caráter - 75: $0 \rightarrow 1$

Caráter - 89: $2 \rightarrow 4$

Caráter - 93: $0 \rightarrow 1$

Caráter - 102: $0 \rightarrow 2$

Caráter - 104: $1 \rightarrow 2$

Clado 76:

Todas as árvores:

Caráter - 0: $0 \rightarrow 1$

Caráter - 30: $01 \rightarrow 1$

Caráter - 38: $0 \rightarrow 01$

Caráter - 46: $0 \rightarrow 1$

Caráter - 47: $01 \rightarrow 1$

Caráter - 51: $2 \rightarrow 1$

Caráter - 62: $0 \rightarrow 01$

Caráter - 73: $1 \rightarrow 2$

Caráter - 86: $0 \rightarrow 1$

Caráter - 96: $2 \rightarrow 03$

Caráter - 98: $0 \rightarrow 01$

Caráter - 131: $1 \rightarrow 0$

Clado 77:

Todas as árvores:

Caráter - 82: $0 \rightarrow 1$

Caráter - 119: $1 \rightarrow 0$

Caráter - 122: $0 \rightarrow 1$

Caráter - 124: $0 \rightarrow 1$

Caráter - 128: $01 \rightarrow 0$

Clado 78:

Todas as árvores:

Caráter - 36: $2 \rightarrow 14$

Caráter - 51: $0 \rightarrow 02$

Caráter - 58: $01 \rightarrow 0$

Caráter - 96: $0 \rightarrow 2$

Caráter - 108: $0 \rightarrow 1$

Caráter - 109: $0 \rightarrow 1$

Clado 79:

Todas as árvores:

Caráter - 3: $2 \rightarrow 0$

Caráter - 19: $12 \rightarrow 0$

Caráter - 21: $0 \rightarrow 1$

Caráter - 35: $1 \rightarrow 2$

Caráter - 36: $1 \rightarrow 0$

Caráter - 39: $0 \rightarrow 1$

Caráter - 46: $1 \rightarrow 0$ 
Caráter - 48: $0 \rightarrow 1$

Caráter - 75: $0 \rightarrow 1$

Caráter - 87: $1 \rightarrow 12$

Caráter - 118: $1 \rightarrow 0$

Clado 80:

Todas as árvores:

Caráter - 30: $2 \rightarrow 0$

Caráter - 79: $1 \rightarrow 0$

Caráter - 104: $1 \rightarrow 0$

\section{Clado 81:}

Todas as árvores:

Caráter - 28: $1 \rightarrow 0$

Caráter - 50: $0 \rightarrow 1$

Caráter - 84: $1 \rightarrow 0$

Caráter - 91: $2 \rightarrow 0$

Clado 82:

Todas as árvores:

Caráter - 19: $1 \rightarrow 0$

Caráter - 20: $0 \rightarrow 1$

Caráter - 53: $02 \rightarrow 1$

\section{Clado 83:}

Todas as árvores:

Caráter - 30: $2 \rightarrow 1$

Caráter - 36: $1 \rightarrow 4$

Caráter - 102: $0 \rightarrow 1$

Clado 84:

Todas as árvores:

Caráter - 51: $1 \rightarrow 2$

Caráter - 104: $1 \rightarrow 2$

Caráter - 122: $0 \rightarrow 1$

Caráter - 124: $1 \rightarrow 0$

Caráter - 130: $0 \rightarrow 1$
Todas as árvores:

Caráter - 46: $1 \rightarrow 0$

Caráter - 51: $1 \rightarrow 0$

Caráter - 111: $0 \rightarrow 1$

Caráter - 119: $1 \rightarrow 0$

Clado 86:

Todas as árvores:

Caráter - 4: $0 \rightarrow 1$

Caráter - 9: $0 \rightarrow 3$

Caráter - 55: $0 \rightarrow 1$

Caráter - 95: $0 \rightarrow 1$

Caráter - 106: $0 \rightarrow 2$

Caráter - 111: $0 \rightarrow 1$

Clado 87:

Todas as árvores:

Caráter - 13: $0 \rightarrow 1$

Caráter - 21: $04 \rightarrow 1$

Caráter - 30: $0 \rightarrow 2$

Caráter - 86: $0 \rightarrow 2$

Clado 88:

Todas as árvores:

Caráter - 30: $1 \rightarrow 2$

Caráter - 46: $1 \rightarrow 0$

Caráter - 111: $0 \rightarrow 1$

Caráter - 117: $1 \rightarrow 0$

Caráter - 122: $1 \rightarrow 0$

Clado 89:

Todas as árvores:

Caráter - 46: $1 \rightarrow 0$

Caráter - 87: $1 \rightarrow 0$

Caráter - 90: $3 \rightarrow 1$

Caráter - 113: $0 \rightarrow 1$

Caráter - 118: $0 \rightarrow 1$

Clado 85:

\section{Transformações}

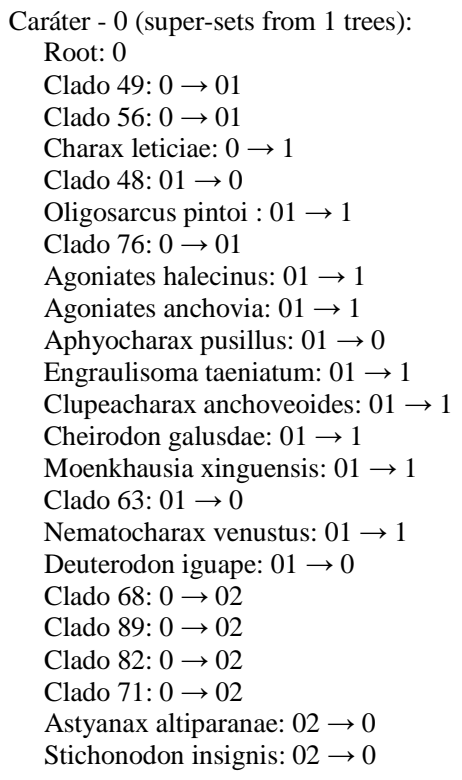

Poptella paraguayensis: $02 \rightarrow 0$

Clado 81: $02 \rightarrow 0$

Gymnocorymbus ternertzi: $02 \rightarrow 1$

Clado 80: $02 \rightarrow 0$

Bryconamericus exodon: $02 \rightarrow 1$

Clado 69: $02 \rightarrow 0$

Astyanax lineatus: $02 \rightarrow 0$

Astyanacinus moorii: $0 \rightarrow 1$

Astyanax fasciatus: $0 \rightarrow 1$

Astyanacinus sp nova Peru: $0 \rightarrow 1$

Caráter - 1 (super-sets from 1 trees):

Root: 0

Clado 51: $0 \rightarrow 01$

Bryconops alburnoides: $01 \rightarrow 1$

Charax leticiae: $0 \rightarrow 1$

Triportheus albus : $01 \rightarrow 1$

Lignobrycon myersii: $01 \rightarrow 1$

Clado 76: $01 \rightarrow 1$

Hydrolycus scomberoides: $01 \rightarrow 1$

Acestrorhynchus falcatus: $01 \rightarrow 0$

Agoniates halecinus: $01 \rightarrow 1$

Agoniates anchovia: $01 \rightarrow 1$

Engraulisoma taeniatum: $1 \rightarrow 0$

Deuterodon iguape: $0 \rightarrow 1$ 
Clado 70: $0 \rightarrow 01$

Astyanax lineatus: $01 \rightarrow 1$

Knodus moenkhausii: $0 \rightarrow 1$

Astyanax paranae: $01 \rightarrow 1$

Astyanax fasciatus: $01 \rightarrow 1$

Markiana nigripinnis: $0 \rightarrow 1$

Caráter - 2 (super-sets from 1 trees):

Root: 0

Clado 53: $0 \rightarrow 01$

Brycon pesu : $01 \rightarrow 0$

Salminus hilarii: $01 \rightarrow 0$

Clado 50: $01 \rightarrow 013$

Bryconops alburnoides: $01 \rightarrow 0$

Clado 78: $013 \rightarrow 12$

Clado 49: $013 \rightarrow 13$

Galeocharax knerii : $01 \rightarrow 0$

Charax leticiae: $01 \rightarrow 0$

Clado 87: $12 \rightarrow 1$

Clado 48: $13 \rightarrow 1$

Clado 54: $13 \rightarrow 1$

Clado 55: $01 \rightarrow 0$

Oligosarcus pintoi : $01 \rightarrow 0$

Rachoviscus graciliceps: $01 \rightarrow 0$

Hollandichthys multifasciatus: $01 \rightarrow 0$

Clado 76: $12 \rightarrow 13$

Hydrolycus scomberoides: $1 \rightarrow 0$

Clado 66: $0 \rightarrow 01$

Engraulisoma taeniatum: $13 \rightarrow 1$

Clupeacharax anchoveoides: $13 \rightarrow 1$

Cheirodon galusdae: $01 \rightarrow 0$

Moenkhausia xinguensis: $01 \rightarrow 0$

Nematocharax venustus: $01 \rightarrow 0$

Deuterodon iguape: $01 \rightarrow 0$

Jupiaba anteroides: $01 \rightarrow 0$

Clado $61: 01 \rightarrow 12$

Tetragonopterus chalceus: $01 \rightarrow 2$

Hyphessobrycon eques: $01 \rightarrow 0$

Mimagoniates microlepis: $01 \rightarrow 0$

Astyanax altiparanae: $12 \rightarrow 2$

Astyanacinus sp nova Bolivia: $12 \rightarrow 2$

Stichonodon insignis: $01 \rightarrow 0$

Poptella paraguayensis: $01 \rightarrow 0$

Gymnocorymbus ternertzi: $01 \rightarrow 0$

Bryconamericus exodon: $01 \rightarrow 0$

Astyanax lineatus: $12 \rightarrow 2$

Astyanacinus moorii: $12 \rightarrow 2$

Ctenobrycon hauxwellianus: $01 \rightarrow 0$

Clado 79: $01 \rightarrow 012$

Knodus moenkhausii: $01 \rightarrow 0$

Astyanax paranae: $12 \rightarrow 2$

Astyanax fasciatus: $12 \rightarrow 2$

"Astyanax" orthodus: $12 \rightarrow 2$

"Astyanax" superbus: $12 \rightarrow 2$

Astyanacinus sp nova Peru: $12 \rightarrow 2$

Stethaprion erythrops: $01 \rightarrow 0$

Markiana nigripinnis: $01 \rightarrow 0$

Piabina argentea: $012 \rightarrow 1$

Creagrutus menezesi : $012 \rightarrow 2$

Caráter - 3 (super-sets from 1 trees):

Root: 0

Clado 50: $0 \rightarrow 01$

Bryconops alburnoides: $0 \rightarrow 1$

Clado 78: $01 \rightarrow 02$

Clado 87: $02 \rightarrow 0$

Clado 48: $01 \rightarrow 0$

Clado 54: $01 \rightarrow 0$

Clado 55: $0 \rightarrow 01$

Triportheus albus : $0 \rightarrow 1$

Cheirodon galusdae: $01 \rightarrow 1$

Moenkhausia xinguensis: $01 \rightarrow 1$

Clado 85: $01 \rightarrow 012$

Nematocharax venustus: $012 \rightarrow 2$

Deuterodon iguape: $012 \rightarrow 0$

Jupiaba anteroides: $01 \rightarrow 1$

Clado 61: $01 \rightarrow 0$

Tetragonopterus chalceus: $01 \rightarrow 1$
Hyphessobrycon eques: $01 \rightarrow 1$

Clado 71: $01 \rightarrow 02$

Mimagoniates microlepis: $01 \rightarrow 1$

Stichonodon insignis: $01 \rightarrow 1$

Poptella paraguayensis: $01 \rightarrow 1$

Gymnocorymbus ternertzi: $01 \rightarrow 1$

Bryconamericus exodon: $02 \rightarrow 2$

Ctenobrycon hauxwellianus: $01 \rightarrow 1$

Clado 79: $02 \rightarrow 0$

Knodus moenkhausii: $02 \rightarrow 2$

Astyanax fasciatus: $0 \rightarrow 2$

Stethaprion erythrops: $01 \rightarrow 1$

Markiana nigripinnis: $01 \rightarrow 2$

Caráter - 4 (super-sets from 1 trees):

Root: 0

Clado 86: $0 \rightarrow 01$

Clado 77: $0 \rightarrow 01$

Rachoviscus graciliceps: $01 \rightarrow 1$

Hollandichthys multifasciatus: $01 \rightarrow 1$

Engraulisoma taeniatum: $01 \rightarrow 1$

Clupeacharax anchoveoides: $01 \rightarrow 1$

Clado 72: $0 \rightarrow 01$

Clado 71: $01 \rightarrow 0$

Mimagoniates microlepis: $01 \rightarrow 0$

Clado 81: $0 \rightarrow 01$

Clado 88: $01 \rightarrow 0$

Ctenobrycon hauxwellianus: $01 \rightarrow 0$

Caráter - 5 (super-sets from 1 trees):

Root: 01

Chalceus epakros: $01 \rightarrow 1$

Brycon pesu : $01 \rightarrow 0$

Salminus hilarii: $01 \rightarrow 1$

Clado 50: $01 \rightarrow 012$

Bryconops alburnoides: $01 \rightarrow 0$

Clado 75: $01 \rightarrow 0$

Clado 78: $012 \rightarrow 01$

Clado 86: $01 \rightarrow 0$

Clado 77: $01 \rightarrow 02$

Clado 48: $012 \rightarrow 01$

Clado 54: $012 \rightarrow 01$

Clado 55: $01 \rightarrow 02$

Oligosarcus pintoi : $01 \rightarrow 0$

Triportheus albus : $01 \rightarrow 0$

Lignobrycon myersii: $01 \rightarrow 1$

Clado 76: $02 \rightarrow 01$

Hydrolycus scomberoides: $01 \rightarrow 0$

Acestrorhynchus falcatus: $01 \rightarrow 0$

Agoniates halecinus: $01 \rightarrow 0$

Agoniates anchovia: $01 \rightarrow 0$

Clado 66: $02 \rightarrow 0$

Clado 64: $0 \rightarrow 01$

Nematocharax venustus: $01 \rightarrow 0$

Deuterodon iguape: $01 \rightarrow 1$

Clado 84: $01 \rightarrow 012$

Jupiaba anteroides: $01 \rightarrow 1$

Tetragonopterus chalceus: $012 \rightarrow 1$

Hyphessobrycon eques: $01 \rightarrow 1$

Astyanax altiparanae: $01 \rightarrow 1$

Clado 59: $01 \rightarrow 1$

Astyanacinus sp nova Bolivia: $01 \rightarrow 1$

Stichonodon insignis: $012 \rightarrow 0$

Poptella paraguayensis: $012 \rightarrow 1$

Clado 81: $012 \rightarrow 01$

Gymnocorymbus ternertzi: $012 \rightarrow 1$

Bryconamericus exodon: $01 \rightarrow 1$

Astyanax lineatus: $01 \rightarrow 1$

Clado 67: $1 \rightarrow 01$

Clado 88: $01 \rightarrow 1$

Ctenobrycon hauxwellianus: $01 \rightarrow 1$

Clado 79: $01 \rightarrow 1$

Knodus moenkhausii: $01 \rightarrow 1$

Astyanax paranae: $01 \rightarrow 1$

Astyanax fasciatus: $01 \rightarrow 1$

"Astyanax" orthodus: $01 \rightarrow 1$

“Astyanax" superbus: $01 \rightarrow 1$

Astyanacinus sp nova Peru: $01 \rightarrow 1$ 
Markiana nigripinnis: $1 \rightarrow 0$

Caráter - 6 (super-sets from 1 trees):

Root: 0

Clado 48: $0 \rightarrow 01$

Clado 55: $0 \rightarrow 01$

Triportheus albus : $0 \rightarrow 1$

Hydrolycus scomberoides: $01 \rightarrow 1$

Acestrorhynchus falcatus: $01 \rightarrow 1$

Clado 66: $01 \rightarrow 0$

Cheirodon galusdae: $0 \rightarrow 1$

Clado 74: $0 \rightarrow 01$

Nematocharax venustus: $0 \rightarrow 1$

Tetragonopterus chalceus: $01 \rightarrow 1$

Hyphessobrycon eques: $01 \rightarrow 1$

Mimagoniates microlepis: $01 \rightarrow 1$

Stichonodon insignis: $01 \rightarrow 1$

Poptella paraguayensis: $01 \rightarrow 0$

Gymnocorymbus ternertzi: $01 \rightarrow 0$

Bryconamericus exodon: $01 \rightarrow 1$

Ctenobrycon hauxwellianus: $01 \rightarrow 1$

Knodus moenkhausii: $01 \rightarrow 1$

Astyanax paranae: $0 \rightarrow 1$

Stethaprion erythrops: $01 \rightarrow 1$

Markiana nigripinnis: $01 \rightarrow 0$

Piabina argentea: $01 \rightarrow 1$

Creagrutus menezesi : $01 \rightarrow 1$

Caráter - 7 (super-sets from 1 trees):

Root: 0

Clado 50: $0 \rightarrow 01$

Clado 56: $0 \rightarrow 01$

Charax leticiae: $0 \rightarrow 1$

Clado 55: $01 \rightarrow 1$

Oligosarcus pintoi : $01 \rightarrow 1$

Triportheus albus : $01 \rightarrow 0$

Lignobrycon myersii: $01 \rightarrow 1$

Hydrolycus scomberoides: $01 \rightarrow 0$

Acestrorhynchus falcatus: $01 \rightarrow 1$

Agoniates halecinus: $01 \rightarrow 1$

Agoniates anchovia: $01 \rightarrow 1$

Clado 66: $1 \rightarrow 01$

Engraulisoma taeniatum: $01 \rightarrow 1$

Clupeacharax anchoveoides: $01 \rightarrow 0$

Cheirodon galusdae: $01 \rightarrow 1$

Moenkhausia xinguensis: $01 \rightarrow 1$

Nematocharax venustus: $01 \rightarrow 1$

Deuterodon iguape: $01 \rightarrow 1$

Jupiaba anteroides: $01 \rightarrow 1$

Tetragonopterus chalceus: $01 \rightarrow 0$

Hyphessobrycon eques: $01 \rightarrow 1$

Mimagoniates microlepis: $01 \rightarrow 1$

Astyanax altiparanae: $01 \rightarrow 1$

Astyanacinus sp nova Bolivia: $01 \rightarrow 1$

Stichonodon insignis: $01 \rightarrow 1$

Poptella paraguayensis: $01 \rightarrow 1$

Gymnocorymbus ternertzi: $01 \rightarrow 1$

Clado 80: $01 \rightarrow 1$

Bryconamericus exodon: $01 \rightarrow 1$

Astyanax lineatus: $01 \rightarrow 1$

Astyanacinus moorii: $01 \rightarrow 1$

Ctenobrycon hauxwellianus: $01 \rightarrow 1$

Clado 79: $1 \rightarrow 01$

Astyanax paranae: $01 \rightarrow 1$

Astyanax fasciatus: $01 \rightarrow 1$

“Astyanax" orthodus: $01 \rightarrow 1$

“Astyanax" superbus: $01 \rightarrow 1$

Astyanacinus sp nova Peru: $01 \rightarrow 1$

Stethaprion erythrops: $01 \rightarrow 1$

Markiana nigripinnis: $01 \rightarrow 0$

Piabina argentea: $01 \rightarrow 1$

Creagrutus menezesi : $01 \rightarrow 1$

Caráter - 8 (super-sets from 1 trees):

Root: 1

Clado 53: $1 \rightarrow 01$

Clado 52: $01 \rightarrow 0$

Brycon pesu : $01 \rightarrow 1$

Clado 54: $0 \rightarrow 01$
Triportheus albus : $0 \rightarrow 1$

Agoniates halecinus: $01 \rightarrow 1$

Agoniates anchovia: $01 \rightarrow 1$

Cheirodon galusdae: $0 \rightarrow 1$

Astyanax fasciatus: $0 \rightarrow 1$

Creagrutus menezesi : $0 \rightarrow 1$

Caráter - 9 (super-sets from 1 trees):

Root: 0

Clado 51: $0 \rightarrow 01$

Clado 58: $0 \rightarrow 01$

Bryconops alburnoides: $01 \rightarrow 0$

Clado 86: $01 \rightarrow 13$

Galeocharax knerii : $01 \rightarrow 2$

Charax leticiae: $01 \rightarrow 0$

Clado 48: $01 \rightarrow 0$

Clado 54: $01 \rightarrow 0$

Rachoviscus graciliceps: $13 \rightarrow 3$

Hollandichthys multifasciatus: $13 \rightarrow 3$

Triportheus albus : $01 \rightarrow 0$

Lignobrycon myersii: $01 \rightarrow 0$

Thoracocharax stellatus: $01 \rightarrow 0$

Clado 76: $01 \rightarrow 0$

Acestrorhynchus falcatus: $0 \rightarrow 1$

Clado 66: $01 \rightarrow$

Aphyocharax pusillus: $01 \rightarrow 0$

Clado 74: $1 \rightarrow 01$

Nematocharax venustus: $1 \rightarrow 3$

Clado 84: $01 \rightarrow 1$

Jupiaba anteroides: $1 \rightarrow 3$

Hyphessobrycon eques: $01 \rightarrow 1$

Clado 71: $01 \rightarrow 1$

Mimagoniates microlepis: $01 \rightarrow 1$

Clado 59: $1 \rightarrow 01$

Poptella paraguayensis: $1 \rightarrow 0$

Clado 81: $1 \rightarrow 01$

Clado 80: $1 \rightarrow 01$

Clado 67: $01 \rightarrow 1$

Astyanacinus moorii: $01 \rightarrow 1$

Clado 88: $01 \rightarrow 1$

Ctenobrycon hauxwellianus: $01 \rightarrow 1$

Clado 79: $01 \rightarrow 1$

Knodus moenkhausii: $01 \rightarrow 1$

Stethaprion erythrops: $1 \rightarrow 0$

Caráter - 10 (super-sets from 1 trees):

Root: 01

Chalceus epakros: $01 \rightarrow 0$

Brycon pesu : $01 \rightarrow 1$

Salminus hilarii: $01 \rightarrow 1$

Bryconops alburnoides: $01 \rightarrow 1$

Galeocharax knerii : $01 \rightarrow 1$

Charax leticiae: $01 \rightarrow 1$

Clado 87: $01 \rightarrow 0$

Clado 48: $01 \rightarrow 0$

Clado 54: $01 \rightarrow 0$

Clado 55: $01 \rightarrow 1$

Oligosarcus pintoi : $01 \rightarrow 1$

Rachoviscus graciliceps: $01 \rightarrow 1$

Hollandichthys multifasciatus: $01 \rightarrow 1$

Lignobrycon myersii: $0 \rightarrow 1$

Thoracocharax stellatus: $01 \rightarrow 0$

Clado 76: $01 \rightarrow 0$

Acestrorhynchus falcatus: $0 \rightarrow 1$

Clado 66: $1 \rightarrow 01$

Cheirodon galusdae: $01 \rightarrow 1$

Moenkhausia xinguensis: $01 \rightarrow 1$

Nematocharax venustus: $01 \rightarrow 1$

Deuterodon iguape: $01 \rightarrow 1$

Jupiaba anteroides: $01 \rightarrow 1$

Tetragonopterus chalceus: $01 \rightarrow 1$

Hyphessobrycon eques: $01 \rightarrow 1$

Mimagoniates microlepis: $01 \rightarrow 0$

Astyanax altiparanae: $01 \rightarrow 1$

Astyanacinus sp nova Bolivia: $01 \rightarrow 1$

Stichonodon insignis: $01 \rightarrow 1$

Poptella paraguayensis: $01 \rightarrow 1$

Gymnocorymbus ternertzi: $01 \rightarrow 1$ 
Bryconamericus exodon: $01 \rightarrow 1$

Astyanax lineatus: $01 \rightarrow 1$

Astyanacinus moorii: $01 \rightarrow 1$

Clado 88: $01 \rightarrow 012$

Ctenobrycon hauxwellianus: $01 \rightarrow 1$

Knodus moenkhausii: $01 \rightarrow 1$

Astyanax paranae: $01 \rightarrow 1$

Astyanax fasciatus: $01 \rightarrow 1$

"Astyanax" orthodus: $01 \rightarrow 1$

“Astyanax” superbus: $01 \rightarrow 1$

Astyanacinus sp nova Peru: $01 \rightarrow 1$

Stethaprion erythrops: $012 \rightarrow 1$

Markiana nigripinnis: $012 \rightarrow 1$

Piabina argentea: $01 \rightarrow 1$

Creagrutus menezesi : $01 \rightarrow 1$

Caráter - 11 (super-sets from 1 trees):

Root: 0

Clado 52: $0 \rightarrow 01$

Salminus hilarii: $01 \rightarrow 1$

Clado 50: $01 \rightarrow 1$

Bryconops alburnoides: $01 \rightarrow 1$

Clado 78: $1 \rightarrow 01$

Galeocharax knerii : $01 \rightarrow 0$

Charax leticiae: $01 \rightarrow 1$

Clado 48: $1 \rightarrow 01$

Clado 54: $1 \rightarrow 0$

Clado 55: $01 \rightarrow 1$

Oligosarcus pintoi : $01 \rightarrow 1$

Hollandichthys multifasciatus: $01 \rightarrow 0$

Triportheus albus : $01 \rightarrow 1$

Lignobrycon myersii: $01 \rightarrow 1$

Clado 76: $01 \rightarrow 0$

Hydrolycus scomberoides: $01 \rightarrow 1$

Acestrorhynchus falcatus: $01 \rightarrow 1$

Agoniates halecinus: $01 \rightarrow 1$

Agoniates anchovia: $01 \rightarrow 1$

Clado 66: $1 \rightarrow 01$

Cheirodon galusdae: $01 \rightarrow 0$

Moenkhausia xinguensis: $01 \rightarrow 1$

Clado 63: $01 \rightarrow 0$

Clado 74: $0 \rightarrow 01$

Nematocharax venustus: $01 \rightarrow 1$

Deuterodon iguape: $01 \rightarrow 1$

Clado 84: $01 \rightarrow 0$

Tetragonopterus chalceus: $0 \rightarrow 1$

Hyphessobrycon eques: $01 \rightarrow 0$

Clado 71: $01 \rightarrow 0$

Mimagoniates microlepis: $01 \rightarrow 0$

Poptella paraguayensis: $0 \rightarrow 1$

Bryconamericus exodon: $0 \rightarrow 1$

Clado 88: $0 \rightarrow 01$

Clado 79: $0 \rightarrow 0$

Stethaprion erythrops: $01 \rightarrow 0$

Markiana nigripinnis: $01 \rightarrow 0$

Piabina argentea: $01 \rightarrow 0$

Creagrutus menezesi : $01 \rightarrow 0$

Caráter - 12 (super-sets from 1 trees):

Root: 02

Clado 53: $02 \rightarrow 01$

Chalceus epakros: $02 \rightarrow 2$

Brycon pesu : $01 \rightarrow 0$

Salminus hilarii: $01 \rightarrow 0$

Clado 50: $01 \rightarrow 0$

Bryconops alburnoides: $01 \rightarrow 0$

Clado 78: $0 \rightarrow 01$

Galeocharax knerii : $01 \rightarrow 1$

Charax leticiae: $01 \rightarrow 0$

Clado 77: $01 \rightarrow 012$

Clado 48: $0 \rightarrow 01$

Clado 54: $0 \rightarrow 12$

Clado 55: $01 \rightarrow 0$

Oligosarcus pintoi : $01 \rightarrow 0$

Rachoviscus graciliceps: $01 \rightarrow 0$

Hollandichthys multifasciatus: $01 \rightarrow 0$

Triportheus albus : $01 \rightarrow 0$

Lignobrycon myersii: $01 \rightarrow 0$
Thoracocharax stellatus: $012 \rightarrow 2$

Hydrolycus scomberoides: $01 \rightarrow 0$

Acestrorhynchus falcatus: $01 \rightarrow 0$

Agoniates halecinus: $12 \rightarrow 2$

Agoniates anchovia: $12 \rightarrow 2$

Clado 66: $0 \rightarrow 01$

Engraulisoma taeniatum: $012 \rightarrow 0$

Clupeacharax anchoveoides: $012 \rightarrow 2$

Cheirodon galusdae: $01 \rightarrow 0$

Moenkhausia xinguensis: $01 \rightarrow 0$

Nematocharax venustus: $01 \rightarrow 0$

Deuterodon iguape: $01 \rightarrow 0$

Jupiaba anteroides: $01 \rightarrow 0$

Tetragonopterus chalceus: $01 \rightarrow 0$

Hyphessobrycon eques: $01 \rightarrow 0$

Mimagoniates microlepis: $01 \rightarrow 0$

Astyanax altiparanae: $01 \rightarrow 0$

Astyanacinus sp nova Bolivia: $01 \rightarrow 0$

Stichonodon insignis: $01 \rightarrow 0$

Poptella paraguayensis: $01 \rightarrow 0$

Gymnocorymbus ternertzi: $01 \rightarrow 0$

Bryconamericus exodon: $01 \rightarrow 0$

Astyanax lineatus: $01 \rightarrow 0$

Astyanacinus moorii: $01 \rightarrow 0$

Ctenobrycon hauxwellianus: $01 \rightarrow 0$

Knodus moenkhausii: $01 \rightarrow 0$

Astyanax paranae: $01 \rightarrow 0$

Astyanax fasciatus: $01 \rightarrow 0$

“Astyanax" orthodus: $01 \rightarrow 0$

“Astyanax" superbus: $01 \rightarrow 0$

Astyanacinus sp nova Peru: $01 \rightarrow 0$

Stethaprion erythrops: $01 \rightarrow 0$

Markiana nigripinnis: $01 \rightarrow 0$

Piabina argentea: $01 \rightarrow 0$

Creagrutus menezesi : $01 \rightarrow 0$

Caráter - 13 (super-sets from 1 trees):

Root: 01

Chalceus epakros: $01 \rightarrow 0$

Brycon pesu : $01 \rightarrow 1$

Clado 51: $01 \rightarrow 0$

Salminus hilarii: $01 \rightarrow 1$

Clado 87: $0 \rightarrow 1$

Clado 48: $0 \rightarrow 0$

Clado 54: $0 \rightarrow 01$

Clado 76: $0 \rightarrow 01$

Hydrolycus scomberoides: $01 \rightarrow 1$

Acestrorhynchus falcatus: $01 \rightarrow 0$

Agoniates halecinus: $01 \rightarrow 0$

Agoniates anchovia: $01 \rightarrow 0$

Engraulisoma taeniatum: $01 \rightarrow 0$

Clupeacharax anchoveoides: $01 \rightarrow 0$

Caráter - 14 (super-sets from 1 trees):

Root: 0

Clado 58: $0 \rightarrow 01$

Clado 78: $0 \rightarrow 01$

Galeocharax knerii : $01 \rightarrow 1$

Charax leticiae: $01 \rightarrow 1$

Clado 87: $01 \rightarrow 0$

Oligosarcus pintoi : $01 \rightarrow 1$

Rachoviscus graciliceps: $01 \rightarrow 1$

Hollandichthys multifasciatus: $01 \rightarrow 1$

Thoracocharax stellatus: $01 \rightarrow 1$

Clado 76: $01 \rightarrow 0$

Aphyocharax pusillus: $01 \rightarrow 1$

Cheirodon galusdae: $01 \rightarrow 1$

Moenkhausia xinguensis: $01 \rightarrow 1$

Nematocharax venustus: $01 \rightarrow 1$

Deuterodon iguape: $01 \rightarrow 1$

Jupiaba anteroides: $01 \rightarrow 1$

Tetragonopterus chalceus: $01 \rightarrow 1$

Hyphessobrycon eques: $01 \rightarrow 1$

Mimagoniates microlepis: $01 \rightarrow 1$

Astyanax altiparanae: $01 \rightarrow 1$

Astyanacinus sp nova Bolivia: $01 \rightarrow 1$

Stichonodon insignis: $01 \rightarrow 1$

Poptella paraguayensis: $01 \rightarrow 1$ 
Gymnocorymbus ternertzi: $01 \rightarrow 1$

Bryconamericus exodon: $01 \rightarrow 1$

Astyanax lineatus: $01 \rightarrow 1$

Astyanacinus moorii: $01 \rightarrow 1$

Ctenobrycon hauxwellianus: $01 \rightarrow 1$

Knodus moenkhausii: $01 \rightarrow 1$

Astyanax paranae: $01 \rightarrow 1$

Astyanax fasciatus: $01 \rightarrow 1$

"Astyanax" orthodus: $01 \rightarrow 1$

“Astyanax” superbus: $01 \rightarrow 1$

Astyanacinus sp nova Peru: $01 \rightarrow 1$

Stethaprion erythrops: $01 \rightarrow 1$

Markiana nigripinnis: $01 \rightarrow 1$

Piabina argentea: $01 \rightarrow 1$

Creagrutus menezesi : $01 \rightarrow 1$

Caráter - 15 (super-sets from 1 trees):

Root: 1

Clado 53: $1 \rightarrow 01$

Brycon pesu : $01 \rightarrow 1$

Clado 51: $01 \rightarrow 0$

Salminus hilarii: $01 \rightarrow 1$

Clado 50: $0 \rightarrow 01$

Clado 78: $01 \rightarrow 0$

Clado 56: $01 \rightarrow 0$

Galeocharax knerii : $01 \rightarrow 1$

Charax leticiae: $01 \rightarrow 1$

Clado 77: $0 \rightarrow 01$

Clado 48: $01 \rightarrow 0$

Clado 54: $01 \rightarrow 0$

Clado 55: $0 \rightarrow 01$

Rachoviscus graciliceps: $01 \rightarrow 1$

Hollandichthys multifasciatus: $01 \rightarrow 1$

Thoracocharax stellatus: $01 \rightarrow 1$

Clado 66: $01 \rightarrow 0$

Aphyocharax pusillus: $01 \rightarrow 0$

Engraulisoma taeniatum: $01 \rightarrow 1$

Clupeacharax anchoveoides: $01 \rightarrow 0$

Deuterodon iguape: $0 \rightarrow 1$

Clado 68: $0 \rightarrow 01$

Astyanax altiparanae: $01 \rightarrow 1$

Clado 69: $01 \rightarrow 0$

Astyanax lineatus: $01 \rightarrow 1$

Astyanacinus moorii: $0 \rightarrow 1$

“Astyanax" superbus: $0 \rightarrow 1$

Markiana nigripinnis: $0 \rightarrow 1$

Caráter - 16 (super-sets from 1 trees):

Root: 0

Clado 53: $0 \rightarrow 02$

Clado 58: $02 \rightarrow 0$

Clado 50: $02 \rightarrow 023$

Bryconops alburnoides: $02 \rightarrow 0$

Clado 75: $0 \rightarrow 01$

Clado 78: $023 \rightarrow 02$

Clado 49: $023 \rightarrow 03$

Clado 87: $02 \rightarrow 0$

Clado 77: $02 \rightarrow 012$

Clado 48: $03 \rightarrow 02$

Clado 54: $03 \rightarrow 02$

Clado 76: $012 \rightarrow 01$

Hydrolycus scomberoides: $02 \rightarrow 0$

Acestrorhynchus falcatus: $02 \rightarrow 0$

Agoniates halecinus: $02 \rightarrow 0$

Agoniates anchovia: $02 \rightarrow 0$

Clupeacharax anchoveoides: $01 \rightarrow 1$

Clado 65: $0 \rightarrow 01$

Clado 85: $01 \rightarrow 1$

Clado 74: $01 \rightarrow 1$

Clado 73: $1 \rightarrow 12$

Jupiaba anteroides: $01 \rightarrow 1$

Clado 72: $12 \rightarrow 012$

Hyphessobrycon eques: $12 \rightarrow 1$

Clado 60: $01 \rightarrow 0$

Clado 89: $1 \rightarrow 01$

Clado 82: $1 \rightarrow 01$

Clado 71: $012 \rightarrow 0$

Mimagoniates microlepis: $012 \rightarrow 0$
Stichonodon insignis: $01 \rightarrow 1$

Poptella paraguayensis: $01 \rightarrow 1$

Clado 81: $01 \rightarrow 12$

Gymnocorymbus ternertzi: $01 \rightarrow 1$

Clado 80: $0 \rightarrow 02$

Clado 88: $12 \rightarrow 1$

Ctenobrycon hauxwellianus: $12 \rightarrow 1$

Clado 79: $02 \rightarrow 012$

Knodus moenkhausii: $02 \rightarrow 0$

Astyanax paranae: $01 \rightarrow 0$

Astyanax fasciatus: $01 \rightarrow 1$

Piabina argentea: $012 \rightarrow 0$

Creagrutus menezesi : $012 \rightarrow 0$

Caráter - 17 (super-sets from 1 trees):

Root: 0

Clado 53: $0 \rightarrow 01$

Clado 51: $01 \rightarrow 013$

Bryconops alburnoides: $013 \rightarrow 0$

Clado 78: $013 \rightarrow 012$

Clado 49: $013 \rightarrow 03$

Clado 87: $012 \rightarrow 01$

Clado 48: $03 \rightarrow 1$

Clado 54: $03 \rightarrow 01$

Oligosarcus pintoi : $01 \rightarrow 0$

Triportheus albus : $01 \rightarrow 0$

Lignobrycon myersii: $01 \rightarrow 0$

Clado 76: $012 \rightarrow 01$

Agoniates halecinus: $01 \rightarrow 0$

Agoniates anchovia: $01 \rightarrow 0$

Aphyocharax pusillus: $01 \rightarrow 1$

Clupeacharax anchoveoides: $01 \rightarrow 0$

Cheirodon galusdae: $01 \rightarrow 0$

Nematocharax venustus: $01 \rightarrow 0$

Jupiaba anteroides: $01 \rightarrow 0$

Tetragonopterus chalceus: $01 \rightarrow 0$

Hyphessobrycon eques: $01 \rightarrow 0$

Mimagoniates microlepis: $01 \rightarrow 0$

Astyanacinus sp nova Bolivia: $01 \rightarrow 0$

Stichonodon insignis: $01 \rightarrow 0$

Poptella paraguayensis: $01 \rightarrow 0$

Gymnocorymbus ternertzi: $01 \rightarrow 0$

Bryconamericus exodon: $01 \rightarrow 0$

Clado 88: $01 \rightarrow 03$

Ctenobrycon hauxwellianus: $01 \rightarrow 0$

Clado 79: $01 \rightarrow 0123$

Knodus moenkhausii: $01 \rightarrow 0$

Astyanax paranae: $01 \rightarrow 0$

Astyanax fasciatus: $01 \rightarrow 0$

“Astyanax" orthodus: $01 \rightarrow 0$

Astyanacinus sp nova Peru: $01 \rightarrow 0$

Stethaprion erythrops: $03 \rightarrow 0$

Piabina argentea: $0123 \rightarrow 0$

Creagrutus menezesi : $0123 \rightarrow 0$

Caráter - 18 (super-sets from 1 trees):

Root: 1

Clado 53: $1 \rightarrow 01$

Brycon pesu : $01 \rightarrow 1$

Salminus hilarii: $01 \rightarrow 1$

Bryconops alburnoides: $01 \rightarrow 1$

Clado 49: $01 \rightarrow 012$

Galeocharax knerii : $01 \rightarrow 1$

Charax leticiae: $01 \rightarrow 1$

Clado 87: $01 \rightarrow 1$

Clado 77: $01 \rightarrow 1$

Clado 48: $012 \rightarrow 01$

Clado 54: $012 \rightarrow 0$

Rachoviscus graciliceps: $01 \rightarrow 1$

Hollandichthys multifasciatus: $01 \rightarrow 0$

Lignobrycon myersii: $1 \rightarrow 0$

Hydrolycus scomberoides: $01 \rightarrow 1$

Acestrorhynchus falcatus: $01 \rightarrow 0$

Aphyocharax pusillus: $01 \rightarrow 0$

Cheirodon galusdae: $01 \rightarrow 1$

Moenkhausia xinguensis: $01 \rightarrow 1$

Nematocharax venustus: $01 \rightarrow 1$

Deuterodon iguape: $01 \rightarrow 1$ 
Clado 84: $01 \rightarrow 0$

Jupiaba anteroides: $01 \rightarrow 1$

Hyphessobrycon eques: $01 \rightarrow 1$

Clado 60: $01 \rightarrow 0$

Mimagoniates microlepis: $01 \rightarrow 0$

Astyanax altiparanae: $01 \rightarrow 1$

Clado 59: $0 \rightarrow 01$

Clado 81: $0 \rightarrow 01$

Bryconamericus exodon: $01 \rightarrow 0$

Astyanax lineatus: $01 \rightarrow 0$

Clado 67: $01 \rightarrow 0$

Astyanacinus moorii: $01 \rightarrow 0$

Clado 88: $01 \rightarrow 02$

Ctenobrycon hauxwellianus: $01 \rightarrow 0$

Astyanax paranae: $01 \rightarrow 1$

Astyanax fasciatus: $01 \rightarrow 0$

Stethaprion erythrops: $02 \rightarrow 0$

Markiana nigripinnis: $02 \rightarrow 0$

Piabina argentea: $01 \rightarrow 1$

Creagrutus menezesi : $01 \rightarrow 1$

Caráter - 19 (super-sets from 1 trees):

Root: 0

Clado 53: $0 \rightarrow 04$

Brycon pesu : $04 \rightarrow 0$

Clado 58: $04 \rightarrow 012$

Salminus hilarii: $04 \rightarrow 0$

Bryconops alburnoides: $04 \rightarrow 0$

Clado 75: $012 \rightarrow 01$

Clado 56: $012 \rightarrow 013$

Clado 86: $012 \rightarrow 1$

Galeocharax knerii : $01 \rightarrow 0$

Charax leticiae: $01 \rightarrow 1$

Clado 87: $04 \rightarrow 02$

Clado 55: $013 \rightarrow 0124$

Oligosarcus pintoi : $013 \rightarrow 1$

Triportheus albus : $02 \rightarrow 0$

Lignobrycon myersii: $02 \rightarrow 1$

Thoracocharax stellatus: $04 \rightarrow 1$

Clado 76: $04 \rightarrow 02$

Hydrolycus scomberoides: $04 \rightarrow 1$

Acestrorhynchus falcatus: $04 \rightarrow 0$

Agoniates halecinus: $04 \rightarrow 0$

Agoniates anchovia: $04 \rightarrow 0$

Clado 66: $0124 \rightarrow 01$

Aphyocharax pusillus: $0124 \rightarrow 0$

Engraulisoma taeniatum: $02 \rightarrow 0$

Clupeacharax anchoveoides: $02 \rightarrow 0$

Cheirodon galusdae: $01 \rightarrow 1$

Moenkhausia xinguensis: $01 \rightarrow 0$

Clado 63: $01 \rightarrow 02$

Clado 74: $02 \rightarrow 1$

Nematocharax venustus: $01 \rightarrow 0$

Deuterodon iguape: $01 \rightarrow 0$

Jupiaba anteroides: $02 \rightarrow 0$

Clado 82: $1 \rightarrow 01$

Clado 71: $1 \rightarrow 12$

Astyanax altiparanae: $02 \rightarrow 0$

Clado 59: $02 \rightarrow 12$

Astyanacinus sp nova Bolivia: $02 \rightarrow 0$

Gymnocorymbus ternertzi: $01 \rightarrow 0$

Bryconamericus exodon: $12 \rightarrow 1$

Astyanax lineatus: $02 \rightarrow 0$

Clado 67: $12 \rightarrow 13$

Astyanacinus moorii: $12 \rightarrow 1$

Clado 88: $01 \rightarrow 0134$

Ctenobrycon hauxwellianus: $01 \rightarrow 0$

Clado 79: $12 \rightarrow 04$

Knodus moenkhausii: $12 \rightarrow 1$

Astyanax paranae: $02 \rightarrow 0$

Astyanax fasciatus: $02 \rightarrow 0$

“Astyanax" orthodus: $13 \rightarrow 1$

“Astyanax” superbus: $13 \rightarrow 0$

Astyanacinus sp nova Peru: $13 \rightarrow 1$

Stethaprion erythrops: $0134 \rightarrow 0$

Markiana nigripinnis: $0134 \rightarrow 0$

Piabina argentea: $04 \rightarrow 0$
Creagrutus menezesi : $04 \rightarrow 0$

Caráter - 20 (super-sets from 1 trees):

Root: 1

Clado 53: $1 \rightarrow 012$

Clado 52: $012 \rightarrow 01$

Brycon pesu : $012 \rightarrow 0$

Salminus hilarii: $01 \rightarrow 1$

Bryconops alburnoides: $01 \rightarrow 0$

Galeocharax knerii : $01 \rightarrow 1$

Charax leticiae: $01 \rightarrow 1$

Clado 87: $01 \rightarrow 0$

Clado 48: $01 \rightarrow 012$

Clado 54: $01 \rightarrow 012$

Clado 55: $01 \rightarrow 1$

Oligosarcus pintoi : $01 \rightarrow 0$

Rachoviscus graciliceps: $01 \rightarrow 0$

Hollandichthys multifasciatus: $01 \rightarrow 1$

Thoracocharax stellatus: $01 \rightarrow 1$

Hydrolycus scomberoides: $012 \rightarrow 1$

Acestrorhynchus falcatus: $012 \rightarrow 1$

Agoniates halecinus: $012 \rightarrow 0$

Agoniates anchovia: $012 \rightarrow 0$

Clado 66: $1 \rightarrow 01$

Engraulisoma taeniatum: $01 \rightarrow 1$

Clupeacharax anchoveoides: $01 \rightarrow 0$

Clado 65: $01 \rightarrow 0$

Cheirodon galusdae: $01 \rightarrow 1$

Clado 82: $0 \rightarrow 01$

Gymnocorymbus ternertzi: $01 \rightarrow 1$

Bryconamericus exodon: $0 \rightarrow 1$

Ctenobrycon hauxwellianus: $01 \rightarrow 1$

Stethaprion erythrops: $01 \rightarrow 0$

Markiana nigripinnis: $01 \rightarrow 1$

Creagrutus menezesi : $0 \rightarrow 1$

Caráter - 21 (super-sets from 1 trees):

Root: 0

Clado 53: $0 \rightarrow 02$

Clado 52: $02 \rightarrow 04$

Brycon pesu : $02 \rightarrow 0$

Clado 58: $04 \rightarrow 02$

Salminus hilarii: $04 \rightarrow 1$

Bryconops alburnoides: $04 \rightarrow 0$

Clado 56: $02 \rightarrow 01$

Clado 86: $02 \rightarrow 01$

Galeocharax knerii : $02 \rightarrow 0$

Charax leticiae: $02 \rightarrow 0$

Clado 87: $04 \rightarrow 12$

Clado 48: $04 \rightarrow 02$

Clado 54: $04 \rightarrow 12$

Clado 55: $01 \rightarrow 034$

Rachoviscus graciliceps: $01 \rightarrow 0$

Hollandichthys multifasciatus: $01 \rightarrow 1$

Triportheus albus : $12 \rightarrow 1$

Lignobrycon myersii: $12 \rightarrow 1$

Thoracocharax stellatus: $04 \rightarrow 0$

Hydrolycus scomberoides: $02 \rightarrow 0$

Acestrorhynchus falcatus: $02 \rightarrow 0$

Agoniates halecinus: $12 \rightarrow 1$

Agoniates anchovia: $12 \rightarrow 1$

Clado 66: $034 \rightarrow 01$

Aphyocharax pusillus: $034 \rightarrow 0$

Engraulisoma taeniatum: $04 \rightarrow 0$

Clupeacharax anchoveoides: $04 \rightarrow 0$

Cheirodon galusdae: $01 \rightarrow 0$

Clado 64: $01 \rightarrow 02$

Moenkhausia xinguensis: $01 \rightarrow 0$

Nematocharax venustus: $02 \rightarrow 0$

Deuterodon iguape: $02 \rightarrow 1$

Clado 73: $02 \rightarrow 0234$

Jupiaba anteroides: $02 \rightarrow 0$

Tetragonopterus chalceus: $02 \rightarrow 0$

Clado 83: $02 \rightarrow 0123$

Clado 72: $0234 \rightarrow 03$

Hyphessobrycon eques: $0234 \rightarrow 0$

Clado 89: $0123 \rightarrow 023$

Clado 82: $0123 \rightarrow 023$ 
Clado 71: $03 \rightarrow 01$

Mimagoniates microlepis: $03 \rightarrow 1$

Clado 70: $02 \rightarrow 01$

Astyanax altiparanae: $02 \rightarrow 0$

Astyanacinus sp nova Bolivia: $02 \rightarrow 0$

Stichonodon insignis: $023 \rightarrow 0$

Poptella paraguayensis: $023 \rightarrow 0$

Clado 81: $023 \rightarrow 013$

Gymnocorymbus ternertzi: $023 \rightarrow 0$

Clado 80: $01 \rightarrow 03$

Bryconamericus exodon: $01 \rightarrow 0$

Clado 69: $01 \rightarrow 02$

Astyanax lineatus: $01 \rightarrow 0$

Clado 67: $02 \rightarrow 01$

Astyanacinus moorii: $02 \rightarrow 0$

Clado 88: $013 \rightarrow 014$

Ctenobrycon hauxwellianus: $013 \rightarrow 1$

Clado 79: $03 \rightarrow 14$

Knodus moenkhausii: $03 \rightarrow 0$

Astyanax paranae: $02 \rightarrow 0$

Astyanax fasciatus: $02 \rightarrow 0$

“Astyanax" orthodus: $01 \rightarrow 0$

“Astyanax" superbus: $01 \rightarrow 0$

Astyanacinus sp nova Peru: $01 \rightarrow 0$

Stethaprion erythrops: $014 \rightarrow 0$

Markiana nigripinnis: $014 \rightarrow 1$

Piabina argentea: $14 \rightarrow 1$

Creagrutus menezesi : $14 \rightarrow 1$

Caráter - 22 (super-sets from 1 trees):

Root: 01

Clado 53: $01 \rightarrow 05$

Chalceus epakros: $01 \rightarrow 1$

Brycon pesu : $05 \rightarrow 0$

Clado 58: $05 \rightarrow 12$

Salminus hilarii: $05 \rightarrow 0$

Bryconops alburnoides: $05 \rightarrow 0$

Clado 75: $12 \rightarrow 13$

Clado 78: $05 \rightarrow 0145$

Clado 49: $05 \rightarrow 06$

Clado 86: $12 \rightarrow 1$

Galeocharax knerii : $13 \rightarrow 1$

Charax leticiae: $13 \rightarrow 1$

Clado 87: $0145 \rightarrow 02$

Clado 77: $0145 \rightarrow 04$

Clado 48: $06 \rightarrow 035$

Clado 54: $06 \rightarrow 05$

Clado 55: $12 \rightarrow 15$

Triportheus albus : $02 \rightarrow 1$

Lignobrycon myersii: $02 \rightarrow 0$

Thoracocharax stellatus: $04 \rightarrow 1$

Clado 76: $04 \rightarrow 05$

Hydrolycus scomberoides: $035 \rightarrow 0$

Acestrorhynchus falcatus: $035 \rightarrow 0$

Agoniates halecinus: $05 \rightarrow 0$

Agoniates anchovia: $05 \rightarrow 0$

Clado 66: $15 \rightarrow$

Aphyocharax pusillus: $15 \rightarrow 1$

Engraulisoma taeniatum: $05 \rightarrow 0$

Clupeacharax anchoveoides: $05 \rightarrow 0$

Clado 64: $1 \rightarrow 13$

Nematocharax venustus: $13 \rightarrow 1$

Deuterodon iguape: $13 \rightarrow 1$

Jupiaba anteroides: $13 \rightarrow 1$

Tetragonopterus chalceus: $13 \rightarrow 1$

Hyphessobrycon eques: $13 \rightarrow 1$

Clado 71: $13 \rightarrow 12$

Mimagoniates microlepis: $13 \rightarrow 1$

Clado 70: $13 \rightarrow 12$

Astyanax altiparanae: $13 \rightarrow 1$

Clado 59: $13 \rightarrow 15$

Astyanacinus sp nova Bolivia: $13 \rightarrow 1$

Stichonodon insignis: $13 \rightarrow 1$

Poptella paraguayensis: $13 \rightarrow 1$

Gymnocorymbus ternertzi: $13 \rightarrow 1$

Clado 80: $12 \rightarrow 13$

Bryconamericus exodon: $12 \rightarrow 1$
Astyanax lineatus: $12 \rightarrow 1$

Clado 67: $15 \rightarrow 12$

Astyanacinus moorii: $15 \rightarrow 1$

Clado 88: $13 \rightarrow 15$

Ctenobrycon hauxwellianus: $13 \rightarrow 1$

Clado 79: $13 \rightarrow 15$

Knodus moenkhausii: $13 \rightarrow 1$

Astyanax paranae: $12 \rightarrow 1$

Astyanax fasciatus: $12 \rightarrow 1$

“Astyanax" orthodus: $12 \rightarrow 1$

"Astyanax" superbus: $12 \rightarrow 1$

Astyanacinus sp nova Peru: $12 \rightarrow 1$

Stethaprion erythrops: $15 \rightarrow 1$

Markiana nigripinnis: $15 \rightarrow 1$

Piabina argentea: $15 \rightarrow 1$

Creagrutus menezesi : $15 \rightarrow 0$

Caráter - 23 (super-sets from 1 trees):

Root: 01

Clado 53: $01 \rightarrow 012$

Chalceus epakros: $01 \rightarrow 0$

Clado 52: $012 \rightarrow 01$

Brycon pesu : $012 \rightarrow 1$

Clado 58: $01 \rightarrow 02$

Salminus hilarii: $01 \rightarrow 1$

Bryconops alburnoides: $01 \rightarrow 0$

Clado 78: $01 \rightarrow 012$

Galeocharax knerii : $02 \rightarrow 0$

Charax leticiae: $02 \rightarrow 0$

Clado 87: $012 \rightarrow 12$

Clado 77: $012 \rightarrow 12$

Clado $48: 01 \rightarrow 12$

Clado 54: $01 \rightarrow 12$

Clado 55: $02 \rightarrow 0$

Rachoviscus graciliceps: $02 \rightarrow 0$

Hollandichthys multifasciatus: $02 \rightarrow 0$

Triportheus albus : $12 \rightarrow 1$

Lignobrycon myersii: $12 \rightarrow 1$

Thoracocharax stellatus: $12 \rightarrow 1$

Hydrolycus scomberoides: $12 \rightarrow 0$

Acestrorhynchus falcatus: $12 \rightarrow 1$

Agoniates halecinus: $12 \rightarrow 1$

Agoniates anchovia: $12 \rightarrow 1$

Clado 66: $0 \rightarrow 02$

Engraulisoma taeniatum: $12 \rightarrow 1$

Clupeacharax anchoveoides: $12 \rightarrow 1$

Cheirodon galusdae: $02 \rightarrow 0$

Moenkhausia xinguensis: $02 \rightarrow 0$

Nematocharax venustus: $02 \rightarrow 0$

Deuterodon iguape: $02 \rightarrow 0$

Jupiaba anteroides: $02 \rightarrow 0$

Tetragonopterus chalceus: $02 \rightarrow 0$

Hyphessobrycon eques: $02 \rightarrow 0$

Clado 89: $02 \rightarrow 0$

Clado 82: $02 \rightarrow 0$

Mimagoniates microlepis: $02 \rightarrow 0$

Astyanax altiparanae: $02 \rightarrow 0$

Astyanacinus sp nova Bolivia: $02 \rightarrow 0$

Clado 81: $0 \rightarrow 02$

Bryconamericus exodon: $02 \rightarrow 0$

Astyanax lineatus: $02 \rightarrow 0$

Astyanacinus moorii: $02 \rightarrow 0$

Clado 88: $02 \rightarrow 0$

Ctenobrycon hauxwellianus: $02 \rightarrow 0$

Clado 79: $02 \rightarrow 0$

Knodus moenkhausii: $02 \rightarrow 0$

Astyanax paranae: $02 \rightarrow 0$

Astyanax fasciatus: $02 \rightarrow 0$

“Astyanax" orthodus: $02 \rightarrow 0$

"Astyanax" superbus: $02 \rightarrow 0$

Astyanacinus sp nova Peru: $02 \rightarrow 0$

Caráter - 24 (super-sets from 1 trees):

Root: 01

Chalceus epakros: $01 \rightarrow 1$

Brycon pesu : $01 \rightarrow 0$

Clado 58: $01 \rightarrow 0$

Salminus hilarii: $01 \rightarrow 1$ 
Bryconops alburnoides: $01 \rightarrow 0$

Clado 55: $0 \rightarrow 01$

Triportheus albus : $01 \rightarrow 1$

Lignobrycon myersii: $01 \rightarrow 0$

Thoracocharax stellatus: $01 \rightarrow 1$

Hydrolycus scomberoides: $01 \rightarrow 0$

Acestrorhynchus falcatus: $01 \rightarrow 1$

Agoniates halecinus: $01 \rightarrow 1$

Agoniates anchovia: $01 \rightarrow 1$

Clado 66: $01 \rightarrow 0$

Aphyocharax pusillus: $01 \rightarrow 1$

Engraulisoma taeniatum: $01 \rightarrow 1$

Clupeacharax anchoveoides: $01 \rightarrow 1$

Clado 71: $0 \rightarrow 01$

Bryconamericus exodon: $01 \rightarrow 1$

Clado 88: $0 \rightarrow 01$

Ctenobrycon hauxwellianus: $0 \rightarrow 1$

Knodus moenkhausii: $01 \rightarrow 1$

Stethaprion erythrops: $01 \rightarrow 0$

Markiana nigripinnis: $01 \rightarrow 0$

Piabina argentea: $01 \rightarrow 0$

Creagrutus menezesi : $01 \rightarrow 0$

Caráter - 25 (super-sets from 1 trees):

Root: 0

Brycon pesu : $0 \rightarrow 1$

Bryconops alburnoides: $0 \rightarrow 1$

Clado 75: $0 \rightarrow 01$

Clado 86: $0 \rightarrow 01$

Galeocharax knerii : $01 \rightarrow 0$

Charax leticiae: $01 \rightarrow 1$

Rachoviscus graciliceps: $01 \rightarrow 0$

Hollandichthys multifasciatus: $01 \rightarrow 1$

Triportheus albus : $0 \rightarrow 1$

Thoracocharax stellatus: $0 \rightarrow 1$

Clado 76: $0 \rightarrow 01$

Clado 66: $0 \rightarrow 1$

Engraulisoma taeniatum: $01 \rightarrow 0$

Clupeacharax anchoveoides: $01 \rightarrow 0$

Clado 59: $1 \rightarrow 01$

Astyanacinus moorii: $01 \rightarrow 1$

Clado 88: $1 \rightarrow 01$

Clado 79: $1 \rightarrow 01$

“Astyanax" orthodus: $01 \rightarrow 1$

“Astyanax" superbus: $01 \rightarrow 1$

Astyanacinus sp nova Peru: $01 \rightarrow 1$

Stethaprion erythrops: $01 \rightarrow 1$

Markiana nigripinnis: $01 \rightarrow 1$

Piabina argentea: $01 \rightarrow 1$

Creagrutus menezesi : $01 \rightarrow 1$

Caráter - 26 (super-sets from 1 trees):

Root: 0

Clado 52: $0 \rightarrow 01$

Salminus hilarii: $01 \rightarrow 0$

Bryconops alburnoides: $01 \rightarrow 1$

Clado 57: $01 \rightarrow 1$

Galeocharax knerii : $01 \rightarrow 0$

Charax leticiae: $01 \rightarrow 1$

Clado 87: $01 \rightarrow 1$

Clado 54: $01 \rightarrow 0$

Clado 55: $1 \rightarrow 01$

Triportheus albus : $1 \rightarrow 0$

Thoracocharax stellatus: $01 \rightarrow 1$

Clado 76: $01 \rightarrow 1$

Hydrolycus scomberoides: $01 \rightarrow 1$

Acestrorhynchus falcatus: $01 \rightarrow 1$

Clado 66: $01 \rightarrow 1$

Aphyocharax pusillus: $01 \rightarrow 1$

Nematocharax venustus: $1 \rightarrow 0$

Clado 88: $1 \rightarrow 01$

Clado 79: $1 \rightarrow 01$

Stethaprion erythrops: $01 \rightarrow 1$

Markiana nigripinnis: $01 \rightarrow 1$

Piabina argentea: $01 \rightarrow 1$

Creagrutus menezesi : $01 \rightarrow 1$

Caráter - 27 (super-sets from 1 trees):

Root: 0
Clado 52: $0 \rightarrow 01$

Salminus hilarii: $01 \rightarrow 1$

Clado 50: $01 \rightarrow 0$

Galeocharax knerii : $01 \rightarrow 1$

Clado 87: $0 \rightarrow 01$

Triportheus albus : $01 \rightarrow 0$

Caráter - 28 (super-sets from 1 trees):

Root: 013

Chalceus epakros: $013 \rightarrow 1$

Brycon pesu : $013 \rightarrow 0$

Clado 51: $013 \rightarrow 03$

Salminus hilarii: $013 \rightarrow 3$

Bryconops alburnoides: $03 \rightarrow 0$

Clado 57: $013 \rightarrow 1$

Clado 75: $013 \rightarrow 03$

Clado 78: $03 \rightarrow 02$

Clado 56: $1 \rightarrow 01$

Clado 86: $1 \rightarrow 01$

Galeocharax knerii : $03 \rightarrow 3$

Charax leticiae: $03 \rightarrow 3$

Clado 87: $02 \rightarrow 01$

Clado 77: $02 \rightarrow 03$

Clado 55: $01 \rightarrow 1$

Oligosarcus pintoi : $01 \rightarrow 1$

Rachoviscus graciliceps: $01 \rightarrow 2$

Hollandichthys multifasciatus: $01 \rightarrow 1$

Triportheus albus : $01 \rightarrow 0$

Lignobrycon myersii: $01 \rightarrow 0$

Thoracocharax stellatus: $03 \rightarrow 2$

Clado 76: $03 \rightarrow 01$

Hydrolycus scomberoides: $03 \rightarrow 3$

Acestrorhynchus falcatus: $03 \rightarrow 3$

Agoniates halecinus: $03 \rightarrow 3$

Agoniates anchovia: $03 \rightarrow 3$

Clado 66: $1 \rightarrow 01$

Aphyocharax pusillus: $1 \rightarrow 2$

Engraulisoma taeniatum: $01 \rightarrow 0$

Clupeacharax anchoveoides: $01 \rightarrow 0$

Cheirodon galusdae: $01 \rightarrow 1$

Moenkhausia xinguensis: $01 \rightarrow 1$

Nematocharax venustus: $01 \rightarrow 1$

Deuterodon iguape: $01 \rightarrow 0$

Jupiaba anteroides: $01 \rightarrow 1$

Tetragonopterus chalceus: $01 \rightarrow 1$

Hyphessobrycon eques: $01 \rightarrow 1$

Clado 68: $01 \rightarrow 0$

Clado 89: $01 \rightarrow 1$

Mimagoniates microlepis: $01 \rightarrow 1$

Clado 59: $01 \rightarrow 1$

Astyanacinus sp nova Bolivia: $01 \rightarrow 1$

Stichonodon insignis: $1 \rightarrow 2$

Clado 81: $01 \rightarrow 0$

Gymnocorymbus ternertzi: $01 \rightarrow 1$

Clado 80: $01 \rightarrow 012$

Bryconamericus exodon: $01 \rightarrow 1$

Clado 67: $1 \rightarrow 01$

Clado 88: $0 \rightarrow 02$

Clado 79: $012 \rightarrow 2$

Knodus moenkhausii: $012 \rightarrow 0$

“Astyanax" orthodus: $01 \rightarrow 1$

“Astyanax” superbus: $01 \rightarrow 1$

Astyanacinus sp nova Peru: $01 \rightarrow 1$

Stethaprion erythrops: $02 \rightarrow 0$

Markiana nigripinnis: $02 \rightarrow 0$

Caráter - 29 (super-sets from 1 trees):

Root: 0

Clado 54: $0 \rightarrow 01$

Agoniates halecinus: $01 \rightarrow 1$

Agoniates anchovia: $01 \rightarrow 1$

Clado 83: $0 \rightarrow 01$

Clado 89: $01 \rightarrow 0$

Clado 81: $01 \rightarrow 0$

Gymnocorymbus ternertzi: $01 \rightarrow 0$

Caráter - 30 (super-sets from 1 trees):

Root: 02

Clado 53: $02 \rightarrow 0$ 
Chalceus epakros: $02 \rightarrow 2$

Bryconops alburnoides: $0 \rightarrow 1$

Clado 87: $0 \rightarrow 02$

Clado 77: $0 \rightarrow 01$

Clado 55: $0 \rightarrow 02$

Triportheus albus : $02 \rightarrow 2$

Lignobrycon myersii: $02 \rightarrow 2$

Thoracocharax stellatus: $01 \rightarrow 0$

Aphyocharax pusillus: $02 \rightarrow 2$

Engraulisoma taeniatum: $01 \rightarrow 1$

Clupeacharax anchoveoides: $01 \rightarrow 1$

Cheirodon galusdae: $02 \rightarrow 1$

Moenkhausia xinguensis: $02 \rightarrow 2$

Nematocharax venustus: $02 \rightarrow 1$

Deuterodon iguape: $02 \rightarrow 2$

Clado 73: $02 \rightarrow 12$

Jupiaba anteroides: $02 \rightarrow 2$

Tetragonopterus chalceus: $02 \rightarrow 2$

Clado 83: $02 \rightarrow 01$

Hyphessobrycon eques: $12 \rightarrow 1$

Clado 71: $12 \rightarrow 02$

Mimagoniates microlepis: $12 \rightarrow 2$

Astyanax altiparanae: $02 \rightarrow 2$

Clado 59: $02 \rightarrow 0$

Astyanacinus sp nova Bolivia: $02 \rightarrow 2$

Stichonodon insignis: $01 \rightarrow 1$

Poptella paraguayensis: $01 \rightarrow 1$

Clado 81: $01 \rightarrow 1$

Gymnocorymbus ternertzi: $01 \rightarrow 1$

Clado 80: $02 \rightarrow 01$

Bryconamericus exodon: $02 \rightarrow 2$

Astyanax lineatus: $02 \rightarrow 2$

Clado 88: $1 \rightarrow 02$

Clado 79: $01 \rightarrow 0$

Knodus moenkhausii: $01 \rightarrow 0$

Astyanax paranae: $02 \rightarrow 2$

Astyanax fasciatus: $02 \rightarrow 2$

Stethaprion erythrops: $02 \rightarrow 2$

Markiana nigripinnis: $02 \rightarrow 2$

Creagrutus menezesi : $0 \rightarrow 1$

Caráter - 31 (super-sets from 1 trees):

Root: 02

Clado 53: $02 \rightarrow 012$

Brycon pesu : $012 \rightarrow 2$

Clado 58: $012 \rightarrow 01$

Salminus hilarii: $012 \rightarrow 0$

Bryconops alburnoides: $012 \rightarrow 2$

Clado 49: $012 \rightarrow 01$

Galeocharax knerii : $01 \rightarrow 0$

Charax leticiae: $01 \rightarrow 0$

Clado 87: $012 \rightarrow 12$

Clado 77: $012 \rightarrow 02$

Clado 55: $01 \rightarrow 12$

Oligosarcus pintoi : $01 \rightarrow 0$

Rachoviscus graciliceps: $01 \rightarrow 0$

Hollandichthys multifasciatus: $01 \rightarrow 0$

Triportheus albus : $12 \rightarrow 2$

Lignobrycon myersii: $12 \rightarrow 2$

Thoracocharax stellatus: $02 \rightarrow 0$

Clado 76: $02 \rightarrow 12$

Hydrolycus scomberoides: $01 \rightarrow 0$

Acestrorhynchus falcatus: $01 \rightarrow 0$

Agoniates halecinus: $01 \rightarrow 0$

Agoniates anchovia: $01 \rightarrow 0$

Aphyocharax pusillus: $12 \rightarrow 2$

Engraulisoma taeniatum: $12 \rightarrow 2$

Clupeacharax anchoveoides: $12 \rightarrow 2$

Cheirodon galusdae: $12 \rightarrow 1$

Moenkhausia xinguensis: $12 \rightarrow 2$

Nematocharax venustus: $12 \rightarrow 2$

Deuterodon iguape: $12 \rightarrow 2$

Clado 73: $12 \rightarrow 2$

Jupiaba anteroides: $12 \rightarrow 2$

Tetragonopterus chalceus: $12 \rightarrow 2$

Hyphessobrycon eques: $2 \rightarrow 1$

Clado $71: 2 \rightarrow 12$
Mimagoniates microlepis: $2 \rightarrow 0$

Astyanax altiparanae: $12 \rightarrow 2$

Astyanacinus sp nova Bolivia: $12 \rightarrow 2$

Stichonodon insignis: $12 \rightarrow 0$

Poptella paraguayensis: $12 \rightarrow 2$

Clado 81: $12 \rightarrow 2$

Gymnocorymbus ternertzi: $12 \rightarrow 2$

Clado 80: $12 \rightarrow 2$

Bryconamericus exodon: $12 \rightarrow 2$

Astyanax lineatus: $12 \rightarrow 2$

Astyanacinus moorii: $12 \rightarrow 2$

Clado 88: $2 \rightarrow 12$

Clado 79: $2 \rightarrow 12$

Astyanax paranae: $12 \rightarrow 2$

Astyanax fasciatus: $12 \rightarrow 2$

"Astyanax" orthodus: $12 \rightarrow 2$

“Astyanax" superbus: $12 \rightarrow 2$

Astyanacinus sp nova Peru: $12 \rightarrow 2$

Stethaprion erythrops: $12 \rightarrow 2$

Markiana nigripinnis: $12 \rightarrow 2$

Piabina argentea: $12 \rightarrow 2$

Creagrutus menezesi : $12 \rightarrow 2$

Caráter - 32 (super-sets from 1 trees):

Root: 2

Clado 53: $2 \rightarrow 02$

Brycon pesu : $02 \rightarrow 2$

Clado 58: $02 \rightarrow 01$

Bryconops alburnoides: $02 \rightarrow 0$

Clado 75: $01 \rightarrow 1$

Clado 86: $01 \rightarrow 1$

Charax leticiae: $1 \rightarrow 0$

Clado 77: $02 \rightarrow 0123$

Oligosarcus pintoi : $01 \rightarrow 3$

Hollandichthys multifasciatus: $1 \rightarrow 3$

Triportheus albus : $02 \rightarrow 2$

Lignobrycon myersii: $02 \rightarrow 2$

Thoracocharax stellatus: $0123 \rightarrow 1$

Clado 76: $0123 \rightarrow 03$

Acestrorhynchus falcatus: $02 \rightarrow 2$

Clado 66: $01 \rightarrow 1$

Engraulisoma taeniatum: $03 \rightarrow 3$

Clupeacharax anchoveoides: $03 \rightarrow 3$

Clado 65: $1 \rightarrow 12$

Moenkhausia xinguensis: $12 \rightarrow 2$

Clado 85: $12 \rightarrow 012$

Nematocharax venustus: $012 \rightarrow 0$

Deuterodon iguape: $012 \rightarrow 1$

Jupiaba anteroides: $12 \rightarrow 3$

Tetragonopterus chalceus: $12 \rightarrow 0$

Clado 72: $12 \rightarrow 02$

Hyphessobrycon eques: $12 \rightarrow 2$

Clado 89: $12 \rightarrow 012$

Clado $71: 02 \rightarrow 12$

Mimagoniates microlepis: $02 \rightarrow 2$

Astyanax altiparanae: $12 \rightarrow 2$

Clado 59: $12 \rightarrow 02$

Astyanacinus sp nova Bolivia: $12 \rightarrow 2$

Stichonodon insignis: $012 \rightarrow 4$

Poptella paraguayensis: $012 \rightarrow 2$

Clado 81: $12 \rightarrow 02$

Gymnocorymbus ternertzi: $12 \rightarrow 2$

Clado 80: $12 \rightarrow 02$

Bryconamericus exodon: $12 \rightarrow 3$

Astyanax lineatus: $12 \rightarrow 2$

Astyanacinus moorii: $02 \rightarrow 2$

Ctenobrycon hauxwellianus: $02 \rightarrow 2$

Knodus moenkhausii: $02 \rightarrow 2$

Astyanax paranae: $12 \rightarrow 2$

Astyanax fasciatus: $12 \rightarrow 2$

"Astyanax" orthodus: $02 \rightarrow 2$

"Astyanax" superbus: $02 \rightarrow 2$

Astyanacinus sp nova Peru: $02 \rightarrow 2$

Stethaprion erythrops: $02 \rightarrow 2$

Markiana nigripinnis: $02 \rightarrow 2$

Piabina argentea: $02 \rightarrow 2$

Creagrutus menezesi : $02 \rightarrow 2$ 
Caráter - 33 (super-sets from 1 trees):

Root: 02

Clado 53: $02 \rightarrow 0$

Chalceus epakros: $02 \rightarrow 2$

Clado 58: $0 \rightarrow 01$

Salminus hilarii: $0 \rightarrow 2$

Clado 49: $0 \rightarrow 01$

Galeocharax knerii : $01 \rightarrow 1$

Charax leticiae: $01 \rightarrow 0$

Clado 87: $0 \rightarrow 01$

Clado 55: $01 \rightarrow 0$

Oligosarcus pintoi : $01 \rightarrow 0$

Rachoviscus graciliceps: $01 \rightarrow 0$

Hollandichthys multifasciatus: $01 \rightarrow 0$

Triportheus albus : $01 \rightarrow 0$

Lignobrycon myersii: $01 \rightarrow 0$

Clado 76: $0 \rightarrow 01$

Hydrolycus scomberoides: $01 \rightarrow 1$

Acestrorhynchus falcatus: $01 \rightarrow 1$

Agoniates halecinus: $01 \rightarrow 1$

Agoniates anchovia: $01 \rightarrow 1$

Clado 66: $0 \rightarrow 01$

Aphyocharax pusillus: $0 \rightarrow 2$

Engraulisoma taeniatum: $01 \rightarrow 0$

Clupeacharax anchoveoides: $01 \rightarrow 3$

Cheirodon galusdae: $01 \rightarrow 0$

Moenkhausia xinguensis: $01 \rightarrow 0$

Nematocharax venustus: $01 \rightarrow 0$

Deuterodon iguape: $01 \rightarrow 2$

Jupiaba anteroides: $01 \rightarrow 0$

Tetragonopterus chalceus: $01 \rightarrow 0$

Hyphessobrycon eques: $01 \rightarrow 0$

Mimagoniates microlepis: $01 \rightarrow 0$

Astyanax altiparanae: $01 \rightarrow 0$

Astyanacinus sp nova Bolivia: $01 \rightarrow 0$

Stichonodon insignis: $01 \rightarrow 0$

Poptella paraguayensis: $01 \rightarrow 0$

Gymnocorymbus ternertzi: $01 \rightarrow 0$

Bryconamericus exodon: $01 \rightarrow 0$

Astyanax lineatus: $01 \rightarrow 0$

Astyanacinus moorii: $01 \rightarrow 0$

Clado 88: $01 \rightarrow 0$

Ctenobrycon hauxwellianus: $01 \rightarrow 0$

Clado 79: $01 \rightarrow 0$

Knodus moenkhausii: $01 \rightarrow 0$

Astyanax paranae: $01 \rightarrow 0$

Astyanax fasciatus: $01 \rightarrow 0$

"Astyanax" orthodus: $01 \rightarrow 0$

"Astyanax" superbus: $01 \rightarrow 0$

Astyanacinus sp nova Peru: $01 \rightarrow 0$

Creagrutus menezesi : $0 \rightarrow 3$

Caráter - 34 (super-sets from 1 trees):

Root: 01

Chalceus epakros: $01 \rightarrow 0$

Brycon pesu : $01 \rightarrow 1$

Clado 51: $01 \rightarrow 0$

Salminus hilarii: $01 \rightarrow 1$

Clado 57: $01 \rightarrow 0$

Galeocharax knerii : $01 \rightarrow 1$

Charax leticiae: $01 \rightarrow 1$

Clado 48: $0 \rightarrow 01$

Clado 76: $0 \rightarrow 02$

Hydrolycus scomberoides: $01 \rightarrow 1$

Acestrorhynchus falcatus: $01 \rightarrow 1$

Engraulisoma taeniatum: $02 \rightarrow 0$

Clupeacharax anchoveoides: $02 \rightarrow 0$

Clado 84: $0 \rightarrow 01$

Tetragonopterus chalceus: $01 \rightarrow 0$

Stichonodon insignis: $01 \rightarrow 0$

Poptella paraguayensis: $01 \rightarrow 0$

Clado 81: $01 \rightarrow 0$

Gymnocorymbus ternertzi: $01 \rightarrow 0$

Caráter - 35 (super-sets from 1 trees):

Root: 1

Clado 52: $1 \rightarrow 01$

Salminus hilarii: $01 \rightarrow 0$
Clado 50: $01 \rightarrow 0$

Bryconops alburnoides: $01 \rightarrow 0$

Galeocharax knerii : $01 \rightarrow 0$

Charax leticiae: $01 \rightarrow 0$

Clado 87: $0 \rightarrow 01$

Clado 48: $0 \rightarrow 01$

Clado 54: $0 \rightarrow 01$

Oligosarcus pintoi : $01 \rightarrow 0$

Rachoviscus graciliceps: $01 \rightarrow 1$

Hollandichthys multifasciatus: $01 \rightarrow 0$

Triportheus albus : $01 \rightarrow 1$

Lignobrycon myersii: $01 \rightarrow 0$

Clado 76: $0 \rightarrow 01$

Hydrolycus scomberoides: $01 \rightarrow 0$

Acestrorhynchus falcatus: $01 \rightarrow 0$

Agoniates halecinus: $01 \rightarrow 0$

Agoniates anchovia: $01 \rightarrow 0$

Clado 66: $01 \rightarrow 1$

Aphyocharax pusillus: $01 \rightarrow 1$

Engraulisoma taeniatum: $01 \rightarrow 1$

Clupeacharax anchoveoides: $01 \rightarrow 0$

Clado 60: $1 \rightarrow 01$

Mimagoniates microlepis: $1 \rightarrow 0$

Astyanacinus sp nova Bolivia: $01 \rightarrow 0$

Astyanacinus moorii: $01 \rightarrow 0$

Clado 79: $1 \rightarrow 012$

"Astyanax" orthodus: $01 \rightarrow 0$

“Astyanax" superbus: $01 \rightarrow 0$

Astyanacinus sp nova Peru: $01 \rightarrow 0$

Piabina argentea: $012 \rightarrow 2$

Creagrutus menezesi : $012 \rightarrow 2$

Caráter - 36 (super-sets from 1 trees):

Root: 12

Chalceus epakros: $12 \rightarrow 1$

Brycon pesu : $12 \rightarrow 2$

Salminus hilarii: $12 \rightarrow 2$

Bryconops alburnoides: $12 \rightarrow 2$

Clado 57: $12 \rightarrow 01$

Clado 78: $12 \rightarrow 124$

Galeocharax knerii : $12 \rightarrow 2$

Charax leticiae: $12 \rightarrow 2$

Clado 87: $124 \rightarrow 14$

Clado 48: $12 \rightarrow 012$

Clado 55: $01 \rightarrow 12$

Oligosarcus pintoi : $01 \rightarrow 0$

Rachoviscus graciliceps: $01 \rightarrow 0$

Hollandichthys multifasciatus: $01 \rightarrow 0$

Triportheus albus : $14 \rightarrow 4$

Lignobrycon myersii: $14 \rightarrow 1$

Thoracocharax stellatus: $124 \rightarrow 4$

Clado 76: $124 \rightarrow 12$

Hydrolycus scomberoides: $012 \rightarrow 2$

Acestrorhynchus falcatus: $012 \rightarrow 3$

Agoniates halecinus: $12 \rightarrow 2$

Clado 66: $12 \rightarrow 1$

Aphyocharax pusillus: $12 \rightarrow 1$

Engraulisoma taeniatum: $12 \rightarrow 1$

Clupeacharax anchoveoides: $12 \rightarrow 1$

Clado 85: $1 \rightarrow 12$

Clado 62: $1 \rightarrow 01$

Nematocharax venustus: $12 \rightarrow 1$

Deuterodon iguape: $12 \rightarrow 1$

Clado 84: $1 \rightarrow 12$

Jupiaba anteroides: $01 \rightarrow 0$

Tetragonopterus chalceus: $12 \rightarrow 1$

Clado 83: $12 \rightarrow 24$

Clado 68: $01 \rightarrow 1$

Mimagoniates microlepis: $1 \rightarrow 4$

Astyanacinus sp nova Bolivia: $01 \rightarrow 0$

Stichonodon insignis: $24 \rightarrow 4$

Poptella paraguayensis: $24 \rightarrow 4$

Clado 81: $24 \rightarrow 04$

Gymnocorymbus ternertzi: $24 \rightarrow 4$

Clado 80: $1 \rightarrow 01$

Astyanacinus moorii: $01 \rightarrow 0$

Clado 88: $04 \rightarrow 24$ 
Ctenobrycon hauxwellianus: $04 \rightarrow 4$

Clado 79: $01 \rightarrow 02$

Knodus moenkhausii: $01 \rightarrow 1$

Astyanax paranae: $1 \rightarrow 0$

“Astyanax” orthodus: $01 \rightarrow 0$

"Astyanax" superbus: $01 \rightarrow 0$

Astyanacinus sp nova Peru: $01 \rightarrow 0$

Stethaprion erythrops: $24 \rightarrow 4$

Markiana nigripinnis: $24 \rightarrow 4$

Piabina argentea: $02 \rightarrow 0$

Creagrutus menezesi : $02 \rightarrow 0$

Caráter - 37 (super-sets from 1 trees):

Root: 0

Clado 58: $0 \rightarrow 01$

Galeocharax knerii : $01 \rightarrow 0$

Charax leticiae: $01 \rightarrow 1$

Clado 87: $0 \rightarrow 01$

Clado 77: $0 \rightarrow 01$

Oligosarcus pintoi : $01 \rightarrow 1$

Rachoviscus graciliceps: $01 \rightarrow 1$

Hollandichthys multifasciatus: $01 \rightarrow 1$

Triportheus albus : $01 \rightarrow 0$

Lignobrycon myersii: $01 \rightarrow 0$

Thoracocharax stellatus: $01 \rightarrow 1$

Aphyocharax pusillus: $01 \rightarrow 1$

Engraulisoma taeniatum: $01 \rightarrow 1$

Clupeacharax anchoveoides: $01 \rightarrow 0$

Cheirodon galusdae: $01 \rightarrow 1$

Moenkhausia xinguensis: $01 \rightarrow 1$

Clado 85: $01 \rightarrow 012$

Nematocharax venustus: $012 \rightarrow 1$

Deuterodon iguape: $012 \rightarrow 1$

Clado 84: $01 \rightarrow 012$

Jupiaba anteroides: $01 \rightarrow 1$

Clado 61: $01 \rightarrow 1$

Tetragonopterus chalceus: $012 \rightarrow 1$

Hyphessobrycon eques: $01 \rightarrow 1$

Mimagoniates microlepis: $01 \rightarrow 1$

Clado 70: $1 \rightarrow 01$

Clado 59: $1 \rightarrow 01$

Stichonodon insignis: $012 \rightarrow 0$

Poptella paraguayensis: $012 \rightarrow 1$

Clado 81: $012 \rightarrow 01$

Gymnocorymbus ternertzi: $012 \rightarrow 1$

Bryconamericus exodon: $01 \rightarrow 0$

Astyanax lineatus: $01 \rightarrow 1$

Astyanacinus moorii: $01 \rightarrow 1$

Ctenobrycon hauxwellianus: $01 \rightarrow 0$

Knodus moenkhausii: $01 \rightarrow 1$

Astyanax paranae: $01 \rightarrow 1$

Astyanax fasciatus: $01 \rightarrow 1$

“Astyanax" orthodus: $01 \rightarrow 1$

“Astyanax” superbus: $01 \rightarrow 1$

Astyanacinus sp nova Peru: $01 \rightarrow 1$

Stethaprion erythrops: $01 \rightarrow 1$

Markiana nigripinnis: $01 \rightarrow 1$

Piabina argentea: $01 \rightarrow 0$

Creagrutus menezesi : $01 \rightarrow 1$

Caráter - 38 (super-sets from 1 trees):

Root: 01

Clado 53: $01 \rightarrow 0$

Chalceus epakros: $01 \rightarrow 1$

Clado 75: $0 \rightarrow 02$

Galeocharax knerii : $02 \rightarrow 0$

Charax leticiae: $02 \rightarrow 0$

Clado 87: $0 \rightarrow 02$

Hollandichthys multifasciatus: $0 \rightarrow 1$

Triportheus albus : $02 \rightarrow 0$

Lignobrycon myersii: $02 \rightarrow 0$

Clado 76: $0 \rightarrow 01$

Hydrolycus scomberoides: $0 \rightarrow 1$

Agoniates anchovia: $0 \rightarrow 1$

Engraulisoma taeniatum: $01 \rightarrow 1$

Clupeacharax anchoveoides: $01 \rightarrow 1$

Clado 85: $0 \rightarrow 02$

Clado 74: $0 \rightarrow 02$
Nematocharax venustus: $02 \rightarrow 0$

Clado 61: $0 \rightarrow 02$

Tetragonopterus chalceus: $02 \rightarrow 0$

Clado 72: $02 \rightarrow 0$

Hyphessobrycon eques: $02 \rightarrow 0$

Clado 70: $02 \rightarrow 0$

Astyanax altiparanae: $02 \rightarrow 0$

Clado 59: $02 \rightarrow 0$

Astyanacinus sp nova Bolivia: $02 \rightarrow 0$

Stichonodon insignis: $02 \rightarrow 0$

Poptella paraguayensis: $02 \rightarrow 0$

Clado 81: $02 \rightarrow 0$

Gymnocorymbus ternertzi: $02 \rightarrow 0$

Creagrutus menezesi : $0 \rightarrow 1$

Caráter - 39 (super-sets from 1 trees):

Root: 1

Clado 53: $1 \rightarrow 01$

Clado 52: $01 \rightarrow 0$

Brycon pesu : $01 \rightarrow 1$

Bryconops alburnoides: $0 \rightarrow 1$

Clado 75: $0 \rightarrow 01$

Clado 56: $0 \rightarrow 02$

Clado 86: $0 \rightarrow 01$

Galeocharax knerii : $01 \rightarrow 0$

Charax leticiae: $01 \rightarrow 2$

Clado 48: $0 \rightarrow 02$

Oligosarcus pintoi : $02 \rightarrow 2$

Rachoviscus graciliceps: $01 \rightarrow 0$

Hollandichthys multifasciatus: $01 \rightarrow 0$

Triportheus albus : $0 \rightarrow 1$

Hydrolycus scomberoides: $02 \rightarrow 2$

Acestrorhynchus falcatus: $02 \rightarrow 2$

Clado 66: $02 \rightarrow 12$

Aphyocharax pusillus: $02 \rightarrow 2$

Clado 65: $12 \rightarrow 01$

Cheirodon galusdae: $12 \rightarrow 2$

Moenkhausia xinguensis: $01 \rightarrow 0$

Nematocharax venustus: $01 \rightarrow 0$

Deuterodon iguape: $01 \rightarrow 0$

Clado 73: $01 \rightarrow 0$

Jupiaba anteroides: $01 \rightarrow 0$

Tetragonopterus chalceus: $01 \rightarrow 0$

Hyphessobrycon eques: $0 \rightarrow 2$

Clado 68: $01 \rightarrow 0$

Clado 60: $01 \rightarrow 0$

Clado 71: $0 \rightarrow 01$

Clado 70: $0 \rightarrow 01$

Poptella paraguayensis: $01 \rightarrow 0$

Clado 81: $01 \rightarrow 0$

Gymnocorymbus ternertzi: $01 \rightarrow 0$

Clado 80: $01 \rightarrow 0$

Bryconamericus exodon: $01 \rightarrow 0$

Astyanax lineatus: $01 \rightarrow 0$

Clado 79: $0 \rightarrow 01$

Astyanax paranae: $01 \rightarrow 0$

Astyanax fasciatus: $01 \rightarrow 0$

Piabina argentea: $01 \rightarrow 1$

Creagrutus menezesi : $01 \rightarrow 1$

Caráter - 40 (super-sets from 1 trees):

Root: 0

Clado 58: $0 \rightarrow 012$

Clado 57: $012 \rightarrow 01$

Clado 78: $0 \rightarrow 01$

Galeocharax knerii : $012 \rightarrow 2$

Clado 87: $01 \rightarrow 0$

Rachoviscus graciliceps: $01 \rightarrow 1$

Hollandichthys multifasciatus: $01 \rightarrow 1$

Thoracocharax stellatus: $01 \rightarrow 0$

Clado 76: $01 \rightarrow 0$

Agoniates halecinus: $0 \rightarrow 01$

Agoniates anchovia: $0 \rightarrow 2$

Engraulisoma taeniatum: $0 \rightarrow 2$

Clupeacharax anchoveoides: $0 \rightarrow 01$

Moenkhausia xinguensis: $01 \rightarrow 1$

Nematocharax venustus: $01 \rightarrow 1$

Deuterodon iguape: $01 \rightarrow 1$ 
Clado 73: $01 \rightarrow 012$

Jupiaba anteroides: $01 \rightarrow 1$

Tetragonopterus chalceus: $01 \rightarrow 1$

Clado 71: $012 \rightarrow 02$

Astyanax altiparanae: $01 \rightarrow 1$

Astyanacinus sp nova Bolivia: $01 \rightarrow 1$

Poptella paraguayensis: $01 \rightarrow 0$

Gymnocorymbus ternertzi: $01 \rightarrow 1$

Bryconamericus exodon: $02 \rightarrow 2$

Astyanax lineatus: $01 \rightarrow 1$

Astyanacinus moorii: $01 \rightarrow 1$

Clado 88: $01 \rightarrow 1$

Ctenobrycon hauxwellianus: $01 \rightarrow 1$

Clado 79: $02 \rightarrow 12$

Knodus moenkhausii: $02 \rightarrow 2$

Astyanax paranae: $01 \rightarrow 1$

Astyanax fasciatus: $01 \rightarrow 1$

"Astyanax" orthodus: $01 \rightarrow 1$

“Astyanax" superbus: $01 \rightarrow 1$

Astyanacinus sp nova Peru: $01 \rightarrow 1$

Markiana nigripinnis: $1 \rightarrow 2$

Caráter - 41 (super-sets from 1 trees):

Root: 0

Brycon pesu : $0 \rightarrow 1$

Clado 78: $0 \rightarrow 01$

Clado 87: $01 \rightarrow 0$

Clado 76: $01 \rightarrow 0$

Clado 88: $0 \rightarrow 01$

Clado 79: $0 \rightarrow 01$

Piabina argentea: $01 \rightarrow 0$

Creagrutus menezesi : $01 \rightarrow 0$

Caráter - 42 (super-sets from 1 trees):

Root: 0

Clado 58: $0 \rightarrow 01$

Clado 75: $01 \rightarrow 1$

Clado 87: $0 \rightarrow 01$

Clado 48: $0 \rightarrow 01$

Clado 55: $01 \rightarrow 02$

Oligosarcus pintoi : $01 \rightarrow 0$

Rachoviscus graciliceps: $01 \rightarrow 0$

Hollandichthys multifasciatus: $01 \rightarrow 0$

Triportheus albus : $01 \rightarrow 0$

Lignobrycon myersii: $01 \rightarrow 0$

Clado 76: $0 \rightarrow 01$

Hydrolycus scomberoides: $01 \rightarrow 1$

Acestrorhynchus falcatus: $01 \rightarrow 1$

Clado 66: $02 \rightarrow 01$

Aphyocharax pusillus: $02 \rightarrow 0$

Engraulisoma taeniatum: $01 \rightarrow 0$

Clupeacharax anchoveoides: $01 \rightarrow 0$

Cheirodon galusdae: $01 \rightarrow 0$

Moenkhausia xinguensis: $01 \rightarrow 0$

Clado 74: $01 \rightarrow 0$

Nematocharax venustus: $01 \rightarrow 0$

Deuterodon iguape: $01 \rightarrow 0$

Clado 84: $0 \rightarrow 01$

Jupiaba anteroides: $01 \rightarrow 0$

Tetragonopterus chalceus: $01 \rightarrow 0$

Clado 71: $0 \rightarrow 01$

Astyanax altiparanae: $01 \rightarrow 0$

Astyanacinus sp nova Bolivia: $01 \rightarrow 0$

Stichonodon insignis: $01 \rightarrow 0$

Poptella paraguayensis: $01 \rightarrow 0$

Clado 81: $01 \rightarrow 0$

Gymnocorymbus ternertzi: $01 \rightarrow 0$

Clado 80: $01 \rightarrow 0$

Bryconamericus exodon: $01 \rightarrow 0$

Astyanax lineatus: $01 \rightarrow 0$

Astyanacinus moorii: $01 \rightarrow 0$

Astyanax paranae: $01 \rightarrow 0$

Astyanax fasciatus: $01 \rightarrow 0$

"Astyanax" orthodus: $01 \rightarrow 0$

“Astyanax" superbus: $01 \rightarrow 0$

Astyanacinus sp nova Peru: $01 \rightarrow 0$

Caráter - 43 (super-sets from 1 trees):

Root: 0
Clado 52: $0 \rightarrow 01$

Clado 58: $01 \rightarrow 0$

Salminus hilarii: $01 \rightarrow 0$

Bryconops alburnoides: $01 \rightarrow 0$

Clado 86: $0 \rightarrow 01$

Clado 55: $0 \rightarrow 01$

Rachoviscus graciliceps: $01 \rightarrow 0$

Hollandichthys multifasciatus: $01 \rightarrow 0$

Triportheus albus : $01 \rightarrow 0$

Lignobrycon myersii: $01 \rightarrow 0$

Thoracocharax stellatus: $01 \rightarrow 0$

Clado 76: $01 \rightarrow 0$

Hydrolycus scomberoides: $01 \rightarrow 0$

Acestrorhynchus falcatus: $01 \rightarrow 0$

Agoniates halecinus: $01 \rightarrow 1$

Agoniates anchovia: $01 \rightarrow 1$

Clado 66: $01 \rightarrow 0$

Aphyocharax pusillus: $01 \rightarrow 0$

Clado 74: $0 \rightarrow 01$

Clado 84: $01 \rightarrow 0$

Clado 61: $0 \rightarrow 01$

Hyphessobrycon eques: $01 \rightarrow 0$

Clado 89: $0 \rightarrow 01$

Clado 71: $01 \rightarrow 0$

Mimagoniates microlepis: $01 \rightarrow 0$

Astyanax altiparanae: $01 \rightarrow 0$

Clado 59: $01 \rightarrow 0$

Astyanacinus sp nova Bolivia: $01 \rightarrow 0$

Stichonodon insignis: $01 \rightarrow 0$

Poptella paraguayensis: $01 \rightarrow 0$

Clado 81: $0 \rightarrow 01$

Clado 80: $0 \rightarrow 01$

Clado 69: $01 \rightarrow 0$

Astyanax lineatus: $01 \rightarrow 0$

Ctenobrycon hauxwellianus: $01 \rightarrow 0$

Knodus moenkhausii: $01 \rightarrow 0$

Stethaprion erythrops: $01 \rightarrow 0$

Markiana nigripinnis: $01 \rightarrow 0$

Piabina argentea: $01 \rightarrow 0$

Creagrutus menezesi : $01 \rightarrow 0$

Caráter - 44 (super-sets from 1 trees):

Root: 0

Clado 52: $0 \rightarrow 01$

Salminus hilarii: $01 \rightarrow 1$

Bryconops alburnoides: $01 \rightarrow 1$

Clado 57: $01 \rightarrow 1$

Clado 75: $01 \rightarrow 1$

Clado 55: $1 \rightarrow 01$

Triportheus albus : $01 \rightarrow 0$

Lignobrycon myersii: $01 \rightarrow 1$

Thoracocharax stellatus: $01 \rightarrow 1$

Hydrolycus scomberoides: $01 \rightarrow 1$

Acestrorhynchus falcatus: $01 \rightarrow 1$

Agoniates halecinus: $01 \rightarrow 1$

Agoniates anchovia: $01 \rightarrow 1$

Clado 66: $01 \rightarrow 1$

Aphyocharax pusillus: $01 \rightarrow 1$

Engraulisoma taeniatum: $01 \rightarrow 1$

Clupeacharax anchoveoides: $01 \rightarrow 1$

Clado 63: $1 \rightarrow 01$

Clado 74: $01 \rightarrow 1$

Jupiaba anteroides: $01 \rightarrow 1$

Clado 71: $1 \rightarrow 01$

Clado 70: $01 \rightarrow 1$

Astyanax altiparanae: $01 \rightarrow 1$

Astyanacinus sp nova Bolivia: $01 \rightarrow 1$

Clado 80: $01 \rightarrow 1$

Bryconamericus exodon: $01 \rightarrow 1$

Clado 69: $1 \rightarrow 01$

Clado 67: $01 \rightarrow 1$

Astyanacinus moorii: $01 \rightarrow 1$

Clado 79: $1 \rightarrow 01$

Astyanax paranae: $01 \rightarrow 1$

Astyanax fasciatus: $01 \rightarrow 1$

Piabina argentea: $01 \rightarrow 1$

Creagrutus menezesi : $01 \rightarrow 1$ 
Caráter - 45 (super-sets from 1 trees):

Root: 0

Clado 51: $0 \rightarrow 0$

Salminus hilarii: $0 \rightarrow 1$

Bryconops alburnoides: $01 \rightarrow 0$

Clado 87: $01 \rightarrow 0$

Clado 54: $01 \rightarrow 0$

Clado 55: $0 \rightarrow 01$

Thoracocharax stellatus: $01 \rightarrow 0$

Clado 76: $01 \rightarrow 0$

Hydrolycus scomberoides: $01 \rightarrow 1$

Acestrorhynchus falcatus: $01 \rightarrow 1$

Clado 66: $01 \rightarrow 0$

Aphyocharax pusillus: $01 \rightarrow 0$

Clado 88: $0 \rightarrow 01$

Clado 79: $0 \rightarrow 01$

Stethaprion erythrops: $01 \rightarrow 0$

Markiana nigripinnis: $01 \rightarrow 0$

Piabina argentea: $01 \rightarrow 0$

Creagrutus menezesi : $01 \rightarrow 0$

Caráter - 46 (super-sets from 1 trees):

Root: 0

Clado 53: $0 \rightarrow 0$

Brycon pesu : $01 \rightarrow 0$

Salminus hilarii: $01 \rightarrow 0$

Clado 50: $01 \rightarrow 0$

Bryconops alburnoides: $01 \rightarrow 1$

Clado 78: $0 \rightarrow 01$

Galeocharax knerii : $01 \rightarrow 0$

Charax leticiae: $01 \rightarrow 0$

Clado 48: $0 \rightarrow 01$

Clado 54: $0 \rightarrow 01$

Clado 55: $01 \rightarrow 0$

Oligosarcus pintoi : $01 \rightarrow 0$

Rachoviscus graciliceps: $01 \rightarrow 0$

Hollandichthys multifasciatus: $01 \rightarrow 0$

Triportheus albus : $01 \rightarrow 0$

Lignobrycon myersii: $01 \rightarrow 0$

Thoracocharax stellatus: $01 \rightarrow 0$

Hydrolycus scomberoides: $01 \rightarrow 0$

Acestrorhynchus falcatus: $01 \rightarrow 0$

Agoniates halecinus: $01 \rightarrow 0$

Agoniates anchovia: $01 \rightarrow 0$

Clado 66: $0 \rightarrow 01$

Engraulisoma taeniatum: $01 \rightarrow 1$

Clupeacharax anchoveoides: $01 \rightarrow 1$

Cheirodon galusdae: $01 \rightarrow 1$

Moenkhausia xinguensis: $01 \rightarrow 1$

Nematocharax venustus: $01 \rightarrow 0$

Deuterodon iguape: $01 \rightarrow 0$

Clado 84: $01 \rightarrow 1$

Jupiaba anteroides: $01 \rightarrow 1$

Hyphessobrycon eques: $01 \rightarrow 1$

Clado 89: $1 \rightarrow 01$

Mimagoniates microlepis: $01 \rightarrow 1$

Astyanax altiparanae: $01 \rightarrow 0$

Astyanacinus sp nova Bolivia: $01 \rightarrow 0$

Stichonodon insignis: $01 \rightarrow 0$

Poptella paraguayensis: $01 \rightarrow 0$

Clado 81: $1 \rightarrow 01$

Bryconamericus exodon: $01 \rightarrow 1$

Astyanax lineatus: $01 \rightarrow 0$

Astyanacinus moorii: $01 \rightarrow 0$

Ctenobrycon hauxwellianus: $01 \rightarrow 1$

Knodus moenkhausii: $01 \rightarrow 1$

Astyanax paranae: $01 \rightarrow 0$

Astyanax fasciatus: $01 \rightarrow 1$

“Astyanax" orthodus: $01 \rightarrow 0$

"Astyanax" superbus: $01 \rightarrow 0$

Astyanacinus sp nova Peru: $01 \rightarrow 0$

Stethaprion erythrops: $01 \rightarrow 0$

Markiana nigripinnis: $01 \rightarrow 0$

Piabina argentea: $01 \rightarrow 0$

Creagrutus menezesi : $01 \rightarrow 0$

Caráter - 47 (super-sets from 1 trees):

Root: 0
Clado 53: $0 \rightarrow 01$

Brycon pesu : $01 \rightarrow 0$

Salminus hilarii: $01 \rightarrow 0$

Bryconops alburnoides: $01 \rightarrow 0$

Galeocharax knerii : $01 \rightarrow 0$

Charax leticiae: $01 \rightarrow 0$

Oligosarcus pintoi : $01 \rightarrow 0$

Rachoviscus graciliceps: $01 \rightarrow 0$

Hollandichthys multifasciatus: $01 \rightarrow 0$

Triportheus albus : $01 \rightarrow 1$

Lignobrycon myersii: $01 \rightarrow 0$

Thoracocharax stellatus: $01 \rightarrow 0$

Clado 76: $01 \rightarrow 1$

Hydrolycus scomberoides: $01 \rightarrow 0$

Acestrorhynchus falcatus: $01 \rightarrow 0$

Agoniates halecinus: $01 \rightarrow 0$

Agoniates anchovia: $01 \rightarrow 0$

Aphyocharax pusillus: $01 \rightarrow 0$

Cheirodon galusdae: $01 \rightarrow 1$

Moenkhausia xinguensis: $01 \rightarrow 0$

Nematocharax venustus: $01 \rightarrow 0$

Deuterodon iguape: $01 \rightarrow 0$

Clado 73: $01 \rightarrow 0$

Jupiaba anteroides: $01 \rightarrow 0$

Tetragonopterus chalceus: $01 \rightarrow 0$

Clado 68: $01 \rightarrow 1$

Clado 82: $01 \rightarrow 1$

Clado 71: $0 \rightarrow 01$

Astyanacinus sp nova Bolivia: $01 \rightarrow 0$

Stichonodon insignis: $01 \rightarrow 1$

Poptella paraguayensis: $01 \rightarrow 0$

Clado 81: $1 \rightarrow 01$

Clado 80: $01 \rightarrow 0$

Bryconamericus exodon: $01 \rightarrow 0$

Astyanacinus moorii: $01 \rightarrow 0$

Clado 88: $01 \rightarrow 1$

Ctenobrycon hauxwellianus: $01 \rightarrow 1$

Clado 79: $0 \rightarrow 01$

Astyanax paranae: $1 \rightarrow 01$

“Astyanax" orthodus: $01 \rightarrow 0$

"Astyanax" superbus: $01 \rightarrow 0$

Astyanacinus sp nova Peru: $01 \rightarrow 0$

Piabina argentea: $01 \rightarrow 0$

Creagrutus menezesi : $01 \rightarrow 0$

Caráter - 48 (super-sets from 1 trees):

Root: 5

Clado 53: $5 \rightarrow 05$

Brycon pesu : $05 \rightarrow 5$

Salminus hilarii: $05 \rightarrow 5$

Bryconops alburnoides: $05 \rightarrow 0$

Galeocharax knerii : $05 \rightarrow 5$

Charax leticiae: $05 \rightarrow 5$

Clado 77: $05 \rightarrow 015$

Oligosarcus pintoi : $05 \rightarrow 5$

Rachoviscus graciliceps: $05 \rightarrow 5$

Hollandichthys multifasciatus: $05 \rightarrow 5$

Lignobrycon myersii: $05 \rightarrow 5$

Thoracocharax stellatus: $015 \rightarrow 1$

Hydrolycus scomberoides: $05 \rightarrow 5$

Acestrorhynchus falcatus: $05 \rightarrow 5$

Agoniates halecinus: $05 \rightarrow 5$

Agoniates anchovia: $05 \rightarrow 5$

Aphyocharax pusillus: $05 \rightarrow 5$

Clado 65: $05 \rightarrow 0$

Nematocharax venustus: $0 \rightarrow 5$

Clado 60: $0 \rightarrow 01$

Mimagoniates microlepis: $0 \rightarrow 5$

Astyanacinus sp nova Bolivia: $01 \rightarrow 12$

Clado 79: $0 \rightarrow 01$

“Astyanax" orthodus: $01 \rightarrow 12$

“Astyanax” superbus: $01 \rightarrow 34$

Piabina argentea: $01 \rightarrow 1$

Creagrutus menezesi : $01 \rightarrow 1$

Caráter - 49 (super-sets from 1 trees):

Root: 0

Clado 58: $0 \rightarrow 012$ 
Bryconops alburnoides: $0 \rightarrow 1$

Clado 75: $012 \rightarrow 01$

Clado 56: $012 \rightarrow 02$

Clado 86: $012 \rightarrow 01$

Galeocharax knerii : $01 \rightarrow 0$

Charax leticiae: $01 \rightarrow 0$

Clado 87: $0 \rightarrow 012$

Clado 55: $02 \rightarrow 0$

Oligosarcus pintoi : $02 \rightarrow 0$

Rachoviscus graciliceps: $01 \rightarrow 1$

Hollandichthys multifasciatus: $01 \rightarrow 0$

Triportheus albus : $012 \rightarrow 1$

Lignobrycon myersii: $012 \rightarrow 0$

Clado 76: $0 \rightarrow 012$

Clado 66: $0 \rightarrow 12$

Clupeacharax anchoveoides: $012 \rightarrow 1$

Clado 65: $12 \rightarrow 1$

Cheirodon galusdae: $12 \rightarrow 1$

Nematocharax venustus: $1 \rightarrow 0$

Clado 68: $1 \rightarrow 01$

Clado 89: $1 \rightarrow 01$

Clado 70: $01 \rightarrow 1$

Clado 59: $1 \rightarrow 12$

Poptella paraguayensis: $01 \rightarrow 1$

Astyanacinus moorii: $12 \rightarrow 1$

Clado 88: $1 \rightarrow 01$

Clado 79: $1 \rightarrow 01$

"Astyanax" orthodus: $12 \rightarrow 1$

"Astyanax" superbus: $12 \rightarrow 1$

Astyanacinus sp nova Peru: $12 \rightarrow 1$

Stethaprion erythrops: $01 \rightarrow 1$

Markiana nigripinnis: $01 \rightarrow 1$

Piabina argentea: $01 \rightarrow 1$

Creagrutus menezesi : $01 \rightarrow 1$

Caráter - 50 (super-sets from 1 trees):

Root: 0

Clado 53: $0 \rightarrow 01$

Clado 52: $01 \rightarrow 012$

Brycon pesu : $01 \rightarrow 0$

Clado 58: $012 \rightarrow 02$

Salminus hilarii: $012 \rightarrow 2$

Clado 50: $012 \rightarrow 02$

Bryconops alburnoides: $012 \rightarrow 0$

Clado 78: $02 \rightarrow 12$

Clado 56: $02 \rightarrow 01$

Galeocharax knerii : $02 \rightarrow 2$

Charax leticiae: $02 \rightarrow 2$

Clado 87: $12 \rightarrow 012$

Oligosarcus pintoi : $01 \rightarrow 1$

Rachoviscus graciliceps: $02 \rightarrow 2$

Hollandichthys multifasciatus: $02 \rightarrow 0$

Triportheus albus : $012 \rightarrow 1$

Lignobrycon myersii: $012 \rightarrow 0$

Thoracocharax stellatus: $12 \rightarrow 2$

Clado 76: $12 \rightarrow 012$

Hydrolycus scomberoides: $02 \rightarrow 2$

Acestrorhynchus falcatus: $02 \rightarrow 2$

Agoniates halecinus: $02 \rightarrow 2$

Agoniates anchovia: $02 \rightarrow 2$

Aphyocharax pusillus: $01 \rightarrow 0$

Clupeacharax anchoveoides: $012 \rightarrow 1$

Cheirodon galusdae: $01 \rightarrow 1$

Clado 64: $01 \rightarrow 0$

Moenkhausia xinguensis: $01 \rightarrow 1$

Clado 74: $0 \rightarrow 01$

Deuterodon iguape: $0 \rightarrow 3$

Clado 84: $01 \rightarrow 0$

Tetragonopterus chalceus: $0 \rightarrow 1$

Hyphessobrycon eques: $01 \rightarrow 1$

Mimagoniates microlepis: $01 \rightarrow 0$

Clado 81: $0 \rightarrow 1$

Clado 80: $01 \rightarrow 0$

Bryconamericus exodon: $01 \rightarrow 0$

Clado 69: $0 \rightarrow 01$

Clado 67: $0 \rightarrow 01$

Clado 79: $0 \rightarrow 01$
Knodus moenkhausii: $0 \rightarrow 3$

Astyanax paranae: $01 \rightarrow 0$

Astyanax fasciatus: $01 \rightarrow 1$

“Astyanax" orthodus: $01 \rightarrow 0$

“Astyanax” superbus: $01 \rightarrow 1$

Astyanacinus sp nova Peru: $01 \rightarrow 0$

Piabina argentea: $01 \rightarrow 0$

Creagrutus menezesi : $01 \rightarrow 0$

Caráter - 51 (super-sets from 1 trees):

Root: 02

Clado 53: $02 \rightarrow 01$

Chalceus epakros: $02 \rightarrow 2$

Brycon pesu : $01 \rightarrow 0$

Salminus hilarii: $01 \rightarrow 0$

Bryconops alburnoides: $01 \rightarrow 0$

Clado 78: $01 \rightarrow 02$

Clado 86: $01 \rightarrow 0$

Galeocharax knerii : $01 \rightarrow 0$

Charax leticiae: $01 \rightarrow 0$

Clado 87: $02 \rightarrow 12$

Clado 55: $01 \rightarrow 012$

Oligosarcus pintoi : $01 \rightarrow 0$

Triportheus albus : $12 \rightarrow 2$

Lignobrycon myersii: $12 \rightarrow 2$

Thoracocharax stellatus: $02 \rightarrow 2$

Clado 76: $02 \rightarrow 1$

Hydrolycus scomberoides: $01 \rightarrow 0$

Acestrorhynchus falcatus: $01 \rightarrow 0$

Agoniates halecinus: $01 \rightarrow 0$

Agoniates anchovia: $01 \rightarrow 0$

Clado 66: $012 \rightarrow 1$

Aphyocharax pusillus: $012 \rightarrow 2$

Clado 85: $1 \rightarrow 01$

Nematocharax venustus: $01 \rightarrow 0$

Deuterodon iguape: $01 \rightarrow 0$

Clado 84: $1 \rightarrow 12$

Tetragonopterus chalceus: $12 \rightarrow 2$

Clado 60: $1 \rightarrow 01$

Astyanacinus sp nova Bolivia: $01 \rightarrow 0$

Stichonodon insignis: $12 \rightarrow 2$

Poptella paraguayensis: $12 \rightarrow 2$

Gymnocorymbus ternertzi: $12 \rightarrow 0$

Astyanacinus moorii: $01 \rightarrow 0$

Ctenobrycon hauxwellianus: $12 \rightarrow 2$

Astyanax paranae: $1 \rightarrow 0$

"Astyanax" orthodus: $01 \rightarrow 0$

“Astyanax" superbus: $01 \rightarrow 0$

Astyanacinus sp nova Peru: $01 \rightarrow 0$

Stethaprion erythrops: $12 \rightarrow 2$

Markiana nigripinnis: $12 \rightarrow 2$

Piabina argentea: $1 \rightarrow 2$

Caráter - 52 (super-sets from 1 trees):

Root: 01

Clado 53: $01 \rightarrow 0$

Chalceus epakros: $01 \rightarrow 1$

Clado 51: $0 \rightarrow 01$

Bryconops alburnoides: $01 \rightarrow 0$

Clado 87: $01 \rightarrow 0$

Clado 54: $01 \rightarrow 12$

Clado 55: $0 \rightarrow 01$

Thoracocharax stellatus: $01 \rightarrow 0$

Clado 76: $01 \rightarrow 0$

Hydrolycus scomberoides: $01 \rightarrow 0$

Acestrorhynchus falcatus: $01 \rightarrow 0$

Agoniates halecinus: $12 \rightarrow 2$

Agoniates anchovia: $12 \rightarrow 2$

Clado 66: $01 \rightarrow 0$

Aphyocharax pusillus: $01 \rightarrow 0$

Clado 88: $0 \rightarrow 01$

Clado 79: $0 \rightarrow 01$

Stethaprion erythrops: $01 \rightarrow 0$

Markiana nigripinnis: $01 \rightarrow 0$

Piabina argentea: $01 \rightarrow 0$

Creagrutus menezesi : $01 \rightarrow 1$

Caráter - 53 (super-sets from 1 trees):

Root: 0 
Clado 51: $0 \rightarrow 012$

Bryconops alburnoides: $012 \rightarrow 1$

Clado 57: $0 \rightarrow 02$

Clado 78: $012 \rightarrow 12$

Clado 49: $012 \rightarrow 02$

Clado 87: $12 \rightarrow 012$

Clado 55: $02 \rightarrow 12$

Oligosarcus pintoi : $02 \rightarrow 2$

Rachoviscus graciliceps: $02 \rightarrow 2$

Hollandichthys multifasciatus: $02 \rightarrow 2$

Triportheus albus : $012 \rightarrow 2$

Lignobrycon myersii: $012 \rightarrow 2$

Thoracocharax stellatus: $12 \rightarrow 2$

Clado 76: $12 \rightarrow 012$

Hydrolycus scomberoides: $02 \rightarrow 2$

Acestrorhynchus falcatus: $02 \rightarrow 0$

Agoniates halecinus: $02 \rightarrow 2$

Agoniates anchovia: $02 \rightarrow 2$

Clado 66: $12 \rightarrow 01$

Aphyocharax pusillus: $12 \rightarrow 2$

Engraulisoma taeniatum: $012 \rightarrow 0$

Clupeacharax anchoveoides: $012 \rightarrow 1$

Cheirodon galusdae: $01 \rightarrow 1$

Moenkhausia xinguensis: $01 \rightarrow 1$

Clado 74: $01 \rightarrow 02$

Nematocharax venustus: $01 \rightarrow 1$

Deuterodon iguape: $01 \rightarrow 1$

Jupiaba anteroides: $01 \rightarrow 1$

Tetragonopterus chalceus: $02 \rightarrow 2$

Hyphessobrycon eques: $02 \rightarrow 2$

Clado 82: $02 \rightarrow 01$

Clado 71: $02 \rightarrow 0$

Mimagoniates microlepis: $02 \rightarrow 2$

Astyanax altiparanae: $01 \rightarrow 1$

Astyanacinus sp nova Bolivia: $01 \rightarrow 1$

Stichonodon insignis: $02 \rightarrow 2$

Poptella paraguayensis: $02 \rightarrow 2$

Gymnocorymbus ternertzi: $01 \rightarrow 1$

Astyanax lineatus: $01 \rightarrow 1$

Astyanacinus moorii: $01 \rightarrow 1$

Clado 88: $01 \rightarrow 1$

Ctenobrycon hauxwellianus: $01 \rightarrow 1$

Clado 79: $0 \rightarrow 01$

Astyanax paranae: $01 \rightarrow 1$

Astyanax fasciatus: $01 \rightarrow 1$

"Astyanax" orthodus: $01 \rightarrow 1$

“Astyanax" superbus: $01 \rightarrow 1$

Astyanacinus sp nova Peru: $01 \rightarrow 1$

Markiana nigripinnis: $1 \rightarrow 0$

Piabina argentea: $01 \rightarrow 0$

Creagrutus menezesi : $01 \rightarrow 0$

Caráter - 54 (super-sets from 1 trees):

Root: 0

Clado 78: $0 \rightarrow 01$

Clado 87: $01 \rightarrow 0$

Clado 54: $0 \rightarrow 01$

Thoracocharax stellatus: $01 \rightarrow 0$

Clado 76: $01 \rightarrow 0$

Agoniates halecinus: $01 \rightarrow 1$

Agoniates anchovia: $01 \rightarrow 1$

Clado 85: $0 \rightarrow 01$

Nematocharax venustus: $01 \rightarrow 0$

Deuterodon iguape: $01 \rightarrow 0$

Clado 84: $0 \rightarrow 01$

Tetragonopterus chalceus: $01 \rightarrow 0$

Clado 89: $01 \rightarrow 0$

Clado 81: $01 \rightarrow 0$

Gymnocorymbus ternertzi: $01 \rightarrow 0$

Caráter - 55 (super-sets from 1 trees):

Root: 0

Clado 51: $0 \rightarrow 01$

Bryconops alburnoides: $01 \rightarrow 0$

Clado 49: $01 \rightarrow 0$

Clado 86: $0 \rightarrow 01$

Clado 87: $01 \rightarrow 0$

Clado 55: $0 \rightarrow 01$
Rachoviscus graciliceps: $01 \rightarrow 1$

Hollandichthys multifasciatus: $01 \rightarrow 1$

Thoracocharax stellatus: $01 \rightarrow 0$

Clado 76: $01 \rightarrow 0$

Clado 66: $01 \rightarrow 0$

Aphyocharax pusillus: $01 \rightarrow 0$

Engraulisoma taeniatum: $0 \rightarrow 1$

Cheirodon galusdae: $0 \rightarrow 1$

Clado 72: $0 \rightarrow 01$

Clado 60: $0 \rightarrow 01$

Mimagoniates microlepis: $01 \rightarrow 1$

Astyanacinus sp nova Bolivia: $01 \rightarrow 1$

Poptella paraguayensis: $0 \rightarrow 1$

Bryconamericus exodon: $01 \rightarrow 1$

Astyanacinus moorii: $01 \rightarrow 1$

Clado 88: $0 \rightarrow 01$

Knodus moenkhausii: $01 \rightarrow 1$

"Astyanax" orthodus: $01 \rightarrow 0$

Stethaprion erythrops: $01 \rightarrow 0$

Markiana nigripinnis: $01 \rightarrow 0$

Piabina argentea: $01 \rightarrow 1$

Creagrutus menezesi : $01 \rightarrow 1$

Caráter - 56 (super-sets from 1 trees):

Root: 0

Clado 58: $0 \rightarrow 01$

Clado 78: $0 \rightarrow 01$

Galeocharax knerii : $01 \rightarrow 0$

Charax leticiae: $01 \rightarrow 0$

Clado 48: $0 \rightarrow 01$

Clado 55: $01 \rightarrow 0$

Oligosarcus pintoi : $01 \rightarrow 1$

Rachoviscus graciliceps: $01 \rightarrow 0$

Hollandichthys multifasciatus: $01 \rightarrow 0$

Triportheus albus : $01 \rightarrow 0$

Lignobrycon myersii: $01 \rightarrow 0$

Thoracocharax stellatus: $01 \rightarrow 0$

Hydrolycus scomberoides: $01 \rightarrow 1$

Acestrorhynchus falcatus: $01 \rightarrow 1$

Clado 66: $0 \rightarrow 01$

Engraulisoma taeniatum: $01 \rightarrow 0$

Clupeacharax anchoveoides: $01 \rightarrow 0$

Cheirodon galusdae: $01 \rightarrow 0$

Moenkhausia xinguensis: $01 \rightarrow 0$

Clado 85: $01 \rightarrow 0$

Clado 84: $01 \rightarrow 0$

Jupiaba anteroides: $01 \rightarrow 0$

Hyphessobrycon eques: $01 \rightarrow 0$

Mimagoniates microlepis: $01 \rightarrow 0$

Astyanax altiparanae: $01 \rightarrow 0$

Astyanacinus sp nova Bolivia: $01 \rightarrow 0$

Clado 81: $0 \rightarrow 01$

Bryconamericus exodon: $01 \rightarrow 0$

Astyanax lineatus: $01 \rightarrow 0$

Astyanacinus moorii: $01 \rightarrow 0$

Clado 88: $01 \rightarrow 0$

Ctenobrycon hauxwellianus: $01 \rightarrow 0$

Clado 79: $01 \rightarrow 0$

Knodus moenkhausii: $01 \rightarrow 0$

Astyanax paranae: $01 \rightarrow 0$

Astyanax fasciatus: $01 \rightarrow 0$

“Astyanax" orthodus: $01 \rightarrow 0$

“Astyanax” superbus: $01 \rightarrow 0$

Astyanacinus sp nova Peru: $01 \rightarrow 0$

Caráter - 57 (super-sets from 1 trees):

Root: 0

Clado 78: $0 \rightarrow 01$

Clado 87: $01 \rightarrow 0$

Clado 48: $0 \rightarrow 012$

Thoracocharax stellatus: $01 \rightarrow 0$

Clado 76: $01 \rightarrow 0$

Hydrolycus scomberoides: $012 \rightarrow 1$

Acestrorhynchus falcatus: $012 \rightarrow 1$

Caráter - 58 (super-sets from 1 trees):

Root: 01

Chalceus epakros: $01 \rightarrow 0$

Brycon pesu : $01 \rightarrow 1$ 
Salminus hilarii: $01 \rightarrow 1$

Bryconops alburnoides: $01 \rightarrow 2$

Clado 57: $01 \rightarrow 02$

Clado 78: $01 \rightarrow 0$

Clado 49: $01 \rightarrow 1$

Galeocharax knerii : $01 \rightarrow 1$

Charax leticiae: $01 \rightarrow 1$

Clado 48: $1 \rightarrow 01$

Clado 54: $1 \rightarrow 01$

Clado 55: $02 \rightarrow 0$

Oligosarcus pintoi : $02 \rightarrow 2$

Rachoviscus graciliceps: $02 \rightarrow 0$

Hollandichthys multifasciatus: $02 \rightarrow 2$

Hydrolycus scomberoides: $01 \rightarrow 1$

Acestrorhynchus falcatus: $01 \rightarrow 1$

Agoniates halecinus: $01 \rightarrow 2$

Agoniates anchovia: $01 \rightarrow 1$

Clupeacharax anchoveoides: $0 \rightarrow 2$

Clado 67: $0 \rightarrow 02$

"Astyanax" orthodus: $02 \rightarrow 2$

“Astyanax" superbus: $02 \rightarrow 2$

Astyanacinus sp nova Peru: $02 \rightarrow 2$

Creagrutus menezesi : $0 \rightarrow 1$

Caráter - 59 (super-sets from 1 trees):

Root: 0

Clado 58: $0 \rightarrow 01$

Galeocharax knerii : $01 \rightarrow 1$

Charax leticiae: $01 \rightarrow 1$

Clado 55: $01 \rightarrow 1$

Oligosarcus pintoi : $01 \rightarrow 1$

Rachoviscus graciliceps: $01 \rightarrow 0$

Hollandichthys multifasciatus: $01 \rightarrow 1$

Clado 66: $1 \rightarrow 01$

Cheirodon galusdae: $01 \rightarrow 1$

Moenkhausia xinguensis: $01 \rightarrow 1$

Nematocharax venustus: $01 \rightarrow 1$

Deuterodon iguape: $01 \rightarrow 1$

Jupiaba anteroides: $01 \rightarrow 1$

Tetragonopterus chalceus: $01 \rightarrow 1$

Hyphessobrycon eques: $01 \rightarrow 1$

Mimagoniates microlepis: $01 \rightarrow 0$

Astyanax altiparanae: $01 \rightarrow 1$

Astyanacinus sp nova Bolivia: $01 \rightarrow 1$

Stichonodon insignis: $01 \rightarrow 1$

Poptella paraguayensis: $01 \rightarrow 1$

Gymnocorymbus ternertzi: $01 \rightarrow 1$

Bryconamericus exodon: $01 \rightarrow 1$

Astyanax lineatus: $01 \rightarrow 1$

Astyanacinus moorii: $01 \rightarrow 1$

Ctenobrycon hauxwellianus: $01 \rightarrow 1$

Knodus moenkhausii: $01 \rightarrow 1$

Astyanax paranae: $01 \rightarrow 1$

Astyanax fasciatus: $01 \rightarrow 1$

"Astyanax" orthodus: $01 \rightarrow 1$

“Astyanax” superbus: $01 \rightarrow 0$

Astyanacinus sp nova Peru: $01 \rightarrow 1$

Stethaprion erythrops: $01 \rightarrow 1$

Markiana nigripinnis: $01 \rightarrow 1$

Piabina argentea: $01 \rightarrow 1$

Creagrutus menezesi : $01 \rightarrow 1$

Caráter - 60 (super-sets from 1 trees):

Root: 1

Clado 52: $1 \rightarrow 01$

Clado 58: $01 \rightarrow 1$

Salminus hilarii: $01 \rightarrow 0$

Bryconops alburnoides: $01 \rightarrow 0$

Clado 78: $01 \rightarrow 0$

Clado 87: $0 \rightarrow 01$

Clado 55: $1 \rightarrow 01$

Triportheus albus : $01 \rightarrow 0$

Lignobrycon myersii: $01 \rightarrow 0$

Clado 76: $0 \rightarrow 01$

Hydrolycus scomberoides: $01 \rightarrow 0$

Acestrorhynchus falcatus: $01 \rightarrow 2$

Agoniates halecinus: $01 \rightarrow 0$

Agoniates anchovia: $01 \rightarrow 0$
Clado 66: $01 \rightarrow 1$

Aphyocharax pusillus: $01 \rightarrow 1$

Engraulisoma taeniatum: $01 \rightarrow 1$

Clupeacharax anchoveoides: $01 \rightarrow 0$

Clado 73: $1 \rightarrow 01$

Clado 72: $01 \rightarrow 012$

Hyphessobrycon eques: $01 \rightarrow 0$

Clado 71: $012 \rightarrow 01$

Mimagoniates microlepis: $012 \rightarrow 0$

Clado 81: $1 \rightarrow 12$

Clado 80: $01 \rightarrow 02$

Bryconamericus exodon: $01 \rightarrow 1$

Clado 88: $12 \rightarrow 1$

Ctenobrycon hauxwellianus: $12 \rightarrow 1$

Clado 79: $02 \rightarrow 01$

Knodus moenkhausii: $02 \rightarrow 0$

“Astyanax" superbus: $1 \rightarrow 2$

Piabina argentea: $01 \rightarrow 0$

Creagrutus menezesi : $01 \rightarrow 1$

Caráter - 61 (super-sets from 1 trees):

Root: 0

Clado 75: $0 \rightarrow 012$

Galeocharax knerii : $012 \rightarrow 1$

Charax leticiae: $012 \rightarrow 2$

Hydrolycus scomberoides: $0 \rightarrow 2$

Clado 62: $0 \rightarrow 01$

Jupiaba anteroides: $01 \rightarrow 0$

Clado 71: $0 \rightarrow 01$

Astyanax altiparanae: $01 \rightarrow 0$

Clado 59: $01 \rightarrow 0$

Astyanacinus sp nova Bolivia: $01 \rightarrow 0$

Bryconamericus exodon: $01 \rightarrow 1$

Astyanax lineatus: $01 \rightarrow 0$

Clado 79: $01 \rightarrow 012$

Knodus moenkhausii: $01 \rightarrow 0$

Astyanax paranae: $01 \rightarrow 0$

Astyanax fasciatus: $01 \rightarrow 0$

Piabina argentea: $012 \rightarrow 1$

Creagrutus menezesi : $012 \rightarrow 2$

Caráter - 62 (super-sets from 1 trees):

Root: 0

Clado 76: $0 \rightarrow 01$

Engraulisoma taeniatum: $01 \rightarrow 1$

Clupeacharax anchoveoides: $01 \rightarrow 1$

Clado 85: $0 \rightarrow 01$

Nematocharax venustus: $01 \rightarrow 0$

Deuterodon iguape: $01 \rightarrow 0$

Clado 84: $0 \rightarrow 01$

Tetragonopterus chalceus: $01 \rightarrow 0$

Stichonodon insignis: $01 \rightarrow 0$

Poptella paraguayensis: $01 \rightarrow 0$

Clado 81: $01 \rightarrow 0$

Gymnocorymbus ternertzi: $01 \rightarrow 0$

Caráter - 63 (super-sets from 1 trees):

Root: 0

Clado 53: $0 \rightarrow 01$

Brycon pesu : $01 \rightarrow 0$

Salminus hilarii: $01 \rightarrow 0$

Clado 50: $01 \rightarrow 0$

Bryconops alburnoides: $01 \rightarrow 0$

Clado 78: $0 \rightarrow 01$

Galeocharax knerii : $01 \rightarrow 0$

Charax leticiae: $01 \rightarrow 0$

Clado 77: $01 \rightarrow 0$

Clado 48: $0 \rightarrow 01$

Clado 54: $0 \rightarrow 01$

Clado 55: $01 \rightarrow 0$

Oligosarcus pintoi : $01 \rightarrow 0$

Rachoviscus graciliceps: $01 \rightarrow 0$

Hollandichthys multifasciatus: $01 \rightarrow 0$

Triportheus albus : $01 \rightarrow 0$

Lignobrycon myersii: $01 \rightarrow 0$

Clado 76: $0 \rightarrow 01$

Hydrolycus scomberoides: $01 \rightarrow 1$

Acestrorhynchus falcatus: $01 \rightarrow 1$

Agoniates halecinus: $01 \rightarrow 0$ 
Agoniates anchovia: $01 \rightarrow 0$

Clado 66: $0 \rightarrow 01$

Engraulisoma taeniatum: $01 \rightarrow 0$

Clupeacharax anchoveoides: $01 \rightarrow 0$

Cheirodon galusdae: $01 \rightarrow 0$

Moenkhausia xinguensis: $01 \rightarrow 0$

Nematocharax venustus: $01 \rightarrow 0$

Deuterodon iguape: $01 \rightarrow 0$

Jupiaba anteroides: $01 \rightarrow 0$

Tetragonopterus chalceus: $01 \rightarrow 0$

Hyphessobrycon eques: $01 \rightarrow 0$

Clado 68: $01 \rightarrow 0$

Clado 60: $01 \rightarrow 0$

Mimagoniates microlepis: $01 \rightarrow 0$

Clado 70: $0 \rightarrow 01$

Clado 59: $0 \rightarrow 01$

Stichonodon insignis: $01 \rightarrow 0$

Poptella paraguayensis: $01 \rightarrow 0$

Gymnocorymbus ternertzi: $01 \rightarrow 0$

Bryconamericus exodon: $01 \rightarrow 0$

Astyanax lineatus: $01 \rightarrow 0$

Astyanacinus moorii: $01 \rightarrow 0$

Ctenobrycon hauxwellianus: $01 \rightarrow 0$

Knodus moenkhausii: $01 \rightarrow 0$

Astyanax paranae: $01 \rightarrow 0$

Astyanax fasciatus: $01 \rightarrow 0$

“Astyanax" orthodus: $01 \rightarrow 0$

“Astyanax" superbus: $01 \rightarrow 0$

Astyanacinus sp nova Peru: $01 \rightarrow 0$

Stethaprion erythrops: $01 \rightarrow 0$

Markiana nigripinnis: $01 \rightarrow 0$

Piabina argentea: $01 \rightarrow 0$

Creagrutus menezesi : $01 \rightarrow 0$

Caráter - 64 (super-sets from 1 trees):

Root: 0

Clado 53: $0 \rightarrow 01$

Brycon pesu : $01 \rightarrow 0$

Salminus hilarii: $01 \rightarrow 0$

Bryconops alburnoides: $01 \rightarrow 0$

Clado 49: $01 \rightarrow 0$

Galeocharax knerii : $01 \rightarrow 1$

Charax leticiae: $01 \rightarrow 1$

Clado 55: $01 \rightarrow 1$

Oligosarcus pintoi : $01 \rightarrow 1$

Rachoviscus graciliceps: $01 \rightarrow 1$

Hollandichthys multifasciatus: $01 \rightarrow 1$

Triportheus albus : $01 \rightarrow 0$

Lignobrycon myersii: $01 \rightarrow 0$

Thoracocharax stellatus: $01 \rightarrow 0$

Clado 76: $01 \rightarrow 0$

Clado 66: $1 \rightarrow 01$

Cheirodon galusdae: $01 \rightarrow 1$

Moenkhausia xinguensis: $01 \rightarrow 1$

Nematocharax venustus: $01 \rightarrow 1$

Deuterodon iguape: $01 \rightarrow 1$

Jupiaba anteroides: $01 \rightarrow 1$

Tetragonopterus chalceus: $01 \rightarrow 1$

Hyphessobrycon eques: $01 \rightarrow 1$

Mimagoniates microlepis: $01 \rightarrow 1$

Astyanax altiparanae: $01 \rightarrow 1$

Astyanacinus sp nova Bolivia: $01 \rightarrow 1$

Stichonodon insignis: $01 \rightarrow 1$

Poptella paraguayensis: $01 \rightarrow 1$

Gymnocorymbus ternertzi: $01 \rightarrow 1$

Bryconamericus exodon: $01 \rightarrow 1$

Astyanax lineatus: $01 \rightarrow 1$

Astyanacinus moorii: $01 \rightarrow 1$

Clado 88: $01 \rightarrow 1$

Ctenobrycon hauxwellianus: $01 \rightarrow 1$

Clado 79: $01 \rightarrow 1$

Knodus moenkhausii: $01 \rightarrow 1$

Astyanax paranae: $01 \rightarrow 1$

Astyanax fasciatus: $01 \rightarrow 1$

"Astyanax" orthodus: $01 \rightarrow 1$

“Astyanax” superbus: $01 \rightarrow 1$

Astyanacinus sp nova Peru: $01 \rightarrow 1$
Caráter - 65 (super-sets from 1 trees):

Root: 1

Clado 53: $1 \rightarrow 01$

Brycon pesu : $01 \rightarrow 0$

Salminus hilarii: $01 \rightarrow 1$

Clado 50: $01 \rightarrow 0$

Bryconops alburnoides: $01 \rightarrow 1$

Clado 75: $01 \rightarrow 0$

Oligosarcus pintoi : $01 \rightarrow 1$

Rachoviscus graciliceps: $01 \rightarrow 1$

Hollandichthys multifasciatus: $01 \rightarrow 1$

Lignobrycon myersii: $0 \rightarrow 1$

Aphyocharax pusillus: $01 \rightarrow 1$

Cheirodon galusdae: $01 \rightarrow 1$

Moenkhausia xinguensis: $01 \rightarrow 1$

Clado 63: $01 \rightarrow 12$

Clado 74: $12 \rightarrow 01$

Nematocharax venustus: $01 \rightarrow 1$

Deuterodon iguape: $01 \rightarrow 1$

Jupiaba anteroides: $12 \rightarrow 1$

Tetragonopterus chalceus: $01 \rightarrow 1$

Hyphessobrycon eques: $01 \rightarrow 1$

Clado 71: $01 \rightarrow 1$

Mimagoniates microlepis: $01 \rightarrow 1$

Clado 70: $12 \rightarrow 1$

Astyanax altiparanae: $12 \rightarrow 1$

Clado 59: $12 \rightarrow 01$

Astyanacinus sp nova Bolivia: $12 \rightarrow 1$

Stichonodon insignis: $01 \rightarrow 1$

Poptella paraguayensis: $01 \rightarrow 1$

Gymnocorymbus ternertzi: $01 \rightarrow 1$

Clado 80: $1 \rightarrow 01$

Clado 69: $1 \rightarrow 12$

Astyanacinus moorii: $01 \rightarrow 1$

Ctenobrycon hauxwellianus: $01 \rightarrow 1$

Knodus moenkhausii: $01 \rightarrow 1$

Astyanax paranae: $12 \rightarrow 1$

Astyanax fasciatus: $12 \rightarrow 1$

"Astyanax" orthodus: $01 \rightarrow 1$

“Astyanax" superbus: $01 \rightarrow 1$

Astyanacinus sp nova Peru: $01 \rightarrow 1$

Stethaprion erythrops: $01 \rightarrow 1$

Markiana nigripinnis: $01 \rightarrow 1$

Piabina argentea: $01 \rightarrow 1$

Creagrutus menezesi : $01 \rightarrow 0$

Caráter - 66 (super-sets from 1 trees):

Root: 0

Clado 58: $0 \rightarrow 01$

Clado 86: $01 \rightarrow 0$

Galeocharax knerii : $01 \rightarrow 1$

Charax leticiae: $01 \rightarrow 1$

Clado 87: $0 \rightarrow 01$

Clado 55: $01 \rightarrow 0$

Oligosarcus pintoi : $01 \rightarrow 0$

Triportheus albus : $01 \rightarrow 0$

Lignobrycon myersii: $01 \rightarrow 0$

Clado 76: $0 \rightarrow 02$

Engraulisoma taeniatum: $02 \rightarrow 0$

Clupeacharax anchoveoides: $02 \rightarrow 0$

Clado 59: $0 \rightarrow 012$

Astyanacinus moorii: $012 \rightarrow 0$

“Astyanax” orthodus: $012 \rightarrow 0$

"Astyanax" superbus: $012 \rightarrow 0$

Astyanacinus sp nova Peru: $012 \rightarrow 0$

Caráter - 67 (super-sets from 1 trees):

Root: 0

Clado 54: $0 \rightarrow 01$

Rachoviscus graciliceps: $0 \rightarrow 1$

Agoniates halecinus: $01 \rightarrow 1$

Agoniates anchovia: $01 \rightarrow 1$

Clado 61: $0 \rightarrow 01$

Clado 70: $01 \rightarrow 0$

Astyanax altiparanae: $01 \rightarrow 0$

Clado 59: $01 \rightarrow 0$

Astyanacinus sp nova Bolivia: $01 \rightarrow 0$

Caráter - 68 (super-sets from 1 trees): 
Root: 0

Clado 53: $0 \rightarrow 01$

Clado 52: $01 \rightarrow 0$

Brycon pesu : $01 \rightarrow 0$

Clado 75: $0 \rightarrow 01$

Galeocharax knerii : $01 \rightarrow 0$

Charax leticiae: $01 \rightarrow 0$

Clado 48: $0 \rightarrow 01$

Clado 54: $0 \rightarrow 01$

Clado 55: $0 \rightarrow 01$

Thoracocharax stellatus: $0 \rightarrow 1$

Hydrolycus scomberoides: $01 \rightarrow 1$

Agoniates halecinus: $01 \rightarrow 0$

Agoniates anchovia: $01 \rightarrow 0$

Clado 66: $01 \rightarrow 0$

Aphyocharax pusillus: $01 \rightarrow 0$

Clado 65: $0 \rightarrow 01$

Moenkhausia xinguensis: $01 \rightarrow 2$

Clado 85: $01 \rightarrow 0$

Clado 74: $01 \rightarrow 0$

Clado 62: $01 \rightarrow 0$

Clado 84: $0 \rightarrow 01$

Tetragonopterus chalceus: $01 \rightarrow 2$

Clado 83: $01 \rightarrow 0$

Clado 70: $0 \rightarrow 02$

Clado 81: $0 \rightarrow 02$

Astyanax lineatus: $02 \rightarrow 2$

Clado 67: $0 \rightarrow 02$

Ctenobrycon hauxwellianus: $02 \rightarrow 2$

Knodus moenkhausii: $0 \rightarrow 2$

Astyanax paranae: $02 \rightarrow 2$

Astyanax fasciatus: $02 \rightarrow 2$

"Astyanax" orthodus: $02 \rightarrow 2$

"Astyanax" superbus: $02 \rightarrow 2$

Astyanacinus sp nova Peru: $02 \rightarrow 2$

Stethaprion erythrops: $02 \rightarrow 0$

Markiana nigripinnis: $02 \rightarrow 2$

Creagrutus menezesi : $0 \rightarrow 1$

Caráter - 69 (super-sets from 1 trees):

Root: 01

Chalceus epakros: $01 \rightarrow 0$

Clado 52: $01 \rightarrow 0$

Brycon pesu : $01 \rightarrow 0$

Clado 50: $0 \rightarrow 01$

Clado 75: $0 \rightarrow 1$

Clado 78: $01 \rightarrow 0$

Clado 86: $0 \rightarrow 01$

Clado 77: $0 \rightarrow 01$

Clado 54: $01 \rightarrow 0$

Rachoviscus graciliceps: $01 \rightarrow 0$

Hollandichthys multifasciatus: $01 \rightarrow 0$

Thoracocharax stellatus: $01 \rightarrow 0$

Hydrolycus scomberoides: $01 \rightarrow 0$

Acestrorhynchus falcatus: $01 \rightarrow 0$

Engraulisoma taeniatum: $01 \rightarrow 0$

Clupeacharax anchoveoides: $01 \rightarrow 0$

Clado 68: $0 \rightarrow 01$

Clado 70: $01 \rightarrow 0$

Astyanax altiparanae: $01 \rightarrow 0$

Clado 69: $0 \rightarrow 01$

Astyanax paranae: $01 \rightarrow 0$

Astyanax fasciatus: $01 \rightarrow 0$

Caráter - 70 (super-sets from 1 trees):

Root: 1

Clado 52: $1 \rightarrow 01$

Clado 58: $01 \rightarrow 12$

Salminus hilarii: $01 \rightarrow 1$

Bryconops alburnoides: $01 \rightarrow 0$

Clado 57: $12 \rightarrow 01$

Clado $75: 12 \rightarrow 13$

Clado 78: $01 \rightarrow 012$

Clado 49: $01 \rightarrow 013$

Clado 86: $01 \rightarrow 1$

Galeocharax knerii : $13 \rightarrow 3$

Charax leticiae: $13 \rightarrow 3$

Clado 87: $012 \rightarrow 01$
Clado 77: $012 \rightarrow 12$

Clado 48: $013 \rightarrow 13$

Clado 54: $013 \rightarrow 0$

Oligosarcus pintoi : $01 \rightarrow 0$

Triportheus albus : $01 \rightarrow 1$

Lignobrycon myersii: $01 \rightarrow 1$

Thoracocharax stellatus: $12 \rightarrow 2$

Hydrolycus scomberoides: $13 \rightarrow 3$

Acestrorhynchus falcatus: $13 \rightarrow 3$

Clado 66: $01 \rightarrow 12$

Aphyocharax pusillus: $01 \rightarrow 1$

Engraulisoma taeniatum: $12 \rightarrow 2$

Clupeacharax anchoveoides: $12 \rightarrow 1$

Clado 65: $12 \rightarrow 01$

Cheirodon galusdae: $12 \rightarrow 1$

Moenkhausia xinguensis: $01 \rightarrow 1$

Nematocharax venustus: $01 \rightarrow 1$

Deuterodon iguape: $01 \rightarrow 1$

Jupiaba anteroides: $01 \rightarrow 1$

Tetragonopterus chalceus: $01 \rightarrow 1$

Hyphessobrycon eques: $01 \rightarrow 1$

Clado 68: $01 \rightarrow 12$

Clado 60: $01 \rightarrow 12$

Clado 89: $01 \rightarrow 1$

Mimagoniates microlepis: $01 \rightarrow 1$

Clado 70: $12 \rightarrow 01$

Astyanax altiparanae: $12 \rightarrow 1$

Astyanacinus sp nova Bolivia: $12 \rightarrow 1$

Gymnocorymbus ternertzi: $01 \rightarrow 1$

Bryconamericus exodon: $01 \rightarrow 1$

Clado 69: $01 \rightarrow 12$

Astyanax lineatus: $01 \rightarrow 1$

Astyanacinus moorii: $12 \rightarrow 1$

Ctenobrycon hauxwellianus: $01 \rightarrow 1$

Knodus moenkhausii: $01 \rightarrow 1$

Astyanax paranae: $12 \rightarrow 1$

Astyanax fasciatus: $12 \rightarrow 1$

"Astyanax" orthodus: $12 \rightarrow 1$

"Astyanax" superbus: $12 \rightarrow 1$

Astyanacinus sp nova Peru: $12 \rightarrow 1$

Stethaprion erythrops: $01 \rightarrow 1$

Markiana nigripinnis: $01 \rightarrow 1$

Piabina argentea: $01 \rightarrow 1$

Creagrutus menezesi : $01 \rightarrow 2$

Caráter - 71 (super-sets from 1 trees):

Root: 0

Salminus hilarii: $0 \rightarrow 2$

Clado 75: $0 \rightarrow 02$

Clado 49: $0 \rightarrow 01$

Galeocharax knerii : $02 \rightarrow 2$

Charax leticiae: $02 \rightarrow 2$

Clado 87: $0 \rightarrow 01$

Clado 77: $0 \rightarrow 02$

Oligosarcus pintoi : $0 \rightarrow 2$

Triportheus albus : $01 \rightarrow 0$

Lignobrycon myersii: $01 \rightarrow 0$

Thoracocharax stellatus: $02 \rightarrow 2$

Hydrolycus scomberoides: $01 \rightarrow 1$

Acestrorhynchus falcatus: $01 \rightarrow 2$

Agoniates halecinus: $01 \rightarrow 1$

Agoniates anchovia: $01 \rightarrow 1$

Engraulisoma taeniatum: $02 \rightarrow 0$

Clupeacharax anchoveoides: $02 \rightarrow 2$

Clado 65: $0 \rightarrow 01$

Moenkhausia xinguensis: $01 \rightarrow 0$

Clado 85: $01 \rightarrow 0$

Clado 74: $01 \rightarrow 0$

Clado 84: $0 \rightarrow 012$

Clado 73: $0 \rightarrow 01$

Jupiaba anteroides: $01 \rightarrow 0$

Tetragonopterus chalceus: $012 \rightarrow 0$

Clado 83: $012 \rightarrow 01$

Hyphessobrycon eques: $01 \rightarrow 0$

Clado 68: $01 \rightarrow 0$

Clado 60: $01 \rightarrow 0$

Clado 89: $01 \rightarrow 0$ 
Mimagoniates microlepis: $01 \rightarrow 0$

Clado 70: $0 \rightarrow 02$

Poptella paraguayensis: $0 \rightarrow 2$

Gymnocorymbus ternertzi: $01 \rightarrow 2$

Bryconamericus exodon: $01 \rightarrow 0$

Clado 69: $02 \rightarrow 0$

Astyanax lineatus: $02 \rightarrow 0$

Ctenobrycon hauxwellianus: $01 \rightarrow 0$

Clado 79: $01 \rightarrow 02$

Knodus moenkhausii: $01 \rightarrow 0$

Stethaprion erythrops: $01 \rightarrow 0$

Markiana nigripinnis: $01 \rightarrow 0$

Piabina argentea: $02 \rightarrow 0$

Creagrutus menezesi : $02 \rightarrow 0$

Caráter - 72 (super-sets from 1 trees):

Root: 0

Clado 75: $0 \rightarrow 01$

Galeocharax knerii : $01 \rightarrow 0$

Charax leticiae: $01 \rightarrow 0$

Triportheus albus : $0 \rightarrow 1$

Thoracocharax stellatus: $0 \rightarrow 1$

Clado 76: $0 \rightarrow 01$

Engraulisoma taeniatum: $01 \rightarrow 0$

Clupeacharax anchoveoides: $01 \rightarrow 0$

Clado 85: $0 \rightarrow 01$

Nematocharax venustus: $01 \rightarrow 0$

Deuterodon iguape: $01 \rightarrow 0$

Clado 71: $0 \rightarrow 01$

Bryconamericus exodon: $01 \rightarrow 1$

Ctenobrycon hauxwellianus: $0 \rightarrow 1$

Clado 79: $01 \rightarrow 0$

Knodus moenkhausii: $01 \rightarrow 1$

Caráter - 73 (super-sets from 1 trees):

Root: 01

Chalceus epakros: $01 \rightarrow 0$

Brycon pesu : $01 \rightarrow 1$

Clado 58: $01 \rightarrow 1$

Salminus hilarii: $01 \rightarrow 1$

Bryconops alburnoides: $01 \rightarrow 0$

Clado 57: $1 \rightarrow 01$

Clado 75: $1 \rightarrow 01$

Clado 78: $01 \rightarrow 1$

Clado 49: $01 \rightarrow 012$

Galeocharax knerii : $01 \rightarrow 1$

Charax leticiae: $01 \rightarrow 2$

Clado 77: $1 \rightarrow 01$

Clado 54: $012 \rightarrow 02$

Oligosarcus pintoi : $01 \rightarrow 0$

Rachoviscus graciliceps: $01 \rightarrow 1$

Hollandichthys multifasciatus: $01 \rightarrow 0$

Thoracocharax stellatus: $01 \rightarrow 1$

Clado 76: $01 \rightarrow 02$

Hydrolycus scomberoides: $012 \rightarrow 2$

Acestrorhynchus falcatus: $012 \rightarrow 1$

Agoniates halecinus: $02 \rightarrow 2$

Agoniates anchovia: $02 \rightarrow 2$

Aphyocharax pusillus: $01 \rightarrow 2$

Engraulisoma taeniatum: $02 \rightarrow 2$

Clupeacharax anchoveoides: $02 \rightarrow 2$

Clado 65: $01 \rightarrow 0$

Cheirodon galusdae: $01 \rightarrow 1$

Clado 63: $0 \rightarrow 01$

Clado 74: $01 \rightarrow 0$

Nematocharax venustus: $0 \rightarrow 1$

Clado 84: $0 \rightarrow 01$

Clado 73: $0 \rightarrow 01$

Jupiaba anteroides: $01 \rightarrow 0$

Tetragonopterus chalceus: $01 \rightarrow 0$

Clado 83: $01 \rightarrow 012$

Hyphessobrycon eques: $01 \rightarrow 0$

Clado 89: $012 \rightarrow 1$

Mimagoniates microlepis: $01 \rightarrow 1$

Astyanax altiparanae: $01 \rightarrow 0$

Astyanacinus sp nova Bolivia: $01 \rightarrow 1$

Gymnocorymbus ternertzi: $012 \rightarrow 2$

Bryconamericus exodon: $01 \rightarrow 0$
Astyanax lineatus: $01 \rightarrow 0$

Astyanacinus moorii: $01 \rightarrow 0$

Ctenobrycon hauxwellianus: $012 \rightarrow 2$

Knodus moenkhausii: $01 \rightarrow 0$

Astyanax paranae: $01 \rightarrow 0$

Astyanax fasciatus: $01 \rightarrow 0$

“Astyanax" orthodus: $01 \rightarrow 1$

“Astyanax” superbus: $01 \rightarrow 1$

Astyanacinus sp nova Peru: $01 \rightarrow 0$

Stethaprion erythrops: $012 \rightarrow 0$

Markiana nigripinnis: $012 \rightarrow 1$

Piabina argentea: $01 \rightarrow 0$

Creagrutus menezesi : $01 \rightarrow 0$

Caráter - 74 (super-sets from 1 trees):

Root: 01

Clado 53: $01 \rightarrow 0$

Chalceus epakros: $01 \rightarrow 0$

Clado 78: $0 \rightarrow 01$

Charax leticiae: $0 \rightarrow 1$

Clado 77: $01 \rightarrow 0$

Clado 54: $0 \rightarrow 01$

Triportheus albus : $01 \rightarrow 0$

Lignobrycon myersii: $01 \rightarrow 0$

Agoniates halecinus: $01 \rightarrow 1$

Agoniates anchovia: $01 \rightarrow 1$

Clupeacharax anchoveoides: $0 \rightarrow 1$

Clado 73: $0 \rightarrow 01$

Clado 83: $0 \rightarrow 01$

Hyphessobrycon eques: $01 \rightarrow 0$

Clado 89: $01 \rightarrow 0$

Mimagoniates microlepis: $01 \rightarrow 0$

Clado 70: $0 \rightarrow 01$

Stichonodon insignis: $0 \rightarrow 1$

Gymnocorymbus ternertzi: $01 \rightarrow 0$

Bryconamericus exodon: $01 \rightarrow 0$

Clado 69: $01 \rightarrow 0$

Astyanax lineatus: $01 \rightarrow 0$

Ctenobrycon hauxwellianus: $01 \rightarrow 0$

Knodus moenkhausii: $01 \rightarrow 0$

Stethaprion erythrops: $01 \rightarrow 0$

Markiana nigripinnis: $01 \rightarrow 0$

Piabina argentea: $01 \rightarrow 0$

Creagrutus menezesi : $01 \rightarrow 0$

Caráter - 75 (super-sets from 1 trees):

Root: 01

Chalceus epakros: $01 \rightarrow 1$

Clado 52: $01 \rightarrow 0$

Brycon pesu : $01 \rightarrow 0$

Clado 58: $0 \rightarrow 01$

Clado 57: $01 \rightarrow 0$

Clado 78: $0 \rightarrow 01$

Clado 49: $0 \rightarrow 01$

Clado 86: $0 \rightarrow 01$

Galeocharax knerii : $01 \rightarrow 1$

Charax leticiae: $01 \rightarrow 1$

Clado 54: $01 \rightarrow 1$

Clado 55: $0 \rightarrow 01$

Rachoviscus graciliceps: $01 \rightarrow 0$

Hollandichthys multifasciatus: $01 \rightarrow 0$

Triportheus albus : $01 \rightarrow 0$

Lignobrycon myersii: $01 \rightarrow 0$

Thoracocharax stellatus: $01 \rightarrow 0$

Hydrolycus scomberoides: $01 \rightarrow 0$

Acestrorhynchus falcatus: $01 \rightarrow 0$

Aphyocharax pusillus: $01 \rightarrow 0$

Engraulisoma taeniatum: $01 \rightarrow 0$

Clupeacharax anchoveoides: $01 \rightarrow 1$

Cheirodon galusdae: $01 \rightarrow 0$

Moenkhausia xinguensis: $01 \rightarrow 0$

Clado 85: $01 \rightarrow 0$

Clado 74: $01 \rightarrow 0$

Clado 84: $0 \rightarrow 01$

Clado 73: $0 \rightarrow 01$

Jupiaba anteroides: $01 \rightarrow 0$

Tetragonopterus chalceus: $01 \rightarrow 0$

Hyphessobrycon eques: $01 \rightarrow 0$ 
Clado 89: $01 \rightarrow 0$

Mimagoniates microlepis: $01 \rightarrow 0$

Astyanax altiparanae: $01 \rightarrow 0$

Astyanacinus sp nova Bolivia: $01 \rightarrow 0$

Gymnocorymbus ternertzi: $01 \rightarrow 0$

Bryconamericus exodon: $01 \rightarrow 0$

Astyanax lineatus: $01 \rightarrow 0$

Astyanacinus moorii: $01 \rightarrow 0$

Ctenobrycon hauxwellianus: $01 \rightarrow 0$

Clado 79: $01 \rightarrow 1$

Knodus moenkhausii: $01 \rightarrow 0$

Astyanax paranae: $01 \rightarrow 0$

Astyanax fasciatus: $01 \rightarrow 0$

“Astyanax" orthodus: $01 \rightarrow 0$

“Astyanax” superbus: $01 \rightarrow 0$

Astyanacinus sp nova Peru: $01 \rightarrow 0$

Stethaprion erythrops: $01 \rightarrow 0$

Markiana nigripinnis: $01 \rightarrow 0$

Caráter - 76 (super-sets from 1 trees):

Root: 0

Clado 53: $0 \rightarrow 01$

Brycon pesu : $01 \rightarrow 0$

Clado 51: $01 \rightarrow 0$

Clado 58: $01 \rightarrow 0$

Salminus hilarii: $01 \rightarrow 0$

Acestrorhynchus falcatus: $0 \rightarrow 1$

Agoniates halecinus: $0 \rightarrow 1$

Caráter - 77 (super-sets from 1 trees):

Root: 0

Clado 58: $0 \rightarrow 01$

Clado 50: $0 \rightarrow 01$

Clado 75: $01 \rightarrow 0$

Clado 78: $01 \rightarrow 1$

Clado 77: $1 \rightarrow 01$

Oligosarcus pintoi : $01 \rightarrow 1$

Rachoviscus graciliceps: $01 \rightarrow 1$

Hollandichthys multifasciatus: $01 \rightarrow 1$

Thoracocharax stellatus: $01 \rightarrow 1$

Hydrolycus scomberoides: $01 \rightarrow 0$

Acestrorhynchus falcatus: $01 \rightarrow 1$

Agoniates halecinus: $01 \rightarrow 1$

Agoniates anchovia: $01 \rightarrow 1$

Clado 66: $01 \rightarrow 1$

Aphyocharax pusillus: $01 \rightarrow 1$

Engraulisoma taeniatum: $01 \rightarrow 0$

Clupeacharax anchoveoides: $01 \rightarrow 1$

Moenkhausia xinguensis: $1 \rightarrow 0$

Clado 85: $1 \rightarrow 13$

Clado 74: $1 \rightarrow 01$

Nematocharax venustus: $13 \rightarrow 1$

Deuterodon iguape: $13 \rightarrow 1$

Clado 84: $01 \rightarrow 1$

Hyphessobrycon eques: $01 \rightarrow 0$

Mimagoniates microlepis: $01 \rightarrow 0$

Stichonodon insignis: $1 \rightarrow 0$

Bryconamericus exodon: $01 \rightarrow 0$

Knodus moenkhausii: $01 \rightarrow 1$

Piabina argentea: $01 \rightarrow 1$

Creagrutus menezesi : $01 \rightarrow 0$

Caráter - 78 (super-sets from 1 trees):

Root: 0

Clado 52: $0 \rightarrow 01$

Salminus hilarii: $01 \rightarrow 0$

Bryconops alburnoides: $01 \rightarrow 0$

Clado 75: $01 \rightarrow 0$

Clado 86: $01 \rightarrow 0$

Clado 87: $01 \rightarrow 012$

Clado 54: $01 \rightarrow 1$

Oligosarcus pintoi : $01 \rightarrow 0$

Triportheus albus : $012 \rightarrow 1$

Lignobrycon myersii: $012 \rightarrow 2$

Hydrolycus scomberoides: $01 \rightarrow 1$

Acestrorhynchus falcatus: $01 \rightarrow 0$

Aphyocharax pusillus: $01 \rightarrow 0$

Clupeacharax anchoveoides: $01 \rightarrow 0$

Cheirodon galusdae: $01 \rightarrow 0$
Moenkhausia xinguensis: $01 \rightarrow 0$

Nematocharax venustus: $01 \rightarrow 0$

Deuterodon iguape: $01 \rightarrow 1$

Jupiaba anteroides: $01 \rightarrow 0$

Tetragonopterus chalceus: $01 \rightarrow 0$

Hyphessobrycon eques: $01 \rightarrow 0$

Clado 89: $01 \rightarrow 0$

Mimagoniates microlepis: $01 \rightarrow 1$

Astyanax altiparanae: $01 \rightarrow 0$

Astyanacinus sp nova Bolivia: $01 \rightarrow 0$

Gymnocorymbus ternertzi: $01 \rightarrow 0$

Bryconamericus exodon: $01 \rightarrow 0$

Astyanax lineatus: $01 \rightarrow 0$

Astyanacinus moorii: $01 \rightarrow 0$

Ctenobrycon hauxwellianus: $01 \rightarrow 0$

Knodus moenkhausii: $01 \rightarrow 0$

Astyanax paranae: $01 \rightarrow 0$

Astyanax fasciatus: $01 \rightarrow 0$

Stethaprion erythrops: $01 \rightarrow 0$

Markiana nigripinnis: $01 \rightarrow 0$

Piabina argentea: $01 \rightarrow 0$

Creagrutus menezesi : $01 \rightarrow 0$

Caráter - 79 (super-sets from 1 trees):

Root: 01

Chalceus epakros: $01 \rightarrow 1$

Clado 52: $01 \rightarrow 0$

Brycon pesu : $01 \rightarrow 0$

Clado 51: $0 \rightarrow 01$

Bryconops alburnoides: $01 \rightarrow 0$

Clado 57: $0 \rightarrow 01$

Clado 49: $01 \rightarrow 1$

Oligosarcus pintoi : $01 \rightarrow 0$

Rachoviscus graciliceps: $01 \rightarrow 0$

Hollandichthys multifasciatus: $01 \rightarrow 0$

Triportheus albus : $01 \rightarrow 1$

Clado 66: $01 \rightarrow 0$

Aphyocharax pusillus: $01 \rightarrow 0$

Engraulisoma taeniatum: $01 \rightarrow 0$

Clupeacharax anchoveoides: $01 \rightarrow 0$

Clado 65: $0 \rightarrow 01$

Moenkhausia xinguensis: $01 \rightarrow 0$

Clado 62: $01 \rightarrow 0$

Nematocharax venustus: $01 \rightarrow 0$

Deuterodon iguape: $01 \rightarrow 0$

Tetragonopterus chalceus: $01 \rightarrow 0$

Clado 83: $01 \rightarrow 0$

Hyphessobrycon eques: $01 \rightarrow 1$

Mimagoniates microlepis: $01 \rightarrow 1$

Clado 80: $01 \rightarrow 0$

Bryconamericus exodon: $01 \rightarrow 1$

Stethaprion erythrops: $0 \rightarrow 1$

Caráter - 80 (super-sets from 1 trees):

Root: 01

Clado 53: $01 \rightarrow 12$

Chalceus epakros: $01 \rightarrow 1$

Clado 52: $12 \rightarrow 01$

Brycon pesu : $12 \rightarrow 1$

Salminus hilarii: $01 \rightarrow 1$

Bryconops alburnoides: $01 \rightarrow 1$

Clado 75: $01 \rightarrow 012$

Clado 49: $01 \rightarrow 0$

Galeocharax knerii : $012 \rightarrow 1$

Charax leticiae: $012 \rightarrow 1$

Oligosarcus pintoi : $01 \rightarrow 1$

Rachoviscus graciliceps: $01 \rightarrow 1$

Hollandichthys multifasciatus: $01 \rightarrow 1$

Triportheus albus : $01 \rightarrow 1$

Clado 76: $01 \rightarrow 012$

Aphyocharax pusillus: $01 \rightarrow 1$

Engraulisoma taeniatum: $012 \rightarrow 1$

Clupeacharax anchoveoides: $012 \rightarrow 1$

Cheirodon galusdae: $01 \rightarrow 1$

Moenkhausia xinguensis: $01 \rightarrow 1$

Nematocharax venustus: $01 \rightarrow 1$

Deuterodon iguape: $01 \rightarrow 1$

Jupiaba anteroides: $01 \rightarrow 1$ 
Tetragonopterus chalceus: $01 \rightarrow 1$ Hyphessobrycon eques: $01 \rightarrow 1$ Clado 89: $01 \rightarrow 1$

Mimagoniates microlepis: $01 \rightarrow 1$ Astyanax altiparanae: $01 \rightarrow 1$ Astyanacinus sp nova Bolivia: $01 \rightarrow 1$ Stichonodon insignis: $1 \rightarrow 0$ Gymnocorymbus ternertzi: $01 \rightarrow 1$

Bryconamericus exodon: $01 \rightarrow 1$ Astyanax lineatus: $01 \rightarrow 1$ Astyanacinus moorii: $01 \rightarrow 1$

Ctenobrycon hauxwellianus: $01 \rightarrow 1$

Knodus moenkhausii: $01 \rightarrow 1$

Astyanax paranae: $01 \rightarrow 1$

Astyanax fasciatus: $01 \rightarrow 1$

"Astyanax" orthodus: $01 \rightarrow 1$

“Astyanax” superbus: $01 \rightarrow 1$

Astyanacinus sp nova Peru: $01 \rightarrow 1$

Stethaprion erythrops: $01 \rightarrow 1$

Markiana nigripinnis: $01 \rightarrow 1$

Piabina argentea: $01 \rightarrow 1$

Creagrutus menezesi : $01 \rightarrow 1$

Caráter - 81 (super-sets from 1 trees):

Root: 01

Chalceus epakros: $01 \rightarrow 1$

Brycon pesu : $01 \rightarrow 0$

Salminus hilarii: $01 \rightarrow 1$

Clado 50: $01 \rightarrow 0$

Bryconops alburnoides: $01 \rightarrow 0$

Clado 78: $0 \rightarrow 01$

Clado 86: $01 \rightarrow 1$

Galeocharax knerii : $01 \rightarrow 1$

Charax leticiae: $01 \rightarrow 1$

Clado 77: $01 \rightarrow 0$

Clado 54: $0 \rightarrow 01$

Hollandichthys multifasciatus: $1 \rightarrow 0$

Triportheus albus : $01 \rightarrow 0$

Lignobrycon myersii: $01 \rightarrow 0$

Agoniates halecinus: $01 \rightarrow 1$

Agoniates anchovia: $01 \rightarrow 0$

Aphyocharax pusillus: $01 \rightarrow 1$

Cheirodon galusdae: $01 \rightarrow 1$

Moenkhausia xinguensis: $01 \rightarrow 0$

Nematocharax venustus: $01 \rightarrow 1$

Deuterodon iguape: $01 \rightarrow 0$

Jupiaba anteroides: $01 \rightarrow 1$

Tetragonopterus chalceus: $01 \rightarrow 1$

Hyphessobrycon eques: $01 \rightarrow 1$

Clado 89: $01 \rightarrow 1$

Mimagoniates microlepis: $01 \rightarrow 0$

Astyanax altiparanae: $01 \rightarrow 0$

Astyanacinus sp nova Bolivia: $01 \rightarrow 1$

Gymnocorymbus ternertzi: $01 \rightarrow 1$

Bryconamericus exodon: $01 \rightarrow 0$

Astyanax lineatus: $01 \rightarrow 1$

Astyanacinus moorii: $01 \rightarrow 1$

Ctenobrycon hauxwellianus: $01 \rightarrow 1$

Knodus moenkhausii: $01 \rightarrow 0$

Astyanax paranae: $01 \rightarrow 1$

Astyanax fasciatus: $01 \rightarrow 0$

“Astyanax" orthodus: $01 \rightarrow 0$

“Astyanax” superbus: $01 \rightarrow 0$

Astyanacinus sp nova Peru: $01 \rightarrow 0$

Stethaprion erythrops: $01 \rightarrow 1$

Markiana nigripinnis: $01 \rightarrow 0$

Piabina argentea: $01 \rightarrow 0$

Creagrutus menezesi : $01 \rightarrow 1$

Caráter - 82 (super-sets from 1 trees):

Root: 0

Clado 58: $0 \rightarrow 01$

Clado 75: $01 \rightarrow 0$

Clado 78: $0 \rightarrow 01$

Clado 86: $01 \rightarrow 0$

Clado 54: $0 \rightarrow 01$

Oligosarcus pintoi : $01 \rightarrow 0$

Triportheus albus : $01 \rightarrow 0$
Lignobrycon myersii: $01 \rightarrow 0$

Thoracocharax stellatus: $01 \rightarrow 1$

Agoniates halecinus: $01 \rightarrow 0$

Agoniates anchovia: $01 \rightarrow 0$

Aphyocharax pusillus: $01 \rightarrow 0$

Engraulisoma taeniatum: $01 \rightarrow 1$

Clupeacharax anchoveoides: $01 \rightarrow 1$

Cheirodon galusdae: $01 \rightarrow 0$

Nematocharax venustus: $01 \rightarrow 0$

Deuterodon iguape: $01 \rightarrow 0$

Jupiaba anteroides: $01 \rightarrow 0$

Tetragonopterus chalceus: $01 \rightarrow 0$

Hyphessobrycon eques: $01 \rightarrow 0$

Clado 89: $01 \rightarrow 0$

Mimagoniates microlepis: $01 \rightarrow 0$

Astyanax altiparanae: $01 \rightarrow 0$

Astyanacinus sp nova Bolivia: $01 \rightarrow 0$

Gymnocorymbus ternertzi: $01 \rightarrow 0$

Bryconamericus exodon: $01 \rightarrow 0$

Astyanax lineatus: $01 \rightarrow 0$

Astyanacinus moorii: $01 \rightarrow 0$

Ctenobrycon hauxwellianus: $01 \rightarrow 0$

Knodus moenkhausii: $01 \rightarrow 0$

Astyanax paranae: $01 \rightarrow 1$

Astyanax fasciatus: $01 \rightarrow 0$

"Astyanax" orthodus: $01 \rightarrow 0$

“Astyanax” superbus: $01 \rightarrow 0$

Astyanacinus sp nova Peru: $01 \rightarrow 0$

Stethaprion erythrops: $01 \rightarrow 0$

Markiana nigripinnis: $01 \rightarrow 0$

Piabina argentea: $01 \rightarrow 0$

Creagrutus menezesi : $01 \rightarrow 1$

Caráter - 83 (super-sets from 1 trees):

Root: 0

Clado 52: $0 \rightarrow 01$

Clado 58: $01 \rightarrow 0$

Salminus hilarii: $01 \rightarrow 0$

Clado 50: $01 \rightarrow 0$

Bryconops alburnoides: $01 \rightarrow 0$

Clado 57: $0 \rightarrow 01$

Clado 75: $0 \rightarrow 01$

Clado 49: $0 \rightarrow 01$

Clado 86: $01 \rightarrow 0$

Galeocharax knerii : $01 \rightarrow 1$

Charax leticiae: $01 \rightarrow 0$

Clado 55: $01 \rightarrow 0$

Oligosarcus pintoi : $01 \rightarrow 0$

Clado 76: $0 \rightarrow 01$

Hydrolycus scomberoides: $01 \rightarrow 1$

Acestrorhynchus falcatus: $01 \rightarrow 1$

Agoniates halecinus: $01 \rightarrow 1$

Agoniates anchovia: $01 \rightarrow 1$

Engraulisoma taeniatum: $01 \rightarrow 0$

Clupeacharax anchoveoides: $01 \rightarrow 0$

Clado 85: $0 \rightarrow 01$

Clado 74: $0 \rightarrow 01$

Nematocharax venustus: $01 \rightarrow 0$

Deuterodon iguape: $01 \rightarrow 0$

Clado 84: $01 \rightarrow 0$

Clado 73: $01 \rightarrow 0$

Clado 69: $0 \rightarrow 01$

Clado 67: $0 \rightarrow 01$

Astyanax paranae: $01 \rightarrow 0$

Astyanax fasciatus: $01 \rightarrow 0$

“Astyanax" orthodus: $01 \rightarrow 0$

“Astyanax” superbus: $01 \rightarrow 0$

Astyanacinus sp nova Peru: $01 \rightarrow 0$

Caráter - 84 (super-sets from 1 trees):

Root: 02

Chalceus epakros: $02 \rightarrow 2$

Brycon pesu : $02 \rightarrow 2$

Clado 58: $02 \rightarrow 0$

Salminus hilarii: $02 \rightarrow 2$

Bryconops alburnoides: $02 \rightarrow 0$

Clado 75: $0 \rightarrow 01$

Clado 78: $02 \rightarrow 012$ 
Clado 49: $02 \rightarrow 023$

Galeocharax knerii : $01 \rightarrow 0$

Charax leticiae: $01 \rightarrow 0$

Clado 87: $012 \rightarrow 1$

Clado 77: $012 \rightarrow 02$

Clado 48: $023 \rightarrow 03$

Clado 54: $023 \rightarrow 0$

Hollandichthys multifasciatus: $0 \rightarrow 2$

Thoracocharax stellatus: $02 \rightarrow 2$

Clado 76: $02 \rightarrow 012$

Hydrolycus scomberoides: $03 \rightarrow 3$

Acestrorhynchus falcatus: $03 \rightarrow 3$

Engraulisoma taeniatum: $012 \rightarrow 2$

Clupeacharax anchoveoides: $012 \rightarrow 2$

Cheirodon galusdae: $0 \rightarrow 2$

Clado 64: $0 \rightarrow 01$

Clado 85: $01 \rightarrow 0$

Clado 84: $01 \rightarrow 1$

Clado 73: $01 \rightarrow 1$

Jupiaba anteroides: $01 \rightarrow 1$

Clado $72: 1 \rightarrow 12$

Clado 71: $12 \rightarrow 012$

Mimagoniates microlepis: $12 \rightarrow 2$

Clado 70: $01 \rightarrow 0$

Astyanax altiparanae: $01 \rightarrow 0$

Clado 59: $01 \rightarrow 0$

Astyanacinus sp nova Bolivia: $01 \rightarrow 0$

Clado 81: $1 \rightarrow 01$

Clado 80: $012 \rightarrow 12$

Bryconamericus exodon: $012 \rightarrow 1$

Clado 69: $0 \rightarrow 01$

Astyanax lineatus: $0 \rightarrow 1$

Clado 67: $0 \rightarrow 01$

Ctenobrycon hauxwellianus: $01 \rightarrow 0$

Clado 79: $12 \rightarrow 02$

Knodus moenkhausii: $12 \rightarrow 2$

Astyanax paranae: $01 \rightarrow 0$

Astyanax fasciatus: $01 \rightarrow 0$

"Astyanax" orthodus: $01 \rightarrow 0$

"Astyanax" superbus: $01 \rightarrow 0$

Astyanacinus sp nova Peru: $01 \rightarrow 0$

Stethaprion erythrops: $01 \rightarrow 0$

Markiana nigripinnis: $01 \rightarrow 0$

Piabina argentea: $02 \rightarrow 2$

Creagrutus menezesi : $02 \rightarrow 0$

Caráter - 85 (super-sets from 1 trees):

Root: 1

Clado 53: $1 \rightarrow 01$

Brycon pesu : $01 \rightarrow 0$

Salminus hilarii: $01 \rightarrow 0$

Clado 50: $01 \rightarrow 013$

Bryconops alburnoides: $01 \rightarrow 1$

Clado 78: $013 \rightarrow 0123$

Galeocharax knerii : $01 \rightarrow 1$

Charax leticiae: $01 \rightarrow 1$

Clado 87: $0123 \rightarrow 03$

Clado 77: $0123 \rightarrow 012$

Clado 48: $013 \rightarrow 03$

Clado 54: $013 \rightarrow 01$

Rachoviscus graciliceps: $01 \rightarrow 2$

Hollandichthys multifasciatus: $01 \rightarrow 1$

Triportheus albus : $03 \rightarrow 3$

Lignobrycon myersii: $03 \rightarrow 3$

Thoracocharax stellatus: $012 \rightarrow 2$

Hydrolycus scomberoides: $03 \rightarrow 3$

Acestrorhynchus falcatus: $03 \rightarrow 3$

Agoniates halecinus: $01 \rightarrow 1$

Agoniates anchovia: $01 \rightarrow 1$

Aphyocharax pusillus: $01 \rightarrow 1$

Engraulisoma taeniatum: $012 \rightarrow 1$

Clupeacharax anchoveoides: $012 \rightarrow 2$

Cheirodon galusdae: $01 \rightarrow 0$

Moenkhausia xinguensis: $01 \rightarrow 1$

Nematocharax venustus: $01 \rightarrow 1$

Deuterodon iguape: $01 \rightarrow 1$

Jupiaba anteroides: $01 \rightarrow 0$
Tetragonopterus chalceus: $01 \rightarrow 0$

Hyphessobrycon eques: $01 \rightarrow 1$

Clado 89: $01 \rightarrow 0$

Mimagoniates microlepis: $01 \rightarrow 1$

Astyanax altiparanae: $01 \rightarrow 1$

Astyanacinus sp nova Bolivia: $01 \rightarrow 0$

Gymnocorymbus ternertzi: $01 \rightarrow 1$

Bryconamericus exodon: $01 \rightarrow 1$

Astyanax lineatus: $01 \rightarrow 1$

Astyanacinus moorii: $01 \rightarrow 0$

Ctenobrycon hauxwellianus: $01 \rightarrow 1$

Knodus moenkhausii: $01 \rightarrow 1$

Astyanax paranae: $01 \rightarrow 1$

Astyanax fasciatus: $01 \rightarrow 0$

“Astyanax" orthodus: $01 \rightarrow 0$

“Astyanax" superbus: $01 \rightarrow 1$

Astyanacinus sp nova Peru: $01 \rightarrow 1$

Stethaprion erythrops: $01 \rightarrow 1$

Markiana nigripinnis: $01 \rightarrow 0$

Piabina argentea: $01 \rightarrow 1$

Creagrutus menezesi : $01 \rightarrow 0$

Caráter - 86 (super-sets from 1 trees):

Root: 01

Clado 53: $01 \rightarrow 0$

Chalceus epakros: $01 \rightarrow 0$

Clado 52: $0 \rightarrow 01$

Brycon pesu : $0 \rightarrow 1$

Salminus hilarii: $01 \rightarrow 0$

Bryconops alburnoides: $01 \rightarrow 0$

Clado 75: $01 \rightarrow 1$

Clado 86: $01 \rightarrow 1$

Clado 87: $01 \rightarrow 02$

Clado 48: $01 \rightarrow 012$

Oligosarcus pintoi : $01 \rightarrow 0$

Triportheus albus : $02 \rightarrow 2$

Lignobrycon myersii: $02 \rightarrow 2$

Thoracocharax stellatus: $01 \rightarrow 0$

Clado 76: $01 \rightarrow 1$

Hydrolycus scomberoides: $012 \rightarrow 2$

Acestrorhynchus falcatus: $012 \rightarrow 2$

Agoniates halecinus: $01 \rightarrow 0$

Agoniates anchovia: $01 \rightarrow 0$

Clado 66: $01 \rightarrow 0$

Aphyocharax pusillus: $01 \rightarrow 1$

Clado 65: $0 \rightarrow 01$

Moenkhausia xinguensis: $01 \rightarrow 0$

Nematocharax venustus: $01 \rightarrow 1$

Deuterodon iguape: $01 \rightarrow 0$

Jupiaba anteroides: $01 \rightarrow 0$

Tetragonopterus chalceus: $01 \rightarrow 0$

Clado 83: $01 \rightarrow 0$

Hyphessobrycon eques: $01 \rightarrow 0$

Mimagoniates microlepis: $01 \rightarrow 0$

Astyanax altiparanae: $01 \rightarrow 0$

Clado 59: $01 \rightarrow 0$

Astyanacinus sp nova Bolivia: $01 \rightarrow 0$

Stichonodon insignis: $0 \rightarrow 2$

Bryconamericus exodon: $01 \rightarrow 0$

Astyanax lineatus: $01 \rightarrow 0$

Clado 67: $0 \rightarrow 01$

Knodus moenkhausii: $01 \rightarrow 1$

Astyanax paranae: $01 \rightarrow 0$

Astyanax fasciatus: $01 \rightarrow 0$

"Astyanax" orthodus: $01 \rightarrow 0$

“Astyanax" superbus: $01 \rightarrow 0$

Astyanacinus sp nova Peru: $01 \rightarrow 0$

Markiana nigripinnis: $0 \rightarrow 2$

Piabina argentea: $01 \rightarrow 1$

Creagrutus menezesi : $01 \rightarrow 0$

Caráter - 87 (super-sets from 1 trees):

Root: 04

Chalceus epakros: $04 \rightarrow 4$

Brycon pesu : $04 \rightarrow 3$

Clado 58: $04 \rightarrow 12$

Salminus hilarii: $04 \rightarrow 4$

Bryconops alburnoides: $04 \rightarrow 3$ 
Clado 57: $12 \rightarrow 012$

Clado 75: $12 \rightarrow 02$

Clado 86: $012 \rightarrow 02$

Galeocharax knerii : $02 \rightarrow 2$

Charax leticiae: $02 \rightarrow 1$

Clado 87: $04 \rightarrow 0134$

Clado 54: $04 \rightarrow 0124$

Clado 55: $012 \rightarrow 013$

Oligosarcus pintoi : $012 \rightarrow 2$

Rachoviscus graciliceps: $02 \rightarrow 2$

Hollandichthys multifasciatus: $02 \rightarrow 2$

Triportheus albus : $0134 \rightarrow 1$

Lignobrycon myersii: $0134 \rightarrow 3$

Thoracocharax stellatus: $04 \rightarrow 0$

Hydrolycus scomberoides: $04 \rightarrow 4$

Acestrorhynchus falcatus: $04 \rightarrow 4$

Agoniates halecinus: $0124 \rightarrow 2$

Clado 66: $013 \rightarrow 13$

Aphyocharax pusillus: $013 \rightarrow 3$

Engraulisoma taeniatum: $04 \rightarrow 4$

Clupeacharax anchoveoides: $04 \rightarrow 2$

Clado 65: $13 \rightarrow 01$

Cheirodon galusdae: $13 \rightarrow 3$

Moenkhausia xinguensis: $01 \rightarrow 1$

Clado 85: $01 \rightarrow 1$

Clado 62: $01 \rightarrow 02$

Clado 73: $01 \rightarrow 1$

Jupiaba anteroides: $02 \rightarrow 2$

Tetragonopterus chalceus: $01 \rightarrow 1$

Clado 83: $01 \rightarrow 1$

Clado 89: $1 \rightarrow 0$

Clado 70: $02 \rightarrow 12$

Astyanax altiparanae: $02 \rightarrow 1$

Astyanacinus sp nova Bolivia: $02 \rightarrow 2$

Clado 81: $1 \rightarrow 01$

Clado 80: $1 \rightarrow 01$

Clado 69: $12 \rightarrow 02$

Astyanax lineatus: $12 \rightarrow 2$

Astyanacinus moorii: $02 \rightarrow 2$

Clado 88: $01 \rightarrow 1$

Ctenobrycon hauxwellianus: $01 \rightarrow 1$

Clado 79: $01 \rightarrow 12$

Knodus moenkhausii: $01 \rightarrow 1$

Astyanax paranae: $02 \rightarrow 2$

Astyanax fasciatus: $02 \rightarrow 2$

"Astyanax" orthodus: $02 \rightarrow 2$

“Astyanax" superbus: $02 \rightarrow 2$

Astyanacinus sp nova Peru: $02 \rightarrow 2$

Piabina argentea: $12 \rightarrow 2$

Creagrutus menezesi : $12 \rightarrow 2$

Caráter - 88 (super-sets from 1 trees):

Root: 012

Chalceus epakros: $012 \rightarrow 2$

Brycon pesu : $012 \rightarrow 1$

Clado 51: $012 \rightarrow 01$

Clado 58: $012 \rightarrow 0$

Salminus hilarii: $012 \rightarrow 2$

Bryconops alburnoides: $01 \rightarrow 0$

Clado 57: $0 \rightarrow 01$

Clado 75: $0 \rightarrow 01$

Clado 78: $01 \rightarrow 0$

Clado 86: $01 \rightarrow 0$

Galeocharax knerii : $01 \rightarrow 0$

Charax leticiae: $01 \rightarrow 0$

Clado 87: $0 \rightarrow 01$

Clado 77: $0 \rightarrow 01$

Clado 54: $01 \rightarrow$

Oligosarcus pintoi : $01 \rightarrow 0$

Triportheus albus : $01 \rightarrow 1$

Lignobrycon myersii: $01 \rightarrow 0$

Thoracocharax stellatus: $01 \rightarrow 0$

Hydrolycus scomberoides: $01 \rightarrow 1$

Acestrorhynchus falcatus: $01 \rightarrow 1$

Clado 66: $01 \rightarrow 0$

Aphyocharax pusillus: $01 \rightarrow 0$

Engraulisoma taeniatum: $01 \rightarrow 0$
Clupeacharax anchoveoides: $01 \rightarrow 0$

Clado 65: $0 \rightarrow 01$

Clado 64: $01 \rightarrow 0$

Moenkhausia xinguensis: $01 \rightarrow 0$

Clado 85: $0 \rightarrow 01$

Clado 74: $0 \rightarrow 01$

Nematocharax venustus: $01 \rightarrow 0$

Deuterodon iguape: $01 \rightarrow 0$

Clado 84: $01 \rightarrow 0$

Clado 73: $01 \rightarrow 0$

Clado 81: $0 \rightarrow 01$

Clado 80: $0 \rightarrow 01$

Astyanax lineatus: $0 \rightarrow 1$

Clado 88: $01 \rightarrow 0$

Ctenobrycon hauxwellianus: $01 \rightarrow 0$

Clado 79: $01 \rightarrow 0$

Knodus moenkhausii: $01 \rightarrow 0$

Caráter - 89 (super-sets from 1 trees):

Root: 02

Clado 53: $02 \rightarrow 12$

Chalceus epakros: $02 \rightarrow 0$

Clado 52: $12 \rightarrow 02$

Brycon pesu : $12 \rightarrow 2$

Clado 51: $02 \rightarrow 04$

Salminus hilarii: $02 \rightarrow 2$

Bryconops alburnoides: $04 \rightarrow 4$

Clado 75: $02 \rightarrow 04$

Clado 78: $04 \rightarrow 14$

Clado 86: $02 \rightarrow 12$

Galeocharax knerii : $04 \rightarrow 4$

Charax leticiae: $04 \rightarrow 4$

Clado 87: $14 \rightarrow 014$

Clado 77: $14 \rightarrow 04$

Clado 54: $04 \rightarrow 034$

Clado 55: $02 \rightarrow 01$

Oligosarcus pintoi : $02 \rightarrow 2$

Rachoviscus graciliceps: $12 \rightarrow 2$

Hollandichthys multifasciatus: $12 \rightarrow 2$

Triportheus albus : $014 \rightarrow 2$

Lignobrycon myersii: $014 \rightarrow 4$

Thoracocharax stellatus: $04 \rightarrow 3$

Hydrolycus scomberoides: $04 \rightarrow 4$

Acestrorhynchus falcatus: $04 \rightarrow 2$

Agoniates halecinus: $034 \rightarrow 3$

Aphyocharax pusillus: $01 \rightarrow 1$

Engraulisoma taeniatum: $04 \rightarrow 1$

Clupeacharax anchoveoides: $04 \rightarrow 4$

Cheirodon galusdae: $01 \rightarrow 1$

Moenkhausia xinguensis: $01 \rightarrow 1$

Clado 63: $01 \rightarrow 02$

Nematocharax venustus: $01 \rightarrow 1$

Deuterodon iguape: $01 \rightarrow 1$

Jupiaba anteroides: $02 \rightarrow 2$

Tetragonopterus chalceus: $02 \rightarrow 4$

Clado 72: $02 \rightarrow 0234$

Hyphessobrycon eques: $02 \rightarrow 2$

Clado 89: $02 \rightarrow 2$

Clado 82: $02 \rightarrow 0123$

Clado 71: $0234 \rightarrow 03$

Mimagoniates microlepis: $0234 \rightarrow 4$

Clado 70: $02 \rightarrow 01$

Astyanax altiparanae: $02 \rightarrow 2$

Astyanacinus sp nova Bolivia: $02 \rightarrow 23$

Clado 81: $0123 \rightarrow 023$

Gymnocorymbus ternertzi: $0123 \rightarrow 1$

Clado 80: $03 \rightarrow 013$

Bryconamericus exodon: $03 \rightarrow 3$

Astyanax lineatus: $01 \rightarrow 1$

Astyanacinus moorii: $02 \rightarrow 2$

Ctenobrycon hauxwellianus: $023 \rightarrow 3$

Clado 79: $013 \rightarrow 03$

Knodus moenkhausii: $013 \rightarrow 3$

Astyanax paranae: $01 \rightarrow 0$

Astyanax fasciatus: $01 \rightarrow 1$

"Astyanax" orthodus: $02 \rightarrow 2$

“Astyanax” superbus: $02 \rightarrow 23$ 
Astyanacinus sp nova Peru: $02 \rightarrow 2$

Stethaprion erythrops: $023 \rightarrow 2$

Markiana nigripinnis: $023 \rightarrow 3$

Piabina argentea: $03 \rightarrow 3$

Creagrutus menezesi : $03 \rightarrow 3$

Caráter - 90 (super-sets from 1 trees):

Root: 035

Clado 53: $035 \rightarrow 05$

Chalceus epakros: $035 \rightarrow 3$

Brycon pesu : $05 \rightarrow 5$

Clado 58: $05 \rightarrow 15$

Salminus hilarii: $05 \rightarrow 6$

Bryconops alburnoides: $05 \rightarrow 5$

Clado 57: $15 \rightarrow 12$

Clado 75: $15 \rightarrow 05$

Clado 78: $05 \rightarrow 15$

Clado 86: $12 \rightarrow 02$

Galeocharax knerii : $05 \rightarrow 5$

Charax leticiae: $05 \rightarrow 4$

Clado 77: $15 \rightarrow 0145$

Clado 48: $05 \rightarrow 06$

Clado 54: $05 \rightarrow 15$

Oligosarcus pintoi : $12 \rightarrow 2$

Rachoviscus graciliceps: $02 \rightarrow 2$

Hollandichthys multifasciatus: $02 \rightarrow 3$

Triportheus albus : $15 \rightarrow 3$

Lignobrycon myersii: $15 \rightarrow 5$

Thoracocharax stellatus: $0145 \rightarrow 1$

Clado 76: $0145 \rightarrow 04$

Hydrolycus scomberoides: $06 \rightarrow 6$

Acestrorhynchus falcatus: $06 \rightarrow 6$

Agoniates halecinus: $15 \rightarrow 5$

Aphyocharax pusillus: $12 \rightarrow 3$

Engraulisoma taeniatum: $04 \rightarrow 4$

Clupeacharax anchoveoides: $04 \rightarrow 4$

Clado 65: $12 \rightarrow 1$

Cheirodon galusdae: $12 \rightarrow 2$

Clado 63: $1 \rightarrow 13$

Jupiaba anteroides: $13 \rightarrow 3$

Tetragonopterus chalceus: $13 \rightarrow 3$

Hyphessobrycon eques: $13 \rightarrow 1$

Clado 68: $13 \rightarrow 12$

Clado 89: $13 \rightarrow 1$

Mimagoniates microlepis: $13 \rightarrow 4$

Astyanax altiparanae: $12 \rightarrow 2$

Astyanacinus sp nova Bolivia: $13 \rightarrow 23$

Gymnocorymbus ternertzi: $13 \rightarrow 0$

Bryconamericus exodon: $13 \rightarrow 3$

Astyanax lineatus: $12 \rightarrow 2$

Astyanacinus moorii: $13 \rightarrow 3$

Ctenobrycon hauxwellianus: $13 \rightarrow 3$

Knodus moenkhausii: $13 \rightarrow 3$

Astyanax paranae: $12 \rightarrow 0$

Astyanax fasciatus: $12 \rightarrow 2$

“Astyanax" orthodus: $13 \rightarrow 3$

“Astyanax” superbus: $13 \rightarrow 3$

Astyanacinus sp nova Peru: $13 \rightarrow 3$

Stethaprion erythrops: $13 \rightarrow 2$

Markiana nigripinnis: $13 \rightarrow 3$

Piabina argentea: $13 \rightarrow 4$

Creagrutus menezesi : $13 \rightarrow 3$

Caráter - 91 (super-sets from 1 trees):

Root: 12

Chalceus epakros: $12 \rightarrow 2$

Clado 52: $12 \rightarrow 012$

Brycon pesu : $12 \rightarrow 2$

Clado 51: $012 \rightarrow 01$

Clado 58: $012 \rightarrow 02$

Salminus hilarii: $012 \rightarrow 2$

Bryconops alburnoides: $01 \rightarrow 0$

Clado 75: $02 \rightarrow 12$

Clado 78: $01 \rightarrow 0$

Clado 86: $02 \rightarrow 12$

Galeocharax knerii : $12 \rightarrow 2$

Charax leticiae: $12 \rightarrow 2$

Clado 77: $0 \rightarrow 012$
Clado 54: $01 \rightarrow 0$

Oligosarcus pintoi : $02 \rightarrow 2$

Rachoviscus graciliceps: $12 \rightarrow 2$

Hollandichthys multifasciatus: $12 \rightarrow 0$

Clado 76: $012 \rightarrow 12$

Hydrolycus scomberoides: $01 \rightarrow 1$

Acestrorhynchus falcatus: $01 \rightarrow 0$

Aphyocharax pusillus: $02 \rightarrow 2$

Engraulisoma taeniatum: $12 \rightarrow 2$

Clupeacharax anchoveoides: $12 \rightarrow 2$

Cheirodon galusdae: $02 \rightarrow 2$

Moenkhausia xinguensis: $02 \rightarrow 2$

Nematocharax venustus: $02 \rightarrow 2$

Deuterodon iguape: $02 \rightarrow 2$

Jupiaba anteroides: $02 \rightarrow 2$

Tetragonopterus chalceus: $02 \rightarrow 2$

Hyphessobrycon eques: $02 \rightarrow 2$

Clado 89: $02 \rightarrow 2$

Mimagoniates microlepis: $02 \rightarrow 0$

Astyanax altiparanae: $02 \rightarrow 2$

Astyanacinus sp nova Bolivia: $02 \rightarrow 2$

Poptella paraguayensis: $2 \rightarrow 0$

Clado 81: $02 \rightarrow 0$

Gymnocorymbus ternertzi: $02 \rightarrow 2$

Bryconamericus exodon: $02 \rightarrow 2$

Astyanax lineatus: $02 \rightarrow 2$

Astyanacinus moorii: $02 \rightarrow 2$

Knodus moenkhausii: $02 \rightarrow 2$

Astyanax paranae: $02 \rightarrow 0$

Astyanax fasciatus: $02 \rightarrow 2$

"Astyanax" orthodus: $02 \rightarrow 2$

“Astyanax” superbus: $02 \rightarrow 2$

Astyanacinus sp nova Peru: $02 \rightarrow 2$

Piabina argentea: $02 \rightarrow 2$

Creagrutus menezesi : $02 \rightarrow 2$

Caráter - 92 (super-sets from 1 trees):

Root: 01

Chalceus epakros: $01 \rightarrow 0$

Brycon pesu : $01 \rightarrow 0$

Clado 58: $01 \rightarrow 0$

Salminus hilarii: $01 \rightarrow 0$

Bryconops alburnoides: $01 \rightarrow 1$

Clado 75: $0 \rightarrow 01$

Clado 86: $0 \rightarrow 01$

Galeocharax knerii : $01 \rightarrow 0$

Charax leticiae: $01 \rightarrow 0$

Rachoviscus graciliceps: $01 \rightarrow 0$

Hollandichthys multifasciatus: $01 \rightarrow 0$

Triportheus albus : $01 \rightarrow 1$

Lignobrycon myersii: $01 \rightarrow 0$

Hydrolycus scomberoides: $01 \rightarrow 0$

Acestrorhynchus falcatus: $01 \rightarrow 1$

Agoniates halecinus: $01 \rightarrow 1$

Engraulisoma taeniatum: $01 \rightarrow 0$

Clupeacharax anchoveoides: $01 \rightarrow 0$

Clado 70: $0 \rightarrow 01$

Poptella paraguayensis: $0 \rightarrow 1$

Clado 69: $01 \rightarrow 0$

Astyanax lineatus: $01 \rightarrow 0$

Clado 79: $0 \rightarrow 01$

Stethaprion erythrops: $0 \rightarrow 1$

Piabina argentea: $01 \rightarrow 0$

Creagrutus menezesi : $01 \rightarrow 0$

Caráter - 93 (super-sets from 1 trees):

Root: 0

Clado 58: $0 \rightarrow 01$

Clado 57: $01 \rightarrow 0$

Clado 78: $0 \rightarrow 01$

Galeocharax knerii : $01 \rightarrow 1$

Charax leticiae: $01 \rightarrow 1$

Clado 77: $01 \rightarrow 0$

Oligosarcus pintoi : $0 \rightarrow 01$

Triportheus albus : $01 \rightarrow 0$

Lignobrycon myersii: $01 \rightarrow 0$

Clado 66: $0 \rightarrow 01$

Clado 65: $01 \rightarrow$ 
Cheirodon galusdae: $01 \rightarrow 0$

Clado 85: $1 \rightarrow 01$

Clado 74: $1 \rightarrow 01$

Nematocharax venustus: $01 \rightarrow 1$

Deuterodon iguape: $01 \rightarrow 1$

Clado 84: $01 \rightarrow 1$

Clado 73: $01 \rightarrow 1$

Mimagoniates microlepis: $1 \rightarrow 0$

Astyanax lineatus: $1 \rightarrow 01$

Knodus moenkhausii: $1 \rightarrow 01$

Astyanax fasciatus: $1 \rightarrow 01$

“Astyanax" orthodus: $1 \rightarrow 0$

Piabina argentea: $1 \rightarrow 01$

Caráter - 94 (super-sets from 1 trees):

Root: 01

Clado 53: $01 \rightarrow 0$

Chalceus epakros: $01 \rightarrow 0$

Clado 51: $0 \rightarrow 01$

Clado 58: $0 \rightarrow 1$

Bryconops alburnoides: $01 \rightarrow 0$

Clado 57: $1 \rightarrow 01$

Clado 56: $01 \rightarrow 1$

Clado 86: $01 \rightarrow 1$

Triportheus albus : $01 \rightarrow 0$

Lignobrycon myersii: $01 \rightarrow 0$

Thoracocharax stellatus: $01 \rightarrow 1$

Hydrolycus scomberoides: $01 \rightarrow 0$

Acestrorhynchus falcatus: $01 \rightarrow 0$

Agoniates halecinus: $01 \rightarrow 0$

Agoniates anchovia: $01 \rightarrow 0$

Engraulisoma taeniatum: $01 \rightarrow 0$

Clupeacharax anchoveoides: $01 \rightarrow 0$

Clado 74: $1 \rightarrow 01$

Clado 84: $01 \rightarrow 1$

Clado 73: $01 \rightarrow 1$

Astyanax altiparanae: $1 \rightarrow 01$

Caráter - 95 (super-sets from 1 trees):

Root: 0

Clado 51: $0 \rightarrow 01$

Clado 58: $0 \rightarrow 01$

Bryconops alburnoides: $01 \rightarrow 0$

Clado 75: $01 \rightarrow 0$

Clado 49: $01 \rightarrow 0$

Clado 77: $01 \rightarrow 0$

Clado 54: $0 \rightarrow 01$

Oligosarcus pintoi : $01 \rightarrow 0$

Rachoviscus graciliceps: $01 \rightarrow 1$

Hollandichthys multifasciatus: $01 \rightarrow 1$

Triportheus albus : $01 \rightarrow 0$

Lignobrycon myersii: $01 \rightarrow 0$

Agoniates halecinus: $01 \rightarrow 0$

Agoniates anchovia: $01 \rightarrow 0$

Aphyocharax pusillus: $01 \rightarrow 0$

Cheirodon galusdae: $01 \rightarrow 0$

Moenkhausia xinguensis: $01 \rightarrow 0$

Nematocharax venustus: $01 \rightarrow 0$

Deuterodon iguape: $01 \rightarrow 0$

Jupiaba anteroides: $01 \rightarrow 0$

Tetragonopterus chalceus: $01 \rightarrow 0$

Hyphessobrycon eques: $01 \rightarrow 1$

Clado 89: $01 \rightarrow 0$

Mimagoniates microlepis: $01 \rightarrow 0$

Astyanax altiparanae: $01 \rightarrow 0$

Astyanacinus sp nova Bolivia: $01 \rightarrow 0$

Gymnocorymbus ternertzi: $01 \rightarrow 0$

Bryconamericus exodon: $01 \rightarrow 0$

Astyanax lineatus: $01 \rightarrow 0$

Astyanacinus moorii: $01 \rightarrow 0$

Ctenobrycon hauxwellianus: $01 \rightarrow 0$

Knodus moenkhausii: $01 \rightarrow 0$

Astyanax paranae: $01 \rightarrow 0$

Astyanax fasciatus: $01 \rightarrow 0$

"Astyanax" orthodus: $01 \rightarrow 0$

"Astyanax" superbus: $01 \rightarrow 0$

Astyanacinus sp nova Peru: $01 \rightarrow 0$

Stethaprion erythrops: $01 \rightarrow 0$
Markiana nigripinnis: $01 \rightarrow 0$

Piabina argentea: $01 \rightarrow 0$

Creagrutus menezesi : $01 \rightarrow 0$

Caráter - 96 (super-sets from 1 trees):

Root: 03

Chalceus epakros: $03 \rightarrow 3$

Clado 52: $03 \rightarrow 013$

Brycon pesu : $03 \rightarrow 0$

Clado 58: $013 \rightarrow 1$

Salminus hilarii: $013 \rightarrow 0$

Clado 50: $013 \rightarrow 03$

Bryconops alburnoides: $013 \rightarrow 0$

Clado 57: $1 \rightarrow 013$

Clado 75: $1 \rightarrow 01$

Clado 78: $03 \rightarrow 2$

Clado 56: $013 \rightarrow 1$

Clado 86: $013 \rightarrow 01$

Galeocharax knerii : $01 \rightarrow 1$

Charax leticiae: $01 \rightarrow 1$

Clado 87: $2 \rightarrow 02$

Clado 77: $2 \rightarrow 02$

Clado 54: $03 \rightarrow 1$

Clado 55: $1 \rightarrow 01$

Rachoviscus graciliceps: $01 \rightarrow 1$

Hollandichthys multifasciatus: $01 \rightarrow 1$

Triportheus albus : $02 \rightarrow 1$

Lignobrycon myersii: $02 \rightarrow 2$

Thoracocharax stellatus: $02 \rightarrow 2$

Clado 76: $02 \rightarrow 03$

Hydrolycus scomberoides: $03 \rightarrow 3$

Acestrorhynchus falcatus: $03 \rightarrow 0$

Aphyocharax pusillus: $01 \rightarrow 0$

Engraulisoma taeniatum: $03 \rightarrow 3$

Clupeacharax anchoveoides: $03 \rightarrow 3$

Cheirodon galusdae: $01 \rightarrow 0$

Moenkhausia xinguensis: $01 \rightarrow 0$

Clado 74: $01 \rightarrow 03$

Nematocharax venustus: $01 \rightarrow 0$

Deuterodon iguape: $01 \rightarrow 0$

Clado 84: $03 \rightarrow 01$

Clado 73: $03 \rightarrow 01$

Jupiaba anteroides: $01 \rightarrow 0$

Tetragonopterus chalceus: $01 \rightarrow 0$

Hyphessobrycon eques: $01 \rightarrow 1$

Clado 68: $01 \rightarrow 0$

Clado 89: $01 \rightarrow 0$

Mimagoniates microlepis: $01 \rightarrow 2$

Clado 70: $0 \rightarrow 01$

Astyanacinus sp nova Bolivia: $01 \rightarrow 0$

Gymnocorymbus ternertzi: $01 \rightarrow 1$

Clado 80: $01 \rightarrow 0$

Bryconamericus exodon: $01 \rightarrow 1$

Clado 69: $01 \rightarrow 0$

Astyanax lineatus: $01 \rightarrow 0$

Clado 67: $01 \rightarrow 0$

Astyanacinus moorii: $01 \rightarrow 0$

Clado 88: $01 \rightarrow 1$

Ctenobrycon hauxwellianus: $01 \rightarrow 0$

Clado 79: $0 \rightarrow 012$

Piabina argentea: $012 \rightarrow 0$

Creagrutus menezesi : $012 \rightarrow 0$

Caráter - 97 (super-sets from 1 trees):

Root: 0

Clado 53: $0 \rightarrow 01$

Clado 52: $01 \rightarrow 0$

Brycon pesu : $01 \rightarrow 0$

Charax leticiae: $0 \rightarrow 1$

Rachoviscus graciliceps: $0 \rightarrow 1$

Thoracocharax stellatus: $0 \rightarrow 1$

Hyphessobrycon eques: $0 \rightarrow 1$

Clado 82: $0 \rightarrow 01$

Gymnocorymbus ternertzi: $01 \rightarrow 1$

Clado 88: $01 \rightarrow 0$

Ctenobrycon hauxwellianus: $01 \rightarrow 1$

Caráter - 98 (super-sets from 1 trees):

Root: 0 
Clado 75: $0 \rightarrow 01$

Clado 86: $0 \rightarrow 02$

Galeocharax knerii : $01 \rightarrow 0$

Charax leticiae: $01 \rightarrow 0$

Clado 87: $0 \rightarrow 02$

Clado 54: $0 \rightarrow 02$

Rachoviscus graciliceps: $02 \rightarrow 0$

Hollandichthys multifasciatus: $02 \rightarrow 0$

Triportheus albus : $02 \rightarrow 0$

Lignobrycon myersii: $02 \rightarrow 0$

Clado 76: $0 \rightarrow 01$

Agoniates halecinus: $02 \rightarrow 0$

Agoniates anchovia: $02 \rightarrow 0$

Engraulisoma taeniatum: $01 \rightarrow 1$

Clupeacharax anchoveoides: $01 \rightarrow 1$

Clado 65: $0 \rightarrow 02$

Moenkhausia xinguensis: $02 \rightarrow 0$

Clado 85: $02 \rightarrow 0$

Clado 74: $02 \rightarrow 0$

Clado 84: $0 \rightarrow 02$

Clado 73: $0 \rightarrow 02$

Jupiaba anteroides: $02 \rightarrow 0$

Tetragonopterus chalceus: $02 \rightarrow 0$

Clado 72: $02 \rightarrow 12$

Hyphessobrycon eques: $02 \rightarrow 0$

Clado 89: $02 \rightarrow 0$

Clado 82: $02 \rightarrow 01$

Mimagoniates microlepis: $12 \rightarrow 1$

Astyanax altiparanae: $02 \rightarrow 0$

Astyanacinus sp nova Bolivia: $02 \rightarrow 0$

Clado 80: $12 \rightarrow 1$

Bryconamericus exodon: $12 \rightarrow 1$

Astyanax lineatus: $02 \rightarrow 0$

Astyanacinus moorii: $02 \rightarrow 0$

Ctenobrycon hauxwellianus: $01 \rightarrow 0$

Clado 79: $1 \rightarrow 01$

Astyanax paranae: $02 \rightarrow 0$

Astyanax fasciatus: $02 \rightarrow 0$

"Astyanax" orthodus: $02 \rightarrow 0$

“Astyanax” superbus: $02 \rightarrow 0$

Astyanacinus sp nova Peru: $02 \rightarrow 0$

Stethaprion erythrops: $01 \rightarrow 0$

Markiana nigripinnis: $01 \rightarrow 0$

Piabina argentea: $01 \rightarrow 1$

Creagrutus menezesi : $01 \rightarrow 1$

Caráter - 99 (super-sets from 1 trees):

Root: 01

Chalceus epakros: $01 \rightarrow 0$

Clado 52: $01 \rightarrow 012$

Brycon pesu : $01 \rightarrow 1$

Clado 58: $012 \rightarrow 12$

Salminus hilarii: $012 \rightarrow 1$

Bryconops alburnoides: $012 \rightarrow 1$

Clado 57: $12 \rightarrow 01$

Clado 78: $012 \rightarrow 12$

Clado 86: $01 \rightarrow 12$

Galeocharax knerii : $12 \rightarrow 1$

Charax leticiae: $12 \rightarrow 1$

Clado 77: $12 \rightarrow 012$

Clado 48: $012 \rightarrow 01$

Clado 54: $012 \rightarrow 12$

Oligosarcus pintoi : $01 \rightarrow 1$

Hollandichthys multifasciatus: $12 \rightarrow 1$

Triportheus albus : $12 \rightarrow 1$

Lignobrycon myersii: $12 \rightarrow 1$

Thoracocharax stellatus: $012 \rightarrow 0$

Clado 76: $012 \rightarrow 02$

Hydrolycus scomberoides: $01 \rightarrow 0$

Acestrorhynchus falcatus: $01 \rightarrow 1$

Agoniates halecinus: $12 \rightarrow 1$

Agoniates anchovia: $12 \rightarrow 1$

Clado 66: $01 \rightarrow 12$

Aphyocharax pusillus: $01 \rightarrow 1$

Engraulisoma taeniatum: $02 \rightarrow 2$

Clupeacharax anchoveoides: $02 \rightarrow 2$

Cheirodon galusdae: $12 \rightarrow 1$
Moenkhausia xinguensis: $12 \rightarrow 1$

Clado 85: $12 \rightarrow 01$

Clado 74: $12 \rightarrow 01$

Nematocharax venustus: $01 \rightarrow 1$

Deuterodon iguape: $01 \rightarrow 1$

Clado 84: $01 \rightarrow 12$

Clado 73: $01 \rightarrow 12$

Jupiaba anteroides: $12 \rightarrow 1$

Tetragonopterus chalceus: $12 \rightarrow 1$

Clado 72: $12 \rightarrow 2$

Hyphessobrycon eques: $12 \rightarrow 1$

Clado 89: $12 \rightarrow 1$

Astyanax altiparanae: $12 \rightarrow 1$

Astyanacinus sp nova Bolivia: $12 \rightarrow 1$

Stichonodon insignis: $1 \rightarrow 0$

Astyanax lineatus: $12 \rightarrow 1$

Astyanacinus moorii: $12 \rightarrow 1$

Ctenobrycon hauxwellianus: $12 \rightarrow 1$

Astyanax paranae: $12 \rightarrow 1$

Astyanax fasciatus: $12 \rightarrow 1$

"Astyanax" orthodus: $12 \rightarrow 1$

“Astyanax” superbus: $12 \rightarrow 1$

Astyanacinus sp nova Peru: $12 \rightarrow 1$

Stethaprion erythrops: $12 \rightarrow 0$

Markiana nigripinnis: $12 \rightarrow 1$

Caráter - 100 (super-sets from 1 trees):

Root: 02

Chalceus epakros: $02 \rightarrow 0$

Brycon pesu : $02 \rightarrow 0$

Salminus hilarii: $02 \rightarrow 1$

Bryconops alburnoides: $02 \rightarrow 0$

Clado 57: $02 \rightarrow 01$

Clado 75: $02 \rightarrow 03$

Clado 86: $01 \rightarrow 02$

Galeocharax knerii : $03 \rightarrow 0$

Charax leticiae: $03 \rightarrow 0$

Clado 54: $02 \rightarrow 01$

Oligosarcus pintoi : $01 \rightarrow 0$

Rachoviscus graciliceps: $02 \rightarrow 0$

Hollandichthys multifasciatus: $02 \rightarrow 01$

Triportheus albus : $02 \rightarrow 0$

Lignobrycon myersii: $02 \rightarrow 0$

Thoracocharax stellatus: $02 \rightarrow 0$

Clado 76: $02 \rightarrow 0123$

Hydrolycus scomberoides: $02 \rightarrow 0$

Acestrorhynchus falcatus: $02 \rightarrow 0$

Agoniates halecinus: $01 \rightarrow 0$

Agoniates anchovia: $01 \rightarrow 0$

Clado 66: $01 \rightarrow 02$

Aphyocharax pusillus: $01 \rightarrow 0$

Engraulisoma taeniatum: $0123 \rightarrow 0$

Clupeacharax anchoveoides: $0123 \rightarrow 0$

Clado 65: $02 \rightarrow 1$

Cheirodon galusdae: $02 \rightarrow 0$

Clado 64: $1 \rightarrow 12$

Clado 85: $12 \rightarrow 1$

Clado 74: $12 \rightarrow 1$

Clado 84: $1 \rightarrow 012$

Clado 73: $1 \rightarrow 12$

Jupiaba anteroides: $12 \rightarrow 1$

Tetragonopterus chalceus: $012 \rightarrow 1$

Clado 83: $012 \rightarrow 12$

Hyphessobrycon eques: $12 \rightarrow 1$

Clado 89: $12 \rightarrow 1$

Clado 71: $12 \rightarrow 02$

Mimagoniates microlepis: $12 \rightarrow 1$

Astyanax altiparanae: $12 \rightarrow 1$

Astyanacinus sp nova Bolivia: $12 \rightarrow 1$

Poptella paraguayensis: $1 \rightarrow 2$

Gymnocorymbus ternertzi: $12 \rightarrow 1$

Bryconamericus exodon: $02 \rightarrow 0$

Astyanax lineatus: $12 \rightarrow 1$

Astyanacinus moorii: $12 \rightarrow 1$

Clado 88: $12 \rightarrow 012$

Ctenobrycon hauxwellianus: $12 \rightarrow 1$

Knodus moenkhausii: $02 \rightarrow 0$ 
Astyanax paranae: $12 \rightarrow 1$

Astyanax fasciatus: $12 \rightarrow 1$

“Astyanax" orthodus: $12 \rightarrow 1$

“Astyanax” superbus: $12 \rightarrow 1$

Astyanacinus sp nova Peru: $12 \rightarrow 1$

Stethaprion erythrops: $012 \rightarrow 2$

Markiana nigripinnis: $012 \rightarrow 0$

Piabina argentea: $02 \rightarrow 0$

Creagrutus menezesi : $02 \rightarrow 0$

Caráter - 101 (super-sets from 1 trees):

Root: 01

Chalceus epakros: $01 \rightarrow 0$

Clado 52: $01 \rightarrow 0$

Brycon pesu : $01 \rightarrow 0$

Clado 58: $0 \rightarrow 01$

Bryconops alburnoides: $0 \rightarrow 1$

Galeocharax knerii : $01 \rightarrow 1$

Charax leticiae: $01 \rightarrow 1$

Clado 48: $0 \rightarrow 01$

Oligosarcus pintoi : $01 \rightarrow 1$

Rachoviscus graciliceps: $01 \rightarrow 1$

Hollandichthys multifasciatus: $01 \rightarrow 1$

Triportheus albus : $0 \rightarrow 1$

Hydrolycus scomberoides: $01 \rightarrow 1$

Acestrorhynchus falcatus: $01 \rightarrow 0$

Aphyocharax pusillus: $01 \rightarrow 0$

Cheirodon galusdae: $01 \rightarrow 1$

Moenkhausia xinguensis: $01 \rightarrow 1$

Deuterodon iguape: $01 \rightarrow 1$

Jupiaba anteroides: $01 \rightarrow 1$

Tetragonopterus chalceus: $01 \rightarrow 1$

Hyphessobrycon eques: $01 \rightarrow 1$

Clado 89: $01 \rightarrow 1$

Mimagoniates microlepis: $01 \rightarrow 1$

Astyanax altiparanae: $01 \rightarrow 1$

Astyanacinus sp nova Bolivia: $01 \rightarrow 1$

Gymnocorymbus ternertzi: $01 \rightarrow 1$

Bryconamericus exodon: $01 \rightarrow 1$

Astyanax lineatus: $01 \rightarrow 1$

Astyanacinus moorii: $01 \rightarrow 1$

Ctenobrycon hauxwellianus: $01 \rightarrow 1$

Knodus moenkhausii: $01 \rightarrow 1$

Astyanax paranae: $01 \rightarrow 1$

Astyanax fasciatus: $01 \rightarrow 1$

"Astyanax" orthodus: $01 \rightarrow 1$

"Astyanax" superbus: $01 \rightarrow 1$

Astyanacinus sp nova Peru: $01 \rightarrow 1$

Stethaprion erythrops: $01 \rightarrow 1$

Markiana nigripinnis: $01 \rightarrow 1$

Piabina argentea: $01 \rightarrow 1$

Creagrutus menezesi : $01 \rightarrow 1$

Caráter - 102 (super-sets from 1 trees):

Root: 01

Clado 53: $01 \rightarrow 0$

Chalceus epakros: $01 \rightarrow 0$

Clado 52: $0 \rightarrow 0$

Clado 58: $01 \rightarrow 0$

Salminus hilarii: $01 \rightarrow 0$

Clado 50: $01 \rightarrow 0$

Bryconops alburnoides: $01 \rightarrow 0$

Clado 57: $0 \rightarrow 01$

Clado 75: $0 \rightarrow 02$

Clado 56: $01 \rightarrow 0$

Clado 86: $01 \rightarrow 0$

Galeocharax knerii : $02 \rightarrow 2$

Charax leticiae: $02 \rightarrow 2$

Rachoviscus graciliceps: $0 \rightarrow 1$

Thoracocharax stellatus: $0 \rightarrow 1$

Hydrolycus scomberoides: $0 \rightarrow 1$

Clado 74: $0 \rightarrow 01$

Nematocharax venustus: $0 \rightarrow 1$

Clado 84: $01 \rightarrow 0$

Clado 73: $01 \rightarrow 0$

Clado 83: $0 \rightarrow 01$

Clado 89: $01 \rightarrow 1$

Gymnocorymbus ternertzi: $01 \rightarrow 1$
Astyanax lineatus: $0 \rightarrow 1$

Ctenobrycon hauxwellianus: $01 \rightarrow 1$

Stethaprion erythrops: $01 \rightarrow 1$

Markiana nigripinnis: $01 \rightarrow 0$

Caráter - 103 (super-sets from 1 trees):

Root: 01

Chalceus epakros: $01 \rightarrow 0$

Clado 52: $01 \rightarrow 1$

Brycon pesu : $01 \rightarrow 1$

Clado 51: $1 \rightarrow 01$

Clado 58: $1 \rightarrow 01$

Bryconops alburnoides: $01 \rightarrow 1$

Clado 78: $01 \rightarrow 012$

Clado 49: $01 \rightarrow 0$

Galeocharax knerii : $01 \rightarrow 1$

Charax leticiae: $01 \rightarrow 1$

Clado 87: $012 \rightarrow 1$

Clado 77: $012 \rightarrow 0$

Clado 54: $0 \rightarrow 01$

Oligosarcus pintoi : $01 \rightarrow 1$

Rachoviscus graciliceps: $01 \rightarrow 1$

Hollandichthys multifasciatus: $01 \rightarrow 1$

Agoniates halecinus: $01 \rightarrow 0$

Agoniates anchovia: $01 \rightarrow 0$

Aphyocharax pusillus: $01 \rightarrow 1$

Clado 65: $01 \rightarrow 1$

Cheirodon galusdae: $01 \rightarrow 1$

Moenkhausia xinguensis: $1 \rightarrow 0$

Clado 85: $1 \rightarrow 01$

Clado 74: $1 \rightarrow 01$

Nematocharax venustus: $01 \rightarrow 1$

Deuterodon iguape: $01 \rightarrow 1$

Clado 84: $01 \rightarrow 1$

Clado 73: $01 \rightarrow 1$

Mimagoniates microlepis: $1 \rightarrow 0$

Clado 59: $1 \rightarrow 01$

Clado 67: $01 \rightarrow 1$

Creagrutus menezesi : $1 \rightarrow 0$

Caráter - 104 (super-sets from 1 trees):

Root: 012

Clado 53: $012 \rightarrow 12$

Chalceus epakros: $012 \rightarrow 0$

Brycon pesu : $12 \rightarrow 1$

Clado 58: $12 \rightarrow 01$

Salminus hilarii: $12 \rightarrow 1$

Bryconops alburnoides: $12 \rightarrow 1$

Clado 57: $01 \rightarrow 12$

Clado 75: $01 \rightarrow 12$

Clado 78: $12 \rightarrow 02$

Clado 56: $12 \rightarrow 01$

Clado 86: $12 \rightarrow 14$

Galeocharax knerii : $12 \rightarrow 2$

Charax leticiae: $12 \rightarrow 2$

Clado 87: $02 \rightarrow 24$

Clado 77: $02 \rightarrow 124$

Oligosarcus pintoi : $01 \rightarrow 1$

Rachoviscus graciliceps: $14 \rightarrow 1$

Hollandichthys multifasciatus: $14 \rightarrow 2$

Triportheus albus : $24 \rightarrow 2$

Lignobrycon myersii: $24 \rightarrow 2$

Thoracocharax stellatus: $124 \rightarrow 2$

Hydrolycus scomberoides: $12 \rightarrow 2$

Acestrorhynchus falcatus: $12 \rightarrow 1$

Agoniates halecinus: $12 \rightarrow 1$

Agoniates anchovia: $12 \rightarrow 2$

Aphyocharax pusillus: $01 \rightarrow 0$

Engraulisoma taeniatum: $124 \rightarrow 1$

Clupeacharax anchoveoides: $124 \rightarrow 2$

Clado 65: $01 \rightarrow 1$

Cheirodon galusdae: $01 \rightarrow 0$

Clado 85: $1 \rightarrow 01$

Clado $74: 1 \rightarrow 12$

Nematocharax venustus: $01 \rightarrow 1$

Deuterodon iguape: $01 \rightarrow 1$

Clado 73: $12 \rightarrow 1$

Clado 61: $1 \rightarrow 0$ 
Tetragonopterus chalceus: $12 \rightarrow 2$

Clado 68: $01 \rightarrow 1$

Clado 89: $12 \rightarrow 2$

Clado 82: $12 \rightarrow 24$

Astyanacinus sp nova Bolivia: $01 \rightarrow 12$

Gymnocorymbus ternertzi: $24 \rightarrow 2$

Clado 80: $1 \rightarrow 04$

Clado 67: $01 \rightarrow 1$

Astyanacinus moorii: $01 \rightarrow 12$

Ctenobrycon hauxwellianus: $24 \rightarrow 2$

Clado 79: $04 \rightarrow 01$

Knodus moenkhausii: $04 \rightarrow 0$

Astyanax paranae: $1 \rightarrow 0$

"Astyanax" orthodus: $1 \rightarrow 12$

“Astyanax" superbus: $1 \rightarrow 12$

Astyanacinus sp nova Peru: $1 \rightarrow 12$

Stethaprion erythrops: $24 \rightarrow 2$

Markiana nigripinnis: $24 \rightarrow 2$

Creagrutus menezesi : $01 \rightarrow 0$

Caráter - 105 (super-sets from 1 trees):

Root: 0

Clado 58: $0 \rightarrow 01$

Clado 78: $0 \rightarrow 01$

Clado 77: $01 \rightarrow 0$

Clado 54: $0 \rightarrow 01$

Oligosarcus pintoi : $01 \rightarrow 0$

Hollandichthys multifasciatus: $01 \rightarrow 1$

Triportheus albus : $01 \rightarrow 0$

Lignobrycon myersii: $01 \rightarrow 0$

Clado 76: $0 \rightarrow 01$

Agoniates halecinus: $01 \rightarrow 0$

Agoniates anchovia: $01 \rightarrow 0$

Aphyocharax pusillus: $01 \rightarrow 0$

Engraulisoma taeniatum: $01 \rightarrow 0$

Clupeacharax anchoveoides: $01 \rightarrow 0$

Cheirodon galusdae: $01 \rightarrow 0$

Moenkhausia xinguensis: $01 \rightarrow 0$

Deuterodon iguape: $01 \rightarrow 0$

Clado 84: $01 \rightarrow 012$

Jupiaba anteroides: $01 \rightarrow 0$

Tetragonopterus chalceus: $012 \rightarrow 2$

Clado 60: $01 \rightarrow 1$

Mimagoniates microlepis: $01 \rightarrow 0$

Astyanax altiparanae: $01 \rightarrow 1$

Bryconamericus exodon: $01 \rightarrow 0$

Knodus moenkhausii: $01 \rightarrow 0$

Astyanax paranae: $01 \rightarrow 0$

Astyanax fasciatus: $01 \rightarrow 0$

Markiana nigripinnis: $012 \rightarrow 1$

Piabina argentea: $01 \rightarrow 0$

Creagrutus menezesi : $01 \rightarrow 0$

Caráter - 106 (super-sets from 1 trees):

Root: 0

Clado 75: $0 \rightarrow 01$

Clado 86: $0 \rightarrow 02$

Galeocharax knerii : $01 \rightarrow 0$

Charax leticiae: $01 \rightarrow 1$

Rachoviscus graciliceps: $02 \rightarrow 2$

Hollandichthys multifasciatus: $02 \rightarrow 2$

Thoracocharax stellatus: $0 \rightarrow 1$

Clado 74: $0 \rightarrow 02$

Tetragonopterus chalceus: $02 \rightarrow 2$

Hyphessobrycon eques: $02 \rightarrow 2$

Clado 60: $0 \rightarrow 02$

Clado 89: $02 \rightarrow 2$

Clado 71: $02 \rightarrow 0$

Mimagoniates microlepis: $02 \rightarrow 2$

Astyanacinus sp nova Bolivia: $02 \rightarrow 2$

Stichonodon insignis: $2 \rightarrow 0$

Gymnocorymbus ternertzi: $02 \rightarrow 1$

Astyanacinus moorii: $02 \rightarrow 2$

Ctenobrycon hauxwellianus: $02 \rightarrow 2$

Astyanax fasciatus: $0 \rightarrow 2$

"Astyanax" orthodus: $02 \rightarrow 2$

“Astyanax" superbus: $02 \rightarrow 2$

Astyanacinus sp nova Peru: $02 \rightarrow 0$
Stethaprion erythrops: $02 \rightarrow 2$

Markiana nigripinnis: $02 \rightarrow 2$

Caráter - 107 (super-sets from 1 trees):

Root: 02

Clado 53: $02 \rightarrow 0$

Chalceus epakros: $02 \rightarrow 0$

Clado 52: $0 \rightarrow 01$

Clado 51: $01 \rightarrow 0$

Clado 58: $01 \rightarrow 0$

Salminus hilarii: $01 \rightarrow 0$

Clado 78: $0 \rightarrow 01$

Charax leticiae: $0 \rightarrow 1$

Clado 87: $01 \rightarrow 0$

Clado 77: $01 \rightarrow 0$

Clado 54: $0 \rightarrow 02$

Clado 55: $0 \rightarrow 02$

Oligosarcus pintoi : $0 \rightarrow 1$

Thoracocharax stellatus: $0 \rightarrow 1$

Hydrolycus scomberoides: $0 \rightarrow 1$

Agoniates halecinus: $02 \rightarrow 0$

Agoniates anchovia: $02 \rightarrow 0$

Clado 66: $02 \rightarrow 0$

Aphyocharax pusillus: $02 \rightarrow 0$

Clado 65: $0 \rightarrow 12$

Clado 64: $12 \rightarrow 01$

Moenkhausia xinguensis: $12 \rightarrow 1$

Nematocharax venustus: $01 \rightarrow 1$

Deuterodon iguape: $01 \rightarrow 1$

Jupiaba anteroides: $01 \rightarrow 1$

Tetragonopterus chalceus: $01 \rightarrow 1$

Clado 72: $01 \rightarrow 0$

Hyphessobrycon eques: $01 \rightarrow 1$

Clado 89: $01 \rightarrow 1$

Astyanax altiparanae: $01 \rightarrow 1$

Clado 59: $01 \rightarrow 0$

Astyanacinus sp nova Bolivia: $01 \rightarrow 1$

Gymnocorymbus ternertzi: $01 \rightarrow 1$

Astyanax lineatus: $01 \rightarrow 0$

Ctenobrycon hauxwellianus: $01 \rightarrow 1$

Astyanax paranae: $01 \rightarrow 1$

Astyanax fasciatus: $01 \rightarrow 1$

Stethaprion erythrops: $01 \rightarrow 1$

Markiana nigripinnis: $01 \rightarrow 1$

Caráter - 108 (super-sets from 1 trees):

Root: 0

Clado 58: $0 \rightarrow 01$

Clado 57: $01 \rightarrow 012$

Clado 75: $01 \rightarrow 0$

Clado 78: $0 \rightarrow 12$

Clado 56: $012 \rightarrow 01$

Clado 86: $012 \rightarrow 0$

Clado 87: $12 \rightarrow 1$

Clado $77: 12 \rightarrow 01$

Clado 54: $0 \rightarrow 01$

Oligosarcus pintoi : $01 \rightarrow 0$

Thoracocharax stellatus: $01 \rightarrow 1$

Hydrolycus scomberoides: $0 \rightarrow 1$

Agoniates halecinus: $01 \rightarrow 0$

Agoniates anchovia: $01 \rightarrow 0$

Aphyocharax pusillus: $01 \rightarrow 0$

Engraulisoma taeniatum: $01 \rightarrow 1$

Clupeacharax anchoveoides: $01 \rightarrow 1$

Cheirodon galusdae: $01 \rightarrow 0$

Moenkhausia xinguensis: $01 \rightarrow 0$

Clado 74: $01 \rightarrow 012$

Nematocharax venustus: $01 \rightarrow 0$

Deuterodon iguape: $01 \rightarrow 0$

Clado 84: $012 \rightarrow 01$

Clado 73: $012 \rightarrow 01$

Jupiaba anteroides: $01 \rightarrow 0$

Tetragonopterus chalceus: $01 \rightarrow 0$

Clado 72: $01 \rightarrow 012$

Hyphessobrycon eques: $01 \rightarrow 0$

Clado 89: $01 \rightarrow 0$

Mimagoniates microlepis: $012 \rightarrow 0$

Clado 70: $01 \rightarrow 02$ 
Astyanax altiparanae: $01 \rightarrow 0$

Astyanacinus sp nova Bolivia: $01 \rightarrow 0$

Gymnocorymbus ternertzi: $01 \rightarrow 0$

Clado 80: $012 \rightarrow 01$

Bryconamericus exodon: $012 \rightarrow 0$

Clado 69: $02 \rightarrow 01$

Astyanax lineatus: $02 \rightarrow 0$

Astyanacinus moorii: $01 \rightarrow 0$

Ctenobrycon hauxwellianus: $01 \rightarrow 0$

Clado 79: $01 \rightarrow 02$

Knodus moenkhausii: $01 \rightarrow 0$

Astyanax paranae: $01 \rightarrow 0$

Astyanax fasciatus: $01 \rightarrow 0$

"Astyanax" orthodus: $01 \rightarrow 0$

“Astyanax” superbus: $01 \rightarrow 0$

Astyanacinus sp nova Peru: $01 \rightarrow 0$

Stethaprion erythrops: $01 \rightarrow 0$

Markiana nigripinnis: $01 \rightarrow 0$

Piabina argentea: $02 \rightarrow 0$

Creagrutus menezesi : $02 \rightarrow 0$

Caráter - 109 (super-sets from 1 trees):

Root: 0

Clado 78: $0 \rightarrow 01$

Triportheus albus : $01 \rightarrow 1$

Lignobrycon myersii: $01 \rightarrow 1$

Thoracocharax stellatus: $01 \rightarrow 1$

Hydrolycus scomberoides: $0 \rightarrow 1$

Engraulisoma taeniatum: $01 \rightarrow 1$

Clupeacharax anchoveoides: $01 \rightarrow 1$

Caráter - 110 (super-sets from 1 trees):

Root: 01

Clado 53: $01 \rightarrow 0$

Chalceus epakros: $01 \rightarrow 1$

Clado 58: $0 \rightarrow 01$

Galeocharax knerii : $01 \rightarrow 1$

Charax leticiae: $01 \rightarrow 1$

Clado 54: $0 \rightarrow 02$

Oligosarcus pintoi : $01 \rightarrow 1$

Rachoviscus graciliceps: $01 \rightarrow 1$

Hollandichthys multifasciatus: $01 \rightarrow 1$

Agoniates halecinus: $02 \rightarrow 2$

Agoniates anchovia: $02 \rightarrow 2$

Aphyocharax pusillus: $01 \rightarrow 0$

Cheirodon galusdae: $01 \rightarrow 1$

Moenkhausia xinguensis: $01 \rightarrow 0$

Clado 74: $01 \rightarrow$

Nematocharax venustus: $01 \rightarrow 1$

Deuterodon iguape: $01 \rightarrow 1$

Clado 84: $1 \rightarrow 01$

Clado 73: $1 \rightarrow 0$

Jupiaba anteroides: $01 \rightarrow 1$

Tetragonopterus chalceus: $01 \rightarrow 1$

Clado 89: $01 \rightarrow 1$

Astyanax altiparanae: $01 \rightarrow 1$

Astyanacinus sp nova Bolivia: $01 \rightarrow 1$

Gymnocorymbus ternertzi: $01 \rightarrow 1$

Astyanax lineatus: $01 \rightarrow 1$

Astyanacinus moorii: $01 \rightarrow 1$

Ctenobrycon hauxwellianus: $01 \rightarrow 1$

Astyanax paranae: $01 \rightarrow 1$

Astyanax fasciatus: $01 \rightarrow 1$

“Astyanax” orthodus: $01 \rightarrow 1$

“Astyanax” superbus: $01 \rightarrow 1$

Astyanacinus sp nova Peru: $01 \rightarrow 1$

Stethaprion erythrops: $01 \rightarrow 1$

Markiana nigripinnis: $01 \rightarrow 1$

Caráter - 111 (super-sets from 1 trees):

Root: 01

Chalceus epakros: $01 \rightarrow 1$

Clado 52: $01 \rightarrow 0$

Brycon pesu : $01 \rightarrow 0$

Clado 51: $0 \rightarrow 01$

Bryconops alburnoides: $01 \rightarrow 1$

Clado 86: $0 \rightarrow 01$

Rachoviscus graciliceps: $01 \rightarrow 1$

Hollandichthys multifasciatus: $01 \rightarrow 1$
Acestrorhynchus falcatus: $01 \rightarrow 1$

Agoniates halecinus: $01 \rightarrow 1$

Agoniates anchovia: $01 \rightarrow 1$

Clado 85: $0 \rightarrow 01$

Nematocharax venustus: $01 \rightarrow 1$

Deuterodon iguape: $01 \rightarrow 1$

Clado 73: $0 \rightarrow 01$

Hyphessobrycon eques: $01 \rightarrow 1$

Clado 60: $0 \rightarrow 01$

Mimagoniates microlepis: $01 \rightarrow 0$

Astyanacinus sp nova Bolivia: $01 \rightarrow 1$

Bryconamericus exodon: $01 \rightarrow 1$

Clado 69: $0 \rightarrow 01$

Astyanacinus moorii: $01 \rightarrow 1$

Clado 88: $0 \rightarrow 01$

Knodus moenkhausii: $01 \rightarrow 1$

Astyanax paranae: $01 \rightarrow 1$

Astyanax fasciatus: $01 \rightarrow 1$

“Astyanax" orthodus: $01 \rightarrow 1$

“Astyanax" superbus: $01 \rightarrow 1$

Astyanacinus sp nova Peru: $01 \rightarrow 1$

Stethaprion erythrops: $01 \rightarrow 1$

Markiana nigripinnis: $01 \rightarrow 1$

Piabina argentea: $01 \rightarrow 1$

Creagrutus menezesi : $01 \rightarrow 0$

Caráter - 112 (super-sets from 1 trees):

Root: 01

Chalceus epakros: $01 \rightarrow 0$

Clado 52: $01 \rightarrow 0$

Brycon pesu : $01 \rightarrow 0$

Clado 51: $0 \rightarrow 01$

Clado 58: $0 \rightarrow 01$

Salminus hilarii: $0 \rightarrow 1$

Bryconops alburnoides: $01 \rightarrow 0$

Clado 56: $01 \rightarrow 1$

Galeocharax knerii : $01 \rightarrow 1$

Charax leticiae: $01 \rightarrow 0$

Clado 87: $01 \rightarrow 1$

Rachoviscus graciliceps: $01 \rightarrow 0$

Hollandichthys multifasciatus: $01 \rightarrow 0$

Thoracocharax stellatus: $01 \rightarrow 1$

Hydrolycus scomberoides: $01 \rightarrow 1$

Acestrorhynchus falcatus: $01 \rightarrow 0$

Agoniates halecinus: $01 \rightarrow 0$

Agoniates anchovia: $01 \rightarrow 0$

Engraulisoma taeniatum: $01 \rightarrow 0$

Clupeacharax anchoveoides: $01 \rightarrow 0$

Cheirodon galusdae: $1 \rightarrow 0$

Clado 62: $1 \rightarrow 01$

Jupiaba anteroides: $01 \rightarrow 0$

Mimagoniates microlepis: $1 \rightarrow 0$

Astyanax altiparanae: $01 \rightarrow 0$

Astyanacinus sp nova Bolivia: $01 \rightarrow 0$

Clado 69: $01 \rightarrow 1$

Astyanax lineatus: $01 \rightarrow 0$

Astyanacinus moorii: $01 \rightarrow 0$

"Astyanax" orthodus: $01 \rightarrow 1$

“Astyanax” superbus: $01 \rightarrow 0$

Astyanacinus sp nova Peru: $01 \rightarrow 0$

Markiana nigripinnis: $1 \rightarrow 0$

Creagrutus menezesi : $1 \rightarrow 0$

Caráter - 113 (super-sets from 1 trees):

Root: 01

Clado 53: $01 \rightarrow 0$

Chalceus epakros: $01 \rightarrow 0$

Clado 50: $0 \rightarrow 01$

Triportheus albus : $01 \rightarrow 1$

Lignobrycon myersii: $01 \rightarrow 1$

Thoracocharax stellatus: $01 \rightarrow 1$

Hydrolycus scomberoides: $01 \rightarrow 1$

Acestrorhynchus falcatus: $01 \rightarrow 0$

Agoniates halecinus: $01 \rightarrow 0$

Agoniates anchovia: $01 \rightarrow 1$

Engraulisoma taeniatum: $01 \rightarrow 0$

Clupeacharax anchoveoides: $01 \rightarrow 1$

Clado 89: $0 \rightarrow 1$ 
Stethaprion erythrops: $0 \rightarrow 1$

Caráter - 114 (super-sets from 1 trees): Root: 01

Clado 49: $01 \rightarrow 0$

Triportheus albus : $01 \rightarrow 1$

Lignobrycon myersii: $01 \rightarrow 0$

Thoracocharax stellatus: $01 \rightarrow 1$

Clupeacharax anchoveoides: $01 \rightarrow 0$

Clado 83: $01 \rightarrow 1$

Clado 88: $1 \rightarrow 01$

Stethaprion erythrops: $01 \rightarrow 1$

Caráter - 115 (super-sets from 1 trees): Root: 01

Chalceus epakros: $01 \rightarrow 1$

Brycon pesu : $01 \rightarrow 1$

Salminus hilarii: $01 \rightarrow 1$

Bryconops alburnoides: $01 \rightarrow 1$

Clado 75: $01 \rightarrow 1$

Clado 87: $01 \rightarrow 1$

Oligosarcus pintoi : $01 \rightarrow 1$

Rachoviscus graciliceps: $01 \rightarrow 1$

Hollandichthys multifasciatus: $01 \rightarrow 1$

Thoracocharax stellatus: $01 \rightarrow 1$

Hydrolycus scomberoides: $01 \rightarrow 1$

Acestrorhynchus falcatus: $01 \rightarrow 1$

Agoniates halecinus: $01 \rightarrow 1$

Agoniates anchovia: $01 \rightarrow 1$

Aphyocharax pusillus: $01 \rightarrow 0$

Engraulisoma taeniatum: $01 \rightarrow 0$

Clupeacharax anchoveoides: $01 \rightarrow 1$

Cheirodon galusdae: $01 \rightarrow 1$

Moenkhausia xinguensis: $01 \rightarrow 1$

Nematocharax venustus: $01 \rightarrow 1$

Deuterodon iguape: $01 \rightarrow 1$

Jupiaba anteroides: $01 \rightarrow 1$

Tetragonopterus chalceus: $01 \rightarrow 1$

Clado 72: $01 \rightarrow 0$

Hyphessobrycon eques: $01 \rightarrow 1$

Clado 68: $01 \rightarrow 1$

Clado 89: $01 \rightarrow 1$

Clado 70: $1 \rightarrow 01$

Astyanacinus sp nova Bolivia: $01 \rightarrow 1$

Clado 81: $01 \rightarrow 1$

Gymnocorymbus ternertzi: $01 \rightarrow 1$

Clado 80: $0 \rightarrow 01$

Clado 69: $01 \rightarrow 1$

Astyanax lineatus: $01 \rightarrow 1$

Clado 67: $01 \rightarrow 1$

Astyanacinus moorii: $01 \rightarrow 1$

Clado 88: $1 \rightarrow 01$

Clado 79: $01 \rightarrow 0$

Knodus moenkhausii: $01 \rightarrow 0$

Stethaprion erythrops: $01 \rightarrow 1$

Markiana nigripinnis: $01 \rightarrow 1$

Caráter - 116 (super-sets from 1 trees):

Root: 05

Chalceus epakros: $05 \rightarrow 0$

Brycon pesu : $05 \rightarrow 0$

Clado 58: $05 \rightarrow 01$

Salminus hilarii: $05 \rightarrow 0$

Bryconops alburnoides: $05 \rightarrow 0$

Clado 57: $01 \rightarrow 05$

Clado 75: $01 \rightarrow 015$

Clado 78: $05 \rightarrow 01$

Galeocharax knerii : $015 \rightarrow 0$

Charax leticiae: $015 \rightarrow 0$

Clado 87: $01 \rightarrow 0$

Clado 77: $01 \rightarrow 05$

Oligosarcus pintoi : $05 \rightarrow 0$

Rachoviscus graciliceps: $05 \rightarrow 1$

Hollandichthys multifasciatus: $05 \rightarrow 0$

Triportheus albus : $0 \rightarrow 1$

Thoracocharax stellatus: $05 \rightarrow 1$

Clado 76: $05 \rightarrow 015$

Hydrolycus scomberoides: $05 \rightarrow 0$

Acestrorhynchus falcatus: $05 \rightarrow 0$
Agoniates halecinus: $05 \rightarrow 0$

Agoniates anchovia: $05 \rightarrow 0$

Clado 66: $05 \rightarrow 01$

Aphyocharax pusillus: $05 \rightarrow 0$

Engraulisoma taeniatum: $015 \rightarrow 0$

Clupeacharax anchoveoides: $015 \rightarrow 0$

Clado 65: $01 \rightarrow 05$

Cheirodon galusdae: $01 \rightarrow 0$

Clado 64: $05 \rightarrow 0$

Moenkhausia xinguensis: $05 \rightarrow 0$

Clado 85: $0 \rightarrow 05$

Clado 74: $0 \rightarrow 05$

Nematocharax venustus: $05 \rightarrow 0$

Deuterodon iguape: $05 \rightarrow 0$

Clado 84: $05 \rightarrow 0$

Clado 73: $05 \rightarrow 0$

Clado 59: $0 \rightarrow 01$

Clado 67: $01 \rightarrow 0$

Astyanacinus moorii: $01 \rightarrow 0$

Caráter - 117 (super-sets from 1 trees):

Root: 0

Clado 58: $0 \rightarrow 12$

Clado 57: $12 \rightarrow 012$

Clado 75: $12 \rightarrow 012$

Clado 78: $0 \rightarrow 01$

Galeocharax knerii : $012 \rightarrow 2$

Charax leticiae: $012 \rightarrow 1$

Clado 77: $01 \rightarrow 0$

Clado 55: $012 \rightarrow 02$

Oligosarcus pintoi : $012 \rightarrow 1$

Rachoviscus graciliceps: $012 \rightarrow 1$

Hollandichthys multifasciatus: $012 \rightarrow 2$

Triportheus albus : $01 \rightarrow 2$

Lignobrycon myersii: $01 \rightarrow 0$

Clado 66: $02 \rightarrow 12$

Aphyocharax pusillus: $02 \rightarrow 2$

Engraulisoma taeniatum: $0 \rightarrow 1$

Cheirodon galusdae: $12 \rightarrow 2$

Clado 64: $12 \rightarrow 1$

Moenkhausia xinguensis: $12 \rightarrow 2$

Clado 85: $1 \rightarrow 01$

Clado 74: $1 \rightarrow 01$

Nematocharax venustus: $01 \rightarrow 1$

Clado 84: $01 \rightarrow 1$

Clado 73: $01 \rightarrow 1$

Tetragonopterus chalceus: $1 \rightarrow 2$

Hyphessobrycon eques: $1 \rightarrow 2$

Stichonodon insignis: $1 \rightarrow 0$

Gymnocorymbus ternertzi: $1 \rightarrow 2$

Astyanax lineatus: $1 \rightarrow 0$

Clado 67: $1 \rightarrow 01$

Clado 88: $1 \rightarrow 01$

“Astyanax" orthodus: $01 \rightarrow 0$

“Astyanax" superbus: $01 \rightarrow 0$

Astyanacinus sp nova Peru: $01 \rightarrow 0$

Stethaprion erythrops: $01 \rightarrow 0$

Markiana nigripinnis: $01 \rightarrow 0$

Caráter - 118 (super-sets from 1 trees):

Root: 02

Chalceus epakros: $02 \rightarrow 0$

Clado 52: $02 \rightarrow 01$

Brycon pesu : $02 \rightarrow 0$

Clado 51: $01 \rightarrow 012$

Clado 58: $01 \rightarrow 0$

Salminus hilarii: $01 \rightarrow 1$

Bryconops alburnoides: $012 \rightarrow 1$

Clado 57: $0 \rightarrow 02$

Clado 75: $0 \rightarrow 012$

Clado 78: $012 \rightarrow 01$

Clado 49: $012 \rightarrow 02$

Clado 86: $02 \rightarrow 012$

Galeocharax knerii : $012 \rightarrow 0$

Charax leticiae: $012 \rightarrow 0$

Clado 87: $01 \rightarrow 1$

Clado 77: $01 \rightarrow 12$

Clado 54: $02 \rightarrow 01$ 
Clado 55: $02 \rightarrow 01$

Oligosarcus pintoi : $02 \rightarrow 0$

Rachoviscus graciliceps: $012 \rightarrow 0$

Hollandichthys multifasciatus: $012 \rightarrow 0$

Thoracocharax stellatus: $12 \rightarrow 1$

Hydrolycus scomberoides: $02 \rightarrow 0$

Acestrorhynchus falcatus: $02 \rightarrow 0$

Agoniates halecinus: $01 \rightarrow 0$

Agoniates anchovia: $01 \rightarrow 0$

Aphyocharax pusillus: $01 \rightarrow 1$

Engraulisoma taeniatum: $12 \rightarrow 1$

Clupeacharax anchoveoides: $12 \rightarrow 2$

Cheirodon galusdae: $01 \rightarrow 1$

Moenkhausia xinguensis: $01 \rightarrow 0$

Clado 63: $01 \rightarrow 0$

Clado 85: $01 \rightarrow 02$

Clado 74: $0 \rightarrow 02$

Nematocharax venustus: $02 \rightarrow 0$

Deuterodon iguape: $02 \rightarrow 0$

Clado 84: $02 \rightarrow 0$

Clado 73: $02 \rightarrow 01$

Hyphessobrycon eques: $01 \rightarrow 1$

Clado 68: $0 \rightarrow 01$

Clado 89: $0 \rightarrow 1$

Mimagoniates microlepis: $01 \rightarrow 1$

Astyanax altiparanae: $01 \rightarrow 1$

Astyanacinus sp nova Bolivia: $0 \rightarrow 01$

Clado 80: $01 \rightarrow 1$

Bryconamericus exodon: $01 \rightarrow 1$

Clado 69: $01 \rightarrow 0$

Astyanax lineatus: $01 \rightarrow 1$

Clado 79: $1 \rightarrow 0$

Stethaprion erythrops: $0 \rightarrow 1$

Caráter - 119 (super-sets from 1 trees):

Root: 01

Chalceus epakros: $01 \rightarrow 1$

Brycon pesu : $01 \rightarrow 1$

Salminus hilarii: $01 \rightarrow 1$

Bryconops alburnoides: $01 \rightarrow 1$

Clado 75: $01 \rightarrow 1$

Clado 78: $01 \rightarrow 1$

Clado 86: $01 \rightarrow 12$

Clado 87: $1 \rightarrow 12$

Clado 77: $1 \rightarrow 02$

Clado 54: $01 \rightarrow 012$

Oligosarcus pintoi : $01 \rightarrow 1$

Hollandichthys multifasciatus: $12 \rightarrow 1$

Triportheus albus : $12 \rightarrow 1$

Lignobrycon myersii: $12 \rightarrow 1$

Thoracocharax stellatus: $02 \rightarrow 0$

Hydrolycus scomberoides: $01 \rightarrow 1$

Acestrorhynchus falcatus: $01 \rightarrow 1$

Agoniates halecinus: $012 \rightarrow 1$

Agoniates anchovia: $012 \rightarrow 1$

Aphyocharax pusillus: $01 \rightarrow 1$

Engraulisoma taeniatum: $02 \rightarrow 0$

Clupeacharax anchoveoides: $02 \rightarrow 0$

Clado 65: $01 \rightarrow 1$

Cheirodon galusdae: $01 \rightarrow 1$

Clado 85: $1 \rightarrow 0$

Clado 74: $1 \rightarrow 01$

Clado 73: $01 \rightarrow 1$

Tetragonopterus chalceus: $01 \rightarrow 1$

Clado 83: $01 \rightarrow 12$

Clado 89: $12 \rightarrow 1$

Mimagoniates microlepis: $1 \rightarrow 0$

Clado 59: $1 \rightarrow 01$

Gymnocorymbus ternertzi: $12 \rightarrow 1$

Clado 80: $1 \rightarrow 12$

Clado 67: $01 \rightarrow 1$

Astyanacinus moorii: $01 \rightarrow 1$

Ctenobrycon hauxwellianus: $12 \rightarrow 1$

Clado 79: $12 \rightarrow 1$

Knodus moenkhausii: $12 \rightarrow 1$

“Astyanax" orthodus: $1 \rightarrow 0$

Stethaprion erythrops: $12 \rightarrow 0$
Markiana nigripinnis: $12 \rightarrow 1$

Caráter - 120 (super-sets from 1 trees):

Root: 01

Clado 53: $01 \rightarrow 12$

Chalceus epakros: $01 \rightarrow 1$

Clado 52: $12 \rightarrow 0$

Brycon pesu : $12 \rightarrow 1$

Clado 50: $0 \rightarrow 01$

Galeocharax knerii : $0 \rightarrow 2$

Rachoviscus graciliceps: $0 \rightarrow 1$

Triportheus albus : $01 \rightarrow 1$

Lignobrycon myersii: $01 \rightarrow 1$

Thoracocharax stellatus: $01 \rightarrow 1$

Hydrolycus scomberoides: $01 \rightarrow 1$

Acestrorhynchus falcatus: $01 \rightarrow 1$

Agoniates halecinus: $01 \rightarrow 1$

Agoniates anchovia: $01 \rightarrow 1$

Engraulisoma taeniatum: $01 \rightarrow 0$

Clupeacharax anchoveoides: $01 \rightarrow 1$

Cheirodon galusdae: $0 \rightarrow 1$

Nematocharax venustus: $0 \rightarrow 2$

Stichonodon insignis: $0 \rightarrow 1$

Astyanax lineatus: $0 \rightarrow 2$

Stethaprion erythrops: $0 \rightarrow 1$

Caráter - 121 (super-sets from 1 trees):

Root: 02

Chalceus epakros: $02 \rightarrow 0$

Clado 52: $02 \rightarrow 0$

Brycon pesu : $02 \rightarrow 0$

Clado 58: $0 \rightarrow 01$

Clado 50: $0 \rightarrow 012$

Clado 57: $01 \rightarrow 0$

Clado 75: $01 \rightarrow 012$

Clado 78: $012 \rightarrow 01$

Clado 56: $0 \rightarrow 02$

Clado 86: $0 \rightarrow 012$

Galeocharax knerii : $012 \rightarrow 0$

Charax leticiae: $012 \rightarrow 0$

Clado 87: $01 \rightarrow 1$

Clado 77: $01 \rightarrow 12$

Clado 48: $012 \rightarrow 02$

Clado 54: $012 \rightarrow 12$

Oligosarcus pintoi : $02 \rightarrow 0$

Rachoviscus graciliceps: $012 \rightarrow 2$

Hollandichthys multifasciatus: $012 \rightarrow 1$

Thoracocharax stellatus: $12 \rightarrow 2$

Hydrolycus scomberoides: $02 \rightarrow 0$

Acestrorhynchus falcatus: $02 \rightarrow 0$

Agoniates halecinus: $12 \rightarrow 1$

Agoniates anchovia: $12 \rightarrow 1$

Clado 66: $02 \rightarrow 01$

Aphyocharax pusillus: $02 \rightarrow 0$

Engraulisoma taeniatum: $12 \rightarrow 1$

Clupeacharax anchoveoides: $12 \rightarrow 1$

Cheirodon galusdae: $01 \rightarrow 1$

Moenkhausia xinguensis: $01 \rightarrow 0$

Clado 85: $01 \rightarrow 02$

Clado 74: $01 \rightarrow 0$

Nematocharax venustus: $02 \rightarrow 0$

Deuterodon iguape: $02 \rightarrow 0$

Clado 84: $0 \rightarrow 01$

Clado 73: $0 \rightarrow 02$

Jupiaba anteroides: $01 \rightarrow 0$

Tetragonopterus chalceus: $01 \rightarrow 0$

Clado 83: $01 \rightarrow 02$

Hyphessobrycon eques: $02 \rightarrow 0$

Clado 89: $02 \rightarrow 0$

Mimagoniates microlepis: $02 \rightarrow 1$

Clado 70: $01 \rightarrow 0$

Astyanax altiparanae: $01 \rightarrow 0$

Astyanacinus sp nova Bolivia: $01 \rightarrow 0$

Stichonodon insignis: $0 \rightarrow 1$

Clado 81: $02 \rightarrow 01$

Gymnocorymbus ternertzi: $02 \rightarrow 1$

Clado 80: $02 \rightarrow 01$

Bryconamericus exodon: $02 \rightarrow 0$ 
Clado 69: $0 \rightarrow 01$

Astyanacinus moorii: $01 \rightarrow 0$

Clado 88: $01 \rightarrow 02$

Ctenobrycon hauxwellianus: $01 \rightarrow 0$

Clado 79: $01 \rightarrow 0$

Knodus moenkhausii: $01 \rightarrow 0$

Astyanax paranae: $01 \rightarrow 0$

Astyanax fasciatus: $01 \rightarrow 0$

“Astyanax" orthodus: $01 \rightarrow 0$

“Astyanax” superbus: $01 \rightarrow 0$

Astyanacinus sp nova Peru: $01 \rightarrow 0$

Stethaprion erythrops: $02 \rightarrow 2$

Markiana nigripinnis: $02 \rightarrow 0$

Caráter - 122 (super-sets from 1 trees):

Root: 0

Clado 53: $0 \rightarrow 01$

Clado 52: $01 \rightarrow 0$

Brycon pesu : $01 \rightarrow 0$

Charax leticiae: $0 \rightarrow 2$

Clado 77: $0 \rightarrow 01$

Thoracocharax stellatus: $01 \rightarrow 1$

Engraulisoma taeniatum: $01 \rightarrow 1$

Clupeacharax anchoveoides: $01 \rightarrow 1$

Moenkhausia xinguensis: $0 \rightarrow 1$

Clado 84: $0 \rightarrow 01$

Jupiaba anteroides: $0 \rightarrow 1$

Tetragonopterus chalceus: $01 \rightarrow 1$

Clado 89: $01 \rightarrow 1$

Gymnocorymbus ternertzi: $01 \rightarrow 2$

Clado 88: $01 \rightarrow 0$

Ctenobrycon hauxwellianus: $01 \rightarrow 1$

Caráter - 123 (super-sets from 1 trees):

Root: 0

Clado 58: $0 \rightarrow 01$

Clado 50: $0 \rightarrow 01$

Clado 57: $01 \rightarrow 0$

Clado 75: $01 \rightarrow 0$

Clado 48: $01 \rightarrow 0$

Triportheus albus : $01 \rightarrow 1$

Lignobrycon myersii: $01 \rightarrow 1$

Thoracocharax stellatus: $01 \rightarrow 0$

Agoniates halecinus: $01 \rightarrow 1$

Agoniates anchovia: $01 \rightarrow 1$

Clado 66: $0 \rightarrow 01$

Engraulisoma taeniatum: $01 \rightarrow 1$

Clupeacharax anchoveoides: $01 \rightarrow 1$

Clado 65: $01 \rightarrow 0$

Cheirodon galusdae: $01 \rightarrow 0$

Clado 85: $0 \rightarrow 01$

Nematocharax venustus: $01 \rightarrow 0$

Deuterodon iguape: $01 \rightarrow 0$

Clado 71: $0 \rightarrow 01$

Clado 70: $0 \rightarrow 01$

Clado 59: $0 \rightarrow 01$

Clado 80: $01 \rightarrow 0$

Bryconamericus exodon: $01 \rightarrow 0$

Clado 69: $01 \rightarrow 0$

Astyanax lineatus: $01 \rightarrow 0$

Clado 67: $01 \rightarrow 0$

Astyanacinus moorii: $01 \rightarrow 0$

Clado 79: $0 \rightarrow 01$

Piabina argentea: $01 \rightarrow 0$

Creagrutus menezesi : $01 \rightarrow 0$

Caráter - 124 (super-sets from 1 trees):

Root: 01

Clado 53: $01 \rightarrow 0$

Chalceus epakros: $01 \rightarrow 0$

Clado 58: $0 \rightarrow 01$

Galeocharax knerii : $01 \rightarrow 1$

Charax leticiae: $01 \rightarrow 1$

Clado 77: $0 \rightarrow 01$

Oligosarcus pintoi : $01 \rightarrow 1$

Rachoviscus graciliceps: $01 \rightarrow 1$

Hollandichthys multifasciatus: $01 \rightarrow 1$

Thoracocharax stellatus: $01 \rightarrow 1$

Aphyocharax pusillus: $01 \rightarrow 1$
Engraulisoma taeniatum: $01 \rightarrow 1$

Clupeacharax anchoveoides: $01 \rightarrow 1$

Cheirodon galusdae: $01 \rightarrow 1$

Moenkhausia xinguensis: $01 \rightarrow 0$

Nematocharax venustus: $01 \rightarrow 1$

Deuterodon iguape: $01 \rightarrow 1$

Clado 84: $01 \rightarrow 0$

Jupiaba anteroides: $01 \rightarrow 0$

Hyphessobrycon eques: $01 \rightarrow 1$

Mimagoniates microlepis: $01 \rightarrow 1$

Astyanax altiparanae: $01 \rightarrow 1$

Astyanacinus sp nova Bolivia: $01 \rightarrow 1$

Gymnocorymbus ternertzi: $0 \rightarrow 1$

Bryconamericus exodon: $01 \rightarrow 1$

Astyanax lineatus: $01 \rightarrow 1$

Astyanacinus moorii: $01 \rightarrow 1$

Knodus moenkhausii: $01 \rightarrow 1$

Astyanax paranae: $01 \rightarrow 1$

Astyanax fasciatus: $01 \rightarrow 1$

“Astyanax" orthodus: $01 \rightarrow 1$

“Astyanax" superbus: $01 \rightarrow 1$

Astyanacinus sp nova Peru: $01 \rightarrow 1$

Markiana nigripinnis: $0 \rightarrow 01$

Piabina argentea: $01 \rightarrow 1$

Creagrutus menezesi : $01 \rightarrow 1$

Caráter - 125 (super-sets from 1 trees):

Root: 012

Clado 53: $012 \rightarrow 0$

Chalceus epakros: $012 \rightarrow 2$

Clado 77: $0 \rightarrow 01$

Thoracocharax stellatus: $01 \rightarrow 1$

Engraulisoma taeniatum: $01 \rightarrow 1$

Clupeacharax anchoveoides: $01 \rightarrow 0$

Astyanacinus sp nova Peru: $0 \rightarrow 02$

Caráter - 126 (super-sets from 1 trees):

Root: 01

Chalceus epakros: $01 \rightarrow 0$

Brycon pesu : $01 \rightarrow 0$

Clado 58: $01 \rightarrow 0$

Salminus hilarii: $01 \rightarrow 0$

Bryconops alburnoides: $01 \rightarrow 0$

Clado 57: $0 \rightarrow 01$

Clado 78: $01 \rightarrow 0$

Clado 56: $01 \rightarrow 02$

Clado 86: $01 \rightarrow 0$

Clado 48: $01 \rightarrow 1$

Clado 54: $01 \rightarrow 0$

Oligosarcus pintoi : $02 \rightarrow 0$

Aphyocharax pusillus: $02 \rightarrow 0$

Clado 65: $02 \rightarrow 0$

Cheirodon galusdae: $02 \rightarrow 0$

Clado 85: $0 \rightarrow 02$

Clado 74: $0 \rightarrow 01$

Nematocharax venustus: $02 \rightarrow 0$

Deuterodon iguape: $02 \rightarrow 0$

Clado 84: $01 \rightarrow 0$

Clado 73: $01 \rightarrow 0$

Caráter - 127 (super-sets from 1 trees):

Root: 0

Clado 58: $0 \rightarrow 01$

Clado 75: $01 \rightarrow 0$

Clado 78: $0 \rightarrow 01$

Clado 86: $01 \rightarrow 0$

Clado 77: $01 \rightarrow 0$

Clado 54: $0 \rightarrow 1$

Oligosarcus pintoi : $01 \rightarrow 0$

Triportheus albus : $01 \rightarrow 0$

Lignobrycon myersii: $01 \rightarrow 0$

Aphyocharax pusillus: $01 \rightarrow 0$

Cheirodon galusdae: $01 \rightarrow 0$

Moenkhausia xinguensis: $01 \rightarrow 0$

Nematocharax venustus: $01 \rightarrow 0$

Deuterodon iguape: $01 \rightarrow 0$

Jupiaba anteroides: $01 \rightarrow 0$

Tetragonopterus chalceus: $01 \rightarrow 0$

Hyphessobrycon eques: $01 \rightarrow 0$ 
Clado 89: $01 \rightarrow 0$

Mimagoniates microlepis: $01 \rightarrow 0$

Astyanax altiparanae: $01 \rightarrow 0$

Astyanacinus sp nova Bolivia: $01 \rightarrow 0$

Gymnocorymbus ternertzi: $01 \rightarrow 0$

Bryconamericus exodon: $01 \rightarrow 0$

Astyanax lineatus: $01 \rightarrow 0$

Astyanacinus moorii: $01 \rightarrow 0$

Ctenobrycon hauxwellianus: $01 \rightarrow 0$

Knodus moenkhausii: $01 \rightarrow 0$

Astyanax paranae: $01 \rightarrow 0$

Astyanax fasciatus: $01 \rightarrow 0$

“Astyanax" orthodus: $01 \rightarrow 0$

“Astyanax” superbus: $01 \rightarrow 0$

Astyanacinus sp nova Peru: $01 \rightarrow 0$

Stethaprion erythrops: $01 \rightarrow 0$

Markiana nigripinnis: $01 \rightarrow 0$

Piabina argentea: $01 \rightarrow 0$

Creagrutus menezesi : $01 \rightarrow 0$

Caráter - 128 (super-sets from 1 trees):

Root: 01

Chalceus epakros: $01 \rightarrow 1$

Clado 52: $01 \rightarrow 1$

Brycon pesu : $01 \rightarrow 1$

Clado $51: 1 \rightarrow 01$

Salminus hilarii: $1 \rightarrow 2$

Bryconops alburnoides: $01 \rightarrow 2$

Clado 75: $1 \rightarrow 01$

Clado 86: $1 \rightarrow 01$

Galeocharax knerii : $01 \rightarrow 2$

Charax leticiae: $01 \rightarrow 1$

Clado 87: $01 \rightarrow 1$

Clado 77: $01 \rightarrow 0$

Rachoviscus graciliceps: $01 \rightarrow 0$

Hollandichthys multifasciatus: $01 \rightarrow 1$

Hydrolycus scomberoides: $01 \rightarrow 1$

Acestrorhynchus falcatus: $01 \rightarrow 1$

Agoniates halecinus: $01 \rightarrow 0$

Agoniates anchovia: $01 \rightarrow 0$

Aphyocharax pusillus: $1 \rightarrow 2$

Cheirodon galusdae: $1 \rightarrow 3$

Clado 72: $1 \rightarrow 01$

Clado 71: $01 \rightarrow 012$

Mimagoniates microlepis: $01 \rightarrow 1$

Clado 70: $1 \rightarrow 01$

Clado 80: $012 \rightarrow 12$

Bryconamericus exodon: $012 \rightarrow 0$

Clado 69: $01 \rightarrow 1$

Astyanax lineatus: $01 \rightarrow 1$

Clado 79: $12 \rightarrow 02$

Knodus moenkhausii: $12 \rightarrow 2$

Markiana nigripinnis: $1 \rightarrow 0$

Piabina argentea: $02 \rightarrow 2$

Creagrutus menezesi : $02 \rightarrow 2$

Caráter - 129 (super-sets from 1 trees):

Root: 0

Clado 78: $0 \rightarrow 012$

Clado 87: $012 \rightarrow 0$

Clado 77: $012 \rightarrow 0$

Oligosarcus pintoi : $0 \rightarrow 1$

Clado 74: $0 \rightarrow 012$

Clado 84: $012 \rightarrow 0$

Clado 73: $012 \rightarrow 0$

Clado 61: $0 \rightarrow 01$

Astyanax altiparanae: $01 \rightarrow 1$

Astyanacinus sp nova Bolivia: $01 \rightarrow 1$

Astyanax lineatus: $01 \rightarrow 1$

Astyanacinus moorii: $01 \rightarrow 1$

Clado 79: $0 \rightarrow 01$

Astyanax paranae: $01 \rightarrow 1$

Astyanax fasciatus: $01 \rightarrow 1$

“Astyanax" orthodus: $01 \rightarrow 0$

“Astyanax" superbus: $01 \rightarrow 1$

Astyanacinus sp nova Peru: $01 \rightarrow 1$

Piabina argentea: $01 \rightarrow 0$

Creagrutus menezesi : $01 \rightarrow 0$
Caráter - 130 (super-sets from 1 trees):

Root: 0

Clado 75: $0 \rightarrow 01$

Galeocharax knerii : $01 \rightarrow 1$

Charax leticiae: $01 \rightarrow 0$

Thoracocharax stellatus: $0 \rightarrow 1$

Clado 84: $0 \rightarrow 01$

Tetragonopterus chalceus: $01 \rightarrow 1$

Clado 89: $01 \rightarrow 1$

Gymnocorymbus ternertzi: $01 \rightarrow 1$

Ctenobrycon hauxwellianus: $01 \rightarrow 0$

Stethaprion erythrops: $01 \rightarrow 1$

Markiana nigripinnis: $01 \rightarrow 1$

Caráter - 131 (super-sets from 1 trees):

Root: 01

Chalceus epakros: $01 \rightarrow 0$

Brycon pesu : $01 \rightarrow 1$

Salminus hilarii: $01 \rightarrow 1$

Bryconops alburnoides: $01 \rightarrow 1$

Clado 49: $01 \rightarrow 0$

Galeocharax knerii : $01 \rightarrow 1$

Charax leticiae: $01 \rightarrow 1$

Oligosarcus pintoi : $01 \rightarrow 1$

Rachoviscus graciliceps: $01 \rightarrow 1$

Hollandichthys multifasciatus: $01 \rightarrow 1$

Triportheus albus : $01 \rightarrow 1$

Lignobrycon myersii: $01 \rightarrow 1$

Thoracocharax stellatus: $01 \rightarrow 1$

Clado 76: $01 \rightarrow 0$

Aphyocharax pusillus: $01 \rightarrow 1$

Cheirodon galusdae: $01 \rightarrow 1$

Moenkhausia xinguensis: $01 \rightarrow 1$

Nematocharax venustus: $01 \rightarrow 1$

Deuterodon iguape: $01 \rightarrow 0$

Jupiaba anteroides: $01 \rightarrow 1$

Tetragonopterus chalceus: $01 \rightarrow 1$

Hyphessobrycon eques: $01 \rightarrow 1$

Clado 89: $01 \rightarrow 1$

Mimagoniates microlepis: $01 \rightarrow 1$

Astyanax altiparanae: $01 \rightarrow 1$

Clado 59: $01 \rightarrow 0$

Astyanacinus sp nova Bolivia: $01 \rightarrow 1$

Gymnocorymbus ternertzi: $01 \rightarrow 1$

Bryconamericus exodon: $01 \rightarrow 1$

Astyanax lineatus: $01 \rightarrow 1$

Ctenobrycon hauxwellianus: $01 \rightarrow 1$

Knodus moenkhausii: $01 \rightarrow 1$

Astyanax paranae: $01 \rightarrow 1$

Astyanax fasciatus: $01 \rightarrow 1$

Stethaprion erythrops: $01 \rightarrow 1$

Markiana nigripinnis: $01 \rightarrow 1$

Piabina argentea: $01 \rightarrow 1$

Creagrutus menezesi : $01 \rightarrow 1$

Caráter - 132 (super-sets from 1 trees):

Root: 0

Clado 52: $0 \rightarrow 01$

Salminus hilarii: $01 \rightarrow 1$

Bryconops alburnoides: $01 \rightarrow 1$

Clado 75: $01 \rightarrow 0$

Clado 78: $01 \rightarrow 1$

Clado 77: $1 \rightarrow 01$

Clado 48: $01 \rightarrow 0$

Clado 54: $01 \rightarrow 1$

Oligosarcus pintoi : $01 \rightarrow 0$

Hollandichthys multifasciatus: $01 \rightarrow 1$

Thoracocharax stellatus: $01 \rightarrow 1$

Aphyocharax pusillus: $01 \rightarrow 0$

Engraulisoma taeniatum: $01 \rightarrow 1$

Clupeacharax anchoveoides: $01 \rightarrow 1$

Cheirodon galusdae: $01 \rightarrow 1$

Moenkhausia xinguensis: $01 \rightarrow 0$

Nematocharax venustus: $01 \rightarrow 0$

Deuterodon iguape: $01 \rightarrow 0$

Jupiaba anteroides: $01 \rightarrow 0$

Tetragonopterus chalceus: $01 \rightarrow 0$

Hyphessobrycon eques: $01 \rightarrow 0$ 
Clado 89: $01 \rightarrow 0$

Mimagoniates microlepis: $01 \rightarrow 1$

Astyanax altiparanae: $01 \rightarrow 0$

Astyanacinus sp nova Bolivia: $01 \rightarrow 0$

Gymnocorymbus ternertzi: $01 \rightarrow 0$

Bryconamericus exodon: $01 \rightarrow 0$

Astyanax lineatus: $01 \rightarrow 0$

Astyanacinus moorii: $01 \rightarrow 0$

Ctenobrycon hauxwellianus: $01 \rightarrow 0$

Knodus moenkhausii: $01 \rightarrow 0$

Astyanax paranae: $01 \rightarrow 0$

Astyanax fasciatus: $01 \rightarrow 0$

"Astyanax" orthodus: $01 \rightarrow 0$

“Astyanax” superbus: $01 \rightarrow 0$

Astyanacinus sp nova Peru: $01 \rightarrow 0$

Stethaprion erythrops: $01 \rightarrow 0$

Markiana nigripinnis: $01 \rightarrow 1$

Piabina argentea: $01 \rightarrow 0$

Creagrutus menezesi : $01 \rightarrow 0$

Caráter - 133 (super-sets from 1 trees):

Root: 0

Clado 52: $0 \rightarrow 01$

Brycon pesu : $0 \rightarrow 3$

Clado 75: $01 \rightarrow 0$

Clado 49: $01 \rightarrow 0$

Clado 86: $01 \rightarrow 0$

Clado 77: $01 \rightarrow 0$

Clado 54: $0 \rightarrow 01$

Oligosarcus pintoi : $01 \rightarrow 1$

Hydrolycus scomberoides: $0 \rightarrow 3$

Aphyocharax pusillus: $01 \rightarrow 0$

Moenkhausia xinguensis: $01 \rightarrow 0$

Clado 74: $01 \rightarrow 0$

Clado 62: $01 \rightarrow 12$

Nematocharax venustus: $01 \rightarrow 1$

Deuterodon iguape: $01 \rightarrow 0$

Clado 84: $0 \rightarrow 01$

Clado 73: $0 \rightarrow 01$

Jupiaba anteroides: $12 \rightarrow 2$

Tetragonopterus chalceus: $01 \rightarrow 1$

Hyphessobrycon eques: $01 \rightarrow 0$

Clado 89: $01 \rightarrow 0$

Clado $70: 12 \rightarrow 1$

Astyanax altiparanae: $12 \rightarrow 2$

Astyanacinus sp nova Bolivia: $12 \rightarrow 2$

Gymnocorymbus ternertzi: $01 \rightarrow 1$

Bryconamericus exodon: $01 \rightarrow 0$

Astyanacinus moorii: $12 \rightarrow 2$

Ctenobrycon hauxwellianus: $01 \rightarrow 0$

Knodus moenkhausii: $01 \rightarrow 0$

"Astyanax" orthodus: $12 \rightarrow 2$

"Astyanax" superbus: $12 \rightarrow 2$

Astyanacinus sp nova Peru: $12 \rightarrow 2$

Stethaprion erythrops: $01 \rightarrow 0$

Piabina argentea: $01 \rightarrow 0$

Creagrutus menezesi : $01 \rightarrow 0$

Caráter - 134 (super-sets from 1 trees):

Root: 0

Clado 58: $0 \rightarrow 012$

Clado 57: $012 \rightarrow 01$

Clado 75: $012 \rightarrow 02$

Galeocharax knerii : $02 \rightarrow 2$

Charax leticiae: $02 \rightarrow 2$

Oligosarcus pintoi : $01 \rightarrow 1$

Rachoviscus graciliceps: $01 \rightarrow 1$

Hollandichthys multifasciatus: $01 \rightarrow 0$

Thoracocharax stellatus: $0 \rightarrow 1$

Clado 66: $01 \rightarrow 012$

Aphyocharax pusillus: $01 \rightarrow 1$

Clado 65: $012 \rightarrow 0$

Cheirodon galusdae: $012 \rightarrow 2$

Clado 74: $0 \rightarrow 01$

Clado 84: $01 \rightarrow 0$

Clado 73: $01 \rightarrow 0$

Tetragonopterus chalceus: $0 \rightarrow 1$

Hyphessobrycon eques: $0 \rightarrow 1$
Ctenobrycon hauxwellianus: $0 \rightarrow 1$

Caráter - 135 (super-sets from 1 trees):

Root: 0

Clado 53: $0 \rightarrow 01$

Clado 52: $01 \rightarrow 0$

Brycon pesu : $01 \rightarrow 0$

Nematocharax venustus: $0 \rightarrow 1$

Clado 60: $0 \rightarrow 01$

Astyanacinus sp nova Bolivia: $01 \rightarrow 1$

Astyanacinus moorii: $01 \rightarrow 1$

"Astyanax" orthodus: $01 \rightarrow 1$

“Astyanax” superbus: $01 \rightarrow 1$

Astyanacinus sp nova Peru: $01 \rightarrow 1$ 


\section{Apêndice 2}

Cladogramas, fotografias e ilustrações 


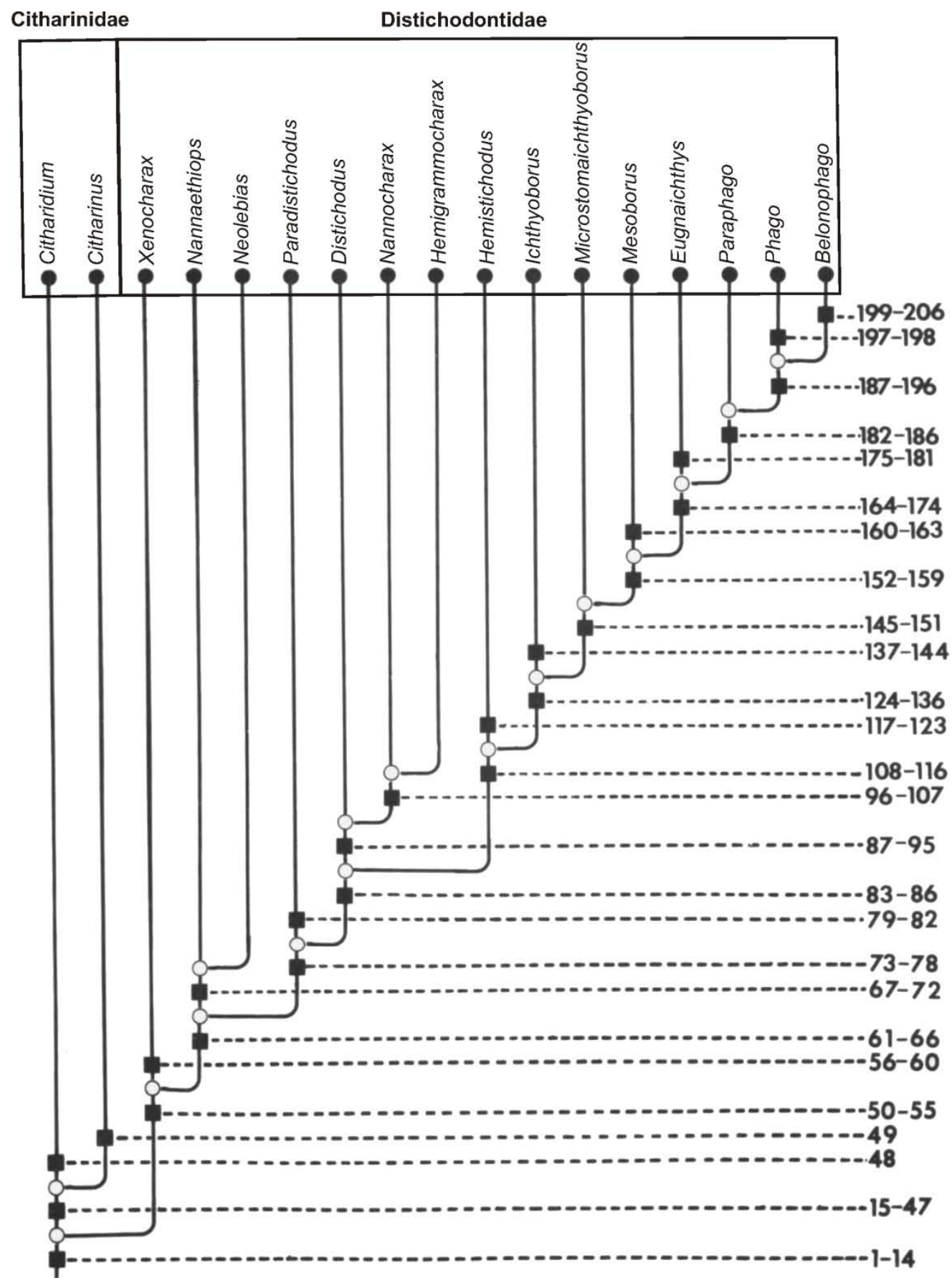

Figura 24. Relações de parentesco entre os Distochodontidae e Citharhinidae na proposta de Vari (1979) (modificado, porém sem alteração da hipótese do autor). 


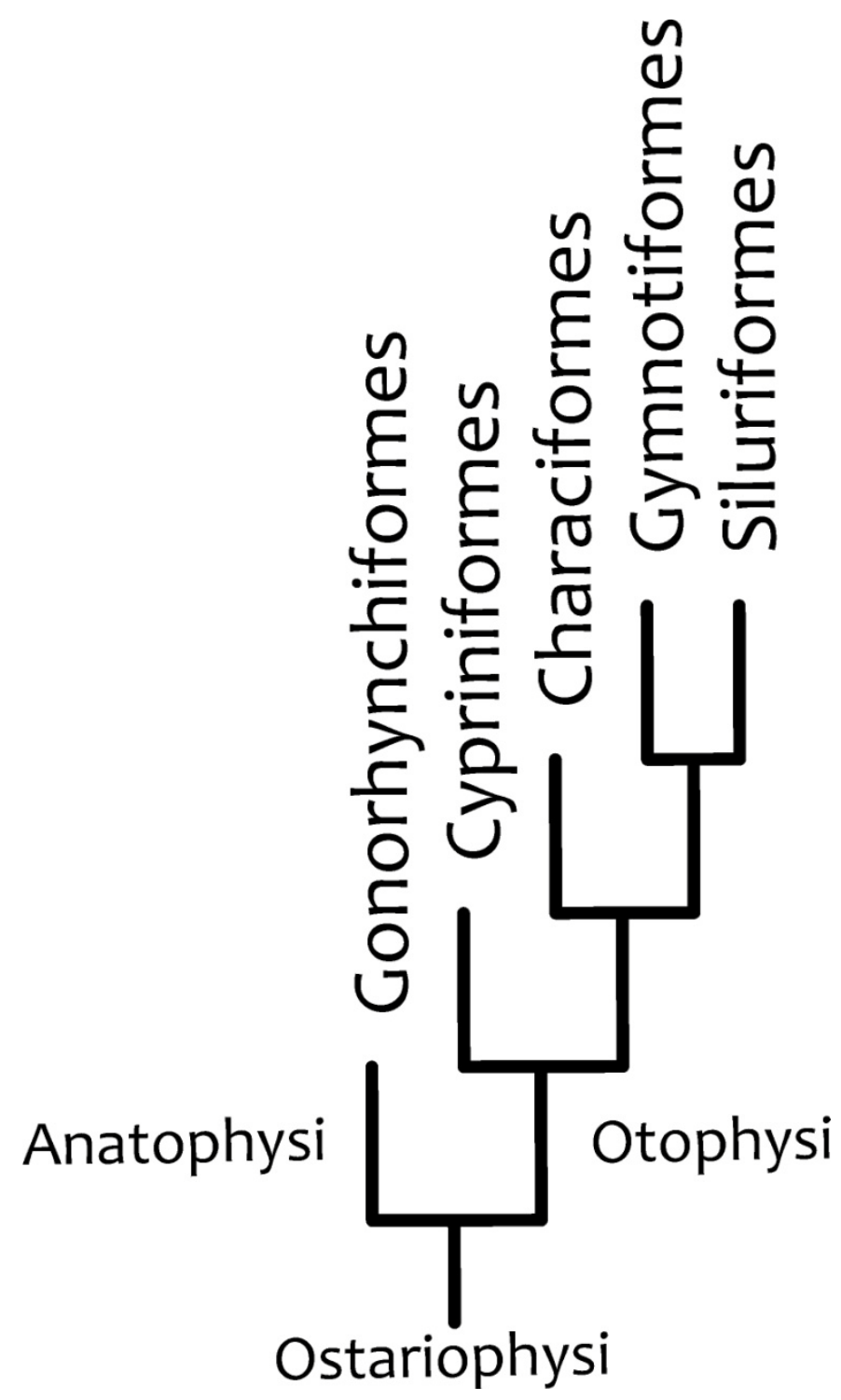

Figura 25. Relações na superordem Ostariophysi segundo Fink \& Fink (1981). Modificado de Fink \& Fink (1981, 1996), porém sem alteração da hipótese dos autores. 


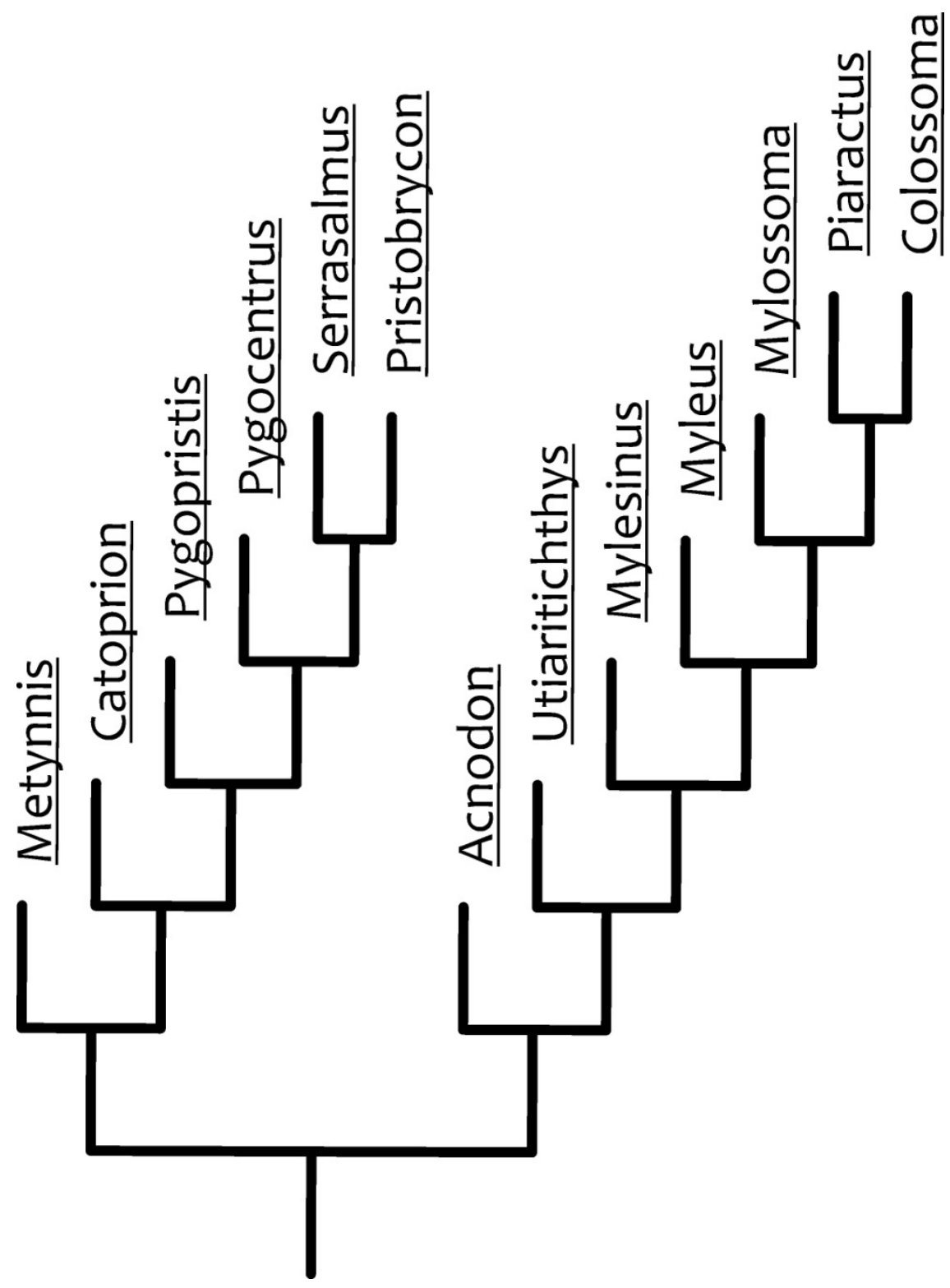

Figura 26. Relações internas entre os serrasalmíneos de acordo com Machado-Allison (1982) (modificado, porém sem alteração da hipótese do autor). 


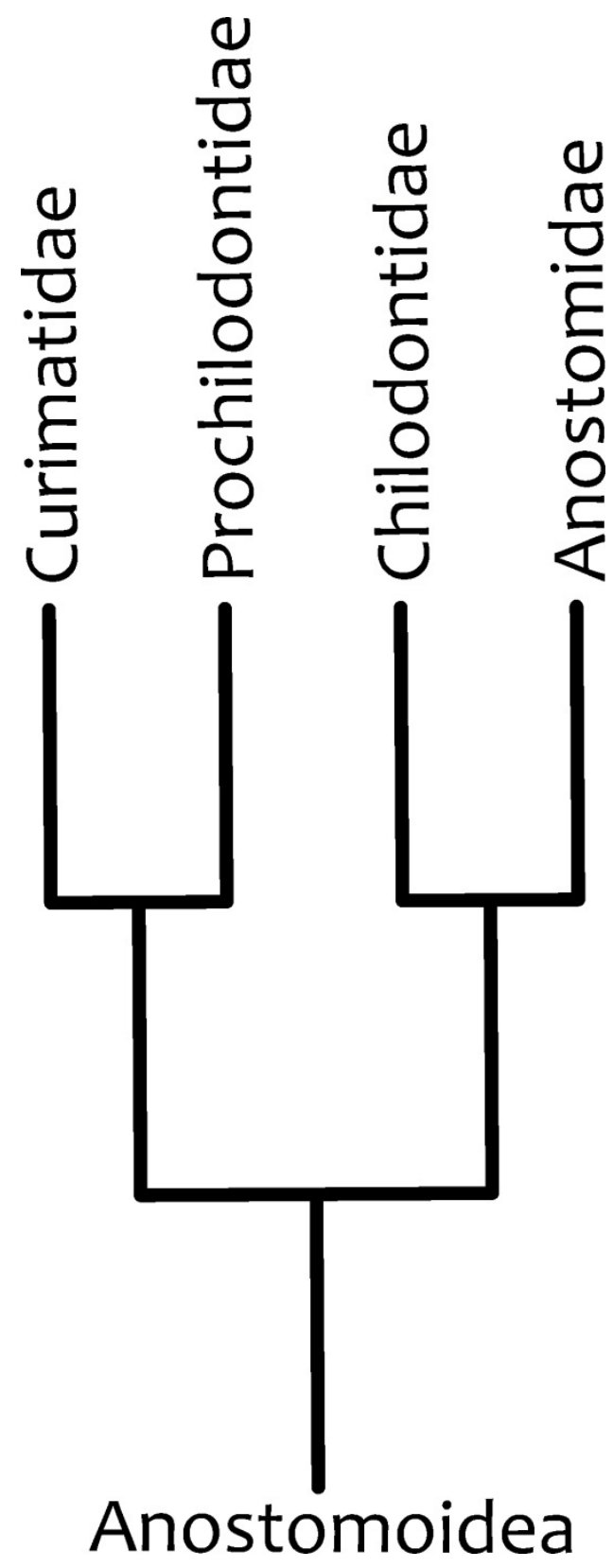

Figura 27. Relações internas entre os Anostomoidea, proposta de Vari (1983) (modificado, porém sem alteração da hipótese do autor). 


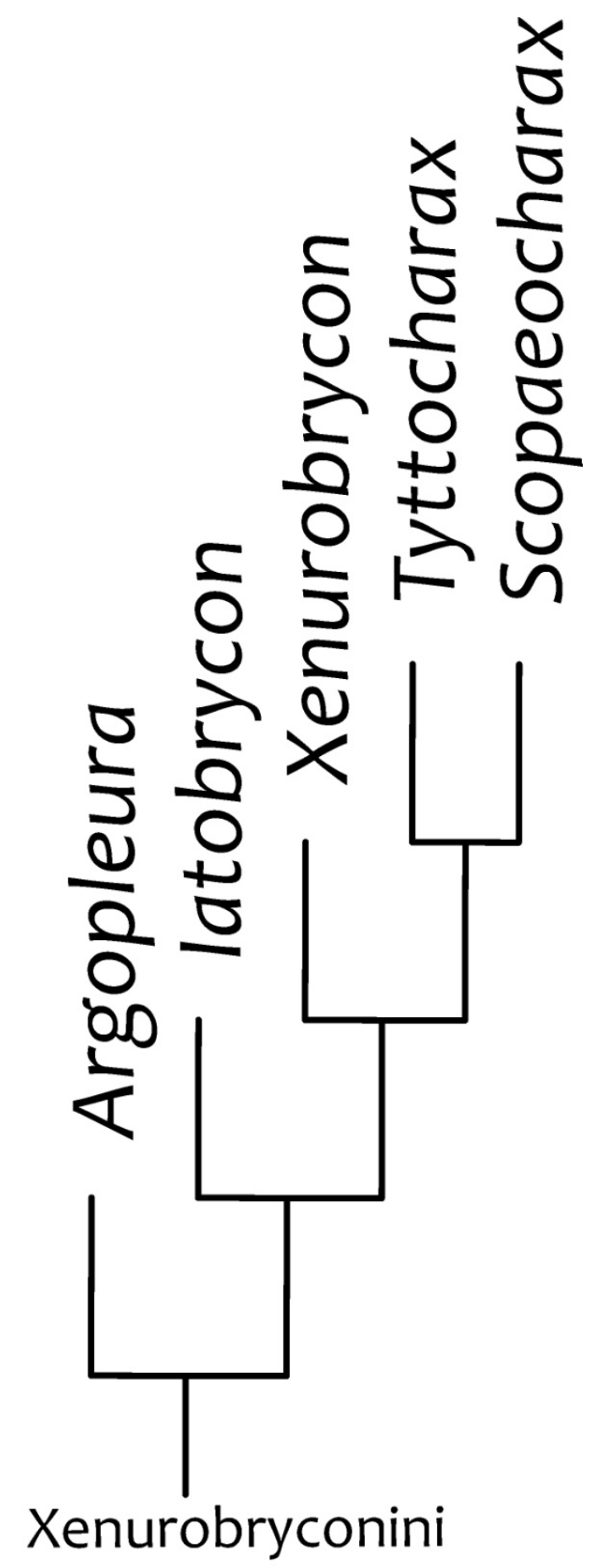

Figura 28. Relações internas entre os Xenurobryconini de Weitzman \& Fink (1985) (modificado, porém sem alteração da hipótese dos autores). 


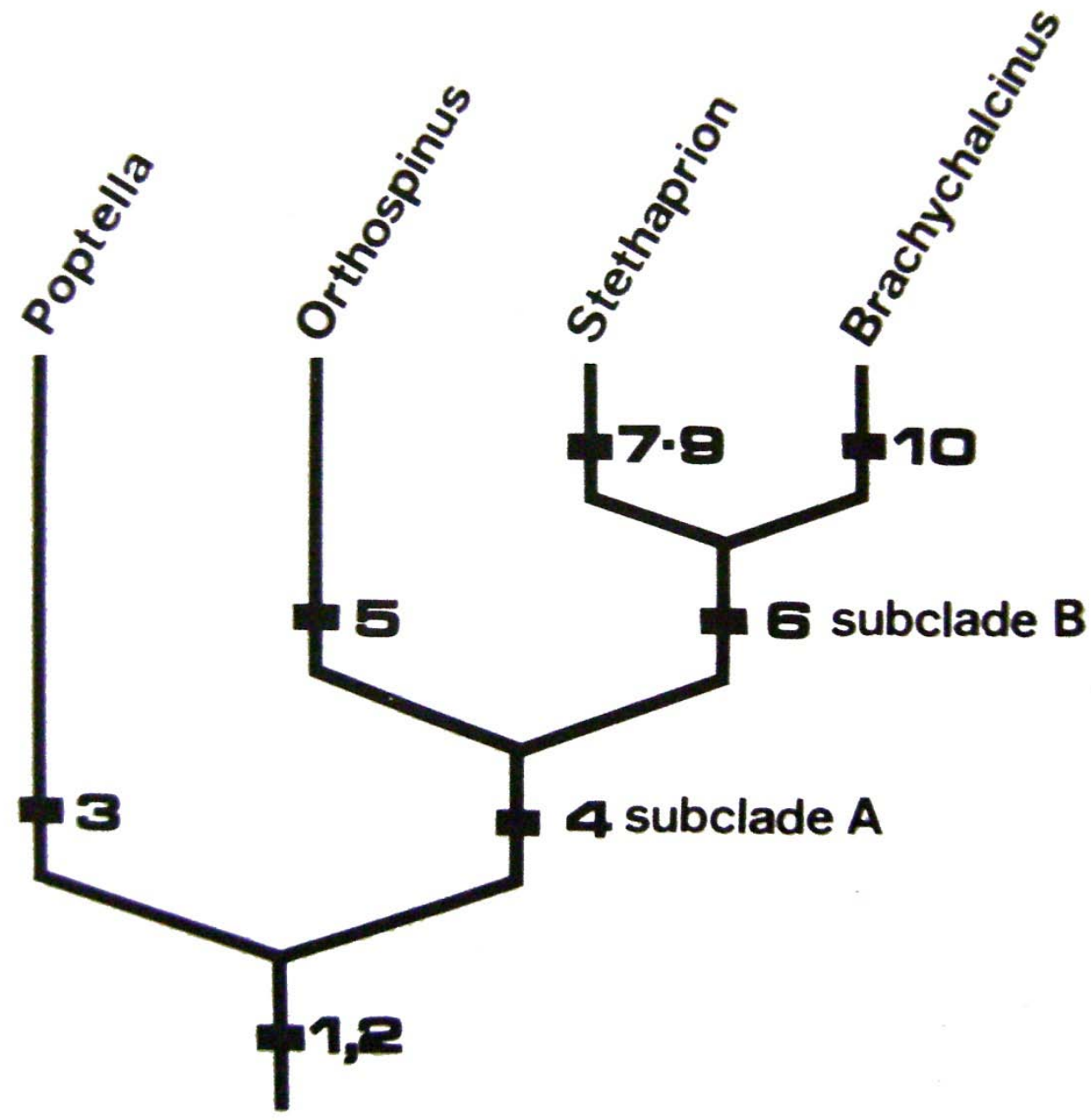

Figura 29. Relações internas entre os Stethaprioninae segundo Reis (1989). 


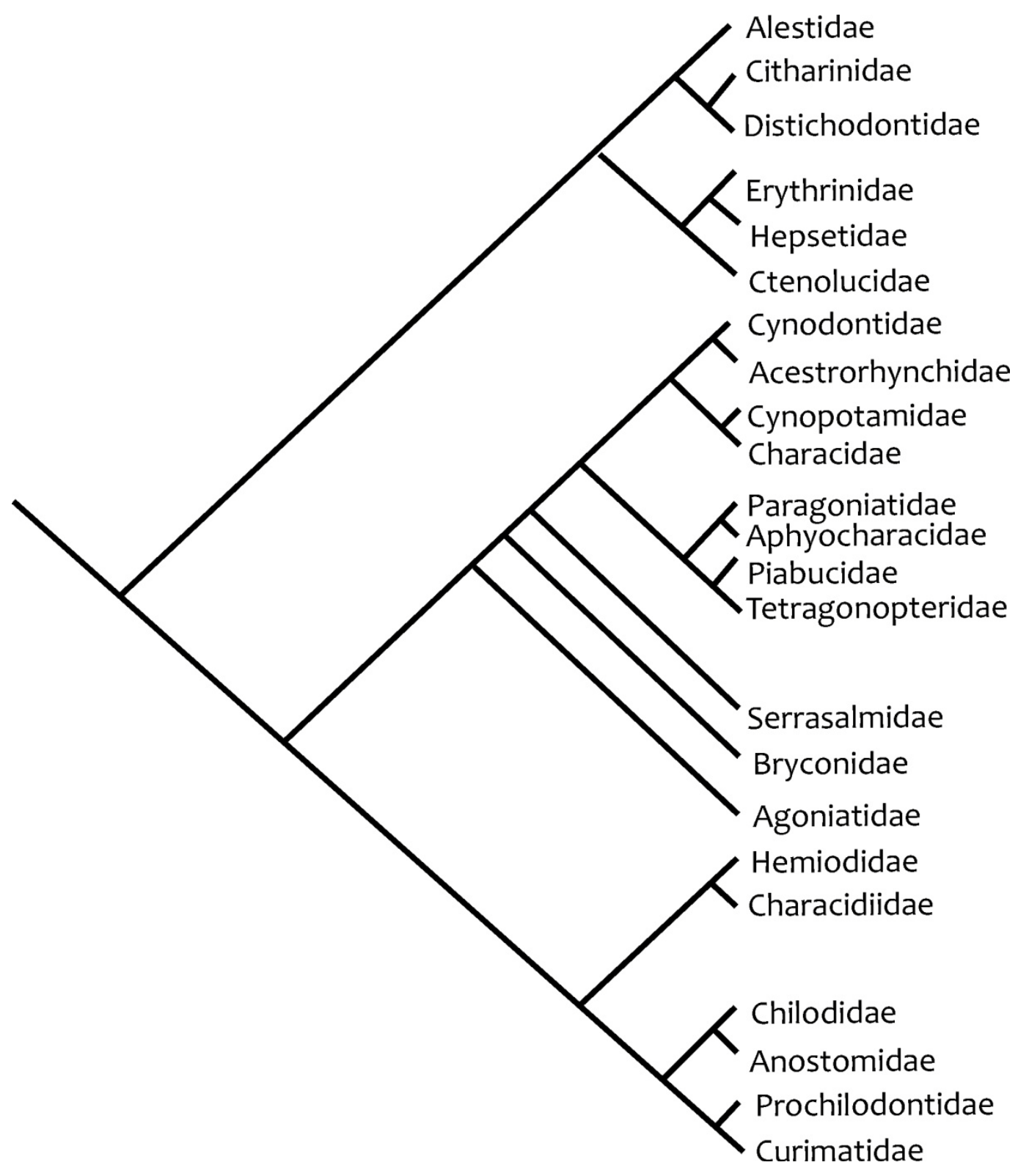

Figura 30. Relações filogenéticas entre as famílias da ordem Characiformes segundo Uj (1990) (modificado, porém sem alteração da hipótese do autor). 


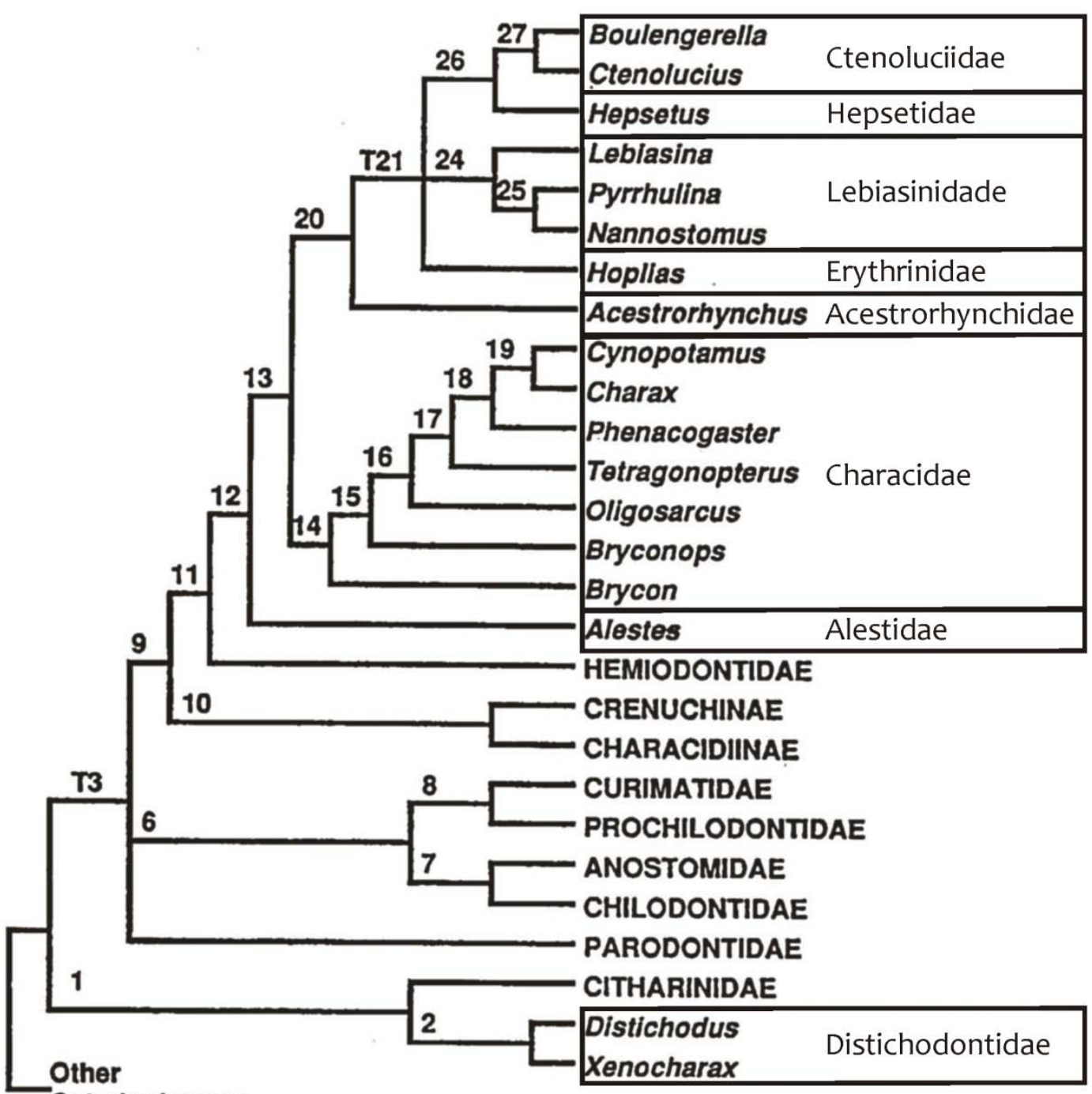

Ostarlophysans

Figura 31. Relações filogenéticas entre as famílias da ordem Characiformes de acordo com Buckup (1998) (modificado, porém sem alteração da hipótese do autor). 


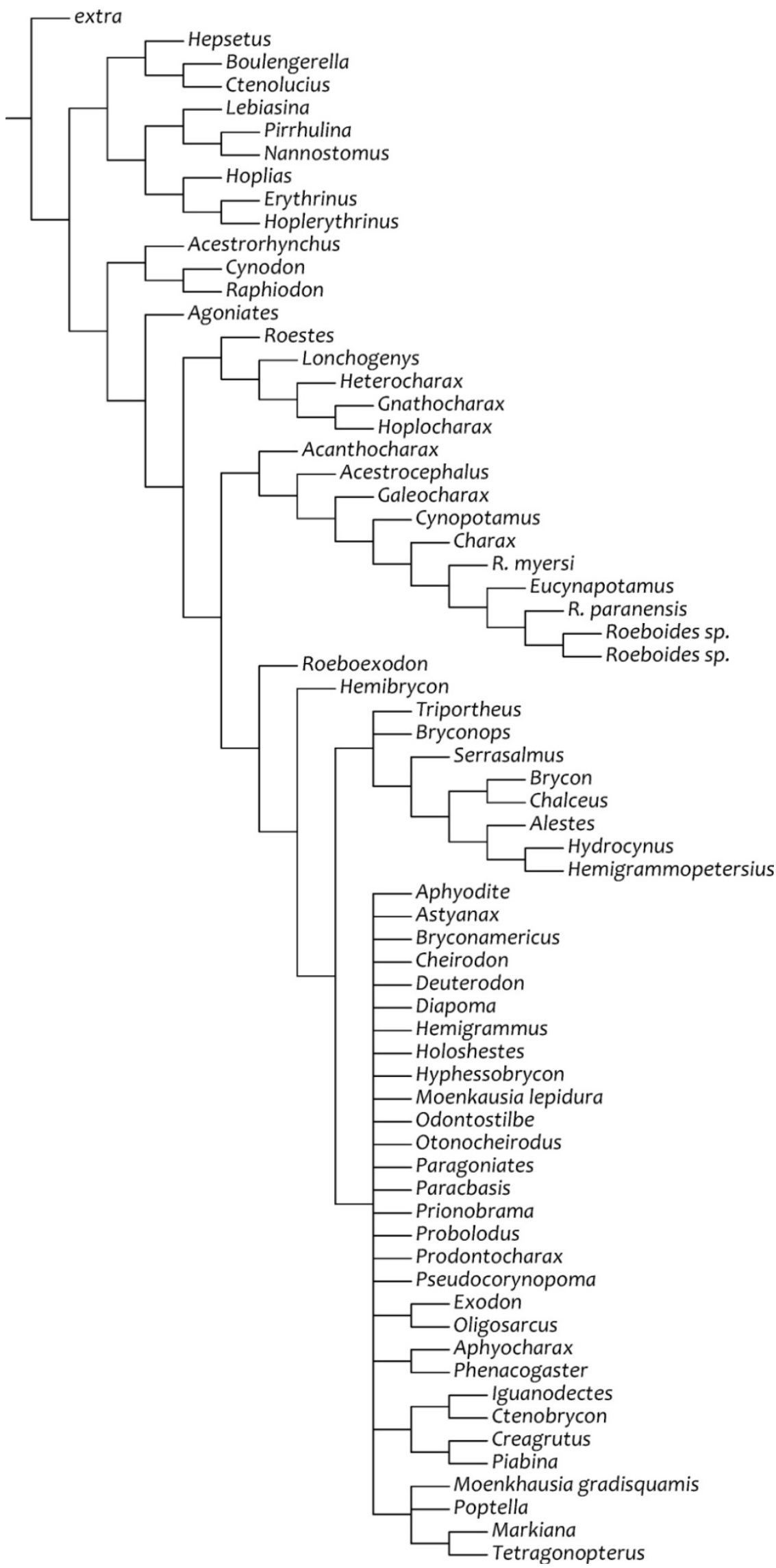

Figura 32. Relações filogenéticas na família Characidae segundo Lucena (1993) (modificado, porém sem alteração da hipótese do autor). 


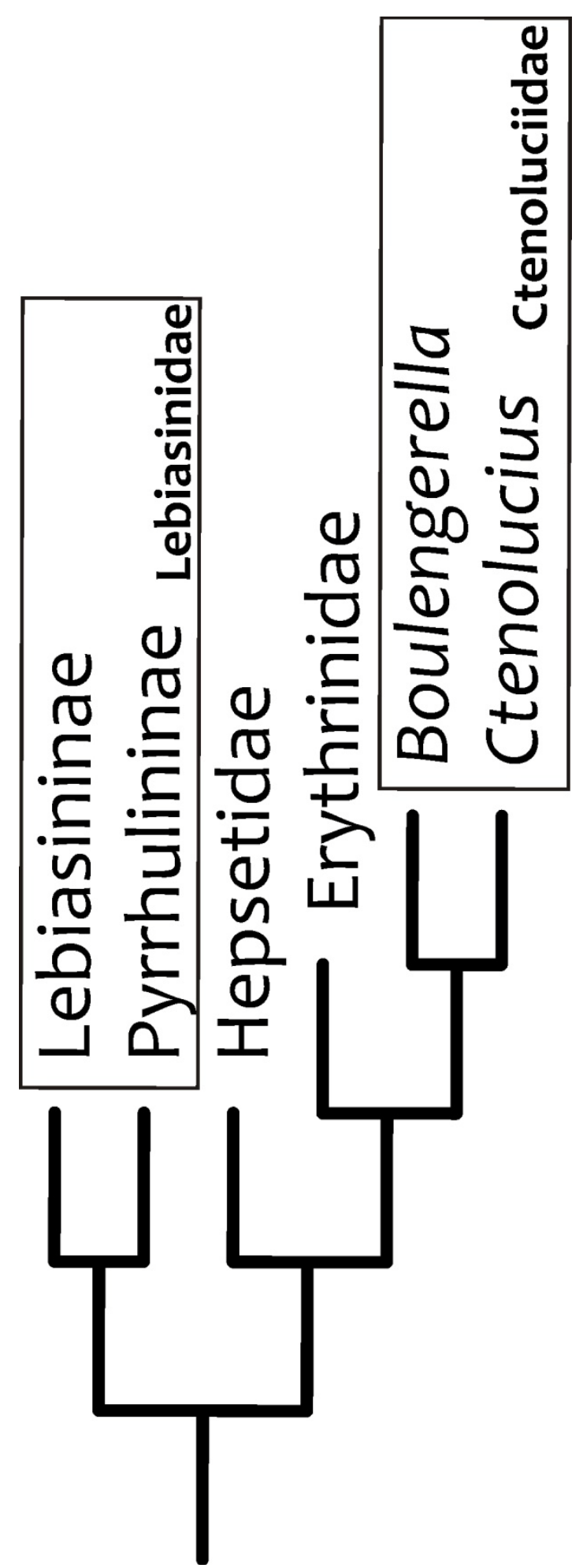

Figura 33. Relações filogenéticas dos de Ctenoluciidaee suas relações com outros Characiformes de acordo com Vari (1995) (modificado, porém sem alteração da hipótese do autor). 


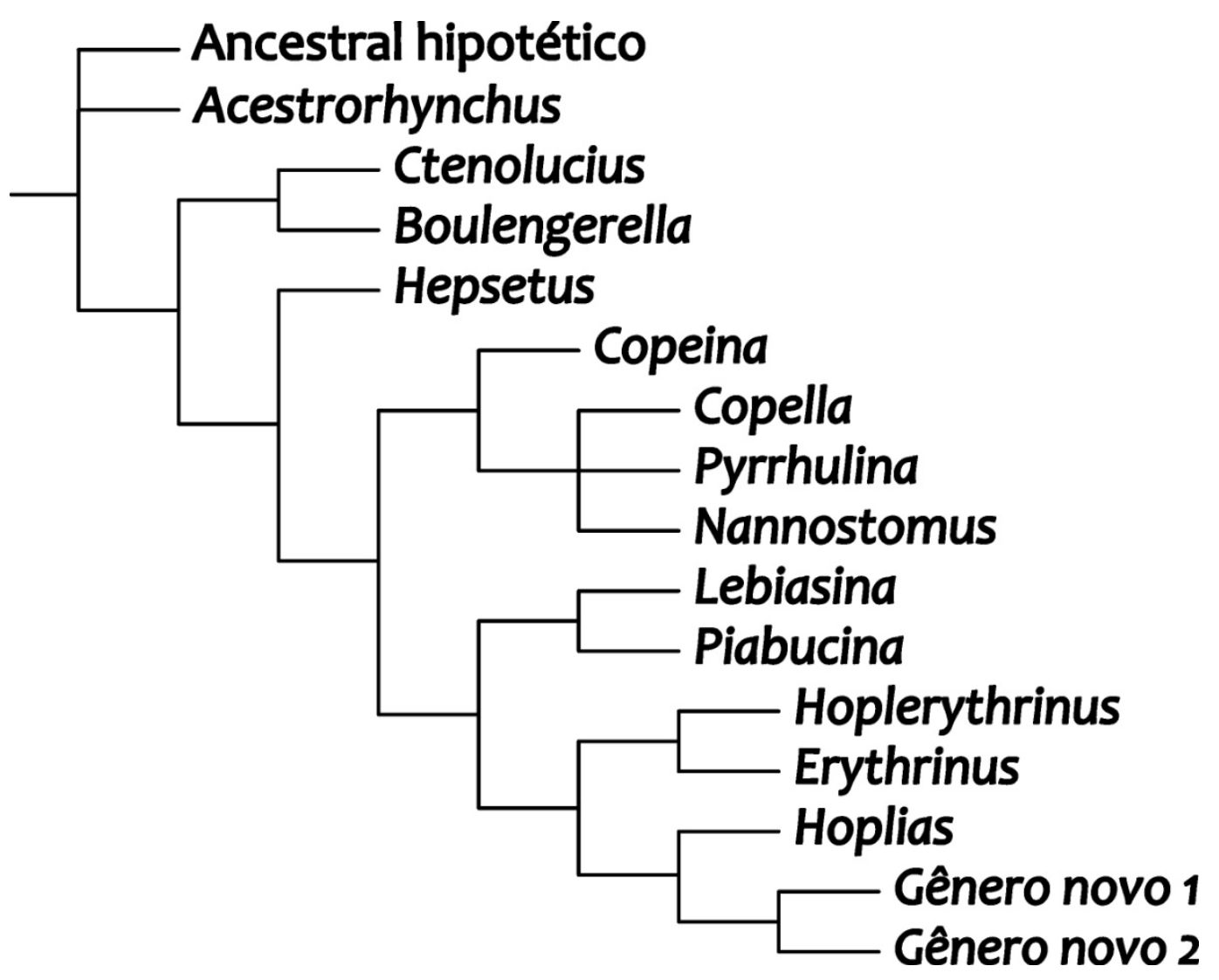

Figura 34. Hipótese das relações das famílias Erythrinidae, Lebiasinidae e Pyrrhulinidae segundo Oyakawa (1998) (modificado, porém sem alteração da hipótese do autor). 


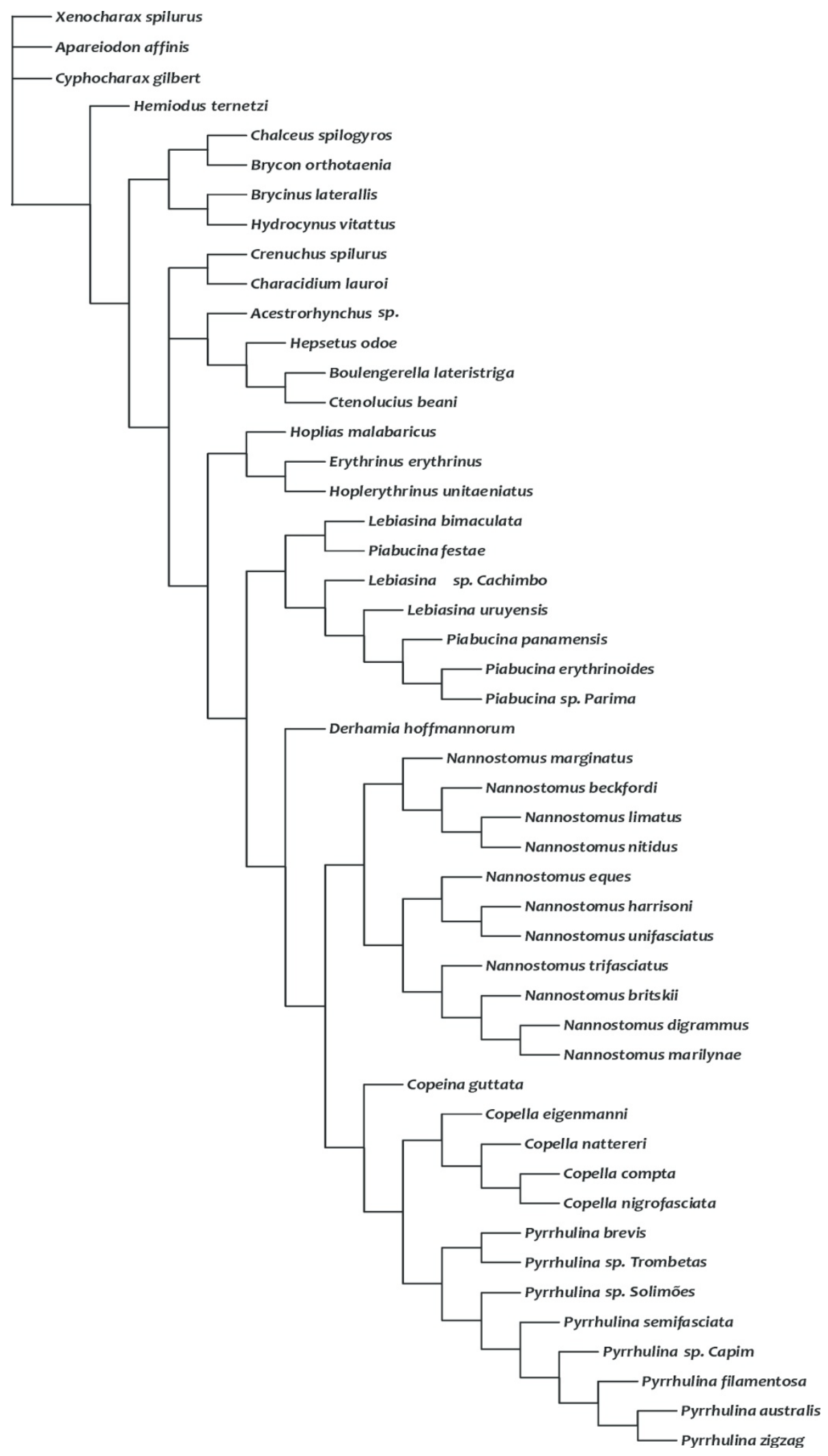

Figura 35. Consenso estrito das relações filogenéticas entre os gêneros de Lebiasinidae e a relação com outras famílias de Characiformes de acordo com Netto-Ferreira (2006) (modificado, porém sem alteração da hipótese do autor). 


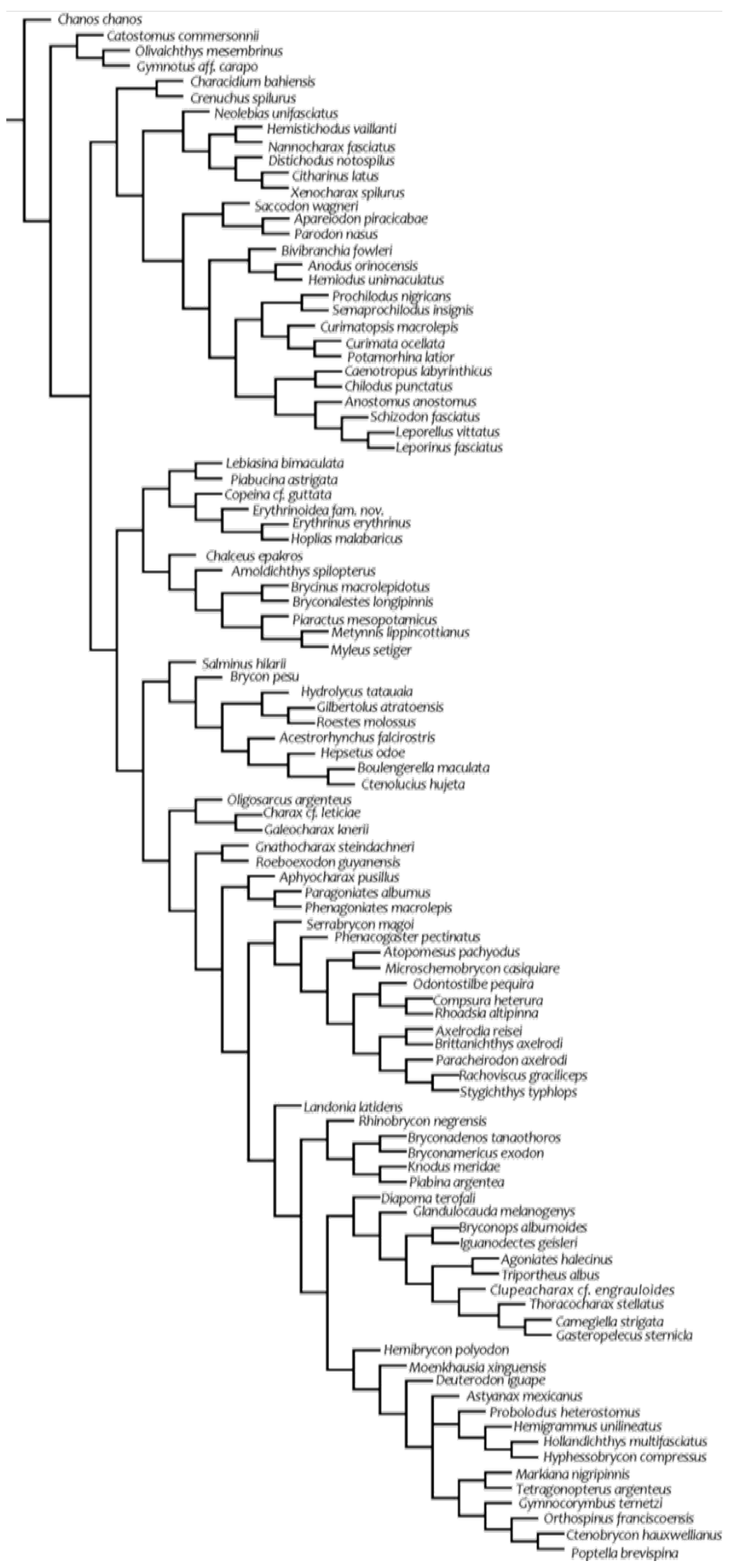

Figura 36. Cladograma de consenso estrito das relações filogenéticas na ordem Characiformes segundo Moreira (2007) (modificado, porém sem alteração da hipótese do autor). 


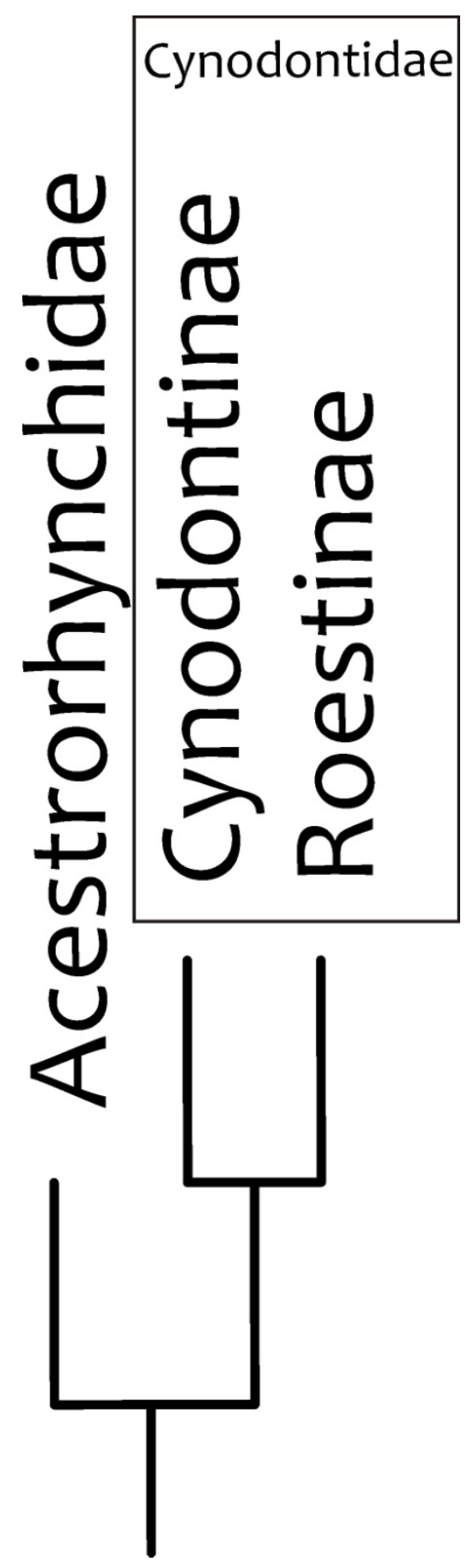

Figura 37. Cladograma de consenso estrito das relações filogenéticas na ordem Characiformes segundo Moreira (2007) (modificado, porém sem alteração da hipótese do autor). 


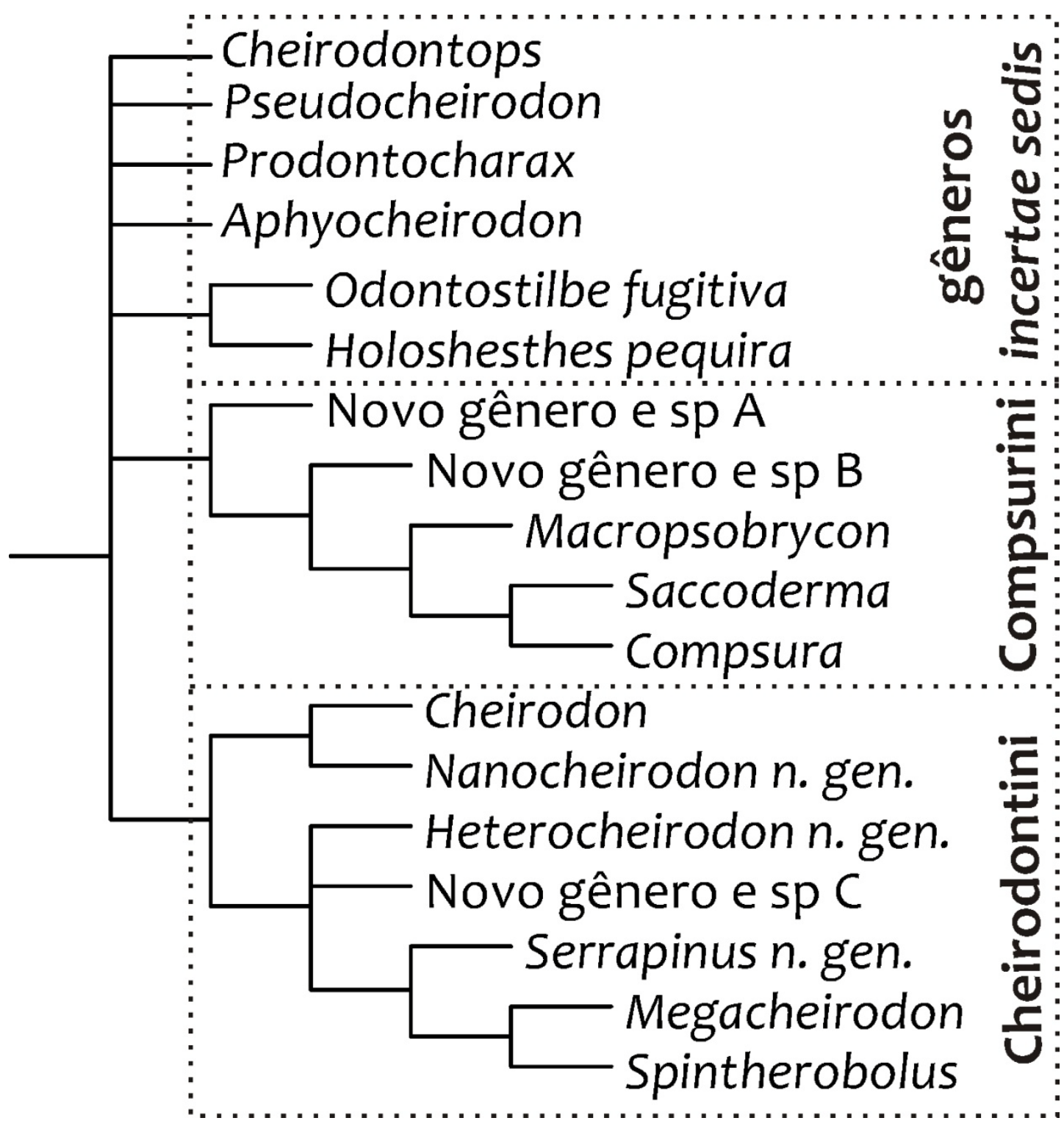

Figura 38. Cladograma de consenso estrito das relações filogenéticas entre os gêneros de Cheirodontinae sem os caracteres 60 e 72 (opção do autor) segundo Malabarba (1998). Cladograma modificado, porém sem alteração da hipótese do autor. 


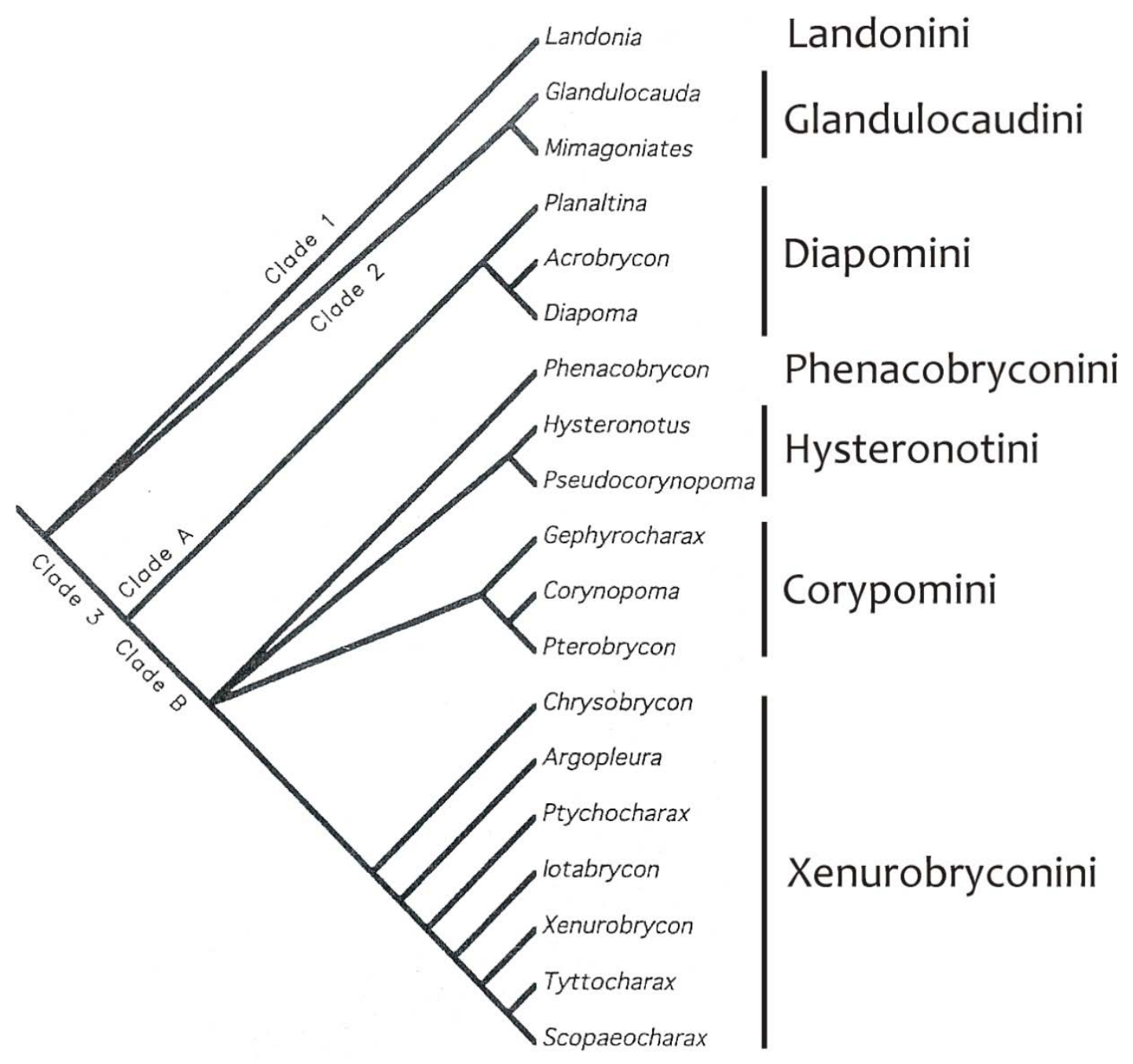

Figura 39. Hipótese das relações filogenéticas entre os gêneros de Glandulocaudinae de Weitzman \& Menezes (1998). Cladograma modificado, porém sem alteração da hipótese do autor. 


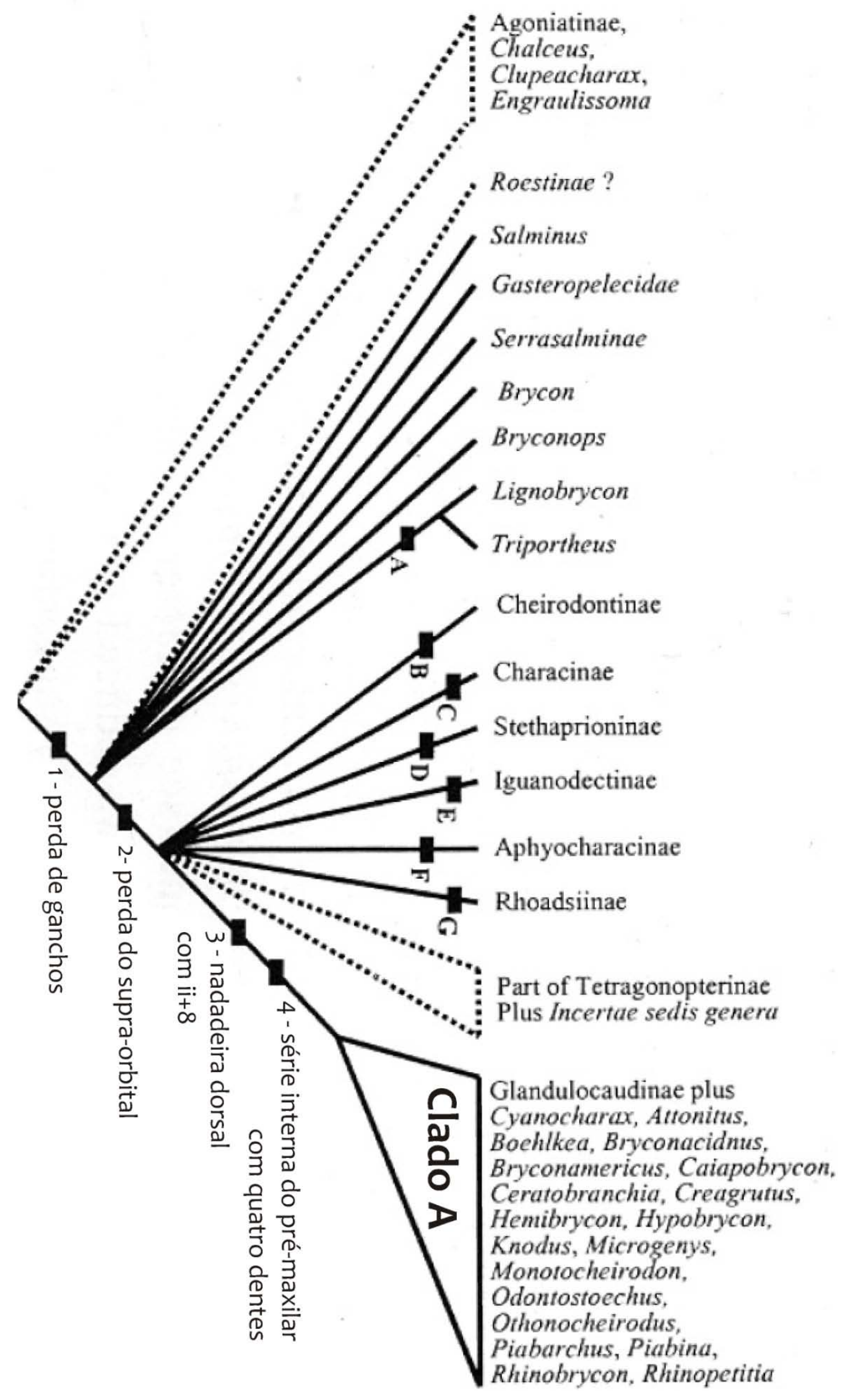

Figura 40. Representação das relações entre gêneros de Characidae segundo Weitzman \& Menezes (2003). 


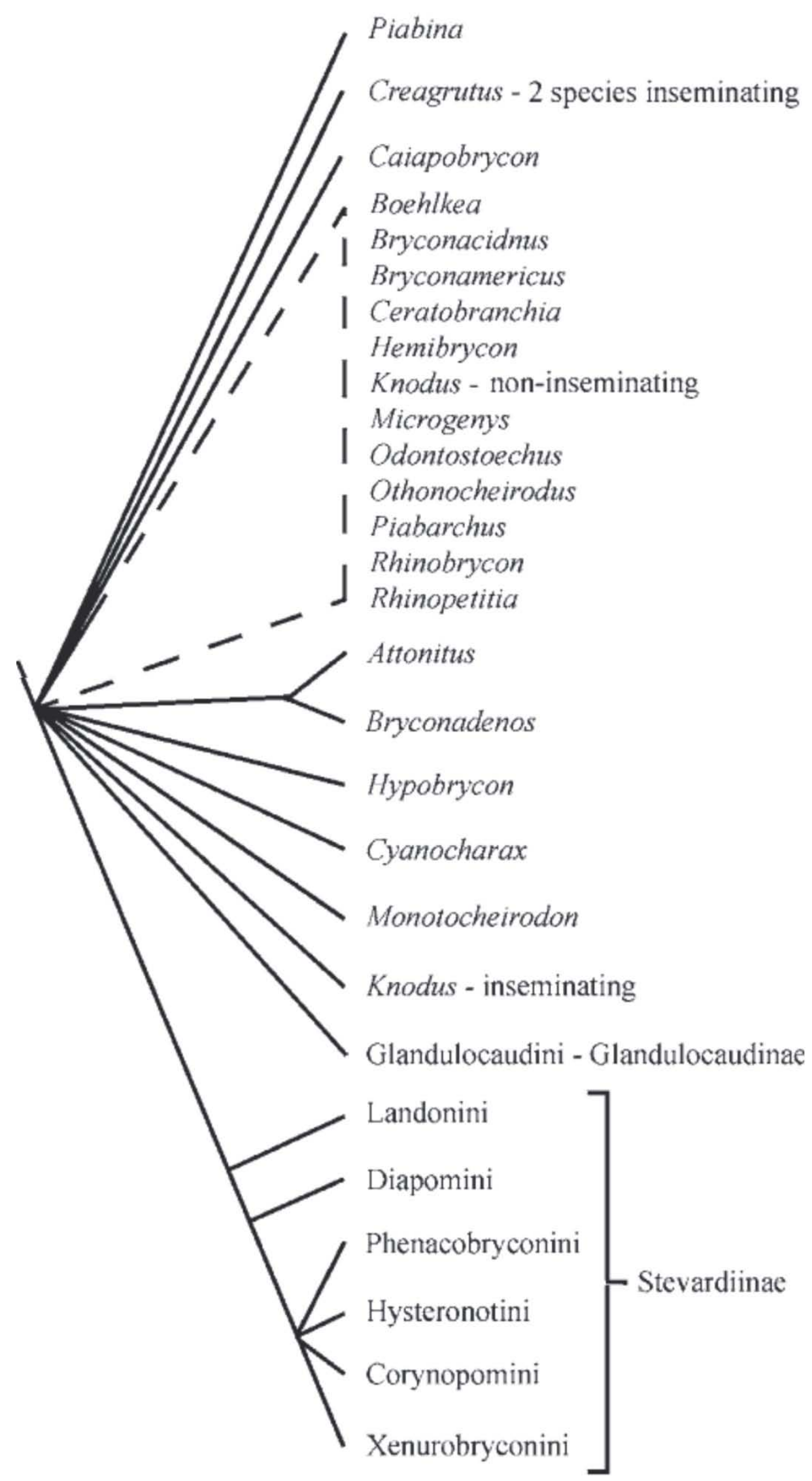

Figura 41. Relações entre os Glandulocaudinae e Stevardiinae segundo Weitzman et al. (2005). 


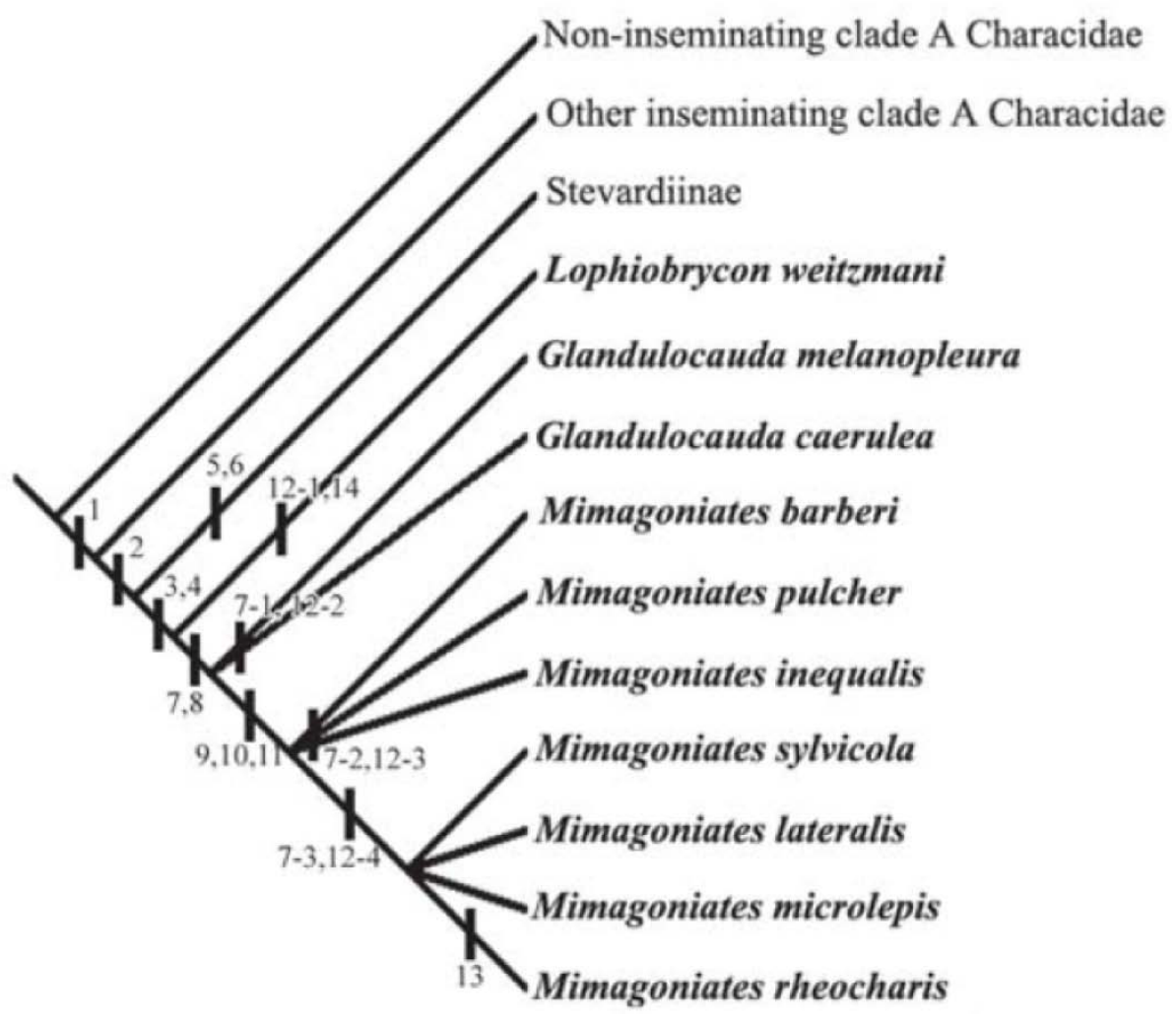

Figura 42. Relações entre os Glandulocaudini segundo Menezes \& Weitzman (2009). 


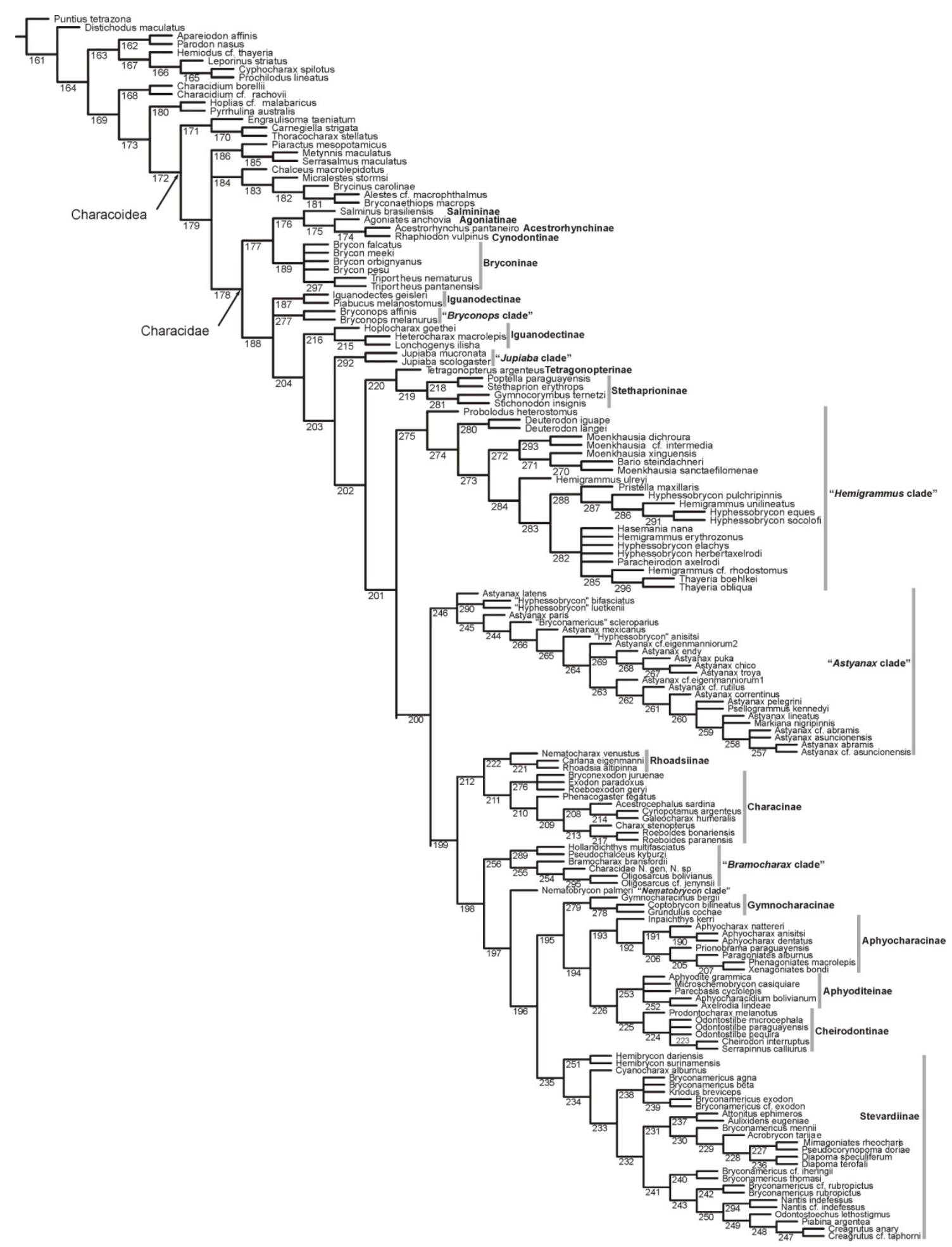

Figura 43. Hipótese das relações em Characidae de Mirande (2009) usando a pesagem implícita. Cladograma modificado, porém sem alteração da hipótese do autor. 


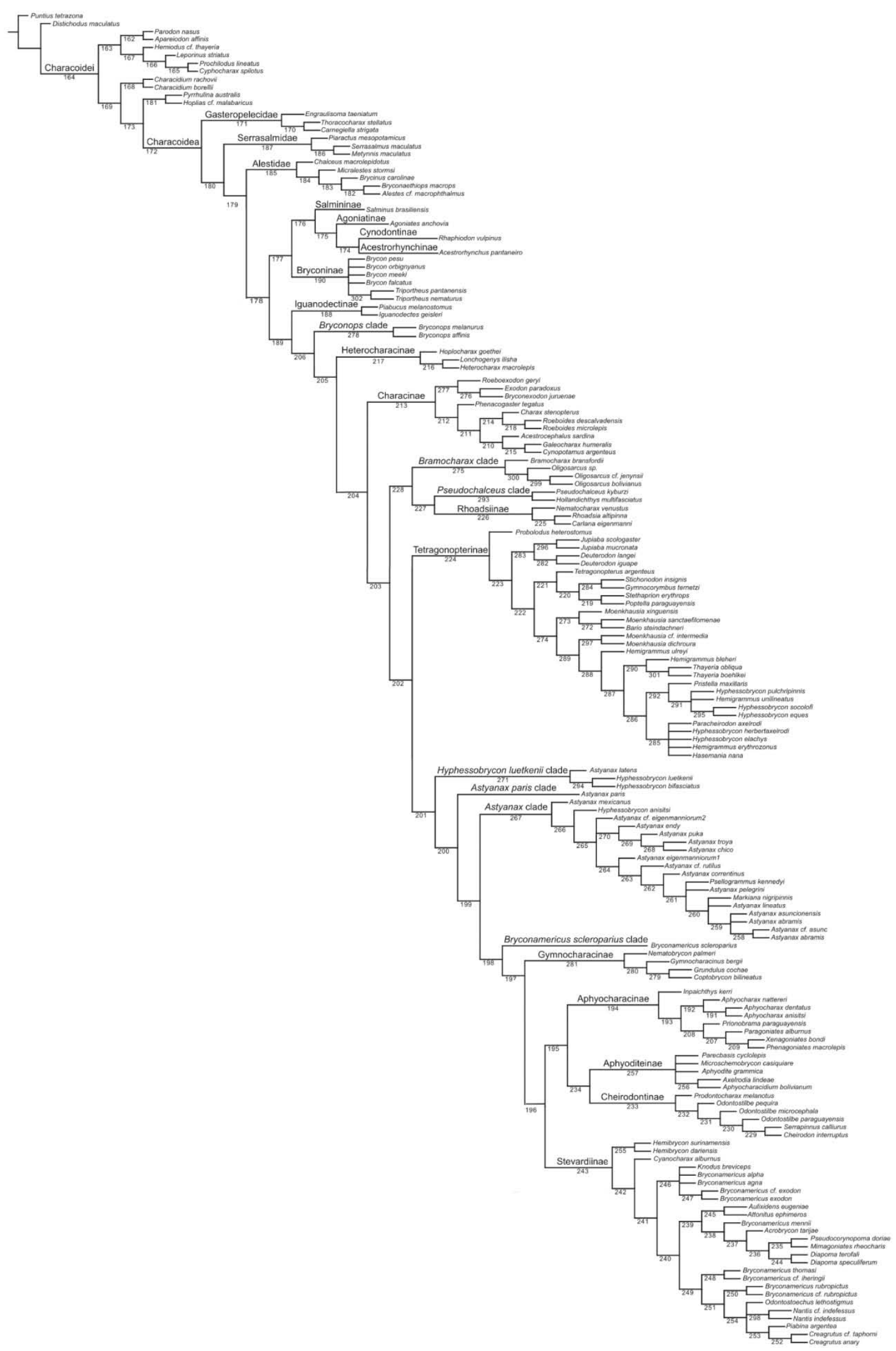

Figura 44. Hipótese das relações entre as grandes linhagens de Characidae segundo Mirande (2010). 


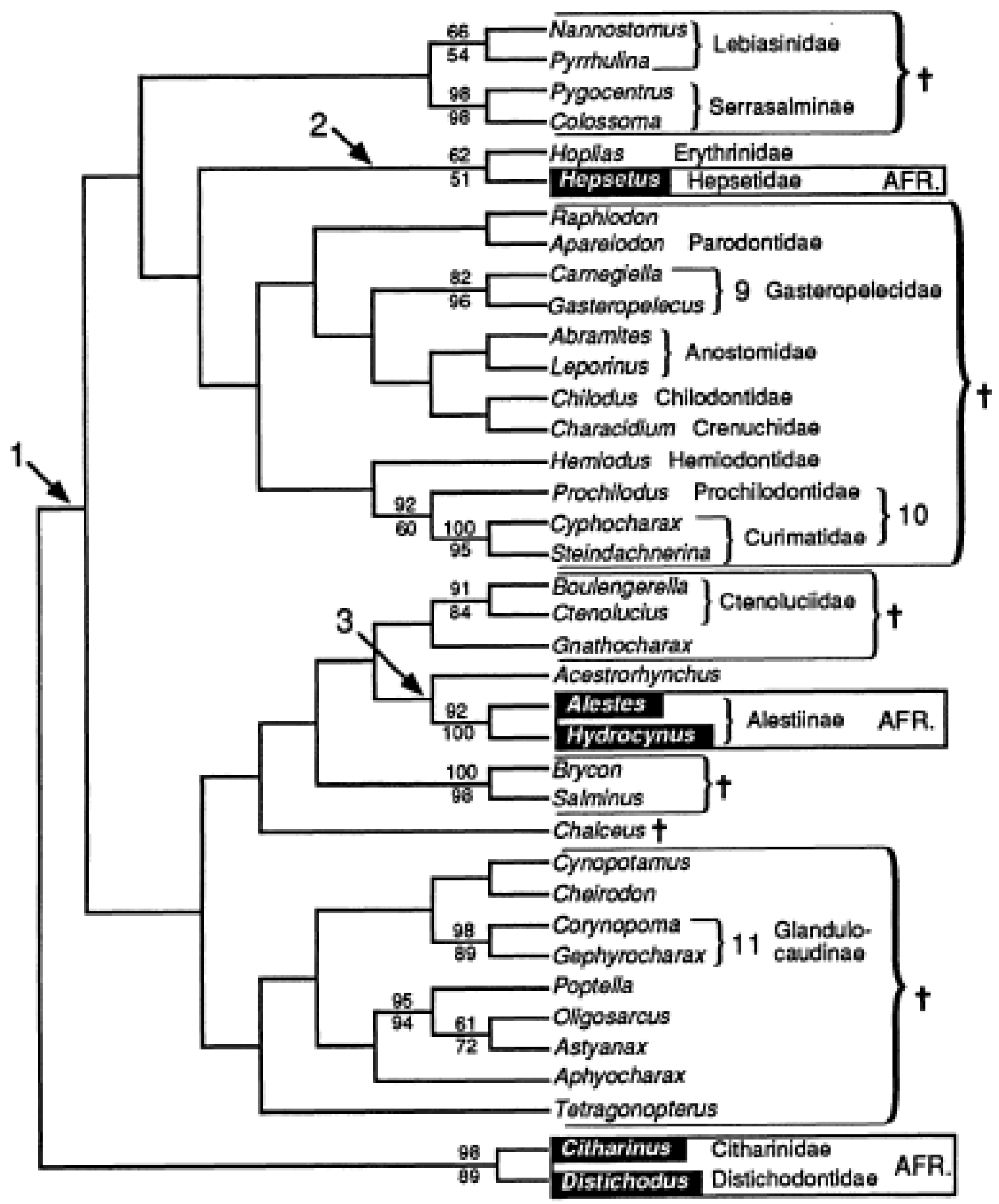

Figura 45. Hipótese das relações entre os Characiformes segundo Orti \& Meyer (1997). 


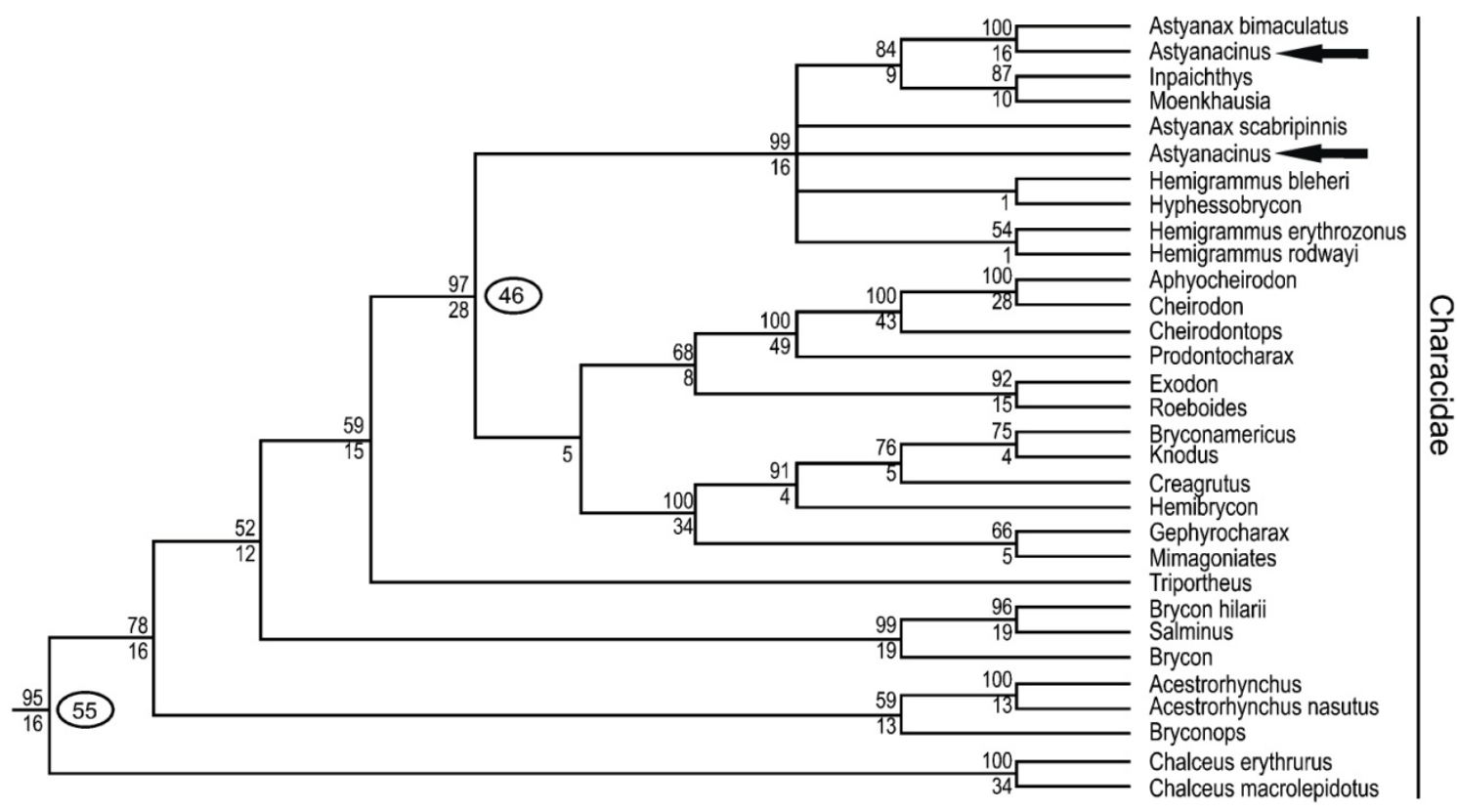

Figura 46. Relações de parentesco entre os Characidae Neotropicais segundo Calcagnotto et al. (2005). Setas indicam a posição das espécies de Astyanacinus na topologia. 


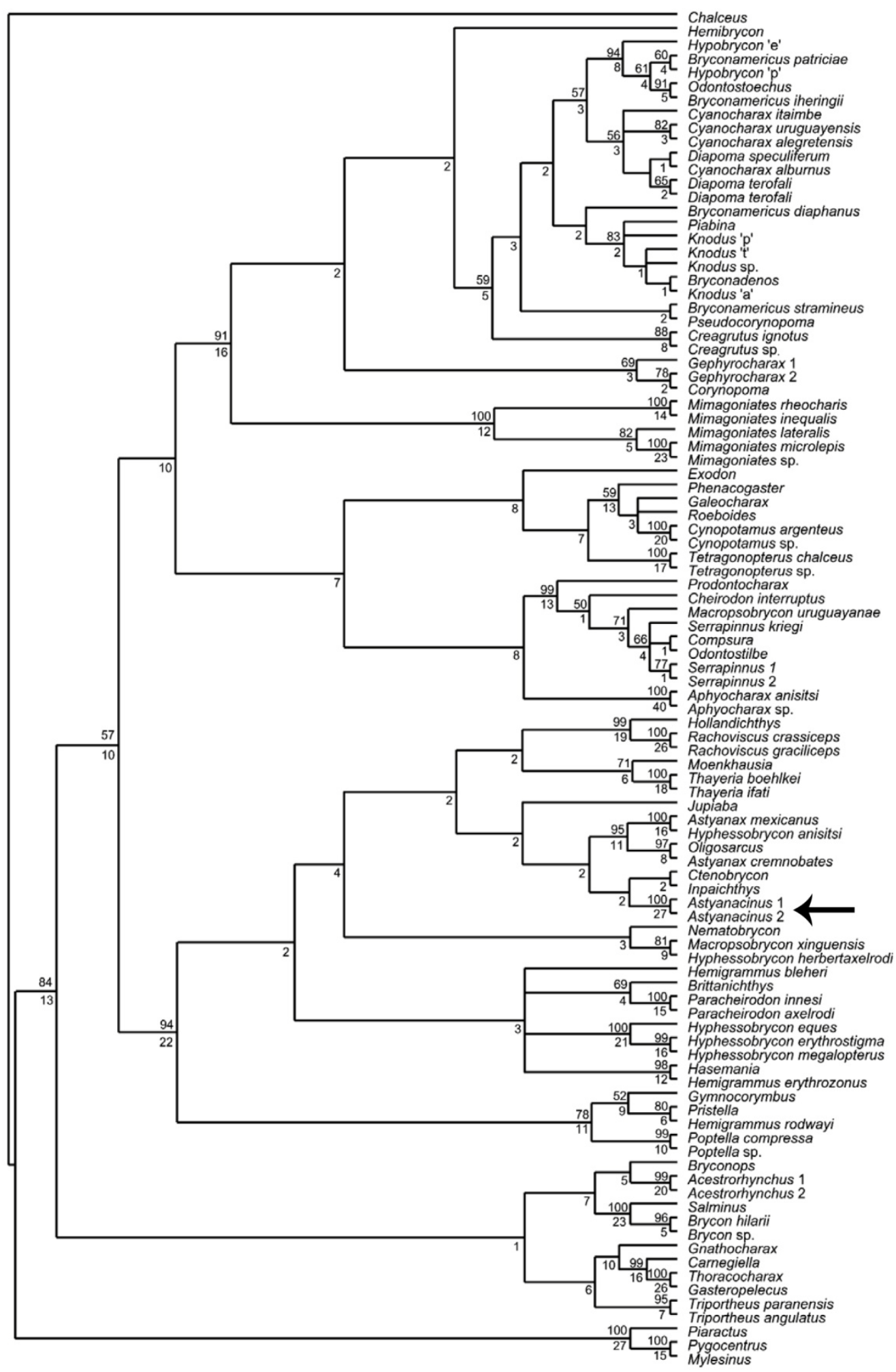

Figura 47. Hipótese das relações entre as grandes linhagens de Characidae segundo Javonillo et al. (2010). Seta indica a posição das espécies de Astyanacinus na topologia. 

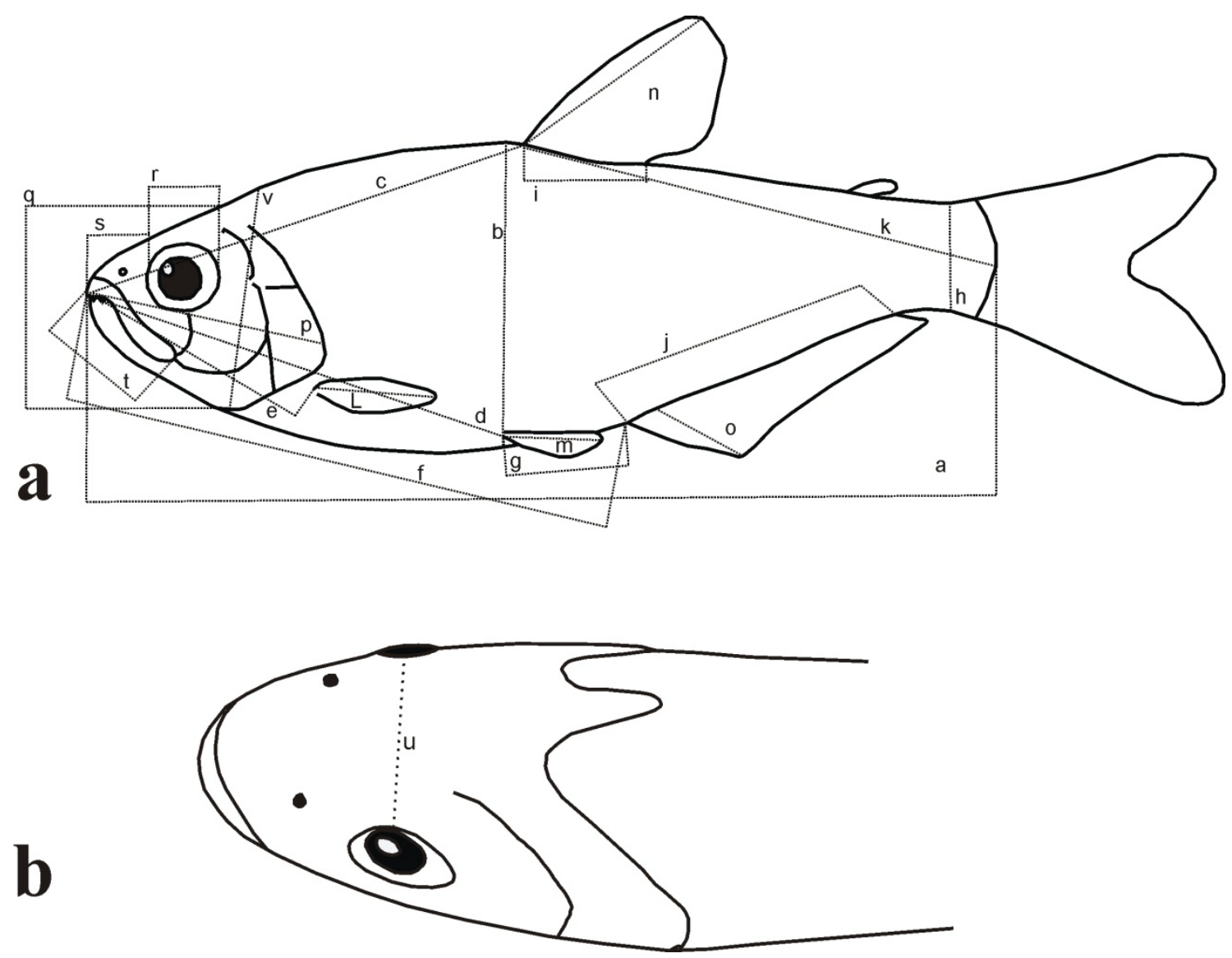

Figura 48. Dados morfométricos utilizados na revisão taxonômica do presente trabalho. Figura a é vista lateral e figura b representa vista dorsal do crânio. Todas as medidas são descritas em maiores detalhes no capítulo Materiais e Métodos. a. Comprimento padrão; b. Altura do corpo; c. Distância pré-dorsal; d. Distância pré-ventral; e. Focinhopeitoral; f. Focinho-anal; g. Pélvica-anal; h. Altura do pedúnculo caudal; i. Base da nadadeira dorsal: distância compreendida entre a inserção do primeiro e do último raio da nadadeira dorsal; j. Base da nadadeira anal; k. Distância dorsal-caudal; l. Maior raio da nadadeira peitoral; m. Maior raio da nadadeira pélvica; n. Maior raio da nadadeira dorsal; o. Maior raio da nadadeira anal; p. Comprimento da cabeça; q. Altura da cabeça; r. Diâmetro da órbita ocular; s. Comprimento do focinho; t. Distância maxilar-prémaxilar; u. Distância interorbital; v. Altura da cabeça. 


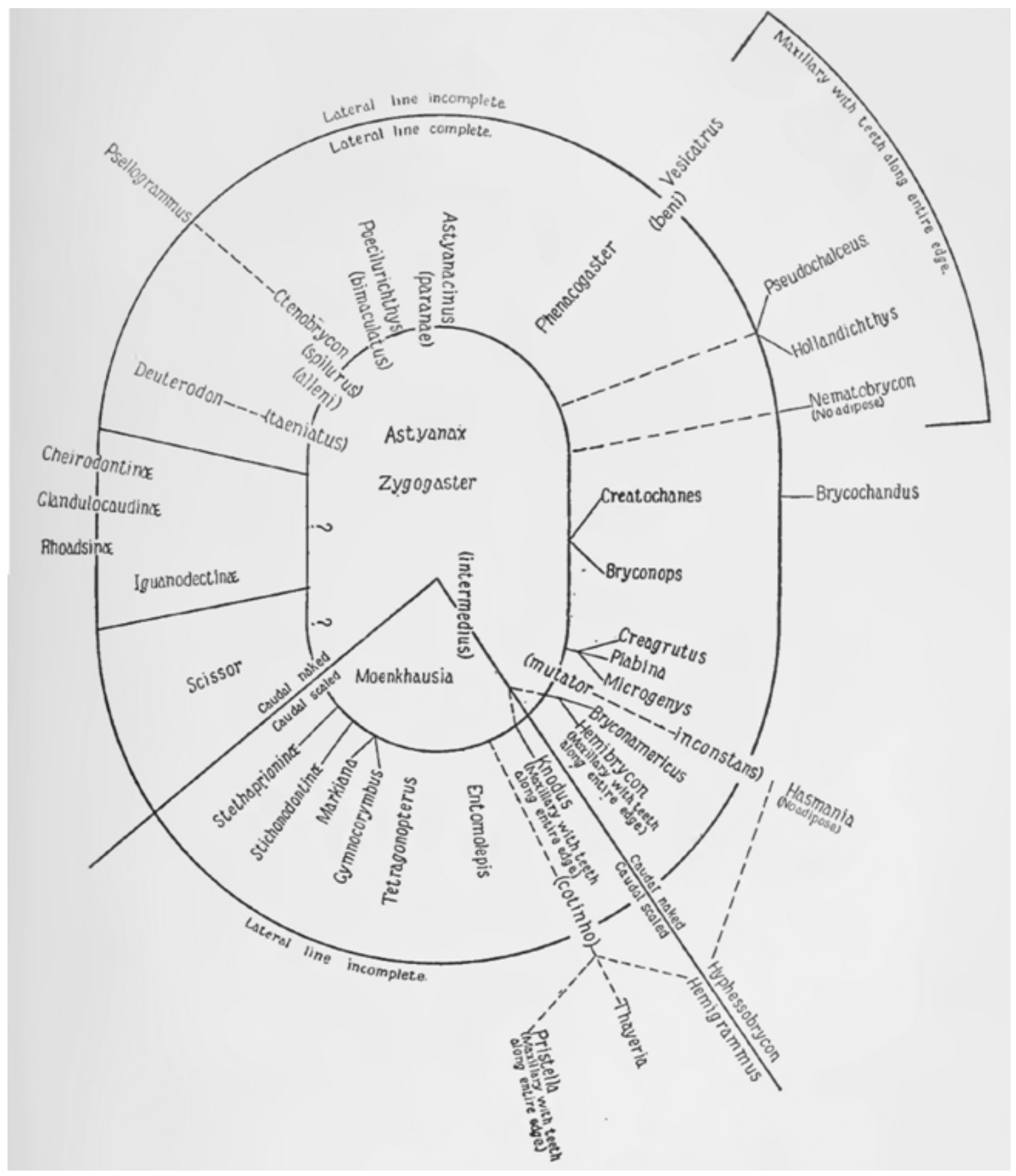

Figura 49. Diagrama apresentado por Eigenmann (1917-1921) indicando as relações entre os Tetragonopterinae. 


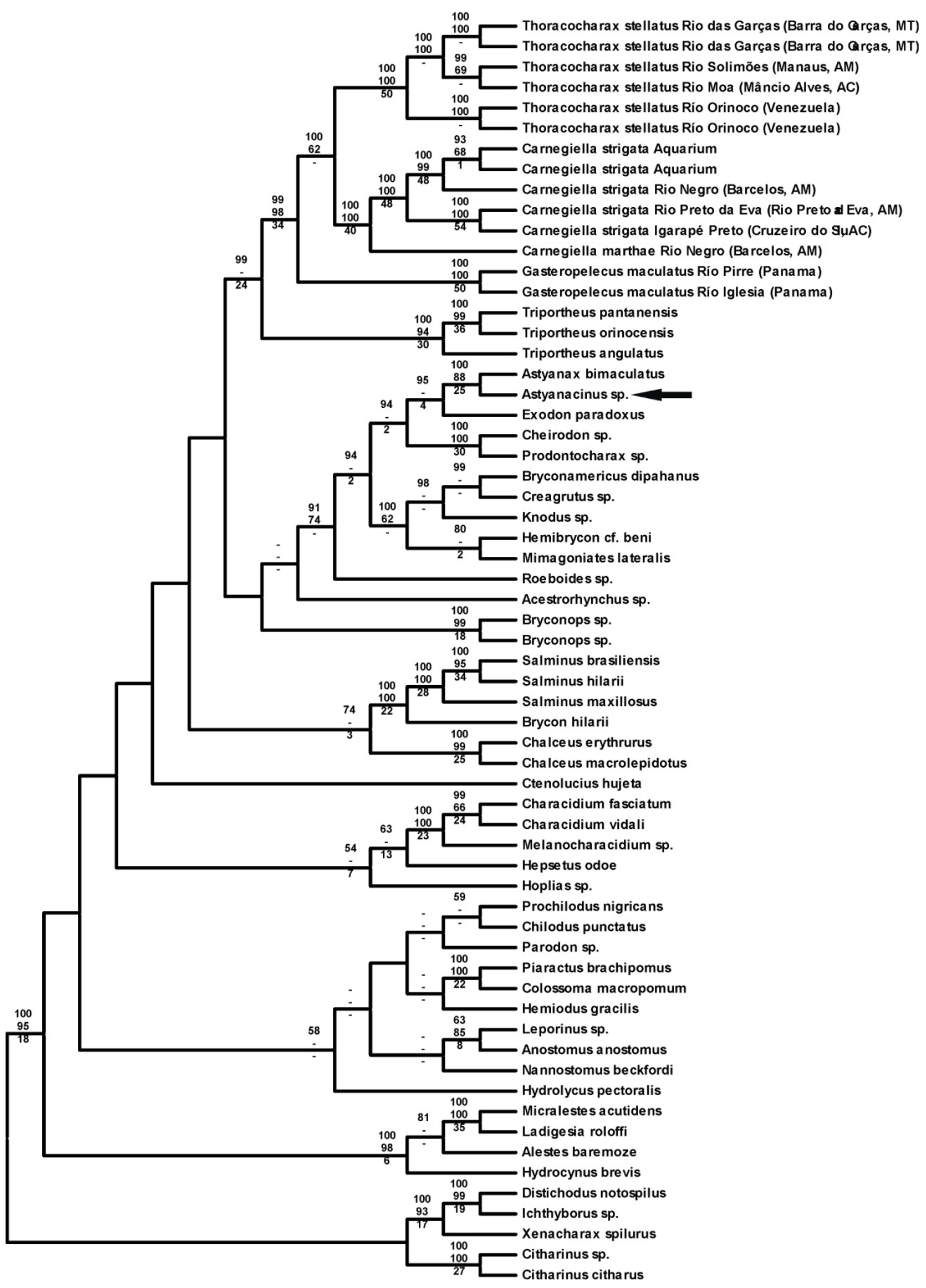

Figura 50. Hipótese das relações filogenéticas de alguns Characiformes, segundo Abe (2007). 


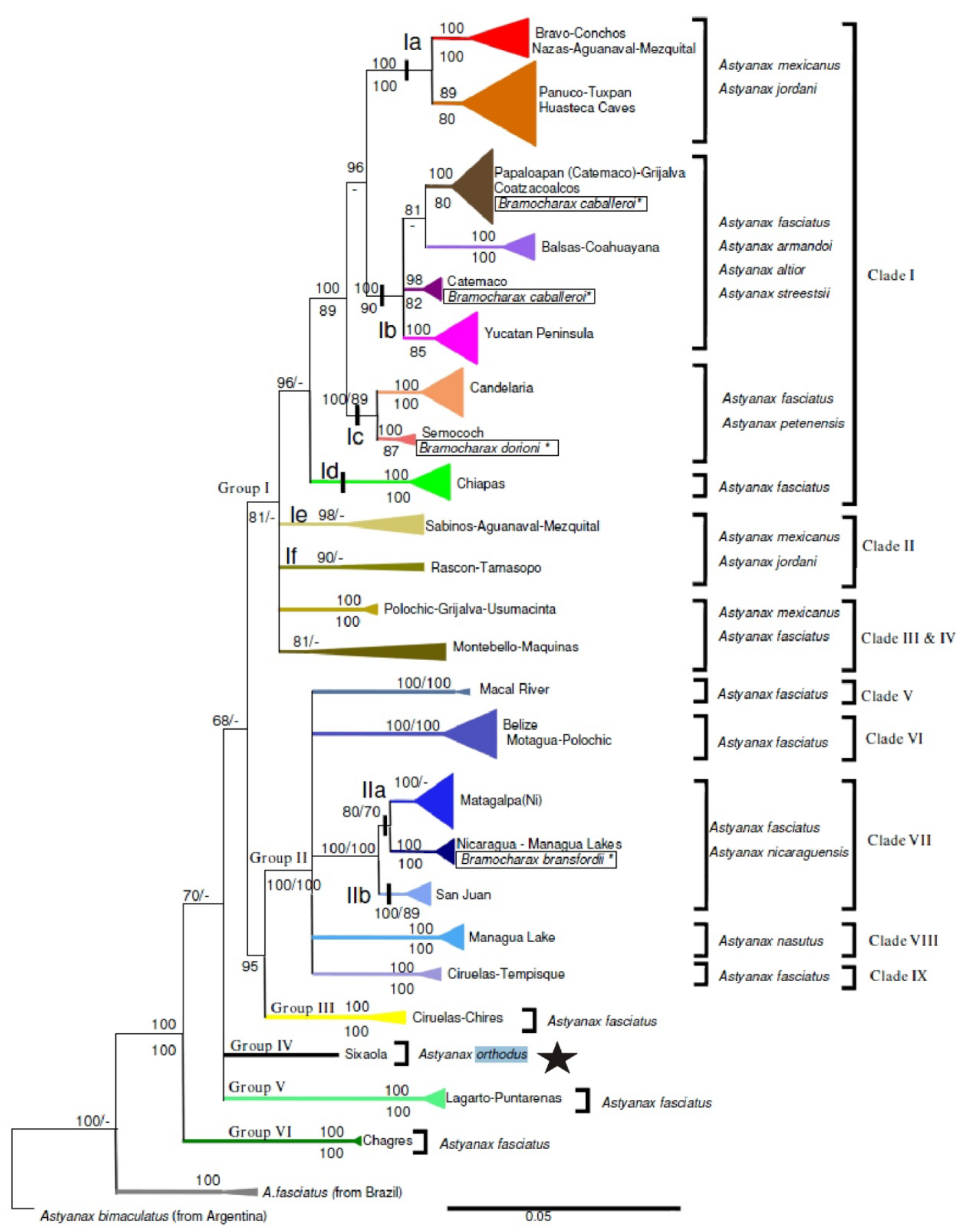

Figura 51. Hipótese das relações entre algumas espécies de Astyanax e Bramocharax centro-americanos segundo Ornelas-Garcia et al. (2008). Estrela indica posição de “Astyanax" orthodus. 


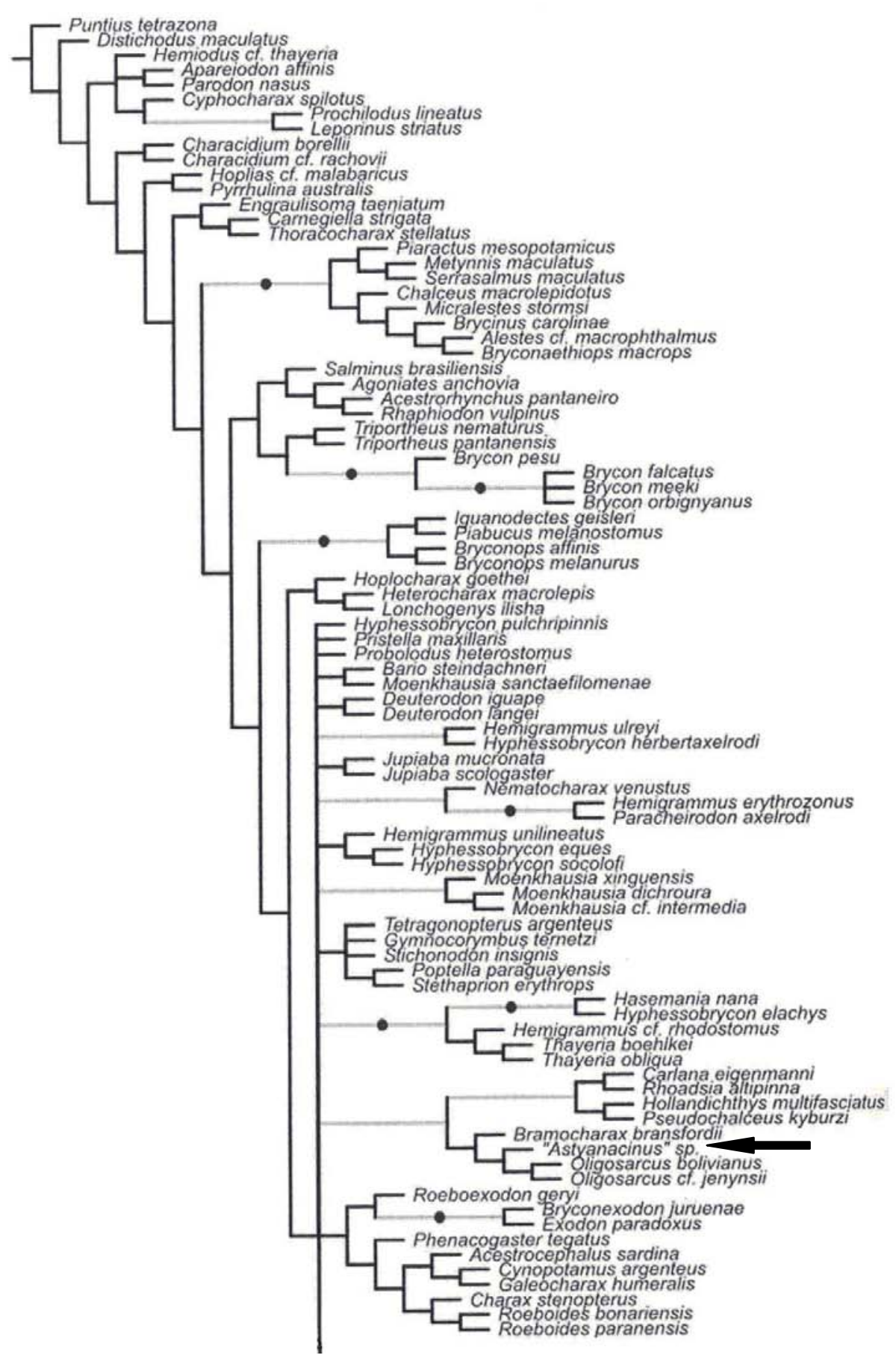

Figura 52. Parte do clado da hipótese das relações filogenéticas de Characidae, segundo Mirande (2007). 

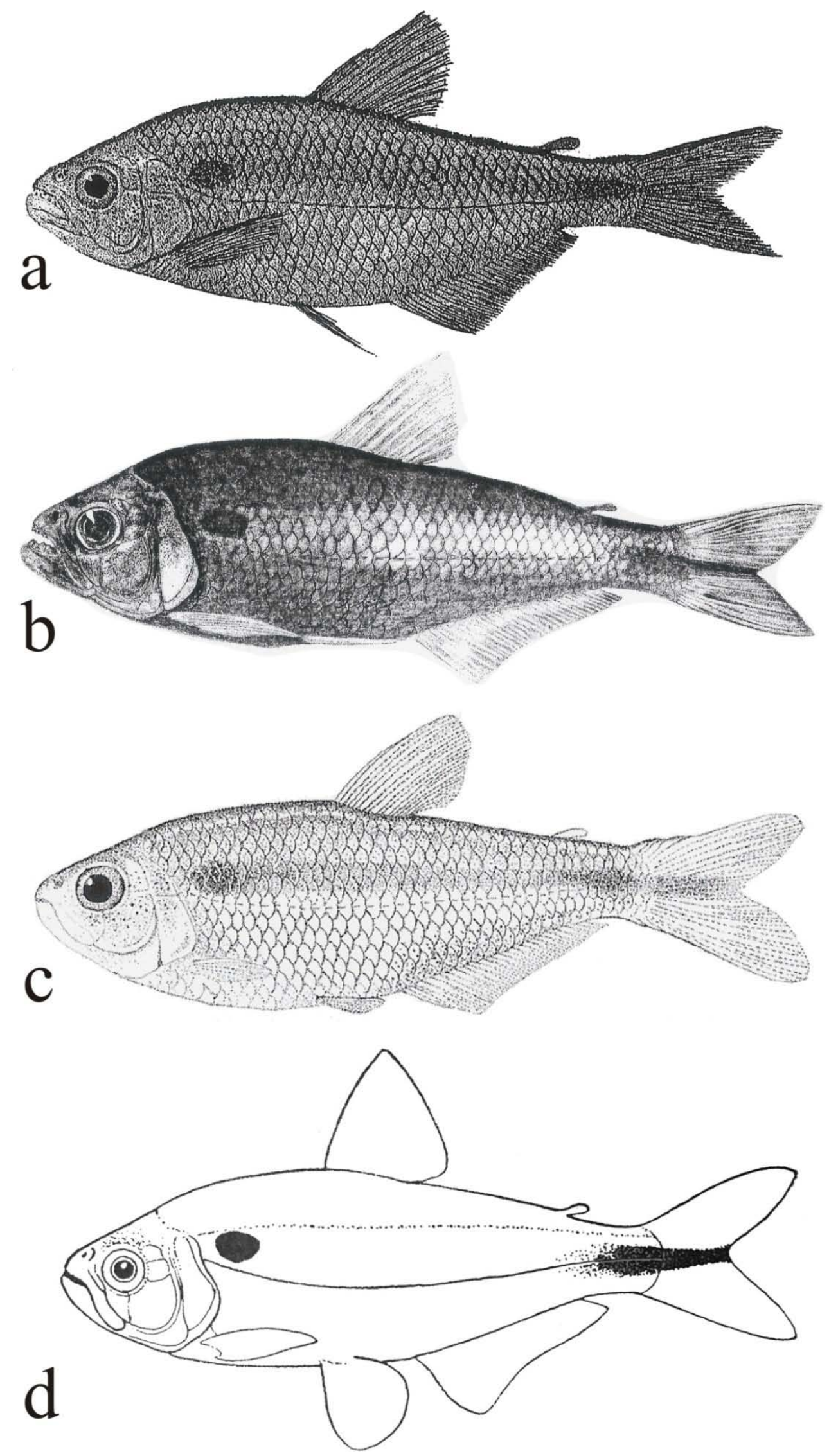

Figura 53. Diferentes ilustrações de Astyanacinus moorii presentes nas publicações de: a) Boulenger (1892); b) Eigenmann (1917-1929); c) Britski et al. (2007); d) Fowler (1948). 


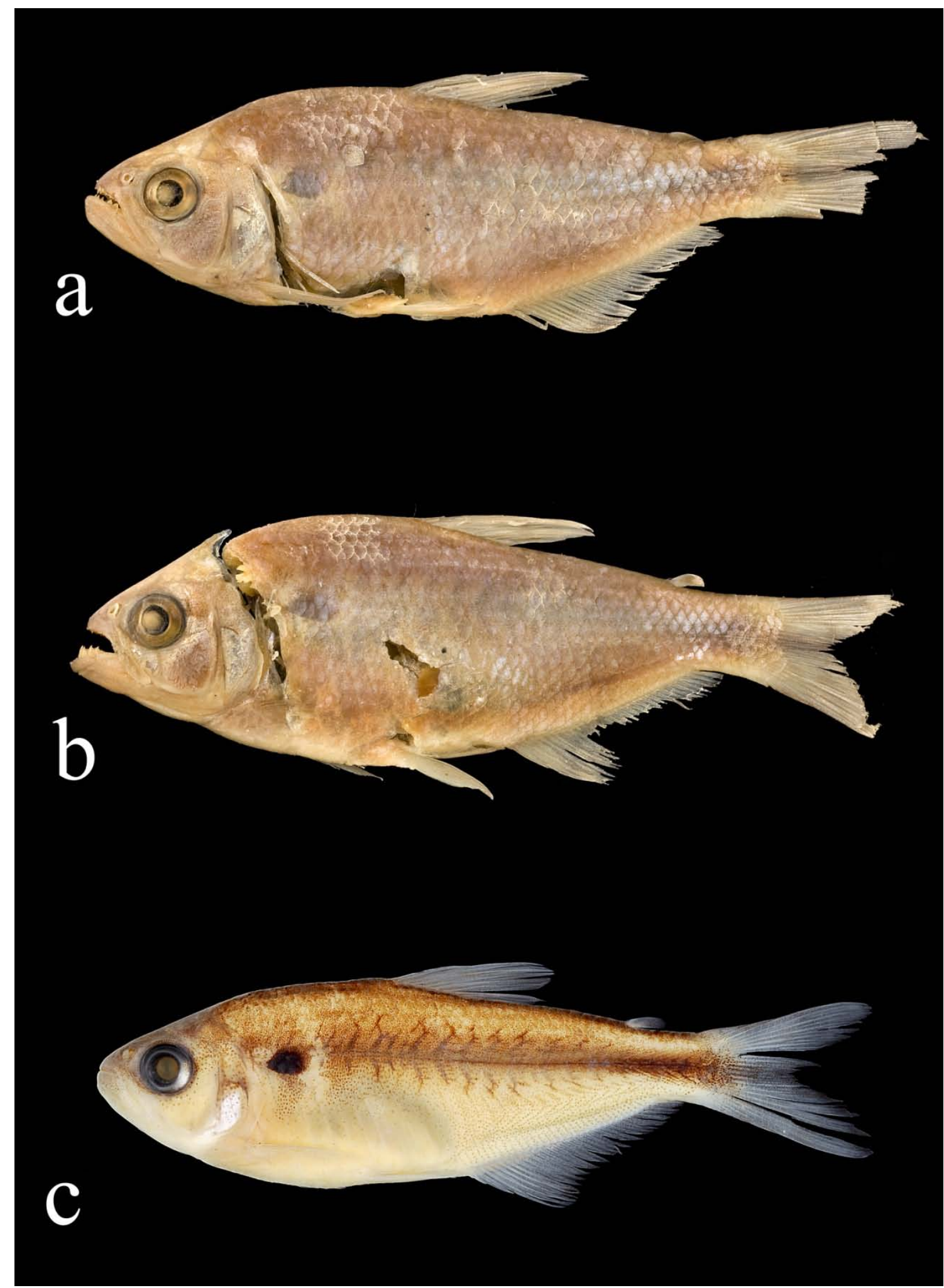

Figura 54. Astyanacinus moorii: a. e b. Síntipos (BMNH 1892.4.20.50-51, foto Natural History Museum, London); c. Topótipo (MZUSP 78752, Foto: Ricardo M. C. Castro) com 43,3mm CP. 


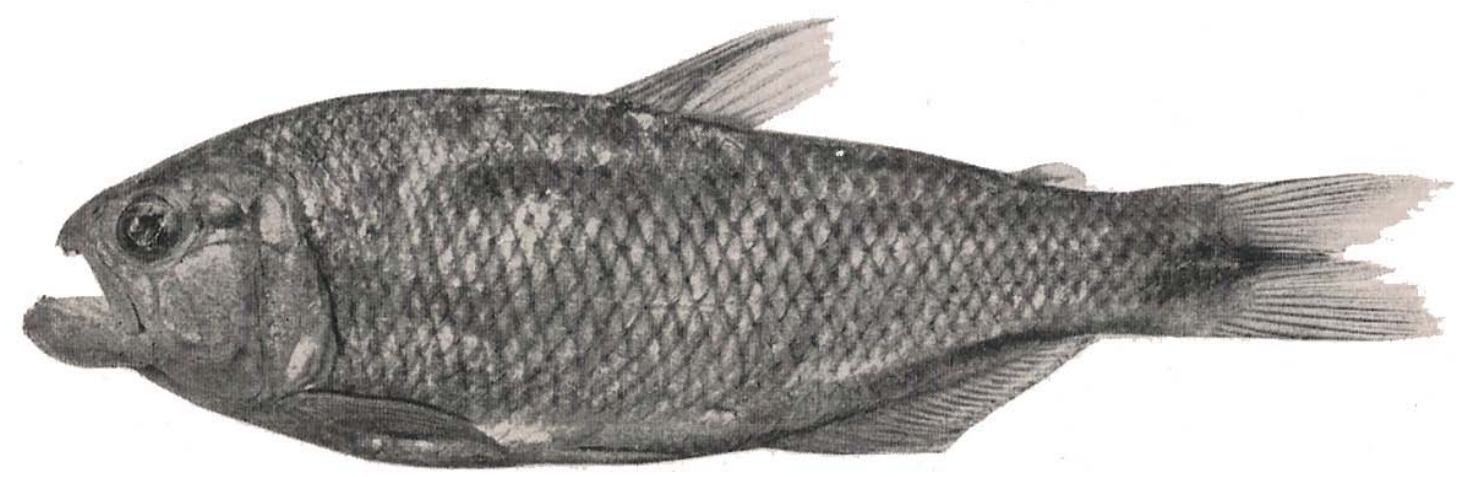

Figura 55. Figura de Astyanacinus multidens presente na publicação de Pearson (1924). “Cotype”, nº 17323, 122 mm.

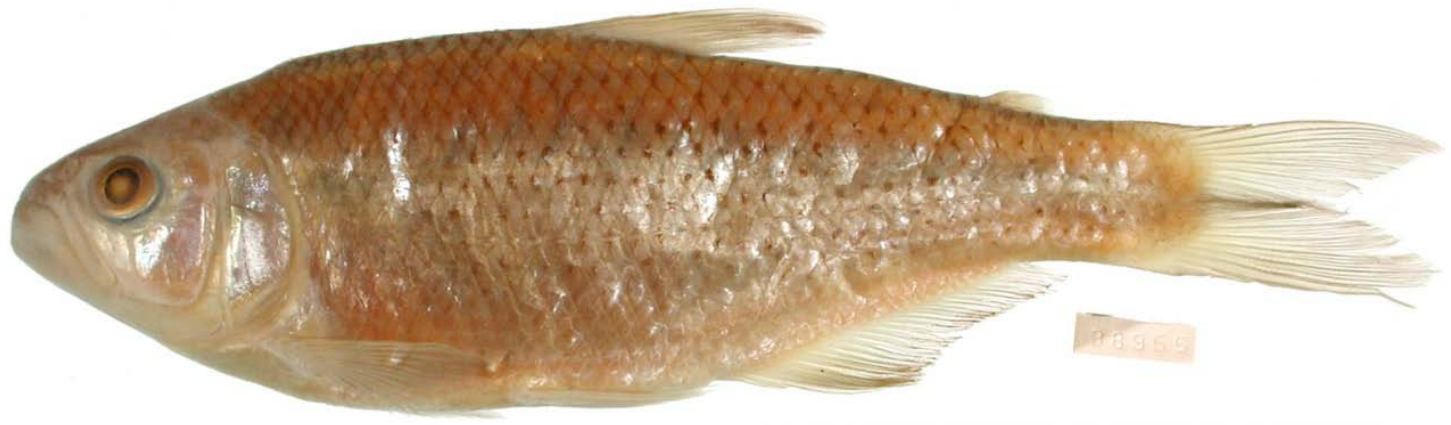

Figura 56. Síntipo de Astyanacinus multidens CAS 38955 (IU 17323). (Foto: CAS)

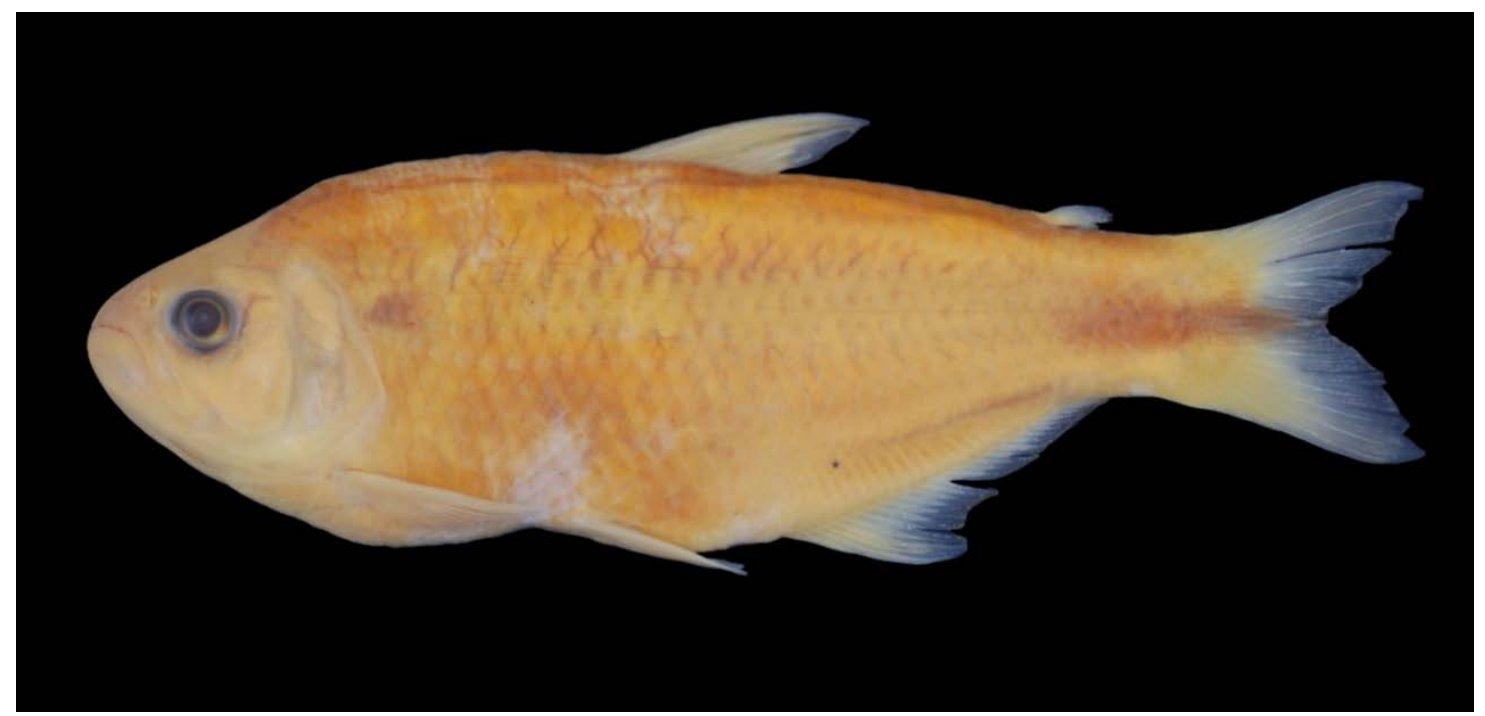

Figura 57. Astyanacinus multidens MZUSP 27829 (94,0 mm CP). 


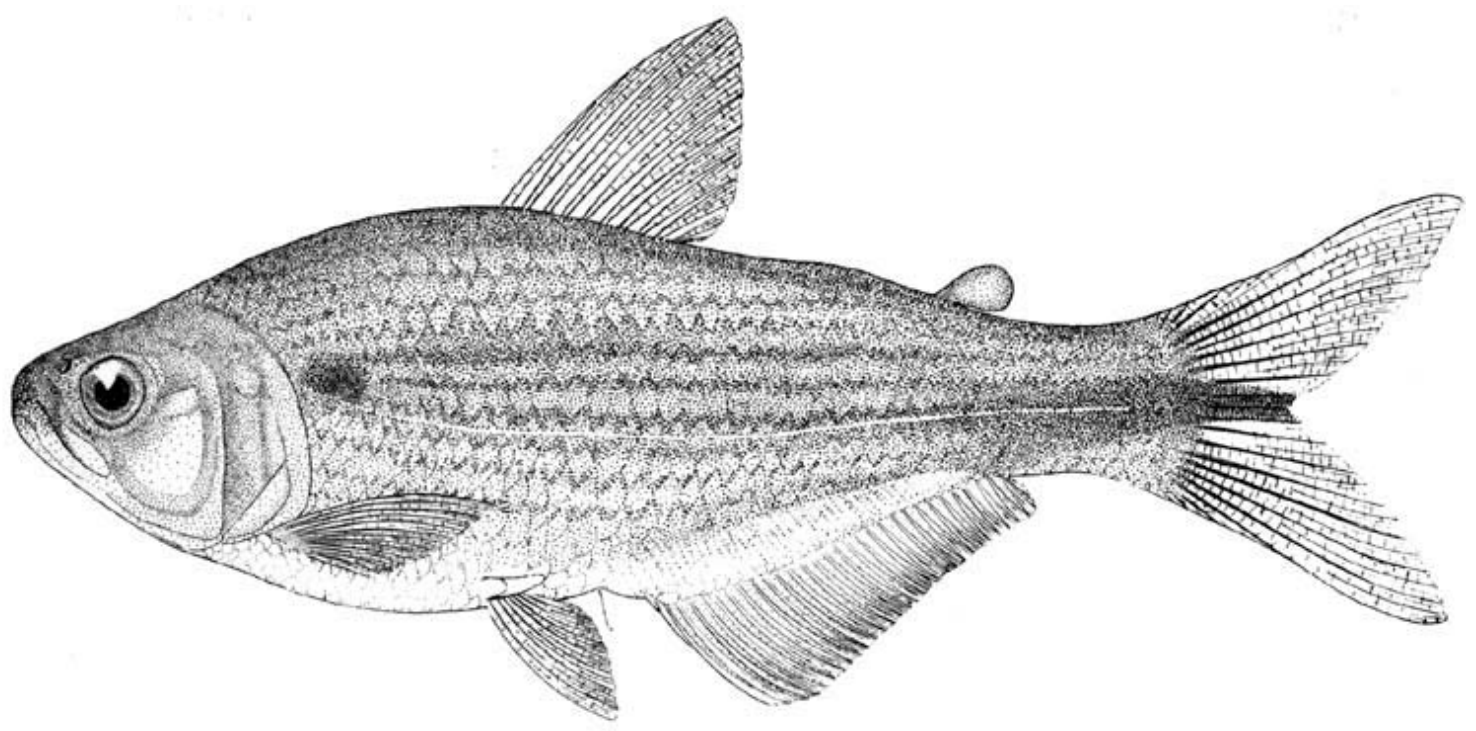

Figura 58. Ilustração do holótipo de “Astyanax" superbus (retirado de Myers (1942)).

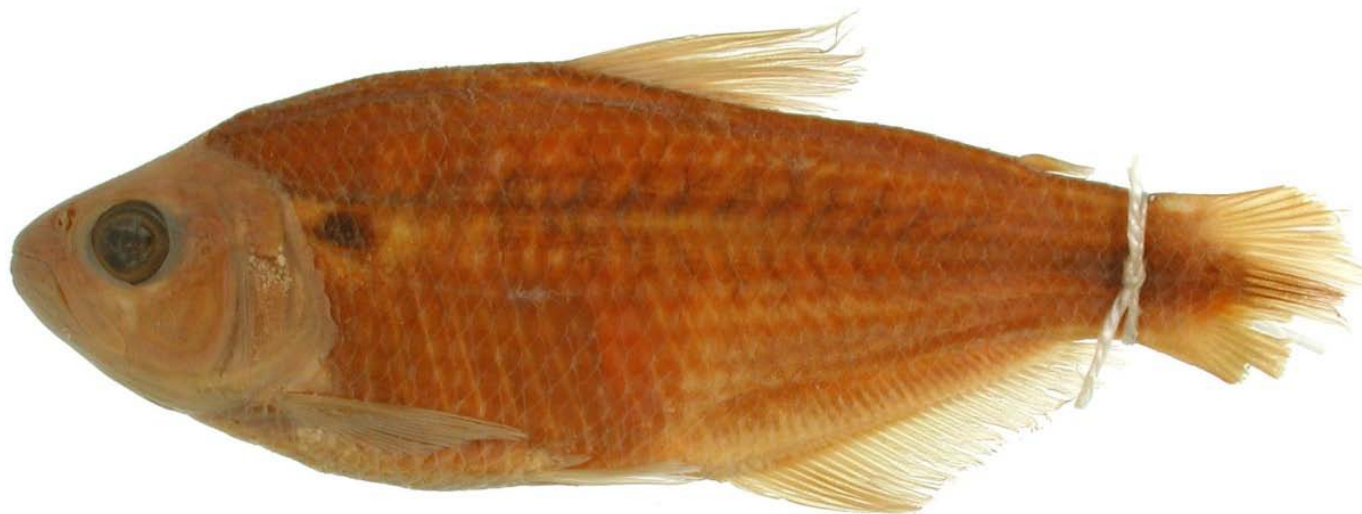

Figura 59. Holótipo de “Astyanax" superbus SU 36489, macho, 107 mm CP. (Foto: CAS)

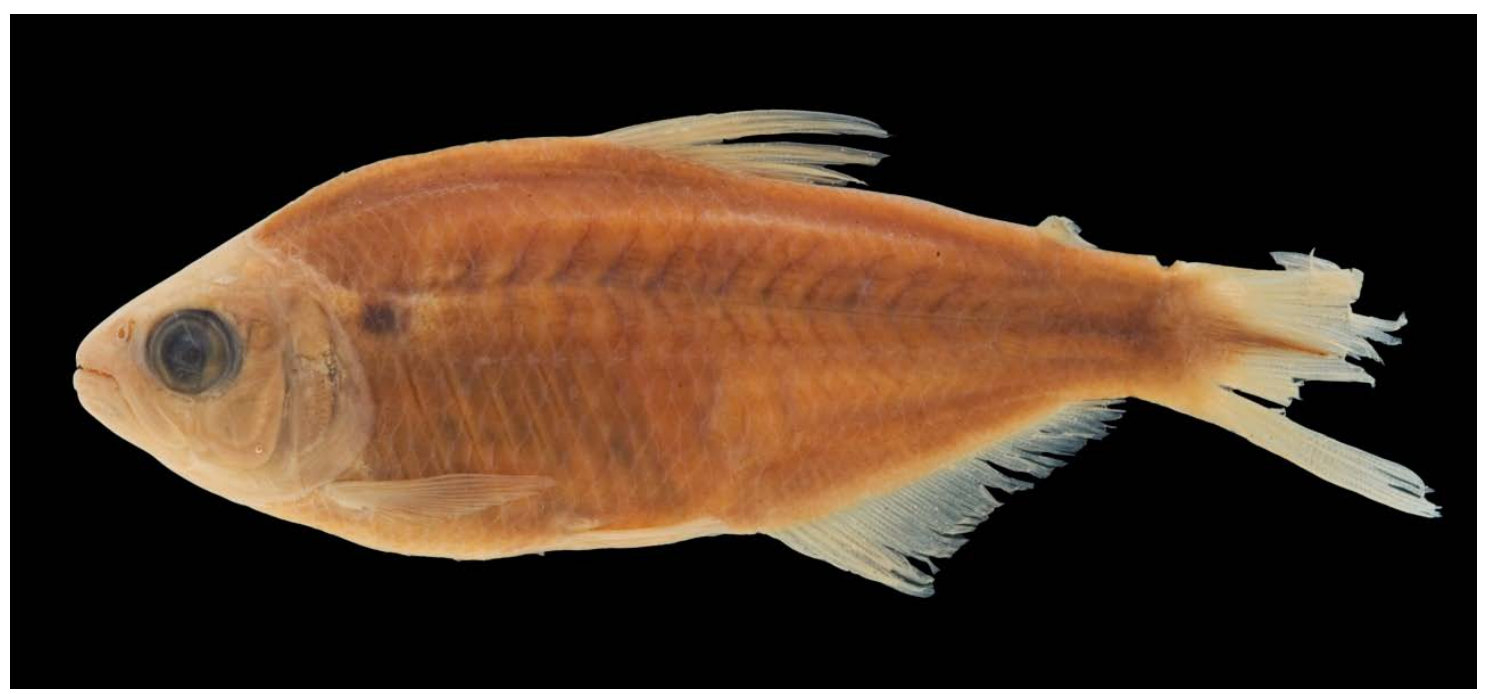

Figura 60. Parátipo de “Astyanax” superbus USNM 130640 (69.93 mm CP). (Foto: Marcel Cavallaro). 


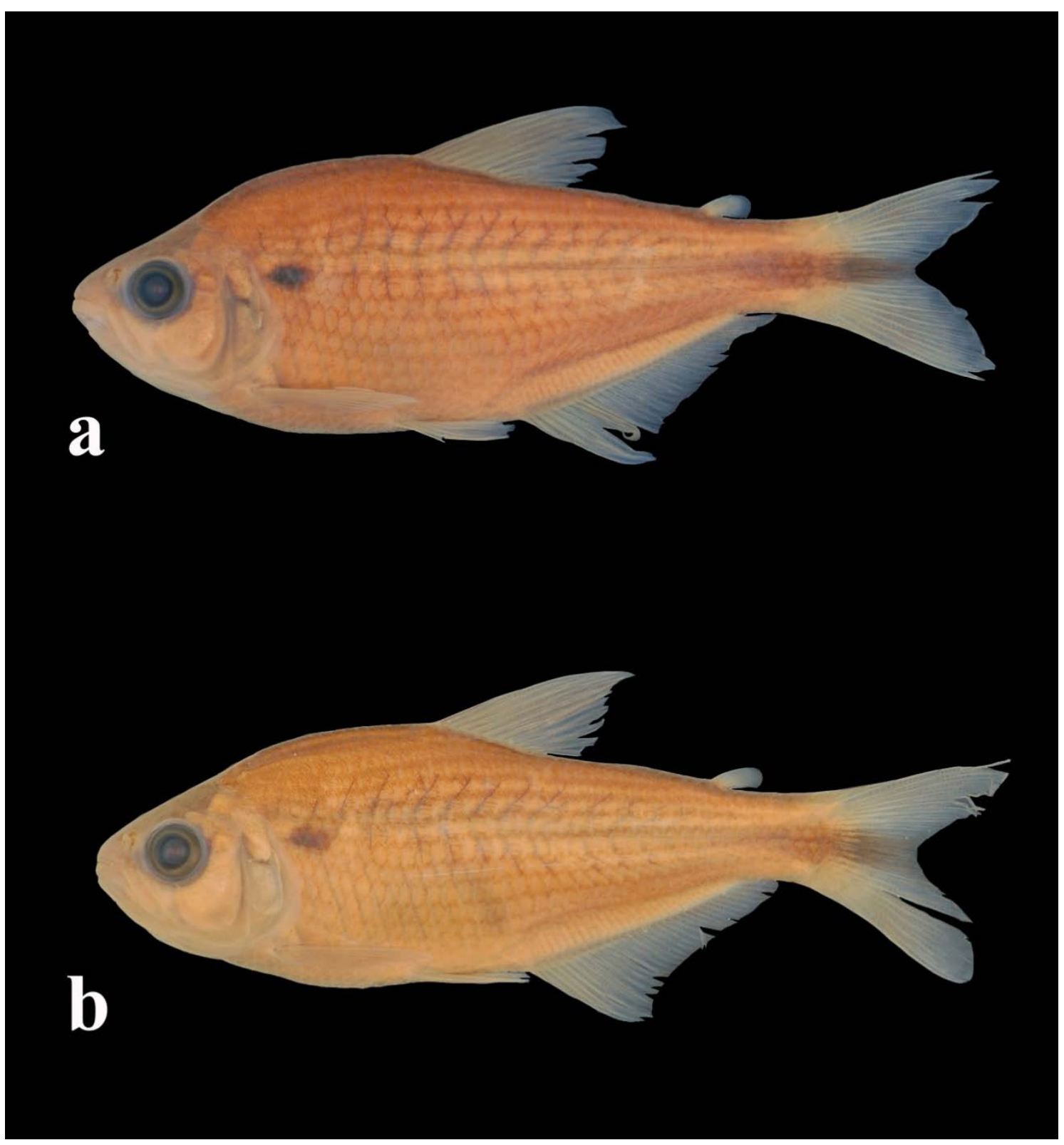

Figura 61. a. "Astyanax” superbus MZUSP 103071 (70 mm CP). b. “Astyanax" superbus MZUSP 103071 (60,8 mm CP). 


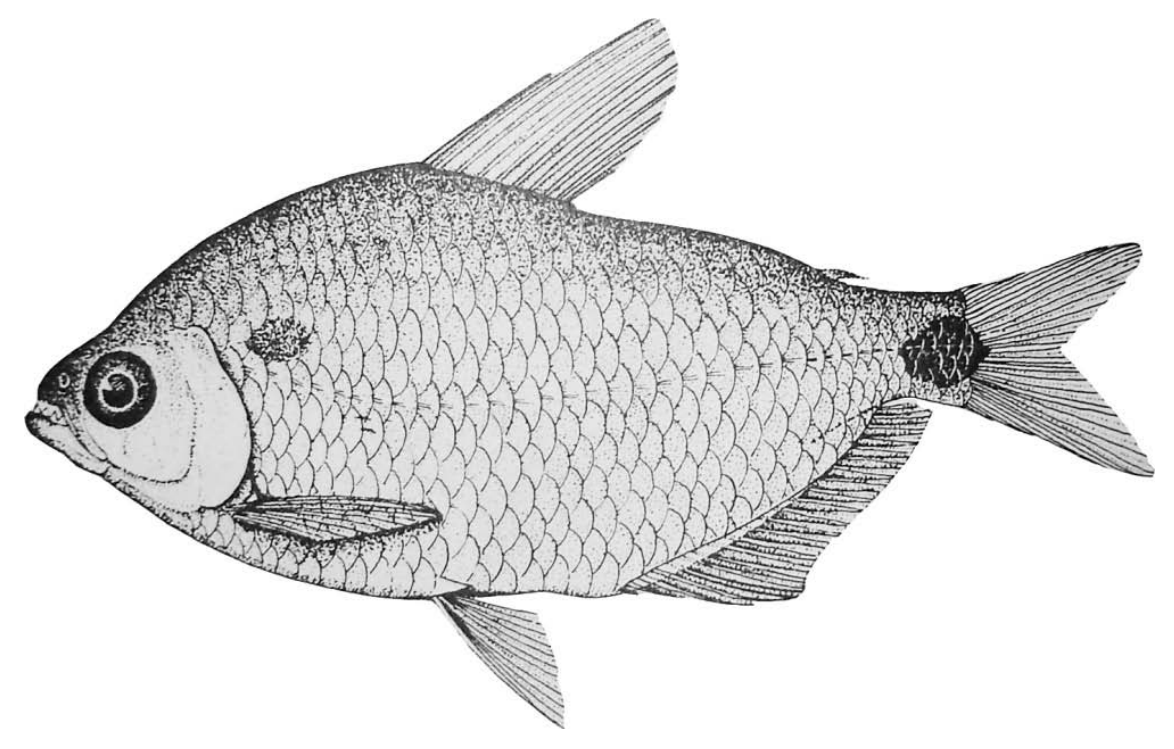

Figura 62. Ilustração de “Astyanax” orthodus (retirado de Dahl (1942)).

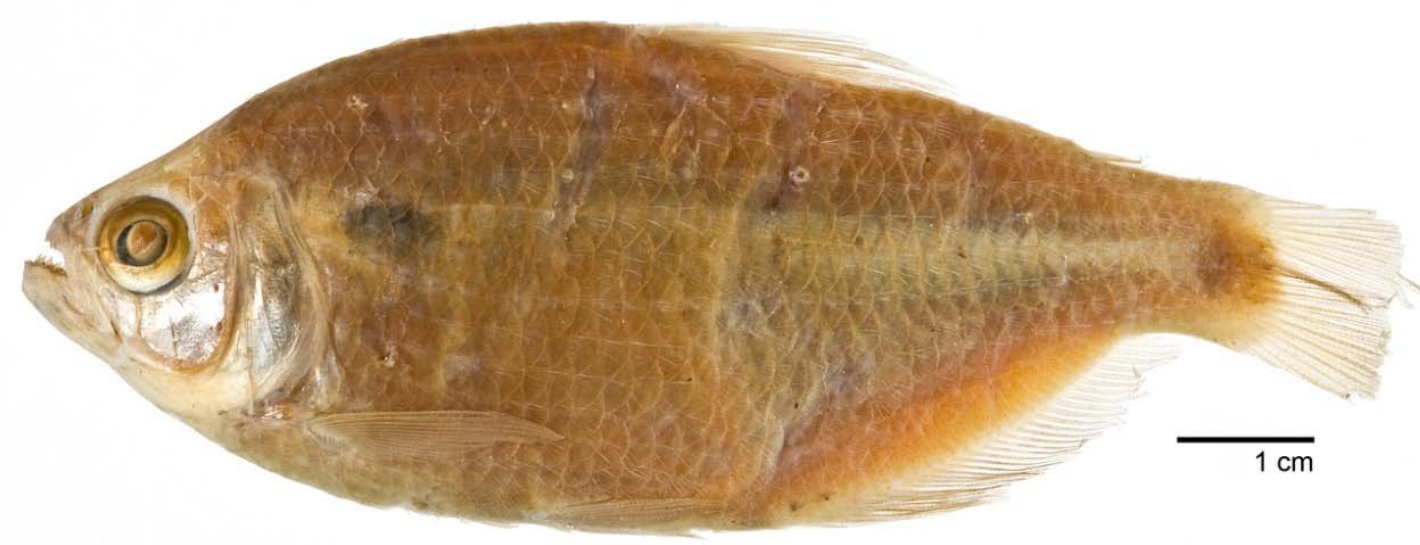

Figura 63. Holótipo de “Astyanax” orthodus USNM 55655. (Foto: USNM)

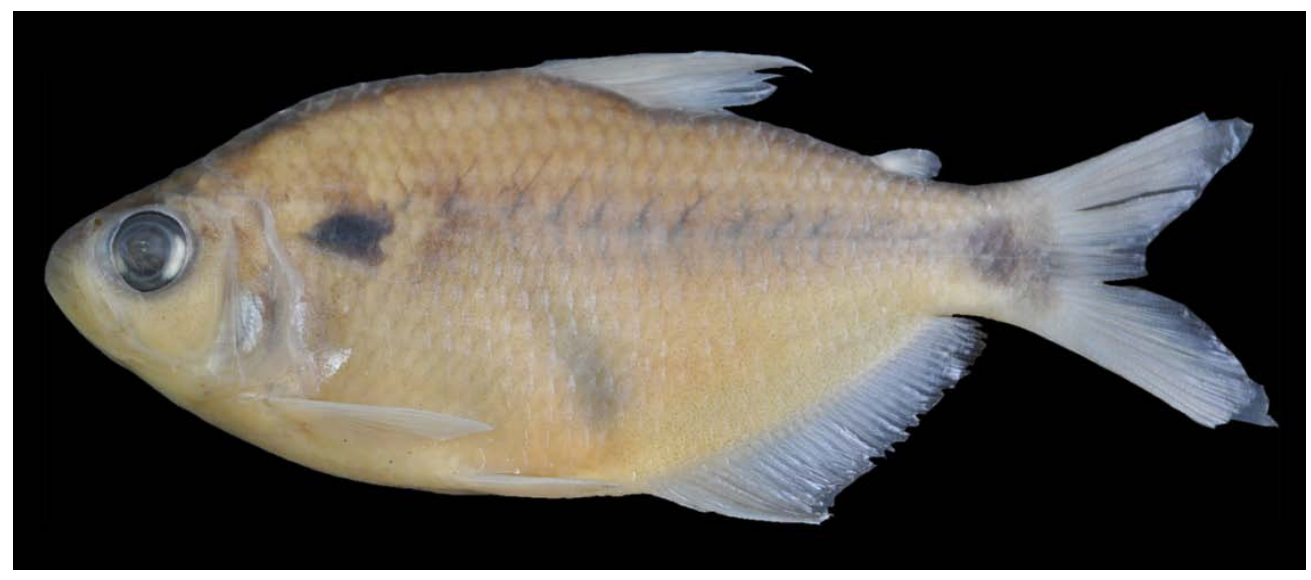

Figura 64. “Astyanax” orthodus IAVHP 7209. (Foto: Raqueli Ruiz-C) 


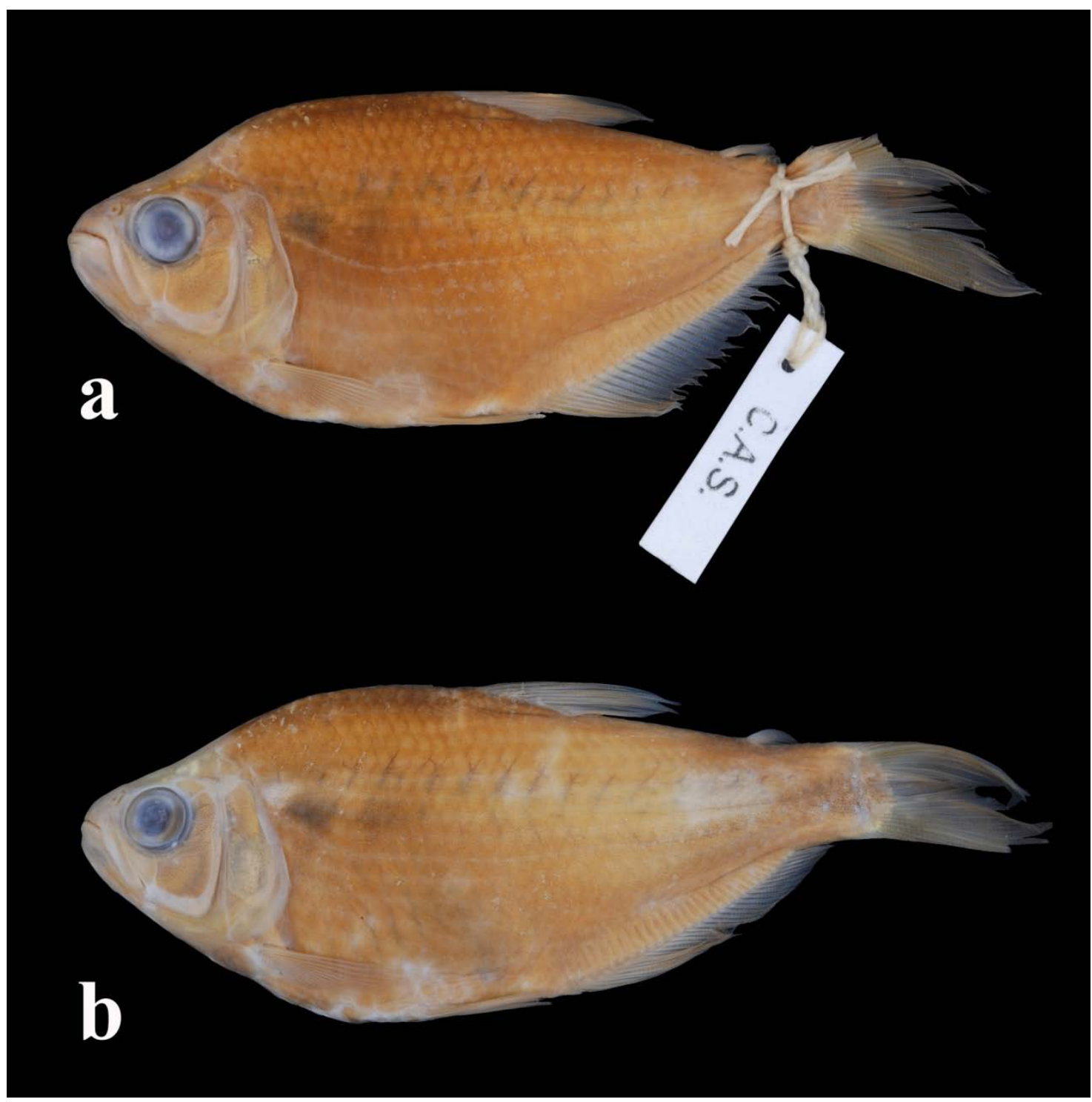

Figura 65. a. “Astyanax" orthodus CAS 68769 (69,8 mm CP). b. “Astyanax" orthodus CAS 68769 (69,0 mm CP). 


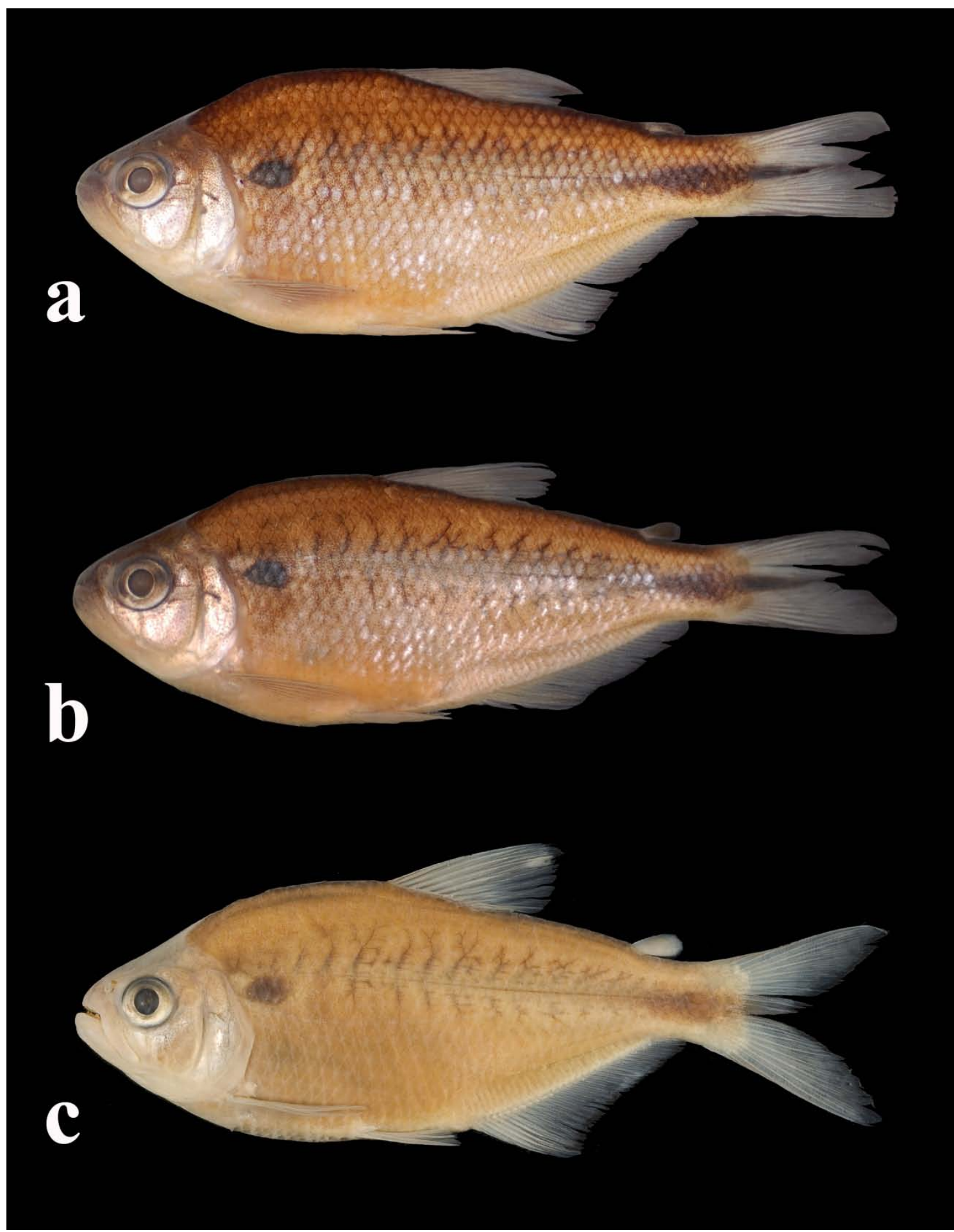

Figura 66. Astyanacinus sp nova Bolívia a. MCP 35017 (65,42 mm CP) macho b. MCP 35017 (60 mm CP) fêmea; c. MZUSP 27809 (66,86 mm CP). (Foto MZUSP 27809 Flávio C. T. Lima). 


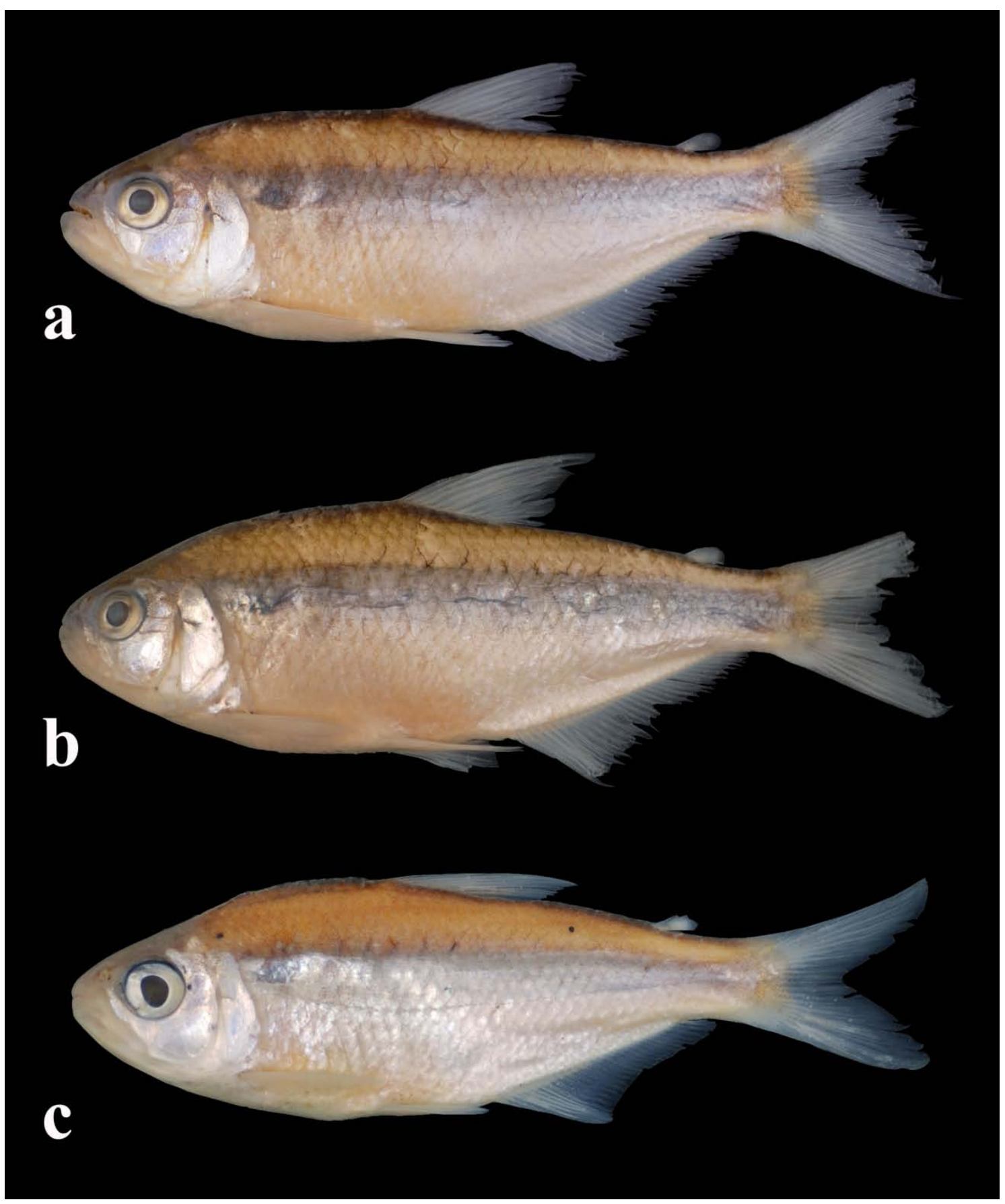

Figura 67. Astyanacinus sp nova Peru a. MUSM 37978 (96,4 mm CP) b. MUSM 37978 (106,7 mm CP); c. MUSM 13101 (56,4 mm CP). 


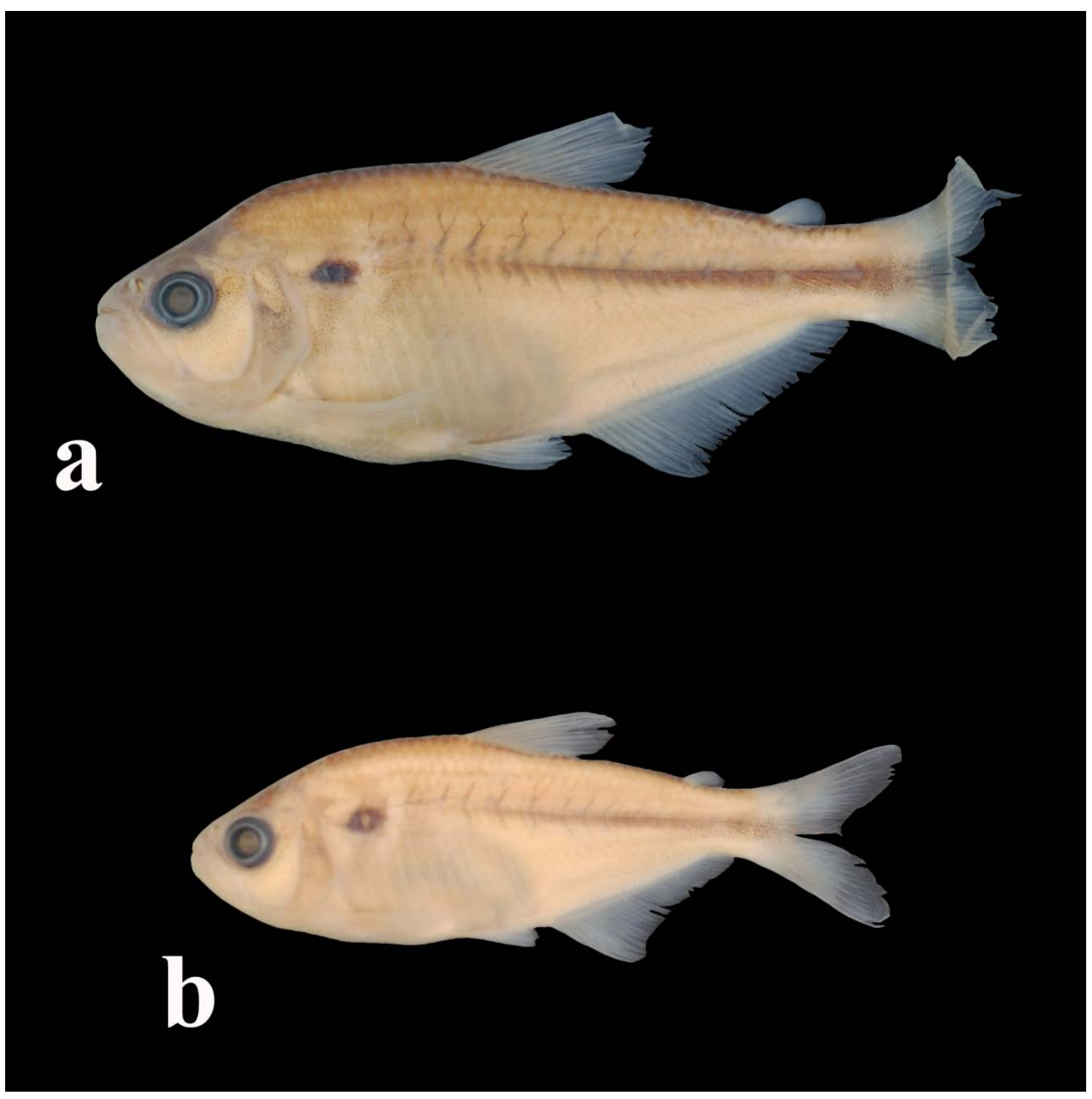

Figura 68. a. Astyanacinus sp nova purus MCP 39773 (58,3 mm CP). b. Astyanacinus sp nova purus MCP 103071 (41,77 mm CP). 


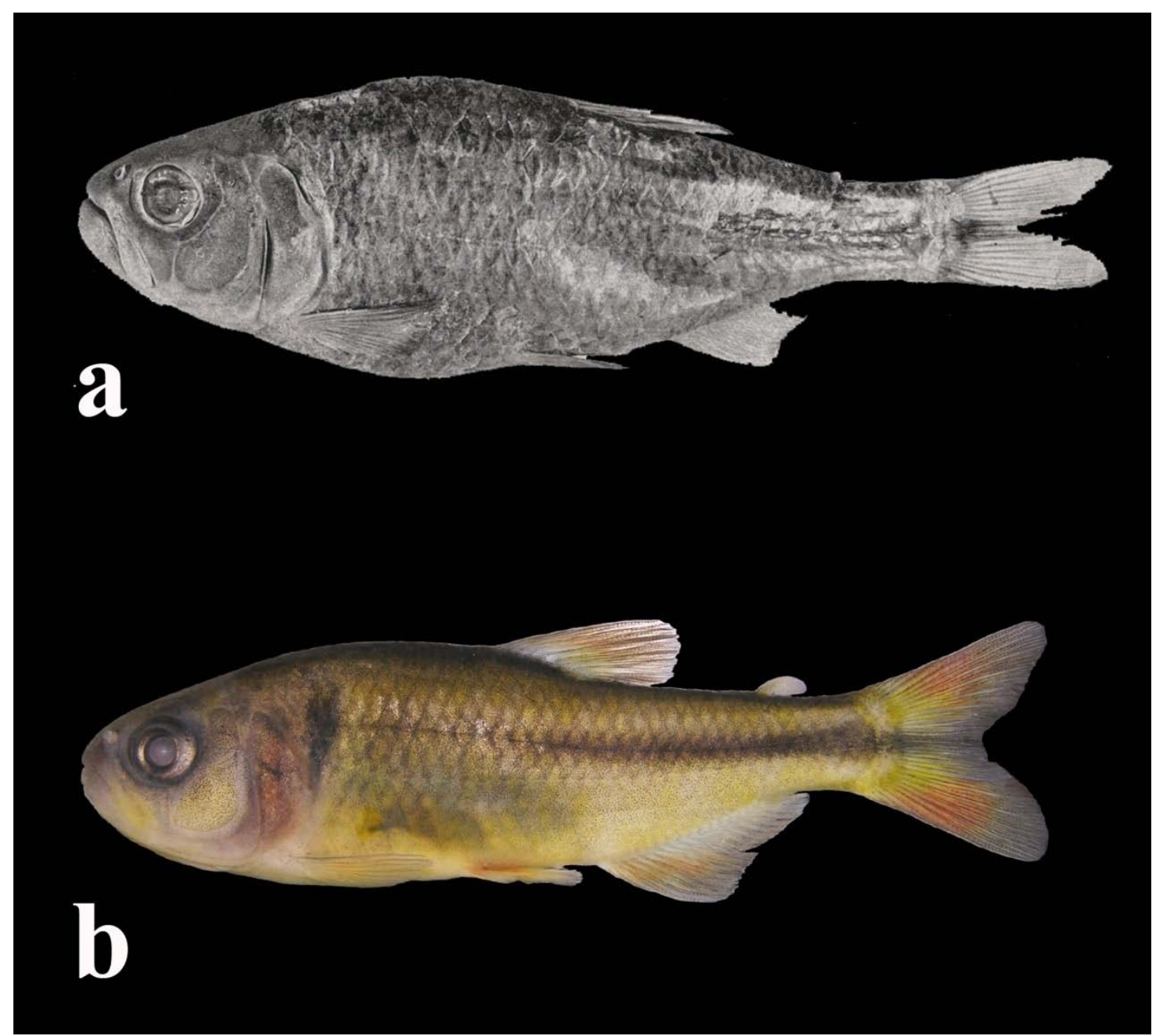

Figura 69. a. Astyanax goyanensis presente na publicação de Miranda-Ribeiro (1944); b. topótipo de Astyanax goyanensis UFRGS 11291, macho, $56.7 \mathrm{~mm}$ CP (retirado e modificado de Bertaco et al. (2010)). 


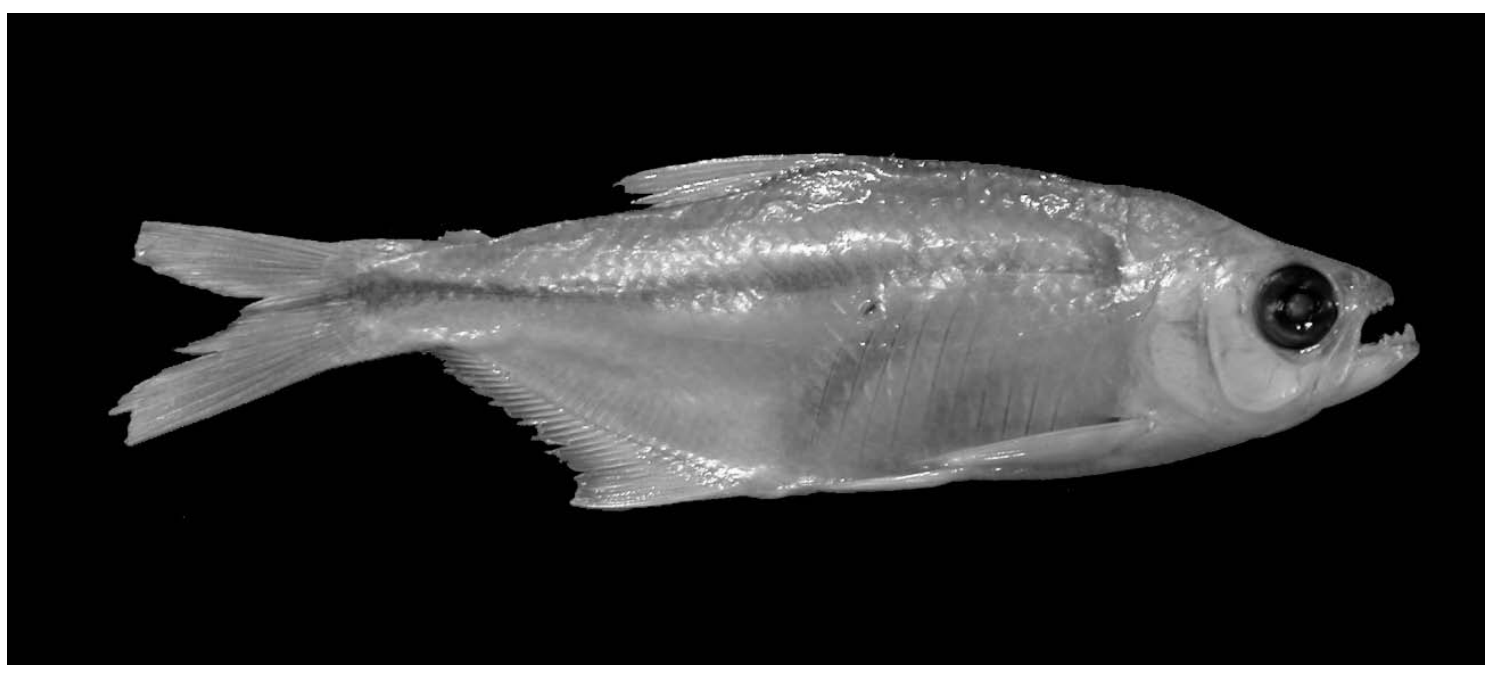

Figura 70. Holótipo de Astyanacinus platensis CL 762 Holótipo fêmea (96,75mm CP). (Foto modificada de Luiz Malabarba). 


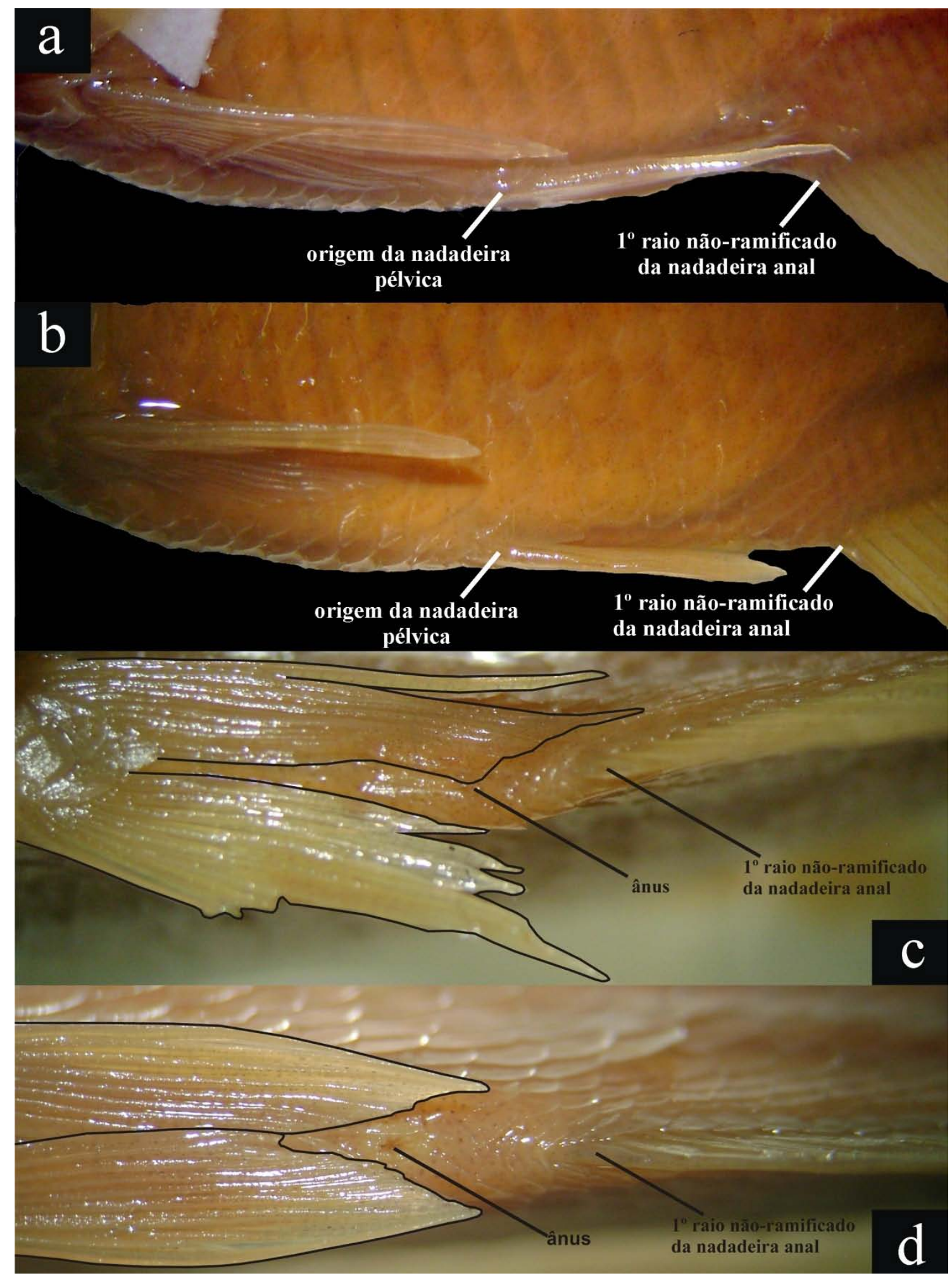

Figura 71. A-B vista lateral esquerda da região ventral de “Astyanax" superbus (MZUSP 103071); C-D vista ventral (MZUSP 103071). 


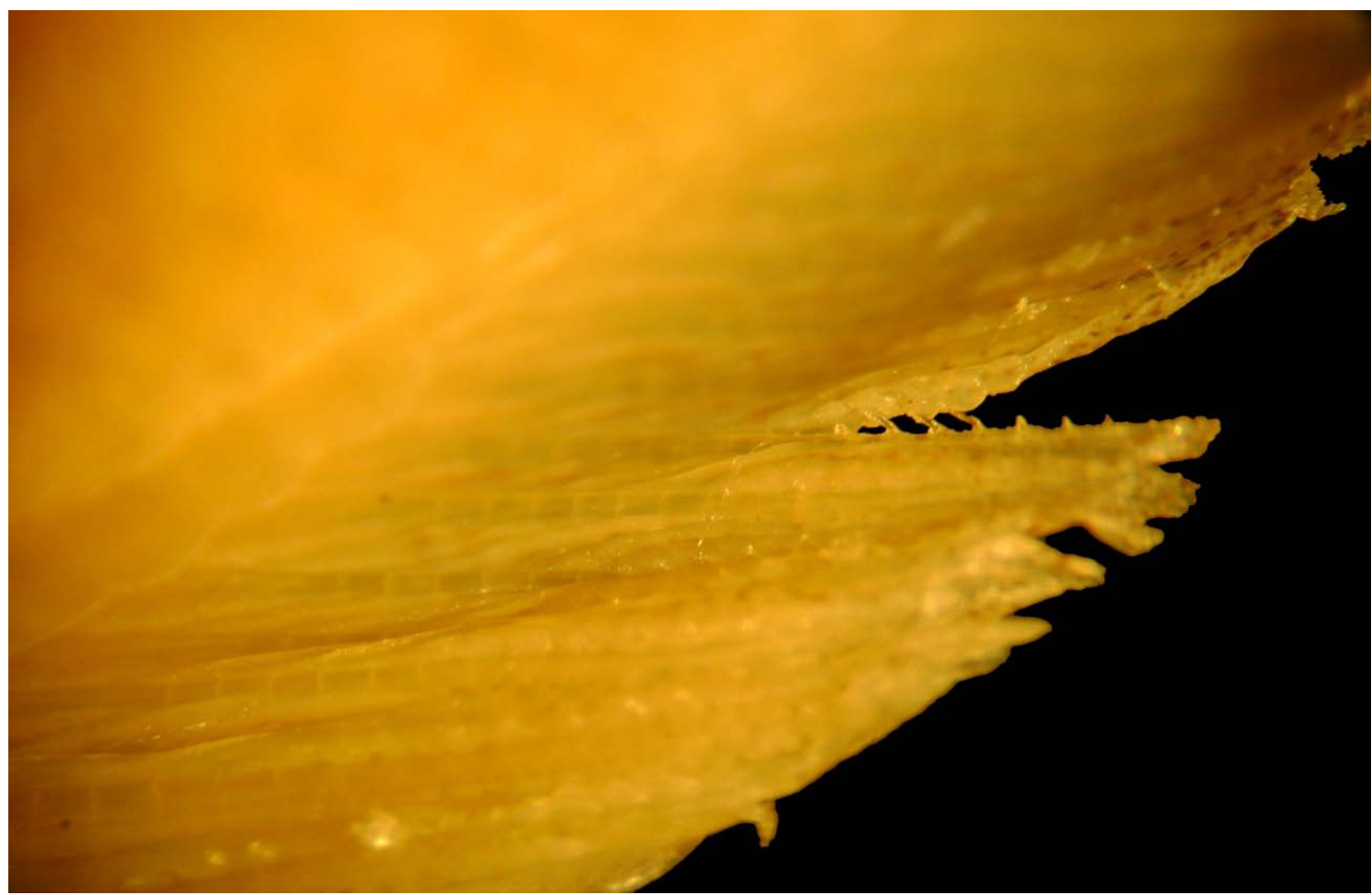

Figura 72. Vista lateral esquerda da nadadeira anal de Astyanacinus sp nov. Bolívia lote CAS 68367.

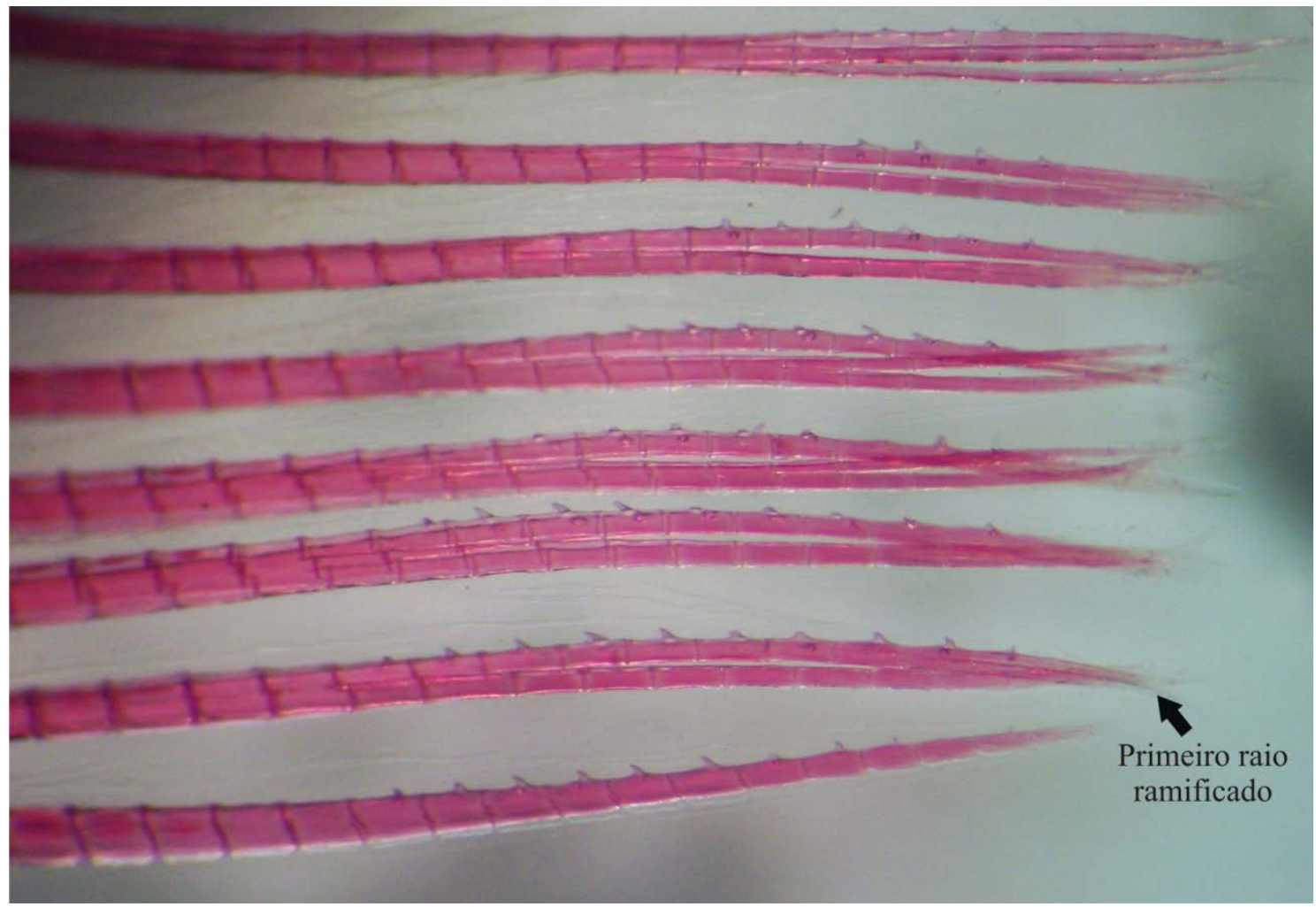

Figura 73. Vista lateral esquerda da nadadeira anal de Astyanacinus sp nova Bolívia lote MCP 35017. 


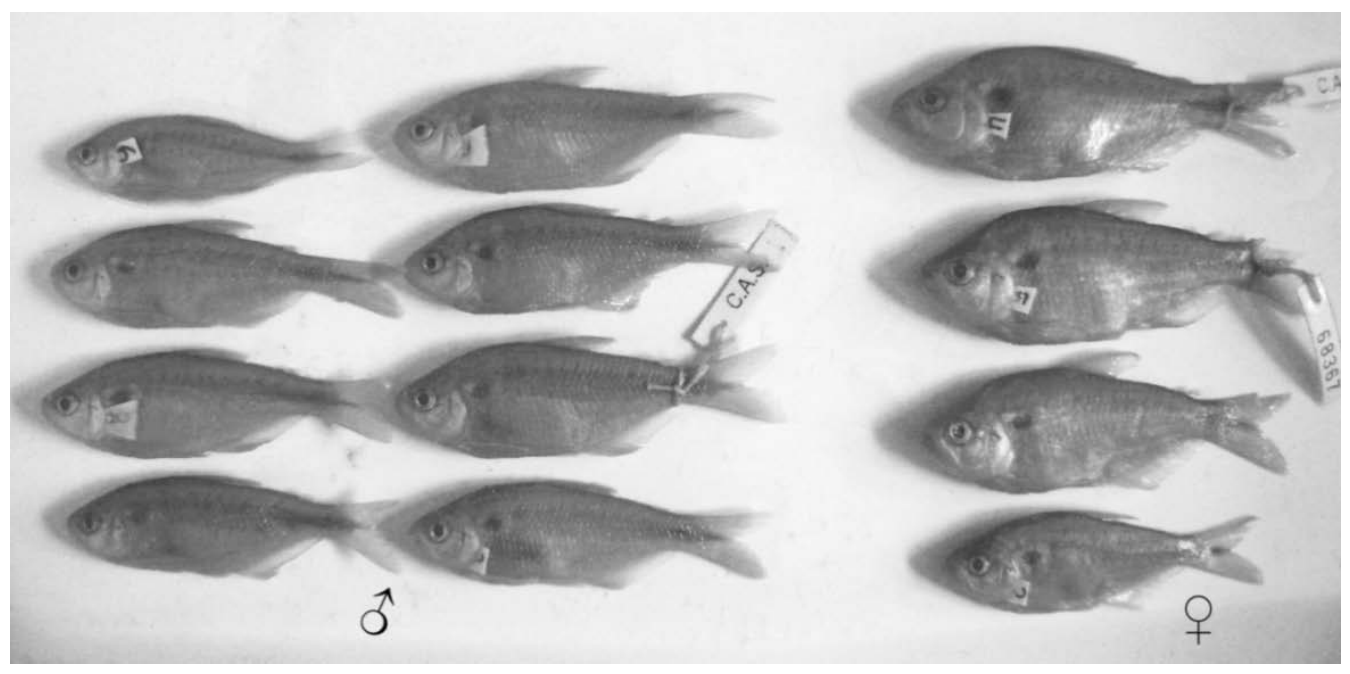

Figura 74. Exemplares de Astyanacinus sp nov. Bolívia lote CAS 68367 demonstrando o dimorfismo sexual com relação no formato do corporal.
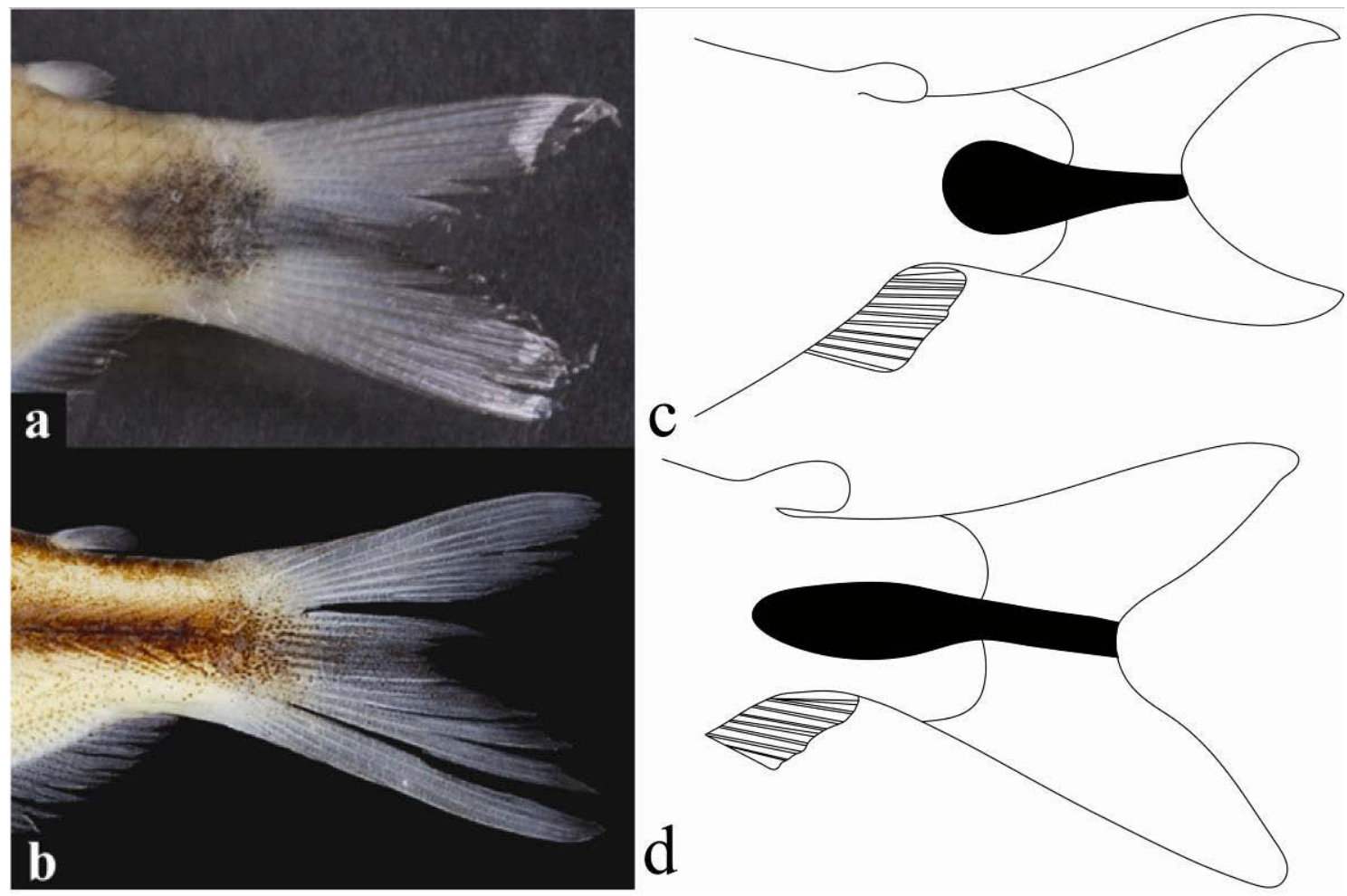

Figura 75. Vista lateral esquerda do formato da mancha no pedúnculo caudal de a. “Astyanax" orthodus (IAVHP 7146, 50mm CP); b. Astyanacinus moorii (MZUSP 78752, 43,3mm CP); c. ilustração do formato da mancha do pedúnculo caudal de “Astyanax" orthodus; d. ilustração do formato da mancha do pedúnculo caudal das demais espécies de Astyanacinus. 


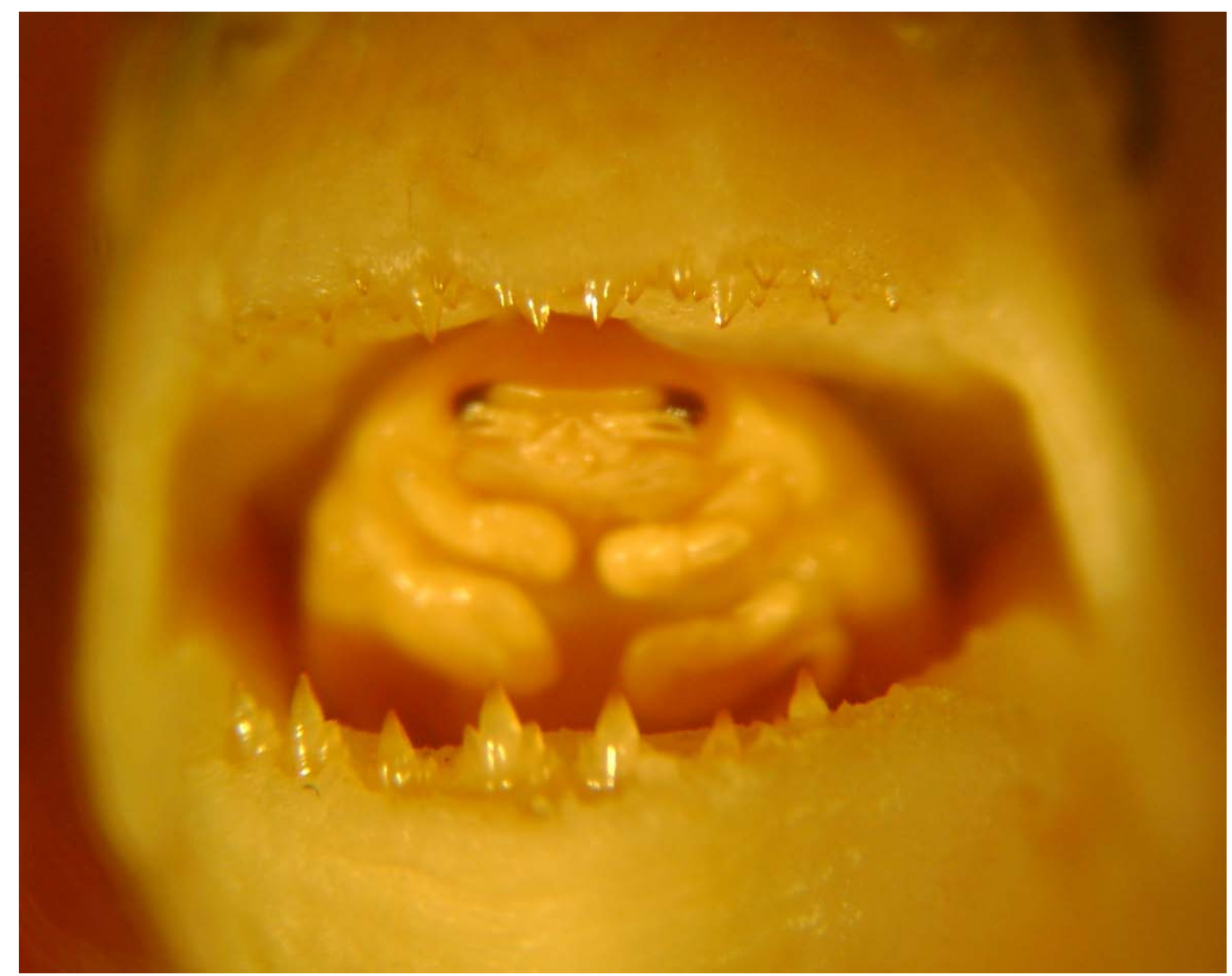

Figura 76. Vista frontal da cavidade bucal de Astyanacinus multidens (CAS 38955) com destaque à presença de um parasita Isopoda. 


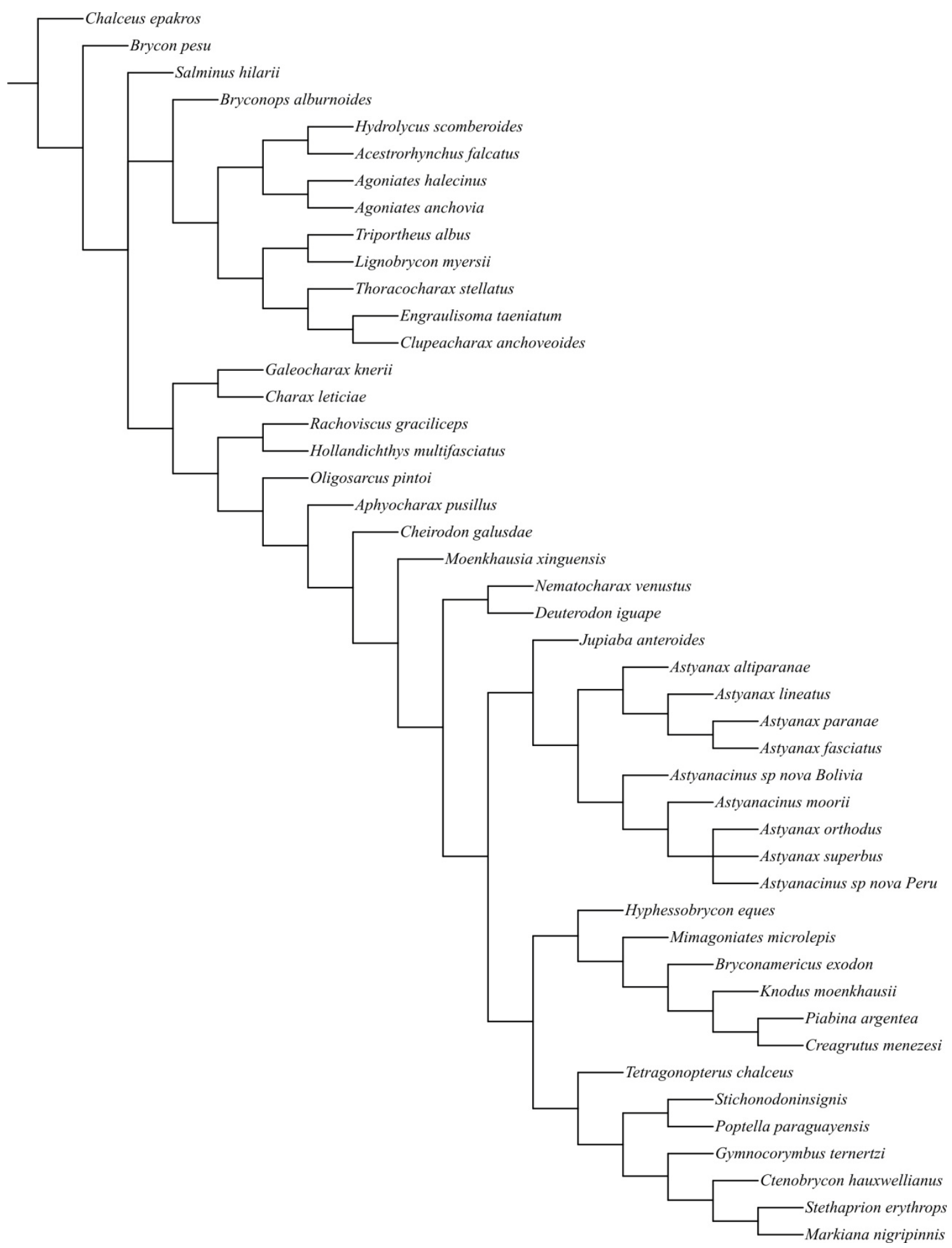

Figura 77. Árvore de consenso com 922 passos das 6 árvores mais parcimoniosas obtidas na análise filogenética sem pesagem. IC 0.228; IR 0.502 . 


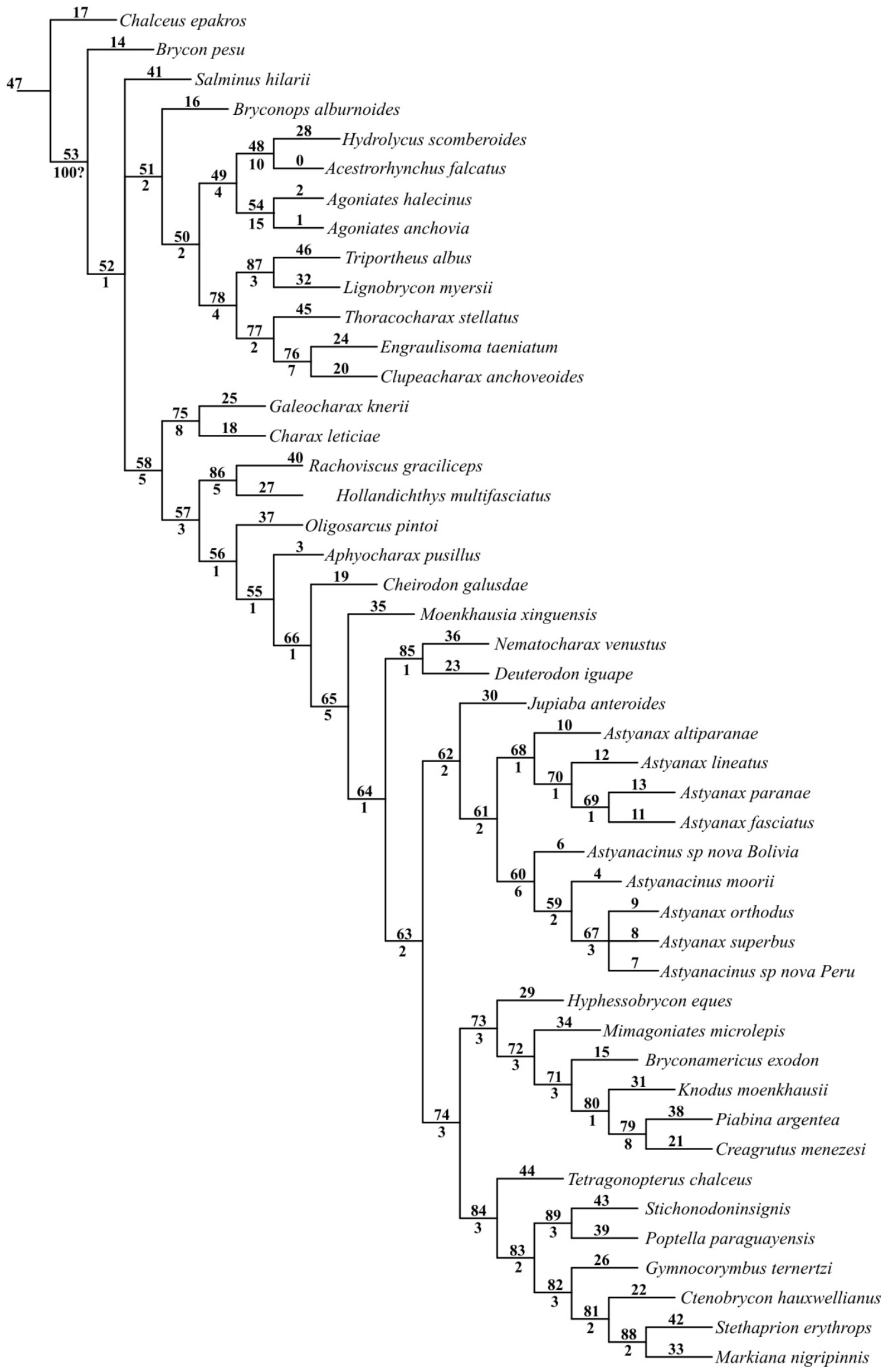

Figura 78. Árvore de consenso das 6 árvores mais parcimoniosas obtidas na análise filogenética. Acima é numeração do clado, embaixo o índice de Bremer de cada nó. 

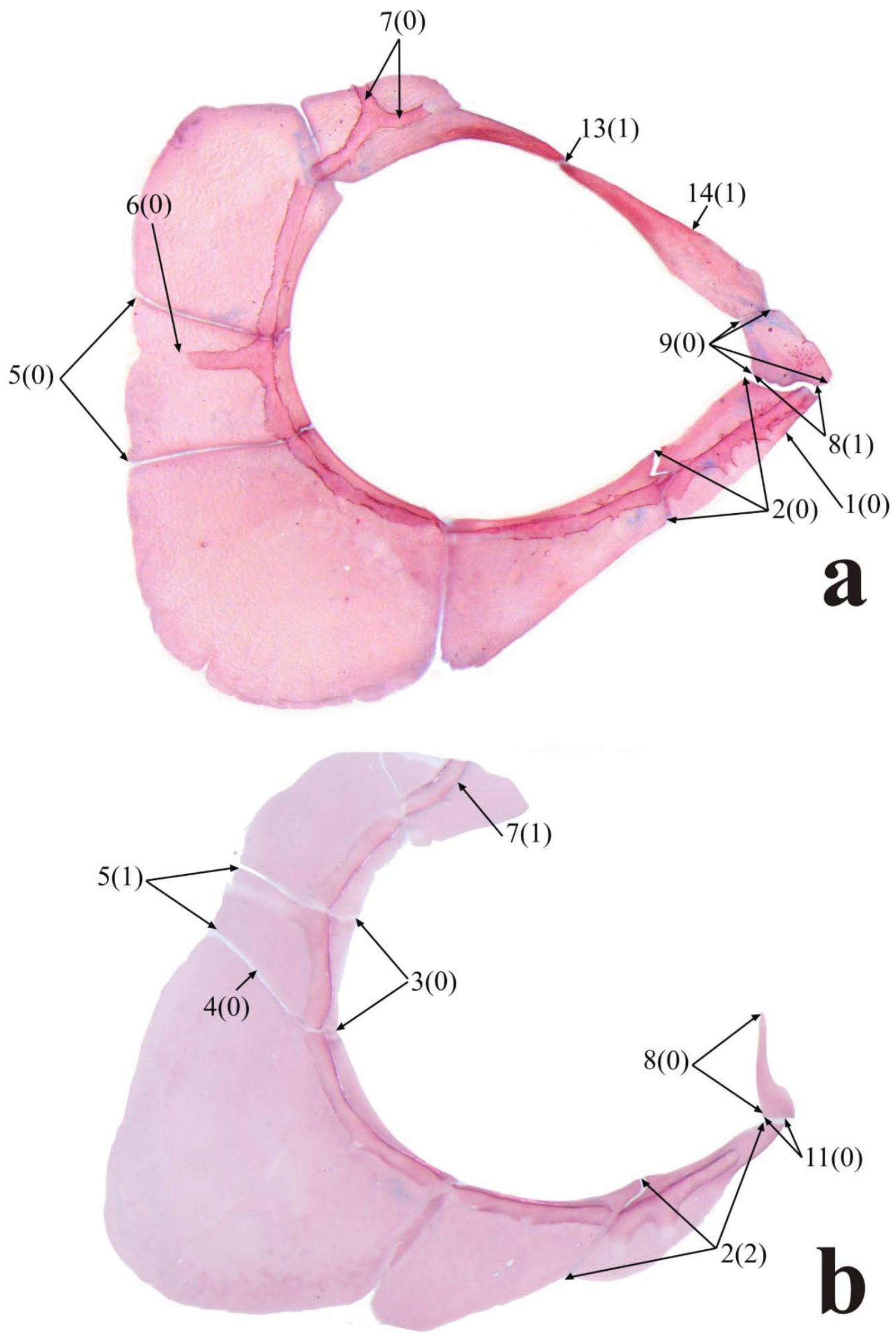

Figura 79. Anel orbital de: a) Brycon pesu LIRP 5962 (82,9 mm CP); b) Astyanacinus moorii MZUSP 78752 (43,3mm CP). 

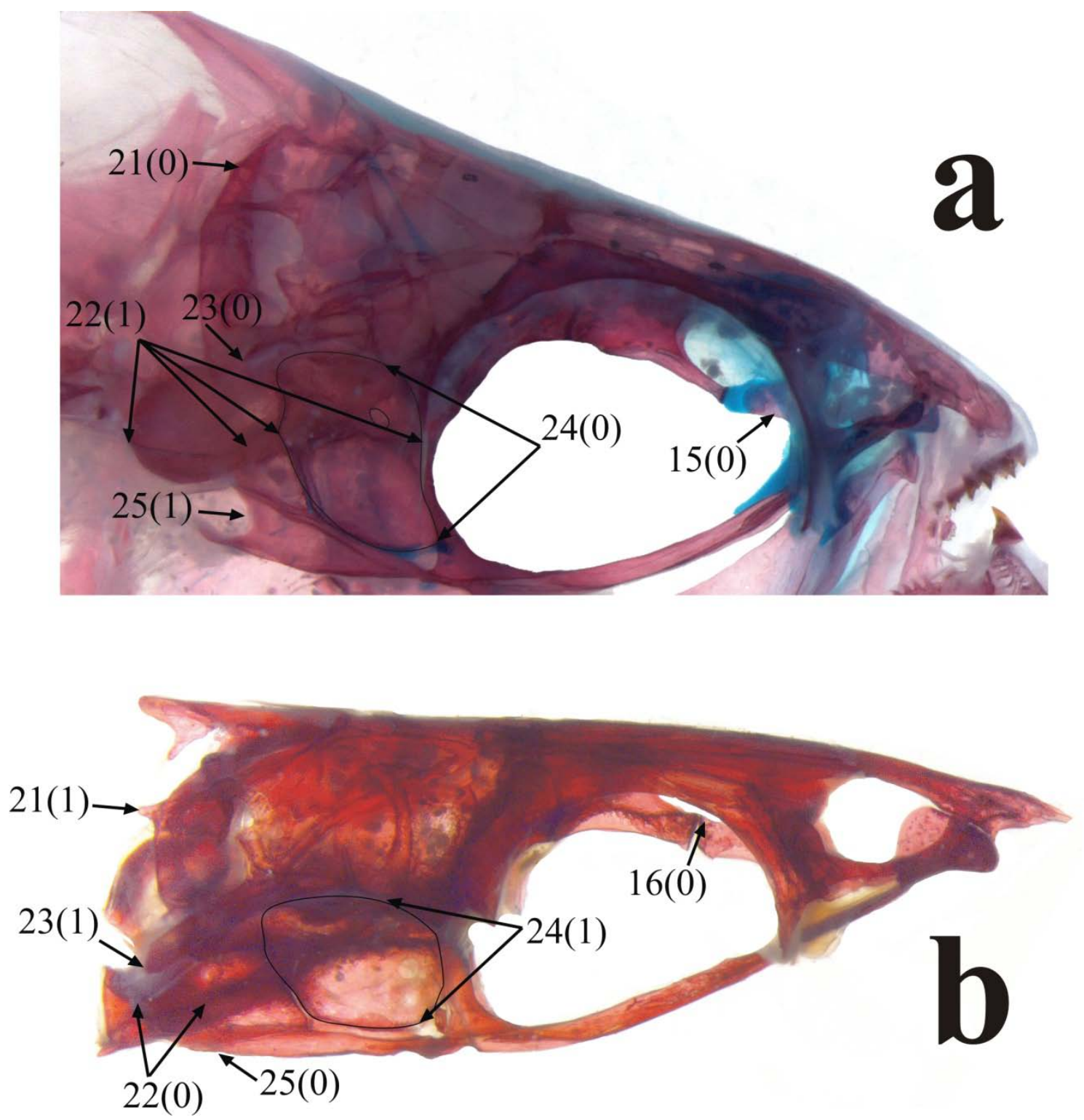

Figura 80. Neurocrânio de: a) Astyanax fasciatus LIRP 132 (75,3 mm CP); b) Agoniates halecinus MZUSP 92807 (104,8mm CP). 

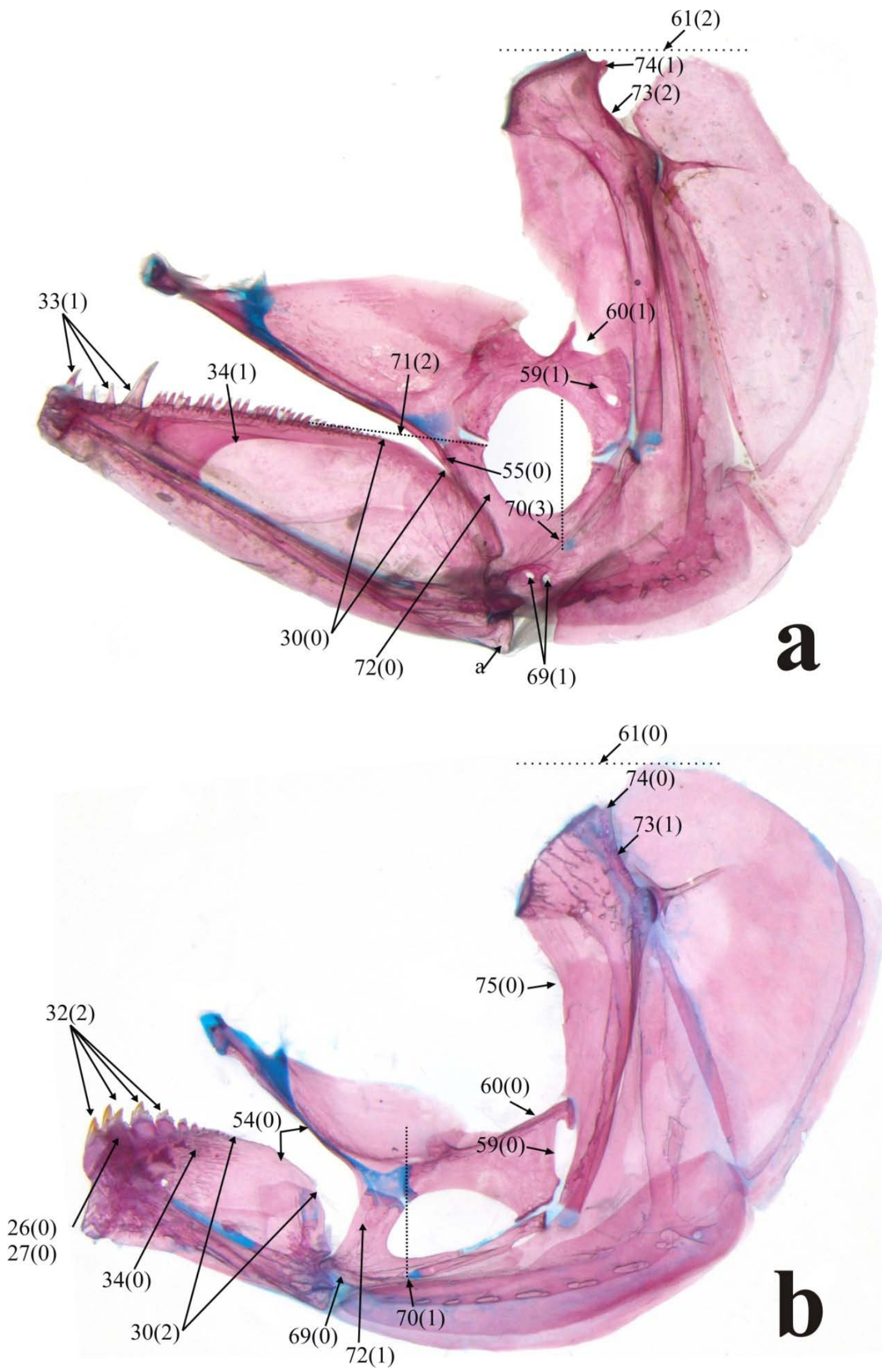

Figura 81. Ossos faciais de: a) Charax leticiae LIRP 5998 (82,43 mm CP); b) Triportheus paranensis LIRP 5935 (67,57 mm CP). 

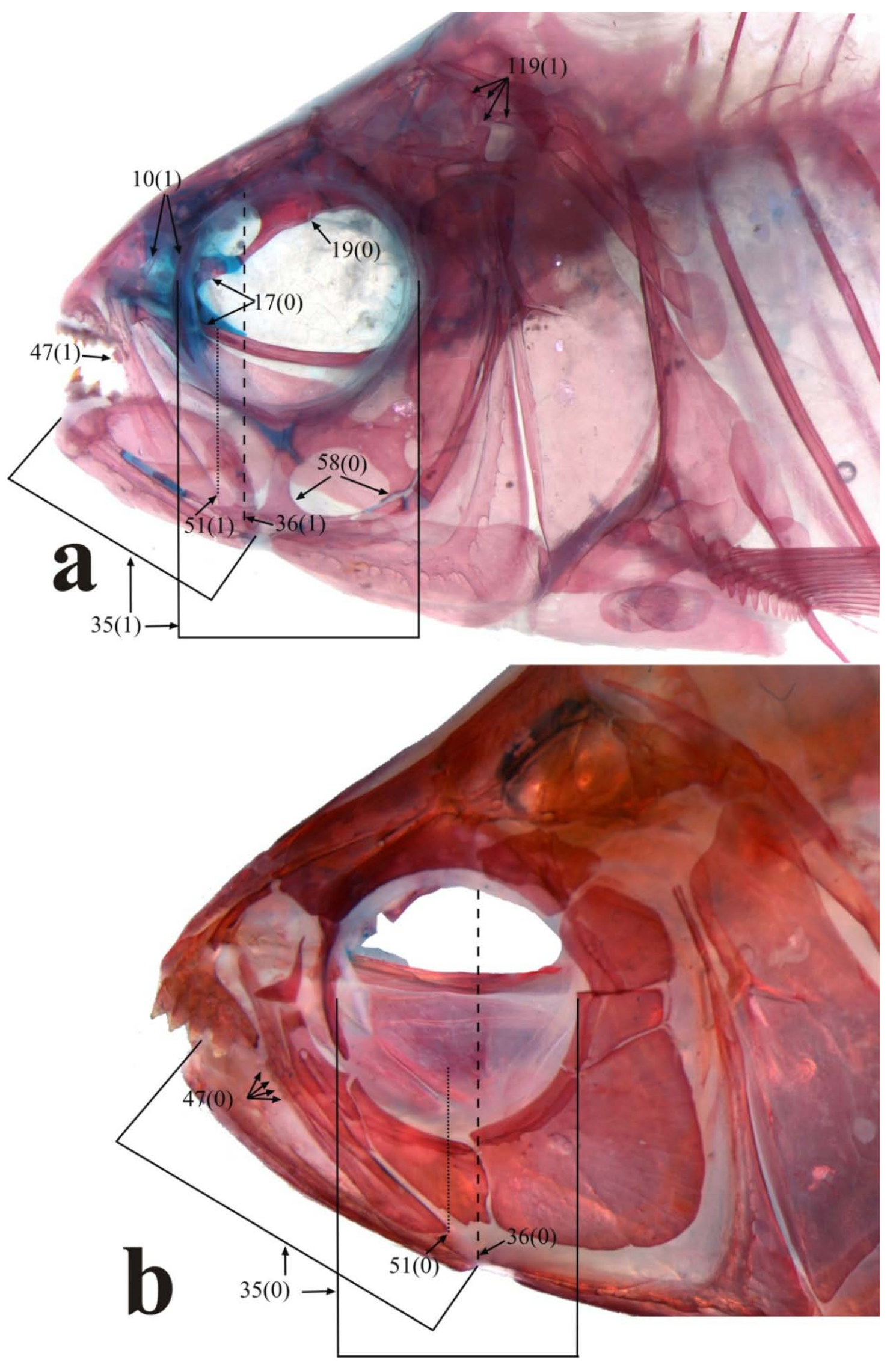

Figura 82. Vista lateral esquerda da cabeça de: a) Astyanax fasciatus LIRP 132 (75,3 mm CP); b) “Astyanax” orthodus CAS 68769 (69,0 mm CP). 

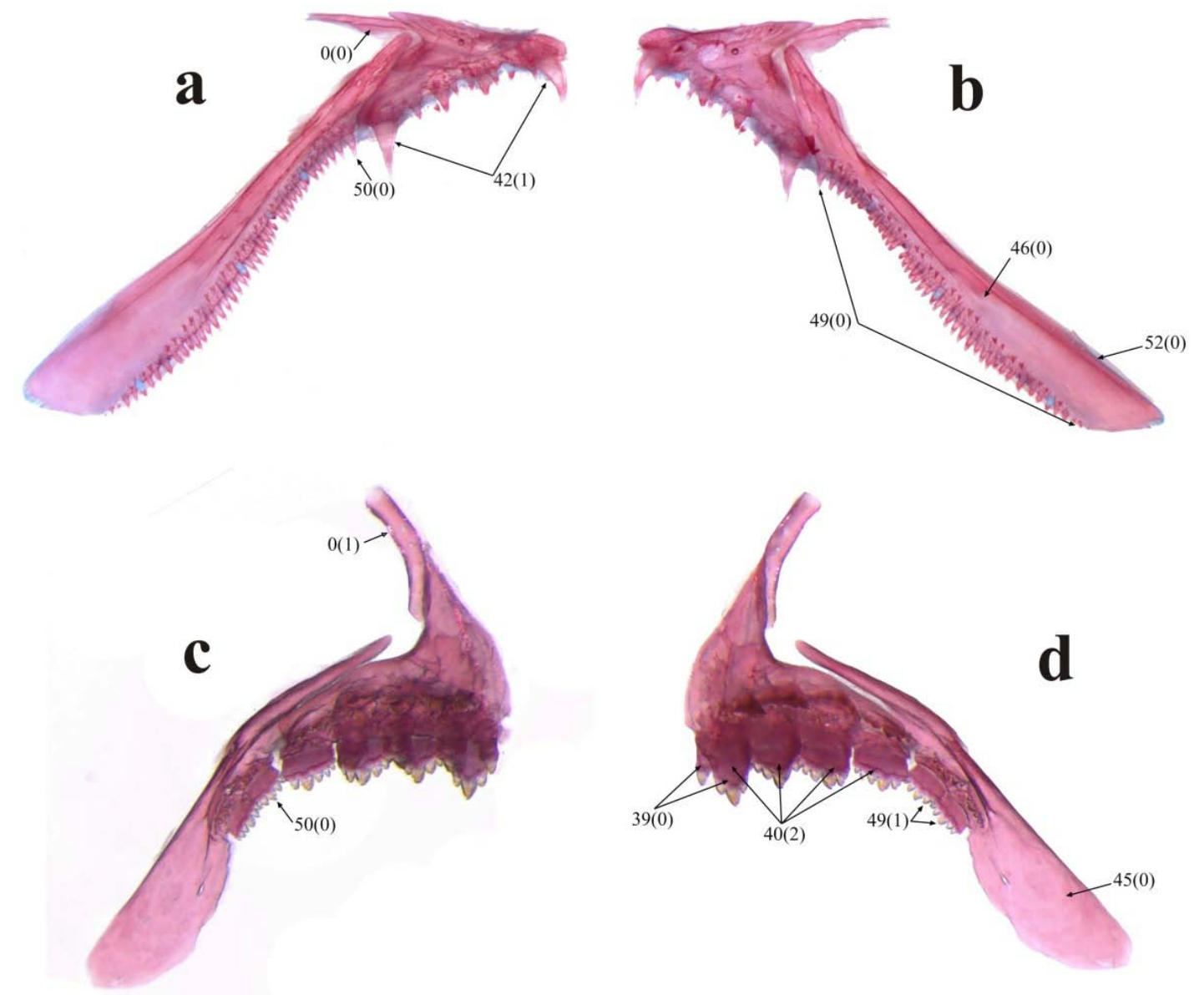

Figura 83. Maxila superior de: a) Galeocharax knerii LIRP 4081 (95,2mm CP); b) Knodus moenkhausii LIRP 2273 (33,05 mm CP). 

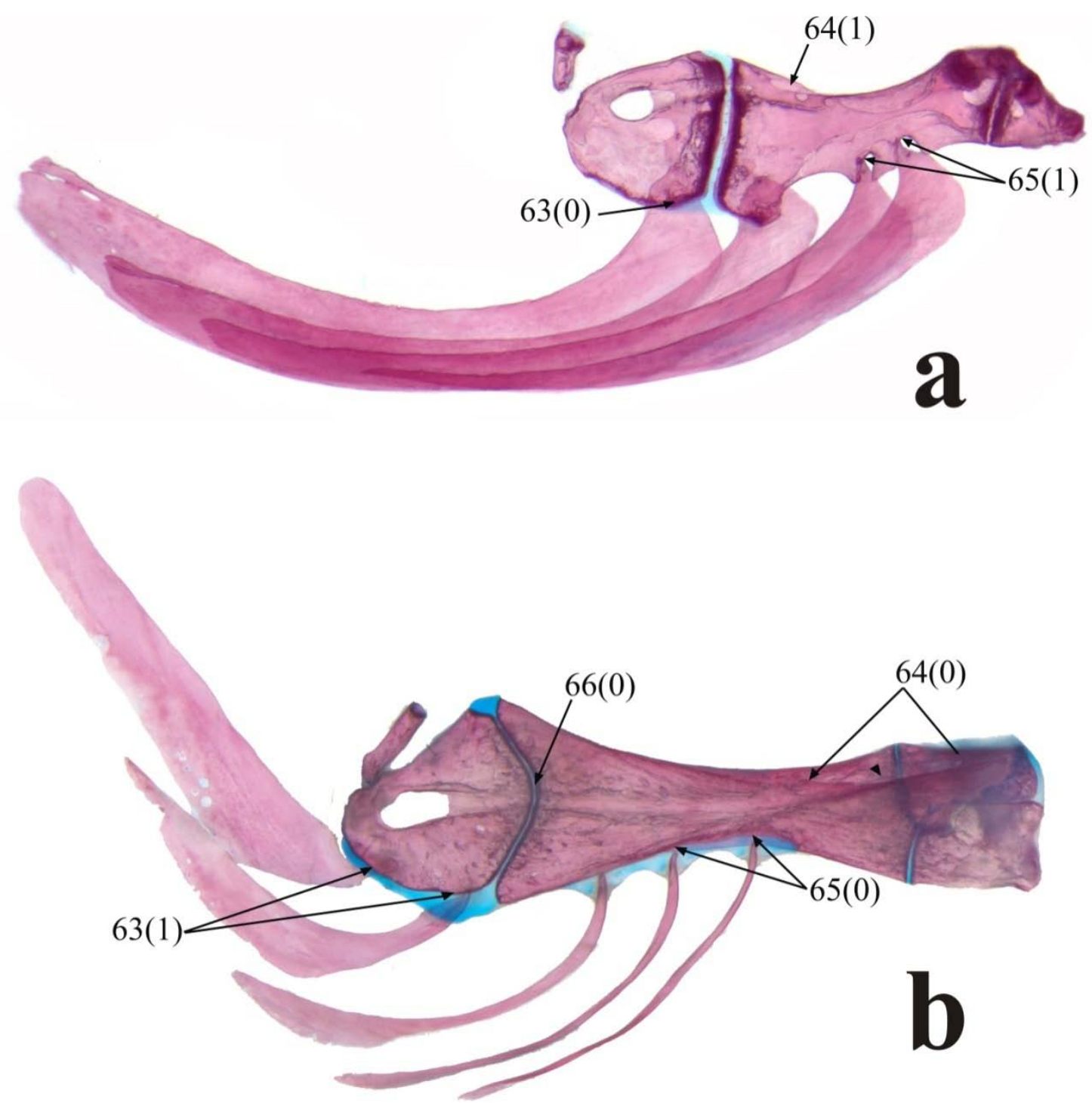

Figura 84. Complexo hióide de: a) Cheirodon cf galusdae LIRP 5968 (45 mm CP); b) Hydrolycus scomberoides LIRP 5943 (133,23 mm CP). 


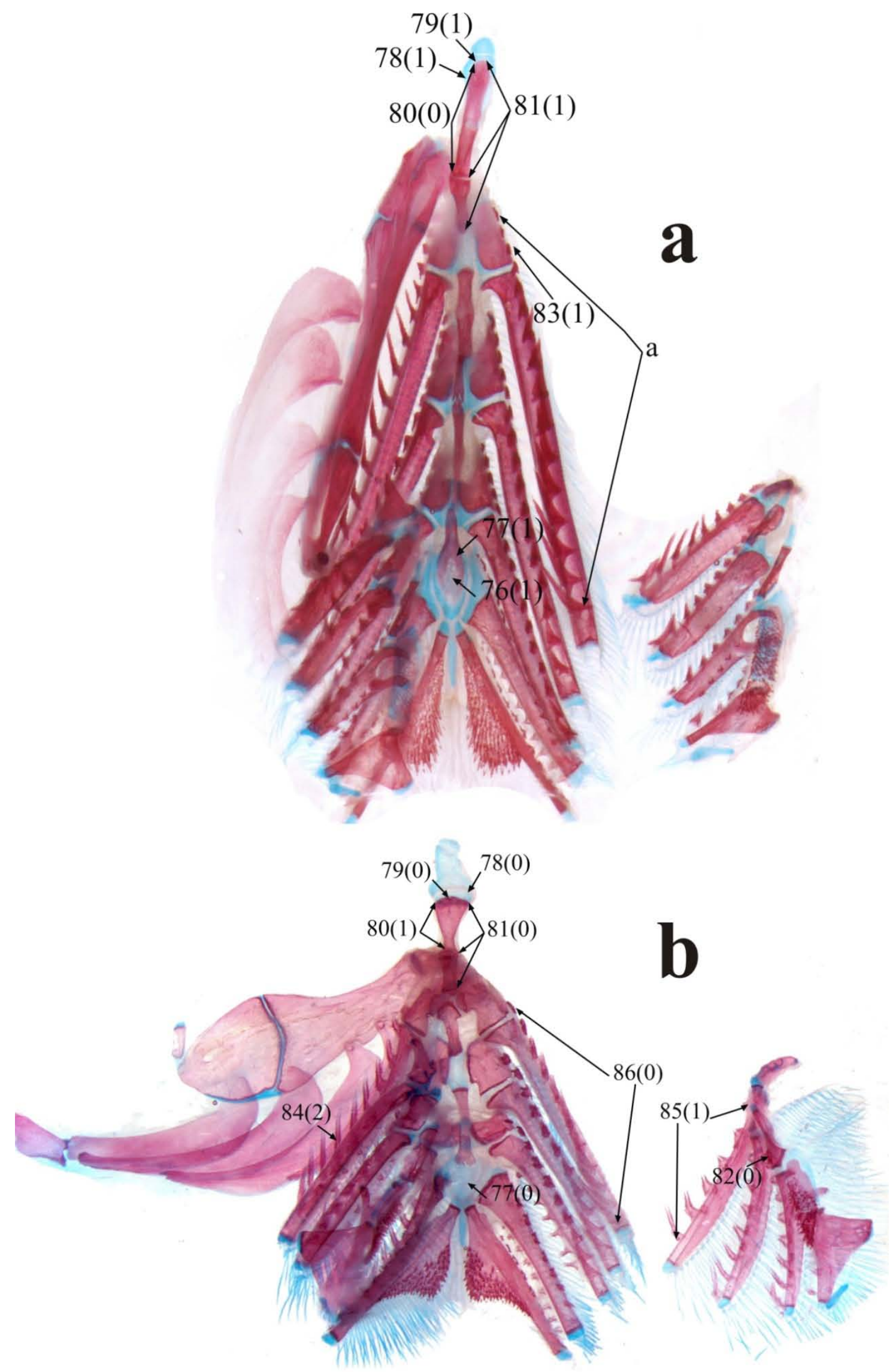

Figura 85. Cesta branquial de: a) Agoniates halecinus MZUSP 92807 (104,8mm CP); b) Hollandichthys multifasciatus LIRP 5744 (70,60 mm CP). 

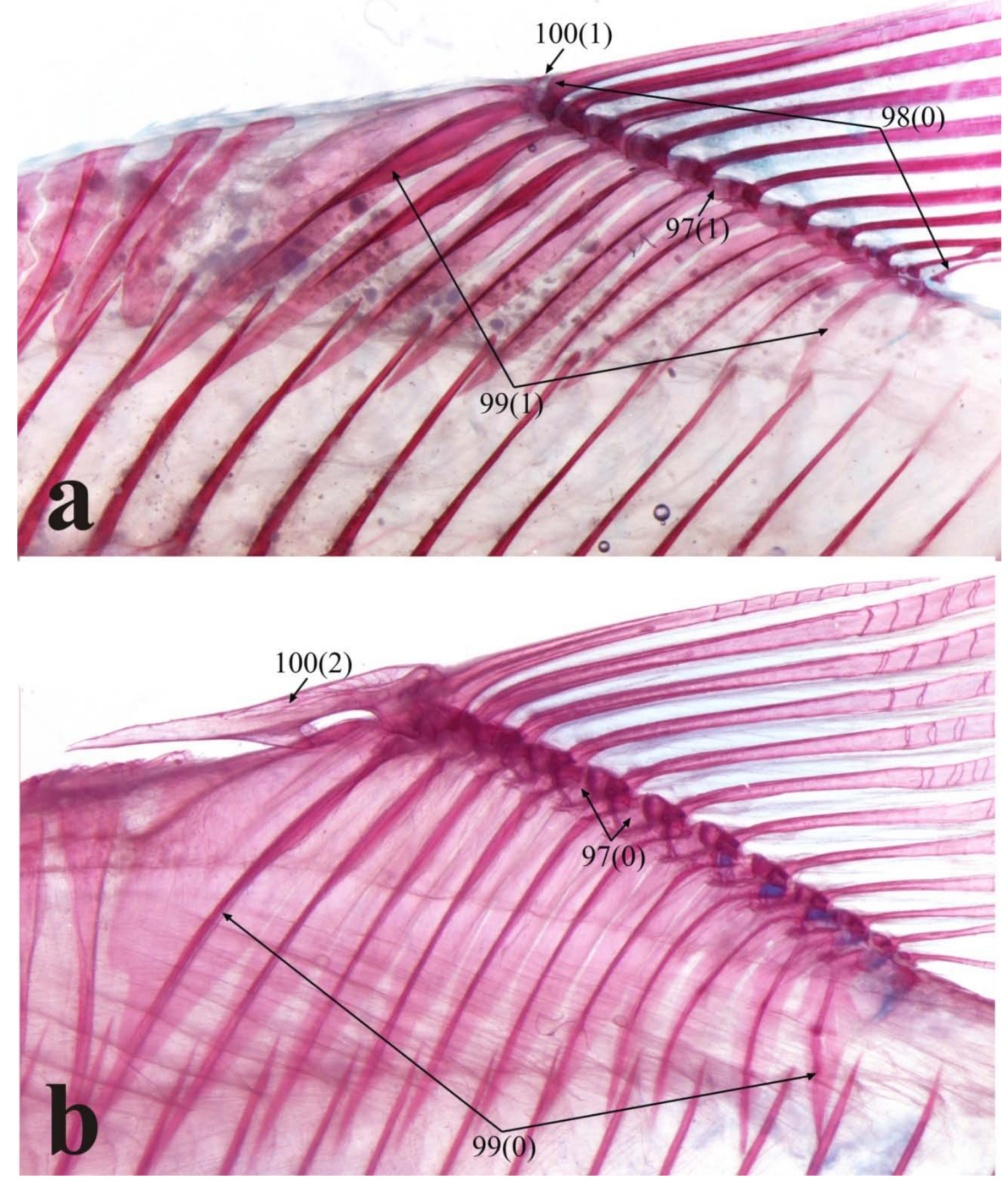

Figura 86. Nadadeira dorsal de: a) Ctenobrycon hauxwellianus LIRP 5932 (68,7mm CP); b) Stethaprion erythrops LIRP 5967 (49,4 mm CP). 

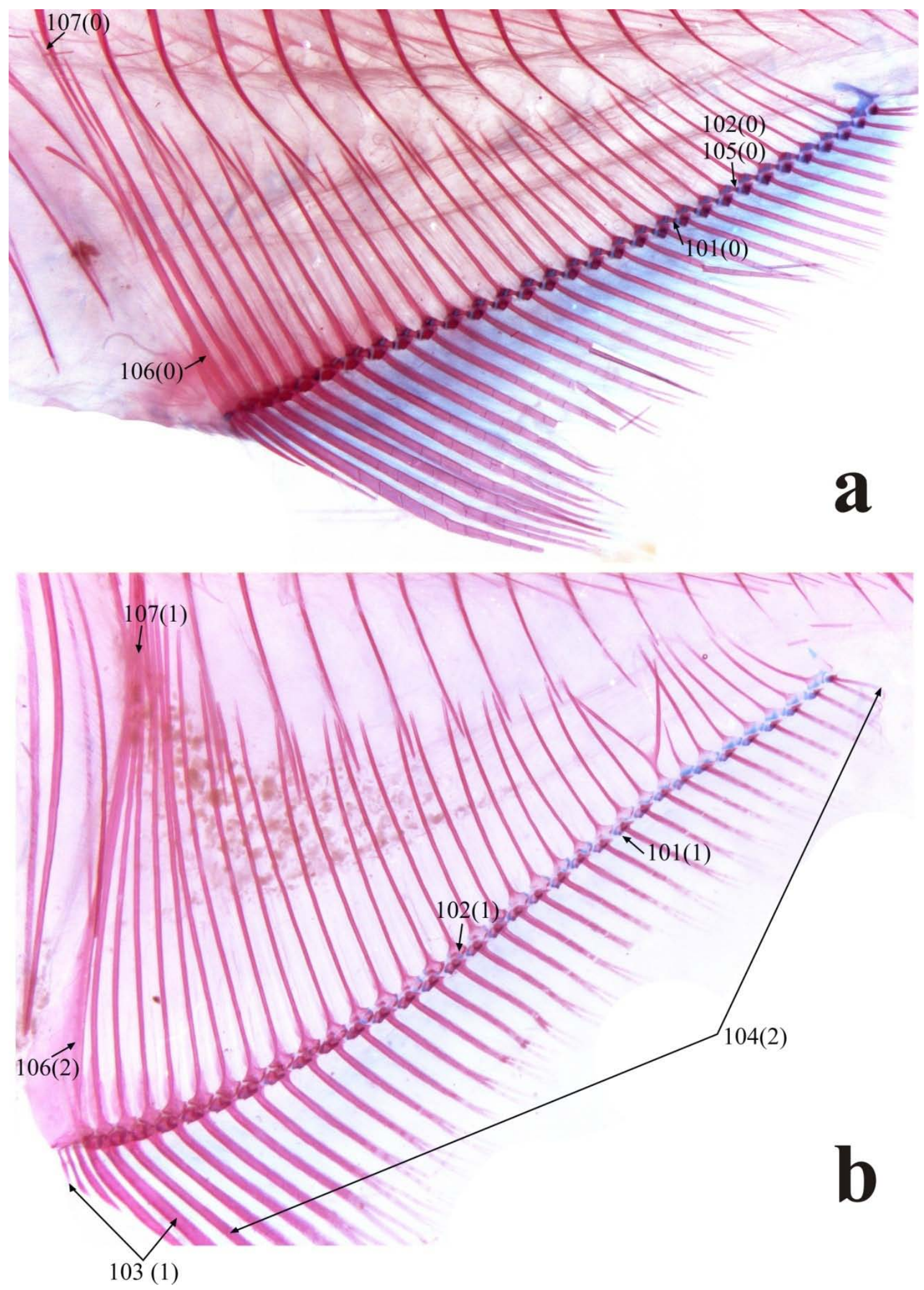

Figura 87. Nadadeira anal de: a) Triportheus paranensis LIRP 5935 (67,57 mm CP); b) Poptella paraguayensis LIRP 5940 (39,8 mm CP). 

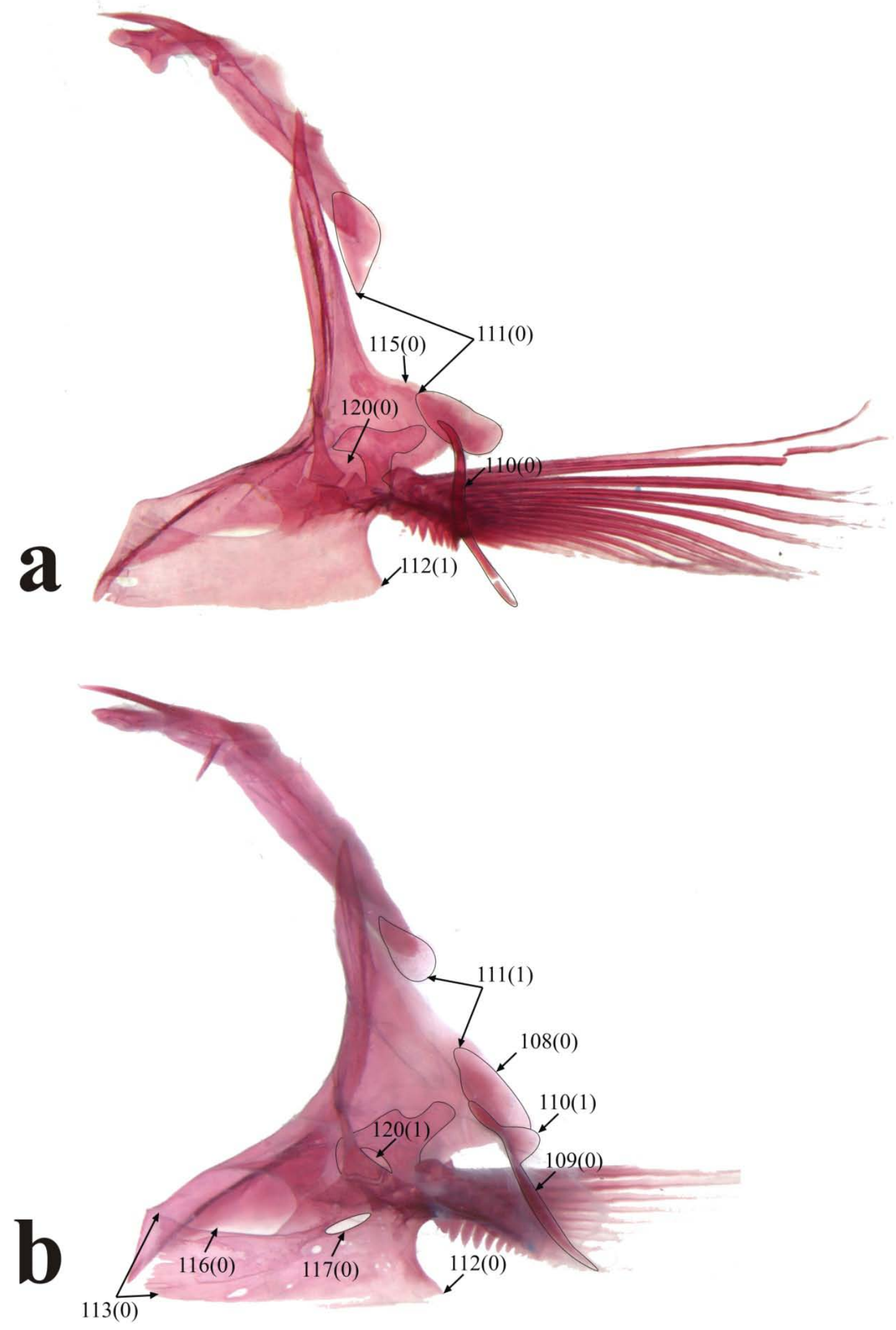

Figura 88. Nadadeira peitoral de: a) Bryconamericus exodon MZUSP 90275 (40,2mm CP); b) Chalceus epakros MZUSP 7054 (102,4mm CP). 


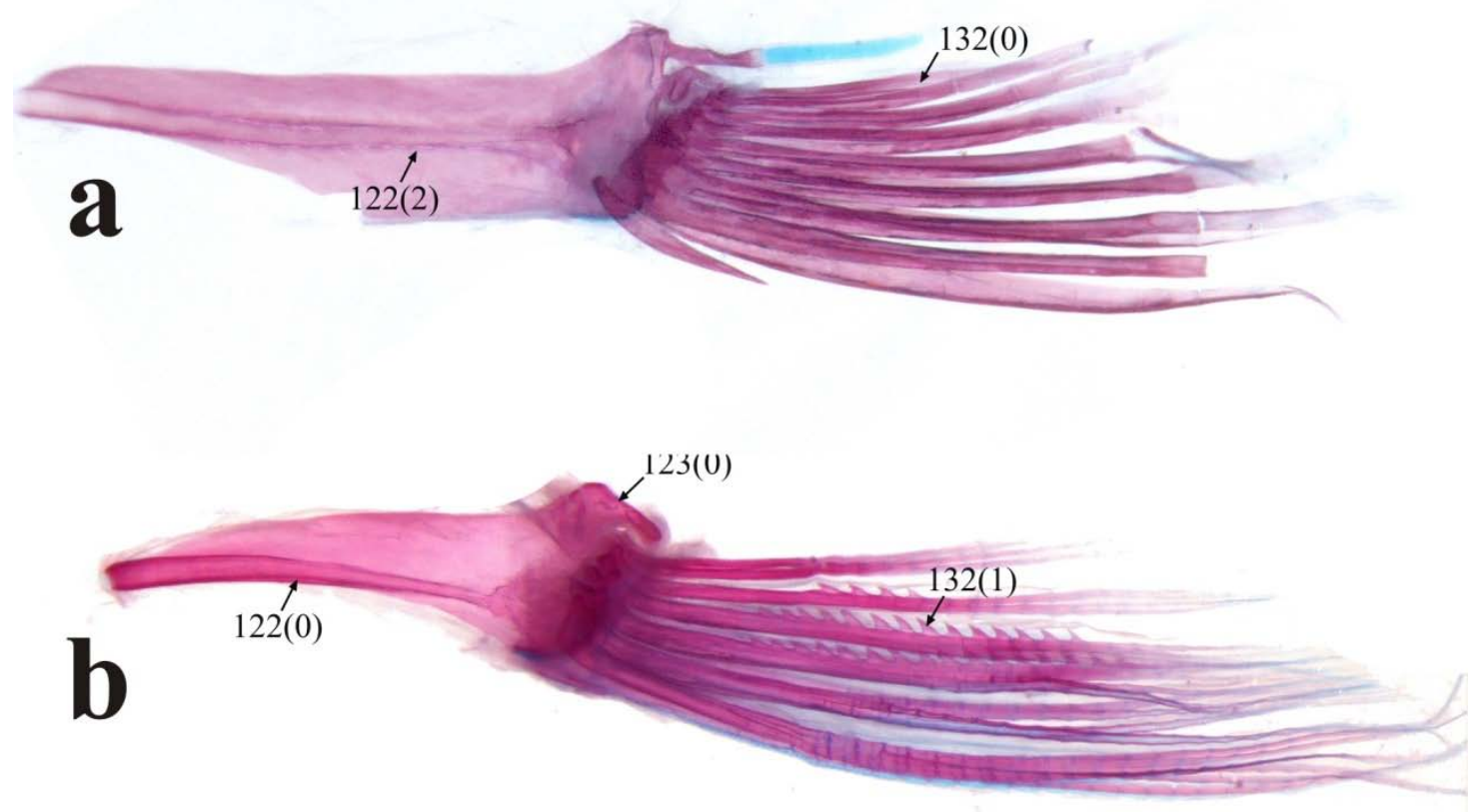

Figura 89. Nadadeira pélvica de: a) Poptella paraguayensis LIRP 5940 (39,8 mm CP); b) Hollandichthys multifasciatus LIRP 5744 (70,60 mm CP). 


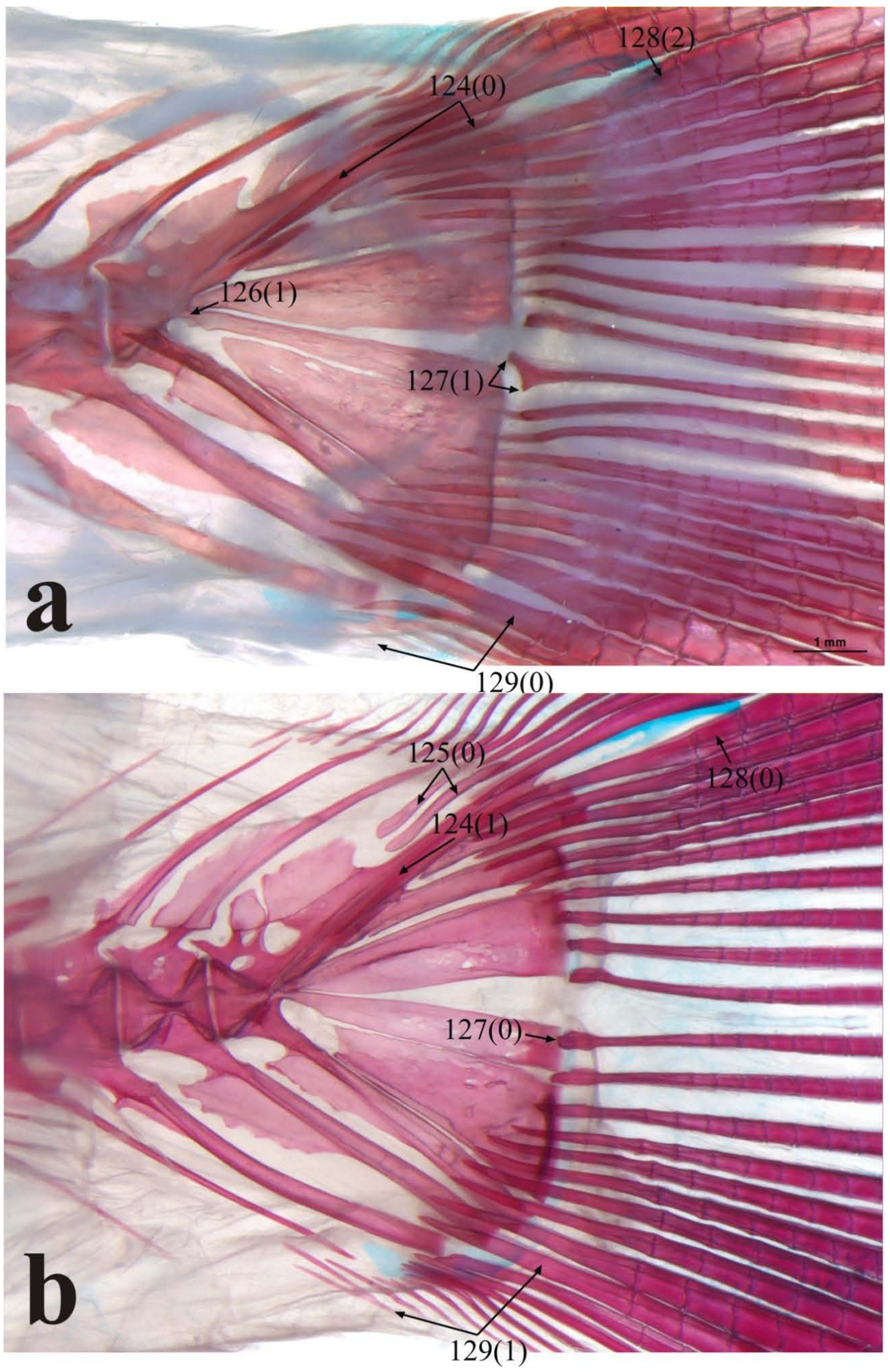

Figura 90. Nadadeira caudal de: a) Agoniates halecinus MZUSP 92807 (104,8mm CP); b) Astyanax lineatus LIRP 5574 (84,4 mm CP). 


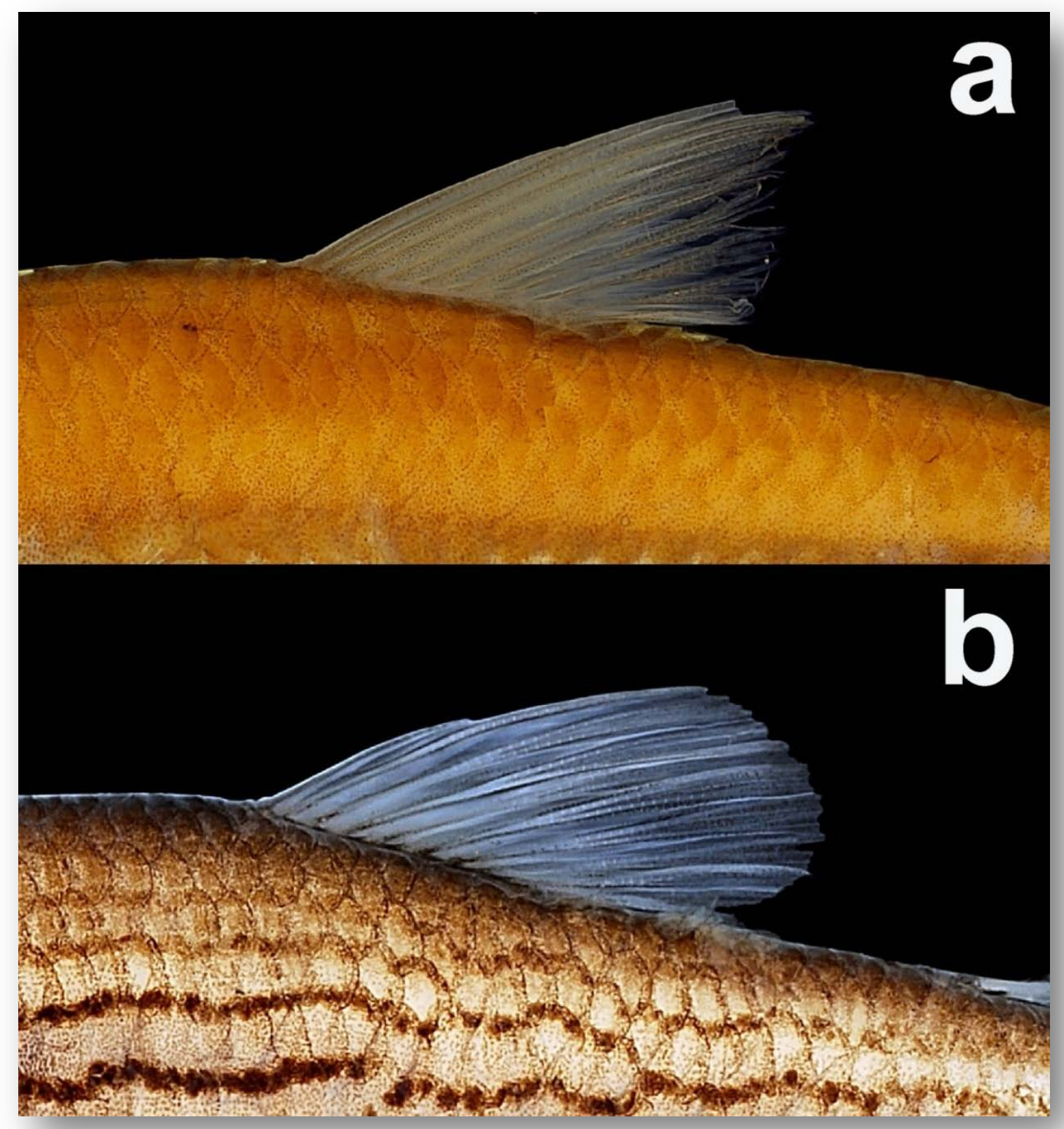

Figura 91. Vista lateral esquerda das nadadeiras dorsais de: a) Astyanax fasciatus LIRP 132 (75,3 mm CP); b) Hollandichthys multifasciatus LIRP 5744 (70,60 mm CP). 


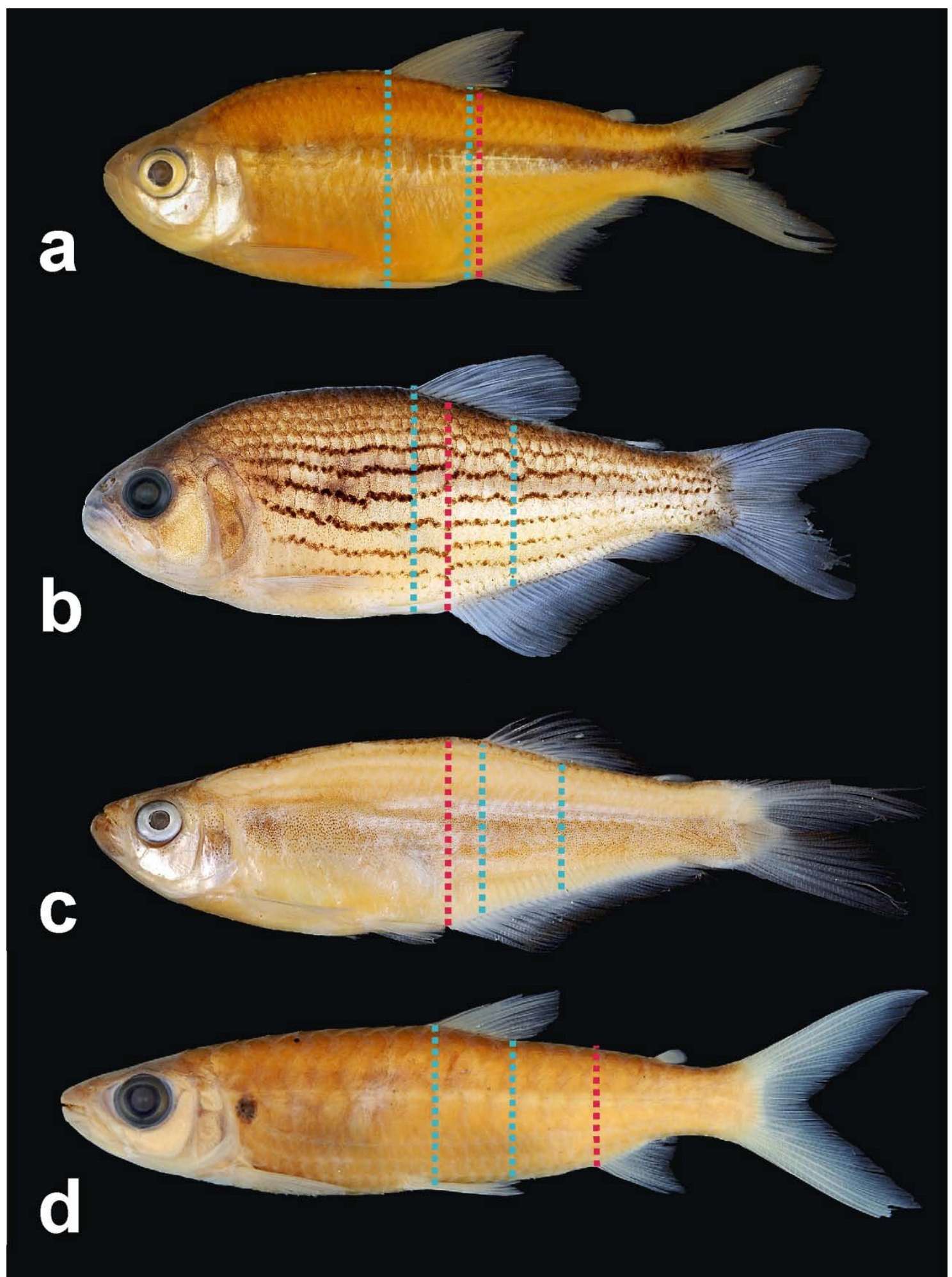

Figura 92. Diferentes posições relativas da nadadeira dorsal. a) Astyanax fasciatus LIRP 132 (75,3 mm CP); b) Hollandichthys multifasciatus LIRP 5744 (70,60 mm CP); c) Mimagoniates microlepis LIRP 5942 (45,61 mm CP); d) Chalceus epakros MZUSP 7054 (102,4 mm CP). 


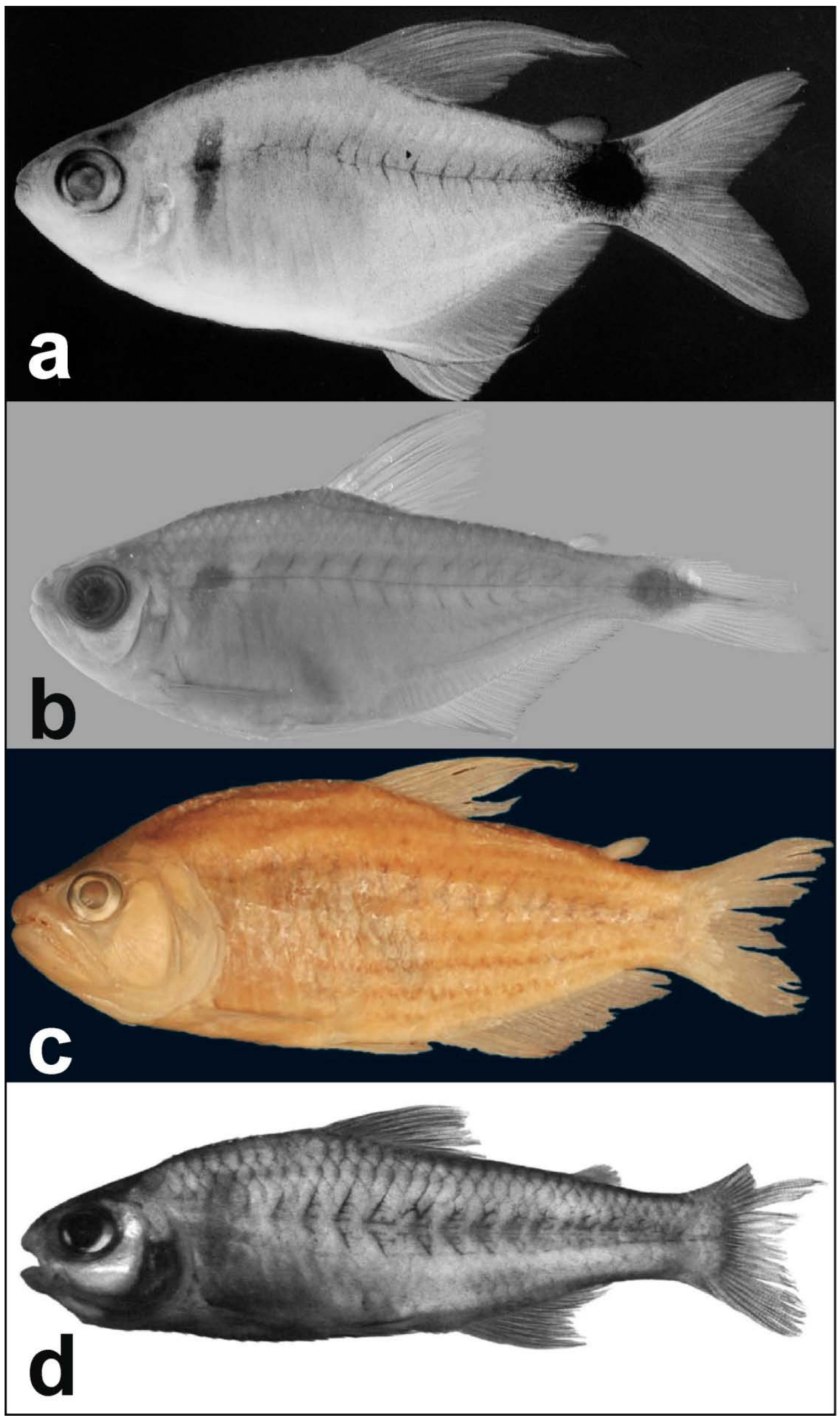

Figura 93. Vista lateral esquerda de: a) Hyphessobrycon heliacus (foto retirada de Moreira et al., 2002); b) Jupiaba pinnatus (fonte USNM) *; c) Pseudochalceus lineatus (foto retirada de Zarske \& Gery, 2006); d) Creagrutus mucipu (foto retirada de Vari \& Harold, 2001). 


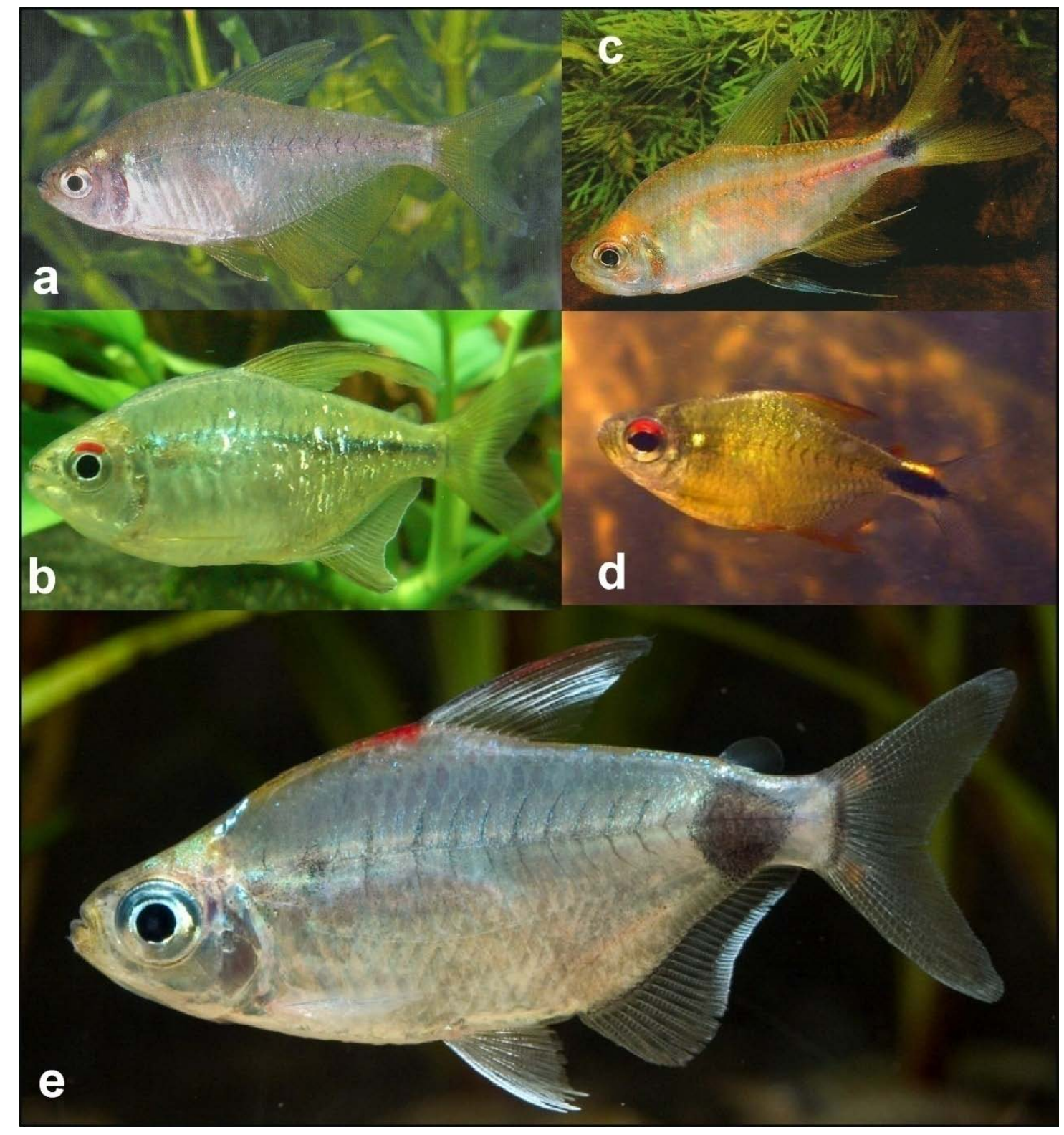

Figura 94. Vista lateral esquerda de: a) Hyphessobrycon bifasciatus (foto modificada de Oyakawa et al., 2006); b) Moenkhausia pittieri *; c) Nematocharax venustus (foto modificada de Menezes et al., 2007); d) Astyanax leopoldi *; e) Phenacogrammus aff. caudomaculatus

* fotos do arquivo pessoal do autor que foram retiradas da internet; peixe de origem desconhecida 


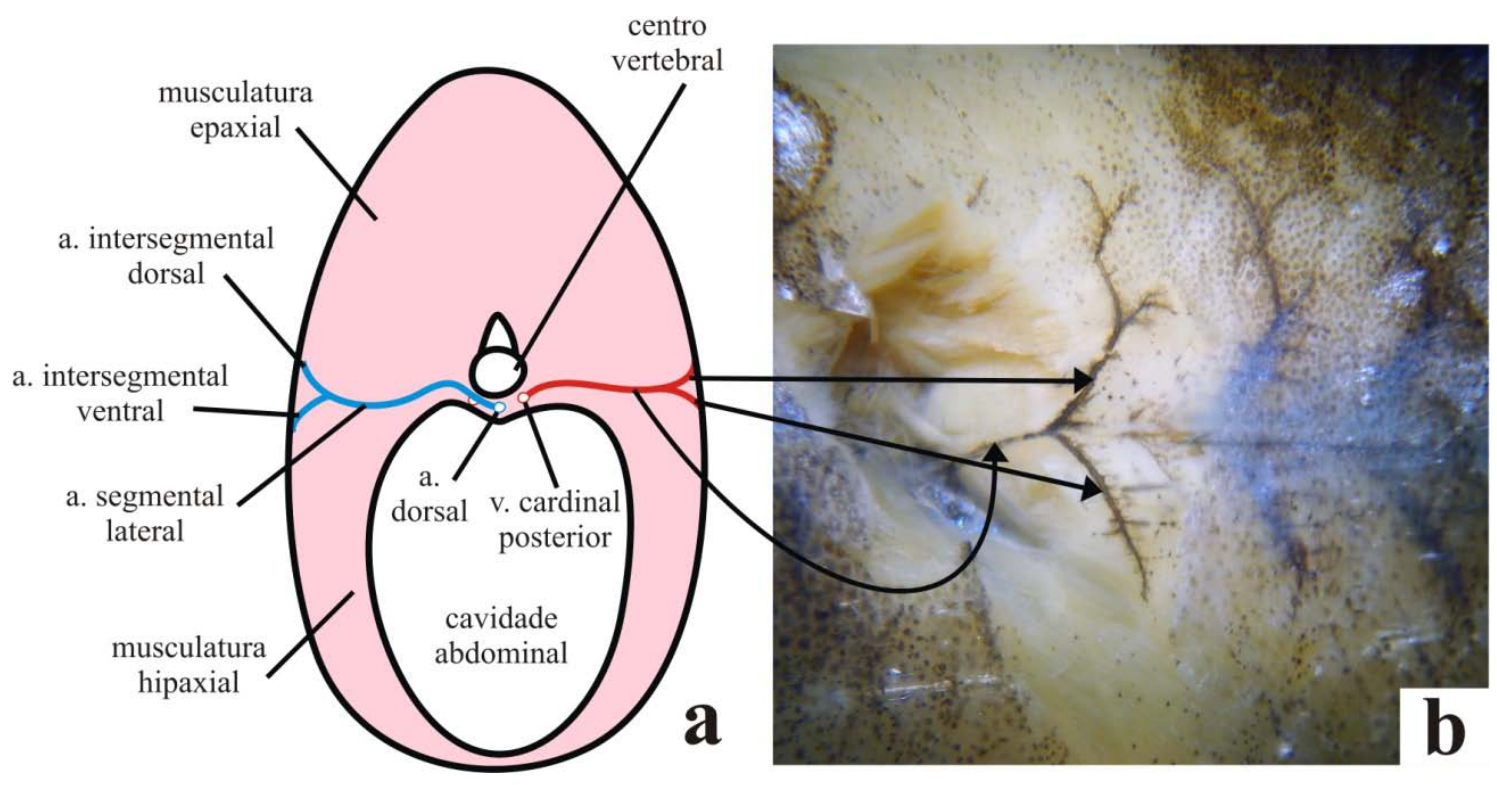

Figura 95. a) Desenho esquemático do corte transversal do corpo de um Astyanacinus. b) Vista lateral esquerda da superfície corporal de Astyanacinus sp nova Bolívia MCP 35017 (52,22 mm CP) com escamas e epiderme removidas expondo a vascularização superficial dos vasos que formam os "chevrons”. (Crédito da foto b: Fernando Jerep). 


\section{Apêndice 3}

Quadros, matriz de caracteres e gráficos 
Quadro 1. Matriz dos estados e caracteres empregados na análise filogenética. Letra A representa o polimorfismo $0 \& 1$, B (0\&2), C (1\&2), D (2\&3) e E (3\&4). [?] representa indeterminado e [-] representa inaplicável.

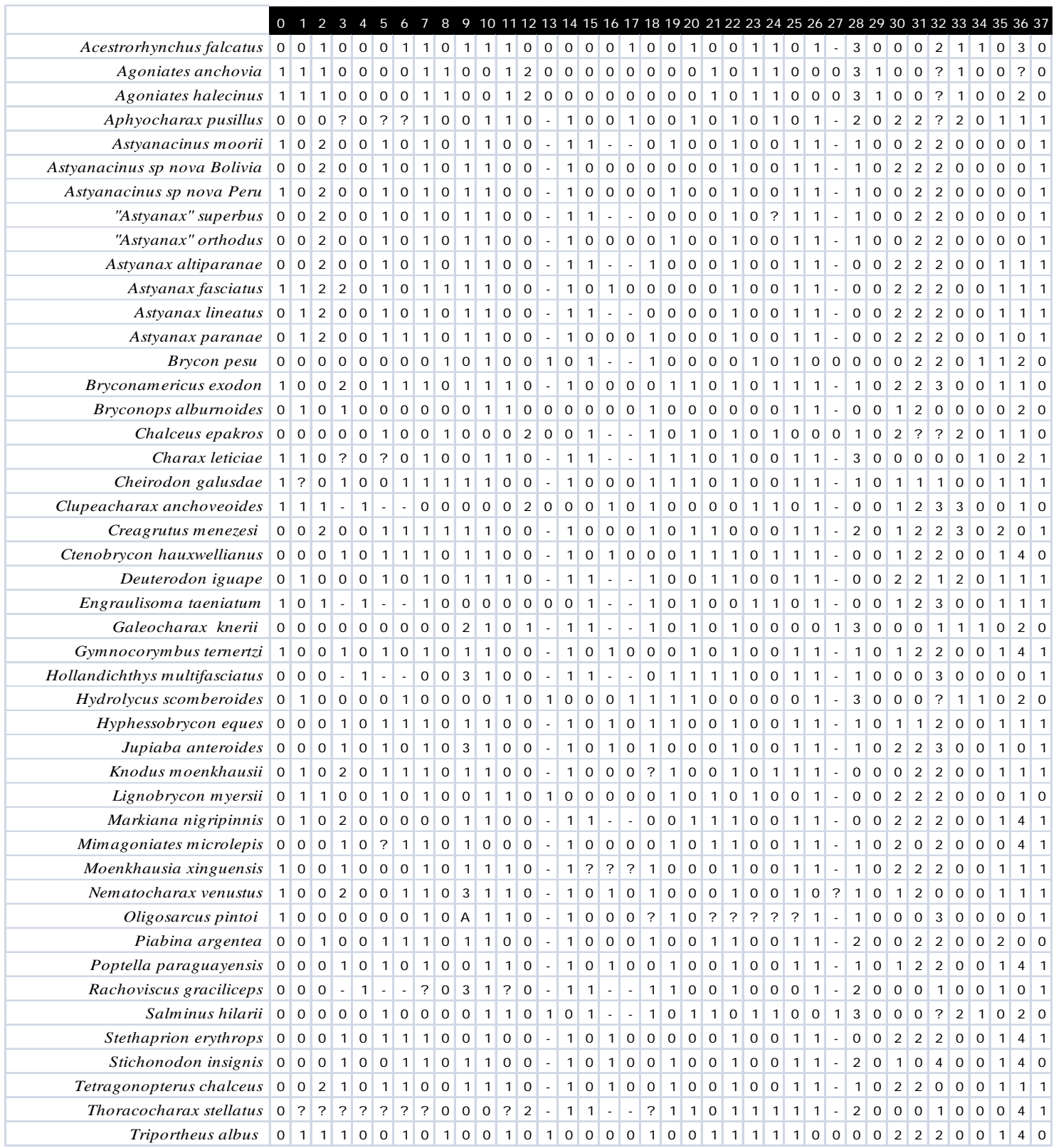


\begin{tabular}{|l|l|l|l|l|l|l|l|l|l|l|l|l|l|l|l|l|l|l|l|l|l|l|l|l|l|l|l|l|l|l|l|l|l|l|l|l|l|l|l|l|l|l|l|l|l|l|l|l|l|l|l}
\hline 1 & 0 & 2 & - & 0 & 1 & 1 & 0 & 0 & 0 & 5 & 0 & 2 & 0 & 2 & 2 & 1 & 0 & 0 & 0 & 1 & 0 & 0 & 0 & 0 & 0 & 0 & 0 & 0 & 1 & 0 & 0 & 0 & 1 & 0 & 2 & 1 & 1 & 0 & 1 & 1 & 1 & 0 & 0 & 0 & 1 & 0 & 1 & 0 & $?$ & $?$
\end{tabular}

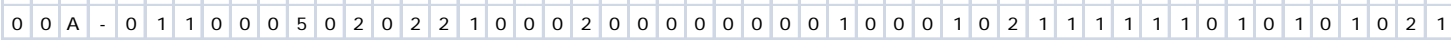

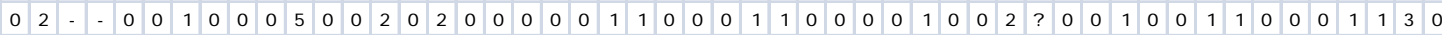

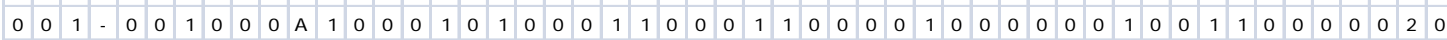

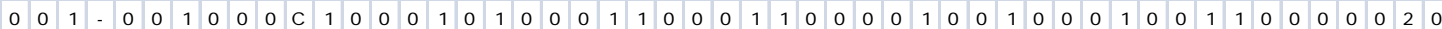

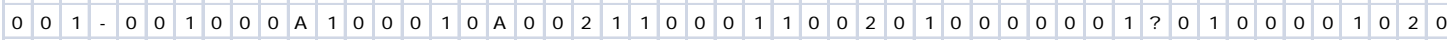
$\begin{array}{lllllllllllllllllllllllllllllllllllllllllllllllllllllllllllllllll}0 & 0 & 1 & - & 0 & 0 & 1 & 0 & 0 & 0 & E & 1 & 1 & 0 & 0 & 1 & 0 & A & 0 & 0 & 2 & 0 & 2 & 0 & 0 & 0 & 1 & 1 & 0 & 0 & 2 & 0 & 1 & 0 & 0 & 1 & 0 & 0 & 0 & 1 & ? & 0 & 1 & 0 & 0 & 0 & 0 & 1 & 0 & 2 & 0\end{array}$

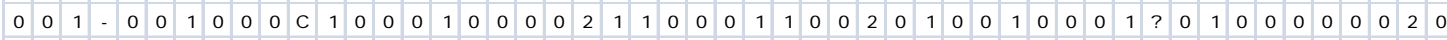

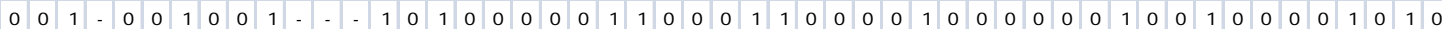

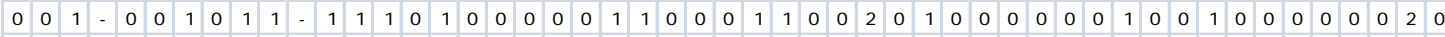

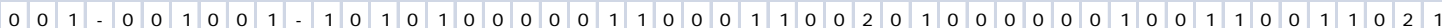

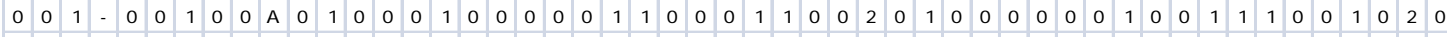

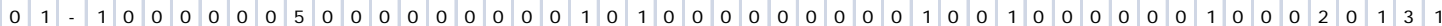

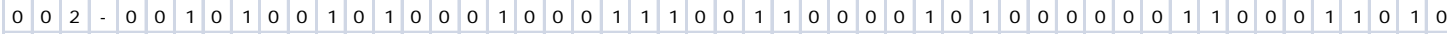

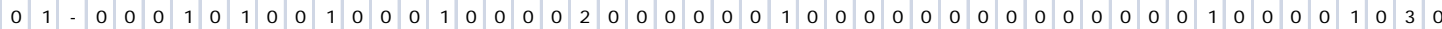

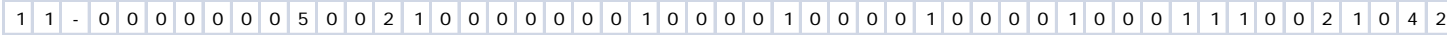

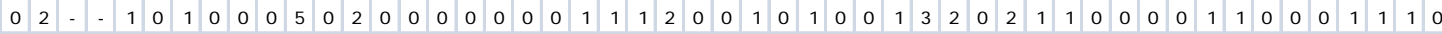

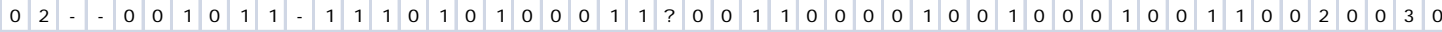

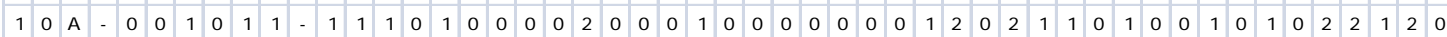

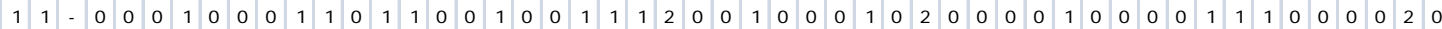

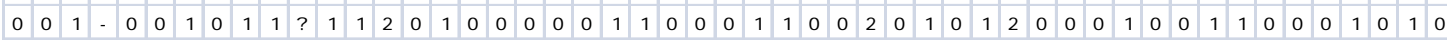
\begin{tabular}{lllllllllllllllllllllllllllllllll|llllllllllllllllllllllllllllll}
$?$ & 0 & 1 & - & 0 & 0 & 1 & 0 & 0 & 0 & 0 & 1 & 3 & 0 & 0 & 1 & 0 & 0 & 0 & 0 & 0 & 1 & 1 & 0 & 0 & 0 & 1 & 1 & 0 & 0 & 0 & 0 & 1 & 0 & 0 & 0 & 0 & 0 & 0 & 1 & 1 & 0 & 1 & 0 & 0 & 0 & 0 & 1 & 0 & 1 & 0 \\
\hline
\end{tabular}

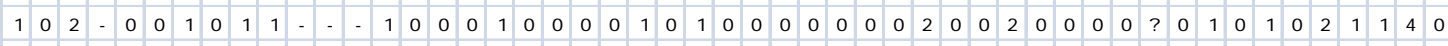

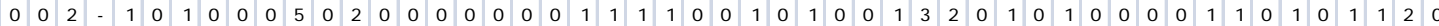

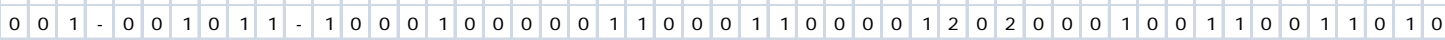
$\begin{array}{lllllllllllllllllllllllllllllllllllllllllllllllllllllllllllllllll}1 & 0 & 1 & - & 0 & 0 & 1 & 0 & 0 & 0 & 5 & 0 & 0 & 0 & 0 & 2 & 0 & 1 & 0 & 0 & 2 & 1 & 1 & 0 & 0 & 0 & 1 & 1 & 0 & 0 & 0 & 0 & 1 & 0 & 0 & 0 & 0 & 0 & 0 & 1 & 0 & 0 & 1 & 0 & 0 & 0 & 2 & 1 & 1 & 2 & 0\end{array}$

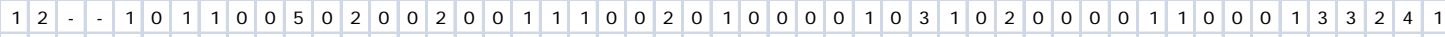
$\begin{array}{lllllllllllllllllllllllllllllllllllllllllllllllllllllllllllllll}0 & 2 & - & - & 0 & 0 & 1 & 0 & 1 & 0 & 0 & 1 & 1 & 1 & 0 & 2 & 0 & 0 & 0 & 0 & 0 & 1 & 0 & 0 & 0 & 0 & 1 & 1 & 0 & 0 & 0 & 0 & 1 & 0 & 0 & 0 & 0 & 0 & 0 & 0 & 0 & 1 & 1 & 1 & 0 & 0 & 1 & 1 & 0 & 1 & 0\end{array}$

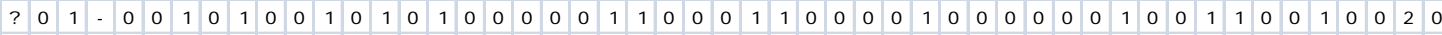

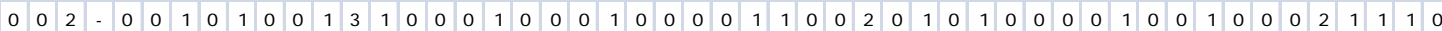

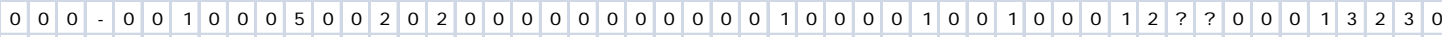

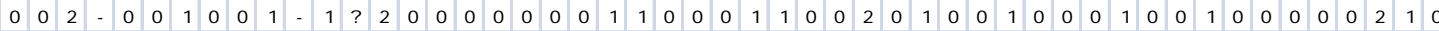

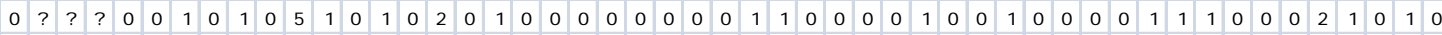

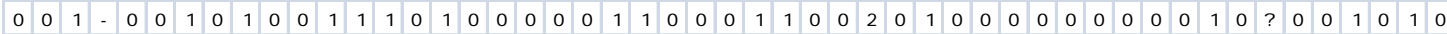

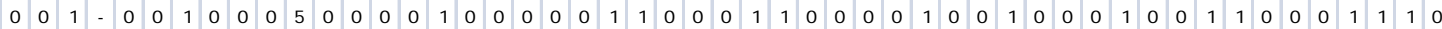

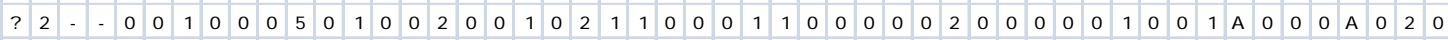
\begin{tabular}{llllllllllllllllllllllllllllllllllllllllllllllllllllllllllllllllll}
0 & 1 & - & 0 & 0 & 0 & 1 & 0 & 0 & 0 & 1 & 1 & 0 & 2 & 0 & 0 & 0 & 1 & 0 & 0 & 0 & 1 & 0 & 1 & 0 & 0 & 1 & 1 & 0 & 0 & 0 & 0 & 1 & 0 & 0 & 0 & 0 & 1 & 0 & 1 & 0 & 0 & 1 & 0 & 0 & 0 & 2 & 1 & 1 & 2 & 0 \\
\hline
\end{tabular}

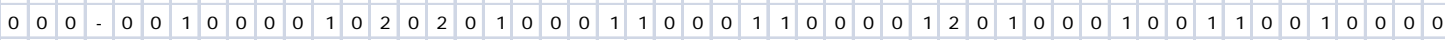
$\begin{array}{llllllllllllllllllllllllllllllllllllllllllllllllllllllllllllllll}0 & 0 & 1 & - & 0 & 0 & 1 & 0 & 0 & 0 & 5 & 1 & 2 & 0 & 0 & 2 & 0 & 1 & 0 & 0 & 0 & 0 & 1 & 0 & 0 & 0 & 1 & 1 & 0 & 1 & 0 & 0 & 1 & 0 & 0 & 1 & 0 & 0 & 0 & 1 & 0 & 0 & 1 & 1 & 0 & 0 & 0 & 2 & 1 & 2 & 0\end{array}$

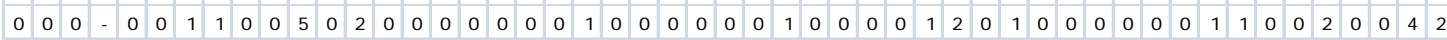

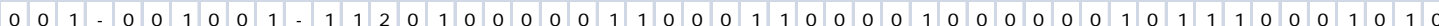

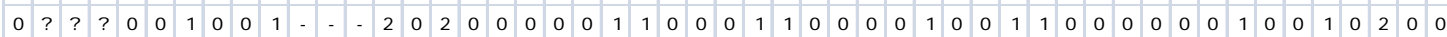
$\begin{array}{lllllllllllllllllllllllllllllllllllllllllllllllllllllllllllllllll}0 & 0 & 1 & - & 0 & 0 & 1 & 0 & 1 & 0 & 0 & 1 & 1 & 2 & 0 & 2 & 0 & 0 & 0 & 0 & 0 & 1 & 1 & 0 & 0 & 0 & 1 & 1 & 0 & 0 & 2 & 0 & 1 & 0 & 0 & 0 & 0 & 0 & 0 & 1 & 0 & 0 & 1 & 1 & 0 & 0 & 1 & 0 & 0 & 1 & 0\end{array}$

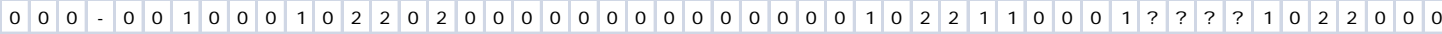

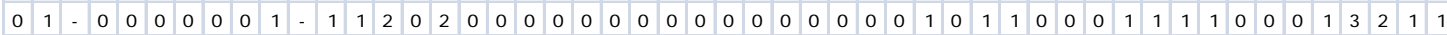




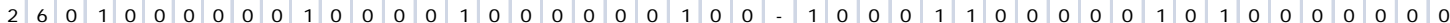

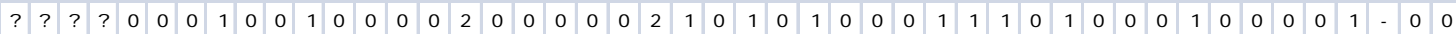
$\begin{array}{lllllllllllllllllllllllllllllllllllllllllllllllllllllllllll}3 & 5 & 0 & 1 & 0 & 0 & 0 & 1 & 0 & 0 & 1 & 0 & 0 & 0 & 0 & 1 & 0 & 0 & 0 & 0 & 0 & 2 & 1 & 0 & 0 & - & 1 & 0 & 0 & 0 & 1 & 1 & 1 & 0 & 1 & 0 & 0 & 0 & 1 & 0 & 0 & 0 & 0 & 1 & - & 0 & 0\end{array}$

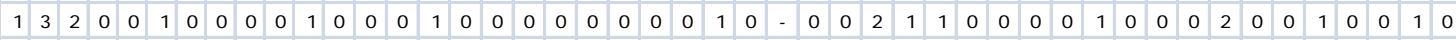

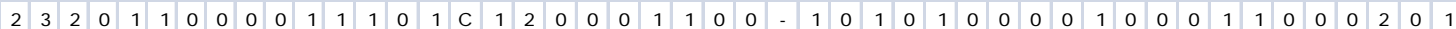

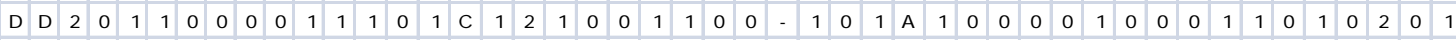
\begin{tabular}{lllllllllllllllllllllllllllllllllllllllllllllllllllll|l|l|l|l|l|l|l}
2 & 3 & 2 & 0 & 1 & 1 & 0 & 0 & 0 & 0 & 1 & 1 & 1 & 0 & 1 & $C$ & 1 & 0 & 0 & 0 & 0 & 1 & 1 & 0 & 0 & - & 1 & 0 & 0 & 0 & 1 & 0 & 0 & 0 & 0 & 1 & $B$ & 0 & 0 & 1 & 1 & 0 & 0 & 0 & 2 & 0 & 1
\end{tabular}

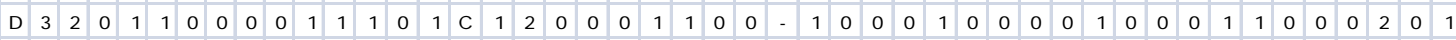

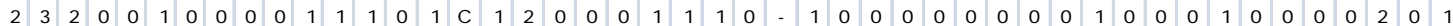

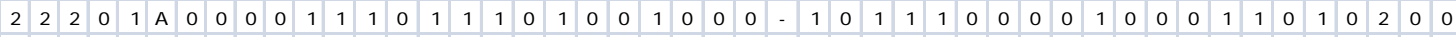
$\begin{array}{lllllllllllllllllllllllllllllllllllllllllllllllllllllllll}1 & 2 & 2 & 0 & \text { A } & 1 & 0 & 0 & 0 & 0 & 1 & 1 & 1 & 0 & 1 & 1 & 0 & 2 & 1 & 0 & 0 & 1 & 1 & 1 & 0 & - & 1 & 0 & 1 & 0 & 1 & 0 & 0 & 0 & 0 & 1 & 0 & 0 & 0 & 1 & 1 & 0 & 1 & 0 & 1 & 0 & 0\end{array}$

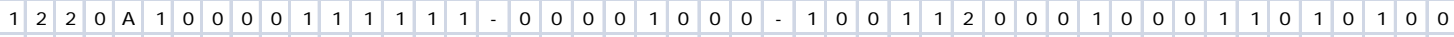
$\begin{array}{lllllllllllllllllllllllllllllllllllllllllllllllllllllllllll}0 & 0 & 0 & 0 & 1 & 1 & 0 & 0 & 0 & 0 & 1 & 1 & 1 & 0 & 1 & 0 & 0 & 0 & 1 & 0 & 0 & 1 & 1 & 1 & 0 & - & 1 & 0 & 1 & 0 & 1 & 0 & 0 & 0 & 0 & 1 & 0 & 0 & 0 & 1 & 1 & 0 & 1 & 0 & 1 & 0 & 0\end{array}$

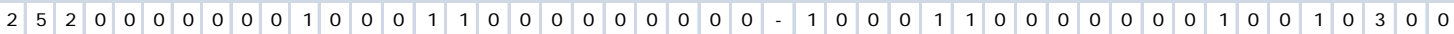
$\begin{array}{lllllllllllllllllllllllllllllllllllllllllllllllllllllllll}3 & 3 & 2 & 0 & 1 & 1 & 0 & 1 & 0 & 1 & 2 & 0 & 1 & 0 & 1 & 1 & 0 & 0 & 0 & 0 & 0 & 0 & 1 & 1 & 0 & - & 0 & 0 & 1 & 1 & 1 & 0 & 0 & 0 & 0 & 1 & 0 & 0 & 0 & 0 & 0 & 0 & 1 & 0 & 0 & 0 & 0\end{array}$

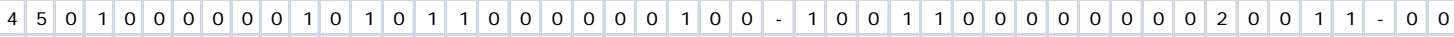
$\begin{array}{llllllllllllllllllllllllllllllllllllllllllllllllllllllllll}0 & 3 & 2 & 0 & 0 & 0 & 0 & 3 & 0 & 0 & 0 & 0 & 0 & 0 & 0 & 0 & 0 & 0 & 0 & 0 & 0 & 1 & 1 & 0 & 0 & - & 1 & 0 & 0 & 0 & 1 & 1 & 0 & 0 & 0 & 0 & 2 & 0 & 0 & 1 & 0 & 0 & 0 & 0 & 0 & 0 & 0\end{array}$

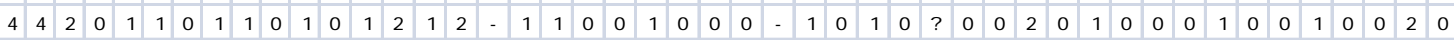

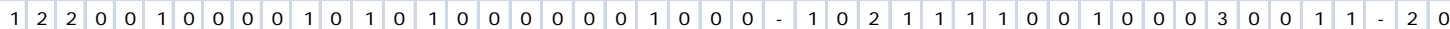

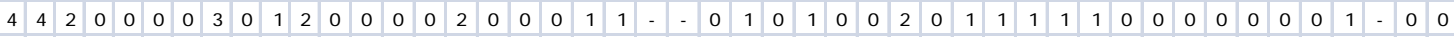

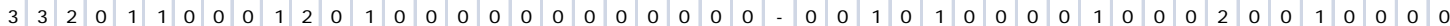

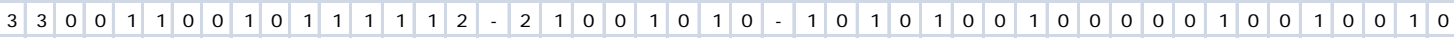
\begin{tabular}{lllll|l|l|l|l|l|l|l|l|l|l|l|l|l|l|l|l|l|l|l|l|l|l|l|l|l|l|l|l|l|l|l|l|l|l|l|l|l|l|l|l|l|l}
1 & 1 & 2 & 0 & 1 & 1 & 0 & 0 & 0 & 0 & 1 & 1 & 1 & 0 & 1 & 1 & 0 & 0 & 1 & 0 & 0 & 1 & 1 & 1 & 0 & - & 1 & 0 & $?$ & 0 & 0 & 0 & 0 & 0 & 0 & 1 & 0 & 0 & 0 & 1 & 0 & 0 & 0 & 0 & 0 & 0 & 0
\end{tabular}

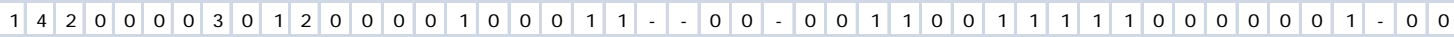
$\begin{array}{llllllllllllllllllllllllllllllllllllllllllllllllllllllllll}4 & 5 & 2 & 0 & 1 & 1 & 0 & 1 & 0 & 0 & 1 & 0 & 1 & 2 & 1 & 2 & - & 0 & 0 & 0 & 0 & 1 & 0 & 1 & 0 & - & 1 & 0 & 2 & 0 & 1 & 2 & 0 & 0 & 0 & 1 & 0 & 0 & 0 & 2 & 0 & 1 & 1 & 0 & 0 & 2 & 0\end{array}$

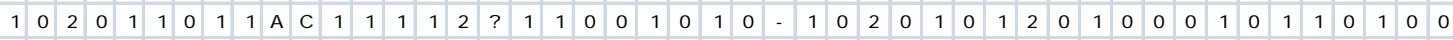
\begin{tabular}{llllllllllllllllllllllllllllllllllllllllllllllllllllllllllll|l|l}
2 & 3 & 0 & 0 & 0 & 1 & 1 & 1 & 0 & 0 & 1 & A & 1 & 0 & 1 & 2 & 1 & 2 & 0 & 0 & 0 & 1 & 1 & 0 & 0 & - & 1 & 0 & 2 & 0 & 1 & 0 & 1 & 0 & 0 & 1 & 0 & 0 & 0 & 1 & 0 & 0 & 1 & 1 & - & 0 & 0 \\
\hline
\end{tabular}

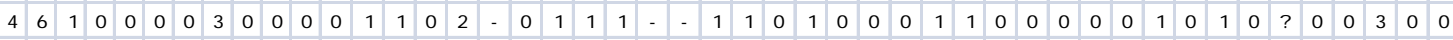
$\begin{array}{lllllllllllllllllllllllllllllllllllllllllllllllllllllllllllll}2 & 1 & 2 & 0 & 1 & 1 & 1 & 1 & 1 & 0 & 1 & 1 & 1 & 0 & 1 & 1 & ? & 2 & 1 & 0 & 0 & 0 & 1 & 1 & 0 & - & 1 & 0 & 2 & 1 & 1 & 0 & 0 & 0 & 0 & 1 & 0 & 0 & 0 & 1 & 0 & 0 & 1 & 0 & 0 & 1 & 0\end{array}$

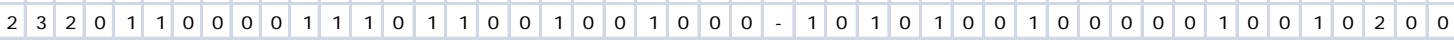
$\begin{array}{lllllllllllllllllllllllllllllllllllllllllllllllllllllllllll}3 & 3 & 2 & 0 & \text { A } & 1 & 0 & 0 & 0 & 1 & 2 & 0 & 1 & 0 & 1 & 0 & 0 & 0 & 0 & 0 & 0 & 0 & 1 & 1 & 0 & - & 0 & 0 & 1 & 1 & 1 & 0 & 0 & 0 & 0 & 1 & 0 & 0 & 0 & 2 & 0 & 0 & 1 & 0 & 0 & 0 & 0\end{array}$

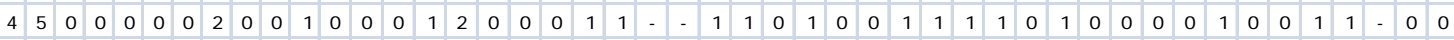
\begin{tabular}{lllll|l|l|l|l|l|l|l|l|l|l|l|l|l|l|l|l|l|l|l|l|l|l|l|l|l|l|l|l|l|l|l|l|l|l|l|l|l|l|l|l|l|l|l}
3 & 3 & 0 & 0 & 1 & 1 & 0 & 1 & 0 & 0 & 1 & 0 & 1 & 0 & 1 & 2 & 1 & 2 & 1 & 0 & 0 & 1 & 1 & 0 & 0 & - & 1 & 0 & 0 & 0 & 1 & 0 & 0 & 0 & 0 & $A$ & 0 & 0 & 0 & 0 & 0 & 1 & 1 & 1 & - & 0 & 0
\end{tabular}

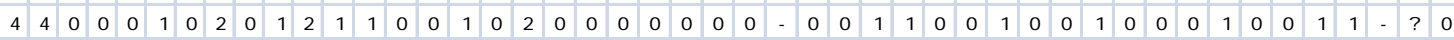
$\begin{array}{llllllllllllllllllllllllllllllllllllllllllllllllllllllllllll}1 & 1 & 2 & 0 & 1 & 1 & 0 & 0 & ? & 0 & 1 & 1 & 1 & ? & 0 & 1 & 0 & 0 & 1 & 0 & 0 & 0 & 0 & 1 & 0 & - & 1 & 0 & 2 & 0 & 1 & 0 & 0 & 1 & 0 & 0 & 0 & 0 & 0 & 1 & 0 & 0 & 1 & 0 & 0 & 0 & 0\end{array}$

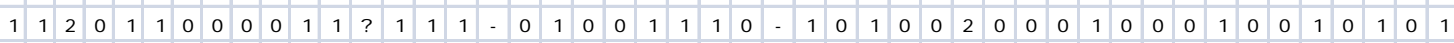
\begin{tabular}{llllllllllllllllllllllllllllllllllllllllllllllllllllllllllllllll}
2 & 2 & 2 & 0 & A & 1 & 0 & 1 & 0 & 0 & 1 & 0 & 1 & 0 & 1 & 1 & 0 & 0 & 1 & 0 & 0 & 1 & 0 & 1 & 0 & - & 1 & 0 & 1 & 0 & 1 & 0 & 0 & 0 & 0 & 1 & 0 & 0 & 0 & 1 & 1 & 0 & 1 & 0 & 1 & 1 & 0 \\
\hline
\end{tabular}

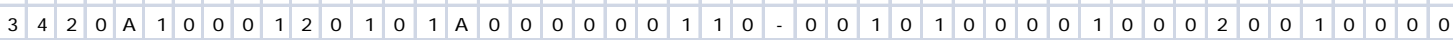

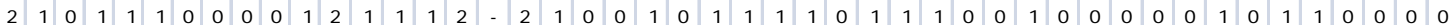

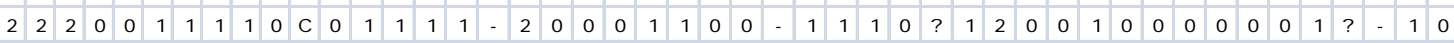
\begin{tabular}{lllllllllllllllllllllllllllllllllllllllllllllllllllllll|l|l|l|l|l}
2 & 6 & 2 & 0 & 0 & 0 & 0 & 0 & 0 & 0 & 1 & 1 & 0 & 0 & 1 & 1 & 0 & 0 & 0 & 0 & 0 & 0 & 0 & 1 & 0 & - & 1 & 0 & 0 & 1 & 1 & 0 & 0 & 0 & 0 & 0 & 0 & 0 & 0 & 2 & 0 & 0 & 1 & 1 & - & 0 & 0 \\
\hline
\end{tabular}

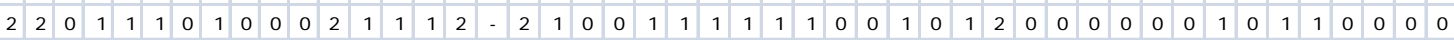

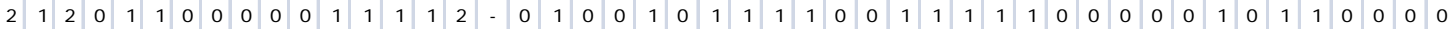

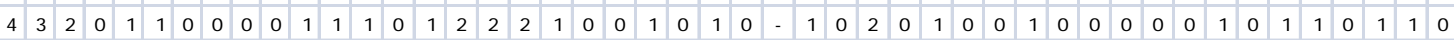

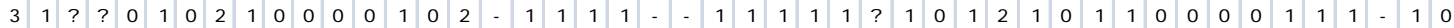

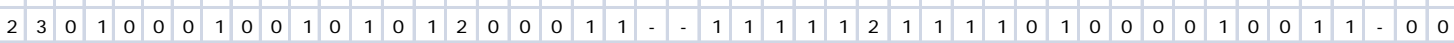




\begin{tabular}{|c|c|c|c|c|c|c|c|c|c|c|}
\hline Espécie (n=62) & Intervalo & 30 & 31 & 32 & 33 & 34 & 35 & 36 & 37 & 38 \\
\hline A. aeneus & $34-36$ & & & & & & & & & \\
\hline A. ajuricaba & $36-37$ & & & & & & & & & \\
\hline A. altiparanae & $35-36 ?$ & & & & & & & & & \\
\hline A. aramburui & $36-37$ & & & & & & & & & \\
\hline A. belizianus & $34-36$ & & & & & & & & & \\
\hline A. biotae & $32-34$ & & & & & & & & & \\
\hline A. bockmanni & $33-34$ & & & & & & & & & \\
\hline A. brachypterygium & $34-36$ & & & & & & & & & \\
\hline A. brevimanus & $36-37$ & & & & & & & & & \\
\hline A. burgerai & 33 & & & & & & & & & \\
\hline A. chico & 33 & & & & & & & & & \\
\hline A. cobanensis & $36-38$ & & & & & & & & & \\
\hline A. cocibolca & $35-36$ & & & & & & & & & \\
\hline A. costaricensis & $36-38$ & & & & & & & & & \\
\hline A. courensis & $34-35$ & & & & & & & & & \\
\hline A. cremnobates & $34-36$ & & & & & & & & & \\
\hline A. cuvieri & $35-37$ & & & & & & & & & \\
\hline "A". dnophos & 34 & & & & & & & & & \\
\hline A. elachylepis & $35-36$ & & & & & & & & & \\
\hline A. endy & $33-35$ & & & & & & & & & \\
\hline A. epiagos & $34-37$ & & & & & & & & & \\
\hline A. erythropterus & 33 & & & & & & & & & \\
\hline A. fasciatus & $35-36$ & & & & & & & & & \\
\hline A. fulgens & 36 & & & & & & & & & \\
\hline A. goyacensis & 36 & & & & & & & & & \\
\hline A. goyanensis & 35 & & & & & & & & & \\
\hline A. henseli & 37 & & & & & & & & & \\
\hline A. hermosus & $34-36$ & & & & & & & & & \\
\hline A. humilis & $34-35$ & & & & & & & & & \\
\hline A. ita & $33-34$ & & & & & & & & & \\
\hline A. jacobinae & $35-36$ & & & & & & & & & \\
\hline A. jequitinhonhae & $35-36$ & & & & & & & & & \\
\hline A. jordanensis & $34-37$ & & & & & & & & & \\
\hline A. latens & $35-37$ & & & & & & & & & \\
\hline A. laticeps & $35-37$ & & & & & & & & & \\
\hline A. leonidas & $32-33$ & & & & & & & & & \\
\hline A. lineatus & 35 & & & & & & & & & \\
\hline A. macrophthalmus & $34-38$ & & & & & & & & & \\
\hline A. mexicanus & $34-37$ & & & & & & & & & \\
\hline A. microschemos & $35-36$ & & & & & & & & & \\
\hline A. obscurus & $36-38$ & & & & & & & & & \\
\hline A. oerstedii & $35-38$ & & & & & & & & & \\
\hline A. oijara & $32-34$ & & & & & & & & & \\
\hline A. pampa & $33-35$ & & & & & & & & & \\
\hline A. panamensis & 35 & & & & & & & & & \\
\hline A. paranae & $35-36$ & & & & & & & & & \\
\hline A. paris & 35 & & & & & & & & & \\
\hline A. pelecus & 35 & & & & & & & & & \\
\hline A. puka & $35-36$ & & & & & & & & & \\
\hline A. pynandi & 35 & & & & & & & & & \\
\hline A. saguazu & $31-33$ & & & & & & & & & \\
\hline A. stenohalinus & 36 & & & & & & & & & \\
\hline A. totae & $35-36$ & & & & & & & & & \\
\hline A. trierythropterus & $35-36$ & & & & & & & & & \\
\hline A. troya & $30-31$ & & & & & & & & & \\
\hline A. tumbayensis & $33-34$ & & & & & & & & & \\
\hline A. tupi & 35 & & & & & & & & & \\
\hline A. utiariti & $34-35$ & & & & & & & & & \\
\hline A. varzeae & $36-38$ & & & & & & & & & \\
\hline A. vermilion & 33 & & & & & & & & & \\
\hline A. viejita & $35-36$ & & & & & & & & & \\
\hline A. xavante & $35-36$ & & & & & & & & & \\
\hline
\end{tabular}

Quadro 02. Quantidade de vértebras nas espécies de Astyanax. Informações retiradas da literatura ou através de observação pessoal. 
Caráter IC IR Caráter IC IR Caráter IC IR

\begin{tabular}{|c|c|c|c|c|c|c|c|c|}
\hline & & & & & & & & \\
\hline 0 & 0,08 & 0,2 & 45 & 0,5 & 0,5 & 90 & 0,3 & 0,4 \\
\hline 1 & 0,12 & 0,5 & 46 & 0,1 & 0,4 & 91 & 0,3 & 0,5 \\
\hline 2 & 0,33 & 0,8 & 47 & 0,3 & 0,5 & 92 & 0,2 & 0 \\
\hline 3 & 0,2 & 0,5 & 48 & 0,6 & 0,6 & 93 & 0,7 & 0,8 \\
\hline 4 & 0,5 & 0,7 & 49 & 0,2 & 0,6 & 94 & 0,7 & 0,9 \\
\hline 5 & 0,14 & 0,5 & 50 & 0,2 & 0,3 & 95 & 0,5 & 0,5 \\
\hline 6 & 0,11 & 0,5 & 51 & 0,2 & 0,6 & 96 & 0,2 & 0,4 \\
\hline 7 & 0,13 & 0,3 & 52 & 0,6 & 0,5 & 97 & 0,2 & 0 \\
\hline 8 & 0,16 & 0,3 & 53 & 0,2 & 0,6 & 98 & 0,7 & 0,8 \\
\hline 9 & 0,44 & 0,7 & 54 & 1 & 1 & 99 & 0,4 & 0,5 \\
\hline 10 & 0,2 & 0,5 & 55 & 0,3 & 0,5 & 100 & 0,4 & 0,8 \\
\hline 11 & 0,11 & 0,5 & 56 & 0,5 & 0,5 & 101 & 0,2 & 0,6 \\
\hline 12 & 0,4 & 0,3 & 57 & 1 & 1 & 102 & 0,3 & 0,4 \\
\hline 13 & 0,25 & 0,3 & 58 & 0,2 & 0,4 & 103 & 0,1 & 0,5 \\
\hline 14 & 0,5 & 0,9 & 59 & 0,3 & 0,8 & 104 & 0,4 & 0,5 \\
\hline 15 & 0,1 & 0,4 & 60 & 0,3 & 0,5 & 105 & 0,4 & 0,6 \\
\hline 16 & 0,2 & 0,6 & 61 & 0,3 & 0 & 106 & 0,2 & 0,5 \\
\hline 17 & 0,5 & 0,5 & 62 & 1 & 1 & 107 & 0,1 & 0,6 \\
\hline 18 & 0,09 & 0,5 & 63 & 1 & 1 & 108 & 0,5 & 0,8 \\
\hline 19 & 0,08 & 0,4 & 64 & 1 & 1 & 109 & 0,5 & 0,8 \\
\hline 20 & 0,08 & 0,3 & 65 & 0,2 & 0,6 & 110 & 0,3 & 0,7 \\
\hline 21 & 0,11 & 0,3 & 66 & 1 & 1 & 111 & 0,1 & 0,5 \\
\hline 22 & 0,2 & 0,6 & 67 & 0,5 & 0,5 & 112 & 0,1 & 0,4 \\
\hline 23 & 0,25 & 0,6 & 68 & 0,2 & 0,3 & 113 & 0,2 & 0,4 \\
\hline 24 & 0,11 & 0,3 & 69 & 1 & 1 & 114 & 0,3 & 0,3 \\
\hline 25 & 0,14 & 0,5 & 70 & 0,4 & 0,4 & 115 & 0,3 & 0,3 \\
\hline 26 & 0,16 & 0,3 & 71 & 0,2 & 0,3 & 116 & 0,3 & 0 \\
\hline 27 & 0,5 & 0 & 72 & 0,2 & 0 & 117 & 0,1 & 0,5 \\
\hline 28 & 0,21 & 0,6 & 73 & 0,1 & 0,3 & 118 & 0,2 & 0,4 \\
\hline 29 & 1 & 1 & 74 & 0,3 & 0,3 & 119 & 0,2 & 0,4 \\
\hline 30 & 0,15 & 0,6 & 75 & 0,2 & 0,4 & 120 & 0,2 & 0,5 \\
\hline 31 & 0,22 & 0,5 & 76 & 0,5 & 0 & 121 & 0,2 & 0,3 \\
\hline 32 & 0,28 & 0,2 & 77 & 0,1 & 0,4 & 122 & 0,3 & 0,4 \\
\hline 33 & 0,37 & 0,4 & 78 & 0,3 & 0,2 & 123 & 0,3 & 0,6 \\
\hline 34 & 0,25 & 0,4 & 79 & 0,2 & 0,4 & 124 & 0,3 & 0,7 \\
\hline 35 & 0,25 & 0,7 & 80 & 0,5 & 0,8 & 125 & 0,8 & 0 \\
\hline 36 & 0,3 & 0,6 & 81 & 0,2 & 0,5 & 126 & 1 & 1 \\
\hline 37 & 0,12 & 0,5 & 82 & 0,3 & 0,5 & 127 & 1 & 1 \\
\hline 38 & 0,16 & 0,2 & 83 & 0,5 & 0,8 & 128 & 0,3 & 0,4 \\
\hline 39 & 0,22 & 0,4 & 84 & 0,2 & 0,5 & 129 & 0,3 & 0,8 \\
\hline 40 & 0,44 & 0,4 & 85 & 0,2 & 0,2 & 130 & 0,3 & 0,6 \\
\hline 41 & 1 & 0 & 86 & 0,2 & 0,3 & 131 & 0,2 & 0,6 \\
\hline 42 & 0,5 & 0,7 & 87 & 0,3 & 0,5 & 132 & 0,1 & 0,5 \\
\hline 43 & 1 & 1 & 88 & 0,3 & 0,3 & 133 & 0,4 & 0,6 \\
\hline 44 & 0,5 & 0,5 & 89 & 0,3 & 0,4 & 134 & 0,2 & 0,1 \\
\hline & & & & & & 135 & 0,5 & 0,8 \\
\hline
\end{tabular}

Quadro 3. Índices de consistência e retenção dos caracteres da análise filogenética. 


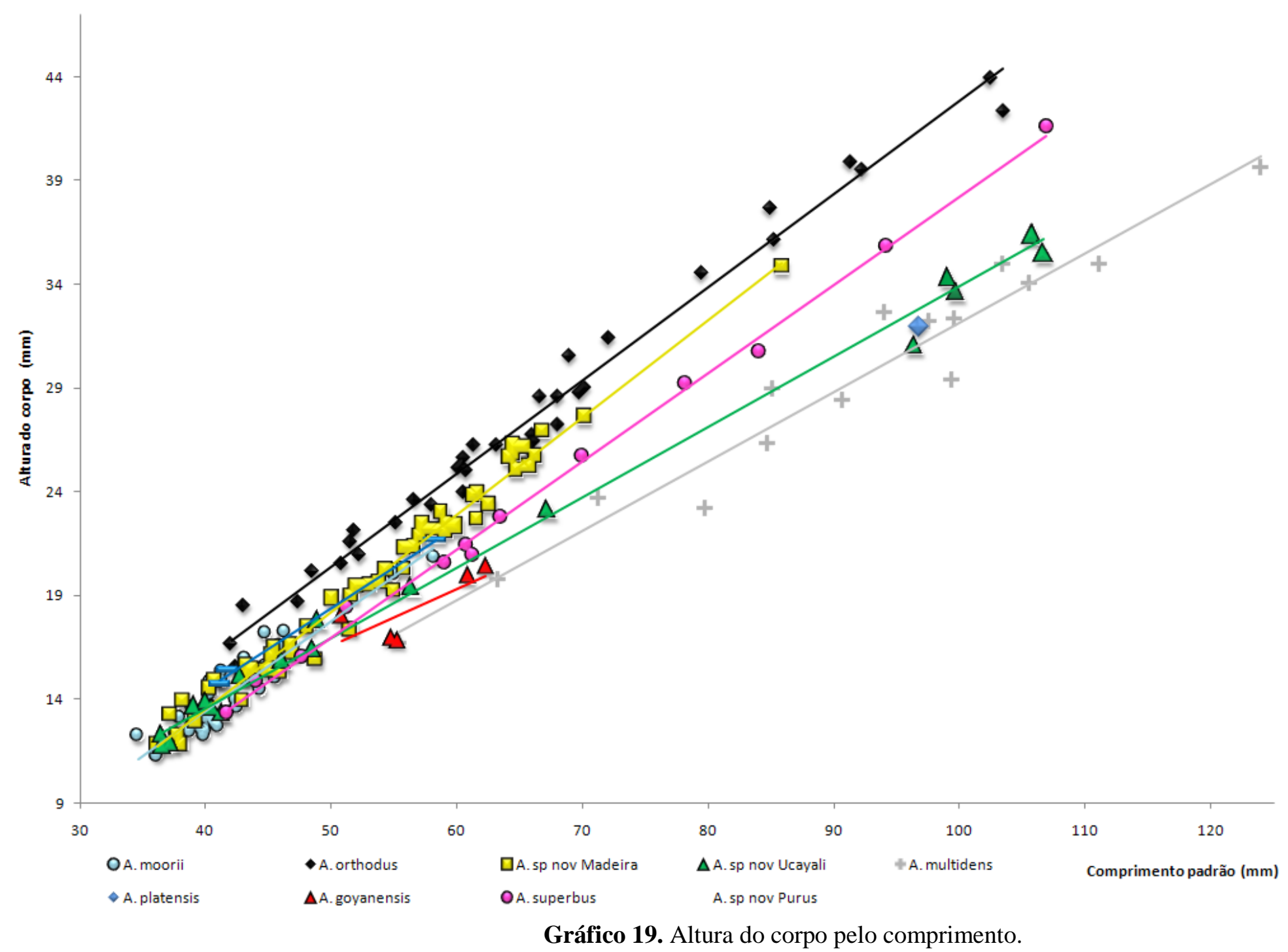




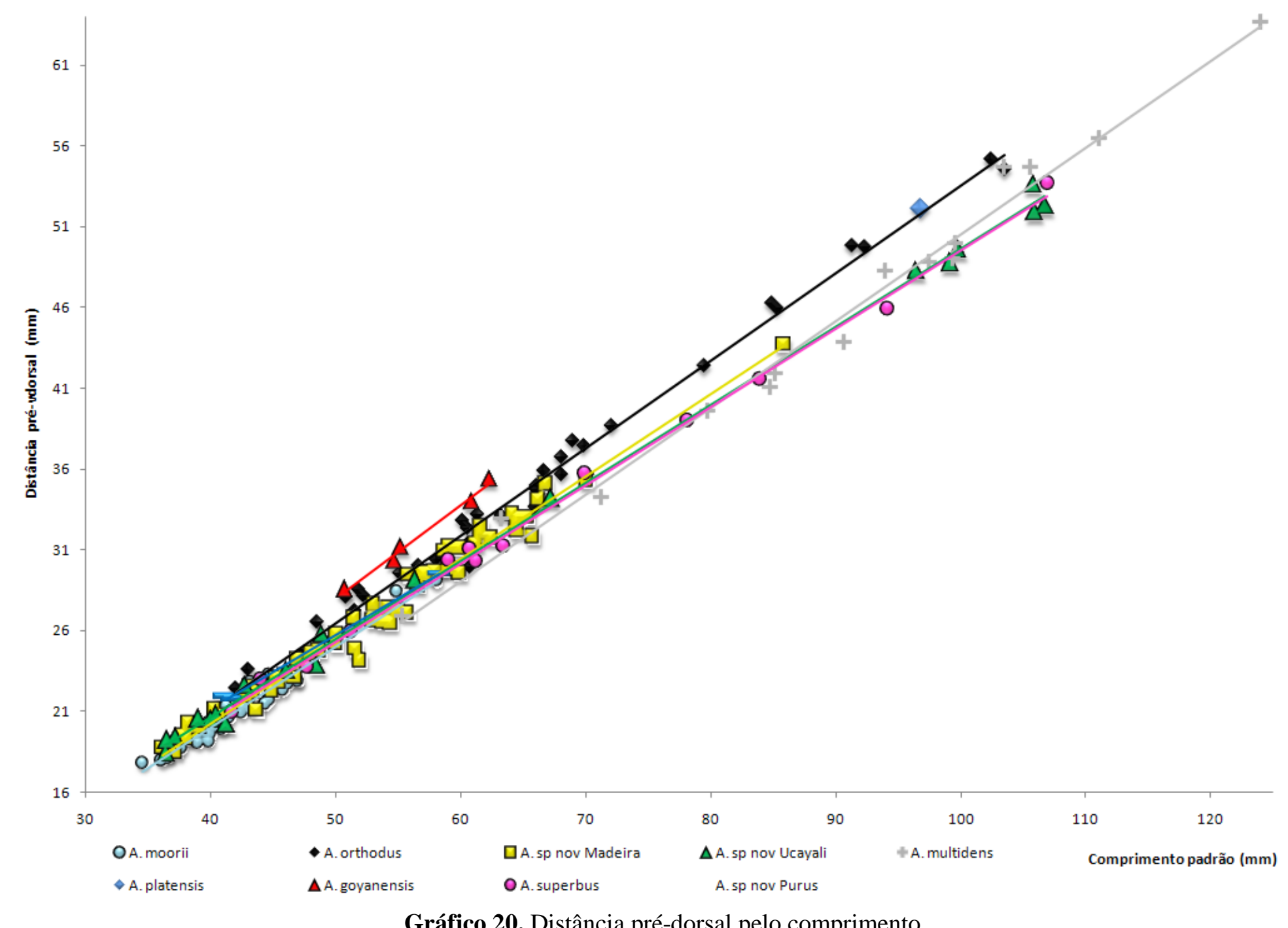

Gráfico 20. Distância pré-dorsal pelo comprimento. 


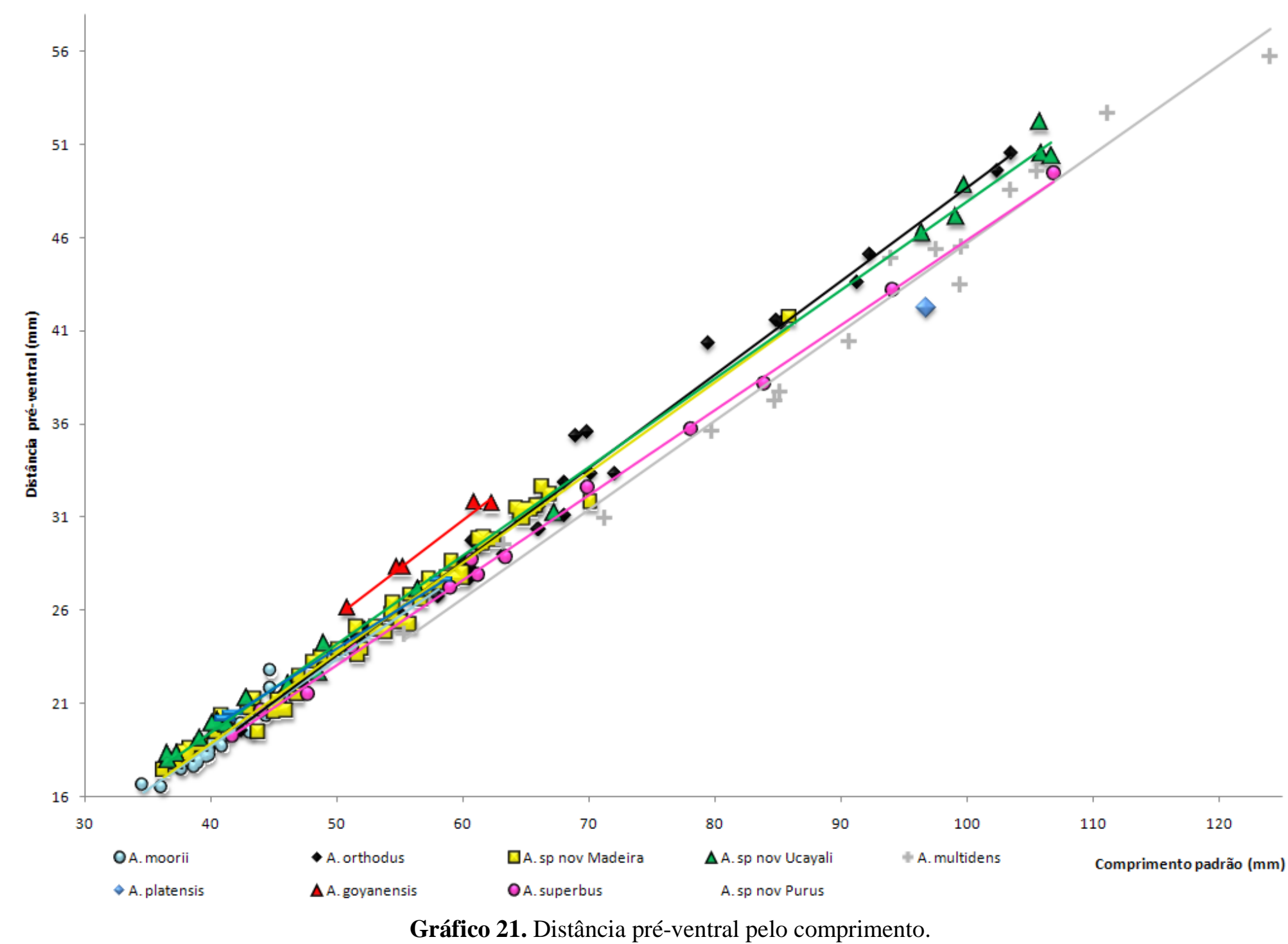




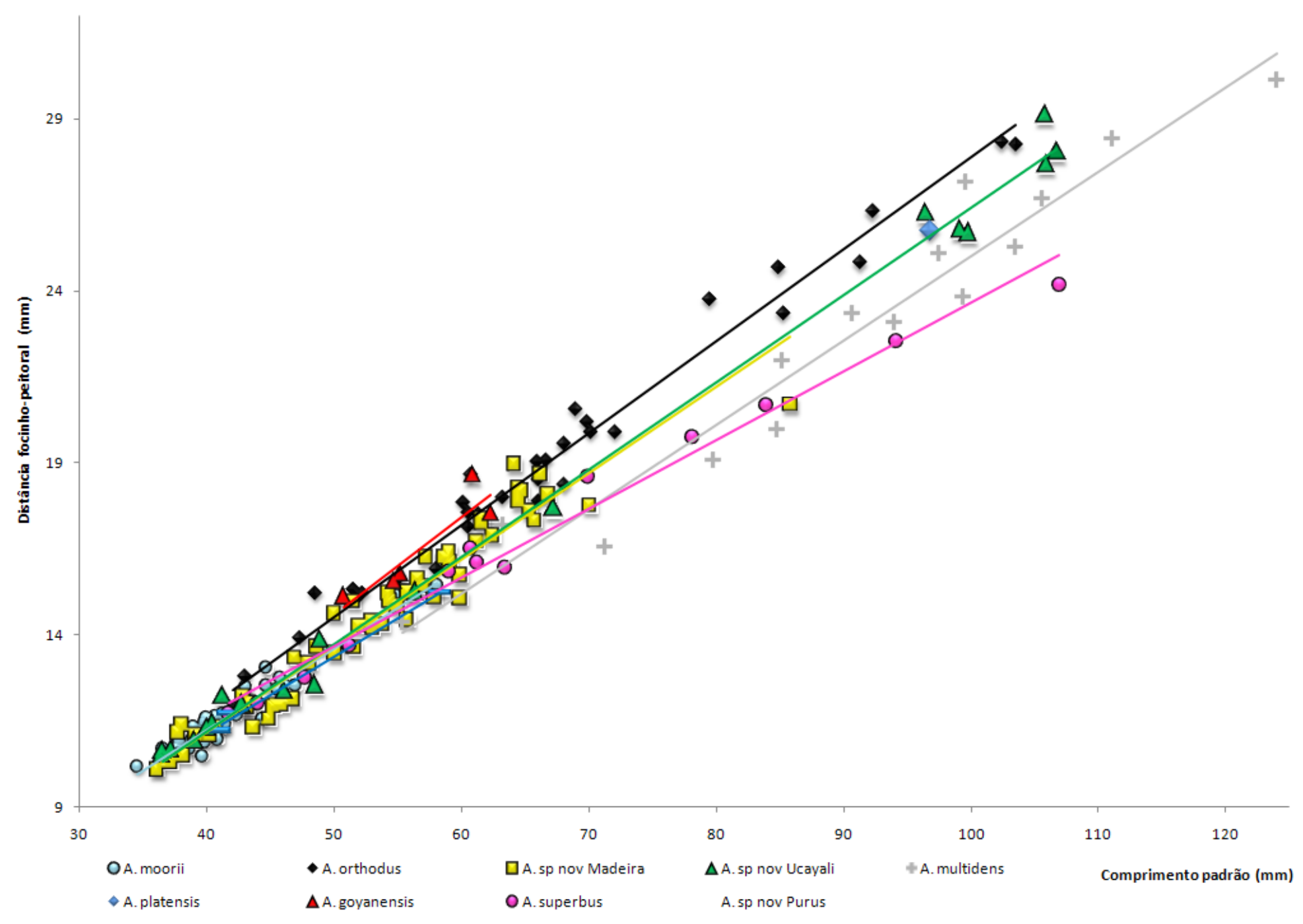

Gráfico 22. Distância focinho-peitoral pelo comprimento. 


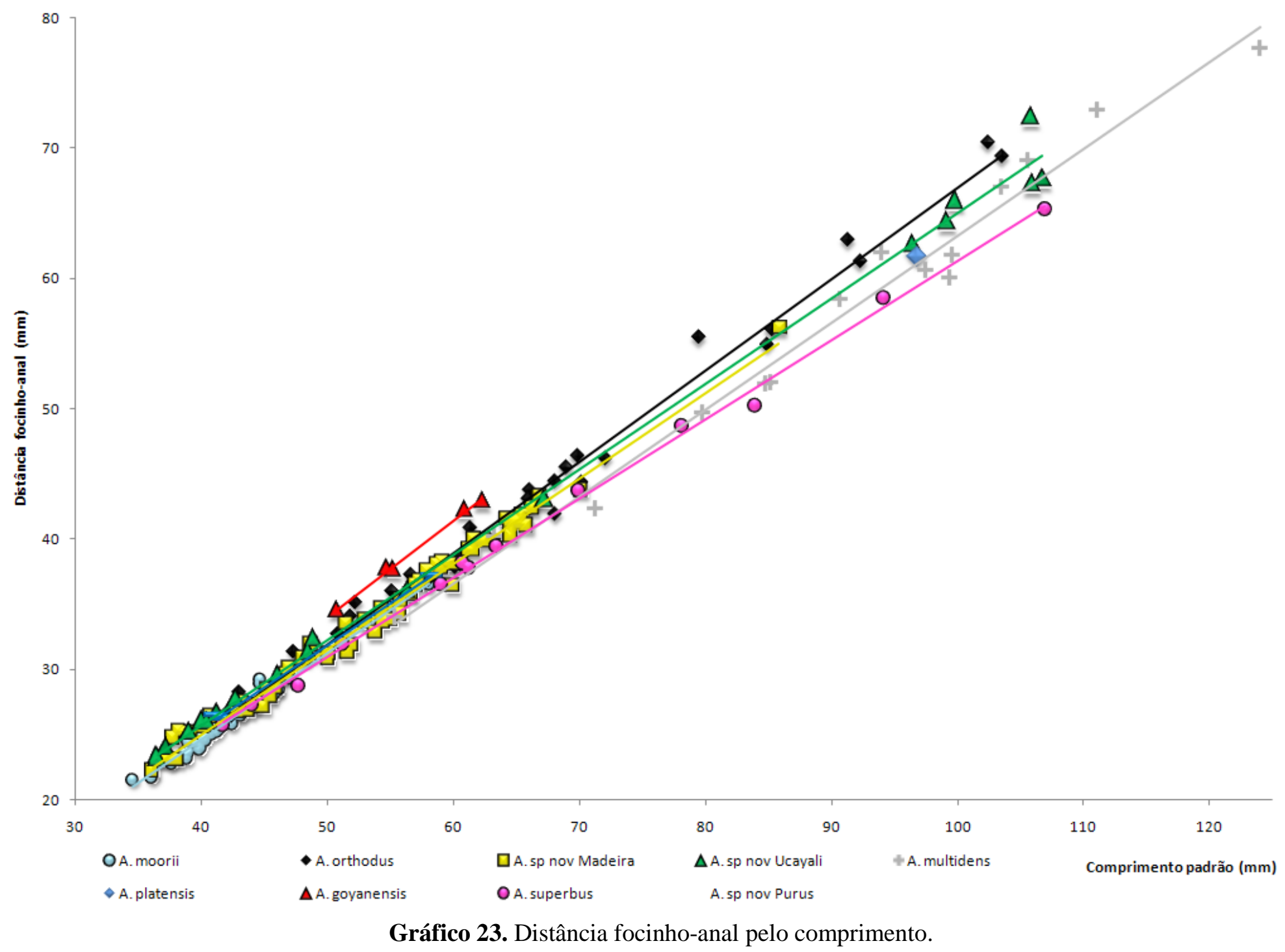




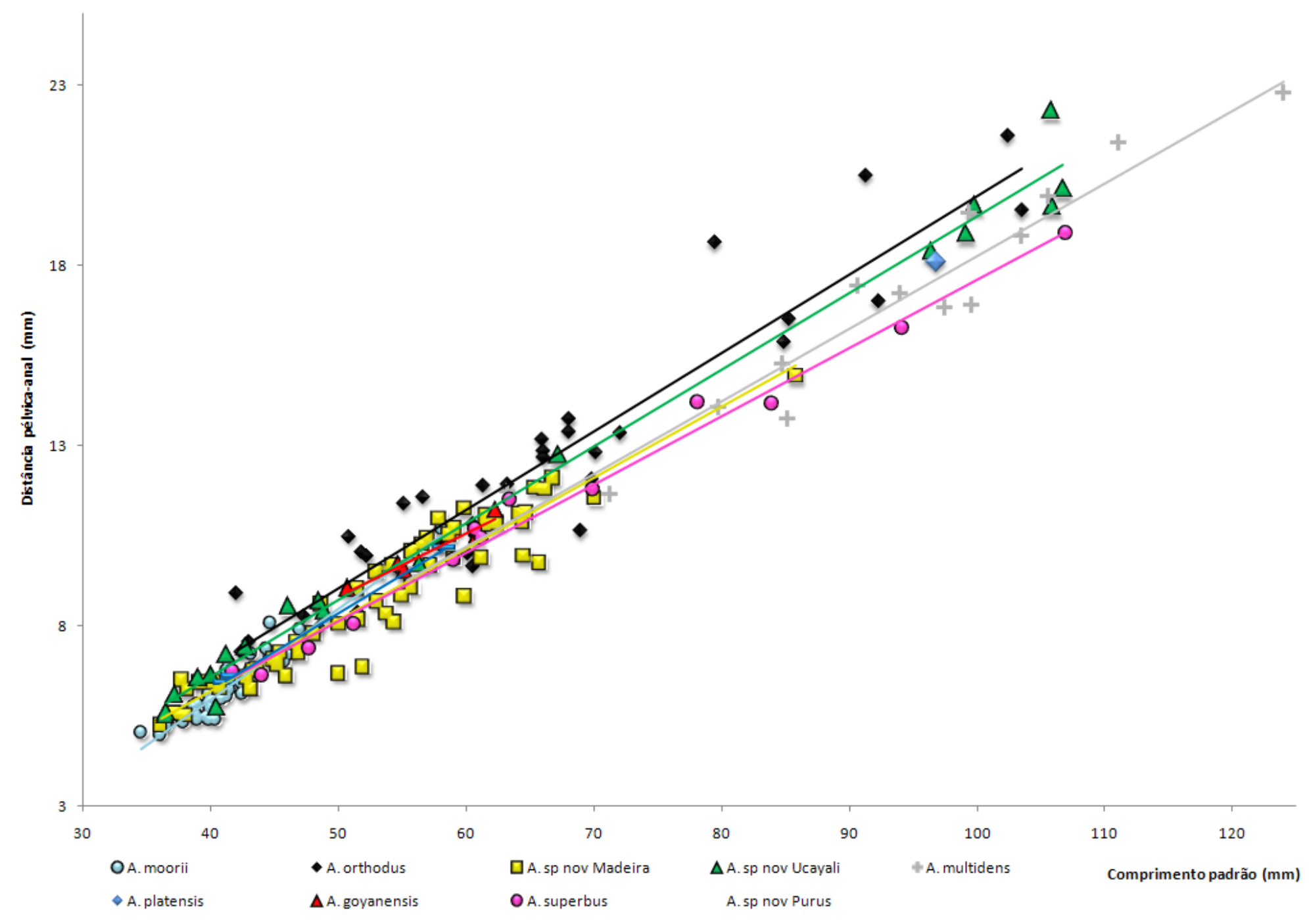

Gráfico 24. Distância pélvica-anal pelo comprimento. 


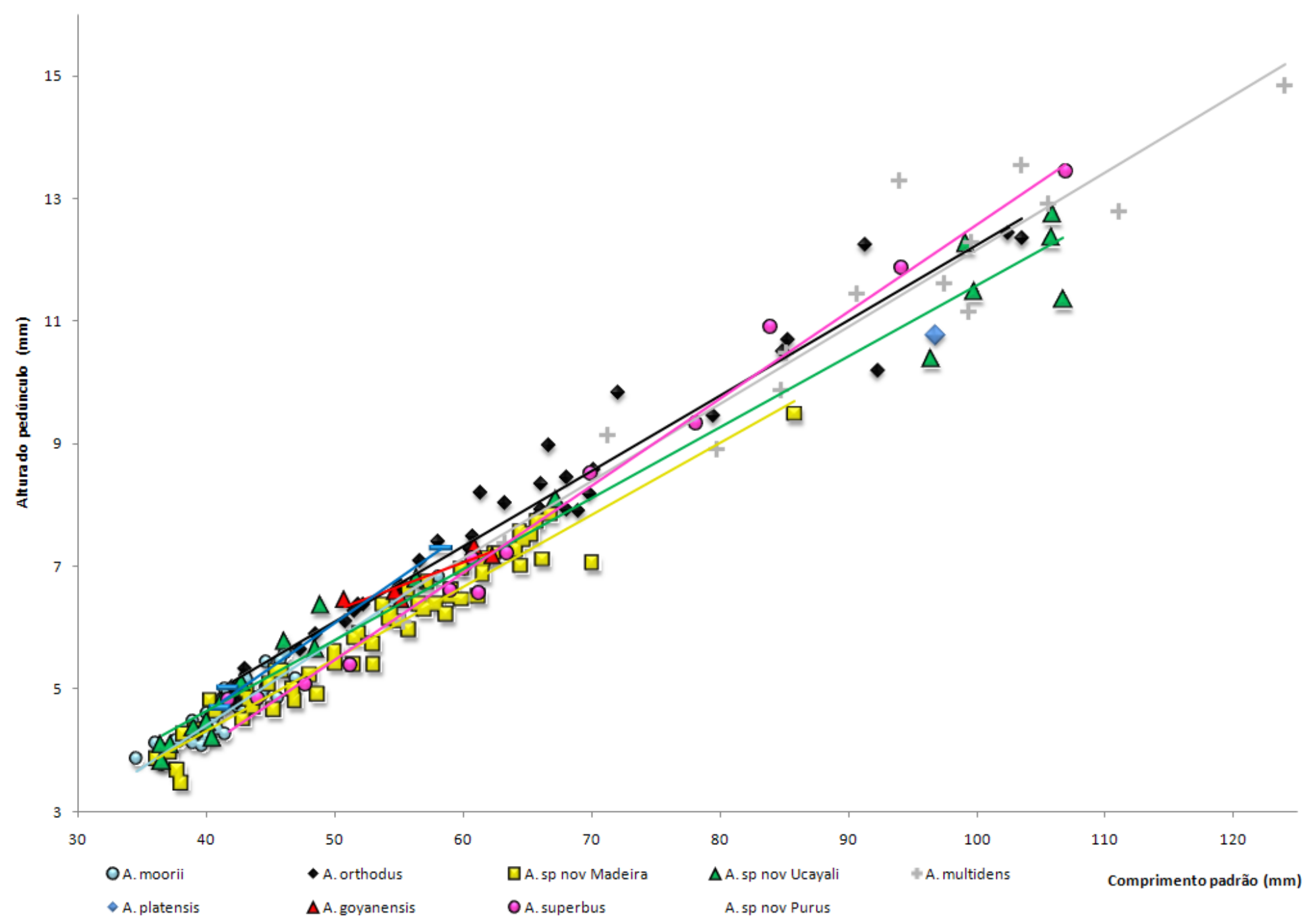

Gráfico 25. Altura do pedúnculo caudal pelo comprimento. 


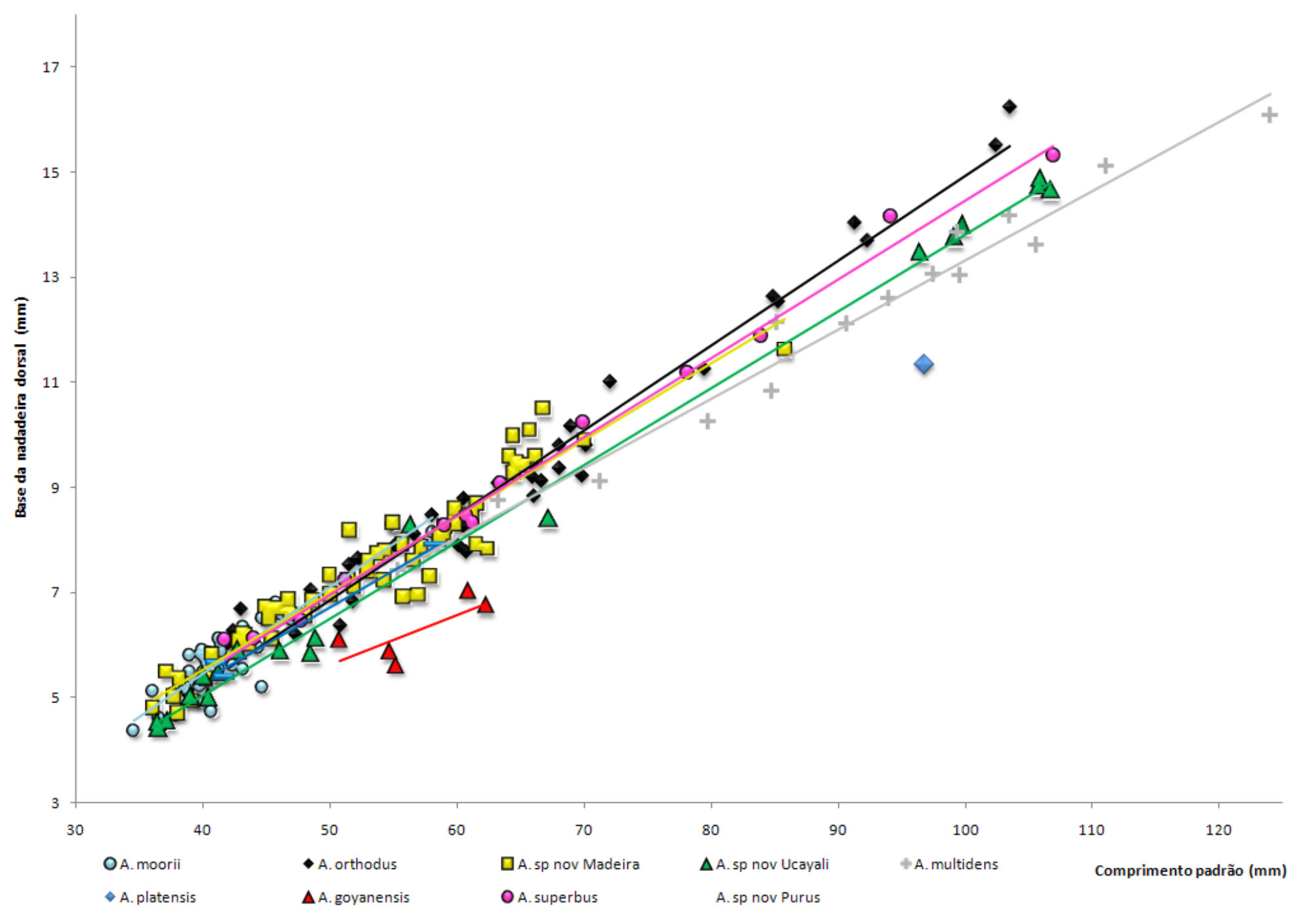

Gráfico 26. Base da nadadeira dorsal pelo comprimento. 


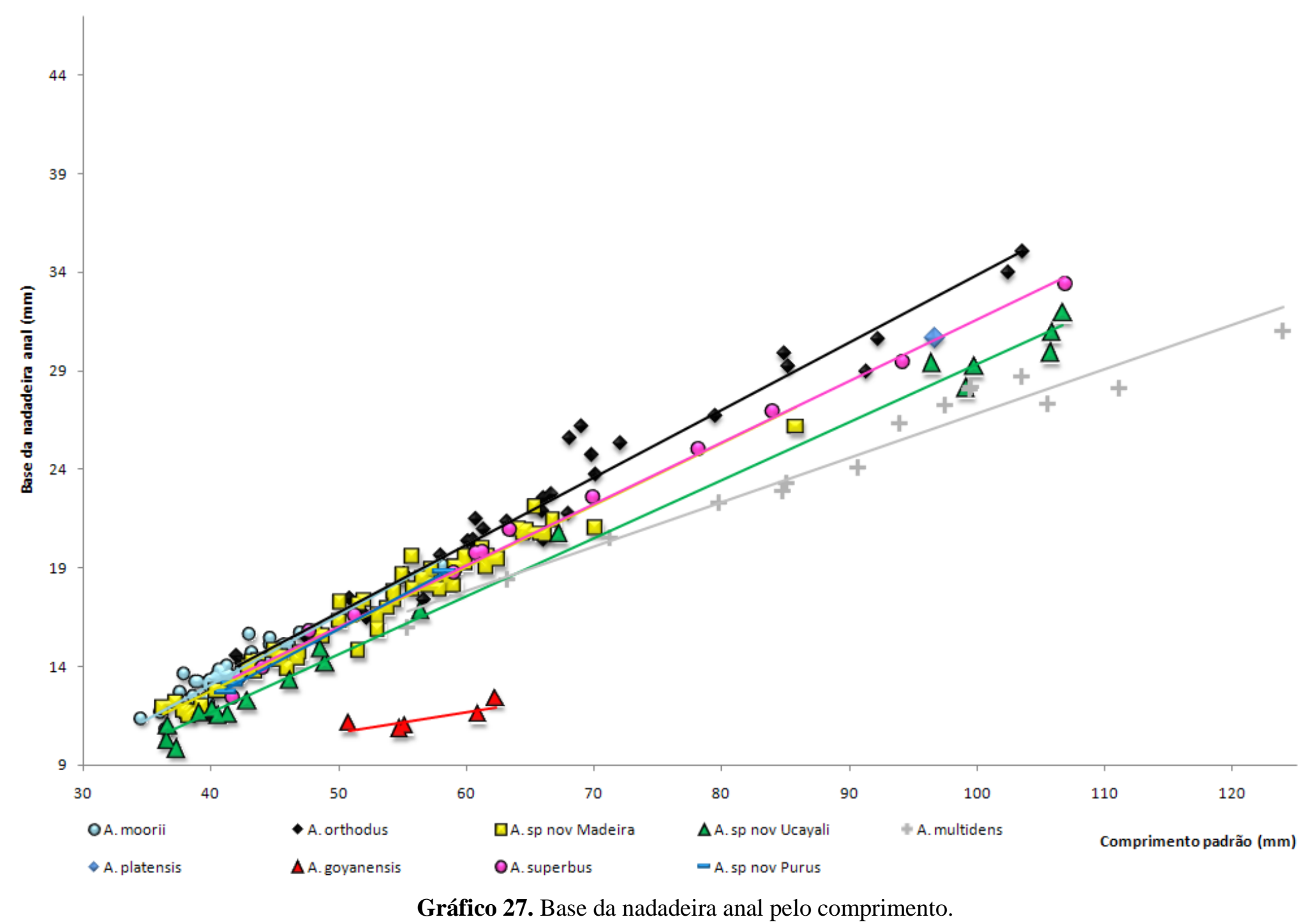




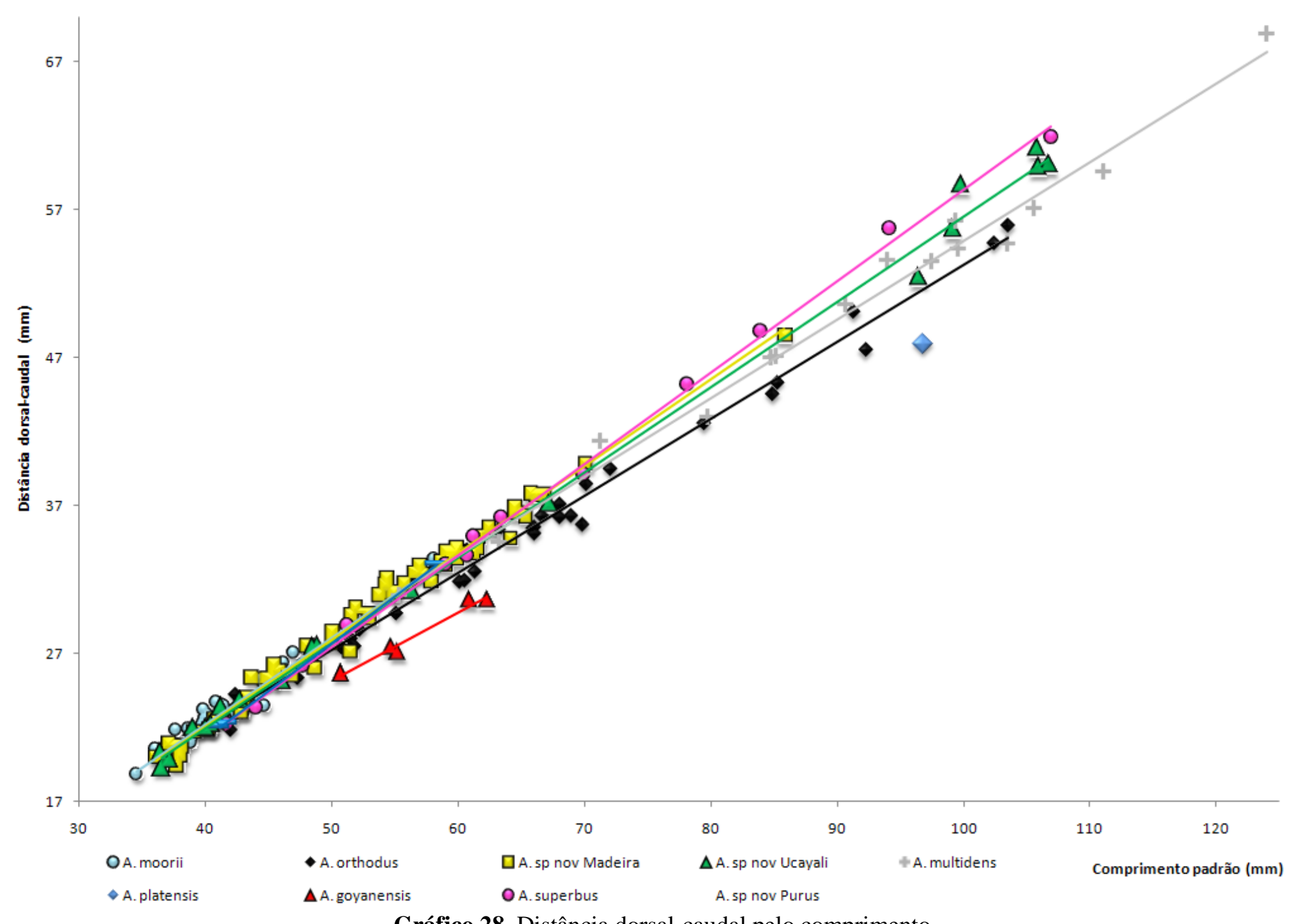

Gráfico 28. Distância dorsal-caudal pelo comprimento. 


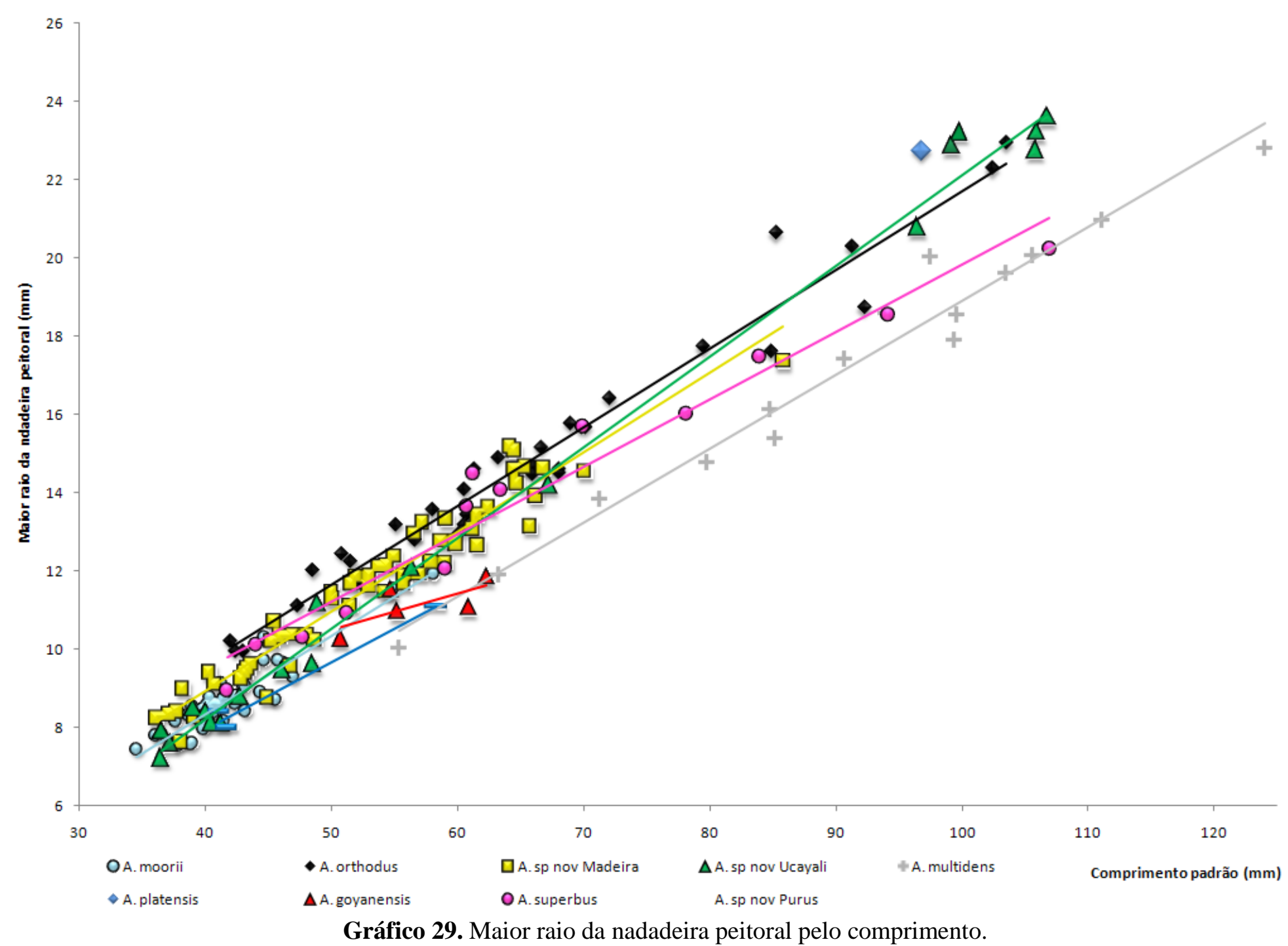




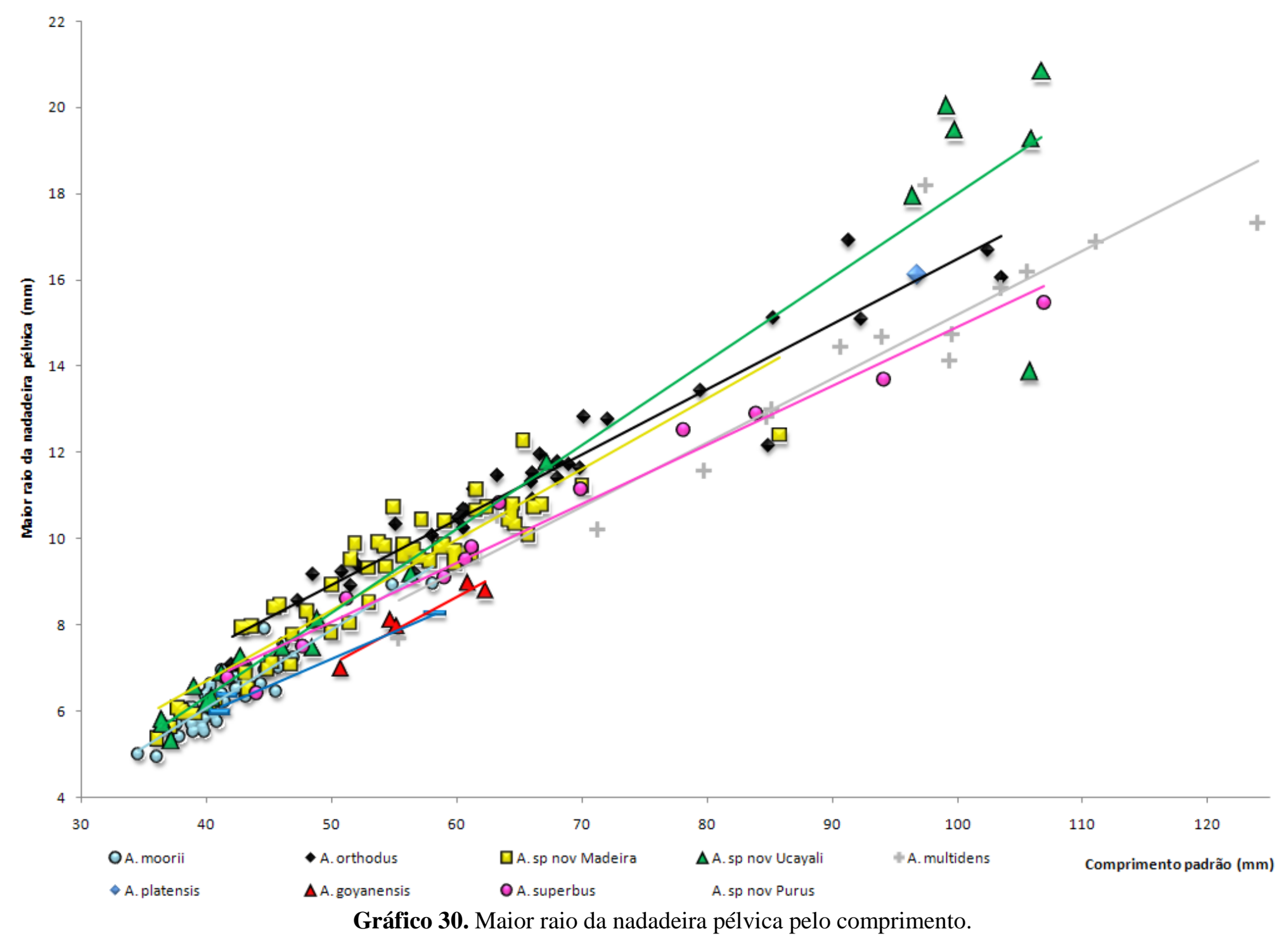




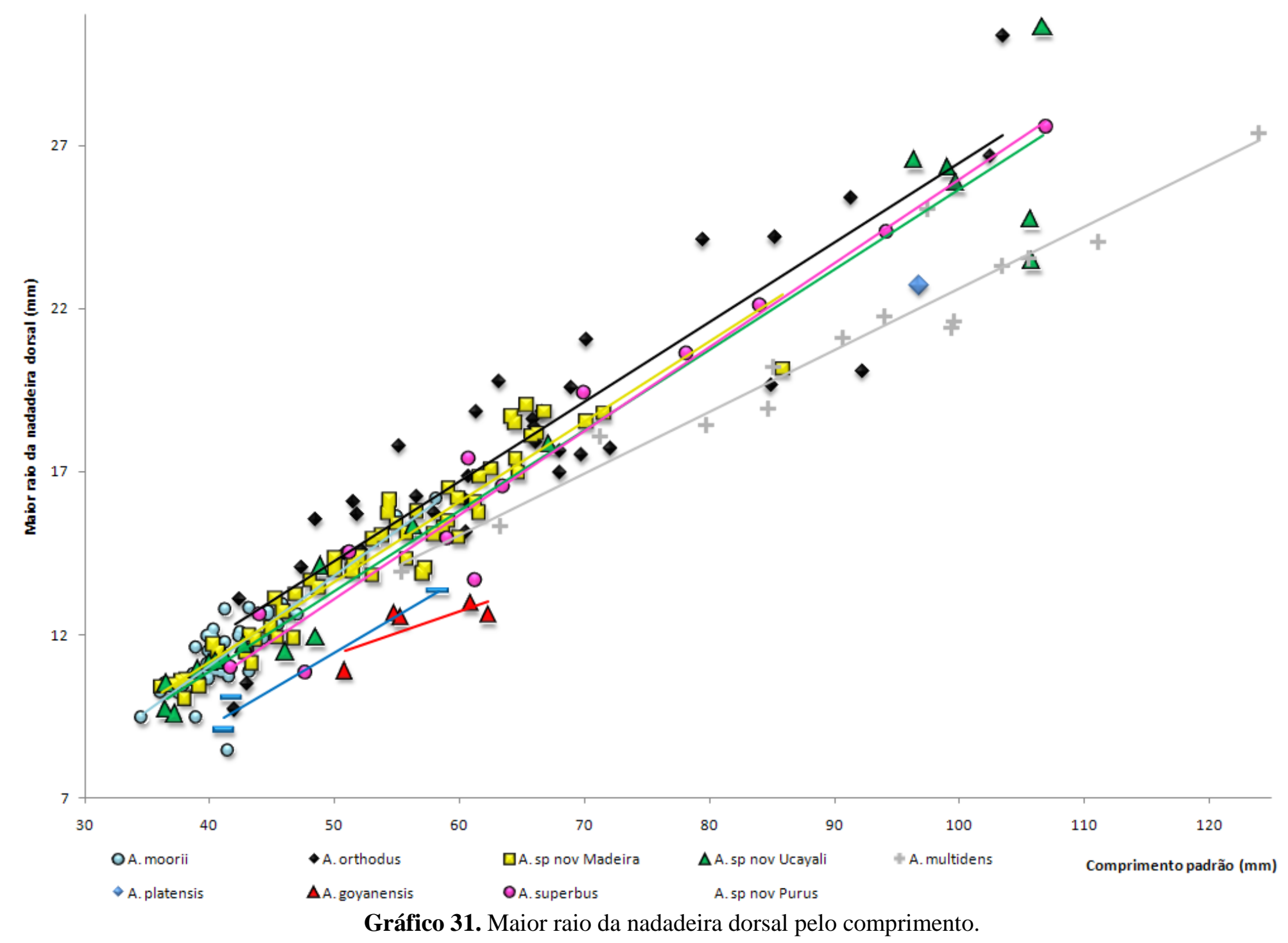




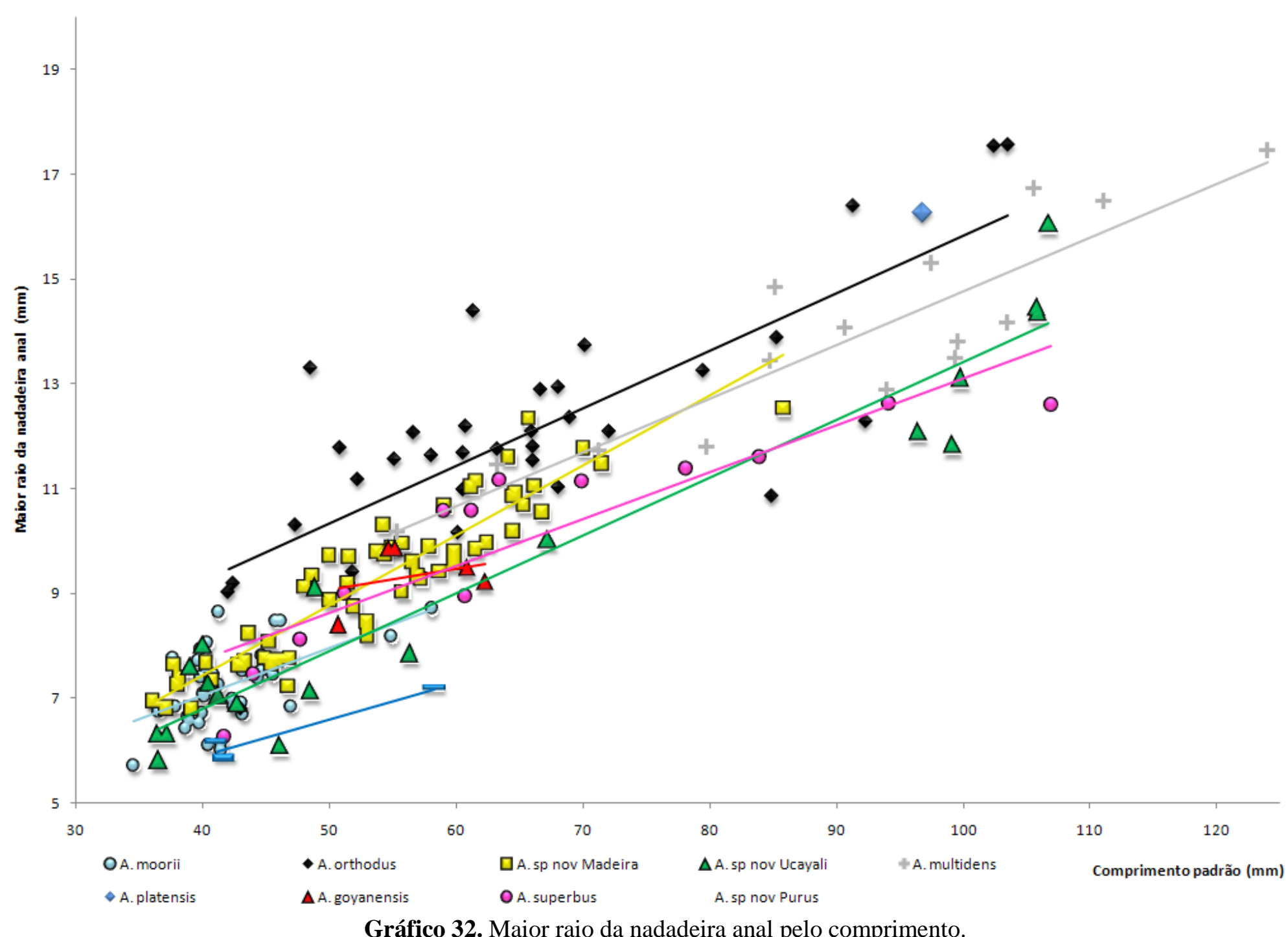




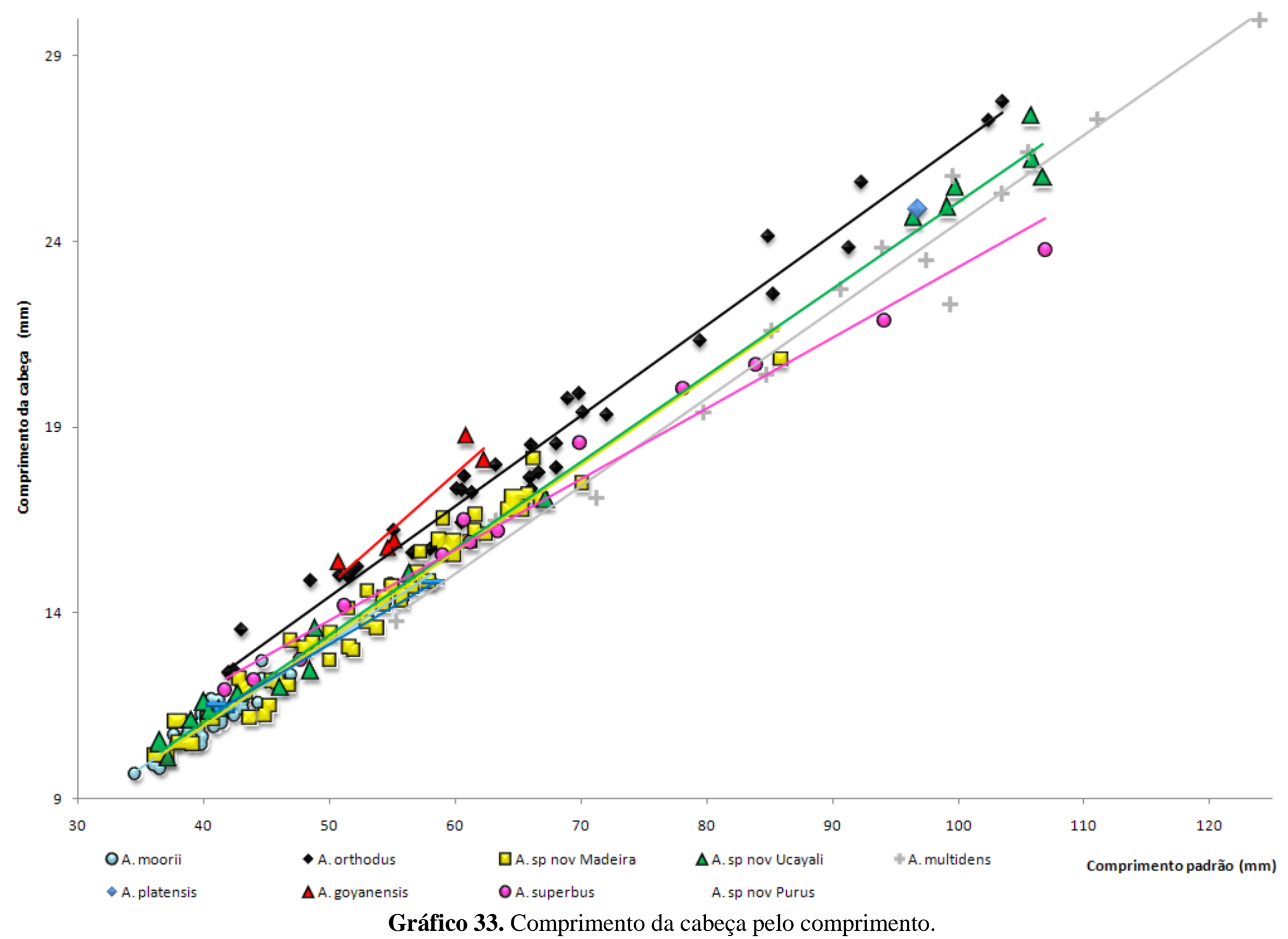




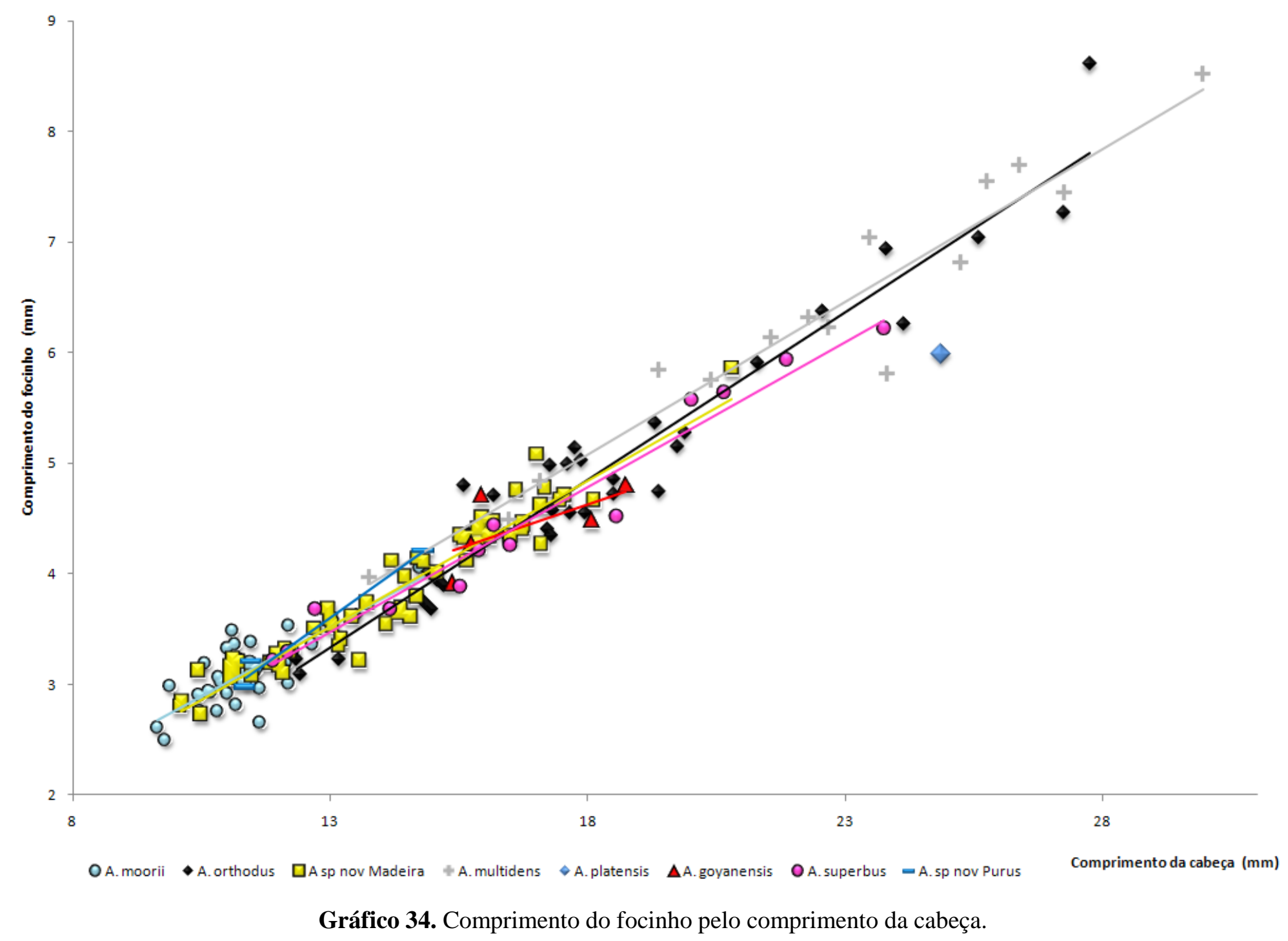




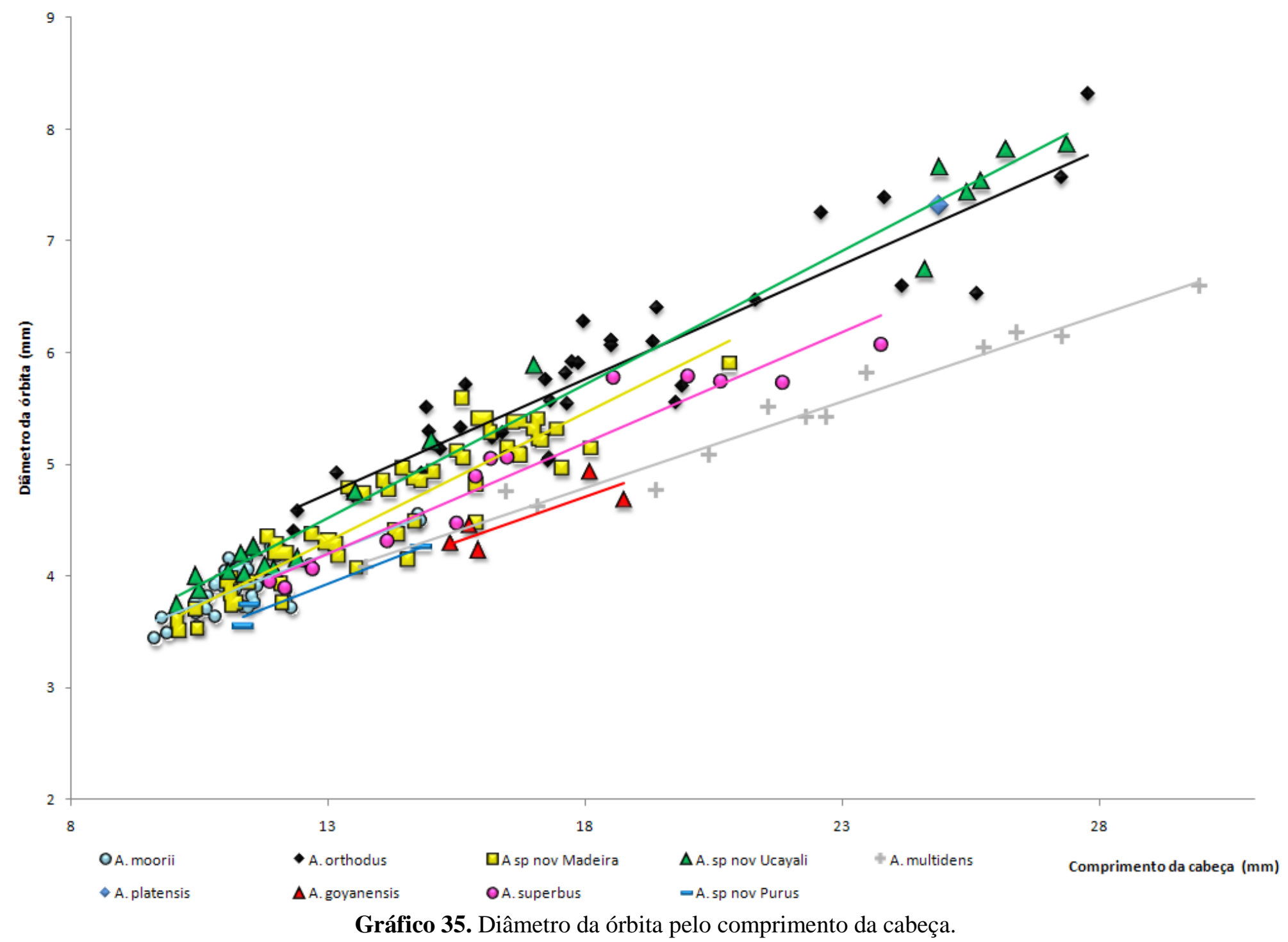




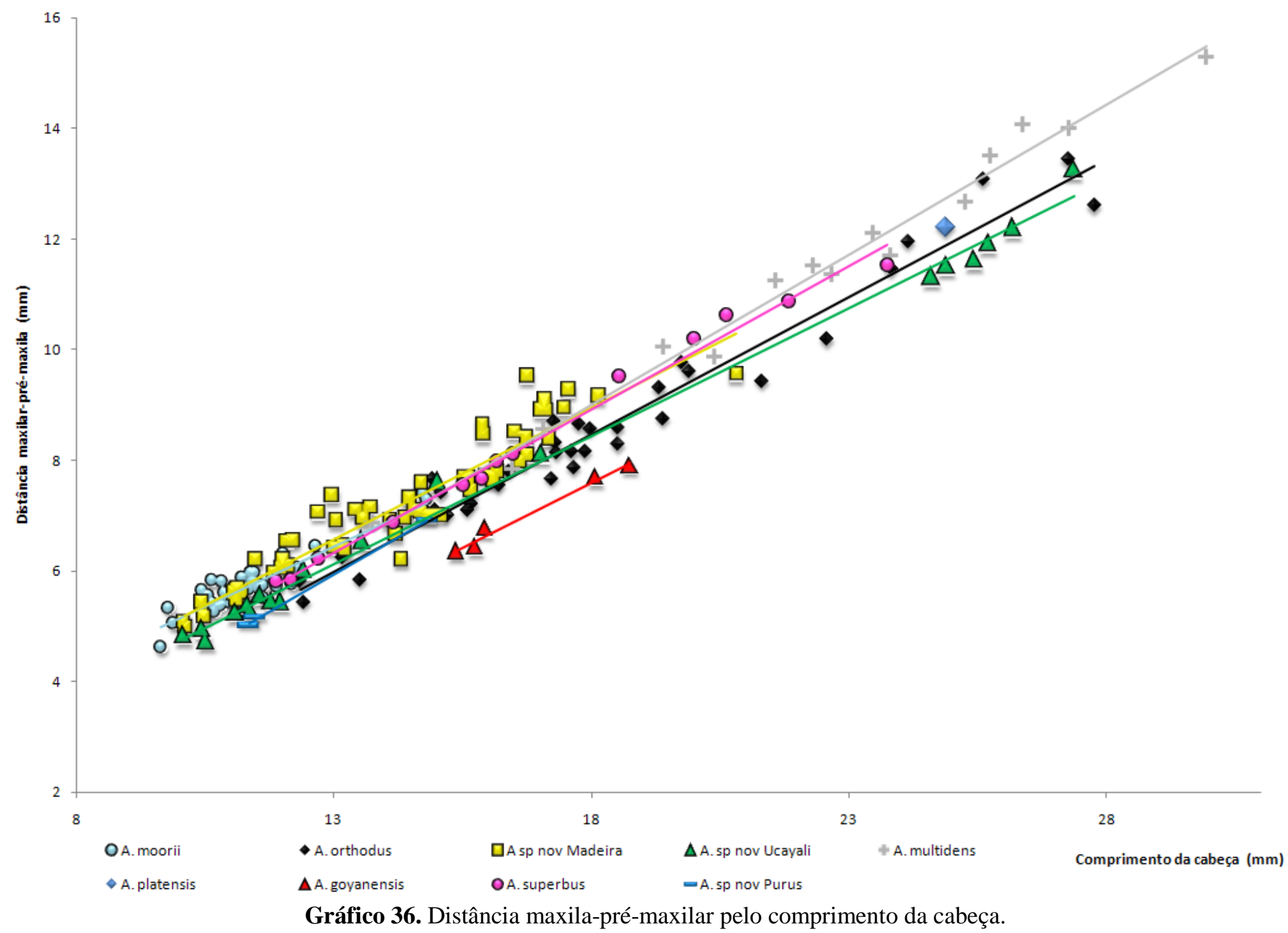




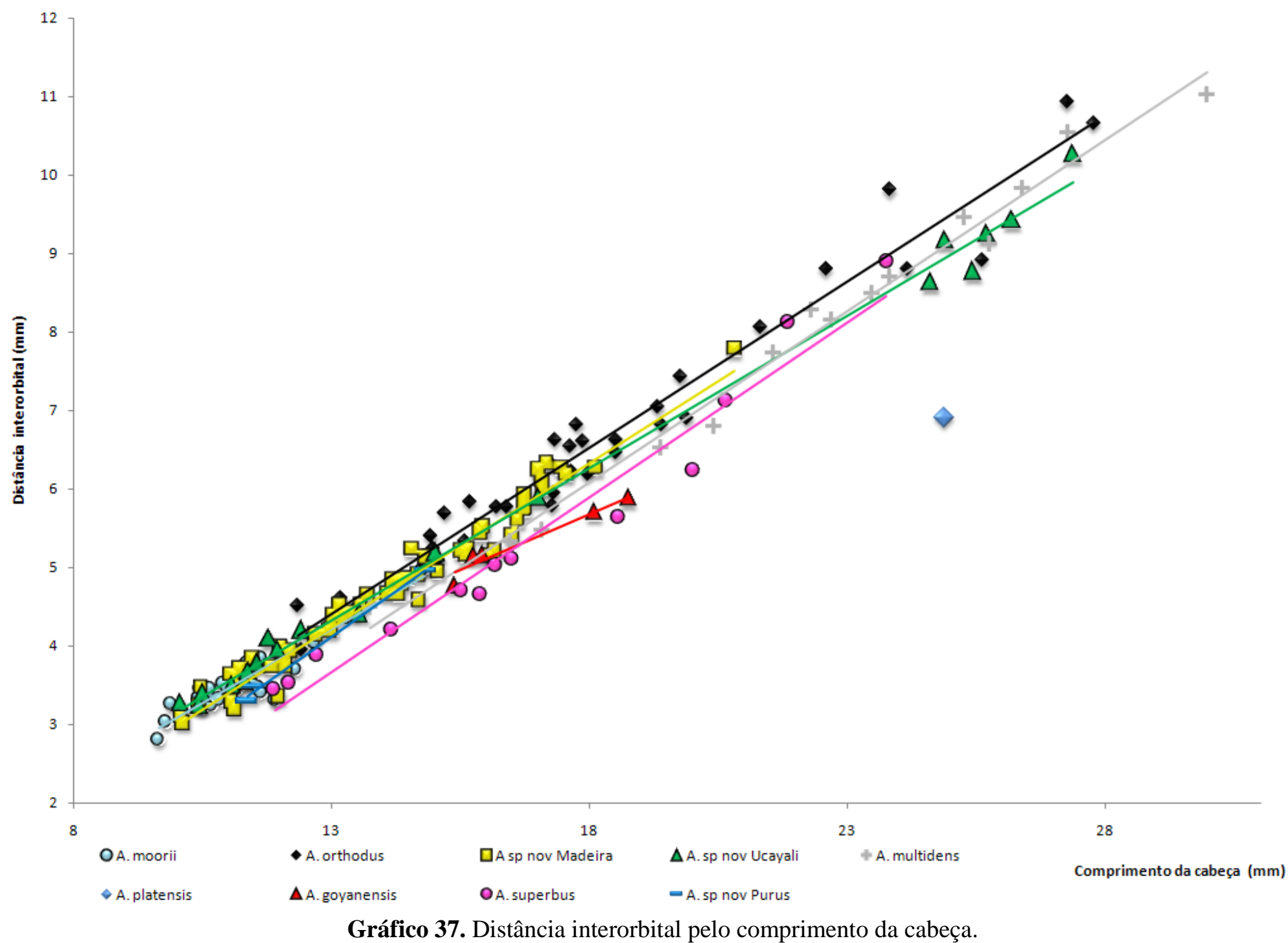




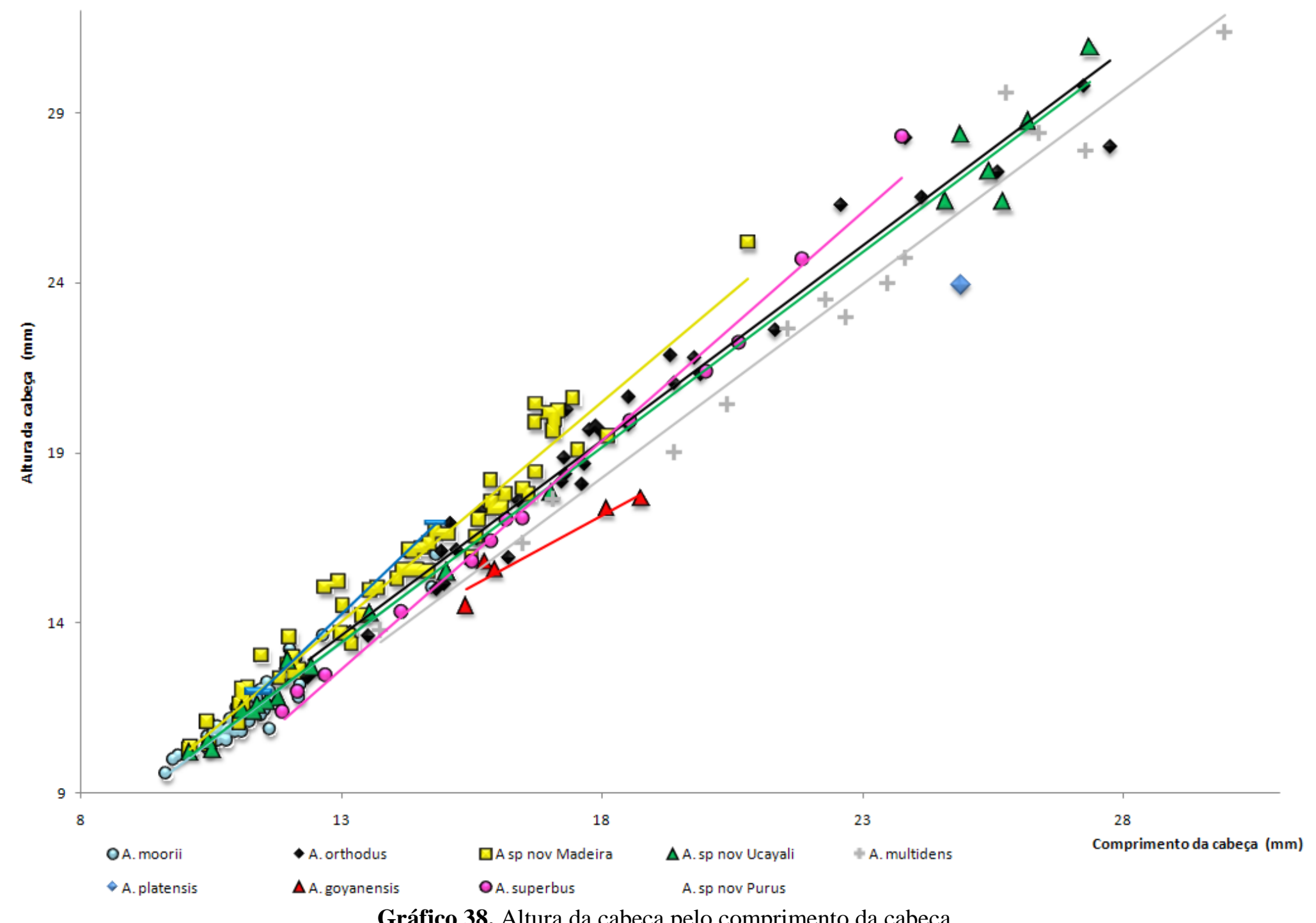

Gráfico 38. Altura da cabeça pelo comprimento da cabeça. 